\title{
Domaszék-Börcsök tanya (Halomsíros település) komplex, régészeti, környezetrégészeti és archaeometriai elemzése
}

Adatok a Dél-Alföld középső és késő bronzkorához.

Ember és környezet kapcsolata a Dorozsma-Majsai Homokháton a bronzkorban

Doktori disszertáció

Készítette: Sánta Gábor

Témavezető: Dr. Sümegi Pál 
Édesanyám emlékének 


\section{Tartalomjegyzék}

Tartalomjegyzék ......................................................... 3

Bevezetés. A dolgozat célja és szerkezete ................................... 6

A vizsgált terület....................................................... 9

Természetföldrajzi viszonyok és földrajzi helyzet........................ 9

Földtörténeti múlt és jelenkori felszíni földtani felépítés......................9

Éghajlat........................................................... 11

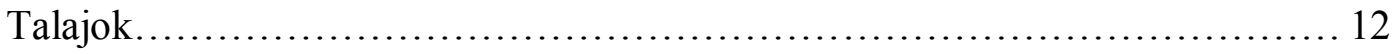

Természetes élövilág................................................. 13

Növényzet.................................................... 13

Állatvilág......................................................14

Az emberi megtelepedés természeti keretei a bronzkorban a lelőhelyen.......... 15

A szűkebb térség bronzkora............................................... 17

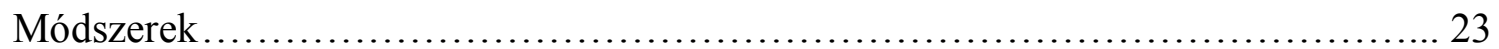

Természettudományos módszerek.......................................24

Radiokarbon (C14) vizsgálat.................................... 24

Fúrások.................................................... 25

Szervesanyag- és karbonáttartalom meghatározása.......................25

Nedves kémiai analízis előkészítése..................................26

Pollenanalízis.................................................. 26

Ösmaradványok vizsgálata........................................ 27

Archaeobotanika................................................. 28

Archaeozoológia................................................. 28

Röntgenfluoreszcencia (XRF)...................................... 29

Cluster-analízis.................................................. 30

Településszerkezet-vizsgálat................................... 30

Régészeti módszerek ................................................ 32

Terepbejárás.................................................. 32

Ásatási módszerek............................................... 32

Elsődleges leletfeldolgozás, restaurálás................................33

Leírás és rajzolás................................................. 33

Tipológia és régészeti datálás..................................... 34

Kontextuális szeriáció, gyakorisági szeriáció.......................... 35

Térhasználat analízis, ,site catchment” analízis....................... 36

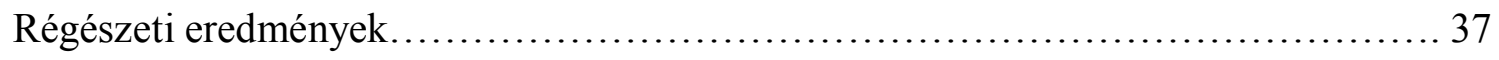

A település feltárása...................................................... 37

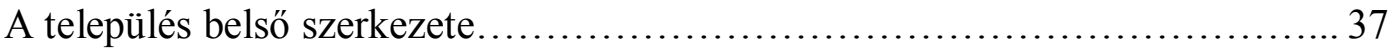

1. objektumcsoport............................................. 38

2. objektumcsoport............................................... 39

3. objektumcsoport...........................................40

4. objektumcsoport..............................................41 
5. objektumcsoport.

A cölöpszerkezetes épületek elemzése.................................. 42

Térhasználat-analízis a tálak és a durvakerámia alapján.......................43

Térhasználat-analízis az állatcsont-anyag segítségével...................... 43

Technológia - kerámiakészítés, fémmüvesség.............................. 44

A leletanyag kerámiatípusai és idörendjük.................................45

Gondolatok a régészeti „tafonómiáról" ............................. 45

A típusok elemzése és datálása........................................4 46

Összefoglalás.................................................... 51

Környezetrégészeti eredmények............................................. 52

A településen mélyített fúrás geokémiai elemzése.......................... 52

Szervesanyag- és karbonáttartalom-vizsgálat........................52

Nedves kémiai analízis............................................ 52

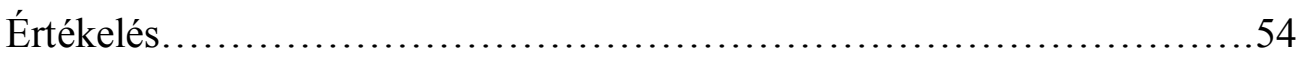

A semlyékben mélyített fúrás eredményei...................................54

Szervesanyag- és karbonáttartalom-mérés............................55

Nedves kémiai analízis.............................................. 55

Értékelés..................................................... 55

Archaeobotanikai eredmények.......................................56

Értékelés............................................................ 57

Archaeozoológiai eredmények........................................58

Értékelés.......................................................

A lelöhely természetes környezete és változásainak tendenciái a késő holocénben a

Maty-ér medrében mélyített fúrások alapján...............................6 60

Éghajlat a bronzkorban..........................................62

A geológiai fúrás................................................6 62

A pollenfúrás...................................................... 63

Értékelés.........................................................64

A középső és késő bronzkori környezet részletes értékelése...............66 66

Archeometriai eredmények..................................................6 69

Kerámialeletek elemzése............................................... 69

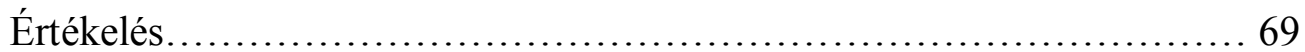

Köanyag elemzése................................................ 71

Fémmüvesség és kereskedelem....................................... 72

Fémelemzések 2009-ben........................................... 72

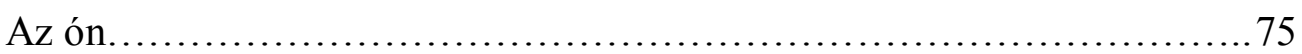

A 2010-2011-ben végzett archeometallurgai mérések................... 75

A vizsgált tárgyak.......................................... 76

Főkomponens-analízis...................................... 76

Elektronmikroszkópos vizsgálatok............................. 77

MicroPIXE vizsgálatok....................................... 78

Érc, bányászat, forrásterület........................................... 79 
Rézkohászat Pliniusnál.

Bányászat, metallurgia, és gyakorlati ásványtani ismeretek a bronzkorban 82

Korrózió, restaurálás, anyagvizsgálat............................ 84

Összegzés, továbblépés........................................... 84

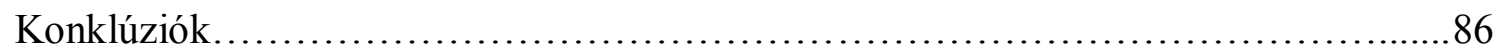

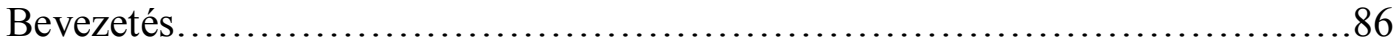

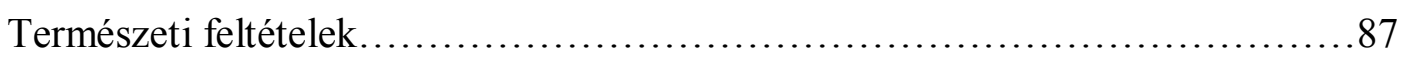

Környezet-átalakítás................................................... 88

A település helye a térség bronzkorában. Időrend és történeti folyamatok........99

Kultúraváltozás..................................................... 95

Településszerkezet................................................ 98

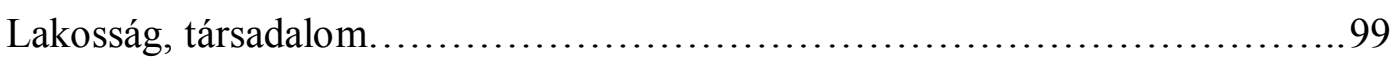

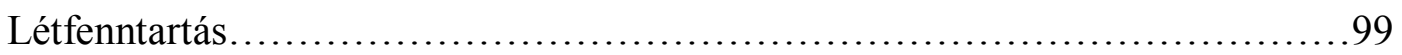

Technológia.........................................................100

Szakrális szféra.......................................................... 103

Köszönetnyilvánítás ....................................................... 104

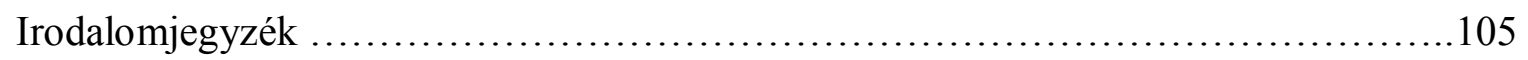

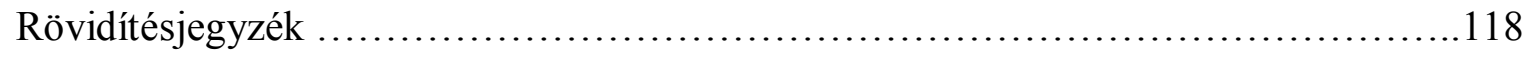

Összefoglalás ......................................................... 118

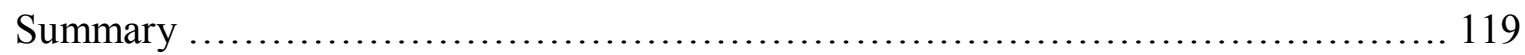

Mellékletek ............................................................ 122 


\section{Bevezetés}

\section{A dolgozat célja és szerkezete}

Ez a doktori dolgozat két, első ránézésre igen eltérő tudományág határmezsgyéjén mozogva kívánja jobban megvilágítani az emberi múlt egy szeletét. A régészet és geológia: mindkettő történeti (idő) tudomány, tehát vizsgálatának tárgyát múltbeli folyamatok képezik. A geológia igen fontos módszertani alapja az aktualizmus elve (Lyell, 1833), amely a régészetben az ethnoarcheológiával (régészeti tények megértése mai, ősi jellegü társadalmak tanulmányozásával) állítható párhuzamba. A lényeges különbség az, hogy a régészet tárgya az „ősi emberi társadalom” és anyagi kultúra. Tudományfilozófiai szempontból egyaránt kiemelhetjük a régészet történeti tudomány voltát, valamint azt a tulajdonságát, hogy az emberrel foglalkozik. Az angolszász országokban az utóbbira hivatkozva az antropológia része (kulturális antropológián belül, a néprajzzal együtt), de hazánkban - a téma gazdaságtársadalom- és technológia-történeti aspektusaira hivatkozva - a történettudományok közt tartják számon. Míg a történettudományok közt jogosan van helye, a történelemtudományba való besorolása (különösen az ősrégészeté) vitatható. Írásos források és államiság nélküli társadalomban a klasszikus eseménytörténet rekonstrukciója nem, vagy csak igen nagy vonalakban lehetséges (Hajdú, 2001). A 19. sz. végének, 20. sz. első felének historikus szemlélete azonban a régészeti kultúrákra, mint „,népekre”, politikai egységekre tekintett, és néha olyan tulajdonságokkal (hódítás, közös politikai és katonai fellépés, pl. védelmi vonalak kiépítése) látta el őket, melyek az államok, esetleg a modern államok sajátjai.

Válaszul a historikus szemlélet tipológiát kronológiát előtérbe helyező kutatási módszerére, az 1950-es években kialakult az ökológiai megközelítés, mely az egykor élt embert és környezetét egységes egészként fogta fel. A kezdeményezésből kinövő újrégészet (processzuális megközelítés) módszertanában már messzemenően interdiszciplináris, felfogásában pozitivista, céljaiban a múlt folyamatainak magyarázatára (processual) koncentrál. A processzuális régészet legfőbb jellemzője a természettudományos megközelítés és a természettudományos módszerek használata, segítségül hívása (Renfrew - Bahn, 1999, Sümegi, 2001a). Dolgozatomban ezen, processzuális alapokon állva, természettudományos szemlélettel és módszerekkel kapott eredményeket mutatok be és értékelek.

$\mathrm{Az}$ ún. környezetrégészet keretébe (eredeti megnevezése alapján environmental archaeology) soroljuk az archaeobotanikát, archaeozoológiát és a régészeti geológiát (Sümegi, 2001a, 2003). Ez utóbbi az a tudományterület, melyhez munkám és dolgozatom legjobban kötődik. A puszta interdiszciplinaritáson túl a régészeti geológia teljes értékü feldolgozásokat hoz létre: lelőhelyek és környezetük egykori kapcsolatának, az emberi élettevékenység számos megnyilvánulásának (élelemtermelés, technológia, tájátalakító tevékenység, stb.) rekonstrukciójára képes.

$\mathrm{Az}$ archaeometria - mérés a régészetben, különös tekintettel a tárgyi emlékek fö- és

nyomelem-vizsgálatára, ásványtani, kőzettani összetételére, származási helyük rekonstrukciójára -, archaeobotanika és archaezoológia szintén jelen van ebben a munkában, így a kiválasztott település elemzése környezetrégészeti jellegü. 
Az elemzés fontos része volt a hagyományos régészeti módszerekkel folytatott tárgytipológia és kronológiai vizsgálat, de ez csak az archeosztratigráfiai, formai elemzési alapot adta meg, amelyre a rekonstrukciót építettem. Ezeket a hagyományos régészeti módszereket azonban igyekeztem a legnagyobb alapossággal és körültekintéssel felhasználni és természettudományi módszerekkel nyert adatokkal együtt értelmezni.

A környezettörténeti rekonstrukció egy konkrét település, Domaszék - Börcsök-tanya feltárásán és környezetében mélyített fúrások elemzésén alapul, melyhez nemzetközileg elfogadott természettudományos módszereket alkalmaztam, valamint felhasználtam a régiót kutató régészeti geológusok friss eredményeit.

Dolgozatom célja egy igen fontos korszak, a középső bronzkori koszideri korszak és a késő bronzkori urnamezős kultúra közé ékelődő halomsíros kultúra, és az időszakához köthetö változássorozat - részben - új szempontú vizsgálata. A kérdéses archeosztratigráfiai szint idöhatárait a koszideri idöszak kezdete (Kr. e. 1650 cal. BC) és a halomsíros kultúra lezárulása (Kr. e. 1250 cal BC) jelenti.

A középső és késő bronzkor határán egy komplex változássorozat zajlik: anyagi és szellemi kultúraváltás, életmódváltás, mely társadalmi és településszerkezeti átrendeződéssel jár együtt. Ennek a kulturális és társadalmi változásnak vizsgáltam meg az anyagi és környezeti hátterét a Dél-Alföld egy kistáján, a Dorozsma-Majsai Homokháton.

A lelőhely kiválasztását a következő tényezők indokolták:

A nagy volumenủ autópálya-ásatások tették lehetővé a település feltárását, mely 19 ezer $\mathrm{m} 2$ felületen biztosít lehetőséget a település belső szerkezetének vizsgálatára. Az előkerült és feldolgozott nagy mennyiségü állatcsont és növénymaradvány lehetővé teszi az életmód (részleges) rekonstrukcióját. A feltárt kerámiaanyag pedig elég gazdag egy komolyabb összehasonlító vizsgálathoz, belső kronológia kidolgozásához.

A település elhelyezkedése több szempontból is szerencsés: a dél-alföldi régióban került először sor a halomsíros kultúra magyarországi jelenlétének felismerésére (Foltiny, 1957). A későbbi kutatások igazolták, e terület sok szempontból kiemelt fontosságú volt abban az időszakban, a Maros menti só-, bronz- és aranykereskedelem ellenőrzőjeként (pl. TápéSzéntéglaégető: Trogmayer, 1975). A Tisza folyó, mint természetes határ elválasztotta a jobb parton élő, döntően közép-európai tradíciójú halomsíros közösségeket a főleg középső bronzkori örökséget hordozó bal parti csoportoktól, de épp a kereskedelem révén hidat is képzett közöttük, s ez a kapcsolat legjobban itt, a Dél-Alföldön fogható meg legpontosabban. Ezen indokokra támaszkodva döntöttem Domaszék-Börcsök tanyai lelőhely feldolgozása mellett.

A következő környezettörténeti, geoarcheológiai, archeológiai kérdésekre kerestem a válaszokat:

1. Településhez kapcsolódó kérdések

- A település kora, periódusai és helye a Dél - Alföld bronzkorában (régészeti módszerekkel).

- Belső szerkezete és a térhasználat kérdései, a korszak településeinek általános jellege (régészeti és statisztikai módszerekkel). 
- A korabeli életszerkezet: a létfenntartás alrendszere - élelemtermesztés, állattenyésztés, vadászat, gyüjtögetés, halászat (archaeozoológiai és archaeobotanikai maradványok elemzése).

- A technológiai alrendszer. Kerámiakészítés, fémmegmunkálás (archaeometria, kísérleti régészet).

- A csere alrendszere. A szükebb régió kapcsolatrendszere a fémnyersanyag beszerzésére koncentrálva (archaeometria).

- A társadalom alrendszere. Társas kapcsolatok, csoportok és hierarchia és szimbólumrendszer a kor dél-alföldi közösségeiben (régészeti módszerek).

2. Környezetrégészeti kérdések.

- A lelőhely földrajzi elhelyezkedése, geológiája, hidrológiája és pedológiája, a lakóhely kiválasztásának természetföldrajzi szempontjai.

- A táj és ember viszonya, az ember tájátalakító tevékenysége (teljes körü régészeti geológiai elemzés).

A dolgozatban tehát nem csupán a településre koncentrálok, hanem környezetére, a régió késő bronzkorában betöltött szerepére is kitérek. A környékbeli lelőhelyekről előkerült bronzleletek archeometallurgiai elemzése, a Kárpát-medencére vonatkozó ásványtani, bányászattörténeti adatokkal együtt a kapcsolatrendszer felvázolásában segít. Ezt tükrözi a címválasztás is.

Eredményeim alapján kirajzolódott egy összefüggő kép a vizsgált régészeti lelőhelyről, amelynek elemeit - mint egy kirakós játék darabjait - egy nagyobb elméletbe illesztve választ kerestem a középső és késő bronzkor fordulóján lezajlott változások okaira, és a változások hátterére.

Bízom benne, hogy munkám segít a Halomsíros kultúra időszakának a középső és késő bronzkor átmenetében történt változások megértésében, az akkor élt emberi közösségek és az egykori környezet viszonyának feltárásban, az egykori emberek megértésében, akik általunk két eltérő korszakra, archeosztratigráfiai szintre osztott világ határán állva, a középső bronzkori tradíciókkal felvértezve, új innovációkat bevezetve kialakították a későbronzkori technológiákat és új környezethasználati modelleket. 


\section{A vizsgált terület}

\section{Természetföldrajzi viszonyok és földrajzi helyzet}

Domaszék-Börcsök tanya bronzkori lelőhelye az Alföldön, a mai Domaszék község határában, a Duna-Tisza közi síkvidék középtájban, a Kiskunsági-homokvidéken belül, a Dorozsma-Majsai homokhát kistájában (Marosi - Somogyi, 1990) helyezkedik el. A régészeti lelöhely földrajzi koordinátái a következők: északi szélesség: $46^{\circ} 14$ ' 12 " és a keleti hosszúság: $20^{\circ} 02$ ’ 06" foka (a Google adatok alapján). A lelöhely egy 80-81 m tengerszint feletti magasságú, hosszan elnyúló ， északnyugat-délkelet irányú homokháton található, melyet dél felől egy vele egyező irányú kisméretű (egykor 600-800 m hosszú), kb. 2 m mély semlyék kísér (a területet - így a semlyéket és a hátat is - ma az M5-ös autópálya szeli át észak-déli irányban). A lelőhely térsége voltaképpen a kistáj keleti peremére esik, néhány száz méterre már a Tisza-völgy déli, eltérő genetikájú kistája kezdődik. A lelőhely tágabb környezete így nagyon változatos morfológiai szempontból, homokbuckák és hátak, semlyékek, a Tisza-völgy infúziós lösszel fedett lapos területei, valamint egykori medrek találhatóak $5 \mathrm{~km}$-es sugarú körön (az ún. SCA - Site Catchment Analysis által javasolt egy napi hatékony járóföldön: Roper, 1979) belül. Kelet felé a lelőhelytől 3 km-re húzódik a Maty-ér völgye észak-déli irányban, déli része horogszerüen visszakanyarodik, és a Tisza-völgy pereménél elvégződik (a II. katonai felmérésen Maty Ágazat, egykori meder, 1. ábra).

\section{Földtörténeti múlt és jelenkori felszíni földtani felépítés}

A félköríves terület belső síkságát - a müholdfelvételek alapján - övzátonyok világosan felismerhető sávjai alkotják (Google Earth). Úgy gondolom, a lelőhely térségének geomorfológiai és kőzettani mozaikossága - mozaikos élőhelyeket és különböző hasznosítási lehetőségekkel rendelkező tájelemeket kialakítva - döntő szerepet játszott a megtelepedés helyének kiválasztásában.

Mivel a régészeti lelőhely a felszín közeli negyedidőszaki rétegekhez és környezethez kötődik, ezért a táj negyedidőszaki geológiai fejlődésére koncentráltunk a földtani fejlődéstörténetben.

A negyedidőszakot a klasszikus beosztás szerint pleisztocén (jégkor: 2,58 millió évtől az utolsó 11600 évig) és holocén (jelenkor: az utolsó 11600 év) szintekre osztjuk (Sümegi, 2001b). A jégkorban a folyóvízi feltöltés és a neotektonikus mozgások játszottak fontos szerepet az Alföldön (Sümeghy, 1944, Miháltz, 1953, Molnár, 1960, 1964, 1967, 1973, Rónai, 1972, 1977, 1985). Az Alföldön Szeged környékén alakult ki egy neotektonikus (ún. Csongrádi) süllyedék, mely a nagy folyókat (Ős-Duna, Ős-Tisza) ebbe az irányba fordította már a negyedidőszak kezdetén.

A Kiskunság területét átlósan keresztülszelő Ős-Duna alapvető szerepet játszott a terület felszínfejlődésében, hiszen a Duna-Tisza közi homokhátság törmelékkúpját a folyó által szállított és lerakott kőzetek alkotják (alul kavics, de túlnyomórészt homok) (Molnár, 1990, 328-339, Rónai, 1981). 
A folyóvízi üledék ciklusokra tagolható, melyekben a szemcseösszetétel folyamatos átmenettel felfelé finomodik, majd az új ciklus kezdetén ismételten durva, homokos üledékre vált. A ciklusok a kéregmozgások és a folyók reliefenergiája változása következtében alakultak ki. A medenceperem emelkedése és az erózióbázis, a részmedencék süllyedése a folyók esését és munkavégző képességét megnövelte, tehát durvább szemű üledéket szállítottak és raktak le. Az erózió lassan letarolta a kiemelkedéseket, valamint feltöltötte a mélyebb területeket, a folyó kisebb energiájúvá vált, így a szemcseméret finomodott. Az ismételt kéregmozgások újra megemelték az eróziós területeket, és süllyesztették a feltöltődési területet, így a ciklus elölről kezdődött (Molnár, 1977, 548-49, Molnár, 1990, Rónai, 1981, 20-29).

A szerteágazó medrekben és folyóvölgyekben a jégkor folyamán folyóvízi üledékképzödés zajlott, míg vele párhuzamosan a neotektonikus mozgások következtében relatíve kiemelt helyzetű folyóvízi törmelékkúpon már a szél formálhatta a felszínt. Míg a homokháton elsősorban a homok mozgott, addig a perem területeken, Bácskában, a Tiszavölgyben eolikus (típusos) és infúziós löszképződés volt az uralkodó (Krolopp et al., 1995). A pleisztocén során legalább négy alkalommal zajlottak jelentős kéregmozgások, amelyek a medence süllyedését okozták. Ezek közül a würm glaciális második felében alakult ki a jelentősebb, melynek hatására a mai Duna-völgy (Kalocsai-süllyedék) lezökkenve kialakult, s vele párhuzamosan a Duna-Tisza közének jelentős területe relatíve kiemelt hordalékkúp helyzetbe került. Így a Duna medre felvette a ma ismerthez közeli futását, elhagyta a kiskunsági törmelékkúpot, ahol a továbbiakban szinte kizárólag a szél felszínalakító munkája érvényesült.

A kiskunsági törmelékkúpon az egykori dunai folyómedrek a homokmozgások következtében részekre darabolódtak és ennek nyomán a medrek helyén hosszú keskeny laposok, ún. semlyékek, azaz időszakos tavak jöttek létre (Miháltz, 1953, Sümegi et al. 2003) A hosszú, neotektonikus okok miatt lefüződött folyómedrekben kialakult tavaknak az aljzatában lévő folyóvízi durvatörmelékes rétegek nyomán fennmaradt a kapcsolat a Kalocsai-süllyedékben kifejlődött dunai allúviummal, ezért a tavak vízháztartása döntő része a Duna áradásaitól függött.

A tavakban mésziszapképződés indult meg, mely sok helyen réti mészkő és képződéséhez vezetett (Mucsi, 1963, Molnár, 1980, 1991). Semlyékek képződhettek még a szélbarázdákban is. A jégkori és jégkor végi homokmozgások és az ezekkel párhuzamos löszfelhalmozódások alakították ki a területen és a jégkor végi futóhomokmozgásokhoz köthető a legjelentősebb futóhomok makroformák (Borsy, 1973, 1978, 1990, 1991). A holocén kori kiskunsági futóhomokmozgások a jégkorival szemben már jóval kisebb területre terjedtek ki és a termelő emberi tevékenység előtt ez a felszínformáló folyamat a táj fejlődése szempontjából csak alárendelten jelentkezett. Ennek ellenére a futóhomokmozgás, bár kisebb intenzitással is - a boreálisban folytatódott (Borsy, 1978, Sümegi - Lóki, 1988). Az atlantikum kezdetén talajosodás jellemző, de az atlantikum végén felerősödő emberi hatások (intenzívebb, külterjes állattenyésztés és a fémkultúrához köthető növényzeti átalakítás után) és talán a szárazabb éghajlati hatások nyomán ismételten futóhomokmozgás alakult ki a vizsgált területen (Nyári - Kiss, 2005). 
A bronzkortól napjainkig is több esetben történtek kisebb homokmozgások, de ezek a lokális események már mind antropogén hatásokhoz köthetőek, és fontos adatokat jelentenek a homokhát emberi közösségeinek életmód-vizsgálatához, rekonstrukciójához (Nyári - Kiss, 2005, Sümegi, 2001c, 314). Különösen a bronzkor végén bekövetkező nagyobb arányú homokmozgás érdekes a téma szempontjából, mivel egyrészt a paleoklimatológiai adatok erőteljes lehűlést és csapadéknövekedést jeleznek a Kárpát-medencében is, ezért a futóhomokmozgás a vizsgált területen egyértelmüen erőteljesebb emberi tevékenységhez kötődhet (Nyári - Kiss, 2005, 141-144). Mivel a dolgozatban bemutatott lelőhely a bronzkor második felében alakult ki és futóhomok területen, ezért a futóhomokmozgások kérdésköre, különösen a holocén kori, emberi hatásra kifejlődött futóhomok rétegek kifejlődése kiemelkedő jelentőségű a dolgozat témája szempontjából.

A vizsgálat alá vont régészeti lelőhely és környezetének geológiai felépítése, valamint a régészeti lelőhely környezettörténeti hátterének feldolgozásának szempontjából kiemelkedő jelentőségű a Maty-ér kialakulása és fejlődése. Több hipotézist is kialakítottak ennek a képződménynek a kialakulásáról, egyes vélemények szerint homokbuckák közötti mélyedés (Molnár, 1991), mások szerint egykori Tisza-völgy (Andó, 1983), de a feltáró fúrások alapján (Sümegi et al., 2003) egyértelmüen egykori, hordalékkúpon fennmaradt, a jégkori futóhomokmozgások következtében részekre fragmentálódott és a würm glaciálistól feltöltődő dunai folyómeder.

A vizsgálat alá vont régészeti lelőhelyünk felszínén az alapkőzet futóhomok, a mellette lévő kisebb semlyékben mésziszap és kotus tavi üledék található (lásd részletesen a fúrás feldolgozását). Alig 1 km-re kelet felé a Tisza-völgyben infúziós lösz, lösz helyezkedik el. Utóbbiból álló nagyobb maradványfelszínt tör át a Maty-ér 3-5 m mély medre, mely visszakanyarodva észak felé a lelőhelytől 1 km-re délre végződik el, és agyagos kőzetlisztet rétegekből álló tavi képződményeket tartalmaz (5. ábra, Síkhegyi - Gyalog, 2005 nyomán).

\section{Éghajlat}

Domaszék és környéke éghajlata - csakúgy, mint a Dél-Alföld többi kistáján - meleg, száraz és forró nyarú. A Szeged környéki táj országunk napfényben leggazdagabb vidéke (30 éves átlagban évi 2200 óra körüli a napfénytartam), bár ez a mennyiség igen jelentős részben a nyári napfénymaximumból adódik, a késő őszi, téli és kora tavaszi felhőborítottság az országos átlaghoz képest rosszabb képet mutat. Ez a tény a magas ködhajlammal magyarázható, lévén Szeged vidéke az ország legalacsonyabban fekvő tája. A ködborítottság és lokális felhőképződés a Tisza-völgy erős párolgásának, a magas relatív páratartalomnak köszönhető (a folyóvíz és a nedves térszínek, valamint az ártéri erdők következtében). Másrészt a téli félévben gyakori mediterrán ciklonok a déli országrészt érintik elsősorban, ami szintén emeli a felhőborítottságot. Mindez a kistáj mediterrán hatásával magyarázható, bár a csapadék még mindig a kontinentális éghajlatra jellemző kettős maximumot mutat (nyár eleji és őszi).

Az évi középhőmérséklet $10,5-10,7{ }^{\circ} \mathrm{C}$, a júliusi $21-22$, a januári $-1,5-2{ }^{\circ} \mathrm{C}$. A napi középhőmérséklet a tenyészidőszak java részében, április 8 . és október 22 . között $10{ }^{\circ} \mathrm{C}$ felett alakul, így a mezőgazdasági termelésnek elvileg kedvező feltételeket kínál. A vegetációs 
periódus középhömérséklete $17,5^{\circ} \mathrm{C}$, a nyári napok száma meghaladja a 80 -at, a táj egyik legfontosabb jellemzője a forró nyár. Gyakori a 34-35 ${ }^{\circ} \mathrm{C}$-os napi maximumhőmérséklet, de nem ritka az e fölötti érték sem. Az ősz általában hosszú és száraz, derült időjárású, az első komoly fagyok csak novemberben lépnek fel. A tél mérsékelten hideg, a minimumhőmérsékletek $-16-17^{\circ} \mathrm{C}$ táján alakulnak, a hótakaróval borított terület mértéke és a havas napok száma évről évre erős ingadozást mutat (általában 20-30 közötti), gyakran a DélAlföld még akkor is hómentes marad, amikor az egész országot hó fedi be. A fagymentes napok száma 200 körül mozog. A csapadék évi összege 560-590 mm, mely kissé magasabb a medence közepére jellemző értékeknél, de még így is rendkívül száraz a terület. Különösen a jó vízáteresztő képességü és szeles homokhátságon nagy probléma a vízhiány, a talaj gyors kiszáradása (éves szinten $130 \mathrm{~mm}$ a hiány). Tavasszal azonban a Tisza megemelkedett vízszintje okoz - a semlyékek területén is - belvizeket. A szelek iránya különböző, általában évszakos változások figyelhetők meg, áprilisban észak-déli, ősszel az északnyugat-délkeleti szelek a legjellemzőbbek. Júniusban és júliusban az északnyugati irányú szelek aránya jelentős. Összel és télen, illetve kora tavasszal magas a déli, délnyugati szelek aránya is. A legnagyobb szélgyakoriság áprilisban mérhető az ún. böjti szeleknek köszönhetően. (Keveiné Bárány - Gulyás, 2001, 19-20, Andó, 1983). Ezek a tényezők a fentebb leírtakkal együtt jelentős mértékben befolyásolták a régi közösségek lehetőségeit és életmódját.

\section{Talajok}

A vizsgált lelőhelyen és szükebb környezetében a homoktalajok a leggyakoribbak, elsősorban a buckafelszíneken. A futóhomok nem gyakori (inkább a hátság belső területeire jellemző), inkább humuszos homok és rétisedő homok fordul elő. A mésziszapos semlyékekben, kifújásos laposokban szoloncsák és szolonyeces réti talajok jöttek létre, míg a löszös területeken mezőségi (csernozjom) talajok típusai és változatai, mélyebb térszíneken sós réti csernozjom és réti csernozjom alakultak ki.

A homoktalajok váztalajok, talajképző folyamataik mérsékeltek, humusztartalmuk csekély és mésztartalmuk általában magas, fizikai minőség szerint finom homokok. Ezen a talajon rosszabb minőségü szántóföld alakítható ki, erdősítésre azonban alkalmas (lásd Ásotthalmi-erdő).

Mechanikai összetétel alapján lehetnek ezek a talajok homok, vályog (csernozjom típusú), agyagos vályog és agyag (szikes) talajok. A mechanikai összetétel a homoktalajokon a legkedvezőbb a mezőgazdaság számára, mivel ezek könnyedén feltörhetők és megmüvelhetők, azonban fokozottan ki vannak téve a talajerózió veszélyének. Tápanyaggazdálkodásukat tekintve igen gyenge minőségüek. A vályogtalajok sokkal alkalmasabbak mezőgazdasági müvelésre, bár ezek valamivel kötöttebbek. A legkedvezőtlenebbek az agyagos, szikes semlyékek talaja, ezeket általában legeltetésre használják, és ez korábban, a fejletlenebb agrotechnikai szinten is így lehetett.

A karbonátos-humuszos és karbonátos-gyengén humuszos homoktalajok humusztartalma alacsony, 1 százalék feletti, termőrétegük vastagsága 30-40 cm. Víztartó- és vízáteresztő-képességük általában megfelelő, de tápanyagokban szegények. 
A csernozjom talajok mélysége 30-75 cm, humusztartalmuk 1-2,5 százalék, vízháztartásuk és tápanyag-ellátottságuk általában jó. Réti csernozjom talajok olyan helyen alakulnak ki, ahol a talajt a víz időszakosan átjárja, területünkön elsősorban a semlyékekben és a Tisza allúviumában, infúziós löszön találkozhatunk vele (Keveiné Bárány - Gulyás, 2001, 21-24).

A vizsgálati terület homokja általában magas karbonáttartalmú, ahogy azt a zákányszéki vizsgálatok is kimutatták (Keveiné Bárány - Gulyás, 2001, 24).

Összefoglalásképpen elmondhatjuk, hogy a lelőhely környékének leggyakoribb talajtípusa a lúgos kémhatású meszes, humuszos homoktalaj, mely mezőgazdasági müveléshez elegendő humusztartalommal rendelkezik, szántóföldi és munkaigényesebb kultúrák egyaránt termeszthetőek (gabona, valamint szőlő, gyümölcs, paprika, stb.). Azonban a termesztés feltétele az öntözés, a szerkezetjavítás és a talajerö-utánpótlás (Keveiné Bárány - Gulyás 2001, 24).

\section{Természetes élővilág}

Domaszék környékének élővilága a földrajzi adottságoknak megfelelően igen mozaikos, bár a hosszú ideje tartó területhasznosítás, szőlőmüvelés (itt voltak az alsóvárosi tanyák, lásd 5. ábra) következtében az eredeti természetes növénytakaró és élővilág szinte teljesen eltűnt. Továbbá a terület - földrajzi helyzetéből adódóan - átmenetet képez a Tiszavölgy és a homokhátság között. A homokbuckák itt már elég alacsonyak, a nedves területek kiterjedése kicsi.

\section{Növényzet}

A terület a Pannóniai flóratartomány Alföld flóravidékének Duna-Tisza közi flórajárásához tartozik. A vízrendezési munkák előtt a táj merőben más képet mutatott, mint ma (1. ábra). Vízjárta terület volt, a semlyékekben kis tavakkal és mocsarakkal, a magasabb térszíneken homokpusztákkal. A 18. század végén, az első katonai felmérés idején a terület jelentős részét a természeteshez közeli, bár erőteljesen legeltetett vegetáció borította. A 19. században lezajlott vízrendezések alatt lecsapolták ezeket az időszakosan vagy teljesen vízzel borított mélyedéseket, melyek így teljesen vagy részben kiszáradtak és a természetes élőhelyek zöme megsemmisült. További környezeti terhelést jelentett az addig csak gyéren lakott tanyavilág benépesülése és falvakká alakulása az 1950-es években, hiszen így a mezőgazdasági müvelés alá volt földterületek aránya jelentősen növekedett. A tanyarendszer - az ország más pontjaival szemben - itt szinte érintetlenül fennmaradt, aminek oka a természeti adottságokban keresendő (Sümegi, 2001c). Domaszék határában már a 18-19. században kiterjedt, szinte megszakítatlan tanyahálózat alakult ki (alsóvárosi tanyák), amire Szeged közelsége ad magyarázatot (4. ábra). A terület jó része ekkor már müvelés alatt állt.

Az egykori természetes környezet fás vegetációját elsősorban a nedvesebb részeken élő füzlápok (Salix alba) jelentették, a mai fás vegetációt az emberi hatásra elterjedt Populus canescens (szürkenyár), Robinia pseudo-acacia (akác), az Eleagnus angustifolia (keskenylevelü ezüstfa) és az Ailanthus altissima (bálványfa) képviseli (Keveiné Bárány Gulyás, 2001, 25).

A lágyszárú vegetáció társulás-típusait a következők képviselik: 
Homoki gyepek. Területük az intenzív mezőgazdasági müvelés következtében visszaszorult, sőt, a lelőhely környékén szinte teljesen eltünt. Tipikus fajuk az Alkanna tinctoria (báránypirosító), melynek gyökerét festékanyag kinyerésére és a birkák gyapjának jelölésére használták, vagy az Echinops ruthenicus (kék szamárkenyér). A megmaradt gyepek másik nagy ellensége a legeltetés, melynek hatására megindul a gyomosodásuk (tövises iglice, mezei iringó, bókoló bogáncs). A tüskés növényeket ugyanis a legelésző állatok kikerülik, utat nyitva elterjedésüknek. Ez a folyamat - ha kisebb mértékben is - már a bronzkorban megindulhatott.

Láprétek. A homokbuckák közötti semlyékeket (feldarabolt egykori medrek és szélbarázdák) kitöltő, vízkedvelő társulások nagyobb arányban károsodtak, mivel a mocsárlecsapolások következtében legtöbbjük kiszáradt. A belvízlevezető csatornák legfontosabbika a Domaszéki-főcsatorna, mely a Maty-érbe vezeti a semlyékek vizét Öttömös, Ruzsa, Zákányszék és Domaszék határából. A semlyékek jellegzetes társulása a kékperjés láprét, mely nevét az $1 \mathrm{~m}$ magasra is megnövő kékperjéről kapta. Számos értékes védett növénynek ad otthont ez a társulás, melyek közül az Iris sibirica (szibériai nőszirom), Gentiana pneumonanthe (kornistárnics) a leginkább kiemelendő, de itt él a Dianthus superbus (baglyos szekfü) és a Veratrum album (fehér zászpa) is. Ez utóbbi hegyvidéki reliktumfaj. A környék leggazdagabb láprét-társulásai Zákányszék határában, lelőhelyünktől kb. $10 \mathrm{~km}$-re találhatóak. A lápréteket legeltetésre, mélyebb fekvésű, időszakosan ma is vízborította foltjaikat kaszálónak használják, mely a társulások legjobb fenntartója.

Szikes gyepek. A semlyékek azon részén, ahol a talajtani folyamatok miatt szikesedés kezdődött (a lefolyástalan délnyugati rész), a kékperjés réteket olyan társulások válják fel, melyek jól türik a szélsőséges vízszint-ingadozást és a magas sótartalmat. A szikesek aránya a Tisza völgye felé haladva növekszik. Ezeken mozaikos társulások, társulás-csoportok alakulnak ki a sziki sásréttől a vakszik növényzeten át az ürmös pusztáig, ahol nagy tömegben él a Lepidium crassifolium (pozsgás zsázsa), az Aster tripolium (sziki őszirózsa), a Plantago tenuiflora (vékonylevelü útifü). A védett fajokat a Cirsium barchycephalum (kisfészkű aszat) és néhány kosborfaj képviseli. A szélsőséges vízingadozás és a legeltetés okozta stressz miatt gyakoriak az ezeket jól tủrő fajok, pl.: Potentilla anserina (libapimpó).

Vizpartok. A még zömmel vizes élőhelyeken gyakoriak a nádasok és gyékényesek, köztük néhol a fehér füz (Salix alba) példányaival. A lelőhelyet dél felől kísérő semlyék legmélyebb részén nádast találunk, mely erősebb vízborítottságát jelzi, ez a Tisza közelsége és alacsony tengerszint feletti magasságának köszönhető. Ahogy arra majd a fúrás elemzésekor kitérünk, ebben a semlyékben a bronzkorban egy fokozatosan eutrofizálódó tó volt, melynek vízparti sávjában akkor is kiterjedt nádasokkal számolhatunk (csakúgy, mint a nem messze lévő Maty-ér partján) - biztosítva ezzel az épületek tetőfedéséhez szükséges nádanyagot (Keveiné Bárány - Gulyás, 2001, 25-29, Margóczi - Aradi, 2008).

\section{Állatvilág}

A fentebb leírt elmúlt kétszáz évben folyt intenzív természetátalakító tevékenység következtében a természetes fauna is sokat szegényedett. Az ízeltlábú fauna azonban továbbra is gazdag, ennek az állatcsoportnak köztudomásúan jó az alkalmazkodó képessége. Néhány fontosabb, védett faj: aranypettyes bábarabló (Calosoma madera auropunctatum), 
kis szarvasbogár (Dorcus paralellepidus), pompás virágbogár (Potosia aeruginosa). A kétéltűek élőhelyei - a semlyékek mocsarai - erősen visszaszorultak, ezen gerincesek nagyfokú populációcsökkenését okozva. Megfelelő vízellátottság esetén azonban a mocsarak állandó lakója a dunai gőte (Triturus dobrogicus), a pettyes gőte (Triturus vulgaris), a zöld varangy (Bufo viridis). A hüllők közül gyakori a fürge- és zöld gyík (Lacerta agilis, L. viridis). A madarak élőhelyei is sokkal kiterjedtebbek voltak régen. Ma a bíbic (Vanellus vanellus), a piroslábú cankó (Tringa totanus) és a nagy goda (Limosa limosa) fészkel szívesen. A víz jelenlétét jelzi a szürke gém (Ardea cinerea).

$\mathrm{Az}$ emlősök java része apró rágcsáló, bár gyakorta látni őzeket a semlyékekben, szántókon kóborolni. A mezei cickány (Crocidura leocodon), a güzüegér (Mus musculus spicilegus), a mezei pocok (Microtus arvalis) a fontosabb rágcsálók, rajtuk kívül még találkozhatunk nyesttel (Martes foina), hermelinnel (Mustela erminea), valamint mezei- és üregi nyúllal (Lepus europaeus, Oryctolagus cuniculus) is.

\section{Az emberi megtelepedés természeti keretei a bronzkorban a lelőhelyen}

A fentiekben leírtak szerint a terület - akkor még jószerivel érintetlen vagy kevéssé bolygatott - természeti adottságai jelentős mértékben meghatározták az ott megtelepült emberi közösségek mozgásterét és életmódját. Ezzel a kérdéssel a következő fejezetekben részletesen is foglalkozunk majd, de szükséges, hogy itt is felvázoljuk azokat a tényezőket, melyek a bronzkorban ott élők életmódját meghatározták.

A lelőhely geológiai múltja és felszíni kőzetei adják azt az alapot, melyhez alkalmazkodniuk kellett. A lefolyástalan, homokbuckás, semlyékes-mocsaras, mozaikos táj a megtelepedés geomorfológiai kereteit adja. Stabil, egész évben lakott lakóhelyeket csakis az egész évben vízmentes hátakon lehetett építeni. A feltört, taposott homoktalajok mind szél-, mind csepperózióra rendkívül hajlamosak, ezért a település mérete, kiterjedési lehetősége geológiai és geomorfológiai adottságok által behatárolt. Leggyakrabban 2-4 házból álló tanyaszerü települések sürü láncolata alakult ki a hátakon, mindig a semlyékek közelében maradva, hiszen ott volt elérhető mélységben a talajvíz, s mivel a hátak vastag homokjában kutat ásni szinte lehetetlen (Sümegi, 2001c, 314).

Ahogy azt a fejezet második felében bemutatásra kerül, ezt a szórt, tanyabokor-szerü települési rendszert a bronzkor óta folyamatosan megtaláljuk a területen, még akkor is, ha bizonyos régészeti kultúrák hordozói más geomorfológiai és hidrológiai viszonyok között más települési struktúrát alakítottak ki. Még ma is a semlyékek partját követik néhány száz méteres távolságban a tanyák. Ez azt mutatja, hogy a homokhát településszerkezetét elsősorban az alapkőzet milyensége, geomorfológiai megjelenése határozta és határozza meg. A hátak feltörése és/vagy legeltetése még így is a szélerózió megerősödését vonták maguk után, amire a történeti idők lokális homokmozgásai jelentenek fontos bizonyítékot (Nyári - Kiss, 2005, Sümegi, 2001c)

Az éghajlat és csapadékmennyiség lehetővé teszi a szántóföldi gazdálkodást, de a talajviszonyok (a talajok zöme alacsony termőképességü, öntözést és talajerő-pótlást igényel, valamint a talajerózió által veszélyeztetett), a legelőnek alkalmas időszakosan vízzel elárasztott semlyékek és a tiszai ártér (Maty-ér környéke) közelsége és kiterjedt felülete 
inkább az állattenyésztésnek kedvezett. A bronzkorban ezért a szántóföldi müvelés szükségképpen az árvízmentes hátakra korlátozódott (a hátak belső területeire, a semlyékek partján a települések álltak), ott magas napfény-, hő- és alacsony vízigényü, szárazságtürő gabonafajtákat, kerti növényeket termeszthettek. A Maty-ér közeli árterének magasabb területein is folyhatott művelés, amikor az árhullám levonult róluk, de valószínű, hogy a Polgár-kenderföldi tellen megállapítottakhoz hasonlóan a Tisza-völgyet és a Tisza völgybe nyíló, a holocén során már elsősorban árvíz elvezető természetes csatornákká alakult, egykori dunai folyómedrek partját itt is erdő fedhette, amely a lakosság faigényét elégítette ki, továbbá legeltethettek a folyóparti nedvesebb aljzatú ártereken (Sümegi, 2009). Valószínü, hogy a sztyepp jellegü pusztákkal fedett hátak nagy területein - rideg pásztorkodással és a településen való teleltetéssel - állatokat tartottak, melyek téli élelmét elsősorban a vetett takarmány biztosíthatta, szálas takarmány gyüjtését nem tartjuk valószínünek, mivel a bronzkorban nem ismerték a kaszát. Aratósarlóval csak kis mennyiségü fü begyüjtése oldható meg, és a nagyobb méretű bronzsarló széles körű elterjedése is a településünk felhagyása után történt meg.

A vadászat és halászat, valamint a gyüjtögetés alárendeltebb szerepet játszott a közösség életében, annak ellenére, hogy a galériaerdő és a Maty-ér vadban és halban igen gazdag lehetett egykor.

A mindennapi élethez szükséges nyersanyagok közül a legfontosabbak a fa, az agyag és a bronz. A fa mindenképp a Tisza-völgyből, és a Maty-ér menti területről kellett, hogy származzon, mivel a hátakon és a semlyékekben nagyobb erdők nem voltak, és azok is borókából és füzből álltak, a folyóvölgyben azonban gyertyán, éger és tölgy biztosította az épületfát. A fütéshez, sütéshez-főzéshez, érc- és fémolvasztáshoz, megmunkáláshoz, illetve a halottak hamvasztásához (Trogmayer, 1975), csónak- és bútorkészítéshez szükséges famennyiség is jelentős lehetett. A kerámiakészítéshez, házépítéshez szükséges agyagot a semlyékek, medrek agyagos-aleuritos rétegeiből szerezhették be, adott esetben mesterséges gödrökben ülepítéssel választhatták szét az agyagfrakciót a nagyobb szemcseméretü összetevőktől. A kerámiaagyag legvalószínűbb származási helye a Maty Ágazat majdnem a lelőhelyig érő laposa lehetett, melyben a megfelelő finom szemcsés üledék a rendelkezésre állt. Az agyagot és aleuritot a házépítésben is felhasználták, ezzel tapasztották be a tartóoszlopok közé font sövényt (paticsfal), ezzel sározták a padlót és ebből építették a kemencéket.

A lakosság számára igen fontos másik nyersanyag, a fém (bronz: réz és ónötvözet, esetleg arany) távolsági kereskedelem útján került hozzájuk, mivel a homokháton érclelőhelyek nem találhatóak, a Mecsek rézércei pedig nem voltak ismertek, de ha ismerték is őket, valószínüleg nem próbálkoztak a csekély fémtartalmú ércek kohósításával (Koch 1966, Szakáll et al, 2005). A kelet-alpi (Mitterberg) régió, a Szepes-Gömöri Érchegység és az Erdélyi-Érchegység lehet a származási helye a réznek, míg az ón forrásaként Csehország jöhet komolyan számításba. A településen feltárt kevés őrlőkő fragmentum egyrészt a növénytermesztés másodrendű szerepére, másrészt a kő nyersanyag lelőhelyeitől való nagy távolságra utal. 
A nyersanyagok közt említhetjük az erdélyi sót, melyet minden bizonnyal használtak a bronzkorban, s ezt a Maros völgyében szállították. Konkrét só-lelet az ásvány oldhatósága miatt eddig még nem került elő a vizsgált korszakból.

\section{A szükebb térség bronzkora}

Domaszék tágabb környékéről több új bronzkori lelet is előkerült, melyek segítségével a korábbinál pontosabban rajzolhatjuk meg a terület benépesülését. A terepbejárási adatok és a pollenfúrások eredményei (lásd a későbbi fejezetekben) azt mutatják, hogy a homokhátság - eltekintve a löszös területektől - a rézkorig csak gyéren népesült be, a lakosság életmódja elsősorban a földművelésen alapult és nem tudták tartósan meghódítani a folyóvölgyekhez képest kedvezőtlen adottságokkal rendelkező pusztákat. Ma még tisztázásra vár, hogy miért épp ekkor népesül be a táj. A környék régészeti kultúráit és kapcsolatrendszerét meghatározó másik nagyon fontos tényező maga a Tisza-völgy és a Maros-torkolat. Két ősi kereskedelmi útvonal találkozott itt, a Tisza az Észak-Balkán felé haladó legfontosabb természetes út, a Maros-völgy útvonala pedig Erdély, a Bánát és a Partium nyersanyagait (só, érc, kőzet) szállította a medence belseje felé (V. Szabó, 1999, Andó, 1983).

A bronzkor kezdetét technológiai alapon definiáló hazai régészet az első bronzkori kultúrának a Vucedol-müveltséget tartja, mely a medence délnyugati peremén települt meg, de hatásai az egész Kárpát-övezetre kiterjedtek. Az itt élő késő rézkori lakosság (badeni, kostoláci - 6-7. ábra - és gödörsíros kultúrák) átvette a vucedoliak fejlett, Égeikumból és a Pontus-vidékről származó fémműves technikáját (arzénréz anyagú lapos- és nyéllyukas balták, vésők és trianguláris tőrök öntése nagyméretü, többrészes agyag öntőformákba) (Ecsedy, 1982, 1995a, 1995b, Bátora, 2003). A kultúrák egymásra hatásaként megszülető, új anyagi kultúrát Makó-Kosihy-Caka (röviden Makó) kultúra néven foglaljuk össze, mely a medence legnagyobb részén a bronzkor kezdetét jelenti. Az elmélet egyik legnagyobb problémája, hogy nem ismerjük a Makó-kultúrát közvetlen megelőző rézkori alaplakosság emlékanyagát, vagy nem tudjuk azt pontosan keltezni. E téren tehát a kutatásnak még fontos feladatai vannak.

A modern bronzkori relatív kronológiai korszakbeosztás (archeosztratigráfia) alapját Bóna István hozta létre, majd finomította egész életén keresztül. Három részre tagolta korszakunkat, korai, középső és késő bronzkorra, majd ezeket 3-3 alszakaszra osztotta fel (Bóna, 1992). Tanítványai jelentősen finomítottak a kronológiai beosztáson, az alszakaszokat a korai és késő bronzkorban további, még rövidebb archeosztratigráfiai szintekre tagolták (Kulcsár - V. Szabó, 1997, Kalicz-Schreiber, 1991, Kemenczei, 1989, V. Szabó, 1999, stb.).

A teljes szisztéma a következö:

Kora bronzkor 1a-b, 2a-b, 3a-b

Középső bronzkor 1, 2, 3 (Koszider)

Késő bronzkor 1a-b, 2a-b, 3a-b

A legfontosabb korszakhatárok cal. radiocarbon adatai: rézkor/kora bronzkor: 2700/2500 cal BC, kora/középső bronzkor: 2000 cal BC, középső/késő bronzkor: 1500 cal BC, késő bronzkor/vaskor: 800 cal BC. A továbbiakban az archeosztratigráfiai beosztásra 
éppúgy fogunk hivatkozni (s vele párhuzamosan más jellegủ kronológiai beosztásokra is), mint a cal $\mathrm{BC}$ dátumokra.

Ebben a szisztémában a Makó-kultúrának egészen az 1990-es évekig „tabula rasa” szerep jutott, azaz rövid ideig tartó létével pusztán elválasztotta a Baden és a Nagyrévkultúrát egymástól. Ehhez járult, hogy a régi, „rövid kronológiának” nevezett régészeti rétegtani szisztéma a kora bronzkorra 150-200 évet feltételezett (1900-1700 BC). A cal BC adatok ezt az időtartamot 6-700 évre növelték, ami maga után vonta a Makó-kultúra szerepének átértékelését is.

A kultúra lelőhelyei kisméretüek, lazán összekapcsolódva nem alkotnak falvakat, hanem inkább a mai bokortanyákhoz hasonlóan képzelhetjük el őket. Hasonló szerkezetű, 110 síros temetőik a települések közvetlen közelében helyezkednek el. Ez a települési struktúra - a lakosság nagyállattartó életmódjával összhangban (Tóth, 2003, Kulcsár, 2009, 67) - alkalmas volt a talajosodó, kötötté váló homokbuckákon való megtelepedésre a szubboreális fázis elején. Domaszék határából a Makó-kultúra leletei egyelőre még nem ismertek, de kissé északabbra, Kiskundorozsma határából, a Maty-ér partjáról az M5-ös autópálya építésekor több településmaradvány és temető is előkerült (Tóth, 2003). A geomorfológiai hasonlóságok miatt várható a kultúra leleteinek felbukkanása Domaszéken is. A szükebb térségben még Jánosszállás-Katonapartról (Kürti, 1971) és ZákányszékHomokkultúra Mezőgazdasági Szakszövetkezet lelőhelyről (Sánta, 2004) ismerünk ide köthető leleteket. Ha a Tisza-völgy déli folytatását megvizsgáljuk, Horgoson ugyancsak van nyoma a Makó-népességnek (Hrabák, 2010), Magyarkanizsán (Kaniža, SR) pedig egy (import?) vucedoli edénytöredék került elő jellegtelen őskori anyag kíséretében. ${ }^{1}$ Mindez a déli kapcsolatok újraértékelése felé terelheti a kutatás figyelmét.

A kora bronzkor 1. periódusa végén a Vucedoli népesség helyét egy újabb égei kulturális hatásra kialakult, de az alaplakosságot helyben hagyó népesség vette át, a Somogyvár-Vinkovci kultúra (Kulcsár, 2009, Ecsedy, 1978, 1984, 1995a, stb.). Ez a lakosság folytatta a korábbi fémművességet, de települési szisztémája részben eltért a vucedolitól, hiszen azokkal ellentétben kevesebb réteges, tell jellegű települést hozott létre. Magaslati telepeik néha követik a vucedoliakat (Zók-Várhegy, Dunaszekcső-Várhegy, Ecsedy, 1982, 1984, 1999). Leletanyaga közel áll mind a Makó-, mind a Vucedol-kultúrához, de településterülete eltér tőlük. A Dunántúl egészét kitölti, valamint a Száva mentét is egészen Belgrád térségéig, ahonnan a Tisza völgyét követve észak felé húzódnak kisebb csoportjaik. A Partium és Erdély, valamint Olténia területén is megjelennek előőrseik (Bóna, 1992). A Tisza mentén észak felé haladó csoportok többé-kevésbé összeolvadnak a Makó-lakossággal és kialakítják az Ada-csoportot (Horváth 1981, Kulcsár 2009, V. Szabó 1999 - utóbbi kétségeket is megfogalmaz a csoport önállóságával kapcsolatban). A kultúrát jellemző kúpos nyakú öblös korsók megjelenése köthető hozzájuk. Ilyen korsókat és más, hozzájuk köthető leleteket Adán (Ada, SR), Ásotthalom-Borgazdaságon, Hajdújáráson (Hajdukovo, SR), Radanovacon (SR), Zentán (Senta, SR), Zomboron (Sombor, SR) (Horváth, 1981, Kulcsár,

\footnotetext{
${ }^{1}$ Jancsó István és Nyúl János Tibor III. éves régészhallagtók BA-s szakdolgozatával kapcsolatos helyszíni szemlét tartottam 2010. 04. 20-án, a kérdéses tárgyakat ekkor láttam és határoztam meg. Közlésük folyamatban van.
} 
2009), és újabban Zákányszéken találtak (Sánta, 2004a). A környék fontos lelöhelye Sövényháza-Kőtörés (a mai Dóc határában, Bóna, 1963), mely talán temető lehetett. Felvetődik, hogy a legfrissebb terepbejárásokon Horgos és Magyarkanizsa területén fellelt kora bronzkori lelőhelyek egy része is ide sorolható (Hrabák, 2010) Úgy tűnik, az Adacsoport létező régészeti egység, de genetikáját alaposabban meg kell vizsgálni.

A kora bronzkor további szakaszában a Tisza- és Duna-vidéken, a folyókat kísérő löszhátakon - Somogyvár és Makó alapokon - kialakul a Nagyrév-kultúra, mely életmódját tekintve messzemenően alkalmazkodott az Alföld természeti viszonyaihoz (Tóth, 2003, 79$80)$.

A mezőgazdasági technika fejlődése állhat a löszös, kedvező vízellátottságú, csernozjom talajokkal borított folyóhátakon létrejött tellek kialakulásához, melyet nagyarányú népességkoncentráció kísért. Ezzel szemben a lakosság sikeresen adaptálódott a homokhát természeti viszonyaihoz is, vagyis megőrizve és továbbfejlesztve a Makó-kultúra örökségét, benépesítette a homokbuckákat (Tóth, 2003, 81). Voltaképp azt mondhatjuk, hogy itt nem ment, mert nem mehetett végbe az a folyamat, amely a tellek kialakulásához vezetett, mivel itt mivel itt hiányoztak a tellképződés komplex, társadalmi - természeti folyamatához szükséges természetes környezeti feltételek. A korábbi, Makó-időszakban a technikai és társadalmi feltételek nem voltak ehhez adottak. Továbbá, a szórt települési struktúra napjainkig való fennmaradása azt jelenti, hogy a kora bronzkorban alakult ki a Homokhát természeti viszonyaihoz legjobban alkalmazkodó településstruktúra és életmód is. Fontos eredmény volt a domaszéki lelőhely ásatásán a Nagyrév-kultúra települési objektumainak, gödreinek előkerülése, sajnos épületet - a cölöplyukakban talált korhatározó leletek hiánya miatt - nem sikerült rekonstruálni (a Nagyrév objektumok elhelyezkedését lásd a 29. ábrán). Valószínű, hogy a cölöplyukak java része a jóval nagyobb számban előkerült és nagyobb kiterjedésü halomsíros telephez tartozott, mely jelen dolgozat homlokterében áll. A Nagyrévtelep szélét minden irányban elérték, az egy 50 méter átmérőjü önálló gazdasági egység (feltehetően egy nagycsalád szállása) lehetett a semlyék partján. Jellegzetes leletanyagukat a 8. ábrán szemléltetem. A 8. ábra 1. sz. bögre analógiái Jánosszállásról ismertek (Kulcsár, 2000), így ezt a teleprészletet talán a korai Nagyrév-kultúra időszakára datálhatjuk. Elképzelhető, hogy a dombháton a Nagyrév-kultúra további kis telepei találhatóak.

A középső bronzkor kezdetén a Nagyrév-kultúra Duna-menti településein átalakul a lakosság anyagi kultúrája, kialakul az egész középső bronzkor egyik legkarakteresebb csoportja, a Vatya-kultúra (Bóna, 1992). A Tisza-mentén ez nem következik be, a lakosság átadja helyét az északi eredetü Hatvan-kultúrának. Talán egyedül a Körös-toroknál, Csongrád térségében van nyoma az élet folyamatosságának, de az itt létrejövő új telepek a jelek szerint nem köthetőek össze a nagyréviekkel. A Csongrád-Vidre-szigeti, baksi, felgyői és tiszaalpári telepek, a csanytelki temető kialakulása zömmel a Vatya kései szakaszára keltezhető (G. Szénászky, 1977, V. Szabó, 1999). Ugyancsak ez a helyzet a homokhát jelentős részén is, onnan a lakosság kiszorult, nem létesített telepeket. Ennek magyarázatára még nem születtek konkrét elképzelések, egyesek a Vatya és a Maros (Szőreg-Perjámos) kultúrák között társadalmi okok miatt kialakított lakatlan területet feltételeznek (Lőrinczy-Trogmayer, 1996), de a két csoport kapcsolatrendszere alapvetően békés, nem utal semmi köztük lévő erőszakos 
cselekményekre, így a határsáv - meglehetősen modern - fogalma értelmét veszti. Itt inkább természeti, éghajlati tényezőkkel kell számolnunk. Ugyanakkor a homokhát kiürülése talán azzal függ össze, hogy a terület egy rövid időre (300-400 év) ismét kiszáradt, és a természeti tényezők sokszoros szorításában élő emberek kiszorultak onnan. Ezzel szemben a legfrissebb geoarcheológiai fúrások a Benta-völgyben a középső bronzkor végén és a késő bronzkor során (Koszider, 1650-1500 cal BC) jelentős csapadéknövekedést mutattak ki (SümegiBodor, 2005). A Vatya-kultúra, időszakának vége felé délkelet felé húzódott (Kovács, 1984), jelentősebb települései Tiszaalpáron (Bóna-Nováki, 1982) és Kelebián (Zalotay, 1957), valamint Csanytelken (Lőrinczy-Trogmayer, 1996) és Bakson (P. Fischl et al. 1999) jöttek létre. A kultúra lakossága ekkor is kerülte a homoktalajokat, a négyböl három helyen löszös, jó vízellátottságú csernozjom talajon, legtöbbször löszös folyóháton, maradékfelszíneken települtek meg. Egyedül Baks késő Vatya telepe található homoktalajon (P. Fischl et al. 1999). Zákányszék határában folytatott terepbejárásunkon (Hornok Péterrel) egyetlen középső bronzkori cserepet sem találtunk, és hasonló tapasztalatokról számoltak be a térségben kutató más régészek is (Gyucha, 1996, Bálint, 1997). Kelebián azonban a Vatyakultúra olyan településkoncentrációja alakult ki (31 lelőhely, köztük 3 igen gazdag leletanyagú) a Körös-ér mentén (Bató, 2001, 110), mely világossá teszi, hogy a lakosság kereste a löszfelszíneket és kifejezetten kerülte a homokot. Ebből a szemszögből nézve a „homokon élő Vatya” típusú közösségek ritkasága talán lehetne kutatásbeli hiányosság, de épp ezek a regionális vizsgálatok szólnak a valós elkülönülés mellett.

A késő bronzkor első szakaszában itt élő Halomsíros-kultúra nevét jellegzetes temetkezési módjáról kapta. Kialakulása a Közép-Duna-medencében történt, amiben éghajlati és társadalmi okoknak egyaránt szerepet játszottak. A Koszider fázisban egyes közösségeik megszállták a Dunántúl jelentős területét és a Dél-Alföldre is betelepültek. Hogy mennyire volt ez a folyamat erőszakos vagy békés, arról nem alkothatunk még pontos képet. Az eltérő emberi közösségek (nemzetségek, törzsek, családok) eltérően reagálhattak a megváltozott helyzetre, egyesek elköltöztek, mások helyben maradtak, mindez azt is mutatja, hogy a középső bronzkori társadalomban megszünt vagy erősen meggyengült a vezetőréteg kontrollja a lakosság felett. Egyedül a Vatya kultúra mutatott stabilitást, illetve néhány Perjámos telepen is a kései stabilitás jelei mutatkoznak (Szőreg, Pécska, Magyarkanizsa helyszíni szemlén 2010. 04. 20-án Halomsíros hatást mutató késő perjámosi cserepeket találtunk). A kérdésre a koszideri kor kapcsán még visszatérünk. Egyelöre még bizonytalan, hogy pontosan mikor jelentek meg a Halomsíros-kultúra hordozói a térségben, de néhány szórványos adat azt bizonyítja, hogy már a középső bronzkor végén, a Vatya-Koszider fázissal egy időben jelen voltak. Közvetve ezt a tényt erősíti meg, hogy a Vatya, Perjámos és Halomsíros kultúrák települési területe kiegészíti egymást. A korai Halomsíros leletek (Ásotthalom-Bilisics, Bogárzó, Kiskundorozsma, Kömpöc, Zákányszék, NagyszéksósOltványi tanya: 9. ábra, stb.) kikerülik a Vatya településeket, és többnyire a homokháton jelennek meg, és ennek az elterjedésnek az életmód szempontjából kiemelkedő a jelentősége. A Vatya döntően földművelő-állattartó, hierarchikus településhálózatban élő (Sümegi-Bodor, 2000) népesség, míg a Halomsíros - a szórványos adatok alapján - szarvasmarha-juh tartó, 
állattenyésztő-földművelő életmódot folytatott az eddigi régészeti lelőhelyekről származó adatok alapján. A kérdést részletesen vizsgálom a jelen dolgozat későbbi fejezeteiben.

Domaszéken és környékén több helyröl ismert a Halomsíros-kultúrához köthető leletanyag (11. ábra). A Móra Ferenc Múzeum egy ismeretlen lelőhelyü, ismeretlen módon előkerült tálat őriz (MFM Ö. 53.4.5, 11. ábra 1.), mely talán temetőhöz tartozott. DomaszékFarkas-tanyán (közelebbi koordináták nélkül) településrészlet került elő, Vörös Gabriella helyszíni szemlén edénytöredékeket és állatcsontokat figyelt meg, amit Egry I. is említ szakdolgozatában (Vörös, 1979, Egry, 1986). Szeged-Kiskundorozsma-Átokháza lelöhelyen egy gazdag temetkezés került elő, urnájának pontos analógiái elsősorban Csehország területéről ismeretesek, ezzel a térség északnyugati irányú kapcsolatrendszerére utal (10. ábra, a kalászmintás urnatöredék analógiái: Čujanová-Jílková, 1970, 44. 7, 84. 8, 86. 4, 89.5, 105. 24. A bögre és a fémmellékletek analógiái gyakoriak a Tápé-Széntéglaégetői temetőben: Trogmayer, 1975.). Az átokházai síregyüttest így a Reinecke BB2-C periódusba, a klasszikus Halomsíros kultúra időszakára datálom. A térségből előkerült jelentősebb, közöletlen Halomsíros leleteket a 13. ábrán mutatom be.

Zákányszék határában regionális kutatásunk (Hornok Péterrel) alkalmával került elő 10 település- és 1 temetőmaradvány. Feltételezem, hogy ez a kiugró lelőhelyszám a korszakot célzó intenzív vizsgálatnak köszönhető, a homokhátság más területein hasonló számú telep előkerülése valószínű. A JATE/SZTE terepbejárási szakdolgozatainak készítői ezen a területen (Ásotthalom, Mórahalom, Üllés, stb.) jelentős Halomsíros megtelepedést állapítottak meg. Különösen jelentős a mórahalmi Nagyszéksós-tó mellett előkerült bronzöv (Trogmayer, 1960) és a Bilisicsi-tó (Ásotthalom) partján feltárt temető (Tömörkény, 1902, 1903). Mindkettő a korai halomsíros periódusba sorolható. A térség számos Halomsíros lelőhelye igen éles ellentétben áll a Vatya kultúra leletanyagának teljes hiányával.

A klasszikus Halomsíros-kultúrának számos települése jött létre az ekkorra már visszaszorult, átalakult Vatya és Perjámos, valamint Hatvan/Füzesabony területen is. A Tisza mentén ekkor már jelentős Halomsíros kultúrához köthető települések és temetők alakultak ki (Tápé: Trogmayer, 1975, Tiszafüred: Kovács, 1975, Jánoshida: Csányi, 1980). Ennek oka abban keresendő, hogy a középső bronzkori alaplakosság nem tűnt el, hanem eredeti életmódjához többé-kevésbé ragaszkodva, megváltozott, Halomsíros kultúrához idomuló anyagi kultúrájával fennmaradhatott a löszhátakon. Ezzel párhuzamosan a homokhátság Halomsíros közösségei is folytatták életüket, a homoktalajok adottságaihoz alkalmazkodva továbbra is kis kiterjedésű tanyaszerü települések laza rendszerében éltek. Ez a struktúra világosan megfigyelhető Zákányszéken, Ásotthalmon, Üllésen és Mórahalmon is (Sánta, 2004a, Bálint, 1997, Gyucha, 1996, Kiss, 1997), de az említett szerzők művei alapján még elsősorban társadalmi okokkal magyaráztam létrejöttét (Sánta, 2004, 2009). Úgy véltem, a kultúra lakossága a homokháton nagycsaládi rendszerben élt, és elsősorban állattartással foglalkozott, a településrendszer pedig a társadalom és életmód eredőjeként alakult ki. Most úgy látom, hogy ez a településstruktúra az életmód következménye, mely életmódot (nagyállattartás) és telepszerkezetet (kis telepek laza rendszere) a geológiai és talajtani adottságok határozták meg. 
A kis telepek élete a homokhátakon a késő halomsíros időszakban jórészt megszünik, ugyanekkor a nagy folyóparti temetők is lezárulnak. A változások oka nem pontosan ismert, mivel az ezt követő periódus lakosságának kerámiaanyaga világosan mutatja a korábbi halomsíros hagyaték továbbélését (V. Szabó, 1996, 1999, 2001, 2005). A Maty-ér mentén új települések alakulnak ki, és ez arra utal, hogy a lakosság egy része bizonyosan helyben maradt. V. Szabó Gábor ezt az időszakot Pre-Gáva periódusnak nevezte el, mivel olyan társadalmi-gazdasági folyamatok zajlottak le (a (fém)kereskedelem megnövekedett intenzitása, egységesülő tendenciák a fém- és kerámiaművességben), melyek a későbronzkor 2b-re (HA2) a Gáva-kultúra kialakulásához vezettek (V. Szabó, 1996, 1999, 2001).

Zákányszék és a környező települések határában ebből a korszakból, a későbronzkor 2a-ból (Reinecke BD - HA1 periódus) csak kevés emlék ismert, melyek kiemelkedő lelete a térségben a zákányszéki bronzkard (részletes elemzés nem készült, említi Zalotay, 1932, 90.1, 100.1), illetve kissé távolabb a csorvai temető. Ennek alapján Trogmayer Ottó 1963-ban körvonalazta a Csorva csoportot (Trogmayer, 1963), melyet 1996-ban V. Szabó Gábor revideált (V. Szabó, 1996). Leválasztotta a csoportról a tiszántúli lelőhelyek zömét és magát a csorvai temetőt is, mivel az szerinte egyedi jelenség a Dél-Alföld késő bronzkorában. A megmaradó lelőhelyeket a Jánosszállás-Kömpöc körbe sorolta be, mely döntően homokháti lelőhelyeket tartalmaz, de nem túl nagy számban. Kőszegi Frigyes ezt a temetőt a dunántúli Uranmezős kultúra Duna-Tisza közi területi csoportjához tartozónak véli (Kőszegi, 1988). A kor nagyobb telepei a Tisza-, Maros- és Körös-völgyben találhatóak. KiskundorozsmaSubasán egy nyugati, keleti és déli (Belegiš kultúra) kapcsolatokkal egyaránt rendelkező, PreGáva korú, de kulturálisan nehezen besorolható (a legjobb megoldás a Jánosszállás-Kömpöc körbe sorolni) telep került elő (Róka, 2010). Domaszék mellett, Kiskundorozsma-Bábadűlőn látott napvilágot egy töredékes bronz kincslelet, melynek két megmaradt darabját a 12. ábra 1-2. mutatja be. A bronz lándzsahegy és a karikás markolatú kurdi típusú bronztőr a Hallstatt A periódusra jellemző (Kőszegi, 1988). A Gáva-kultúra jelenlétére a kincsen kívül (mely talán még Pre-Gáva korú) egyetlen, árkolt díszű edénytöredék utal (12. ábra 3.).

Ezek az adatok a homokhátság betelepültségének csökkenését mutatják, de annak teljes kiürülése - mint a középső bronzkor első két szakaszában - nem következett be. A régészeti topográfiai kutatások alapján ez a szórványos betelepültség egészen a késő vaskorig maradt fenn, amikor a kelták, illetve kelta kultúrát hordozó helyi lakosság újra sűrün benépesíti a homokbuckákat (terepbejárási megfigyelésünk Zákányszék határában - S. G.). Ez a sürü településszerkezet - a korábban megfogalmazottak alapján kis telepek laza rendszereként (tanyabokros szerkezetben) - egészen napjainkig fennmaradt. 


\section{Módszerek}

Napjainkban a régészettudomány fejlődésének egyik, igen fontos iránya a régészeti geológia és más, természettudományos módszerek komplex alkalmazása a lelőhelyek, régészeti problémák elemzése során. (A régészeti feldolgozásokban alkalmazható geológiai és őslénytani módszerek összefüggéseit az 14. ábrán láthatjuk.) A vizsgálatba bevont területen egy régészeti és egy környezettörténeti lelöhelyet dolgoztam fel, melyek eredményeit összehasonlítottam a szükebb és tágabb régióban (Dél-Alföld és Kárpátmedence) nyert adatokkal. A geoarcheológiai jellegü interdiszciplináris vizsgálatok teljes spektrumát nem használhattam fel, de igyekeztem a legszélesebb körben bevonni ezeket, így illeszkedve más, hasonló, komplex geoarcheológiai vizsgálatokhoz. Más, természettudományos és régészeti módszereket is alkalmaztam, melyek az eredmények matematikai és statisztikai feldolgozásában játszottak szerepet. A munkámban alkalmazott elsődleges természettudományos és régészeti módszerek a következőképp épülnek egymásra:

1. a lelőhely feltárásának módszerei

2. elsődleges feldolgozás, nyilvántartásba vétel, restaurálás

3. a leletek makroszkópos leírása és rajzolása

4. történeti állattani és archaeobotanikai vizsgálatok

5. a lelőhely alaprajzának, a település belső szerkezetének elemzése térhasználat vizsgálattal

6. a kerámiaanyag tipológiai, tipokronológiai vizsgálata

7. a településen és környékén előkerült fémtárgyak archaeometriai vizsgálata

8. geoarcheológiai fúrás mélyítése a település területén és a mellette húzódó vizenyős semlyékben

9. pollenanalízis, szervesanyag- és karbonáttartalom meghatározás, nedves kémiai analízis a fúrásmintákon

10. C14 vizsgálat a fúrásmag kritikus mélységéből vett mintán.

Az elsődleges mérési eredményeket feldolgozó, másodlagos módszerek a következők:

1. régészeti leletek forma és funkció alapján történő besorolása, kontextuális szeriációja, a belső (régészeti) kronológia kidolgozása, beillesztése a megfelelö archeosztratigráfiai szintbe

2. a településszerkezeti jellemzök összehasonlítása más korabeli településekkel, a szükebb térség települési rendszere a korszak idején, központi hely léte/hiánya, a társadalom (közösség) mérete és szerveződésének módja

3. a terület geológiai, geomorfológiai, vízrajzi, pedológiai viszonyainak tanulmányozása, régi térképek vizsgálata (II. katonai felmérés), a fúrási eredmények értelmezéséhez történő felhasználásuk

4. a fémtárgyak mérési eredményeinek további vizsgálata cluster-analízissel

5. a fúrás eredményeinek összevetése más fúrásszelvényekkel, azonosságok és eltérések keresése. 


\section{Természettudományos módszerek}

Radiokarbon (C14) vizsgálat (Renfrew-Bahn, 1999, Renfrew, 2001)

A módszer egyike a földtudományban és a régészetben alkalmazott radiometrikus módszereknek, melyek bizonyos instabil izotópok radioaktív tulajdonságát használják fel kormeghatározásra. A radiokarbon módszer a régészetben és a negyedidőszak (különösen a késő pleisztocén és holocén) geológiájában alkalmazott abszolút kronológiai eljárás, amely a szén 14-es tömegszámú izotópjának mintában lévő mennyiségén és a felezési idő ismeretén alapul. Az izotóp 6 protont és 8 neutront tartalmaz. A módszert Willard Frank Libby fejlesztette ki a Chicagói Egyetemen 1949-ben, aki az eredményeiért 1960-ban Nobel-díjat kapott.

A légkörben található nitrogén egy részét a világürből folyamatosan érkező kozmikus sugárzás a következő módon C14-é alakítja (15. ábra).

A szén-14 termelés legnagyobb mértékben a 9-15 km-es magasságban és magas geomágneses szélességeken játszódik le. Keletkezése után a szén-14 reakcióba lép a légköri szabad oxigénnel, és szén-dioxid jön létre, majd a növények a fotoszintézis során felveszik, s beépítik szervezetükbe. Az állatok és az ember a növényi táplálék elfogyasztásával lép be a körforgásba. Az izotóp keletkezése és bomlása dinamikus egyensúlyban van, mely csak a keletkezési feltételek megváltozása esetén borul fel. Az élő szervezetekben egy második egyensúly is fellép, hiszen a radioaktív szén beépül és kiürül a sejtekből. A két folyamat eredményeként a dinamikus egyensúly mindaddig fennáll (és a C14 mennyisége állandó), amíg a lény anyagcserét folytat, tehát élő. Amint elpusztul, a C14 felvétel leáll és a továbbiakban a megmaradó szerves anyag izotóptartalmát kizárólag a lebomlás határozza meg (17. ábra).

A vizsgálat során a minta minden esetben megsemmisül, azt szén-dioxiddá égetik el, majd tömegspektrométerrel elemzik. A vizsgálathoz szükséges szerves anyag tömege a széntartalomtól függ. A legalkalmasabb a tiszta faszén vagy elszenesedett mag (1-5 g), ám ezek mennyisége gyakran nagyon kicsi vagy nincsenek is jelen a datálandó együttesben. Legszélesebb körben az állatcsont fordul elö, amelyből viszont $300 \mathrm{~g}$ szükséges a megfelelően pontos eredményhez. A pontosság a mérési idő növelésével is javítható. A kiindulási és mért C14/C12 tömegarány és a felezési idő (5568 év) ismeretében kiszámítható a minta kora. A számított kor pontossága fordítottan arányos a minta korával, vagyis a benne lévő radiokarbon mennyiségével. A módszer jellegzetes hibáját statisztikai úton számolják, és +- évben jelölik. A legpontosabb C14 dátumok pontossága jelenleg +/- 40-50 év. Az 1950-es éveket követő atomkísérletek hozzávetőleg kétszeresére emelték a légkör C14 tartalmát, ezért a keltezésnél az 1950 elötti állapotokat veszik figyelembe.

A módszer pontossága kezdetben elég kicsi volt, és a számos zavaró tényező kiküszöbölése sem sikerült. Emiatt rengeteg támadás érte a módszert, melyek egy részét mint jogos kritikát az atomfizikusok részletesen körüljárták és megoldották. A legfontosabb a kalibráció kidolgozása, amely a dendrokronológia segítségével történik. A rendkívül hosszú életü kaliforniai, simatűjü szálkásfenyő (Pinus longaeva) törzseiből nyert fúrásmagok korát a faévgyürüs módszerrel néhány évtized pontossággal meghatározzák. Más fafajták segítségével is lehetséges a kalibráció, de a szálkásfenyő előnye a hosszú élettartamon túl az 
is, hogy élöhelye viszonylag távol fekszik a nagy ipari centrumoktól, így a szennyeződés esélye kisebb.

A kiválasztott, nagy pontossággal ismert korú famintát C14 vizsgálatnak vetik alá. A dendrokonológiával nyert dátumok függvényében ábrázolják a C14 dátumokat, amely a kalibrációs görbét alkotja (18. ábra). Bárhol a világon mért C14 adatot a különféle laborok által nyert kalibrációs görbék valamelyikével (az adott viszonyokhoz leginkább megfelelövel) korrigálni kell. A kalibrált adatok legtöbbször jóval idősebbek a kalibrálatlan dátumoknál.

A radiokarbon datálás jelölésrendszere az 1. táblázatban látható.

A módszer - mint sok más természettudományos vizsgálat - rendkívül érzékeny a külső hatásokra. A legfontosabb, hogy a kiásott mintát ne érje hosszú időn keresztül levegő, széndioxiddal vagy más széntartalmú anyaggal nem kerülhet kapcsolatba, mert a szennyeződés eredményeképp hamis eredményt ad. A módszert ezen kívül számos más tényező is befolyásolja, legjelentősebbek a kozmikus okok, így a naptevékenység 11 éves ciklusa, és kozmikus sugárzás intenzitásának változása (a hirtelen megugrásokat általában ki lehet szürni).

Fúrások (Sümegi, 2003, 66)

A településen és a mellette fekvő üledékgyüjtőben Orosz-fejes kézi fúróval végeztünk fúrást. A 60-100 cm vastagságú üledéksorból a településen $5 \mathrm{~cm}$-enként, az üledékgyüjtőben $10 \mathrm{~cm}$-enként vettünk mintát. A fúrás iránya függőleges ( 90 fok) volt. A mintákat müanyag fóliazacskókba csomagoltuk, feliratoztuk, majd a vizsgálat megkezdéséig +4 fokon hütve tároltuk. Az egyes minták, rétegek makroszkopikus tulajdonságait - litofácies - leírtuk (Troels-Smith rendszer szerint, Troels-Smith, 1955, ismerteti Sümegi, 2001, 169-171, 2003, 69). A településen végzett fúrásból $5 \mathrm{~cm}$-enként, az üledékgyüjtő rétegsorából $10 \mathrm{~cm}$-enként vettünk mintát. A mintákból szervesanyag-karbonát meghatározást és nedves kémiai analízist végeztünk. A mintákat kiiszapoltuk, a bennük lévő ősmaradványokat leírtuk és meghatároztuk.

Szerves anyag- és karbonáttartalom meghatározása

A szerves anyag- és karbonáttartalom meghatározása Dean 1974-ben Galle és Runnels (1960) munkája alapján kidolgozott módszer szerint történik, mely nagyszámú minta (pl. egy vagy több fúrásszelvény) egyidejü elemzésére alkalmas (Dean, 1974).

A mérési folyamat lépései:

1. Előkészítés. Az 5 ill. 10 cm-enként vett mintákból kisebb darabokat kiemeltünk, dörzsmozsárban leporítottuk, az üres kerámia tégelyeket analitikai mérlegen lemértük.

2. Mérés. A tégelyekbe helyezett mintákat 24 órára $105^{\circ} \mathrm{C}$-ra hevített kemencébe helyeztük, majd exszikkátorban szobahőmérsékletre hűtöttük. A kihült minták tömegét analitikai mérlegen lemértük. Ezen a hőmérsékleten a minta nedvességtartalma (a kristályosan kötött víz kivételével) eltávozik, megállapítható a légszáraz tömeg:

$105^{\circ} \mathrm{C}$ - tégely tömege $=$ légszáraz tömeg $($ gramm $)$

A következő lépés a minták $550^{\circ} \mathrm{C}$-on történő kiégetése egy órán keresztül, majd a szobahőmérsékletre hütött minta lemérése következik.

Ekkor kapjuk a szervesanyag tartalmat: 
$105^{\circ} \mathrm{C}-550^{\circ} \mathrm{C}=$ szervesanyag-tartalom (gramm), illetve ezek után százalékban: szervesanyag-tartalom (gramm)/légszáraz tömeg $($ gramm) $=$ szervesanyag-tartalom (\%)

A hevítést és a mérést még egyszer elvégezzük, amíg tömegállandóságot nem tapasztalunk. Ha a második mérés a hibahatáron túl eltér az elsőtől, a második eredményét fogadjuk el.

Harmadik lépcsőfokként a karbonáttartalom kiégetése következik, ehhez a mintát $1000^{\circ} \mathrm{C}$-ra hevítjük és 1 órán keresztül ott tartjuk, mialatt a karbonát-ásványokból a széndioxid kiég.

Az exszikkátorban lehült mintákat ismételten lemérjük. A karbonát-tartalom a következőképp adódik:

$550^{\circ} \mathrm{C}-1000^{\circ} \mathrm{C}=$ karbonát-tartalom (gramm), illetve ebből: karbonát-tartalom $($ gramm$) /$ légszáraz tömeg $($ gramm $)=$ karbonát-tartalom $(\%)$.

Újabb $1000^{\circ} \mathrm{C}$-os hevítést követően megismételjük a mérést, és ha változást tapasztalunk az előzőhöz képest, a második eredményt fogadjuk el.

A fent leírt módszer az egykori éghajlatra és a tó eutrofizációs állapotára enged következtetni.

Nedves kémiai analízis előkészítése

$\mathrm{Az}$ atomabszorpciós (AAS), Perkin-Elmer lángfotometriás spektrofotométerrel történő mérésekhez a mintákat vizes feltárással oldatba vittük. A módszer tehát a vízoldható elemek (a gyenge kötésben előforduló, mállott ásványok felületén jelen lévő elemek) feltárására alkalmas. Ennek lépései a következők voltak:

1. A 105 fokon kiszárított és leporított mintákból a 250 ml-es bőnyakú Erlenmeyerlombikba 4 tizedesjegy pontossággal kimértünk 1 gramm anyagot.

2. Mérőlombikkal $100 \mathrm{ml}$ ultratiszta desztillált vizet mértünk hozzájuk.

3. Az Erlenmeyer-lombikok száját laborfóliával lefedtük (az esetleges szennyeződések elkerülése végett), majd a lombikokat rázóasztalon 6 órán keresztül rázattuk.

4. Szüknyakú Erlenmeyer-lombikokba üvegtölcséreket helyeztünk, a tölcsérbe szürőpapírt tettünk. A rázatás után a mintákat a szürőpapíron átcsöpögtettük.

5. A szürletet mérőlombikok segítségével $150 \mathrm{ml}$-es térfogatba vittük át (ultratiszta víz felhasználásával).

6. A mintát előzetesen kitisztított müanyag mintatartókba öntöttük.

7. $1 \mathrm{~cm} 3$ salétromsavat pipettáztunk a mintákhoz tartósítás céljából, és mérésig hütőszekrényben tároltuk.

A mérés során a következő elemek analízisét végeztük el: $\mathrm{Ca}, \mathrm{Mg}, \mathrm{Na}, \mathrm{K}, \mathrm{Cu}, \mathrm{Fe}, \mathrm{Mn}$.

Különösen fontos a réz mérése, hiszen a településen végzett esetleges bronzfeldolgozás válik így kimutathatóvá.

Pollenanalízis

(Sümegi, 2001, 2003)

A virágporszemek (pollenek) a negyedidőszaki rétegekben legnagyobb mennyiségben és leggyakrabban előforduló mikrofosszíliák (fennmaradásuk azonban savas közegben nem lehetséges). Leginkább az egykori környezet rekonstrukciójára használható, de az üledékgyüjtőben található pollenek nem csak az adott pont, hanem egy tágabb térség 
növényzetét reprezentálják. Méghozzá minél nagyobb a medence, annál nagyobb területről gyüjti be a polleneket. Ma már Jacobson és Bradshaw munkája nyomán (Jacobson GL, Bradshaw RHW. 1981. The selection of sites for paleovegetational studies. Quat. Res. 16:8096.) általánosan elfogadott, hogy egy 200m-nél kisebb üledékgyüjtő a legideálisabb az őskörnyezeti rekonstrukció céljaira, mivel az itt lerakódó pollenek zöme bemosódásból származik, ezért a lokális vegetáció (20-1000m) nyomjelzője (19-20. ábra). A nagyobb felület ugyanis négyzetes összefüggés alapján emeli a szél és csapadék által közvetlenül a medencébe juttatott távoli (regionális és exotikus) pollenek számát. A csapdázódás ezen kívül a széliránytól, a medence partjának lejtésszögétől, a csapadék mennyiségétől, a felszín növényzeti borítottságától és az üledék keveredésének mértékétől függ.

A környezetrekonstrukcióban való felhasználhatóságuknak gátat szab az egyes pollenek különféle szintű meghatározhatósága. A füfélék (Poaceae) pollenjei nem vagy nehezen különíthetőek el, a rózsafélék (Rosaceae) is csak genus szinten határozhatóak meg. Hasonló problémák adódnak a fészkesvirágzatúak (Compositae) esetében is, de itt a pollenek nemzetség-, vagy fajszintü besorolása nagy gyakorlattal megoldható.

Pollenvizsgálatokat környezettörténeti és régészeti lelőhelyek esetében végezhetünk. A legfontosabbak a tavakat kitöltő üledékrétegek, melyekben hosszú időn keresztül csapdázódhatnak pollenek. A tavak átlagos élettartama (néhány ezer - 10 ezer év) miatt ezek a csapdák a negyedidőszaki környezet változásairól adnak hírt. A meghatározott növények vegetációs igényeit (éghajlat, talaj, csapadékmennyiség) képet kaphatunk a rétegekhez tartozó időszakok természeti, környezeti és ökológiai viszonyairól, valamint annak változásairól. Szintén megrajzolhatók a természetes környezetet érő emberi hatások is.

A régészeti lelőhelyeken található árkok, kutak természetes, pontszerü pollencsapdaként müködnek, ezért kizárólag a lelőhelyröl, azaz az emberi környezetről szolgáltatnak információkat. A mezőgazdasággal foglalkozó településeken kimutathatóak a termesztett növények, emellett az emberi hatásokhoz alkalmazkodott gyomok (pl. a taposást elviselő fehér libatop, Chenopodium album) és fúfélék pollenjei. Egyes esetekben a tárológödrök is hasznos mintákat szolgáltathatnak.

A domaszéki régészeti lelőhely egykori környezetének rekonstrukciójához egy másik, közelben mélyített fúrás adatait is felhasználtuk, mivel a település közvetlen közelében mélyített magfúrás nem adott megfelelő alapanyagot a pollenanalízishez, az üledék kiszáradása folytán a pollenanyag jelentős része megsemmisült. Az említett másik furás a lelőhelytől néhány km-re mélyült, tehát jó eséllyel nyújt használható információkat mind a településről, mind természetes környezetéröl.

\section{Ösmaradványok vizsgálata}

A szabad szemmel is jól látható, vagy egyszerü binokuláris mikroszkóppal meghatározható, nagyobb vagy közepes méretű fosszíliák tartoznak ebbe a csoportba, melyek a vízi környezet miatt döntően Mollusca-héjak. Ezek a domaszéki fúrásban kizárólag Gastropoda héjak és héjtöredékek voltak, Bivalvia maradványok nem kerültek elö.

A fosszilis csigaházak alkalmasak az egykori környezet jellemzésére, különösen a hőmérsékleti viszonyok rekonstruálására használják (malakohőmérő). 
Iszapolt mintáinkban ezeken kívül még tőzegesedett növényi maradványok is előkerültek.

Az üledékgyüjtőből vett fúrásmintákat kiiszapoltuk, az ősmaradványokat kiválogattuk és meghatároztuk (Richnovsky-Pintér, 1979).

Archaeobotanika

(Gyulai, 2001, Jacomet-Kreuz, 1999)

Az archaeobotanika vagy angolszász nyelvterületen paleo-ethnobotanika foglalkozik a régészeti lelőhelyeken előkerült - legtöbbször termesztett - növények maradványainak vizsgálatával. E maradványok köre széles, makro-, mezo- és mikrofosszíliákat foglalnak magukba, így például szenült és nem szenült magvakat, szárrészeket, famaradványokat, fitolitokat, illetve mindezek lenyomatait (agyagban: paticsban, tapasztásban, edénytöredékben). A fitolitok vizsgálata hazai szinten még nem túl elterjedt, és munkamódszere is teljesen más feltételeket igényel, ezért ezek kutatása nem része az archaeobotanikai munkának. Valójában itt makrolelet-analízisről van szó, főleg növényi magvak és termések képezik a vizsgálat tárgyát. A fosszilizáció történhet szenüléssel (pl. gabonamagvak), nedves környezetben anaerob, ún. szubfosszilis konzerválódással, mineralizációval, kiszáradással, fagyással, valamint különféle sók is konzerválhatnak növényi részeket. Gyakori még a lenyomatképződés is, olyannyira, hogy egyes kutatók ezek vizsgálatán keresztül közelítették meg a vizsgált közösségek növénytermesztését (Füzes, 1990). A megmaradás pontos feltételeit a hőmérséklet, nedvességtartalom, pH, és az oxigéntartalom határozza meg. Beszélhetünk száraz és nedves talajú megmaradásról is, a befogadó közeg jellemző állapotától függően (ez a lelőhelyek zömében a gödrökben száraz, a kutakban és mély árkokban nedves). Az ásatáson tett megfigyeléseink alapján a domaszéki halomsíros településen száraz és nedves térszínek egyaránt előfordultak (az objektumok egy részét nem lehetett kibontani a magas talajvízszint miatt), bár a nedves térszín tipikus példája, a kút nem került elő. A fosszilizáció során a vízvesztés miatt a maradvány alakjában többkevesebb változás következik be, mely a határozást megnehezíti. A mineralizáció néhol olyan fokú lehet, hogy csak a magokat kitöltő ásványos „kőbél” marad meg. Ezek értelmezése faj szintjén már nem lehetséges, a család azonban meghatározható.

A településen kizárólag szenült növényi maradványok (elsősorban magok) fordultak elő, a leletek vizsgálatát Dr. Gyulai Ferenc végezte el. 30 db objektumból vettek mintát, ezek közül azonban - kerámialeletekkel - csak 13 db datálható biztosan a Halomsíros kultúrába. A maradványokban gazdagabb objektumokból ugyanakkor jól meghatározható régészeti leletanyag látott napvilágot. A nyers adatokat a középső és késő bronzkori növénytermesztésre vonatkozó korábbi eredményekkel összevetve a szakirodalom ide vonatkozó részének (Nováki, 1969, K. Berzsényi-Gyulai, 1998, Gyulai, 1991, 1993, 1996, 1999, 2001, 2004, Gyulai-Torma, 1993, Endrődi-Gyulai, 1999, Pomázi, 2010, stb.) segítségével értelmeztük.

\section{Archaeozoológia}

$\mathrm{Az}$ arcaheozoológia vagy régészeti állattan a településeken talált tenyésztett és vadászott gerinces állatok maradványainak meghatározásával, elemzésével, természet- és társadalomtudományi értelmezésével foglalkozik. Néha vizsgálatának tárgyába beleértik a 
gerinctelenek fosszilis maradványait is (csigák, kagylók - Bartosiewicz, 2006, 14), de a leggyakrabban csak gerinces maradványokat elemeznek (Vörös, 1998, 252). Az archaeozoológia szerepe kiemelkedő az egykori környezet és emberi környezet-átalakítás, valamint az állati populációkban végrehajtott emberi szelekció rekonstruálásában. Az a tény, hogy a lelőhelyek állatcsont-anyaga emberi kiválasztást és nagyon komoly, életmódhoz kötődő jellegzetességeket mutat, lehetővé teszi, hogy az ember és állat kapcsolatának gazdasági, társadalmi és kognitív vonatkozásait felvázoljuk. Az elemzés során nem csupán az állatfajokat és mennyiségi arányukat határozzák meg, hanem az elpusztult állatok korát, nemét és a fiatal egyedek esetében elpusztulásuk évszakát. Ezek alapján fontos következtetések vonhatók le az ember és állat közötti viszonyról (ethnozoológia). (Vörös, 1998, Bartosiewicz, 2006, Csippán et al., 2010, Csippán, 2010)

A régészeti állattani vizsgálatokat a régészeti és geoarcheológiai elemzésekkel párhuzamosan Tóth Anikó végezte. Meghatározta az előforduló fajokat, azok arányát és marmagasság számítást végzett, ahol lehetett. A nyers adatok értelmezését magam végeztem a szakirodalom (Bökönyi, 1974, Vörös, 1998-1999, Bartosiewicz, 2006, Csippán et al., 2010) és a megjelenés alatt álló szakcikk (Tóth, 2011 in print) alapján. Dolgozatomban - a gödrök datálásának ismeretében - a halomsíros anyagot a település fó szakaszának életmódrekonstrukciójához használtam fel, a nagyrévi anyaggal összevetve a bronzkor korai és kései szakaszának állattartását hasonlítottam össze. Kísérletet tettem a háztartási egységek belső szerkezetének rekonstrukciójára is.

\section{Röntgenfluoreszcencia (XRF)}

A röntgenfluoreszcenciás (XRF) analízis az emissziós eljárások közé sorolható, mivel a mintából kibocsátott sugárzást, ez esetben röntgensugárzást hasznosítja. A szükséges gerjesztés is röntgensugarakkal történik. A mintába hatoló röntgensugarak (röntgenfotonok) magas energiájuk révén az atommaghoz közel levő telített elektronhéjakon lévő elektronokat gerjeszti, ami azzal jár, hogy a gerjesztett elektronok az elektronburkon kívülre kerülnek és az eredeti belső elektronhéjon egy üres hely marad. Erre a helyre egy külsőbb pályáról azonnal egy nagyobb energiájú elektron kerül. Az átmenet energiakülönbsége - az elektron egy magasabb energiájú pályáról egy alacsonyabb energiájúra ugrik - egy röntgenfoton kisugárzásában mutatkozik, mely elemenként eltérö energiájú. Ezt a jelenséget röntgenfluoreszcens emissziónak nevezzük és föleg a nehezebb elemekre jellemző. Röntgenspektroszkóppal mérve megkapjuk a minta röntgenspektrumát, melyben határozott csúcsok jelzik az egyes elemeket. Méréstechnikai szempontból fontos a sugárforrás emissziójából adódó hamis csúcsok elkülönítése, illetve a közeli energiaszintek elválasztása. A mérés pontossága annak időtartamának növelésével javítható, régészeti fémtárgyak esetében 600 másodperc expozíciós időt alkalmaztunk, amely tisztán kimérhető csúcsokat eredményezett a spektrumban. A gerjesztéshez használt röntgensugárzás energiájának legalább olyannak, vagy magasabbnak kell lennie, mint az eltávolított elektron energiája, és nagy intenzitásúnak, hogy a méréshez elegendő sugárzás keletkezzék. A kimutatott elemek száma a használt röntgenforrás energiájától függ, alacsonyabb energián csak a nagy tömegszámú, magasabb energián az alacsonyabb tömegszámú elemek is gerjesztődnek. A módszer kiválóan alkalmas régészeti fémleletek, elsősorban színesfémeknek és ötvözeteiknek 
fó- és nyomelem-vizsgálatára, az eredményeket mühelykörök és a származási hely rekonstrukciójához használtuk fel.

Vizsgálatom tárgyát bronzleletek képezték, melyek felületét vastag patina borítja. Mivel a röntgensugárzás csak kis mélységig (néhány 100 mikrométer) képes a mintába behatolni, ezért a mérések csak a patina összetételét tükrözték volna. Így fontos volt, hogy a mérendő, 1-2 mm2-es felületen a patinát eltávolítsuk, ezt kőzettani csiszológéppel és finom csiszolóporokkal végeztük. A módszer roncsolásmentes, mivel a patinaréteg nem képezi szerves részét az eredeti tárgynak, annak felszínén lévő karbonát- és oxidréteg. A réz- és bronzleleteken ugyanakkor sokszor a patina őrzi meg az egykori díszítést, ezért a méréseket töredékes vagy jellegtelen tárgyakon végeztük, melyek régészeti értéke egyébként is csekély. Ahol elkerülhetetlen volt értékesebb tárgyak (bronz ékszerek) elemzése, ott a minta díszítéseket nem tartalmazó, általában takarásban lévő területét választottuk ki. Összességében elmondhatjuk, hogy ez a méréstechnikailag szükséges beavatkozás a leletek régészeti értékét nem csökkentette, tehát roncsolás-mentes. Az XRF és SEM módszerek másik fajtája, amikor a mintából $1 \mathrm{~mm}$ átmérőjü furatot vesznek, de ez a megoldás komolyabb technikai hátteret igényel (1mm-es belső átmérőjü magfúró), másrészt a minták egy részén végrehajthatatlan lett volna kis méretük miatt (drót- és lemezékszerek), vagy a minta méretéhez képest jelentős károsodást okozott volna a tárgy régészeti értékében. Épp ezért a fúrómagos módszert csak a nagyobb méretű eszközök és fegyverek elemzésekor tartom megvalósíthatónak.

\section{Cluster-analízis}

(Renfrew-Bahn, 1999, 189, Geiger, 2007, 108-113)

A cluster-analízis fizikai egységek vagy együttesek vizsgálatára szolgál a köztük lévő hasonlóságok vagy különbségek alapján. Ha hasonló genetikájú mintákat a rajtuk történt több mérés tulajdonságainak koordináta-rendszerében helyezzük el, azok térben nagyon közel lesznek egymáshoz. Ezek a pontok egy hierarchikus térbeli szerkezetet alkotnak, melyek egy speciális diagramon, a dendrogramon jeleníthetőek meg. A klaszteranalízishez használt algoritmusok lehetnek hierarchikusak és nem hierarchikusak, az előbbiek a minták valós aláfölé rendeltségi viszonyait tárják fel, a nem-hierachikus módszerek célja a mintacsoporton belül alcsoportok elkülönítése úgy, hogy az alcsoportokon belül a heterogenitás kisebb legyen, mint közöttük. Munkám során ezt az eljárást a fémtárgyak csoportokba sorolására használtam.

\section{Településszerkezet-vizsgálat}

(Renfrew-Bahn, 1999, 170-174, Christaller, 1933)

A regionális régészeti kutatások alapvető módszere a terepbejárás és ásatás, melyek segítségével a vizsgált kistérség adott korú településszerkezete vizsgálható. Az elkészült elterjedési térkép (településszerkezet) hátránya, hogy az eltérő időben használt települések egyszerre jelennek meg rajta. Sajnos a terepbejárás módszertana csak ritkán tesz lehetővé néhány 100 évnél jobb időbeli felbontást, de a legalapvetőbb adatok így is kinyerhetők. A lelőhelyek mérete és intenzitása szoros összefüggésben áll a társadalommal. A következő kategóriákat különíthetjük el: regionális központ, helyi központ, zárt falu, szórványfalu, szer (néhány házból álló falvacska). 
Kis települések sürü láncolata egy mobil közösségre utal, míg a terepen is világosan felismerhető központok szervezettebb, stabilabb (letelepült), hierarchikusabb társadalom képét vetítik felénk.

A központi hely elméletet Walter Christaller német földrajztudós dolgozta ki az 1930-as években. Célja az volt, hogy megmagyarázza vele az akkori Dél-Németország nagy- és kisvárosainak méret- és funkcióbeli eloszlását. Azt találta, hogy egy egységes, képzeletbeli tájon, melyen az ásványkincsek, folyók, domborzati elemek elhelyezkedése egyenletes, a településszerkezet is erős szabályosságot mutatna. A szerkezet hierarchikus lenne, melyben az egyes elemek mérete és funkciója azonos. A központi helyek egymástól azonos távolságra, hatszöges struktúrába rendeződve helyezkednének el, őket pedig kisebb központok, falvak és falvacskák szabályos hálózata venné körül (21. ábra). Ilyen eszményi helyzet a természetben sosem áll elő, de bizonyos síkságokon valóban kimutatható egy ehhez közeli állapot a modern vagy ókori települések elhelyezkedésében. A központi hely az elmélet szerint azért központi hely, mert központi funkciókkal bír, ellenőrzi és ellátja késztermékekkel és szolgáltatásokkal az általa ,uralt” hatszögletü területeket (22. ábra).

A településszerkezet valós képe azonban ettől jelentősen eltér, bár az elmélet nagyon jó kiindulópont lehet valós helyzetek rekonstrukciójára. Legnagyobb hibája, hogy a régészeti lelőhelyek sosem alkotnak egységes mérettartományba eső csoportokat, kiterjedésük és lélekszámuk erősen változik. Annyi azonban bizonyos, hogy kisebb településekből mindig lényegesen több van, mint nagyobbakból.

A Thiessen-poligonok. A településszerkezet vizsgálatának azon módszere, melyben a rendelkezésre álló teret - a központi helyek köré húzott - sokszögek töltik ki. A poligonokat úgy hozhatjuk létre, ha egyenes vonallal kötünk össze minden szomszédos lelöhelyet, majd e vonalak felezőpontjához újabb, rájuk merőleges vonalakat húzunk. Ezeknek a másodjára megrajzolt vonalaknak az összekötésével jönnek létre a Thiessen-poligonok, melyek az egész területet felosztják a lelöhelyek között (23. ábra). A módszer hibája, hogy nem veszi figyelembe a települések méretét és fontosságát: egy kis lelőhelynek ugyanakkora poligonja lehet, mint egy nagynak. Épp ezért csak a hasonló nagyságú és fontosságú, valamint azonos időben lakott lelőhelyek vizsgálatára alkalmas. A településszerkezeti térkép rossz időbeli felbontása leginkább itt bosszulja meg magát, bár a nagyobb településekről feltehető, hogy hosszabb ideig is használták őket, így 100-200 éves pontosság már mindjárt nem tekinthető olyan rossznak.

XTENT. A fenti módszerek egyik nagy hibája, hogy nem biztos, hogy a településhierarchiában ugyanazt a szintet elfoglaló lelőhelyek mérete, fontossága megegyezik. Az XTENT képes áthidalni ezt a problémát. A módszer célja, hogy nagyságrendjük arányában rendelje a központokhoz a területeket, s közben feltételezi, hogy a nagyobb központok befolyással vannak a kisebb központokra, ha elég közel fekszenek egymáshoz. Az elemzés feltételezi, hogy minden központ mérete egyenesen arányos befolyási övezetének méretével. Feltételezi továbbá, hogy minden központ befolyási övezetének alakja harang alakú sátorhoz hasonló (térbeli Gauss-görbe, Gauss-harang): minél nagyobb a központ, annál nagyobb a harang. A központok akkor válnak a másik központ alárendeltjeivé, ha a hozzájuk tartozó harangsátor teljes területe a másik központ területére esik. Amennyiben 
kívül maradnak, önálló központként autonóm létük lehetett. Bár a módszert állami léttel rendelkező ókori civilizációkra dolgozták ki (Mezopotámia, 24. ábra), a hierarchikus szerkezetü brozkori kultúrákra is alkalmazható lehet.

\section{Régészeti módszerek}

\section{Terepbejárás}

A régészeti lelőhelyekről felszíni bejárással szerezhető információk köre igen széles. Az eke és a talajerózió felszínre hozza a kultúrrétegből a régészeti leletek egy részét, melyek szóródása és intenzitása megadja a lelőhely hozzávetőleges $(+-10 \mathrm{~m})$ kiterjedését, irányát. Az ásatásokból már jól ismert és datált tárgyak típusai alapján lehetséges a település vagy temető körülbelüli korhatározása (a pontossága általában néhány 100 év), a hely lakottságának időtartama, esetleg a település funkciója (nyersanyag-feldolgozó, földmüves, állattenyésztő, stb.), valamint rétegzettsége ill. annak hiánya (központi hely vagy nem) (Jankovich, 1993). Vizsgált településünket a geológiai fúrás alkalmával bejártuk, mely során kétséget kizáróan azonosítottuk a fúrás helyét a feltáráséhoz képest, továbbá néhány jelentős datáló értékkel rendelkező, díszített bronzkori edénytöredéket találtunk.

Ásatási módszerek

A régészeti feltárás (megelőző feltárás vagy tervásatás) a régészeti információszerzés egyik alapvető eszköze. A bolygatott (szántott, növények gyökereivel szabdalt) talajréteg eltávolítása után a kultúrréteget kézi vagy gépi erővel tárjuk fel. Réteges települések esetén a régészeti rétegtan (régészeti sztratigráfia) törvényei szerint haladva távolítjuk el az egy időben keletkezett föld-, omladék- és hulladékrétegeket (Harris-mátrix: 26. ábra, Harris, 1997, Greene, 1990, 65). Egyrétegü település esetében a talaj A szintnél világosabb, B vagy C szintjébe mélyedő, elszíneződésként jelentkező objektumokat (régészeti jelenségeket, 25. ábra) kibontjuk (helyreállítjuk az egykori, használat korabeli állapotot). A régészeti munka minden fázisáról írásos (ásatási napló, folyamatnapló, objektumleírás), rajzos (folt- metszet-, részlet- és felszínrajzok) és fotografikus dokumentációt készítünk. A kézi bontás során van lehetőség talajminták vételére. A mintákat iszapolhatjuk és minden olyan geoarcheológiai vizsgálatot elvégezhetünk, mint bármely más talajmintán (szervesanyag- és karbonáttartalom mérés, kémiai analízis, szemcseösszetétel, ásványi összetétel, stb.). A régészeti leleteket (kerámia, kő, fémtárgy, üveg, ember- és állatcsont, kagyló, stb.) objektumok, rétegek szerint külön csomagoljuk és tároljuk.

A Domaszék-Börcsök tanyai település feltárását nagyberuházáshoz (M 5 autópálya építése) kapcsolódóan végezték, amely speciális munkamódszert igényelt. A felső talajréteget és a B szint jelentős részét gépi humuszolással (iszapoló kanalas markolóval) távolították el. Így az egykori beásások (gödrök, kemencék, árkok, sírok stb.) a világos $\mathrm{C}$ talajszintben sötétebb (világos- vagy sötétbarna, fekete humuszos, esetenként égett, hamus) foltként jelentkeztek, melyeket az ún. felező (negyedelő, stb.) módszerrel először metszetre bontottak (a jelenség egyik felét (negyedét, stb.) tárták fel, így világos profilt/profilokat kaptak a betöltéséről). A metszeteket rajzban és fotón dokumentálták. Ezt követően tárták fel a jelenség másik felét (negyedét, stb.) és csomagolták el a leleteit. A feltárás során a kedvezőtlen, csapadékos időjárás és a magas talajvízszint jelentősen nehezítette a munkát 
(Paluch, 2005). A régészeti jelenségek geoinformatikai feldolgozását (pontos helyük és kiterjedésük térbeli rögzítése) a Móra Ferenc Múzeum Térinformatikai Laborja végezte. Szintén ők készítették el az ásatási dokumentáció digitális változatát.

\section{Elsődleges leletfeldolgozás, restaurálás}

Az ideiglenes raktárakba kerülő leletanyagot először megmossák és megszárítják, illetve - ha anyaga sérülékeny - más módon tisztítják meg. A kerámia esetében általában elegendő az áztatás, lágy sörtés kefével dörzsölés és csapvizes öblítés, de sokszor van szükség a lúgos talajokban eltemetődött tárgyak felületen kivált kalcium-karbonát feloldására, amit híg citromsavval végeznek. A kerámia ezzel a módszerrel sérülésmentesen kezelhető, lévén anyaga zömmel szilikátokból áll. A restaurálás célja a tárgyak eredeti állapotának, vagy azt legjobban megközelítő alaknak a visszaállítása, további aprózódásuk meggátolása. A kerámiatöredékeket összeragasztják, szükséges esetben ún. statikai kiegészítéssel látják el. A fémtárgyak felületén kivált karbonát- és oxidréteget nagyon finoman eltávolítják, de a patina tartósabb rétegét meghagyják, ez ugyanis megőrzi a tárgy eredeti díszítését (Cronyn, 1992).

A restaurált tárgyakat a munka következő lépéseként beleltározzák abban a múzeumban, mely területileg illetékes (jelen esetben a Móra Ferenc Múzeum). A leltári szám a következőkből áll:

Évszám.tételszám.sorszám, pl. 2007.2.211, azaz a 2007-ben leltározott 2. tétel 211. tárgya.

\section{Leírás és rajzolás}

A régészeti feldolgozás következő lépése képi és szöveges információk előállítása. A leltározási munka része egy makroszkopikus leírás készítése a leletről, mely magába foglalja:

- a tárgy alakjának,

- díszítésének,

- anyaga makroszkopikus jegyeinek,

- készítési módjának,

- sérüléseinek

meghatározását és a jellemzők világos, mások számára is egyértelmű szöveges megfogalmazását.

A leletegyüttes bemutatásához elengedhetetlenül szükséges a képi információ előállítása, mely a legtöbb esetben értelmező rajz. Elkészítéséhez a lelet (döntően kerámia) további, méréssel és interpolációval előállítható metrikus adatai szükségesek: perem, has, fenék átmérője, melyeket milliméter-papíron ábrázolva $(M=1: 2)$ müszaki rajz jellegü ábrát kapunk, amelyen megrajzoljuk az egykori edény profiljának ránk maradt részét is. A perem átmérője még akkor is megállapítható, ha annak csak igen kis töredéke (negyede-ötöde, vagy még kisebb része) maradt fenn. A peremet egy koncentrikus körökből álló mértékre tesszük, és amelyik sugarú körre pontosan illik a perem, az lesz a perem sugara is. Az érték kétszerese pedig megadja a perem átmérőjét. Ezt felvéve, a tárgyat vízszintesbe forgatva az edény formájáról összehasonlíthatatlanul többet mondhatunk, mint puszta ránézésre. Amennyiben a perem annyira kicsi, hogy görbülete alig észrevehető (és így eldönthetetlen, pontosan melyik izovonalra is illeszkedik), a leletet egyszerüen látás után lerajzoljuk, majd mellé rajzoljuk 
elméleti profilját, amit úgy kapunk, mintha középen függőlegesen kettévágtuk volna. A rajzon mindig fel kell tüntetni a méretarányt (vonalas cm-skála) is.

A képi megjelenítés fontos eszköze a fotó, a látványosabb, fontosabb leletekről vagy részleteikről felvételek készültek a méretarány feltüntetésével. Ha szükséges volt (metallurgiai vagy kőzettani vizsgálatoknál), sztereobinokuláris mikroszkóppal is megvizsgáltuk a tárgyakat és lefotóztuk jellegzetességeiket.

Tipológia és régészeti datálás

Régészeti értelmezés szerint a típus vagy tárgytípus a leletanyag ember által létrehozott, többé-kevésbé formatartó eleme, amelynek elterjedése térben és időben korlátozott. Ezért az egyedileg készített tárgyak - bár ember hozta létre őket - tárgytípusnak nem minősülnek. A típus területhez és időrendi egységhez kölcsönösen egyértelmüen hozzárendelhető. Azonos problémák megoldására, azonos funkcióra kialakított tárgyak még akkor is - néha erős hasonlóságot mutatnak, ha térben és időben olyan nagy a különbség, hogy irreális kulturális kapcsolatot feltételezni köztük. Ebben az esetben funkcionális alaki konvergencia érvényesül, tehát az egységes emberfajhoz tartozó, azonos kognitív képességekkel rendelkező emberi közösségek egy azonos problémára hasonló megoldásokat adtak.

Kérdéses viszont, hogy a ránk maradt régészeti anyagban - mely az eredetinek általában alig 1-10\%-a - egyediként feltűnő tárgy valóban egyedi vagy csak ritka volt-e az adott közösségben. Épp ezért a régészeti ásatásokon feltárt tárgyi anyagot kivétel nélkül típusokba sorolják. Kivételt csupán a legkorábbi előember telepek jelentenek, melyek eszközkészlete nem formatartó, tehát vagy mindegyiküket önálló típusnak nevezzük, vagy a közel azonos funkciójú eszközöket azonos funkcionális csoportokba szervezzük. A tipológiai rendszer létrehozásánál törekedni kell arra, hogy elsősorban a funkcionális egységeket azonosítsuk, ne alkossunk kicsiny, önálló típusokat jelentéktelen eltérések alapján. Másik oldalról viszont a tárgy sosem pusztán funkcionális, hanem egyszersmind annak a közösségnek vagy egyénnek a tradícióit is magán viseli, amely létrehozta, így a nem funkcionális eltérések is lehetnek formatartóak és kultúra-specifikusak, s jelentős szerephez juthatnak a tipokronológia kidolgozásában.

A bronzkorban - de más jóval korábban is - az egyedi tárgyak száma azonban igen csekély, a típusok jól elválaszthatóak és formatartóak. Bár a kerámia még kézzel készül, a társadalom konzervativizmusa, hagyományai rendkívüli erővel hatnak a formák megmaradásának irányába.

A tipológia és tipokronológia a típusok pontos leírásával, funkciójával, térbeli és időbeli elterjedésével (relatív datálásával) foglalkozik a régészeten belül. A tárgyak funkcionális (tökéletesítés) vagy kulturális (forma, díszítés átvétele) okok miatt - fejlődnek, néhány generáció után a hagyomány nem képes legyőzni az innovációkat (melyek a társadalmon belülről, illetve azon kívülről is fakadhatnak), és a tárgyak alakja, díszítése megváltozik. A funkcionális alapon változó (tökéletesedő) fegyverek és használati eszközök (bronztőrök, kardok és balták) könnyedén sorba rendezhetőek aszerint, hogy melyik milyen „fejlettségi” szintet tükröz (27. ábra). Így kapjuk az adott eszköz- vagy fegyvertípus tipológiai sorát, amely - ha jól állítottuk sorrendbe őket - megadja a típusok relatív korát is. Ezek az elsődlegesen ismert relatív korú típusok a vezértípusok, melyeket kultúrákhoz, 
archeosztratigráfiai szintekhez, stb. lehet rendelni. Itt kell utalnunk a vezértípusok és a vezérkövületek segítségével történő datálási módszerek alapvető módszertani azonosságára a régészetben és a geológiában.

Ha a típusok nem funkcionális alapon változnak, relatív korukat kell előbb meghatározni. Ez a vezértípusokkal is történhet: a vezértípust is tartalmazó leletegyüttes (gödör, ház, árok, sír, stb.) többi tárgya hozzávetőleg a vezértípussal egykorú. A pontosabb relatív datáláshoz rétegtanra van szükség.

A rétegtan (Harris, 1997) biztosítja a datálás harmadik lehetőségét. A réteges települések hosszabb időn keresztül egy helyben lakás következtében keletkeztek (ún. tell telepek - a tell arab szó, dombot jelent), így a település fennállása alatt a típusok megváltozhattak. A rétegek leleteit külön tartva, majd azokat összehasonlítva ki kell választani azokat a típusokat, melyek azonos funkciójúak voltak. A módszer fordítottja a tipológiai sorok képzésének: ott ismertek a változás alanyai, keressük a helyes sorrendet, itt a helyes sorrend ismert, és keressük az összetartozó típusokat. A módszer a kerámiaformák és díszítések relatív datálására kiválóan alkalmas.

A cross dating (keresztdatálás) lényege a kultúrák kapcsolataiban rejlik. Két emberi közösség, melyek eltérő anyagi kultúrát hordoztak, de térben és időben egymás mellett éltek, kereskedhettek egymással, vagy összefüzhették őket egyéb szociális kötelékek (barátság, szövetség, házassági kapcsolatok). Az import tárgyak (leggyakrabban kerámiák) szükségképpen megjelennek a másik kultúra területén, ha volt köztük kapcsolat. Szerencsés esetben (kedvező betemetődési, konzerválódási és megtalálási feltételek) előbukkannak a régészeti ásatásokon. Amennyiben a kérdéses import tárgy és a befogadó közeg (leletegyüttes) relatív kora a saját kultúrájukon belül pontosan ismert, megadható a két relatív archeosztratigráfiai egység egymáshoz viszonyított kora is (Renfrew-Bahn, 1999, Green, 1990). Ez a geológiában használt rétegtani korreláció egyik régészeti megfelelője.

\section{Kontextuális szeriáció, gyakorisági szeriáció}

$\mathrm{Az}$ archeosztratigráfiai egységeket meghatározásuk módja alapján relatív és abszolút datálással tudjuk pontosan lehatárolni. Az abszolút datálás elsősorban fizikai módszer, bár a Közel-Kelet és Észak-Afrika, valamint Délkelet-Európa területén a csillagászati és történeti módszerekkel megállapított, egyiptomi naptáron és kronológián alapuló történeti datálás is nagyon fontos. Munkámban azonban ez a módszer csak érintőlegesen vetődik fel, a település leletanyagát összehasonlító módszerekkel kell datálni. Ennek oka a Közel-Kelet és Égeikum, valamint Közép-Európa között lévő idő- és térbeli „törésvonal”, mely annak következtében jött létre, hogy a két régió kultúráit nem vagy csak időszakosan füzte össze kapcsolat, ezért érdemi import leletek nem várhatóak. A két régió kulturális és szociális fejlettsége különösen a korai és középső bronzkorban - igen eltérő volt a mediterrán térség javára. Ezek relatív módszerek, tehát a régészeti objektumok, tárgyak egymáshoz viszonyított sorrendjét adják meg. Az abszolút keltezést a vezértípusok lelőhelyeinek radiokarbon adatai jelentik.

Mivel az ásatáson - a település és a feltárási módszer jellegéből adódóan - csak ritkán sikerült a jelenségek szuperpozícióját megfigyelni, rétegek pedig egyáltalán nem kerültek elő, a datálást vezértípusokra kell építeni. A leletegyüttesek tárgyainak rekonstrukciója megadja az adott egység tárgytípusainak összességét, szériáját. Ezután az együttesek (gödrök, házak) 
típusait úgy kell sorba állítani, hogy köztük legalább egy azonos típus legyen. Az így létrejövő sorrend ideális esetben megadja a jelenségek időbeli egymásutániságát. A kontextuális szeriáció módszere a gyakorlatban azt jelenti, hogy a szériák típusait feltünésük sorrendjében egy táblázat vízszintes sorában helyezzük el, míg a jelenségek (kontextusuk) azonosítói a függőleges sorba kerülnek. Minden egyes jelenség jelzést kap a benne megtalált típusoknak megfelelő rubrikában. A szeriációs datálás akkor helyes, ha a pontok egy 45 fokos meredekségü egyenest adnak, vagy azzal illeszthetőek. Jellegéből fakadóan a módszer nem egyedi tárgyak, hanem jelenségek datálására alkalmas, pontossága a forrásanyag mennyiségétől, a típusok számától és változékonyságától függően alakul.

A gyakorisági szeriáció azt vizsgálja, hogy az adott jelenségen vagy településen belül az adott típus milyen gyakran fordul elő. A tárgyak ugyanis nem hirtelen jelennek meg vagy tünnek el, a „divat” eleinte csak kis csoportok körében terjed el, majd válik általánossá. És ugyanúgy, az új innovációk csak lassan képesek kiszorítani a régi tárgyakat, sőt, adott esetben egy régen készült, de több generáción keresztül használt tárgy hosszú idővel elkészülte után kerülhet földbe (elsősorban sírmellékletek). A tárgyak számát a lelőhelyek függvényében ábrázoljuk, a datálás akkor helyes, ha a görbe maximuma hozzávetőleg középen van (persze eltolódhat a két vége irányába is). Plató is előfordulhat (a tárgy azonos mennyiségben készül), de a kettős csúcs (a tárgy kimegy a divatból, majd egy idő múlva újra divatba jön) a régészeti anyagban elég ritka. Ezzel a módszerrel is elsősorban jelenségek, vagy még inkább egész települések, temetők vizsgálhatóak, pontossága azonban kicsi (Renfrew-Bahn 1999, Greene 1990).

Térhasználat analízis, „site catchment” analízis

(Roper, 1979, Clarke, 1977, Renfrew-Bahn, 1999, Greene, 1990, Robertson et al., 2006, Sümegi, 2009)

A településen belül fontos célom volt az egyes emberi tevékenységek térbeli helyének meghatározása a régészeti leletek segítségével. A feltárási módszerek sajnos csak a legfontosabb funkciók elkülönítésére adnak lehetőséget. Pusztán az alaprajz tanulmányozásával, a régészeti objektumok pontos funkciójának meghatározásával érdekes eredményekre jutottam. Ezen túlmenően a kerámiaformákat vizsgáltam, azt keresve, kimutatható-e az edénytípusok, egyéb tárgytípusok terén valamiféle területi eltérés, gyakoriságbeli változás. Az állatcsontanyag száma és minősége adhat felvilágosítást az egykori állattartás és esetleg az állatvágás helyszínéről. Ezeket az információkat az alaprajzi jellegzetességekkel kombinálva kialakul a település belső szerveződése.

A „site catchment” elmélet (Roper, 1979), avagy analízis arra keresi a választ, hogyan függött az ember élete a környezettől, szükségleteit mekkora területről, milyen térbeli eloszlást követve tudta kielégíteni. Számba vettem a lakosság hozzávetőleges nyersanyag- és területigényét (fa, fazekasagyag, víz, kereskedelmi utak helyzete, szántóföldek, legelők), melyek beszerzési területe világos rendszer szerint épül fel (Sümegi, 2009), és a környezet rekonstrukciója révén igyekeztem megrajzolni a zónák elhelyezkedését (Greene, 1990, Robertson et al, 2006). 


\section{Régészeti eredmények}

\section{A település feltárása}

2005. május 19. és június 20. között megelőző feltárás folyt a tervezett M5-ös autópálya nyomvonala Szegedet keletről elkerülő szakaszának 166+540 és 166+740 km-szelvénye között talált 17/51 (M5 81. sz.) lelőhelyen, Domaszék-Börcsök-tanya mellett. A kiásott terület Domaszéktől DK-re, az 51. sz. fơúttól délre mintegy 1000 m-re található egy, a környezetéből laposan kiemelkedő dombháton.

A feltárással érintett felület $19800 \mathrm{~m} 2$, a település szélét egyik irányban sem érték el. Ezen a területen 486 régészeti jelenséget dokumentáltak (28. ábra), melyek igen nagy százaléka a halomsíros kultúrába sorolható (29. ábra). Mivel ezek zöme cölöplyuk, melyekben korhatározó lelet általában nem került elő, a későbronzkori településjelenségek pontos számát sem ismerjük. Napvilágot látott néhány - igen gazdag leletanyagú - kora bronzkori, Nagyrévi kultúrába tartozó gödör, valamint három csoportban néhány urnás, kora bronzkori temetkezés. A lelőhelyen feltehetően avar sírok is mutatkoztak, és újkori bolygatás nyomaira is bukkantak (Paluch, 2005, 226). A feltárás időtartama alatt végig megfeszített tempóban, néha rossz időjárási körülmények között folyt a munka, ennek ellenére a leletanyag és a dokumentáció is jól áttekinthetö. Sajnos a leletek igen töredékesek, csupán néhány edényt lehetett kiegészíteni vagy kiszerkeszteni, ezek is főleg nagyréviek. A kerámiaanyag igen jelentős mennyiségü, formákban gazdag, benne világos tipológiai különbségek ismerhetők fel. Néhány gödörböl - zárt, dokumentált körülmények közt - olyan jellegzetes töredékek is napvilágra kerültek, melyek fontos, régóta hiányolt információkkal szolgálnak a Dél-Alföld halomsíros kultúrájának kronológiai viszonyait illetően.

\section{A település belső szerkezete (Sánta, 2009)}

A település egykori szerkezetének, a tér felosztásának és használatának rekonstrukcióját két módszerrel közelítettem meg. Egyrészt a feltárt jelenségek hagyományos régészeti interpretációjával, mely a megmaradt és feltárt objektumcsoportok közötti kapcsolatot vizsgálja, lehetőleg a korszak más feltárt településein előkerült épülettípusok párhuzamba állításával. Másrészt néhány kerámiatípus gyakoriságán, illetve a leletek töredékességén, az állatcsontok előfordulási arányán alapuló térhasználat analízist végeztem.

A halomsíros település belső szerkezete jól tanulmányozható. Öt, nagyjából ötvenméteres átmérőjü csoport különíthető el, melyekben egyaránt előfordulnak cölöplyukak (általában nagy számban) és gödrök is (29. ábra). Az öt csoport mindegyike a halomsíros kultúrához kapcsolható (még akkor is, ha némelyikben nagyrévi jelenségek is napvilágot láttak), valós régészeti együtteseknek tarthatók. Gödröket és cölöplyukakat tartalmaznak, melyek térben elkülönülnek. Egy csoport leletanyagán belül kronológiai különbségek vannak, méghozzá az egész telep belső fejlődése nyomon követhető, ezért az öt csoport mindegyike egykorúnak tartható.

Objektumokban leggazdagabb az 1. csoport, ahol félig földbe ásott ház, cölöpszerkezetes épületek nyomai és kisebb földbe vájt épületek (ólak?) kerültek elő, valamint az 5. csoport, ahol karám(?)árok látott napvilágot. A 2. csoport jelentősebb számban 
tartalmazott nagyrévi gödröket. Az 5. számú csoportosulás területén is kerültek elő kora bronzkori jelenségek, így azok két csoportot alkotnak a feltárt felszín észak-déli tengelye mentén. A településen összesen 14 cölöpszerkezetes és egy félig földbe ásott házat tudtunk részben vagy teljesen rekonstruálni, ezek tájolása a korszakban megszokott módon ÉNy-DKi, méretük 12 esetben 8-10 x 4-5m, 2 esetben 5-7 x 3-3,5 m. A két épülettípus abban is különbözik, hogy az előbbiek között 2 esetben osztófalat is meg lehetett figyelni, mely a házakat egy nagyobb és egy kisebb helyiségre tagolja 2/3 és 1/3 arányban. Ez a jellegzetesség megfelel a korai-középső bronzkorból másutt előkerült házaknak. Az analógiák alapján a bejárat a déli, délnyugati oldalon lehetett a kisebb helyiségnél, mely alvóhely funkciót tölthetett be. A nagyobb szoba volt az ún. lakókonyha, közepén az analógiák szerint tűzhellyel, melyek a lelőhelyen a dombtető eróziója és a feltárás módszerei miatt nem voltak megfigyelhetők. A házak berendezéséről nem tudunk sokat mondani, kemencék vagy hamusgödrök nem kerültek elő bennük, ezek ugyancsak a mára elpusztult tapasztott, döngölt padlószintre lehettek építve. Egyéb, földbe mélyedő objektum (munka- és tárológödör) sem található a házakban, bár két-három épület esetében a falak vonalához illeszkedő gödröt, gödröket tártak fel, egyszer pedig a lakókonyha közepe táján került felszínre egy gödör (202. objektum). Ez a gödör nem tartalmazott konyhahulladékot, csupán egyetlen, nagyobb méretű bögre összeilleszthető töredékeit, így gyaníthatóan épségben került a kisméretü gödör földjébe. A ház központi részén (a tüzhely szokásos helye alatt) való előkerülése azt sugallja, hogy ez az együttes építési áldozat lehetett, melyre számos példát ismerünk az őskor és más korszakok emlékanyagából. (Az építési áldozat kérdéskörét a Konklúzióknál fejtem ki bővebben.)

Megfigyelhető volt, hogy az ásatáson feltárt cölöplyukak látszólag rendszertelen csoportokban helyezkednek el. A tájolás (melyre néhány jól megfigyelhető épület alapján következtethettünk), valamint a cölöplyukakból előkerült leletanyag ismeretében elkülöníthetőek voltak a házak. Több esetben a két épület alaprajza egymást metszi, itt későbbi megújítást lehet feltételezni. A házakat, amikor azok elöregedtek, elhasználódtak, lebontották és megközelítően azon a helyen építették fel újra. Ilyenkor sosem pontosan fedte a két épület egymást, legtöbbször kissé eltérő tengellyel épült újra a ház. A házak felépítménye nagyon hasonló lehetett a más őskori településeken megfigyeltekhez: felmenő paticsfal jellemzi őket, melyre a házak környezetében jelentkező, paticsot tartalmazó gödrök (114., 463. gödör) és néha a cölöplyukakban megfigyelhető paticsos betöltés utal (19., 53., 115. stb.). Az épületek egy részének pusztulását tehát a tüz okozta. Felépítményük leggyakrabban ágasfás-szelemenes szerkezetű lehetett, amire a rövidebb oldal közepén lévő, általában nagyméretű oszlophely utal. Néha azonban nem volt erre szükség, csak a sarokoszlopok tartották a tető súlyát. Az ágasfát több esetben aszimmetrikusan helyezték el a ház rövidebb oldalán.

1. objektumcsoport (30. ábra). Az ásatási felszín északi részén található, mind közül a legérdekesebb, legtöbb objektumtípust felvonultató csoport. Egy nagy, félig földbe ásott ház (278. objektum - 1. ház) jelöli ki a keleti szélét a szelvény sarkában. Falai ÉNy-DK/ÉKDNy-i tájolásúak: ha elfogadjuk a 2. számú, cölöpszerkezetes ház (lásd 4. objektumcsoport) ÉNy-DK-i tájolását, akkor egy nagyobb méretủ épületet kell benne sejtenünk, mely javarészt 
feltáratlan maradt. Ehhez hasonló házakat több Halomsíros lelőhelyen is megfigyeltek (Budapest-Vízakna u.: Kőszegi, 1973, Szák: Kőszegi, 1988, 183, 1088. 1h.) Tőle déldélnyugatra egy részben kiszerkeszthető, felszínre épült ház alaprajza bontakozik ki, melyet egyszer megújítottak, de a két épület alaprajza nem ismerhető fel pontosan. Az itt lévő cölöplyukakban (282-299. objektum) számos Halomsíros kerámiatöredék került elő, így ezeknek az épületek a kialakítására a település életének későbbi szakaszában kerülhetett sor. Nyugati irányban egy kb. 10 m hosszú, nyugat-keleti tengelyü gödörsor fut (40., 51-52., 6570. objektum), bennük háztartási hulladék volt, feltehetőleg itt egy kerítéshez vagy egyéb térhatároló elemhez (fasor, vetemény?) igazodtak a hulladékgödrök. Ezek közelében található egy rosszul kiszerkeszthető kisméretü épület, mely talán gazdasági funkciót töltött be (53., 55-57., 59., 60-63. objektum). A gödörsortól észak felé közvetlenül egy nagyobb méretü, kb. 10x5 m-es cölöpszerkezetes épület bontakozik ki (8-10., 19-20., 22., 24., 26., 28., 42., 48., 64. objektum), területén több gödörrel, melyek feltehetőleg nem egykorúak vele.

A 30-as gödörtől nyugat felé egy nagy épület rajzolódik ki (75-80. objektum), melynek egyik sarokcölöpét a 30-as objektum roncsolta, vagy arra ásták, de az ásatáson nem volt megfigyelhető. Az északnyugati rövidebb oldal 3 markáns cölöplyuka azonban épségben maradt, sőt az északnyugati sarokoszlop gödrében (80. obj.) nagyméretű cserépdarab kerül elő (építési áldozat vagy stabilitást növelő elem - a telepen többször előfordul). Ha elfogadjuk a fenti rekonstrukciót, akkor 12-13x5-6 méteres épületet kell valószínűsíteni.

A csoport további érdekes objektumai azok a lapos aljú, téglalap alakú sekély gödrök, melyek alján cölöplyukak kerültek elő. A 31. számú négyszögletes objektum kisméretű házra hasonlít, melynek négy sarkában és közepén is található egy-egy cölöplyuk. Talán ól, gabonatároló hombár vagy más funkciójú melléképület lehetett, de 1,5x2 m-es területe meglepően kicsi (31. ábra). Melléképület lehetett a Soltvadkerten kiásott cölöpszerkezetes épület (Gazdapusztai, 1959, Abb. 2.) Kora bronzkori példák alapján felmerülhet a kis épület gabonatároló hombárként való hasznosítása is, jellegüket (kisméretű, lakás céljára alkalmatlan cölöpszerkezetes objektum) tekintve hasonló jelenségeket figyeltek meg a Harangedény-kultúra Budapest (XI. kerület)-Albertfalva lelőhelyén is (Endrődi-Reményi, 2005, 131). Hasonló volt még a 40. objektum, de ebben csak két cölöphely mutatkozott, viszont a ház közvetlen közelében került elő. A 30. objektum közel háromszor hosszabb, de ugyanolyan széles, mint a 30. és 31 ., nyugati oldala mellett két cölöplyukkal. Talán mühely vagy karám lehetett, felhagyása után kevés hulladék került bele. Az állatcsont-anyag értékelésénél kitérek arra, hogy a településen a többi bronzkori lelőhelyhez képest nagyobb számú kutya élt. Ez alapján a kérdéses objektumok kutyaólak is lehettek.

2. objektumcsoport (32. ábra). Nagyrévi és Halomsíros gödröket, cölöplyukakat tartalmazott. A terület egyik legérdekesebb jelensége a 425. gödör, mely körül egy íves sorba rendeződött cölöpsor (89-92., 94-104., 481. objektum) került elő, talán egy ház északnyugati sarka. A házhoz vagy megújításához tartozó 94. és 104. cölöplyuk aljára nagyobb fazékvagy pithostöredéket helyeztek, talán az épület stabilitását szerették volna növelni (süllyedést megakadályozni), de az is lehet, hogy építési áldozatról van szó. A fentebb, az 1. objektumcsoportban leírt cölöpszerkezetes épületek méretadatai alapján (12x6 m) a ház déli oldalát a 420. és 431. objektum jelölheti ki (33. ábra). A valószínüsíthető épület körül gazdag 
leletanyagú halomsíros objektumok kerültek elő. Közülük a legérdekesebb a háztól délkelet felé a 172-173. és 482-484. objektumok alkotta komplexum. A 483. objektum egy gödör, benne halsütő tál és egy fordított csonkakúpos, enyhén kihajló peremü tál töredéke került elö. A 172. objektum egy kemence, melyet a felhagyott, betemetett 483. gödörbe építettek (34. ábra). Egyes gödrök tűzzel való lezárására az M7-es autópálya nyomvonalán, OrdacsehiBugaszegen Kiss Viktória talált bizonyítékokat, megjegyezve, hogy a gödörben égetés egyaránt szolgálhatott egészségügyi okokat, és lehetett egy szakrális cselekvéssor része is (Kiss, 2007, 221). Itt azonban nem szabad tüzelés nyomai találhatóak, hanem egy épített sütőkemence, mely az északabbi házhoz tartozott, a gödörben állati hulladék, csont nem volt. A kemence tapasztásából és betöltéséböl jellegzetes, korai Halomsíros leletanyag került elö, tehát az alatta lévő gödör, benne a halsütö tállal, a település egyik, ha nem a legkorábbi objektuma lehet. A 173. objektum egy ép, gyürütalpas, kora halomsíros korsó töredékeit tartalmazta, hasonlót a 202. objektumban feltárthoz. Ép edények kisméretű gödörbe helyezése inkább szakrális cselekvéssorral magyarázható, hisz a kis gödör és a benne lévő összeroppant, de egykor az aljára állított (esetleg a gödör falához támasztott) edény (korsó) jelenléte sokkal tudatosabb tevékenység eredménye, mint a gödrökbe dobott, összetöredezett, alig kiegészíthető hulladék. A telepen máshol is előfordul ugyanez a lelettípus (202. objektum), méghozzá szintén egy ház közelében, sőt azon belül. Meg vagyok gyöződve, hogy ezek a gödör-együttesek építési áldozatként azonosithatók (bövebben l. a Következtetéseknél). A 484-es cölöplyuk talán egy, a kemence fölé boruló féltető tartására szolgálhatott (több elpusztult cölöplyukkal együtt), ám a 482-es (leletmentes) cölöphely, mely metszi a kemencét, egyértelműen későbbi.

Nyugatra, az ásatási szelvény szélénél egy nagyjából kiszerkeszthető ház (109-113., 116-119., 121-123. objektum, 35. ábra) található, két cölöplyukkal, melyek Halomsíros kerámiát tartalmaztak (112. és 115. obj.). A 115-ös cölöplyuk betöltésében paticsot is megfigyeltek, csakúgy, mint a ház északi rövid fala mellett ásott 114-es számú, hulladékgödörben. Feltételezhető, hogy a gödörbe a ház pusztulása után került paticstörmelék.

3. objektumcsoport (36. ábra). Jelentős része a szelvény szélén túl, nyugati irányban fekszik, de a feltárt területen is akadtak benne érdekes objektumok. Terepbejárásom során lehatároltam a település nyugati szélét, mely a semlyék peremével esik egybe, nem messze a feltárt rész nyugati szélétől. Véleményem szerint nyugati irányban ez volt az utolsó objektumcsoport. Két épület (az egyik talán megújítva) állhatott itt (128-132. objektum és 138-139, 143-148., 150-151. objektum). A 141. objektumból egy teljes profilú, fenékbélyeges tál töredékei láttak napvilágot. Ez a gödör, a 164. objektummal együtt paticstörmeléket is tartalmazott, a 164-esben a patics egy közbülső betöltési rétegben került elő. A felszíni megfigyelés során, a település peremén (a 3. csoport területén) egy bekarcolt, mészbetéttel kitöltött, sraffozott háromszögekkel gazdagon díszített, tálalóedény (mély tál vagy esetleg nagyobb korsó) töredéke került elö, amelyhez nagyon hasonló, ép darabot Ordacsehi-Bugaszegen tártak fel (Kiss, 2007, 221, 214. kép balról az első edény). A 164-es emellett kagylót is tartalmazott, csakúgy, mint az északabbra lévő 133-as gödör. A legkevésbé intenzív ez a csoport volt, bár feltételezhető, hogy a semlyék partjára 
támaszkodva itt voltak a kutak, és néhány gazdagabb leletanyagú hulladékgödörrel is számolni kell (a felszíni leletek nagy száma miatt).

4. objektumcsoport (37. ábra). Zömmel cölöplyukak alkotják, az 1-2. csoporttal összehasonlítva feltűnően kevés a hulladékgödör, amit a feltárás körülményei sem magyaráznak. Itt bukkantak rá egy 7x3,5 m-es alapterületü, ÉNy-DK-i tájolású cölöpszerkezetes házra (265-271. és 357-360. objektum, 1. ház). Mellette további, látszólag kusza összevisszaságban elhelyezkedő cölöplyukak találhatóak (349-356. objektum), esetleg a ház egy korábbi/későbbi periódusának tanúságaként, amikor az épület tengelye eltérő (NyK-i) volt (38. ábra). Északabbra néhány kevés vagy jellegtelen agyagot adó gödör és cölöplyuk mellett a szintén szegényes leletanyagú 329. és 331. gödör került elő. A kisméretü háztól keletre egy nagyobb cölöplyuk-csoportot tártak fel (245-264. és 361-363., 367. objektum). Ezt két épületként határoztuk meg (39. ábra). Az északabbi épület falait több kisebb, látszólag rendszertelen oszlophely mutatja, a fal vonalából kilógóak szerintem az öregedő épület falának külső és belső támasztékait jelzik. A másik egy kevesebb cölöpöt tartalmazó, világosan felismerhető falakkal rendelkező épület, melynek délnyugati oldalát a mély 246., 248. és 249. cölöplyukak jelölik ki. Az objektumcsoport déli peremén - gödrökkel körülvéve - két újabb, kétszer ugyanott megújított, ÉNy-DK-i tájolású cölöpház található (369-388., 390-391., 398. objektum, 40. ábra). Mindkét épület sarokpontjait igen mély (40-50 $\mathrm{cm})$ cölöplyukak jelölik ki. Az egyik ház alig tartalmazott halomsíros kerámiát, míg a másik legtöbb cölöphelyében voltak ilyenek. A második, kisebb háznak nem volt ágasfája, tengelye mintegy 25-30 fokkal észak felé eltért a korábbi ház tengelyétől, és ami különösen érdekessé teszi, hogy világosan megfigyelhető volt az osztófal három oszlopa (382-83., 386. objektum), melyek így két, kb. $2 / 3$ és $1 / 3$ arányú helyiségre tagolják a házat. Talán a másik háznak is lehetett osztófala. A közelben lévő 241-es gödörben kevés, tárolóedényekből származó kerámia mellett paticsot is találtak. Jelentősebb leletanyag ebből a csoportból nem került felszínre, a hulladékgödrök talán kelet felé, az ásatási szelvényen túl lehetnek.

Az a lehetöség sem zárható ki, hogy ennek az objektumcsoportnak a településen belül eltérö funkciója volt. A lakóépületek mellett a gazdasági tevékenység és a hulladékelhelyezés nyomai sokkal kevésbé intenzívek, mint a többi csoportban. Ha ez az elkülönülés valós, akkor a lakóegység funkciója a közösség kiemelkedő tagjainak (nemzetségfö és családja?) lakhelye, esetleg szakrális tér lehetett.

5. objektumcsoport (41. ábra). Ennek a csoportnak meghatározó objektuma a 211. számmal jelzett árok, amely egy 15-20 m-es ovális területet ölel körül, nyugati oldalán a bejárattal. Feltehetőleg karám lehetett. Sajnos csak kevés cserép került elő belőle, ezért az objektumot csak feltételesen lehet a Halomsíros lakossághoz kötni. Mégis erre utal az, hogy sok gazdag leletanyagot tartalmazó későbronzkori gödör veszi körül, s azok látszólag kikerülik. Közvetlen közelében több korai objektum is napvilágot látott, közülük a gazdag leletanyagú 402. gödör érdemel különös figyelmet. A feltáráskor a 402. és 403. objektum szuperpozícióját figyelték meg; a 403. objektum egyértelmủen vágta a 402-est, tehát a 402. korábbi volt. A 402. gödörben a Halomsíros kultúra nagy mennyiségü anyaga került elő, a 403-asban csupán néhány jellegtelen fazék- és bögretöredék volt, így ez a rétegtani helyzet nem segíti a település belső kronológiájának tisztázását. 
Az árok szerepére visszatérve, úgy véljem, hogy az objektumcsoportot használó közösség állatállományát, vagy annak egy részét tartották benne. Az egyes csoportok között világosan kirajzolódó nagyobb „üres” foltok mérete hozzávetőleg egyezik a karámárokéval, így nem lehetetlen, hogy ezek a területek is az állatok tartására szolgáltak. A talajerózió és a nehéz megfigyelési körülmények miatt ezek árkai - ha voltak - nem kerültek elő (a 211-es árok is nagyon sekély volt). Számolni lehet esetleg kerítésszerü, sürü karósorból álló karámokkal is, melyek sekély karólyukai bizonyosan elpusztultak. Így az állatállomány az együtt lakó csoportok foltszerü lakóterei között helyezkedhettek el a nyílt szerkezetü településen belül, jobb védelmi lehetöséget biztositva az állománynak. A fent vázolt kép markánsan különbözik a centralizáltabb társadalmak - a megelőző tell-kultúrák állattartásától, ahol a telep belső része körül kialakított néhányszor 10 m-es sávban tartották a faluközösség állatállományát (ez az ún. „black earth ring”, melynek létét HéhalomTemplomdomb esetében kimutatták, Bácsmegi-Sümegi, 2005, 172-172). Ez a birtoklási forma a lakosság vérségi kapcsolatai fölé emelkedő struktúra meglétét igazolja a középső bronzkorban (fönöki vagy másképp centralizált törzsi társadalom). A településen belül feltételezett többcentrumú állattartás - más, korábban kifejtett érvekkel (Sánta et al. 2007) együtt - egy olyan társadalomra enged következtetni, melyben a kisebb társadalmi struktúrák kerültek előtérbe a nagyobbakkal szemben, így a gazdálkodás és a vagyonbirtoklás a kisebb közösségek szintjén történt. Az állományt hatékonyabban lehetett védelmezni a rablók és a ragadozók ellen is.

A karámtól délre két cölöpház rajzolódik ki (42. ábra, 186., 192-198., 200-207. objektum), egyik (192-195., 200-206. objektum) az a kéthelyiséges épület, amelynek a nagyobbik, északnyugati helyiségének közepén egy gödörben (202. objektum) nagyobb, ép bögre (kiskorsó) töredékei láttak napvilágot. A jelenség több esetben előfordul a telepen, azt feltételesen építési áldozatként interpretáltam (lásd a Konklúzióknál). Az osztófalat a két ajtófélfa jelöli ki (194-195. objektum). Nyugatra tőle néhány hulladékgödörből (189-191. objektum) szegényes és jellegtelen Halomsíros kerámiaanyag látott napvilágot.

Ezek a most bemutatott objektumcsoportok minden bizonnyal egy-egy társadalmigazdálkodási egység, háztartás régészeti nyomát képezik. Bennük több ház (egyszerre 2 nagyobb és egy kisebb) is állhatott párhuzamosan, amelyekben szoros vérrokonok (nagycsalád, esetleg magukat egyazon őstöl eredeztetö ágazat tagjai) élhettek (Bodrogi, 1997). Tehát a Halomsiros kultúra alapvetö gazdálkodási egységeként ezeket az ágazatokat vagy nagycsaládokat jelölöm meg.

A cölöpszerkezetes épületek elemzése. Cölöpszerkezetes házak több helyről ismertek, így többek között Dunakesziről, Oszlárról, Kóny-Barbacsi tópartról, Gelseszigetről, Tatabánya-Bánhidáról. Ezek keltezése a BB1 és BD periódusok közötti szakaszt, tehát a halomsíros kultúra egész életét felöleli (Horváth et al, 2001, 119-123, Kalicz-Koós, 1997, Egry, 2002, 9-14, Horváth, 1994, 219, Kissné Cseh, 1996. 28-29).

Dél-Németországban, az Alpok előterében folytatott regionális kutatás során egy nagy kiterjedésü korai Halomsíros lelőhely feltárására is sor került. A Bad Buchau melletti Federsee partján épült Forschner 1 településen 14 házat sikerült azonosítani a feltárt mintegy 5000 cölöpmaradvány között. A házak mérete 3-4x6-8m, meglepően hasonlítanak a 4. 
csoportban található 2. házra. Az Oberpfalz tartománybeli Tannenhausenből ismert halomsíros település cölöpszerkezetes házai is ugyanekkorák, és itt megfigyelték az épületek legkevesebb kétszeri megújítását is. Az 1. csoport kisméretủ négyszögletes épületéhez (ól?) jelenthetnek analógiát a Hegauban és Heuneburgban feltárt 2,5-4 m-es, derékszögü cölöpépítmények. A nagyobb települések mellett kisebb, erődítetlen tanyák szolgáltak a kisebb közösségek szállásaként. Az urnamezős kor kezdetén jelennek meg ott is azok a hosszúházak, melyek hazai képviselői Dunakeszin (Horváth et al, 2001, 119-123) láttak napvilágot. A cikk írója kiemeli a halomsíros településkutatás elmaradottságát, és egyszersmind igazolja a halomsíros kultúra állandó falvainak és cölöpépítményeinek meglétét (Schauer, 1996. 469-476., Abb. 5-6.).

\section{Térhasználat analízis a tálak és a durvakerámia alapján}

A tálak és a fazekak a háztartásokban általánosan használt, de eltérő funkciójú edénytípusok. Azt vizsgáltam, hogyan oszlanak el térben a tálakat (is) és a túlnyomórészt vagy kizárólag durvakerámiát tartalmazó objektumok. Kiindulásképp feltételeztem, hogy az asztalra tálaláskor kerülő tálak a házak közvetlen közelében koncentrálódnak, s ugyanezt feltételeztem a főzés során használt durvább kerámiaanyagról is. A tálak térbeli elhelyezkedése valóban a házakhoz kötődik, azokat kikerüli, de sosem távolodik messze tőlük (43. ábra). Ez alól csak az 5. objektumcsoport kivétel, itt a település tálakban leggazdagabb objektumai (401-402.) a 211. körárok közelében kerültek elő. Ez az egyetlen kétséges - adat, mely arra utal, hogy mégsem karám lehetett az árok funkciója. Különösen az 1. és 2. csoportban ismerhető fel az a jelenség, hogy a tálak töredékeit tartalmazó szemetesgödrök kikerülik a házak foltjait.

Sokkal érdekesebb eredményre vezetett a túlnyomórészt vagy kizárólag durvakerámiát tartalmazó objektumok térbeli szeriációja (44. ábra). A település szemétgödreibe legtöbbször vegyesen került háztartási hulladék, tehát finom- és durvakerámia is. Ezek a gödrök tartalmazzák a direkt kidobott szemét jelentős részét, és természetesen a házak környezetében szóródnak. Azonban számos kisméretü objektum, döntően cölöplyuk tartalmazott kis mennyiségben kizárólag durvakerámia töredékeket. Sőt, a cölöplyukakban döntően ezek fordulnak elő. Odakerülésükre a legjobb magyarázat, hogy a szemét - pl. a kerámia - egy része a szabadban viszonylag hosszú ideig hevert, majd a házak lebontásakor, omladék eltakarításakor a betömött cölöplyukakba kerültek. Hasonló jelenség a recens paraszti udvarokban is megfigyelhető, ahol a kerámia egy része a gazdasági udvarban szabadon kallódik. Az ilyen kerámiák fokozott taposásnak, mechanikai és kémiai mállásnak vannak kitéve, így méretük fokozatosan csökken. Természetesen a legnagyobb mennyiségben a fözőés tárolóedények készültek, ráadásul nagy méretük folytán nagy mennyiségü kerámiatöredéket szolgáltattak, így a cölöplyukak ,,post mortem” betöltődésében való magas arányuk is érthető.

\section{Térhasználat analízis az állatcsont-anyag segítségével}

Az ásatás legtöbb objektumában találhatóak állatcsontok, az egykori étel kézzelfogható maradványai (45. ábra). A csonthulladék nem csupán direkt módon, az étkezés 
maradványainak eltakarításával került a szemetesgödrökbe, hanem - feltételezhetően - egy része az udvarokon, utcákon, kertekben taposásnak volt kitéve, s csak később, esetleg tereprendezés vagy takarítás alkalmával kerültek az objektumokba. Elhelyezkedésük követi a más módszerekkel kapott mintázatot, azaz a legnagyobb számban az 1. és 2., valamint 5. objektumcsoportban fordulnak elő. A 3-4. csoportokban nagyon kevés csontot találtak, de ugyancsak kevés a szemetesgödör is. Talán ez a zóna elsősorban lakóövezetként funkcionált. Ismét érdekes az 5. objektumcsoport, ahol az állatcsontokat tartalmazó gödrök a körárok körzetében fordulnak elő, és nem a házak körül. Itt az a törekvés figyelhető meg, hogy a hulladék a házhoz képest „,hátul”, északra, a karám mögött helyezkedjen el.

\section{Technológia - kerámiakészítés, fémmüvesség}

A régészeti tárgyak készítés-technikai vizsgálata nem új keletü, de a tipológiai megfigyelések mellett viszonylag kevés figyelmet fordítottak erre. Azonban ha az akkor élt közösséget, környezetével való viszonyát akarjuk megérteni, a technológia vizsgálata nagyon fontos. Colin Renfrew és Peter Warren az Égeikum kapcsán a társadalmak hagyományos, kulturális antropológiai rendszer-elméletét továbbfejlesztette (Sahlins, 1973, Warren, 1989, Renfrew-Bahn, 1999). E szerint az emberi kultúra olyan rendszer, mely bizonyos alapelemekből, a kultúra alrendszereiből épül fel, s ezek egy része nélkülözhetetlen, más részük nélkülözhető ugyan, de a Homo Sapiens Sapiens közösségek alapvető jellegzetessége. A közösség ismeretanyaga, a szellemi kultúra teljessége a generációról generációra továbbadott hagyományokból és a kultúrát ért pozitív innovációkból áll össze. Az alrendszerek közötti határ nem éles, folyamatos kapcsolatban állnak s alakítják egymást. A kultúra belső fejlődése a rendszerszemléletű megközelítés szerint az alrendszerek kisebb egységekre való strukturálódását eredményezi, tehát egy bonyolultabb, magasabban szervezett társadalom kultúrája sokkal több, kölcsönható rendszerből áll, és sérülékenyebb is. A kultúra alapvető alrendszerei a következők:

\section{Létfenntartás}

2. Technológia

3. Társadalom, társas kpacsolatok, rang és méltóság

4. Ideológia vagy szimbolika

5. Kereskedelem és csere

A kultúra hagyományrendszere szabályozza a létfenntartást azoknak a módszereknek az alkalmazásával és továbbadásával, melyek az élelmiszer előállításához vagy megszerzéséhez szükségesek. Ezek a tevékenységek eszközöket igényelnek, melyek elkészítésére, a hozzájuk szükséges nyersanyagok beszerzésére vonatkozó ismereteket és szabályokat a technológia alrendszere tárolja. A nyersanyagok és egyéb termékek beszerzéséhez a csere és kultúraközi kapcsolatok alrendszerében „tárolt” ismeretek szükségesek. Ez a három alrendszer tehát elsősorban funkcionális, és döntően a lét puszta fenntartását szolgálja, ezért létezésük elengedhetetlen. A társadalmi kapcsolatok alrendszere az egyének közötti kapcsolatokat rokonság, vezetés, rangok, stb. - vizsgálja. A csere és létfenntartás nem válik el élesen a társadalmi kapcsolatoktól (interakcióktól), hiszen a horda- és törzsi társadalmakban az élelmiszer és egyéb anyagi javak elosztása a rokoni szervezetben, gazdálkodási egységenként 
történik. Az anyagi javak, eszköz-nyersanyagok cseréje és beszerzése még akkor is társadalmi jellegű esemény lehet, amennyiben nem a saját csoporton belül, hanem egy másik csoporttal folyik a csere.

Az ötödik alrendszer, az ideológia foglalja magában a csoport világról alkotott elsősorban leíró jellegü - információit, különösen a természetfeletti jelenségekét (azaz azokét, melyeket adott ismereti szintjén, a modern fizika eredményeit nélkülözve nem tud természeti törvényekkel magyarázni), a hitvilág elemeit, a mondákat, mítoszokat, meséket, rítusokat, énekeket. Az ideológia vagy szimbolika alrendszere túlmutat a puszta létfenntartáson, de annak munkafolyamatait át- meg átszövik a babonás, rituális cselekvések - építőáldozat, edénydíszítési szimbolika, stb. Az alrendszer megjelenése a szimbolikus, elvont gondolkodásra való képesség kifejlődéséhez kapcsolható, ennek időpontjáról azonban vita folyik, feltehetőleg már a neandervölgyi ember is rendelkezett valamiféle szimbolikával és képes lehetett egyes elvont képzetek - pl. a túlvilág, ahogy azt a temetkezései mutatják absztrahálására.

Az archaeometriai és régészeti ökológiai vizsgálatok alapvető kiindulópontja az anyag, forma és funkció közötti összefüggés (46. ábra). E feltételeket vizsgálva jutunk közelebb a készítés-technika rekonstrukciójához.

A leggazdagabb leletcsoport a kerámia, mely valószínúleg helyi eredetü agyagból, különféle soványítóanyagok (homok, kő, tört, őrölt és szitált kerámia, szerves anyagok, talán hamu) felhasználásával készült. Kőleletek egyes esetekben sűrün, de a vizsgált településen csak nagyon ritkán kerültek felszínre, A fém leletek előkerülése nem gyakori, jelen esetben két fémtárgy látott napvilágot. Ami nem maradt ránk: a textil, fa, bőr. Ezeket - melyek az egykori tárgyi anyag akár 90 \%-át is alkothatta - mindig oda kell képzelnünk a kerámia-, kőés fémleletek mellé.

\section{A leletanyag kerámiatípusai és időrendjük}

Gondolatok a „régészeti tafonómiáról”

„Régészeti tafonómia” - avagy mi történik a tárgyakkal „haláluk” után? A tafonómia az elhullott tetemek betemetődésig tartó sorsát vizsgálja, mely döntő fontosságú annak kövületté válásában. Ha gyorsan eltemetődik, jól megőrződik a fosszília, ha lassan, akkor esetleg csak egy-egy csonttöredék vagy héjtöredék kerül elő. Így van ez a régészeti tárgyakkal is: ha gyorsan a földbe kerülnek, sokkal jobb esélyük van a fennmaradásra. És ahogy a gerinces paleontológiában a csontokra leselkedő egyik legnagyobb veszélyt a taposás és a fagy jelenti, a kerámia is ezektől szenved leginkább. A gödrökben sok esetben - így a feldolgozott telepen is - a legtöbb kerámiatöredék egyedi darab, nem illeszthető össze egy másikkal. Esetleg 2-3 darab illik össze csupán. Gyakoriak a kicsi, kopott, fagyásnyomokat mutató cserepek is. Ugyanakkor néha a gödrökből összeillő cserepek, esetleg ép edények kerülnek felszínre, ami gyors betemetődést, esetleg különleges szándékot (szakrális ok?) sejtet. A leggazdagabb leletanyagú gödröket a 47. ábra mutatja be.

Egy bronzkori településen számos edényt használtak egyszerre. Ezek egy idő után elkoptak, eltörtek, kicsorbultak - szemétbe kerültek. A szemét az udvaron vagy szemétkupacokban hevert, ott taposták, megfagyott és szétrepedezett. A másik része gyorsan 
gödrökbe került, ott betemetődött. A szétszórt, felszínen heverő anyag is gödrökbe kerülhetett egy idő után, de ott is maradhatott, és vagy beágyazódott a kultúrrétegbe, vagy az erózió kimozdította eredeti kontextusából. Végül a kerámia teljesen meg is semmisülhetett.

Az, hogy egy háztartásban egyszerre mennyi, és milyen edény volt, igen izgalmas kérdés, melyet a feltárt terület nagysága, intenzitása, a házcsoportok száma, a telep élettartama, valamint a típusok ismeretében meg lehet becsülni. Azt a durva becslést alapul véve, miszerint majd' minden egyes beleltározott tétel önálló edény, kb. 800-1000 kerámiaedényből származhat a feltárt leletanyag. A szám nem állhat messze a valóságtól, hiszen igen kevés tárgyat lehetett összeilleszteni, kiegészíteni, s ezek többnyire azonos leltári szám alatt találhatóak. Ez a mennyiség kb. 150-200 év alatt jött létre, azaz évente kb. 5 edényt dobtak ki - háztartásonként egyet. Így ez a szám máris igen alacsonynak hat, hisz a könnyen törő kerámia - különösen a fazekak - gyorsan fogyhattak, és pótolni is viszonylag egyszerü volt őket. A teljes településen - mely a feltárt résznél nagyjából 4-5-ször nagyobb összesen ezen idő alatt kb. 5000, esetleg 10.000 edény lehetett használatban. Ez csak az az anyag, ami a gödrökbe került: a taposott, rétegbe ágyazódott, majd a dózerral letakarított kerámiatöredékek mennyiségét még csak becsülni is nehéz. Talán ha háztartásonként és évenként 1 és 10 közötti „edény-fogyással” számolunk, nem járunk messze a valóságtól. Ez azt jelenti, hogy egy fazekasnak évente mondjuk 20-200 edényt kellett készítenie. Ha azt is figyelembe vesszük, hogy a fazekakat a háziipar is elkészithette, könnyen belátható, hogy az évi, nagyságrendileg 100 körüli edény nem igényelte „föállású” fazekas munkáját, a fazekasság csak , részmunkaidő” specializáció volt.

A primer módon gödörbe került nagyobb, összeillő darabokat egyben „dobhatták ki”, ezek mindig nagyobb fazekak és tálak (1. 230. objektum $50 \mathrm{~cm}$ átméröjü tálját, 320 . objektum fazekait és tálját, stb.), amiből arra következtethetünk, hogy egyszeri, nagyobb munkával járó főzési események (közös ünnepek) maradványaival van dolgunk, tehát eltemetődésük egyáltalán nem tipikus. 230. objektum esetében kizárólag a nagy tál töredékei voltak a gödörben, ez azt jelenti, hogy az objektum létrejötte egyértelmüen az étkezés (lakoma? ünnep?) utáni takarítás része volt. Valószínű, hogy a normál használat során elsősorban a fazekak, étkezésre használt tálak törtek leghamarabb. Egy nagyobb sürgéssel járó esemény alkalmával azonban sokkal nagyobb volt az esélye a különlegesebb, nagyobb edények törésének, melyek önmagukban elég nagy bosszúságot okozhattak a háztartás vezetőjének, és a nagy tömegü cseréphulladék (esetleg az étel hulladékával együtt) önálló gödörbe került. A kallódó szemét minden bizonnyal alkalmanként, egy-egy takarítás után került gödrökbe, így sok edény 1-2 darabja került egymás mellé. A 479. objektum egy ép pithoszt, tárolóedényt rejtett, a gödör eredeti funkciója a belé ásott edényben történő tárolás volt. Ugyanakkor a gödörből számos kisebb, össze nem illő cseréptöredék is felszínre került, nem túl nagy mennyiségben. Ezek a gödör felhagyása és betemetése után kerülhettek oda, miután egy darabig a felszínen hevertek.

\section{A típusok elemzése és datálása}

A településen előkerült kerámiaanyag számos edénytípust képvisel, melyeket a régészet hagyományos, formán és díszítésen alapuló tipológiai módszerével osztályoztam, meghatároztam a kerámialeletek kulturális és időrendi összefüggéseit, kidolgoztam a 
táltípusok egy lehetséges tipokronológiai sorozatát, s felvázoltam a település belső időrendjét (a részletes tipológiai rendszert terjedelmi korlátok miatt a Mellékletekben, külön Tipológiai Táblázatként csatolva közlöm.). Ezek nyomán a település beilleszthetővé vált a Dél-Alföld, s tágabban a Kárpát-medence hasonló korú lelőhelyei közé.

A rendszerben 7 alapvető edénytípust és közöttük számos altípust különítettem el. A típusok - a temetkezésekkel összevetve - jól fedik a korszak teljes kerámia-repertoárját, annak ellenére, hogy az egyedi tárgyak reprezentációja viszonylag kicsi, egy-egy típust néha csupán egyetlen töredék képvisel. A kerámiatípusokkal történő datálással a Konklúziókban is foglalkozok, ahol a lelőhelyet más, dél-alföldi lelőhelyekkel hasonlítjuk össze.

\section{Asztali edények}

\section{A-Bögrék, korsók (48. ábra)}

Folyadékok tálalására és fogyasztására alkalmas, egyfülü edények. Formáik nagyon hasonlók, eltérés csak a méreteikben adódik. Magasságuk legtöbbször 7-8 cm és 20-25 cm közötti, kidolgozásuk jó, felületük simított vagy fényezett. Vékony falúak, őrölt, szitált kerámiával (samott: 0,3-3 mm szemcsenagyságú, jól osztályozott zúzott, szitált kerámiából álló soványítóanyag - Véninger Péter szóbeli közlése), vagy ritkán homokkal soványítottak. Legtöbbször díszítetlenek, illetve bütykökkel díszítettek, bekarcolt, böködött, plasztikus dísz igen ritka. A bütyöklábas korsó (48. ábra 1.) a telep régészeti kormeghatározására igen alkalmas. A koszideri korszak jól ismert tárgytípusa, mely felbukkan a késő magyarádi kultúrában (Točík, 1978, Typ A2-5), a Vêtêrov-kultúra böheimkircheni csoportjában (Benkovksy-Pivovarová, 1976, Abb. 2, 6, 11), korai Halomsíros környezetben (Dušek, 1969, Abb 7. etc., Kovács, 1997, Egry, 2002, 9. kép 4, 7. stb.), valamint koszideri korú tell-kultúrák leletanyagában is (Kovács, 1988, Abb. 4. 2, 10, Schreiber, 1967, 1. kép 2., Kiss, 1997, 5. kép 2.). Használata azonban nem tart sokáig, a BB2-BC korú leletek között már nem találkozunk vele (hiányzik a nagy sírszámú temetőkből: Kovács, 1975, Trogmayer, 1975, Csányi, 1980).

A 49. ábrán a szeged-bogárzói temető néhány korsó- és bögretípusát tanulmányozhatjuk. A telep egyes formáival való nagyfokú hasonlóság feltűnő (különösen a 48. ábra 2.). A 48. ábra 5. számú kiöntőcsöves korsótöredék analógiái azonban klasszikus (Tápé-Széntéglaégető, Trogmayer, 1975) és késői (Németbánya, Ilon, 1996) leletegyüttesekből láttak napvilágot, így ez a tárgytípus a telep későbbi szakaszára datálható. Analógiák alapján a 48. ábra 4. bögre is a telep késői szakaszára keltezhető (Tápé, Trogmayer 1975, Csorva, Trogmayer 1963, stb.). A részletes kronológiai elemzést a Konklúziókban közlöm.

\section{B - Tálak \\ B1 - Csonka kúpos tálak (50. ábra) \\ B2 - Mély tálak (51. ábra 1.) \\ B3 - Svédsisak alakú tálak (51. ábra 2.)}

Szilárd és folyékony étel tálalására és fogyasztására alkalmas asztali edények, illetve feltehetően bizonyos ételek (tészták, kásák, stb.) elkészítéséhez használt keverőedények. A tálak anyaga jó kivitelü, de nem olyan jó, mint a bögréké, korsóké, illetve ezen a téren nagy különbségek vannak közöttük. Igen finom anyagú, jól kidolgozott tálak mellett nem ritkák a durvább, nagy átmérőjü, vastag falú tálak sem. Belsejük minden esetben fényezett (néha igen 
magasan), míg külső részük legtöbbször elsimítva sincs, csak ritka a fényezés, és szintén ritka a tudatos durvítás is (pl. a 230. gödörben). A belső oldal fényezése a tál tisztán tartását segítette.

A tálak formákban gazdagok, különösen a perem és a bütykök kialakítása változatos, melyek alapján a település keltezéséhez adatokat kaptam. A kissé behajló, perem alatt bütyökkel ellátott és a vízszintesen levágott, vízszintesen kihúzott csücsökkel rendelkezö tálak térben és időben legközelebbi, tökéletes párhuzamait a szeged-bogárzói temető ( 52 . ábra) leletei között találtam meg, amelyet a korszak kutatói egyöntetüen a Dél-Alföld legkorábbi Halomsíros leletcsoportjába sorolnak (Foltiny, 1957, V. Szabó, 1999, stb.). A többi táltípus keltezéséhez nem sok adat van, azok hosszú időn keresztül használatban lehettek. Ahogy az 50. és 52. ábrán láthatjuk, a szeged-bogárzói temető és a vizsgált település táltípusai, ezek peremprofiljai és a rajtuk alkalmazott technikai megoldások (perem- fül és csücsökkiképzés, bütykök használata) lényegében azonosak, a legtöbb objektumból ezek a táltípusok kerültek elő, profilált peremü, talán kissé későbbi típus (50. ábra 8) csak néhol fordul elő. Leggyakoribb a félgömbös testü, egyenes, csücskökkel ellátott peremü tál, bütykökkel vagy anélkül (50. ábra 2, 4-6, 9-10).

A tálakon szinte kizárólag plasztikus díszítést alkalmaztak ebben a korban, a domaszéki településen nincs is olyan, melyen karcolt dísz fordulna elő. A leggyakoribb elem a peremből kihúzott csücsök, mely háromszög alakú, és vagy egyszerü, lapos forma, vagy kívül, belül, esetleg mindkét oldalon egy bordával tagolt. A csücsök állása lehet vízszintes, vagy ferde, esetleg ívesen kihajló. A csücsköt ritkán középen kifúrják (479. objektum), amely a bogárzói temetőben (Foltiny, 1957) fordul elő térben és időben legközelebb (52. ábra 2). A perem alatt, a csücsök két oldalán néha előfordul vízszintes rés (50. ábra 10.), illetve egy urnaperemen kerek, fúrt lyuk. Igen figyelemre méltó, hogy szinte az összes táltípus és ezek formajegyei - csonka kúpos és behúzott peremü, peremen egyszerü vagy kettös csücsökkel tagolt formák, perem alatt bütykökkel ellátott típusok, kifúrt csücsök, réselés megtalálhatóak a Vatya kultúra Dunaújváros-Duna-dülöi temetőjében, méghozzá mind Vatya-Koszider, mind Halomsíros környezetben. Söt, a Vatya és Halomsíros sírok leletanyaga olyan hasonló egymáshoz, hogy feltétlenül kontinuitást kell feltételeznünk (Vicze, 2011, Pl. 171-229.). Ezek alapján a vizsgált település leletanyagát még egyértelmübben származtathatjuk a Vatya fazekasságból.

A lelőhelyek részletes összehasonlítása, melyet a konklúziókban ismertetek, a táltípusok vázlatos sorrendjét tisztázza, és segíti a település keltezését. A belső kronológia kialakítása önmagában, a település leletei segítségével, meglehetősen nehéz a szuperpozíciók ritkasága miatt. A táltípusok elterjedését az 53. ábra mutatja be.

\section{C-Urnák és urna alakú edények - Amforák (54. ábra)}

Víz és más folyadékok hosszabb távú tárolására alkalmas edények. Anyaguk többnyire jó minőségű, durvább vagy finomabb őrölt (és gyakran szitált) kerámiával soványított agyag, de kidolgozásuk és felületkezelésük a tálakéhoz hasonlóan elég változatos. A szükebb szájú, porózus anyagú amforákban a víz a pórusokon történő lassú párolgás miatt hűvös maradt. A legfinomabb, sárgára, vagy világosszürkére égetett, fényezett felületü darabok mellett sok a gyatrább minőséget tükröző áru. Gyakori a belső oldal fényezése, illetve néha az urna alsó 
részén seprüzés mutatható ki. Többnyire bütyökdíszesek, csak ritkán van rajtuk bekarcolt vagy plasztikus díszítés.

Jellemző tulajdonságuk, hogy töredékes formakincsük, peremprofiljaik alapján keltezésre nem, vagy csak korlátozottan alkalmasak, egymáshoz nagyon hasonló amforák több korábbi és későbbi kultúrára is jellemzőek (Vatya-kultúra: Bóna, 1975, Bóna-Nováki, 1982, újabban Vicze, 2011, Halomsíros-kultúra: Kovács, 1966, Trogmayer, 1975, stb., Urnamezős-kultúra, Gáva-kultúra: Köszegi, 1988, Kemenczei, 1984, stb.)

\section{D - Csuprok (55. ábra)}

Kisméretü, kétfülü vagy fületlen, ételek melegítésére, tárolására, felszolgálására alkalmas edények. Anyagukban és kivitelükben nem különböznek a fentiektől. A telepen talált töredékeik díszítetlenek voltak. A kétfülű csuprokkal számos, eltérő korú Halomsíros leletegyüttesben találkozhatunk (Bogárzó, Tápé: Foltiny, 1957, Trogmayer, 1975, stb.), így ezek a település keltezését nem segítik. A 336. objektum fazékszerü csupra (bögréje?) egyszerü formája és töredékessége miatt nem keltezhető.

\section{Funkcionális vagy házi kerámia.}

\section{E-Fazekak (56. ábra)}

Étel elkészítésére (főzésére), készétel melegítésére alkalmas edények. Anyaguk minden esetben durvább (általában 1-5 mm) kiégetett és összetört kerámiaszemcsékkel soványított agyag, de minőségükben különbségek tapasztalhatók. Leginkább felületkezelésben térnek el az asztali edényektől, bár néha átmeneti típusok figyelhetők meg (egyfülü csuporfazekak, melyek előfordulására azonban nincs konkrét bizonyíték településünkön). Felületük kívül legjobb esetben elsimított, de leggyakrabban fröcskölt vagy elkent barbotin, seprüzés, fésüzés durvítja. Gyakori a rövid, peremből induló fül, a bütykös peremkiképzés és a nyak alatt felrakott ujjbenyomkodásos bordadísz. Belsejük ugyanakkor sokszor simított vagy fényezett.

Az erős soványítás a formálhatóság és a hőállóság biztosítását szolgálja, mind az égetés, mind a főzés során. A felületkezelésre használt bevonó anyag pépes, szerves anyaggal, homokkal vagy apró szemü zúzott kerámiával igen erősen soványított massza volt. A pép erős soványítására azért volt szükség, hogy száradáskor le ne repedezzen a felületről. Ez a massza alig zsugorodik száradás és égetés során, szemben a gyorsan lerepedező kövér agyaggal.

\section{F - Tárolóedények - Pithoszok (57., 58., 59. ábra)}

A pithoszok nagyméretü, kb. 60-100 cm magas, 30-50 cm széles, vastag falú edények, melyek szilárd táplálék (gabona) tárolására szolgáltak. Több esetben a földbe ásták őket, ahogy a vizsgált településen is előfordult (55. ábra, 479. obj.). A pithoszok a fazekaktól méretükben különböznek leginkább, illetve abban, hogy sosincs fülük, csak fogóbütykök találhatóak rajtuk. Emellett formailag is változatosabbak. Anyagukban, felületkezelésükben alig térnek el a fazekaktól. Peremkiképzésük érdekessége, hogy szinte mindig megvastagodóak, vízszintesen levágottak. Belső oldaluk legtöbbször simított vagy fényezett.

Készítéstechnikájuk sajátossága: A tárolóedények anyagába durvább szemü (akár 10 mm-t is meghaladó méretü) tört kerámiát kevertek soványító anyagnak. Ennek célja itt nem a hőtartás biztosítása, hanem az edény készítésével és kiégetésével függ össze. Erősen sovány (,agyonsoványított”) agyagból lehet csak nagyméretű edényeket készíteni, mert a durva 
kerámiaszemcsék fokozzák az agyag mechanikai szilárdságát felrakás közben, ugyanakkor plasztikusságát csökkentik, kidolgozási idejét növelik. Így csak igen egyszerü formák voltak előállíthatók. Nem tudjuk, hogy a készítés során egy sekély gödörben kezdték-e felrakni az edényt, vagy szabadon formálták, mindkettőnek megvan az előnye. A hordóforma azért előnyös, mert saját súlyát jobban elbírja az edény. Az erőteljes soványítás az égetéskor is előnyös. Tárolóedényeket nem tudtak fazekaskemencében égetni, a nagy edények nem fértek el bennük, ezért csak gödörégetéssel tudták kiégetni őket. Az eljárás során jókora gödröt ásnak az égetendő edények számára, majd abba az agyagtárgyakat a tüzelővel együtt felhalmozzák. A meggyújtott máglya elhamvadásakor földdel borítják és hagyják lassan kihülni. Mivel a gödör a felfütéskor nyitott és a hő eloszlása is egyenetlen, csak azok a kerámiák égethetők jól az elrepedés veszélye nélkül, melyek annyira soványak, hogy alig mutatnak méretváltozást. Ugyanezért jók a kaviccsal erősen túlsoványított edények (Dunántúl, Kreiter, 2006, 2007). A kerámiavizsgálatok általában nem érintik a készítéstechnikát, és ezek a gyakorlati fogások nincsenek leírva. Az SZTE Régészeti Tanszékén Véninger Péter tartott gyakorlati szakkört kerámiakészítés technikai fogásairól, valamint végeztünk együtt készítéstechnikai kísérleteket. A tárgyak anyagába kevert, egyszer már kiégetett kerámia már nem zsugorodik, és hőállóbb. Természetesen minél soványabb és hőállóbb volt az eredeti kerámia, annál inkább szívesen törték össze a darabjait és keverték az új tárolóedényhez használt agyagba. Ez a magyarázata, hogy a soványításra használt töredékekben is látszanak régebbi, szintén soványításra használt darabok. Ehhez a folyamathoz kapcsolódhattak rituális gondolatok, de összességében nem erről van szó. A nagyfokú soványítás, korábbi hasonló edények darabjaival, elsősorban technológiai fogás, ugyanakkor az a vélemény is napvilágot látott, miszerint a soványítás speciális időfelfogásról tanúskodik (Kreiter, 2007). Mivel az őskorban ezek általánosan ismert fazekas-fogásoknak számítottak, a régészeti csoportok jellemzésére, történeti következtetések levonására is csak erősen korlátozva használhatók - ha használhatók egyáltalán.

\section{G-Különleges típusok, funkcionális kerámia (60. ábra)}

A háztartásban használ funkcionális edények, melyeket ételek előkészítéséhez, sütéséhez, illetve a tűz őrzéséhez használtak, általában nem önmagukban. Legfontosabb típusaik: szürők, hordozható tűzhelyek, parázsborítók, halsütő tálak, fedők. Funkciójuktól függően anyaguk jobb vagy rosszabb, de inkább a fazekak kiviteléhez állnak közel. A bronzkor, de többnyire az egész őskor folyamán használták ezeket, a messzemenően funkcionális tárgyakat. Kivételt a pyraunosok (hordozható katlantüzhelyek, 60. ábra 2-3) képeznek, melyeket a középső bronzkor jellegzetes tárgyainak tartottak, de az újabb elemzések szerint a késő bronzkorban és a kora vaskorban ugyanúgy jelen vannak (P. Fischl et al, 2001). A településen előkerült, valamint a környék több Halomsíros településéröl ismert pyraunos-töredékeket jellegzetes, a tárolóedényekére jellemző anyaguk, erős kiégettségük és a $2 \mathrm{~cm}$ körüli átmérőjü, peremes lyukak alapján lehet azonosítani. Töredékességük miatt eddig csak a 401. objektumból előkerült peremes példányt (60. ábra 2) sikerült a jelzett cikk alapján pontosabb típusba sorolni, ez a Brno-Obranyban előkerült darabhoz hasonlít leginkább, melyet az Urnamezős kultúrába sorolnak. A cikk a Halomsíros kultúrából egy, ausztriai darabot közöl (Deutschkreutz, Sopronkeresztúr, RBD-Ha A, P. Fischl et al, 2001, 
Abb. 7. 35, 33.). A Halomsíros kultúra Csongrád megyei anyagában TápéKemeshát/Szőlőföldek lelőhelyről kerültek elő további pyraunos-töredékek. Hódmezővásárhely határában, egy M43-as autópályához kötődő célkitermelőhelyen folytatott ásatásán Csányi Viktor talált egy érdekes bronzkori leletegyüttest, mely az elözetes vizsgálatok alapján a Rákóczifalva-kultúra emlékanyaga. Ebben több, pyraunoshoz tartozó töredék is napvilágot látott (a leletanyag vizsgálatát én végzem Csányi Viktor szíves engedélyével).

A szürő (58. ábra 4) és a parázsborító (60. ábra 1) a korszak anyagában ritka lelet, analógiáik a középső bronzkorban kereshetők (Bóna, 1975). Néhány újabban közölt, középső bronzkor végi, illetve korai Halomsíros leletegyüttesben is megtalálhatók (V. Vadász, 2001, 18. t. 4-5).

A halsütő tálak ovális, viszonylag alacsony oldalú, lapos aljú edények, melyek étel sütésére szolgáltak. Méretük széles skálán mozog, a domaszéki példány (60. ábra 5) a kisebbek közül való. Gyakorta csónakmodellnek vélik, valamint felmerült az is, hogy mécsesekként szolgáltak. Erre azonban nem utalnak felületükön kormos vagy másodlagosan átégett foltok, így nem lehettek magas hőmérsékletnek, kormozó anyagnak kitéve. Ilyen halsütő tálak számos középső bronzkori lelőhelyről ismeretesek (Bóna, 1975). A SzegedAlsóközpont-Dobó(-tanya) mellett elökerült anyagból is ismerjük (13. ábra 10), ennek kora klasszikus Halomsíros kultúra. Egyetlen, fedőként értelmezhető töredéket találtam a leletek között, mely szórványként került elő (60. ábra 6).

Összefoglalás

A V. Vadász Éva által közölt Dunaalmás-foktoroki késő Mészbetétes és kora Halomsíros telep több jellegzetessége megvan a domaszéki település anyagában is: fedők, pyraunos-töredékek, B1b és B1c-d típusú tálak, kívül bordás csücsökdíszítés, kettős, ívelt bordadísz (V. Vadász, 2001, 14., 17-18. tábla). A fejezetben elmondottak, az idézett párhuzamok és a bogárzói temető tárgyaival elvégzett összehasonlitás alapján a település életének kezdetét a középső bronzkor záró szakaszára, a koszideri korszakra teszem (Sánta, 2009), a végét pedig a Reinecke C idöszakra, annak elejére datálom. A telep élete a Reinecke BB1 második felére, végére és a teljes BB2 szakaszra (abszolút értékben 1550/1500 és 1400/1350 cal BC között), nagyjából 150-200 esztendőre terjedt ki. A fenti datálás egyik alapja a kannelúrázás, grafitozás és síkozás teljes hiánya, mely alapján a Reinecke D időszakot, de talán a $C$ javarészét, végét sem érte meg a teleprészlet. A települést a környék további Halomsíros és pre-Gáva lelőhelyeivel hasonlítom össze a Következtetésekben. A 61. ábrán a leletanyag kifejezetten korai jellegzetességeinek elterjedését mutatom be. A telep kerámianyagának kontextuális szeriációját a 2. táblázaton mutatom be. 


\section{Környezetrégészeti eredmények}

\section{A településen mélyített fúrás geokémiai elemzése}

2008. 11. 23-án Dr. Sümegi Pállal geoarcheológiai (talajtani) fúrást végeztünk a lelöhelyen (62. ábra). Mivel az M5-ös autópálya ekkor már megépült és használatban volt, a lelőhely azonosítása nem tünt könnyü feladatnak. A rendelkezésre álló $M=1: 10.000$-es térkép (KÖH Adatbázis M5/81. lh.) és a lelőhelyről készített légifelvételek segítségével sikeresen megtaláltuk a lelöhelyet, ahonnan kizárólag Halomsíros cserepeket gyüjtöttünk az autópálya kerítése és a semlyék közötti sávból, a lelőhely nyugati széléről.

A talajfúrást Orosz-fejes kézifúróval végeztük. $40 \mathrm{~cm}$ mélységben elértük az alapkőzetet, felette barna színű humuszos homoktalaj A és B szintje helyezkedett el. A két talajréteg élesen vált el egymástól. Határuk $20 \mathrm{~cm}$ mélységben található. Az A szint barna színü, nagyobb rögös szerkezetű homoktalaj. A B szint szemcsékre széteső világosbarna homok. A $\mathrm{C}$ szint sárgás-barnás színű mállatlan homok. Éles határ nem húzódik a $\mathrm{B}$ és $\mathrm{C}$ szint között. A talaj kialakulása és az A/B szint éles határa a szántóföldi művelésnek köszönhető (szántás határa, eketalp), vékony kifejlődése a homoktalaj erős eróziójának tudható be. Valószínü, hogy a talajfelszínen mélyszántás nem történt. A talajt alkotó homok a sztereobinokuláris mikroszkópos vizsgálatok szerint közép- és aprószemü, lekerekített szemcsékből álló eolikus, kötött futóhomok, mely a pleisztocén Duna hordalékkúpjából származik, és jégkor végi (Würm időszakra tehető) homokmozgások révén rakódott le a térségben.

Szervesanyag- és karbonáttartalom-vizsgálat

A vizsgálatot a módszertani részben leírtak alapján végeztem el Páll Dávid geológus PhD hallgató iránymutatásával, önállóan. Eredményeimet a 2. táblázat és a 63. ábra mutatja be.

Az adatok a talajfúrásnál egy alacsony szervesanyag- és közepes karbonáttartlamú talajt mutatnak, $-20 \mathrm{~cm}$-nél egy világos talajkémiai határvonallal, ahol a szervesanyag mennyisége 1,5\%-ra, a karbonát 1\% alá csökken. Ez a B szint határa, ahonnan ezek az alkotórészek kimosódtak.

Az A szintben bekövetkező karbonát dúsulás enyhe szikesedést jelez. A fúrás talpa fölött $5 \mathrm{~cm}$-rel kezdődik (35-40 cm-es mélyégben) a $\mathrm{C}$ szint, itt a szervesanyag mennyisége $0,1 \%$ körüli értékre csökken, a karbonáttartalom növekedésnek indul (2\%). Az alapkőzet alacsony karbonáttartalmú, kissé vasas (sárgásbarna színű) homok.

Nedves kémiai analízis

A talajmintákat nedves kémiai módszerrel tártam fel és lángfotometriával elemeztük (Gulyás Sándorral). A mérés eredményeit a 3. táblázatban foglaltam össze.

A település mintái 9-16. számmal szerepelnek a 2. táblázatban, s azonnal szemet szúr a 9-12. minta kiugró kalcium-tartalma. Ez a talaj A szintjében kivált kalcitot jelzi, mely a talaj rögeit is cementálja, megadja szerkezetét. A karbonátok mennyisége a mállás és talajosodás következtében erősen lecsökken, ezzel párhuzamosan a Ca és a Mg tartalomban is visszaesik. A magas kalcium tartalom ezért a talajművelés eredménye is lehet (talajjavítás). A 
magnézium az 5-10 cm-es szintben dúsul és mutat excesszust (1000 ppm), a felső $20 \mathrm{~cm}$-es szint többi rétegében a normál érték felső határa közelében van (5-600ppm).

A nátrium gyenge szintemelkedést mutat a felső $10 \mathrm{~cm}$-es rétegben, de ez nem kiemelkedő.

A $\mathrm{K}$ és a $\mathrm{Na}$ mennyisége egymással fordított arányban változik. A $\mathrm{Na}$ a K-mal ellentétben könnyebben mobilizálódik, így a talajosodott szintekben a $\mathrm{Na}$ koncentrációja erősen lecsökken. Ennek következtében a K/Na arányban tapasztalható kiugró csúcsokból jól kirajzolódnak az egyes talajosodott zónák. A felső $20 \mathrm{~cm}$-es réteg egyértelműen talajosodott zóna.

A vas a talaj 5-10 cm-es szakaszán jelentős dúsulást mutat. A mállás fokozódásával az Fe mennyiségének a növekedése tapasztalható. Eolikus homokban a vas hordozóásványai általában vastartalmú szilikátok (csillámok, piroxének, amfibolok, stb.) és esetleg nehézásványok (almandin, magnetit, spinell, hematit) apró frakciói. A mállás során a szilikátokban található vas feloxidálódik, leggyakrabban limonit, klorit, goethit keletkezik. Ezek a vasoxidok általában stabil kolloidok, vagy agyagásványokhoz és szervesanyaghoz kötötten jelenik meg. A vastartalom növekedésével párhuzamosan növekszik a $\mathrm{Mn}, \mathrm{Zn}, \mathrm{Cu}$, $\mathrm{K}$ valamint a $\mathrm{K} / \mathrm{Na}$ mennyisége, ahogy a táblázatban is látható.

A vastartalom változásával szoros kapcsolat mutatható ki a Mn változásában is. Ennek oka, hogy a $\mathrm{Mn}^{2+} \mathrm{Mn}^{4+}$-á oxidálódik. Ezt a folyamatot jelentős mértékben felgyorsítja a vasoxidokon és agyagásványokon lezajló adszorpció. Mivel a $\mathrm{Mn}^{2+}$-al szemben a $\mathrm{Mn}^{4+}$ vízben rosszul oldódik, ezért ez az elem a Fe-hoz hasonlóan a mállottabb szintekben halmozódik fel.

A Cu-t a homokban, lösztartalmú homokban előforduló ásványok közül leggyakrabban az olivin, cirkon, amfibol, gránát, plagioklász, biotit, klorit és kaolinit tartalmazzák, mállás során ezekből az ásványokból szabadul fel. A $\mathrm{Cu}^{2+}$ abszorbeálódik az agyagásványokon, vasoxidokon és szerves anyagokon, emiatt a talajosodott szintekben megnövekszik a mennyisége. A réztartalom mindenütt egyforma a talajszelvényben, ezért a jelenleg megfigyelhető állapot nem lehet természetes folyamat eredménye. A réz azért is érdekes elem, mivel a bronzkori településen elvileg foglalkozhattak réz- és bronzművességgel, amit a 30 ppm-es excesszus akár alá is támaszthat. A réz a jelenkori vagy közel recens talajmúvelés (elsősorban a 19. századi szőlőmüvelés - rézgálicos permetezés!) révén is a talajba juthatott, valamint a vastartalom növekedésével is feldúsul. Tehát jelenleg nincs adatunk arra nézve, hogy a réz a bronzkorban került volna a rendszerbe, sőt, valószínübb, hogy másodlagos, antropogén hatások miatt emelkedett meg a mennyisége.

A Zn mennyisége a $\mathrm{K}, \mathrm{Fe}, \mathrm{Mn}, \mathrm{Cu}$ és a szervesanyag tartalommal mutat hasonlóságot. A kalciummal erősen negatívan korrelál. A Zn mobilitása alacsony, agyagásványokon, vasoxidokon, és szerves anyagon abszorbeálódik, ezért a talajosodott szintekben mért mennyisége nagyobb, mint az üledékben. Ez a talajszelvényben nem jól látható, de összevetve a tőle 50 m-re lévő semlyék üledékes rétegsorának Zn-tartalmával, ott feleakkora értékeket találunk. 
Összegzésként elmondható, hogy a település régészeti leletanyagát magában foglaló talajréteg gyengén talajosodott, rosszul fejlett, vékony talajszintekkel rendelkező homoktalaj, melyben világos emberi beavatkozás látszik.

\section{Értékelés}

A lelőhely talaja alig kötött, nagy homok-tartalmú, bolygatott állapotában erózióra rendkívül hajlamos. A szervesanyag-karbonáttartalom alapján elváló igen éles B/C szint határt az eketalpként értelmezhető, ami igen vékony talajt, gyenge talajosodást jelez, és folyamatos talajeróziót feltételez. A lelőhely szempontjából ennek három következménye van. Egyrészt a bronzkorban feltehetően még kötött homokbucka felszínét ért bármekkora bolygatás azonnal erős talajeróziót indított be, mely valószínüleg felelős a semlyékben kifejlődött tavi rendszer gyors feltöltődéséért (lásd bővebben a semlyék fúrásánál). Másrészt a gyenge talajon csak igénytelenebb, szárazságtürő növényeket termeszthettek (árpa). Harmadrészt a régóta müvelés alatt álló lelőhely-felszínen magát a régészeti lelőhelyet és objektumokat igen erős károsodás érte. A talajrétegben kb. $20 \mathrm{~cm}$-es szikesedést mutató humuszréteg (A-szint) található, és egy 30 ppm-es $\mathrm{Cu}$-excesszus vonul végig egyenletesen a szelvényen, amit utólagos emberi hatásnak (19-20. sz-i rézgálicos permetezés) tulajdonítunk. A Ca-escesszus is emberi hatásra, talajmüvelésre alakulhatott ki (rigolírozás - $\mathrm{CaCO} 3$ vagy CaSO4). A Ca valószínűleg nem eredhet a $\mathrm{C}$ szint kissé meszes homokjából, mivel a tavi rendszerben a talajvízszint alatt cirkuláló oldatok inkább Mg-dúsak (recens dolomitképződés!), és egy felfelé vándorló oldatban egyértelműen nagyobb $\mathrm{Mg}$ koncentrációt kellene mérnünk. Ezzel ellentétben a Ca mennyisége kétszerese a Mg-nak. A rigolírozás, mint talajmüvelés, kalcium-karbonát, vagy vízmentes kalcium-szulfát (anhidrit) talajba keverésével történik.

\section{A semlyékben mélyített fúrás eredményei}

A semlyékben lévő fúrást $90 \mathrm{~cm}$ mélységig, a fehér színű, mésziszap eléréséig mélyítettük. A fúrás rétegsora a következőképp írható le:

1. 0-10 cm. Humuszos, gyengén talajosodott tőzeg - Sh2Th2 (Troels-Smith, 1955)

2. 10-60 cm Humuszos, eutróf tavi üledék - Sh1 As3

3. $60 \mathrm{~cm}$ alatt tavi mésziszap apróhomokkal (0,06-0,6 mm) - Lc2Ga2

A mintákat kiiszapoltam, de bennük nem találtam jelentősebb mennyiségű ősmaradványt. A minták 0-40 cm-ig (1-4. minta) Mollusca szempontból sterilek, de sok tőzegesedett növényi szár- és gyökérmaradványt tartalmaznak. A 40-60 cm-es szint (5-6. minta) Mollusca héjtöredékekben viszonylag gazdag, de ép héj nem gyüjthető, a minta kis térfogata miatt elemzés nem lehetséges.

Szervesanyag- és karbonátttartalom-mérés (2. táblázat, 64. ábra)

A sorozatban a szervesanyag folyamatos, kvázilineáris csökkenése tapasztalható a 6 . mintáig, ahol a csökkenést stagnálás váltja fel, sőt a legalsó mintában csekély növekedés mutatható ki. Ez a szint már teljesen fehér színü, karbonátiszappal gyengén cementált apróhomok, melyben mikroszkóp alatt sem látszik szerves törmelék, sem Mollusca héj. A 
karbonát-tartalom már a tőzegben is elég magas, $10 \%$ körüli, s az 5. mintában $(40-50 \mathrm{~cm})$ egyértelmű dúsulást (15\%) mutat, majd az alsó rétegben 13\% körül állandósul.

Nedves kémiai analízis (4. táblázat)

A látható üledékföldtani jegyeken kívül a 7. mintában $(60-70 \mathrm{~cm}$, a mésziszap felső szintje) kimutatott egy jelentős Ca-, Mg-, Fe-, Mn-dúsulást (a felette és alatta lévő réteghez képest 2-3-szoros mennyiség). Ez a 60-70 cm-es szint a talajvíztükör átlagos szintjével feleltethető meg, ahol a talajvízmozgás hatására vashidroxidos és karbonátos kicsapódás történik. A mangán mint a vashoz kapcsolódó elem, szintén itt dúsul (lásd feljebb). Ennek a talajvíztükörnek a kialakulása a folyamszabályozások és a mocsárlecsapolások miatt lecsökkenő talajvízszint számlájára írható.

A $\mathrm{Ca}$ és $\mathrm{Mg}$ aránya eltér a talajszelvényben tapasztaltaktól, hiszen a magnézium mennyisége mindenütt felülmúlja a kalciumét, a $\mathrm{Ca} / \mathrm{Mg}$ arány kb. 0,5 körül mozog, csak néha éri el a 0,7 körüli értéket (4. minta, 7. minta). Ez a Duna-Tisza közén létrejött szikes semlyékekben már máshol is megfigyelt dolomitképződéssel áll összefüggésben, azaz a mintákban lévő karbonát döntő mértékben nem kalcit, hanem dolomit (Bozsó - Pál-Molnár, 2011). A Na és K mennyisége jelentősen felülmúlja a talajszelvényben mért értékeket, ami a mélyedésbe való bemosódással értelmezhető, a semlyék üledéke nagymértékben szikes jellegü. A szikes anyagok elsősorban karbonátok és hidrokarbonátok formájában lehetnek jelen. Koncentrációjuk a szelvény alsó része felé haladva csökken, ami egy felülről lefelé történő elemvándorlásnak felel meg, ami szintén a bemosódás eredménye lehet.

A semlyék medencéjében, egy lokális, kisméretü üledékgyűjtőben, oligotróf tavi környezet fejlödött ki a holocén folyamán, mely viszonylag gyors ütemben eutróf tavi rendszerbe ment át, a szervesanyag mennyisége jelentősen megemelkedett. Ez a szint elvi megfontolások alapján a bronzkorral párhuzamosítható. Alapjául a Kiskundorozsma-Putriréti fúrás szolgált (lásd lentebb), mely során a C14 adatokkal datált szelvényben csak a késő rézkortól, bronzkortól kezdve lehetett antropogén hatásokat kimutatni. Mivel a semlyék partján mind a korai, mind a kései bronzkorban település volt (sem korábban, sem később nem volt emberi megtelepedés a lelőhelyen), a bemosódás, feltöltődés megmagyarázható a bronzkorban feltört, taposott homoktalaj eróziójával.

\section{Értékelés}

A holocén folyamán a vizsgált semlyékben sekély, oligotróf tavi rendszer alakult ki, mely később eutróf rendszerré alakult és szervesanyagban gazdagabb üledékkel erősen feltöltődött. Ez a feltöltődési folyamat az erózió fokozódásával magyarázható, mely eróziót viszont emberi hatás: erdőirtás, gyep feltörése, szántók kialakítása, település létrehozása váltotta ki. Mivel a szűkebb térségben, a tó néhány km-es környezetében csak a bronzkorból ismerünk településeket, s a közeli pollenfúrás rétegsorában (radiokarbon adatokkal datáltan) csak a késő rézkortól, kora bronzkortól mutatható ki emberi hatás, az erózió beindulását a kora bronzkorhoz kötjük, amikor egy legeltető állattartást folytató csoport, a Nagyrév-kultúra lakossága települt meg a semlyék partján közvetlenül (4-5. minta). A legeltetést a nagy mennyiségü szarvasmarha- és juhcsont bizonyítja. A legelőterületek kialakításához vagy kibővítéséhez erdőirtásokkal kell számolnunk, mely a közvetlen környék ligeterdős sztyeppi környezetét részben füves pusztává alakította, a legelés és a korlátozott talajművelés, az 
emberi település számára feltört bucka pedig meggyorsította az eróziót. Ez a folyamat a késő bronzkor elejére érte el maximumát (a 3-4. mintát párhuzamosíthatjuk ezzel a szinttel - Kr. e. 1500-1300), amikor a lelőhelyen feltárt jelenségek, leletek alapján a lakosság száma minimum háromszorosára emelkedett, ugyanakkor pontosan ugyanazt az életmódot folytatták, mint korábban a Nagyrév népesség. Ahogy az archeozoológiai fejezetben látjuk majd, az állatállomány összetétele nem mutat lényeges különbséget, de még nagyobb a ló aránya. A lovak patái a füvel gyengén kötött buckák felszínét még jobban feltörhették. Ezt követően a szervesanyag mennyisége lassabb, de folyamatos emelkedést mutat (2-3. minta). Ez a késő bronzkor és a vaskor idejével párhuzamosítjuk, amikor a lelőhelyen település nem volt, de néhány km-es körzetben több intenzív települést feltártak, s a környéken egyre inkább füves sztyepp fejlődött ki. Ez a folyamat a római császárkorban és az avar korban folytatódott. Az 1-2. minta a tó feltöltődése után kifejlődött tőzeges mocsár üledéke, mely azt jelzi, hogy a tó a népvándorlás és a honfoglalás korára valószínűleg teljesen feltöltődött, $\mathrm{s}$ ilyen mocsaras rendszer maradt az Árpád- és középkorban, valamint az újkorban is. A mocsarat a közelmúltban lecsapolták. Területén a mai napig nádas található.

A 4. mintában megfigyelt talajvíztükör kialakulása a mocsár lecsapolásához kötődik. A lecsapoló csatornákat a 20. században ásták, mai napig jól megfigyelhetők. Ez a felső $50 \mathrm{~cm}$ kiszáradását és a pollenanyag megsemmisülését okozta. Az eltelt rövid idő okozza természetesen a talajvíztükör geokémiailag gyenge jelentkezését is.

\section{Archaeobotanikai eredmények}

A településen szenült gabona- és gyommagvak, szárrészek is előkerültek, melyek elemzését Gyulai Ferenc végezte el. Mivel eddig halomsíros településről archaeobotanikai adatokat nagyon gyéren közöltek, ezek tudományos értéke jelentős. Az itt összeszámlált 298 db diaspóra 30 mintából származik. A nem keltezhető minták kivételével a késő bronzkori Halomsíros kultúra idejéből valók, Nagyrévi maradvány nincs köztük. A leletek között egyértelmüen dominál az árpa (durván az anyag 60\%-át alkotja), emellett járulékosan jelen vannak a pelyvás búzák, a tönke és az alakor. A hüvelyes növények közül csak az őskorra jellemző cicorlencse fordult itt elő. A gyomnövények közül a tavi káka és a fehér libatop mutatható ki, előbbi a tavi környezet, utóbbi az antropogén, taposott felszín nyomjelzője (Sümegi, 2009). Különös jelentőséggel bír az 5. gödörből előkerült, durvára őrölt, nem kelesztett, sütött gabona darakása szenült maradványa. A tavi káka (csuhu) makkok előfordulásából nedves környezet közelségére következtetek.

A biztosan Halomsíros objektumokból előkerült gabonaszemek nagyobb részét nem lehetett pontosabban meghatározni (rossz állapotuk miatt). Belölük az árpa (Hordeum vulgare L.) és a termesztett tönke (Triticum dicoccum) szinte azonos arányban került elö, az alakor (Triticum monococcum L.) termesztése a megfelelő régészeti datálhatóság hiányában nem bizonyítható egyértelmüen (17 szem árpa és 13 szem tönke, ill. 1 szem alakor és 1 szem alakor vagy tönke). A köles (Panicum miliaceum L.) nagyjából feleakkora mennyiségben van jelen (7 szem).

A 308. objektumból előkerült egy karbonátos kiválás, mely a gödörben lévő egykori növényi eredetű hulladékot őrizte meg. A hulladék egy része szenült, más része lenyomat 
formájában maradt fenn. Gabona pelyva lenyomat és kalászorsók szenült maradványai mellett köles lenyomatok ismerhetők fel a finomhomokból karbonátos kötőanyaggal kialakult szubrecens kőzetben (66-67. ábra).

\section{Értékelés}

A település növényleletei elsősorban a termesztett növényekröl, valamint az éghajlati, talajtani adottságokról nyújtanak információkat. Az ásatáson a mostoha körülmények (magas talajvízszint, gyors munkatempó) csak kevés minta begyüjtésére nyílt lehetőség, a kis mintaszám ennek a következménye. Ugyanakkor egyértelműen dominál az árpa (Hordeum vulgare L.), mely a talajjal és a hőmérséklettel szemben igénytelen, tág türésű, tenyészideje rövid, s ma is világszerte a legelterjedtebb gabonaféle. Száraz viszonyok közepette és tápanyagban szegény talajokon is jól termeszthető. Emberi táplálékul, kása (1. 5. objektum), kenyér és sör készítésére szolgált; állati takarmányul a lóállomány etetésére használhatták. A rossz vízgazdálkodású, vízhiányos, gyenge termőképességü talajon, mely a lelőhelyet jellemzi, ez a gabonaféle is jól megél. (Gyulai, 2001, 32). A második leggyakoribb tönke (Triticum monococcum L.) tetraploid búzafaj, mely elsősorban az enyhe telü, száraz és meleg nyarú, mediterrán-szubmediterrán klímához alkalmazkodott (Gyulai, 2001, 30). A köles (Panicum miliaceum L.) nagyon rövid (60-90 nap) tenyészidejü, tavaszi vetésű kultúrnövény, nyári másodvetése is beérik. Jól türi a szélsőséges körülményeket (szárazság, meleg, gyenge talaj). Európában a késő neolitikum és rézkor óta termesztik (Gyulai, 2001, 35-36.)

A cicorlencse (Vicia ervilia) termesztését az 1 előkerült mag alapján feltételezhetjük, de nem lehetett széles körü.

A középső bronzkori Vatya-kultúrában a hatsoros árpa fontos gabonanövény, melyet emberi fogyasztásra termeltek. A kultúra területének északnyugati részén, a Duna mentén fő terményként az alakor szerepel, míg a délkeleti csoportban (Alpár-csoport), igazodva a természeti adottságokhoz, a tönke termesztése elsődleges. Ugyanakkor a Vatya lelőhelyeken számos más faj, pl. tönköly, kenyérbúza, törpebúza, rozs, kismagvú lencse, cicorlencse, borsó, lóbab, vetési bükköny, csicseriborsó is előkerült.

A korai Vatya időszakban a termesztett gabonanövények következők: tönke, alakor, két- és hatsoros árpa, csupasz árpa, kenyérbúza, tönköly. A második szakasztól ezek közül hiányzik a kétsoros árpa, de a többit termesztik továbbra is. Ebben a szakaszban a gabona mennyisége megnövekszik. A legtöbb szemtermés az alakoré, majd a tönke következik. A harmadik szakaszban (Vatya III - Vatya-Koszider) a gabonafajok diverzitása magas, valamennyi, korábban említett faj előfordul. Emellett a kétsoros árpa újra megjelenik és fontossá válik. Feltünik a köles. A hüvelyesek a 2. szakaszban terjednek el, és általánossá a harmadik periódusban válnak. A fentiekből egy igen fejlett gabonatermesztéssel rendelkező lakosság képe bontakozik ki. (Gyulai, 2001, 90-96).

Településünkön az árpa-tönke-köles nagyjából 40-40-20\% arányú termelésére épülő mezőgazdaság képe rajzolódik ki, ugyanakkor a fajok száma jelentösen lecsökken a Vatya lelőhelyekhez képest. Az igénytelenebb, rövid tenyészidejü fajok előtérbe kerülése folytatása a Vatya III - Vatya-Koszider periódusban zajló folyamatnak (köles megjelenése), a tönke azonban a teljes Vatya időszakban is a Duna-Tisza köze DK-i részének kedvelt terménye volt. Végső soron a Halomsíros periódus növénytermesztése fajokban szegényes volt, de a 
három fó faj jól illeszkedik a térség Koszideri korú termesztési struktúrájához, annak folytatásaként fogható fel. Ezek a tendenciák azonban - a rövid tenyészidejü, igénytelen fajok elötérbe kerülése - az állattenyésztés egyre növekvö súlyára is utalnak. Talán legfontosabb különbség a két kultúra növénytermesztése között, hogy míg a Vatya települések elsősorban löszös magaspartokhoz kötődnek (Duna mente, Tiszaalpár, Kelebia), addig a Halomsíros települések a homoktalajokon, sürün előfordulnak. A régészeti keltezés a településünk korai fázisát a legkésőbbi Vatya településekkel ráadásul párhuzamosnak feltételezi. Ehhez képest a különbség nem is olyan nagy: hasonló fajokat termesztenek eltérö talajon, kihagyva az igényesebb gabonafajtákat, hüvelyeseket.

\section{Archaeozoológiai eredmények}

A településen előkerült állatcsont-anyagot Tóth Anikó vizsgálta meg. Miután elkezdtem a település leletanyagát feldolgozni, készítettem egy listát a Halomsíros-, a Nagyrév- és az ismeretlen korú objektumokról. Ennek segítségével Tóth Anikó értékelte a csontanyagot (Tóth, 2011).

A lelőhelyről leírt, töredékes és igen rossz megtartású maradványokk száma $1880 \mathrm{db}$, a meghatározható állatcsontoké $1108 \mathrm{db}$, a nem meghatározhatóké $772 \mathrm{db}$. A lelőhely bronzkori objektumaiból származó csontleletek száma 1247 db (a többi állatcsont olyan objektumból került elö, melyben semmiféle kerámia nem volt található, így még az sem biztos, hogy bronzkoriak). Ezen mennyiségből 357 db a Nagyrév-kultúrához köthető, míg $890 \mathrm{db}$ csont (a teljes leletanyag 47,34 \%-a) a Halomsíros-kultúrába sorolható (Tóth, 2011, 1). A település állattani anyaga sokkal bőségesebb, mint a növénytani, így az itt tett megállapítások statisztikailag is jobban megalapozottak. A továbbiakban a Nagyrévobjektumokból felszínre került állatcsont-anyaggal nem foglalkozunk részletesebben, csupán a késő bronzkorival összehasonlításban mutatjuk be. Az a tény ugyanis, hogy azonos lelőhelyen, nagyjából azonos környezeti feltételekkel, kb. 5-600 év különbséggel, két, egymástól alapjában eltérő életmódot folytatónak gondolt népesség települt meg, érdekes összehasonlításra ad lehetőséget.

A Nagyrév-kultúra állati maradványai (68. ábra) között a szarvasmarha dominál, ezt a juh és a sertés követi. Kis mennyiségben a ló és a kutya észlelhető, a sertés maradványainak aránya csekély, csakúgy, mint a kora bronzkor korábbi szakaszába (Makó-kultúra) keltezhető üllői településen (Körösi, 2005, 138-142). Ez arra utal, hogy a helyi Nagyrév közösség nem a Duna- és Tisza-melléki rokonai növénytermesztő (tell-) kultúráját folytatta, hanem sokkal inkább a korábbi Makó népesség nagyállattartó, mozgékonyabb életmódját követte, melynek nem jellemzője a sertéstartás. A Nagyrév telep szerkezete (szórt, gödrökből álló csoportok 50 m távolságban egymástól) is pontosan megfelel a Makó településeken korábban megfigyelt szerkezetnek (Tóth, 2004). Az itt előkerült Nagyrév telep lakosságának életmódja, és a település szerkezete sokkal inkább hasonlít a korábbi Makó lakosságéra, mint a Duna vagy a Tisza mentén létrejött Nagyrév tellekre.

A Nagyrév leletek testtájék-megoszlása alapvetően húsfogyasztásra utal. Vadászatra csak $1 \mathrm{db}$ őz csont utal, és hasonlóan alacsony a halászat és gyüjtögetés aránya is (Tóth, 2011, 3-4.). 
A Halomsíros kultúrához köthető állatcsont-anyag (5. táblázat) mennyisége és minősége is megfelelő, ezek a korabeli helyi lakosság állattenyésztéséről igen hasznos adatokkal szolgálnak. A 890 db csont 59,5\%-a, 530 db meghatározható. A hosszú csöves csontok megtartása rossz, számos esetben csak a diaphysis töredéke marad meg.

Háziállatok: szarvasmarha, juh, sertés, ló és kutya. Vadászott állatok: gímszarvas, mezei nyúl. Vadon élő madár és rágcsáló (közönséges ürge) is előkerült. A víz közelségére utalnak a hal (csuka), és a kagyló maradványok, ezek között álló- és folyóvizet kedvelő fajok is vannak:

\section{Folyamkagyló (Unio tumidus)}

2. Tompa folyamkagyló (Unio crassus) (Tóth, 2011, 4)

Ezek csekély számú előfordulása nem igazolja rendszeres fogyasztásukat. A kagyló gyüjtögetése elvileg más célt is szolgálhat: kerámiakészítéshez eszköz a kagylóhéj (edényfal megtámasztása, simítása), mészbetét készíthető a porrá tört héjból. Egy töredék karcolt díszítésében észleltünk valódi mészbetétet, de anyagvizsgálat nem történt, így nem jelenthetjük ki, hogy biztosan porrá tört kagylóhéjat használtak fel erre a célra.

A folyóvíz-kedvelő csuka a tiszai halászatot bizonyítja, mely alapján a tiszai ártér a település ellenőrzése alatt állt.

A háziállatok fajmegoszlása a következö (69. ábra):

1. Szarvasmarha $(42,4 \%)$, 2. Juh $(38,7 \%)$, 3. Kutya $(8,1 \%)$, 4. Sertés $(5,8 \%)$, 5. Ló $(5,1 \%)$.

A lakosság tehát elsősorban háziállatokat tartott, de a szarvasmarha mennyisége kevesebb a Nagyrév anyagban észlelhetőnél (42\% kontra $52 \%$ ). A juh és sertés aránya pontosan azonos a két korszak leletei között. Jelentős különbség mutatkozik a kutya és a ló számarányában, ezek az állatok egyrészt a pásztorkodás (kutya), másrészt a pásztorkodás és a hadviselés (ló) céljait szolgálták. Ugyanakkor a lóállomány a gazdagság fokmérője is lehetett.

A háziállatok jelentős részét fiatal, juvenilis példányok (szarvasmarha, juh, sertés) alkották, így ezek esetében a húsfogyasztás bizonyítható. Az adultus példányok a másodlagos felhasználást (tenyésztés, tej, gyapjú, igavonás) is alátámasztják. Anatómiailag a maradványok jelentős része (kb. negyede) a fej és a húsos végtagok közé tartozik (6. táblázat, 70-72. ábra). A fejrégió dominanciája a nagyszámú állkapocs és foglelet alapján igazolható. Patológiás elváltozás nem jellemző, egyetlen ló medencecsonton látszott gyulladás nyoma. Egyes juh és sertés csontokon égés nyoma volt megfigyelhető, ami a hússütés eredményeként jöhetett létre (Tóth, 2011, 6). Valószínü, hogy a marhahúst inkább főzték, a juh- és sertéshúst inkább sütötték.

Vadászat és gyüjtögetés: a gímszarvas és a mezei nyúl vadászott állat, de egyik sem utal nagyobb arányú vadászatra.

A halászat és gyüjtögetés szintén nem volt nagyobb arányú. Erre már korábban kitértem - nem is biztos, hogy táplálékként gyüjtögették az állatokat. A két faj (folyamkagyló, tompa folyamkagyló) többnyire természetes folyóvízi környezetben, keskeny, homokos medrü folyókban gyakori. A Maty-érben áradáskor áramló vízborítás lehetett, így ezek a kagylófajok megjelenhettek benne. Ugyanakkor a Tisza maga is számításba jöhet. 
A gödrökben talált rágcsáló és csiga (Gastropoda) leletek nem biztos, hogy korabeli maradványok. Azonban a lelőhelyről leírt, Helicidae családba tartozó Cepaea vindobonensis (pannon csiga) szárazföldi melegkedvelő faj, mely vízzel nem borított térszíneken nyílt, erdőszéli, bokros-füves környezetet feltételez. Ez a környezet megfelelhet a bronzkori település szélén kialakult vegetációnak, a későbbi komoly erdőirtás miatt nem lehet recens.

\section{Értékelés}

A Halomsíros lakosság a középső bronzkorhoz képest jelentősebb számban tartott juhot. A szarvasmarha jelentősége azonban továbbra is nagy. A kutya- és lótartás a pásztorkodással áll összefüggésben. A nyílt sztyeppi vegetációjú területeken (1. feljebb) juhot legeltettek, a szarvasmarha a dúsabb füvü (ártéri) legelőket kedveli. A folyami kagylók gyüjtése, és a folyami agyag felhasználása (1. az archeometriai fejezetben) arra utal, hogy az árteret a lakosság egyértelmüen használta (1. még a pollenanyag értékelésénél). Innen származhatott az épület- és tüzelőfa nagyobb része is. A kiirtott vagy szálalt erdő helyén ugyanakkor dúsabb füvü legelők maradtak vissza, melyek a szarvasmarha-tarásnak kedveztek. $A z$ állattenyésztésben azonban egyre meghatározóbbá vált a füves területeteken folytatott külterjes juhtartás. A telepobjektumok közül néhány karámként értelmezhető, ezekben a marha- és lóállományt tarthatták. Vannak ólszerü, kis objektumok, melyek 1-2 méteres méretükkel, négyszöges alaprajzukkal talán kutyaólak lehettek (30-31. obj., stb.).

Szombathely-Kámon település állatcsont-anyagát Vörös István vizsgálta, benne a szarvasmarha dominanciája (56\%) mellett a sertés és a kiskérődzők magas arányát (33\% ill. $11 \%$ ) állapította meg. Ez az arány hasonló a németbányai késő halomsíros településről ismerthez, csak ott a szarvasmarhát a juh követi. A Süttő-hosszúvölgyi telep állatcsontanyaga a németbányaival azonos jellegü, a vadászott fajok kiugró arányával (Vörös, 19981999, 293.). Ez azért is érdekes, mert a süttői települést a koszideri időszakban lakták, a másik kettőt viszont később, s kulturálisan sem sorolhatóak egy csoportba. Az állattartás jellegében mégsem következett be komolyabb törés. A vizsgált település állatcsont-anyaga a németbányaihoz áll a legközelebb. A szórványos adatokból messze vezető következtetést levonni azonban még korai lenne.

\section{A lelőhely természetes környezete és változásainak tendenciái a késő holocénben a Maty-ér medrében mélyített fúrások alapján}

A lelőhelyünktől nem messze lévő Maty-ér völgye (egykori Duna meder) fontos szerepet játszott a korabeli lakosság életében, s földrajzi közelsége lehetővé teszi, hogy a területén végzett geoarcheológiai kutatások eredményeit e helyütt felhasználhassuk. A munkát az M5-ös autópálya megelőző feltárásaihoz kötődően, azokkal párhuzamosan végezte Dr. Sümegi Pál, Juhász Imola, Hunyadfalvi Zoltán, Molnár Sándor és Herbich Katalin (Sümegi et al, 2003).

Geomorfológiai, régészeti geológiai, pollenanalitikai vizsgálatokat végeztek, számunkra különösen jelentős a Kiskundorozsma-Putri-réten mélyült pollenfúrás, mely a lelöhelyünktől alig néhány kilométerre található, a Maty-ér egyik holtágában, a Maty Ágazatban (Sümegi et al, 2003, 169.).

Alkalmazott módszereik: 
1. Szedimentológiai elemzés Casagrande-féle aerométeres szemcseösszetételmeghatározó berendezéssel,

2. Üledékföldtani elemzés Troels-Smith (1955) rendszere alapján,

3. Talajvíztükör meghatározása vasborsókkal

4. Pollenfúrás $10 \mathrm{~cm}$-es mintatávolsággal

5. Malakológiai mintavétel $10 \mathrm{~cm}$-es mintatávolsággal

(Sümegi et al, 2003, 172)

Eredményeikből a táj (elsősorban a meder) holocén kori története bontakozik ki. A Kiskundorozsma-vágóhídi fúrás alapján a meder egy erősen feltöltődött folyómeder maradványa, melyet a dunai vízrendszer alakított ki. Ennek feküjében metamorf ásványok (gránát, sztaurolit, kianit) dominálnak, melyek a tiszai lehordási területre nem jellemzőek, de a dunaira tipikusak (Molnár, 1977). A medernek (Maty-ér) a hátság (Zsombó) felöli része betemetődött és feldarabolódott. A futóhomokmozgást a két tektonikai süllyedék (Duna- és Tisza-völgy) kialakulása, a Duna-Tisza köze kiemelkedése, a talajvízszint csökkenése előzte meg. Ez a Würmben játszódott le, 15-30 ezer évvel ezelőtt, így a holocén kezdetére a meder Zsombó felőli részét vastag homokréteg fedte (Sümegi et al, 2003, 173).

A folyómederben kékesszürke, durvább kőzetlisztes tavi üledék (Mollusca héjakkal) halmozódott fel. Kialakulása: a lefüződött folyómederben kialakult morotvatóban jelentős mennyiségü, szél által hordott poranyag halmozódott fel, így mállatlan ásványokat tartalmazó feltöltődés alakult ki egy tiszta vizü, szerves maradványoktól mentes tavi rendszerben. Ennek faunája hidegtürő és -kedvelő (Valvata pulchella, Bithynia leachi stb.), a szakasz a felső Würmre, 16-13 évvel ezelőttre datálható. A medret kísérő folyóhátat 3-4 m vastag infúziós löszréteg fedi, a belőle előkerült csigafauna a tavi rétegekből előkerültekkel párhuzamosítható, tehát egyidősek (Sümegi et al, 2003, 174).

Ez a tó a holocén kezdetére jelentős részben feltöltődött, ugyanakkor a mederben időszakosan jelentős vízborítás alakult ki egészen a 19. század végéig. A holocén üledékek szerves anyagban dúsak. A megmaradt tó mélysége 1,5-2 m lehetett, mely a Tisza áradmányvizéből táplálkozott. A Maty-ér tehát nem önálló vízfolyás, hanem a Tisza árvizeit vezette le 10-12 ezer évtől egészen a 19. századig. A mai árvízszintből nem lehet kiindulni, mivel az ártér tizedére zsugorodott, és így az árvizek tetőzési magassága is többszörösére nőtt. Ha azonban a mai árvizek térfogatát a Tisza-völgyben szétterítjük (elméletben, modellek útján), akkor jó közelítést kaphatunk az egykori vízborításról. Ez alapján a Maty.ér legmélyebb, 79 m-es tszf. Területét 1-2 m mély, lassan emelkedő, jelentős szervesanyagtartalmú víz boríthatta az áradások (kora tavasz, kora nyár) idején.

A víz másik forrása a Duna felől áramló talajvíz. Ez egyrészt a Duna-Tisza közének talajvizéből táplálkozott (a csapadék a homoktalajban azonnal elszivárog, abban mozog), másrészt a Duna árvizei is beszivárogtak a homokba és abban messzire vándoroltak (Rónai, 1985). A magas vízállás időszaka a tavaszi-nyári félév volt, ezen belül a legmagasabb vízállás kora tavasz és a kora nyár idejére esett, a kétmaximumos csapadékeloszlás alapján. Összel és télen a talajvíz szintje minimálisra csökkent.

A holocénben tavi-mocsári rendszer fejlődött ki a mélyedésekben, a vízborítás a meder egykori morfológiáját követte - peremén sekély, centruma felé mélyülő, ott kb. 2 m-es 
vízborítás. Ennek megfelelően a növénytársulások zonálisan fejlődtek ki (Sümegi et al, 2003, 174-175).

\section{Éghajlat a bronzkorban}

A Kutzbach-féle átfogó matematikai alapú éghajlati modell (Sümegi - Krolopp, 2002) alapján vázolható.

A nyári félévben leesett csapadék mennyisége jelentős mértékben megnövekedett a bronzkor folyamán, miközben a nyári párolgás csak minimálisan emelkedett, a téli csapadék és párolgás lecsökkent. A bronzkor folyamán a nyár kezdetén lehullott csapadék hatására kialakult árvizek nagyobb hatással lehettek a Maty-ér vízrendszerére, mint a hóolvadás nyomán elöállt kora tavaszi árhullámok. A gabonaérés idejére jelentős csapadék és vizboritás rekonstruálható, mely a gabonatermesztés számára kifejezetten kedvezötlen, míg az állattenyésztésnek kedvez. (Sümegi et al, 2003, 175)

A Sóskúton mélyített fúrás mintáiból a középső bronzkori júliusi középhőmérséklet a Mollusca fauna („malakohőmérő”) alapján 20-22 ${ }^{\circ} \mathrm{C}$-nak, a késő bronzkori júliusi középhőmérséklet $18-20{ }^{\circ} \mathrm{C}$-nak adódott (Sümegi - Bodor, 2005). Előbbi érték a helyi, jelenkori viszonyoknak megfelelő, míg az utóbbi inkább az Alpokaljára és a Bécsimedencére jellemző manapság. Épp azokra a területekre, ahol a korai Halomsíros kultúra középső bronzkor végi intenzív megtelepedése mutatható ki (Mistelbach-Regelsbrunn, Benkovsky-Pivovarová, 1976), s ahol feltételezhetően egy közép-európai (közép-Dunai) sajátosságokhoz igazodó, döntően állattartó életmódot alakítottak ki.

\section{A geológiai fúrás}

A fúrásra Kiskundorozsma-Putri-réten, azaz a nagyszéki területen található villás elágazású medrek közelében (Maty Ágazat) került sor. A Maty Ágazat egy kampószerü, délről nyugat, majd észak felé kanyarodó, nagyjából félkör alakú meder, melynek északi elvégződése a lelöhely közvetlen közelében, 1-2 km-re található. Ezek a villás medrek a pleisztocén során alakultak ki a korábbi szakaszok feldarabolódásával, melyet a hulló por okozott. A geológiai fúrás a folyóhát üledékeit harántolta.

0-30 cm: Sötétbarna, jelentős szervesanyag-tartalmú, karbonátos, szántott, poliéderes szerkezetű, régészeti leleteket tartalmazó agyagos kőzetliszt, réti csernozjom talaj (Sh1As3).

30-60 cm: Szervesanyag és bolygatottság csökken, a karbonát- és agyagtartalom emelkedik. Fahéjbarna, kőzetlisztes agyag, a talaj B szintje. Benne csiga, vasas és karbonátos kiválások (Lc1As3).

60-70 cm: A talaj és az alapkőzet határa, karbonát- és vastartalom nő, benne 1-5 mm-es karbonátos konkréciók vannak ( $\operatorname{Lc3} \mathrm{Ag} 1)$.

70-340 cm: Jelentős mennyiségü vízi és szárazföldi Mollusca maradvány, cm-es karbonát-konkréciók, vasborsók (infúziós lösz), finomkőzetlisztes durvakőzetliszt (Lf1, Lc1Ag2), ezen a kőzeten alakult ki a talaj. $320 \mathrm{~cm}$ mélyen erősen vasas, mészlepedékes, vízszintes réteg: ez a talajvízszint határa a folyószabályozás előtt. Ez a 81 m-es tengerszintfeletti magasságnak felel meg, így a víztükör határa 80-81 m körül lehetett, az ennél alacsonyabb területeken számolhatunk vízborítással.

370-700 cm: egyenesen rétegzett, a fekü felé helyenként keresztrétegzett homokos, szürkésbarna, enyhén karbonátos agyagos kőzetliszt, kőzetlisztes agyag, folyóháton 
felhalmozódott üledék (Lc1Ag1As2). (Ez a réteg lehet a kerámia-alapanyag egyik potenciális származási rétege - lásd archeometriai fejezet)

A fúrás 7 m-nél karbonátos kiválásban akadt el.

Mollusca fauna: a vízicsigák alapján az áramló vizet kedvelő fajok azt jelzik, hogy a mederben néha áramló víz lehetett (áradmányvizek). Az infúziós löszben szárazföldi és vízi fajok sírközössége látszik, mely az áradások során mosódott össze (Krolopp - Szónoky, 1982, 1989).

A meder késő glaciális szakaszával izokron, de heterotip fáciese.

A holocénben lezajlott talajosodás a folyóháton már szárazföldi környezetben zajlott.

(Sümegi et al, 2003, 176-179)

A pollenfúrás

A Putri-réti Maty-ér mederszakaszán került rá sor (73. ábra). A fúrást Orosz-fejes, zavartalan magfúrást biztosító fúróval végezték. A fúrás 2-3 $\mathrm{m}$ vastag holocén, vízi üledéksort harántolt, majd 3 m mélyen karbonátos kiválásban akadt el (réti „mészkő”). A pollenek megtartása rossz az időszakos kiszáradás miatt.

Az üledékrétegekben sok nád, sás, gyékény szövetmaradvány és pernye észlelhető, ami alapján elsősroban lágyszárú növényzet élhetett a tó partjai mentén, a fás szárú növényzet aránya alacsony. A tőzegesedő taxonok egyszikű, vízi, vízparti, lápi növények. Találtak vízzel szállított másodlagos pollent (Pinus). Az algák alkálikus, szikes vizet jeleznek.

Összesen 3 pollenszint különíthető el:

1. 1,9-2,5 m. Fás szárú növények jellemzik: Quercus, Alnus, Fraxinus - tölgy, éger, kőris. Algák közül az eutróf zöldalga (Pediastrum) maradványai kerültek elö, a nád (Prhagmites), gyékény (Typha), sás (Cypreaceae) a partközeli részen nőtt. A füfélék (Poaceae) a parton telepedtek meg. A fenyőfélék pollenjei nem lokálisak, azokat a víz és a szél hordja ide.

A szint kialakulása a holocén kezdetén, de a termelő gazdálkodás megjelenése előtt történt. A természetes vegetáció: kiterjedt kőris-szil-tölgy keményfás ligeterdő, nedves térszíni páfrányokkal (Dryopteris) jellemezhető aljnövényzettel. A vízparton zonálisan sásos, gyékényes, nádas övezet alakult ki. A füfélék az infúziós lösszel fedett felszínen telepedtek meg, köztük vízi fúfélék (harmatkása - Glyceria) is vannak. Ez a fázis a holocén kezdetétől egészen 3800 cal BC-ig (atlantikum vége) fennáll.

2. 190-130 cm. Fás szárúak és páfrányfélék pollenjei eltünnek, sás- és füfélék aránya kiemelkedővé válik, megjelennek az első antropogén nyomok: Plantago (útifü), Rumex (lórom) - taposást bizonyító fajok. Nincs gabonapollen, ami azt jelzi, hogy a közelben nem volt gabonaföld.

A változást jelentős lélekszámú lakosság okozta: települések, szociális terek, utak, legelők létrehozásával.

Az állatállomány növekedése valószínüsíthető folyamatos és erőteljes környezetátalakítás mellett, mely után a vegetáció a továbbiakban nem regenerálódott. A hátak a bronzkortól folyamatosan lakottak voltak. 
3. 130 cm-től felfelé. Üröm (Artemisia), szikesedés (Tytthodiscus alga). Oka: erózió, az infúziós lösz lemosódása, periodikus vízborítás. $100 \mathrm{~cm}$-től a behordott fenyőpollen aránya is megnő, ami a római korra jellemző (Willis et al, 1998, Sümegi-Bodor, 2000).

(Sümegi et al, 2003, 179-180)

Értékelés (74. ábra)

2011-ben a fúrást, különösen $130 \mathrm{~cm}$ feletti szakaszát Sümegi Pál újraértékelte, és ebben öt pollenzónát sikerült lehatárolnia, melyekből az utolsó kettő a rézkorral és a bronzkorral párhuzamosítható. Sajnos épp ennek a felső szintnek a pollenjei gyenge megtartásúak. E helyütt most a neolitikumtól kezdődően tekintjük át a környezet pollenek vizsgálata nyomán kirajzolódó változásait. Sümegi Pál és munkatársai adatai alapján, a 2003as munkából még hiányzó pontos radiokarbon (cal BC) koradatok birtokában értékeltem a szelvényt, elsősorban a középső és késő bronzkori szakaszát.

Az világosan látható, hogy a 130-98 cm közötti, neolit és kora-középső rézkori (59004000 cal. BC), harmadik pollenzónában nincs komoly emberi hatás, legfeljebb foltszerü, szálalt erdőirtással, legeltetéssel számolhatunk, emberi település a közelben nem volt. Sümegi Pál a nagy kiterjedésü üledékgyűjtőkkel kapcsolatos külföldi szakirodalom (JacobsonBradshaw, 1981) alapján úgy véli, hogy a pollenanyag föleg a regionális, és nem a lokális környezetről ad információt. Ugyanakkor igyekeztek ezeket a zavaró tényezőket kiküszöbölni, és a mintákból válogatott taxonokat közöltek, kiszürve a folyóvízzel szállított exotikus és kimosott fosszilis polleneket. Ennek figyelembe vételével elég valószínü, hogy sem a Maty-ér környezetében, sem a Dorozsma-Majsai Homokhátság keleti területén nem volt neolit és kora-középső rézkori megtelepedés, azaz kizárható, hogy a holocén ezek szakaszában esetlegesen lejátszódott homokmozgások temették volna el a lelöhelyeket, mint ahogy azt a régészetben több esetben feltételezték.

A fentiek figyelembe vételével a pollendiagramot a mikrojelenségekre koncentrálva elemeztem:

Az egyes pollenzónák cal BC adatainak felhasználásával a 130-98 cm-es szakaszban 60 év/cm (0,017 cm/év), a 98-32 cm-es szakaszon 32 év/cm $(0,031 \mathrm{~cm} /$ év), a 32-2 cm-es szakaszon 43 év/cm $(0,023 \mathrm{~cm} /$ év $)$ üledékképződési sebességet állapíthatunk meg. Jó közelitéssel az emberi megtelepedés idöszakában 50 év alatt 1 cm-nek megfelelö üledék képzödött.

A 98-32 cm közötti zóna 4000-1800 cal BC között fejlődött ki, azaz a középső rézkor második felével, a késő rézkorral, a kora bronzkorral és a középső bronzkor elejével párhuzamos. Emberi hatások, termesztett gabonafélék, gyomok (útifúfélék, imolafélék, ürömfélék - Plantago, Centaurea, Artemisia) megjelenése, erőteljes növekedése, a lombos fák arányának jelentős, és egyes fák esetében drasztikus csökkenése mutatható ki ebben a szintben. A változások alapján a középső/késő rézkortól egészen a középső bronzkorig tartó szelvényszakaszban erőteljes emberi hatások jellemzik az üledékgyüjtő medence környezetét. Mindez összhangban van a régészeti leletanyaggal, hiszen a környékről (Kiskundorozsma határából, 6. ábra) ismerünk késő rézkori szórványleleteket, de a régióban több helyütt előfordultak ilyen korú települések (Banner, 1956, Banner-Kutzián, 1960, 1961, Bondár, 1984, 74, Abb. 6., Bálint-Párducz, 1933-34, Bognár-Kutzián, 1973). Ugyanakkor a középső rézkorból 
nem ismerünk helyi leletanyagot, holott az erdőirtási ciklusok biztosan megkezdődtek már ekkor. A rézkor második felében a Quercus (tölgy), Salix (füz), Ulmus (szil), Tilia (hárs) állományában bekövetkező ciklikus ingadozások alapján intenzívebb erdőirtási periódusok követték egymást, melyeket regenerációs időszakok választanak el. A gabonapollenek megjelennek a területen, azaz ez a lakosság nem teljesen állattenyésztő, hanem inkább komplex életmódot folytatott. Az erdőirtási és regenerációs ciklusok úgy képzelhetőek el, hogy a meder környezetében egy erdőirtást legeltetés és gabonatermesztés követett, majd a területet kimerülése után felhagyták, és csak jóval később, kb. 150 év múlva tértek oda vissza, mialatt a fás vegetáció jobbára regenerálódott. Ciklikus megtelepedés vázolható fel tehát. A késő rézkorra tehető az első gabonapollen-csúcs is (73 cm körül), amikor késő badeni és kostolaci telepek jöttek létre a környéken.

A környezet-átalakítás ugyanakkor nem volt erőteljes. $70 \mathrm{~cm}$ körül (interpolálva $3500 / 3300$ cal BC) történik a szelvényben kimutatható egyik legjelentősebb változás. A Quercus (tölgy), Ulmus (szil), Corylus (mogyoró), Salix (füz) és - egy csúcsot kivéve - a Tilia (hárs) mennyisége lecsökken (felére, harmadára), ugyanakkor a Fagus (bükk) mennyisége megnő. Az imola- és útifüfélék (Centaurea, Plantago) mennyisége drasztikusan, az ürömé (Artemisia) lassabban, de biztosan nő. Ez a legeltetett, taposott területek, a nyílt vegetáció elterjedését jelzi. A gabonapollen ugyanakkor nagyon alacsony, vagyis elsősorban legelőket, utakat és településeket alakítottak ki, de valószínűleg közvetlenül a megtelepedés környezetében kismértékű gabonatermesztést is folytathattak a pollenanyag összetétele alapján. A taposást is elviselő gyomok alapján a meder közvetlen környezetében lakóházak és utak húzódhattak a rézkor végén és a bronzkor első felében. Mindez a klasszikus badeni és kostolaci periódustól kezdődő és egészen a kora bronzkor végéig tartó régészeti periódussal jól párhuzamba állítható, hiszen a korszak élete, életmódja rendkívül mobilissá vált az állattenyésztés, valamint később a réz nyersanyaghoz való hozzájutást biztosító kereskedelem, cserekapcsolatok megélénkülése miatt. A nem stabil falvakban élö lakosság a késö rézkor találmányán, a kocsin utazva vándorolt egy meghatározott kisebb zónán belül, legelőváltó és irtásos-égetéses gazdálkodást folytatva. Megtelepedése azonban már folyamatos, nincsenek regenerációs periódusok. A régészeti bizonyítékok alapján megélénkülő déli kapcsolatok egy kiterjedtebb cserekereskedelmi rendszerre utalnak, melynek lebonyolítói déli eredetű csoportok lehettek, és akik meg is telepedtek a környéken (Somogyvár-Vinkovci kultúra/Ada csoport - 1. Horváth, 1981, ÓbébaPitvaros csoport, Bóna, 1992). Az úthálózat tehát az őskorban szokatlanul jelentős „forgalmat” bonyolított.

Az ötödik lokális pollenzóna 32-2 cm, 1800-500 cal BC évek között fejlődött ki. A bronzkor második felétől a vaskor középső szakaszáig tartó szelvényszakaszban a fák dominanciájának csökkenése már drasztikus (30\% alatti az összdominanciájuk), és a heliofil lágyszárúak megjelenése kiemelkedő (50 \% feletti az összdominanciájuk). Ezzel párhuzamosan a legeltetett, taposott, szántott felszíneket jelző gyomok arányának növekedése is látványos volt. A cickafark (Achillea) megjelenése a terület hasznosításának intenzívebbé válását, gazdálkodási típusváltás jelzi. Ez a változás párhuzamosítható a későbronzkorral. A későbronzkor és a kora vaskor során a fás szárúak pollenaránya $20 \%$ alá csökkent, míg a lágyszárú pollenek dominanciája meghaladta a $60 \%$-ot. Az egész terület antropogén hatású kultúrsztyeppé alakult 
és a gyomok jelenléte alapján egyértelmüen aktív megtelepedési felszín volt a vizsgált meder környezete.

\section{A középső és késő bronzkori környezet részletes értékelése}

26-23 cm környékén a gabonapollen 4-szeresére emelkedik, azaz a kora bronzkorra és a középső bronzkor első felére jellemző állattartó-gabonatermesztő életmód helyébe a földművelés lép. Az imola és útifü (Centaurea és Plantago) mennyisége lecsökken, az útifüé jelentősen. Ez a szakasz 2-3 mintában, 5-6 cm vastagságban fejlődött ki, tehát a bronzkor jelentős, rövidebb periódusa lehet. A cal BC koradatok közötti interpolációval - egyenletes üledékképződéssel számolva - ez a mintegy 150 esztendős szakasz a koszideri időszakkal párhuzamosítható. Jelentős gabonatermesztés folyhatott a meder közelében. Az életmód alapján és a szélirányok figyelembe vételével a Vatya lakossághoz kapcsolhatjuk ezt a gabonacsúcsot, azonban Vatya település vagy temetö nem került elö a térségböl, legközelebb Baks, Csanytelek és Csengele környékén ismerünk Vatya leletanyagot. Ez alapján a gabonapollen regionális (és szél által szállitott) is lehet, ami viszont igen nagyfokú, kiterjedt, intenzív földmüvelésre enged következtetni. A gabonaföldek ugyanakkor nagyobb település nélkül is jelen lehettek, esetleg egy-egy kis tanyával, aminek nem sok régészeti nyoma marad. A Vatya településszerkezet centralizált volt, a Maty-ér környéke hinterlandként szolgálhatott. A Perjámos kultúra nem lépte át a Tisza vonalát, de a szél a túlpart gabonapollenjeit is átszállíthatta.

A következő mintákban $(23-18 \mathrm{~cm})$ a gabonapollen aránya a felére csökken és az útifúé (Plantago) a kétszeresére, majd egy mintával följebb újra a kétszeresére emelkedik (két minta alatt összesen a négyszeresére a koszideri szinthez képest), és megjelenik a cickafark (Achillea). A 23 cm-es szint egyidös a középső és késö bronzkor határával, melyet a cal BC adatok interpolációjával 1500 BC körülre datálhatunk. Egy kisebb gabonacsúcs (2/3-a a kosziderinek) mutatkozik, de a taposott felületeket jelzö útifü (Plantago), imola (Centaurea), üröm (Artemisia) és cickafark (Achillea) egy teljesen más környezetet jelez, mint a koszideri idöszakban volt. A lokális, kismértékü gabonapollen emelkedést annak a számlájára irjuk, hogy ezúttal egy nagyobb település jött létre közel az üledékgyüjtőhöz, és ez épp a vizsgált, Domaszék-Börcsök tanyai település. Így a gabonapollen viszonylag magas másodlagos csúcsa a taposott felszint jelző lágyszárúakkal együtt csupán a település közelségére $(1 \mathrm{~km})$, és nem nagyfokú földmüvelésre vezethetö vissza. Jelzi ugyanakkor, hogy a lakosság visszatért a késő rézkor és kora bronzkor vegyes gazdálkodásához, melyben az állattenyésztésnek jutott vezető szerep. Ugyanakkor a tájhasználat nem ciklikus, mint a középső és késő rézkorban, hanem folyamatos és erőteljes, ami a népesség növekedésével van összhangban. Ez, a 23-18 cm között kifejlödött, kb. 5 cm-es zóna (interpolációval kb. 200 év) a Halomsíros-kultúra, valamint a pre-Gáva időszak hagyatéka. A Halomsíros-kultúra datálása, valamint a település keltezése szintén egy Kr. e. 1500/1400-1300/1250 között virágzó, kb. 200 éves régészeti kultúrára, archeosztratigráfiai egységre enged következtetni (lásd a régészeti fejezetben). Ebben a zónában a legmagasabb az útifü (Plantago) aránya az egész szelvényben. Az ehhez a szakaszhoz tartozó lakosság másik, pre-Gáva korú települését néhány kilométerrel északabbra, szintén az M5 autópálya nyomvonalán, Szeged-Kiskundorozsma-Subasa lelőhelyen találták meg (Róka, 2010). A Maty-ér délebbi régióját ez a lakosság legelőként hasznosította, de a település néhány km-es közelsége miatt gabonapollenek is megjelennek. Terepbejárási adatok (összefoglalja Sánta, 
2004, 2011) alapján a Dorozsma-Majsai Homokhátság településszáma az őskorban a Halomsíros időszakban volt a legmagasabb, ami jelezhet ténylegesen megnövekedő népsűrüséget, de inkább a lakosság mobil életmódjának, gyakoribb helyváltoztatásának tudható be. A késő bronzkor későbbi időszakában (Kr. e. 1100-tól) és a kora vaskorban a gabonapollen szinte nullára csökken, de az útifü (Plantago), üröm (Artemisia), imola (Centaurea) és cickafark (Achillea) aránya magas marad, ami a térség legeltető állattartásra való használatát, illetve kifejlett úthálózatot mutat, a közelben szántóföld nem volt. Az Urnamezős periódus települései a Dorozsma-Majsai Homokhátságon ritkásan fordulnak elő, de nem ürül ki teljesen a terület. Terepbejárásaink szerint a viszonylag sürü Halomsíros településszerkezet után 1/10-ére esik vissza a településszám (Zákányszék, Sánta, 2004, 2011). A korszak egyik legjelentősebb lelőhelye Ruzsa-(Öreg)Csorva (Trogmayer, 1963), de a Tisza mentén több település is kialakult, pl. Baks-Temetőparton, (Gáva-kultúra, V Szabó, 2006, 152, 2007, 163, 2008,143), mely jelentős központ volt, komoly fémmüvességgel. Ebből adódóan a szükebb térség viszonylagos elnéptelenedése valószínűleg településkoncentráció eredménye.

A fák pollenje összességében nagyon erősen lecsökken, a késő rézkortól kezdődően erdőirtás mutatható ki. Igen érdekes, hogy a bükk és a gyertyán (Fagus és Carpinus) csak a kora bronzkorban jelenik meg. Ennek okát nem tudjuk.

Az éger (enyves éger, Alnus glutinosa) ártéri állománya a késő rézkorig állandó, enyhén változó. A késő rézkorban több irtási ciklus figyelhető meg, az egyik az állomány felét elpusztítja (80-82 cm körül). Ezután az éger állománya regenerálódik, és mennyisége holocén (őskori) maximumot ér el a kora bronzkorban, $48 \mathrm{~cm}$ körül. Mindez arra utal, hogy ebben az időszakban a lakosság az árterületet nem, vagy alig hasznosította, legalábbis fakitermelést a környéken nem végzett az ártérben.

Az éger állománya a középső bronzkor közepén kezd el számottevően csökkenni, és egy igen jelentős minimumot ér el $22 \mathrm{~cm}$-nél, a vizsgált Halomsíros település időszakában. $15 \mathrm{~cm}$ táján, a késő bronzkorban (Kr. e. 1000 körül) az égen populációja gyakorlatilag ismét regenerálódik, bár a kora vaskortól ismét erdőirtás kezdődik az árterekben. A gabonapollen alapján a terület viszonylagos kiürülése Kr. e. 1100-1200 között (jó közelítéssel 1150 körül) következett be, míg az éger regenerációja inkább 1000 táján tapasztalható. Ez a különbség az erdőállomány regenerációjához szükséges 100-150 esztendőt tükrözi. Mindez alátámasztja azt az elképzelést, hogy a késő bronzkor második felében - egyelőre ismeretlen okok miatt - a jelzett terület elnéptelenedett. Ez a változás jól szinkronizálható a Halstatt A1 periódus végével és a Gáva-, Kyjatice-kultúra kialakulásával és az Urnamezős-kultúra késői szakaszának kezdetével. Igen valószínűnek tartom, hogy e nagy kultúrák kialakulása és/vagy átrendeződése áll a terület elnéptelenedésének, a településszerkezet változásának hátterében.

Az éger (Alnus) és némileg a gyertyán (Carpinus) középső bronzkor végi, késő bronzkor eleji nagyarányú irtása, ugyanakkor a többi fafaj egyenletes csökkenése, állományának stagnálása vagy a bükknél megfigyelhető holocén (őskori) pollenmaximuma mellett a két fafaj, de elsősorban az éger szelektív irtására utal. Úgy véljük, hogy a kora bronzkorban érintetlen árterek mezőgazdasági hasznosításának (állattenyésztés céljára legelők kialakítása) lehetünk tanúi. Az éger fája puhasága miatt építkezésre alkalmatlan, ugyanakkor jól tűri a víz alatti környezetet, így hidak, kútbélések kialakítására, talán csónakfának használhatták. Jól faragható 
puha fája bútorfának is alkalmas lehetett, és csersavban való gazdagsága miatt bőrcserzésre is használhatták. Feltételezzük, hogy a halotthamvasztást is a puha, jól égő fájával végezték. Mindazonáltal az éger kiirtásának fő oka mindenképp a legelők, esetleg alacsony térszíneken fekvő szántók létrehozása volt.

A felszín felé haladva a rétegtömörödés, üledék kiszáradás nyomán az üledék megsemmisülés és ezzel együtt pollenveszteséggel kell számolni. A pollenösszetétel alapján a késő holocén, az utolsó 2500 évet átfogó bükk II. pollenfázist már nem maradt fenn a Sümegi Pál és munkatársai által vizsgált szelvényben. 


\section{Archeometriai eredmények}

\section{Kerámialeletek elemzése}

A régészeti kerámiák a leggyakoribb leletek az ásatásokon. Vizsgálati módszereik közül a következöket említhetők (Kreiter, 2010):

- makroszkópos vizsgálat, leírás, készítéstechnikai jegyek megfigyelése

- sztereomikroszkópos megfigyelés (szemcseméret, soványítás, zárványok, készítéstechnikai jegyek)

- vékonycsiszolat (a durvább frakció ásványainak azonosítása, származási hely)

- röntgen-pordiffrakció (ásványos összetétel, származási hely, égetési hőmérséklet)

- kísérleti régészet (technológiai fogások gyakorlati kipróbálása, égetési hőmérséklet alsó korlátjának meghatározása, adott nyersanyag tesztelése)

A fent megnevezett módszerek közül a makroszkópos, a sztereobinokuláris mikroszkópos vizsgálatot és a kísérleti kerámiakészítést használtam fel. Lehetőség hiányában nem nyílt mód röntgen-pordiffrakciós és vékonycsiszolatos vizsgálatok elvégzésére. Ugyanakkor így is számos megállapítást tehettem a lelöhely kerámiakészítési technikájára, valamint a bányászati helyekre vonatkozóan.

A lelöhelyröl 39 db kerámiát vizsgáltam. A tárgyak a kiselejtezett kerámiaanyagból kerültek ki, így leltári számuk nincs, ezért a gödör számával és azon belül sorszámmal jelöltem őket (pl. 1/1.: 1. gödör 1. tárgy). A makroszkópos vizsgálat alapján nagyon hasonlók vagy legalábbis nem mutatnak többet a lelöhely más kerámiáinál, sőt, igen jellegtelen töredékek (ezért is selejtezték ki őket). Többön viszont bevonat (schlickwurf) azonosítható. Ezután beépített fényforrással ellátott 40x nagyitású sztereomikroszkóppal vizsgáltam meg őket, több oldalról is, igyekeztem viszonylag friss törésfelületet, vagy lekopott felületet találni, ahol a kerámia szemcsézettsége világosan látható. A megfigyelés közben jegyzeteket és vázlatrajzokat készítettem róluk, fényképfelvételek készítésére nem volt mód. A mikroszkópos leírásokat a Mellékletekben közlöm.

\section{Értékelés}

A kerámiakészítéshez felhasznált agyag szemcseösszetétele eltéréseket mutat, mely alapján 6 nyersanyag-típust lehetett elkülöníteni (7. táblázat, 82. ábra). Ezek a típusok azonban alapvetően három csoportba sorolhatóak:

1. kőzetliszt-mentes,

2. durvakőzetlisztes és

3. amfibolos/piroxénes, folyóvízi apróhomokos-kőzetlisztes nyersanyagokra.

A kőzetliszt-mentes nyersanyag mindössze 2 gödörből került elő 3 példányban, ezek közül $2 \mathrm{db}$ az 1. számú gödörből, melyet régészeti, tipológiai megfontolások alapján a telep egyik legkorábbi gödreként értékeltem. A 17. objektum leletanyaga is korai vonásokat mutat, ezért ezt a nyersanyagot vagy egy jobb minőséget gyártó fazekas-tradíciónak, vagy egyszerűen a telep alapításakor máshonnan hozott tárgyaknak tulajdonítom.

A durvakőzetlisztes nyersanyag a legelterjedtebb, 36 mintában lehetett kimutatni ezt az alkotórészt. Némelyikben olyan nagy mennyiségben van jelen, hogy kőzettanilag inkább agyagos aleuritnak nevezhető a nyersanyag. Ugyanakkor Véninger Péter keramikus legújabb 
régészeti, kerámiakészítési kísérletei azt az eredményt adták, hogy még a legsoványabb agyagból is lehet felrakással edényt készíteni, a sovány agyagból készült edény ugyanakkor száradáskor nem reped és alig zsugorodik, kevéssé érzékeny az égetéskor kialakuló hőmérséklet-különbségek repesztő hatásaira, valamint hőállóbb. A régészeti kísérlet során az agyag képlékenységének meghatározására a talajtanban és lazaüledék-geológiában használt perec-karika-hurka módszert alkalmazta. Kimutatta, hogy azokból az üledékekből, melyekből már karikát sem lehet hajlítani, még nagyon jól lehet felrakással edényt készíteni. Sőt, a már hurkává sem görgethető ,agyagból” is sikerült edényt felraknia, de a nyersanyag erősen összerepedezett (Véninger, 2011). Ilyen repedésnyomok nagyon sok, a településen feltárt kerámián megfigyelhetők (pl. 479/2).

A kísérletet megismételtem a már nagyon sovány, de nem legsoványabb agyaggal, melyből már nem lehetett karikát hajlítani. A „kishajmási” agyagot (boltban vásárolható) osztályozatlan homokkal soványítottam. Véninger Péterrel közös korábbi kísérletünkben azt vizsgáltuk, hogyan soványítanak egyes anyagok, és azt találtuk, hogy a finom szemcsés anyagok erösebben soványítanak, ezekből kevesebb hozzákeverésével is olyan sovány nyersanyag állítható elő, mint több, durva szemü soványítóanyag hozzáadásával. Az edény egy viszonylag bonyolultabb, gömbös hasú, szük nyakú, ívelt hurkafüllel ellátott kora bronzkori krétai edény (kora minószi I-II): egy 10-12 cm magas kiöntőcsőrös kancsó volt. Az edényt különösebb nehézség nélkül, könnyen el lehetett készíteni az erősen sovány agyagból, a formázás sem tartott sokkal tovább (1,5-2-szeres volt az időnövekedés). Az edény 1 óra alatt elkészült.

A nagyon erősen sovány agyagokhoz adott víz a képlékenységet növeli, tehát kövérít, így a formálhatóság fokozható. Megállapítható, hogy a településen felhasznált agyagok nagyon, néha szélsőségesen soványak, kőzettanilag az agyagos aleurit vagy aleuritos agyag között mozognak, de találunk apróhomokos-aleuritos agyag összetételüt is. Mivel ezeket a nyersanyagokat még zúzott, néha szitált kerámiával is soványították, az aleurit és a homok valószínüleg nem mesterségesen hozzáadott alkotóelem, hanem a bányahely kőzettani sajátosságait örzi. A benne megjelenő vasborsók alapján ez a lelőhely egy vízhatású, folyóvízi vagy infúziós löszös feltárás lehetett. A lekerekített eolikus és a szögletes folyóvízi homok ritka (2-2 eset) megjelenése szennyezésként értékelhető.

Igen izgalmas az amfibol vagy piroxén, néha augit vagy biotit fenokristályokat tartalmazó, de még mindig kőzetlisztes nyersanyag. Ezek a nehézásványok idiomorfok, vagy kristálytöredékek, vízi szállításuk bizonyos. Származási helyük az Északi-középhegység, elsősorban a Zempléni-hegység, hiszen a térség a Tisza árterülete. A többfajta aleuritos nyersanyag több bánya, bányagödör meglétét feltételezi, ugyanakkor a legáltalánosabban a vasborsós, vízhatású nyersanyagot kedvelték, és valószínűleg a bányagödrökben iszapolták. Összegzésképp elmondhatjuk, hogy a lelőhely megvizsgált kerámiáinak nyersanyaga döntően helyi eredetü, és a 6 típus kétféle anyagot takar: az egyik egy finoman iszapolt, mely talán nem helyi származású, és egy másikat, mely aleuritos: ennek lelőhelye a Maty-ér vízrendszerében, a Tisza árterében keresendő, a lerakott folyami üledékek között. Az amfibolos, nehézásványos nyersanyag talán a Tisza élő medréhez kötődik. Ugyanakkor a 
Maty-ér üledékes rendszerének alját agyagos-aleuritos Duna-üledék jellemzi, mely nehézásványokban nagyon gazdag (Sümegi et al, 2003).

\section{Kőanyag elemzése}

A lelőhelyen az ásatás során 4 db kőtárgy és 6 db kőzetszerü minta került elő. 2008-ban folytatott terepbejárásunkon $1 \mathrm{db}$ nagyobb kőzetdarabot találtunk, mely a vastag karbonátos kéreg miatt nem lehet recens, valószínüleg az egyik bronzkori szintből származik (Nagyrévvagy Halomsíros-szint). A 11 db minta vizsgálata puszta szemmel és 20x nagyítású sztereomikroszkóppal történt.

Régészeti lelőhelyeken gyakoriak a különféle kőeszközök, és a kő mint nyersanyag felhasználása:

1. pattintott kőeszközök és szilánkok,

2. csiszolt kőeszközök,

3. őrlő- és zúzó kövek,

4. öntőformák,

5. üllők,

6. formázó és fényező kavicsok (kerámiához),

7. kőnyersanyag zúzott állapotban, kerámiába keverve,

8. kődarabok kemencék, tűzhelyek aljába, oldalába tapasztva, a jobb hőtartás elérésére.

A fentiek közül az 1. és a 8. felhasználási módszer bizonyítható, ami a kőben szegény régió adottságaival magyarázható. Feltünő viszont a más alföldi lelőhelyeken gyakori örlökövek teljes hiánya, ami talán ásatás-technikai okokra vezethető vissza, de az is elképzelhető, hogy a korabeli lakosság az értékes kőanyagot nem dobta a gödrökbe, hanem valami más módon újrahasznosította (kemencékbe építette, összetörve és megőrölve agyagba keverte). Érdemes végiggondolni azt a lehetőséget is, hogy (a hazai őskorban teljesen szokatlanul) talán famozsarakban történt a gabona összezúzása (lásd durvára őrölt darakása az 5. gödörből).

A kőanyag helyi eredetű, vagy a Maros vagy a Tisza vízi útján szállították a lelőhelyre. Erre utalnak a Maros, valamint a Száraz-ér mentén, illetve Marosvásárhelyen feltárt, részben korai Halomsíros település- és temetőmaradványok. A Tisza mentén ugyanakkor ez a szerkezet nem figyelhető meg, itt a kevéssé kutatott, de a Halomsíros közösségektől határozottan elkülönülő Rákóczifalva csoport él. Tápé temetőjében találtak néhány Rákóczifalva import tárgyat, s kissé északabbra a Kárpát-vidéki Halomsíros kultúra képvisel hasonló leletanyagot. Azonban míg ezek közvetett kapcsolatok, addig a Maros völgyében közvetlenül a mi területünkkel kapcsolatba hozható leletanyag jelenik meg, olyannyira, hogy a Marosvásárhelyen feltárt kis temető leletei szinte a Szeged környékiekkel (különösen a bogárzói és bilisicsi leletekkel) kicserélhetőek (Roska, 1942, 199. kép). Úgy vélem, ez komoly érv a lakosság Maros menti kapcsolataira nézve. Természetesen mindez nem zárja ki az északi kapcsolatokat sem, figyelembe véve, hogy a középső bronzkorban a Tisza mente igen fontos vízi út, melyet az északi Füzesabony-kultúra Sövényházán (Sándorfalva-Dóc környéke) való megjelenése mutat (lásd a Konklúzióknál). 


\section{Fémmüvesség és kereskedelem}

A bronzkori településen 2 db fémtárgy került elö, egy apró, görbült lemeztöredék a 17. gödörből, és egy bronzfürész szórványként a humuszból (88-89. ábra). A lemeztöredék egy kevert anyagú gödörből, igen rossz állapotban (törötten, gyakorlatilag teljesen oxidálódva, fémmag nélkül) került felszínre, ezért nem lehetett méréseket végezni rajta. A fürész jóval izgalmasabb: bármennyire is szórvány, pontosabban köthető korszakhoz, ez esetben a dolgozat fö témáját jelentő Halomsíros-kultúrához. A tárgy magas óntartalmú bronz, és tudjuk, hogy ónbronzot a Nagyrév-kultúra idején nem, vagy csak igen kis mennyiségben állítottak elő (Kiss, 2009). A bronzfürészeket még a legutóbbi időkben is a Reinecke BD időszak végétől keltezték (Kemenczei, 1991, 42-43). Nagyszámú előfordulásuk valóban ekkortól észlelhető (Kemenczei, 1984, Mozsolics, 1985, stb.), de néhány újabb lelet, köztük a domaszéki is, a tárgytípus kialakulását korábra tolja. Bató Szilvia feltehetően fürészlemez töredékét találta kelebiai terepbejárásán (Kelebia-Vermes-járás, 17. lelőhely), a Vatya-kultúra leleteivel. Itt korábban Gallina Zsolt ásatásán bronz peremes balta került elö, amely a lelőhelyet a koszideri periódusba datálja (Bató, 2001, 46-47, 18. kép 2.). A térségben ez a fürész legkorábbi előfordulása.

Bianka Nessel foglalkozott legutóbb ezekkel a leletekkel. A bronzfürész elsősorban késő bronzkori tárgytípus, a fém fürészlap a Kr. e. 2. évezredben Délkelet-Európában és az Égeikumban jelenik meg (Nessel, 2009, 239). A kutatónő alapvetően két csoportra osztotta őket: az egy- és kétoldalas fürészekre (Nessel, 2009, Abb. 6-7.). A domaszéki darab egyértelműen kétoldalas, erősen használt (kopott) penge (a vágóélek konkáv alakúak), egyik oldalán a rögzítésre szolgáló lyukkal. Nessel tipológiai rendszerében a Tăuteu-i (PetrescuDîmbovița, 1978, Taf. 247 B, 13), a karcagi (Mozsolics, 2000, Taf. 45, 10) és a Suceava-i (Hansel, 1999, Abb. 6, 11) fürész a legközelebbi párhuzama. Fülkiképzésében (átfúrt lyuk) a Boljanic-i (König, 2004, Taf. 18, 50), és a velemi, tállyai darabokhoz hasonlít leginkább (Miske, 1908, Taf. XXXII, 15, Taf. XVII, 20, Mozsolics, 1985, Taf. 162, 4). A fürészek a Felső-Tiszavidéken, az Erdélyi-medencében és a Szerémségben kerültek elő nagyobb számban. A Duna-Tisza közéröl egyetlen fürész ismert, leszámítva a domaszéki, most közölt darabot. V. Szabó Gábor Baks-Temetőparton 2007-ben, a Gáva-kultúra településén elrejtett kincsleletek hitelesítése közben tárt fel egy gazdag leletanyagú Halomsíros gödröt, melyben pecsétfejü tủ mellett fürészpenge is elökerült (V. Szabó, 2007, 163). Hódmezővásárhelyen a IV. téglagyárból elökerült fürészpengét öriznek, de ennek datálása már Gáva-kultúra (V. Szabó, 1996. 22. kép 16.).

Fémelemzések 2009-ben

A fürész összetételét (10. táblázat) XRF módszerrel az SZTE TTIK Geokémiai, Kőzetés Ásványtani Tanszékén Dr. Bozsó Gáborral vizsgáltuk, 19 további Halomsíros mintával kiegészítve (9. táblázat). Ezek a tárgyak részben a Dél-Alföld ősrégészeti szempontból kulcsszerepet játszó korai Halomsíros temetőiből (Szeged-Bogárzó B, Röszke-Sárosvölgy), részben újabban ásott vagy feldolgozott lelőhelyekről kerültek elő (Zákányszék-Zákány dűlő, Domaszék-Börcsök tanya és Ásotthalom-Királyhalom, 8. táblázat). Az eredményeket clusteranalízissel értékeltük, és 3 különálló, természetes csoportot (A, B1, B2) különítettünk el. 
Elsősorban arra voltunk kíváncsiak - az összetételen túl -, hogy a 2007 folyamán a debreceni MTA Atommagkutató Intézetben (ATOMKI) PIXE-vel mért eredményeink (Sánta el al, 2007) mennyire megbízhatóak. A 9. táblázatban mutatjuk be eredményeinket, melyek alapján kijelenthető, hogy a két helyszínen, két különböző módszerrel végrehajtott mérések nagymértékben egyező mérési eredményeket adtak, azok a tárgyak valós összetételét tükrözik. Az eltérés csak néhány százalékos.

A minták fö-, és nyomelem-tartalmát XRF módszerrel határoztuk meg. Két tárgy (mintaszám: 2,10) esetében a fö- és nyomelem-összetétel megállapításán túl megvizsgáltunk egy-egy óndús foltot és környezetüket. Így összesen a 19 tárgyról 22 röntgenspektrumot vettünk fel. A kapott eredményeket (tömegszázalékos összetétel) Dr. Geiger János értékelte cluster-analízissel (90. ábra).

A kapott, számszerü eredményeket cluster-analízissel vizsgálta meg, ahol a réz, ón, vas, nikkel és arzén arányát vette alapul, hiszen ez az öt elem volt megtalálható minden mintában. Két, eltérő, természetes csoportot, $\mathrm{s}$ az egyikben két alcsoportot (összesen tehát 3 cluster-t) azonosított, melyeket A-nak, B1-nek és B2-nek neveztünk el. Egy tárgy külön csoportot alkot, a többi háromba nem sorolható be (12. táblázat).

Az A csoport jellemzője a magas, $10 \%$ feletti, de néha a 15-18\%-ot is elérő óntartalom, valamint a magas nikkel és ennél alacsonyabb arzéntartalom. Antimon csak nyomokban mutatható ki a csoport tárgyainak anyagában. Igen jellegzetes az ón mennyiségének változatossága, mely a csoport legfontosabb tulajdonsága. A fürész az A csoportba tartozik, és nincs benne sem antimon, sem arzén, ezért biztosan nem lehet az ércek között fakóérc.

A B1-es csoport 5 tárgya 5-6\%-os óntartalmával a leghomogénebb, tárgyai általában antimonban, arzénben és nikkelben gazdagok. A B2 csoportban kissé magasabb az ón aránya (7-10\%), és jellemzőek a magas arzéntartalmú bronzok, míg továbbra is jelen van szinte az összes mintában az antimon és a nikkel is.

Néhány mintában ólom is előfordul, jelenlétét a polimetallikus érctestekben szinte mindig megjelenő, gyakori ólomérc, a galenit $(\mathrm{PbS})$ szennyezésének tulajdonítjuk. Fontos kiemelni, hogy a B2-es csoportba tartozó 17. és 18. tárgy (háromszög átmetszetű karperectöredékek) egyazon nyersanyagból készült, így együvé tartozásuk - azonos formájukon túl - bizonyítottnak tekinthető.

A három (négy) csoport eredetének magyarázatául három lehetőség adódik:

1. kronológiai különbség

2. származási hely eltérö

3. készítés-technika eltérő.

Valószínű, hogy mindhárom ok egyaránt közrejátszik a megállapított cluster-ek létrehozásában.

A 12. táblázat utolsó oszlopában a David Liversage (Liversage, 1994) által bevezetett bronztípus-elnevezéseket láthatjuk. Liversage a Kárpát-medence bronzkori fémtípusait elemezte cluster-analízissel, a SAM (Stuttgarti fémanalízis projekt) mérései alapján. Az elemzett minták közül csak egyet nem sikerült besorolni közéjük, ezt Rüdiger Krause munkája (Krause, 2003) alapján tudtuk azonosítani. Krause értékelte újra a régi méréseket, melyek a stuttgarti adatbázisban vannak, és számos cluster-csoportot tudott kimutatni. A 
méréseket ömlesztve kezelte, míg Liversage csak a Kárpát-medenceiekkel foglalkozott. Nem véletlen, hogy bár ugyanazt a mintaanyagot használták, Liversage cluster-ei teljes mértékben illeszkednek méréseinkhez. A fémtípusok többsége (11 db) klasszikus AsNi összetételü fém, mely Liversage szerint a Reinecke A2-B1 periódus jellemzö típusa (FD III-MDI-II, Hänsel, 1968, rendszerében). Ennek alacsony arzén- és nikkeltartalmú változata az igen ritka „dasni” típus, mely a mintasorozatban három példánnyal van jelen. Az AsNi összetételü minták felében (6) nincs mérhető antimon. A magasabb antimontartalmú bronzokat Liversage az ASN típusba sorolja, mely szerinte az AsNi-ból alakult ki, és időben követi azt oly módon, hogy az új, ASN összetételü bronzok kiszorítják az AsNi összetételüeket. Ezt az új fémtípust a Reinecke B2-től figyelhetjük meg, és jellemző marad egészen a bronzkor végéig, miközben az ólomtartalma megemelkedik. A típust Liversage feltételesen erdélyi forrásterülethez köti, magyarázatot kínálva az AsNi típustól való eltérésére (Liversage, 1994, 72-74, Table xvxvi.). A mintasorozatban 4 db klasszikus ASN összetételü fémet látunk, így kijelenthető, hogy a mintasorozatban a koszideri időszakra jellemző AsNi típus dominanciája mellett megfigyelhető a késő bronzkorra jellemző ASN típus fellépése. A típusok ugyanakkor nem köthetőek kronológiai szakaszokhoz, hiszen az ASN összetételü fém egyaránt megjelenik a Röszke-sárosvölgyi - elvileg korai - temetőben, és a későbbre datált ásotthalmi és zákányszéki együttesekben. Ugyanakkor a Szeged-bogárzói fémek kivétel nélkül AsNi típusúak, összhangban koszideri datálásukkal. A fürész nem sorolható be ebbe a rendszerbe, anyaga elég tiszta, magas ón-, nikkel- és vastartalmú bronz. Esetében a kelet-alpi, felvidéki származás megfontolandó (Krause, 2003). A származási hely kérdésére később még visszatérünk. Azt elmondhatjuk, hogy a mintákon végzett 2009-es mérések alapján nem állapitható meg egyértelmüen a fém nyersanyag származási helye.

Felmerül a kérdés, hogy valóban alkalmazhatóak-e Liversage csoportjai, miközben a saját cluster-analízisünk eltérő csoportokat hozott létre. Ha megnézzük Liversage csoportjait, azokban az ón $6 \%$ körüli átlagos értékkel szerepel, és csak kismértékben (1-3\%) változik (Liversage, 1994, Table xv-xvi.). A méréssorozat tárgyainál az óntartalom jelentős kilengéseket mutat. A cluster-analízisben az ón mennyiségét is figyelembe vettük, ezért alakultak ki az első ránézésre eltérő csoportok. Ha azonban az ónt figyelmen kívül hagyjuk, megkapjuk Liversage alcsoportjait. Az ón egy újabb fontos kérdéskör, az újrahasznosítás szempontjából fontos.

A bronzok újrafelhasználása (recycling) kapcsán nem tehetünk egyértelmü megállapításokat. Az A csoportban nagyobb mennyiségben, de mintánként eltérő arányban megjelenő ón inkább amellett szól, hogy nem történt komolyabb újrahasznositás. A B csoportban az egységesen alacsony óntartalom kifejezetten az újrahasznositás mellett szól (Liversage, 1994, 77). Hasonlóan érdekes eredményre jutunk, ha a kognitív régészet szemszögéből közelítjük meg a kérdést. Mai, gazdaságosságot előtérbe helyező szempontjaink alapján azt gondolnánk, hogy a bronzkorban sủrün előfordulhatott a használt tárgyak újraolvasztása, de azt tudjuk, hogy a kor embere teljesen másképp viszonyult a fémekhez, azokat kultikus és társadalmi jelentéssel (méltóságjelvény) is felruházta. Mind a koszideri periódusból, mind a korai halomsíros kultúra időszakából nagyszámú fémlelet ismert, melyeket „kivontak” a forgalomból, azaz deponálták vagy sírba helyezték (Bóna, 
1992). Ezt a vélhetően nem csekély mennyiségü fémet pótolni kellett, hisz újrafelhasználásuk a fenti okok miatt nem volt lehetséges. A halomsíros temetőkben csak ritkán van jele sírrablásnak (Csányi, 1980), még a gazdag bronzmellékletes temetkezések is jobbára érintetlenek. Igen érdekes, hogy a fém „profanizálódása” csak a későbronzkor nagy kultúráiban megy végbe (Piliny, Kyjatice, Urnamezős, Gáva, Lausitz), bár a temetők fémszegénysége minden bizonnyal magán viseli az erős társadalmi rétegződés hatását. A pilinyi kultúrában megfigyelhető a fémek miniatürizálása, azaz a halott mellé temetett tárgy eredeti funkciójának, ,animájának” átültetése egy hasonló formájú, de jóval kisebb tárgyba, mely a fémhez való viszony racionalizálódását mutatja (Kemenczei, 1984). Ezt a képet árnyalja kissé a B csoportban valószínüsíthető újrafelhasználás.

\section{Az ón}

A Halomsíros kultúra dél-alföldi lelőhelyei mind kapcsolatot mutatnak a Közép-Dunavidék hasonló korú lelőhelyeivel, ezért feltételezhető, hogy az itt élő közösségek kapcsolatrendszere nagyobb mértékben irányult abba az irányba, mint korábban. A Csehérchegység ónjának kereskedelme, félkész termékek formájában, fontos lehetett, valószínü, hogy a Halomsíros „egység” kialakulása (Kovács, 1995, V. Szabó, 1999) is ennek a kereskedelmi-kapcsolati hálónak, s a szálai mentén terjedő innovációknak köszönhető. Igen érdekes, hogy az AsNi fém megjelenése egybeesik a Halomsíros kultúra kialakulási periódusával (késő Aunjetitz, kora Halomsíros időszak, R B A2-B1, Liversage, 1994, 72-73). Talán maguk a nagy területen hasonló formában készülő csüngők (fordított szív alakú, középtagos és tüskés korong alakú formák) is egyfajta „félkész termékek”, vagyis a csere kiváló alanyai lehettek. Alaki és méretbeli homogenitásuk ezt az elképzelést alátámasztja, továbbá elterjedésük megelőzi a Halomsíros-kultúra kárpát-medencei megjelenését (Reinecke BB1 időszak), a koszideri cserekapcsolatok révén nagy területre terjednek ki. A korai bronzkor első nagy egysége, az aunjetitzi kultúra csereárui és értékmérői is részben egyszerü ékszerek voltak (Ösenring - nyakperec, Kiss, 2009). Nyugat-Európából több helyről ismertek óngyöngyök, melyek még inkább alátámasztják a szív alakú csüngő félkész termékként való értelmezését (Primas, 2002).

\section{A 2010-11-ben végzett archeometallurgiai mérések}

2010-ben az EU-s CHARISMA programon belüli SPIRIT pályázati rendszerben a debreceni kollégákkal (Dr. Uzonyi Imre, Dr. Kertész Zsófia, Csedreki László) együtt pályázatot adtunk be a Ljubljana-i Jožef Štefan Intézetben (Szlovénia) végzendő archeometallurgiai mérésekre (91. ábra). A mintasorozat kezdetben 50 db koszideri és Halomsíros bronztárgyat foglalt magába (92. ábra). A leletek kiválogatása során 10 mintát kivettem a célcsoportból, mivel az erős oxidáció miatt rendkívül rossz állapotban voltak, fémmagot nem tartalmaztak. A megmaradó 40 minta közül 39 bronzkori, 1 db kora népvándorlás kori (szarmata). A használt módszer PIXE ionsugaras mérés volt $3 \mathrm{MeV}$-os lineáris gyorsítón (Tandetron), levegőben, Al és Co abszorbenseken keresztül. Az abszorbensek célja az volt, hogy az együtt vagy egymás közelben jelentkező csúcsokat a spektrumon belül jól el lehessen különíteni. A minta-előkészítés során a felületi oxidréteget egy néhány $\mathrm{mm}^{2}$-es területen a fémmagig eltávolítottuk. Munkatársak: Dr. Žiga Šmit és David Jezeršek. 2011 februárjában microPIXE mérést végeztünk az ATOMKI debreceni 
laborjában, 6 tárgy elemtérképeit vettük fel, egy tárgyat SEM-EDX-szel (pásztázó elektronmikorszkóp, visszaszórt elektronkép, mikroszonda) vizsgáltunk a tárgyból származó 2 mm-es töredék vágott, polírozott felületén.

\section{A vizsgált tárgyak}

A leletek Csongrád megyében, elsősorban Szeged környékén előkerült Halomsíros és Vatya temetők mellékletei, egy részük közöletlen (14-15. táblázat, közlések: Tömörkény, 1902, 1903, Foltiny, 1957, Trogmayer, 1975, Sánta, 2004a-b).

A kiválasztás szempontjai voltak:

1. A tárgyak fedjék le az egész Halomsíros időszakot,

2. a lehető legtöbb tárgytípust képviseljék.

A tárgyak eltérő korúak. A koszideri periódusba tartozó, Vatya-kultúrához köthető a Csengele-(Belsö)Mételyesi lelet, koszideri korú Halomsíros a Tömörkény-újmajori, Ásotthalom-bilisicsi sarlós tü, a Szeged-bogárzói és Röszke-sárosvölgyi leletek. A többi tárgy a klasszikus Halomsíros időszakban készült (a legnagyobb mintasort a Tápészéntéglaégetői leletek alkotják). Kifejezetten késői tárgy nincs a leletek között, datálásuk nem terjed ki a R BD időszakra.

A leletek között előforduló típusok: pecsét- és korongfejü, sarlós és pödrött végű tűk, tütöredékek, karperecek (mindenféle típus) és töredékeik, csüngők (több típus) és töredékeik, lemezöv töredék, pinzetta, kés, csákány. Az 1. ábrán válogatást láthatunk a vizsgált tárgyakból.

\section{Fökomponens-analizis}

A főkomponens-analízist Dr. Žiga Šmit végezte, az eredményeket a kapott grafikon alapján én értékeltem. A minták között csoportok különíthetőek el a $\mathrm{Zn}, \mathrm{Pb}, \mathrm{Ni}, \mathrm{Sb}, \mathrm{As}, \mathrm{Ag}$ tartalom alapján (93. ábra). Egy minta rögtön kiugrik, ez ezüstözött ónbronz (szarmata).

Csoportok:

1. Zn-dús csoport. Korai temetők (Röszke-Sárosvölgy, Bogárzó-B, ÁsotthalomBilisics) leletei tartoznak ide, melyek már a koszideri időszak végén is használatban lehettek. Ez a csoport nagyon élesen különválik, és mögötte kronológiai okokat kell látnunk. $A$ kronológiai különbség a fémek összetételében azért nyilvánulhat meg, mert ebben a korai Halomsíros szakaszban más lehetett a fémek beszerzési területe.

2. Ólomban gazdag öntvénynek mutatkozott három lelet, a Tápé-széntéglaégetői 326. és 444. sírból származók, valamint egy zákányszéki felszíni szórvány. A szükebb perióduson belül csak a középső Halomsíros szakaszra jellemző, igen ritka bronztípus. A későbbi periódusokban az ólommal ötvözött bronztárgyak száma emelkedik, sőt jellegzetessé válik (Liversage, 1994, Trampuž-Orel et al, 1996, Fig. 4, 211-212).

3. A többi fém anyaga egymáshoz közel áll, mindegyikben van $\mathrm{Ni}, \mathrm{Sb}$ és As, $0,5 \%$ körüli mennyiségben, azaz ezek AsNi, 'dasni” és ASN fémtípusok (Liversage, 1994), melyek nagyon homogén és zárt csoportot alkotnak. Ezeket a típusokat a fémmüvességgel foglalkozó kutatók közül többen azonosították, de eltérően nevezték el. Így Schubert - Schubert (1967) munkájában ez a típus az SAM FA/B. Krause (2003) „Einheitskupfer” vagy „Ostalpines Kupfer” néven nevezi, ami azt jelenti, hogy jellegzetes, arzén-nikkel-antimon összetételt mutat. Ma már nem lehet egyértelmüen kijelenteni, hogy ez a réztípus kelet-alpi származású 
(Liversage, 1994). Néhány tárgy, így az ásotthalmi sarlós tü, egy korai jellegü kiskunmajsai tü (wetzleinsdorfi típus), valamint egy Szeged-bogárzói tüskés-körbordás tutulus Ni-gazdag csoportként különül el kissé (a megadott variabilitási értékek alapján nem minősülnek önálló csoportnak). Ezek korai keltezésüek, igy lehetséges, hogy az eltérések oka kapcsolatban van az idörendi helyzetükkel.

A mintákban mért 0,1\% körüli ezüsttartalom igen alacsony. Az AsNi és ASN típusú bronzokban ugyanakkor még ennél is alacsonyabb, 0,05 \% körüli értékek általánosak. A Liversage (1994) munkájában megadott variabilitás (kb. 0,03-0,05\%) alapján ezek még nem minősülnek önálló bronztípusoknak, de a típusokra megadott maximális, vagy annál kissé nagyobb ezüsttartalommal rendelkeznek.

A Rüdiger Krause (2003) által publikált teljes Stuttgarter Datenbank adatai között számos dél-alföldi tárgy is van. A bogárzói temetőből több tárgyat is megelemeztek, de ezek nem azonosak, illetve nem azonosíthatóak az általunk vizsgált darabokkal. Az adatok alapján a bogárzói fémek 6-7\% ónt, 0,5-0,7 \% arzént, 0,1-1\% antimont, 0,2-0,4 \% nikkelt tartalmaztak, bizmut és ezüst jelenléte nem igazolható (Stuttgarter Datenbank, Krause, 2003 CD-melléklete). Az adatok igen közel állnak a mi mérési adatainkhoz. Az adatbankban szereplő további dél-alföldi Halomsíros leletek (Bilisics, Tisza-meder Szegednél) 6-10 \% ónt, 3 esetben (bilisicsi karperecek) 0,3\% körüli ólmot, 0,2-1,65\% arzént 0,15-1,85\% antimont 0,37-0,84 \% nikkelt tartalmaztak minimális ezüst (0,05\% vagy az alatt) mellett. A jellemzett tárgyakat az Einheitskupfer/Ostalpines kupfer csoportba sorolták A stuttgarti törzsfán (Junghans et al, 1968) a fémek az FB1-2 csoportba tartoznak.

Alapvetően két fémtípus ismerhető fel az általunk vizsgált tárgyak között is:

1. As-Ni összetételű réz kevés antimonnal, bizmut, kobalt és ezüst nélkül, valamint ennek „dasni”-ként leírt változata (Liversage, 1994). Ez az ún. Einheitskupfer, vagy FA réz (Krause, 2003, Schubert - Schubert, 1967). Liversage-nél ez az AsNi-dasni típus.

2. As-Ni-Sb összetételü fém, ahol az antimon szignifikánsan magasabb az előzőeknél (kb. kétszerese). Ezt nevezte Liversage (1994) ASN típusnak, Krause (2003) Einheitskupfernek, Schubert - Schubert (1967) FB-nek.

Elektronmikroszkópos vizsgálatok (94. ábra)

A méréssorozatban másik célunk volt a tárgyak nagyfelbontású SEM-EDX vizsgálata. A tárgyak közül a 128/1885/18/3-as számú lelet egy apró (3 mm) darabját elvágtuk és SEMEDX módszerrel, elektronmikroszkóppal vizsgáltuk. A tárgy egy ötbordás lemezkarperec töredéke, mely a máglyán megégett, összetöredezett, a sírból sok töredék formájában került elő. A hőhatás ugyanakkor nem olvasztotta meg még a felszínét sem, kilágyulás sem történt, így a tủz hőfoka néhány száz $\mathrm{C}$ fok lehetett, ami megfelel a szabad tüzön, máglyán történő hamvasztás körülményeinek (Szabó, 2004).

Az elektronmikroszkópos vizsgálatokat Dr. Daróczi Lajos végezte az ATOMKI elektronmikroszkóp-laborjában. A 3 mm-es szemcsét, mely a karperec széléről tört le, elektromos szikravágóval kettévágta és a beágyazott darabokat polírozta. Az elektronmikroszkópos felvételeket a 94. ábrán láthatjuk. Nagyobb méretű, 100-150 mikronos, hatszöges kristályokat figyeltünk meg, melyek a minta utólagos hökezelését és újrakristályosodását igazolják (Kienlin, 2011, 94. ábra 1-2). A kis számban megfigyelhető 
ikerkrisztallitok gyenge utólagos megmunkálásra engednek következtetni, mely a lemez karpereccé hajlítását jelenti. A mintában sok üreget figyeltünk meg, melyek az elörehaladott korróziót jelzik, a korrózió mindig a kristálylapok mentén indul meg (94. ábra 2). A minta számos zárványt is tartalmaz, melyek közül a legfontosabban a szulfidos zárványok (94. ábra 3), ezek összetétele $\mathrm{Cu}_{2} \mathrm{~S}$, néha pontosan a ,tankönyvi” arányok szerint (66 - 33 atom \%). Ez az ásvány a kalkozin, a réztelepek cementácós övének gyakori, igen magas réztartalmú ásványa. A szulfidzárványok szabályos csepp alakúak, de előfordulnak amorf alakúak is, méretük 5-20 mikron közötti. Tartalmaz továbbá kicsiny buborékokat, hólyagokat, nem egyszer a szulfidos fázishoz tapadva (94. ábra 4), valamint hasonló jellegü szilikát/kvarczárványokat, melyek a salakképző kvarchomok (Ecsedy, 1982) melléktermékeként jelennek meg. Egy esetben a salak és a szulfid mellett szénzárványt észleltünk, mely a kohósításkor használt faszén maradványa lehet. Nem gyakori, de két esetben is előforduló zárvány egy réteges, viszonylag lassabban kihült, 30-40 mikronos, szabályos ovális csomó. Ennek összetétele réz-oxidnak és réz-szulfidnak adódott. Az el nem keveredett oxid olvadékcsepp belső felületén réz-oxid (kuprit) kristályok kezdtek növekedni, szabályos oktaédereik metszetét észleltük (94. ábra 7-8). Egy esetben találtunk ólom vázkristályt, mely a bronz alapanyagban található (94. ábra 6). Az ólom a bronzzal nem keveredik, nem alkotnak ötvözetet. Néhol megfigyelhető volt az ón szételegyedése a réztől.

Az üregekben mutatkozó sötét foltok szénhidrogének (94. ábra 5), a felületen látható gömbös-vesés, karfiolszerű kivirágzások pedig talán réz-karbonáttól származnak. A fémtárgyak archeometallurgiai vizsgálatára a SEM-EDX bizonyult a leghasznosabbnak, ez adta a legtöbb adatot a készítés technológiájáról.

MicroPIXE vizsgálatok (95-97. ábra)

Az ATOMKI-ban Dr. Kertész Zsófiával, Dr. Uzonyi Imrével és Csedreki Lászlóval néhány tárgy polírozott törésfelületéről microPIXE elemzést végeztünk, a felület 1x1 mm-es területének elemtérképét kaptuk meg. A felület korróziójára és a felszíni óndúsulásra vonatkozó adatokat reméltünk. A felszín valóban erősen korrodált, néha 1,5 mm mélységig, ami a tárgyak 3-5 mm-es vastagságát figyelembe véve azt jelenti, hogy a korrózió - még ha kezdeti fázisában is - de a teljes vastagságában átjárja a legtöbb mintát (95. ábra 1, 4). Ugyanakkor ezek a minták alapvetően épnek tűnnek, csak a részletes elemzés fedi fel a kristálylapok mentén megindult korróziót. Ez arra figyelmeztet minket, hogy kisméretü tárgyak, ékszerek esetében még a jól látható maggal rendelkező darabokat is részben korrodáltnak kell tekinteni addig, amíg ennek ellenkezője be nem bizonyosodik.

Minden mintát keresztmetszetben vizsgáltunk. A felületen sosem találtunk egybefüggő, tömör bevonatot, hanem szerkezete laza, porózus vagy sejtes volt. Előfordult a felületen óndúsulás, de épp ugyanazon a tárgyon, alig néhány száz mikronnal arrébb már inkább ónhiány mutatkozott (95. ábra 2, 96. ábra 2). Az óndúsulás - ha előfordul - néhány 10-100 mikron vastagságban jelentkezik. Az viszont nyilvánvaló, hogy ez a dúsulás nem az öntéskor, hanem a korrózió során keletkezett, és ezeknél a kis átmérőjü tárgyaknál a jó mintaelőkészítéssel (korróziós réteg eltávolítása) kiküszöbölhető. Természetesen a legmegfelelőbb módszer az volna, ha minden egyes tárgyat a belsejéből vett mintán vizsgálnánk, de ez mütárgyvédelmi okokból kifolyólag általában nem lehetséges. 
A felületi oxidrétegben jelentős mennyiségű szenet és oxigént mutattunk ki (95. ábra 3, 96. ábra 1). Ezt kezdetben a karbonátos oxidáció (malachit) számlájára írtuk, holott a (restaurált) felszínen nem láttunk zöldes bevonatot. Restaurátorral (Véninger Péter) való konzultáció után a szén- és oxigéntartalmat az állagmegóvás során alkalmazott szénhidrogéneknek (paraffinoknak) tulajdonítottuk. Ezt a kezelést a régebbi időkben előszeretettel alkalmazták.

Erős kloridos oxidáció nyomait észleltük (95. ábra 4). A klorid a restaurátorok számára nagyon kellemetlen anyag, mivel a tisztítás és állagmegóvás után is képes tovább roncsolni a tárgyakat (Véninger Péter szóbeli közlése). A talajvízben, így a régészeti tárgyakban is jelen lévő, egyébként oldott klór a minta kiszáradása után lép reakcióba a rézzel.

A korróziós rétegben réz-szulfidok és réz-oxidok is jelen vannak, a kén a réz átalakulása során a primer szulfidzárványok oxidációjakor szabadul fel, majd a minta felületén eltérő redoxi-viszonyok közé kerülve ismét reakcióba lép a rézzel (97. ábra 1). A fekete színű réz-oxid (tenorit) valószínüleg a minta kiemelése és restaurálása óta keletkezett.

A tárgyak pereme mentén egy esetben As és Zn dúsulást mértünk, mely azonban nem volt jelentős, ez a dúsulás egy nagyságrendet nem haladt meg (97. ábra 2-3).

A tárgyak mállatlan belső részén a kén apró foltjai az elektronmikroszkópos megfigyelések során azonosított szulfidzárványoknak felelnek meg (95. ábra 5, 97. ábra 1. bal felső része).

Hasonló, apró szemcsék formájában mutatkozik a Si-dús salak is (95. ábra 6, 96. ábra $3)$.

Érc, bányászat, forrásterület

Kiindulási ércként nem egyetlen ásvány, hanem egy ásványkeverék képzelhető el. A telepeket az oxidácós zóna színes (zöld és kék) rézásványainak segítségével találhatták meg, és részben ezeket fejtették is, főleg a kuprit és a termésréz miatt. Egyes rézérceket, így a kalkozint, covellint és tetraedritet kizárólag a mállásuk során keletkező zöld rézásványok alapján lehet rézércként azonosítani, mivel friss állapotban színük fekete, kékes vagy acélszürke. A réz fö tömegének előállítására a bronzkorban már szulfidos érceket használtak.

A mintában talált szulfidos zárványok összetétele $\mathrm{Cu}_{2} \mathrm{~S}$, azaz kalkozin, mely az érctelepek cementációs övezetében keletkezik. Ez az anyag azonban a rézkohászat mellékterméke is („feketeréz”), mely a primer szulfidércből a kén egy részének eltávozásával keletkezik, egyfajta félig redukált állapotú anyag. Ennek a beolvadására is sor kerül, amint azt a cseppek szabályos alakja mutatja. Ebből következik, hogy a kalkozin (feketeréz) a kohóban létrejöhet: 1. egy kalkozinos érc tökéletlen (nem teljes tömegében lezajlott) redukciójával,

2. kalkopirit és bornit nem teljes mértékű (részleges) redukciójával, ahol a vas eltávozik a rendszerből,

3. valamint keletkezhet antimon- és arzénfakóércből hasonló úton, miközben az antimon és arzén a rendszerből eltávozik, ill. az olvadékba vándorol.

Tehát ha az érceket és érces zónákat keressük, egyetlen olyan helyet sem szabad kihagynunk, ahol ezek az ásványok - főleg együtt - előfordulnak, és a kultúrák kapcsolatrendszerét figyelembe véve, szóba jöhetnek forrásterületként. 
A kárpát-medencei lelőhelyek kataszterét is összeállítottam, ennek közlésétől azonban hely hiányában itt el kell tekinteni. Most csupán azokat a helyeket emelem ki, melyek a legvalószínűbb jelöltként szerepelnek az érc származási helyeként.

Bányászati nyomok Úrvölgy mellől Homokhegyről (Špania Dolina - Piesky, SK) ismertek, ezek főleg teléresek (Žebrák, 1990, Točik - Žebrák, 2003). Az Alpokból is előkerültek középső bronzkori, Halomsíros csoportokhoz köthető bányavágatok alagútépítési munkák (Arthurstollen) során (Stöllner et al, 2006), melyek a megmaradt bányafa dendrokronológiai adatai alapján a Kr. e. 15-14. századra, a közép-európai középső bronzkorba, vagyis a Halomsíros-kultúrába (Hügelgräberzeit) keltezhetőek, és vizsgált mintáinkkal javarészt egykorúak. A bányákat igen szük, 60x80 cm-es keresztmetszetü vágatokkal és felszíni horpákkal müvelték. A vágatokat kalkopirit-ankerit-fakóérc kitöltésü, ún. alpi típusú (metamorfózishoz kapcsolódó elemmobilizáció révén létrejött) telérekre hajtották, fillitben és kvarcitban. Az érc kobalt- és nikkeltartalmú volt. Feltárták a bányászat eszközeit, így a fejtőcsákányok (?) (tokosbalták) fanyelét, a kő és érc zúzására használt kőkalapácsokat, valamint az érc kihordására használt, lapos, sajkaszerü faedényeket (Stöllner et al, 2006, 87, 92, Abb. 21, 24, 32, 37, 38-40, 45, 48, 50.). A mitterbergi rézércek bányászata bizonyíthatóan visszavezethető a korai bronzkorra (Stöllner et al, 2006, további irodalommal).

Mitterbergben bányásztelepülések is napvilágot láttak. Közvetlenül a horpák, aknák és vágatok mellett, időszakos telepeken dolgozták fel és kohósították, tisztították az ércet. Érce a kalkopirit volt, melynek kohósításakor fayalitos (vas-szilikát) salak keletkezett (Eibner-Persy - Eibner, 1970). A salak mennyisége és a horpák mérete alapján itt mintegy 18.000 tonna nyersrezet termeltek ki a teljes bronzkor folyamán. Az érc 2,5\% réztartalmú volt kvarc mátrixban. A számítások szerint a nagyarányú bányászat sok ember munkáját igényelte (Zschocke - Preuschen, 1932, Pittioni, 1951, 1957).

A nagyobb, metaszomatikus-metamorf telepek bányászati nyomai - ahogy ezek oxidációs-cementációs zónája is - a modern bányászat eredményeként megsemmisültek. Ilyen telepek Dobsina (Dobšina, SK), Rozsnyó (Rožnava, SK), Libetbánya (L’iubetová, SK), Úrvölgy (Špania Dolina, SK), Rudabánya, Oravicabánya (Oraviţa, RO), és Bor-Majdanpek (SR) környékén találhatóak. Ma már egyiket sem müvelik (Gimesi, 1994, Szakáll 2002).

Az AsNi és ,dasni”(SAM FA/B, Einheitskupfer/Ostalpines Kupfer) nyersanyagok jellemző nyomeleme az arzén és a nikkel, kevés antimontartalom mellett. A Kárpátmedencében csak néhány olyan lelőhely van, melynek rézérce, és más (rézércekhez hasonló, és velük együtt kitermelt) szulfidos ércei kohósítás után ilyen összetételt adnak. Ezek főleg Dobsina (Dobšina, SK) környékére (Szepes-Gömöri Érchegység) jellemzőek, ahol a kontakt metaszomatikus vas- és rézérctelep jelentős mennyiségü gersdorffitot (NiAsS) tartalmaz. A bánya fő érce a kalkopirit és a fakóérc (Szakáll, 2002, Gimesi, 1994). A gersdorffit külső tulajdonságai alapján a fakóérchez igen hasonló, acélszürke ásvány, melyen nikkeltartalmának köszönhetően ugyanúgy zöld színủ oxidációs réteg (annabergit) jelenik meg, mint a rézásványokon, így az őskorban pusztán külső jegyek alapján nem, csak kohósításkor lehetett eldönteni, milyen fémet tartalmaz. A gersdorffitot vagy véletlenül, vagy állandó ötvöző anyagként keverhették a rézérchez. 
Bár a fenti eredmények önmagukban nem bizonyitó erejüek, mégis erös érvet jelentenek a koszideri korú, AsNi, ,dasni” és talán az ASN (SAM FA/B, Einheitskupfer) típusú fémek Szepes-Gömöri Érchegységböl való származása mellett. A fém a tiszai úton, a Füzesabonymajd Hatvan-kultúrák közvetitésével érkezhetett a Dél-Alföldre. Késöbb a Halomsiros-kultúa újonnan kiépült nyugati irányú kapcsolatrendszere a kelet-alpi fém elterjedését is segithette. Az arzén-nikkel réz legvalószinübb származási helye tehát a Szepes-Gömöri Érchegység vagy a Kelet-Alpok.

Az ASN típus erdélyi eredetét (magasabb antimontartalma miatt) Liversage (1994) vetette fel. A késő bronzkorban azonban az eddigi adatok alapján egyre inkább kísérleteznek más, ónt helyettesítő ötvözőanyagokkal, így az ólommal (Trampuž-Orel et al, 1996, Fig. 4, 211-212), és az antimonnal (kérdéses, Költő, 1996). Ennek hátterében talán az ónlelőhelyek kezdődő kimerülése vagy a fokozott, iparszerü bronzfeldolgozás (Velem-Szent Vid) megnövekedett nyersanyagigénye állhat, amit az ónlelöhelyek talán nem tudtak teljes mértékben kielégíteni, ezért kerülhetett sor más, az ónhoz hasonlóan viselkedő, ötvöző anyagok használatára is.

A Maros menti út fontosságára utalnak bizonyos leletek, így a marosvásárhelyi sírlelet és a mezősámsondi (Şincai, RO) Keszthely-Boiu típusú kard (Roska 1942, 199. kép, 215. kép). E szórvány leletek a Maros felső folyásánál, Parajd (Praid, RO) közelében kerültek elő, jelenlétük egyértelmüen a sókereskedelemhez köthető, és nincs közük a réz beszerzéséhez.

\section{Rézkohászat Pliniusnál}

C. Plinius Secundus (Idősebb Plinius) a Naturalis Historia-ban (Plinius 2001, Nat. Hist.XXXIV, 117) értekezik a rézércekről. Plinius chalcitis-nek nevezi a réz ércét, melyről két dolgot állít: egyrészt, hogy ez az anyag a kohóban is keletkezik, másrészt, hogy nem egységes ásvány, hanem három részből tevődik össze. Ezeket az összetevőket réz-és vasszulfid, valamint ezek oxidjainak keverékeként határozták meg. A chalcitis kifejezés valószínủleg mállott kalkopirit-pirit ásványtartalmú kőzetet takar (Forbes, 1964, 8), Plinius együtt említi a chalcitis-t a cadmea-val (mely gálma néven is közismert), ez utóbbi réz- és cink-oxidok, hidroxidok és karbonátok, víztartalmú karbonátok (kuprit, tenorit, malachit, azurit, hidrocinkit, smithsonit stb.) keveréke lehet. Plinius fontosnak tartja e két anyagnak az elkülönítését, mert megjegyzi, hogy a cadmea-t a felszínen és annak közelében találják, míg a chalcitis-t mélyen a föld alatt. A kifejezés etimológiai vizsgálata azonnal elárulja, hogy kapcsolatban kell állnia ennek a rézércnek a kalkozinnal, melynek hivatalos angol nyelvü ásványneve Chalcocite, mely nagy valószínüséggel a chalcitis névre vezethető vissza. A chalcitis=kalkozin azonosítás másik fó támpontja Plinius utalása, miszerint a chalcitis a kohóban is keletkezik, és épp ezt, a kalkozint találtuk meg szulfidzárványok formájában, a bronztárgyakban. A „feketeréz” a (kalkozin porszerüen fekete, ásványként sötét acélszürke színü) a rézfeldolgozás utolsó állomása a tiszta réz kinyerése előtt, így világos, hogy a mintákban ez fog benne maradni zárványként (Forbes, 1964, 30, Table 1). Természetesen nem lehetséges a római, és egyéb ókori adatokból a pontos bronzkori technikát és ismereteket rekonstruálni, de bizonyosak lehetünk abban, hogy az ércfeldolgozás alapvető mikéntje az ipari forradalom előtt nem sokat változott. 
Bányászat, metallurgia és gyakorlati ásványtani ismeretek a bronzkorban

A bronzkorban fejlett, horpa-, akna- és mélymüvelésü bányászat folyt, mely a római, középkori bányászattól nem sokban különbözhetett. Megfelelő szerszámokkal, így 3 féle tömegü kőkalapáccsokkal (1 kg alatti, 1-2,5 kg, 3-7 kg, Točik - Žebrák, 2003, Žebrák, 1990), tokosbaltákkal (Stöllner et al, 2006), és vélhetően faékekkel, hevítésel és vízzel, esetleg savas anyaggal (ecet) való lelocsolás után fejtették az ércet (hevítés nyomai Walesben: Pickin Timberlake, 1988). Ezt zúzták, őrölték, a meddőtől elválasztották. Ez a folyamat egyszerüen, először kézi válogatással, majd az ércek nagyobb fajsúlyát kihasználva széreléssel (mosás) történhetett, ahogy ezt Mitterbergben feltételezik (a kohók a patak partján voltak, feltehetőleg itt történt a válogatás és a mosás: Harding, 2000, 215, Eibner-Persy - Eibner, 1970). A pörkölést követően került sor a kohósításra, melyhez $1083{ }^{\circ} \mathrm{C}$ szükséges (a réz olvadáspontja). Ezt a hőfokot faszénen hevítéssel érhették el, a faszénégetés jelentős erdőirtáshoz vezetett az ércfeldolgozó területeken, hiszen $5 \mathrm{~kg}$ réz kinyeréséhez $100 \mathrm{~kg}$ faszén szükséges. Könnyen belátható, hogy a mitterbergi bányákból a bronzkorban kitermelt 18.000 tonna réz kinyeréséhez összesen 360 ezer tonna faszénre volt szükség. $100 \mathrm{~kg}$ faszénhez $700 \mathrm{~kg}$ fára van szükség, így kb. 2,5 millió tonna fát használtak fel a bronzkorban rézolvasztáshoz (Horne, 1982). A fa sürüsége fajonként eltérő, a leggyakoribb tölgy, bükk 0,65-0,7 kg/dm3 körüli, a fenyő $0,43 \mathrm{~kg} / \mathrm{dm} 3$. Ha $0,6 \mathrm{~kg} / \mathrm{dm} 3-\mathrm{t}$ veszünk alapul, nem tévedhetünk nagyot. Ez alapján kb. 4 millió m3 fát vágtak ki Mitterberg környékén a bronzkor folyamán.

Az érc döntően szulfidos fázisokat tartalmazott, azaz a primer érceket és a cementációs zóna másodlagos szulfidjait fejtették. A szulfidos rézércek közül gyakorlatilag az összes fellelhetőt bányászhatták, így a kalkopiritet, bornitot, fakóérceket, kalkozint, talán a covellint is, mivel a pörkölés során mindegyik hasonlóképp viselkedik, és rézoxidhoz, valamint „feketeréz”-hez jutunk. Fejthették még az oxidos érceket, így a cadmea-nak nevezett anyagot, talán a kupritot is, mely vas-oxidokkal együtt képezi az ún. téglaércet.

A kitermelt érces anyagot válogatták, törték, tisztították, pörkölték és kohósították. Sajnos a Kárpát-medencéből olvasztókohót nem ismerünk. A Kárpát-medecében ismert kohászati emlékek mind a finomítás (salak eltávolítás) fázisához kötődnek. Ilyen mühelyeket a kora bronzkorból Zók-Várhegyen (Ecsedy 1982, 1995b), a középső bronzkorból (Vatyakultúra) Lovasberényben tártak fel (F. Petres - Bándi, 1969). Gyanítjuk, hogy ekkor történt az ónnal való ötvözés is. Ötvözőanyag - ha nem szennyező - talán az arzén és az antimon is.

Külön szeretném kiemelni a kalkozin és a bornit szerepét, melyeket eddig nem méltattak nagyobb figyelemre. Mindkettő a cementációs zónában feldúsuló, de akár elsődleges keletkezésủ ércásvány. Mind Dobsinán (Dobšina, SK), mind a bánáti Csiklován (Ciclova Montană, RO) és Oravicabányán (Oravița, RO), és különösen a bihari Rézbányán (Bâița Bihor, RO) igen gyakori, elterjedt ércásvány volt a cementációs övben, melyet mára teljes egészében lefejtettek (Gimesi, 1994, 151-156, Szakáll 2002).

Tisztában voltak az ón és az ólom közötti különbséggel (bár az ónt még Plinius is „fehér ólom”-nak mondja, de a görögök kassziterosz-nak nevezik, Plinius 2001, Nat. Hist. XXXIV. 156.), és egyes Alpok-vidéki késő bronzkori bronzok magas antimon-tartalmából (Költő, 1996) ítélve az antimonnal is (itt az antimon-tartalmú telérek nem a rézzel együtt 
jelennek meg, így, ha ezt használták, magát az antimont kellett keresniük, és megtalálniuk). Antimont a közép- és újkorban pl. Városszalónakon (Stadtschlaining, A) és környékén bányásztak (Gimesi, 1994, 9-10). Ezeknek az ásványait a rézércekétől eltérő színük, keménységük, kristályformájuk, hasadásuk és különféle színü oxidációs bekérgezéseik alapján különítették el: a szürke galenit, kocka alakban kristályosodik, ilyen a hasadása is (hasonló színű a fakóérc, de az nem hasad), az antimonit színében a galenithez hasonlít, de tűs-oszlopos, hosszában hasadó kristályokat alkot, a kassziterit kemény és sötét színű, ezt torlatokból mosták (Plinius, 2001, Nat. Hist. XXXIV. 157. A kassziterit 80\%-át ma is torlatból mossák!). Ezek - nem mellékesen - a bronzkori bányászok és fémművesek magas szintü gyakorlati mineralógiai tudására utalnak. A szándékosan magas antimontartalmú bronzok gyártását Szabó Géza erősen vitatja. Saját vizsgálati eredményeire (alacsony antimon- és arzéntartalom) támaszkodva elveti a fakóércek komolyabb felhasználását a késő bronzkori Dunántúlon, ugyanakkor az ón eredetét a sztanninra $\left(\mathrm{CuFeSnS}_{4}\right)$ vezeti vissza (Szabó, 1999). Mivel a sztannin csak nyomokban fordul elő a térségünkben (és általában véve is jelentéktelen, mint ónérc), az ónt nem lehet ebből származtatni (Szakáll, 2002).

A kohósítás során az arzén szublimál, jelentős része eltávozik a rendszerből. Ezért a kiindulási mennyiséget legfeljebb csak becsülni lehet a bronzban maradó mennyiség alapján. $\mathrm{Az}$ arzénfakóérc [tennantit, $(\mathrm{Fe}, \mathrm{Zn})_{2} \mathrm{Cu}_{10}(\mathrm{As}, \mathrm{Sb})_{4} \mathrm{~S}_{13}$ ] gyakori és komolyan számításba vehető nyersanyag.

Czajlik Zoltán és munkatársai (Czajlik et al, 1999) Velem-szentvidi bronzokban zárványként $\mathrm{Cu}_{2} \mathrm{~S}$ közelítő képletü anyagot (kalkozin, feketeréz) találtak, melyet akár $\mathrm{Cu}_{2} \mathrm{~S}$ és $\mathrm{CuS}$ (covellin) keverékeként is értelmezhetünk. A benne lévő vas arra utal, hogy a salakképzés előtt az érc vasat tartalmazott (kalkopirit, bornit, és az őket szennyező pirit).

Az ón nagy tömegben, bányászható formában a Kárpát-medencében és az alpi régióban nem található meg. Az ásványtani irodalom (Szakáll, 2002, további hivatkozásokkal) alapján el kell vetnünk a Felvidéken található ónra vonatkozó adatokat (pl. Schalk, 1998, Abb. 3., újraközli Krause, 2003, Abb. 15.). Ónt egyedül a Cseh-Szász Érchegységből szerezhettek be távolsági kereskedelem útján. Ez a távolsági kereskedelmi rendszer, tehát maga az ón nagy szerepet játszhatott mind a koszideri egységesülés, mind a Halomsíros-kultúra létrejöttében. Ebben a kereskedelmi rendszerben nagy szerepet játszott a kelet-alpi réz is.

Az ónbronzok feltünéséröl, különösen a korai ónkeresekedelemről M. Primas (2002) értekezett. Véleménye szerint a kora bronzkori (hazai kronológiában a korai és a középső bronzkor határára datálható) ónkereskedelemben nagy szerepet játszottak a ritkán feltűnő óngyöngyök, melyek létét a Maros csoportban (Pitvaros, majd Perjámos kultúra) is felveti.

A tárgyak elsősorban formába öntéssel készültek, ilyen öntőformákat Soltvadkerten tártak fel a Halomsíros-kultúra településén (Gazdapusztai, 1959). Köztük megtalálhatók a karperecek, tűk öntésére szolgáló formák, így bizonyos, hogy ezek az egyszerü ékszerek sem kalapálással előállított lemezből, vagy húzott drótból készültek. Nagyméretü, 100 mikron nagyságrendủ hatszöges kristályok keletkeztek a fém utólagos hőkezelésekor. A karperec kristályszerkezetében megfigyelt ritka ikerkrisztallitok kismértékű hideg megmunkálásra utalnak, mely az egyenes lemezként öntött karperec meghajlításakor történt (Czajlik et al, 1999). 


\section{Korrózió, restaurálás, anyagvizsgálat}

A fémvizsgálatok egyik fontos célja volt a korróziós felületek szerkezetének, a felületi óndúsulás jelenségének vizsgálata. Ezzel kapcsolatban eredményeinket a következöképp foglalhatjuk össze.

1. A kisméretű tárgyak korróziója sokszor a makroszkópikusan épnek látszó fémben is előrehaladott állapotú, ezért a vékony lemezek és tük akár teljes mélységükben részben oxidálódhatnak. A korrózió a kristályhatárok mentén halad előre.

2. A felületen leveleses felváló, laza szerkezetű korróziós réteg keletkezik, mely alatt egy nemespatinának nevezett rézoxid réteg húzódik (Cronyn, 1992). A tárgyakon a leveles, zöld színű réteget eltávolították, a díszítéseket is megőrző nemespatinát nem. A metszetekben világosan látszik a szintén réteges, leveles szerkezetü, de nem elváló oxidréteg, mely döntően réz-oxidokból (tenorit, kuprit), réz-szulfidból és réz-kloridból áll. A réz-klorid a rezet erősen roncsolja, a tárgy pusztulását okozhatja, mivel a restaurált tárgyakban is benne maradhat (különösen régen restaurált tárgyakban), és azután is kifejti hatását. A réz.-klorid vízben jól oldódik, ezért a talajban lévő tárgyakban nem alakul ki szilárd réz-kloridos fázis, ennek keletkezése a tárgy kiemelése és kiszáradása után kezdődik el.

3. A tárgyak felszínén és üregeiben megjelenő szén és oxigén a 100 éve alkalmazott szénhidrogénes átitatás (paraffin) hatásának tulajdonítható.

4. A tárgyak felszínén csak egy esetben, foltszerüen és vékony (néhány 10 mikron vastag) rétegben tudtunk óndúsulást kimutatni, mely arra utal, hogy bár a jelenség valóban létezik, a kis tömegü tárgyaknál ezzel a folyamattal nem kell számolni. Az öntés és hủlés során keletkező óndúsulásra nem találtunk adatokat.

5. A korróziós rétegben elemmobilizáció történik, a kén az oxidálódó réz-szulfidból felszabadul, és a minta felszíne felé vándorolva másodlagos réz-szulfidokká alakul. Az ón a korróziós fronton részben mobillá válik és a korrodált rétegből kioldódik, esetleg foltszerüen összegyülik. Az arzén és a cink ugyancsak mobilizálódik, és a minta felszínén rétegszerűen dúsulnak, míg a korróziós fronton lecsökken a koncentrációjuk.

Ezek alapján a tárgyak vizsgálatára - hacsak nem igen jó állapotú a minta - a különféle módszerek kombinációját tartjuk célravezetőnek. Meg kell állapítani, hogy a fó- és nyomelemzéssel vizsgált mintarész valóban az intakt fém összetételét tükrözi-e, vagy a korrózió - makroszkopikus nyomoktól függetlenül - befolyásolhatja-e az eredményeket. A mikrofúrásos mintavételezést a kisméretü, vékony, sokszor díszített ékszereknél mütárgyvédelmi okokból nem tartjuk helyes eljárásnak. A minta kiválasztott pontjáról néhány négyzetmilliméteres felületen a patinát a fémmag eléréséig - amit makroszkopikusan, esetleg binokuláris mikroszkóppal ellenőrzünk - eltávolítjuk.

\section{Összegzés, továbblépés}

Vizsgálataink jól illeszkednek az eddigi fémelemzések eredményeihez, azok a csoportok körvonalazhatók bennük, amelyeket a közép-európai kutatás már korábban felismert (Krause, 2003, Liversage, 1994, etc.). Igazolható volt a metallurgiai folyamat néhány kisebb részlete a SEM-EDX vizsgálatokkal, melyekhez történeti adatokat is felhasználtam (Plinius, 2001, Forbes, 1964). Ugyanakkor a származási hely kérdését nem tudtam megoldani, bár jelentősen szükítette a kört az arzén és a nikkel együttes jelenléte, 
melyekre új magyarázatként a gersdorfittal való szennyezést vetettem fel. E ritka ásvány Dobsinán (Dobsina, SK) és környékén elég gyakori járulékos érc (ugyanakkor a legtöbb más helyeről hiányzik), így az AsNi/dasni típus (Eunheitskupfer/ostalpines Kupfer) forrásaként igen komolyan számításba kell venni a területet. Az ásványtani irodalom (Szakáll, 2002, Gimesi, 1994 stb.) alapján nagy valószínűséggel el kell vetni a kárpát-medencei ónbányászat lehetőségét, ez a fém itt csupán nyomelemként található, beszerzése távolsági kereskedelem útján kellett, hogy történjen, mely kereskedelem a koszideri egységesülés és a Halomsíroskultúra létrejöttéhez vezethetett.

Közös munkánk folytatása a következő területeken kecsegtet új eredményekkel. A SEM-EDX mérések folytatása és a metallurgiai folyamatra vonatkozó interpretációk elmélyítése (kohászati szakemberekkel) hozhat még számos újdonságot. Ehhez kapcsolódva elengedhetetlen egy rézolvasztási és ötvözési kísérlet elvégzése korabeli módszerekkel. Az érc forrásterületének pontos megjelöléséhez az ólomizotópos méréseket tartanám igazán célravezetőnek. 


\section{Konklúziók}

\section{Bevezetés}

A doktori dolgozat elején a következő témát jelöltem meg: egy dél-alföldi bronzkori település (Domaszék-Börcsök tanya) komplex, környezetrégészeti, régészeti és archaeometriai feldolgozása, kitekintéssel a lelöhely szükebb környékére. Kérdéseket tettem fel, melyek megválaszolásában ez a vizsgálat segíthet. Állításokat, hipotéziseket vizsgáltam, melyek árnyalásában, illetve valóságtartalmuk eldöntésében a jelen eredmények segítséget nyújthatnak. A következö kérdésekre térek ki ebben a fejezetben:

1. Környezetrégészeti kérdések

- A lelöhely földrajzi elhelyezkedése, geológiája, hidrológiája és pedológiája, a lakóhely kiválasztásának természetföldrajzi szempontjai.

- A táj és ember viszonya, az ember tájátalakító tevékenysége (teljes körű régészeti geológiai elemzés).

2. Településhez kapcsolódó kérdések

- A település kora, periódusai és helye a Dél-Alföld bronzkorában.

- Belső szerkezete, a térhasználat kérdései, a korszak településeinek általános jellege.

- A korabeli életszerkezet: a létfenntartás alrendszere - élelemtermesztés, állattenyésztés, vadászat, gyüjtögetés, halászat (archaeozoológiai és archaeobotanikai maradványok elemzése).

- A technológiai alrendszer. Kerámiakészítés, fémmegmunkálás (archaeometria, kísérleti régészet).

- A csere alrendszere. A szükebb régió kapcsolatrendszere a fémnyersanyag beszerzésére koncentrálva (archeometria).

- A társadalom alrendszere. Társas kapcsolatok, csoportok, hierarchia és szimbólumrendszer a korszak dél-alföldi közösségeiben.

3. Végeredményben arra irányult a kutatásom, hogy a kárpát-medencei középső és késö bronzkor határán lezajlott változássorozathoz (a kutatás eredményeit összefoglalva lásd: Sánta el al, 2007), egy település konkrét példáján, teljességre törekvő és mélyreható régészeti-környezetrégészeti elemzéssel új adatokat nyerjek, esetleg megkíséreljem rekonstruálni ennek a változásnak az okait és folyamatát.

Úgy vélem, erre csakis regionális, sőt kistérségi szinten nyílik lehetőség, mivel a középső bronzkori emberi közösségek a környezeti feltételektől függően már eleve eltérő életmódot és létfenntartási stratégiát követtek, és ezeknek megfelelően reagáltak a változásokra.

A továbbiakban az elért eredmények alapján levonható következtetéseket közlöm rendszerezve, és a környék egyéb régészeti lelöhelyeiről vett adatokkal kiegészítve, így kialakítva egy komplex képet a terület bronzkoráról, különösképpen késő bronzkoráról. Ez azt jelenti, hogy az újabb adatok alapján megvizsgálom Csongrád megye középső és nyugati részének (Tisza-völgy és Dorozsma-Majsai Homokhátság) bronzkori történetét, ahogy az a korábbi és jelen kutatások alapján kibontakozik. Felvázolom a koszideri és Halomsíros periódus átmenetének egy lehetséges modelljét a Dél-Alföldön. 


\section{Természeti feltételek}

A Dorozsma-Majsai Homokháton található, annak peremére (a Tisza-völgyhöz közel) eső lelőhely homoktalajon helyezkedik el, melynek termőképessége alacsony. Egy ÉNy-DK-i irányú homokháton terül el a régészeti lelőhely, mely mellett semlyék található. A talaj rossz víztartó képességü, az időjárás aszályra hajlamos, ezért ezen a területen a mezőgazdaság fő formája az őskornak általunk vizsgált szakaszában az állattenyésztés volt. A homoktalaj feltörése futóhomokmozgást indított el, illetve a magasabb hátakat csepperózióra hajlamossá tette.

Elterjedt régészeti toposz, hogy a terület egykor nagyszámú neolit és kora rézkori lelőhelyét atlantikumi homokmozgások temették el. Így azok kimutathatatlanok a normál, felszíni régészeti módszerekkel, csak nagyobb földmunkák alkalmával várható leletek előbukkanása. A magam részéről ezt a véleményt nem tartom megalapozottnak. Azt feltételezné, hogy a neolitikum és a rézkor után a teljes homokhátságra (sőt, minden hazai homokterületre) kiterjedő homokmozgások zajlottak, ami a holocénben biztosan nem fordult elö. Cselédes Szilvia a Duna-tisza közének mezolit és neolit lelőhelyeit gyüjtötte össze (Cselédes, 2009). Kizárólag a folyóvölgyekben, és egykor időszakosan vízzel borított medrek közelében találta neolit megtelepedés nyomait. Arra az álláspontra helyezkedik, hogy a leletek hiánya természeti feltételekre vezethető vissza. Hozzáteszi ugyanakkor, hogy néhány löszös területen (pl. Kecskemét környékén) sincsenek neolit leletek, de ezt a tényt magyarázat nélkül hagyja. A folyóvölgyek, erek mentén talált szórványos neolit leleteket sem tartja feltétlenül települések maradványainak, felveti, hogy az egykori útvonalak mentén létesült szállások, időszakos tanyák nyomai voltak (Cselédes, 2009, 38-42.).

A rézkorban megnő a településsürüség, több helyütt ez az első régészeti kultúra a homoktájakon (pl. Gyucha, 1996). A kora bronzkorban tovább növekszik a településszám, Zákányszéken a Makó-kultúra jelenti a megtelepedés kezdetét (Sánta, 2004). Ezt követően egyetlen más régészeti korszakból sem hiányoznak a lelőhelyek. Az éghajlati tényezők valós hatását inkább abban látom, hogy a késő atlantikum száraz klímájában meginduló homokmozgások nem elsősorban „elfedték” a lelőhelyeket, hanem egyszerűen nem tették lehetővé a lakosság megtelepedését a futóhomokon. A szubboreális, csapadékosabb klímaperiódus beköszöntével leállt a homokmozgás, és a talajosodó homokon megtelepültek az emberek. Azóta is volt homokmozgás, méghozzá a népvándorlás-, valamint korai középkorban elég nagymértékü (Nyári - Kiss, 2005), ennek ellenére lelőhelyeink egyetlen említett korszakból sem hiányoznak.

Domaszéken a pollenszekvenciában a középsö rézkorig komolyabb emberi hatás nem mutatható ki, nagyobb neolit és kora rézkori településekkel nem számolhatunk. A késő rézkorban (badeni és kostolaci kultúra, kb. 3500-2800 cal BC) irtásos-égetéses földmüvelés alakult ki, melyet a fás szárú növényzet pollenjének ciklikus ingadozása mutat. A természetes környezet ekkor változott meg olyan mértékben, hogy teljes egészében már soha nem tudott regenerálódni. A tájátalakítás ugyanakkor csak a középső és különösen a késő bronzkorban vált intenzívvé. 
A lelőhely természetes élővilágát a homokhátakon erdős sztyepp (tölgy, hárs és szil dominanciájával, a szegélyvegetációban mogyoróval) alkotta, a mélyebben fekvő területeken füzláp fejlődött ki, a Tisza-völgyben megtalálható volt az éger. A lelőhely előnyös helyzetben volt a korabeli kereskedelem szempontjából is, hiszen két nagyon fontos útvonal, az északdéli irányú, Tisza menti út és a kelet-nyugati irányú, Maros menti út metszéspontja közelében helyezkedett el. Mind a középső, mind a késő bronzkorban számos település létrejöttéhez vezetett ez az előnyös helyzet. A tiszai út fontosságát és használatát bizonyos kerámiák és stílusok északról délre, és délről északra történő elterjedése bizonyítja, ahogy erre a következőkben még ki fogok térni. Északon ez az út egészen a gömöri hegyek lábáig tart, ahonnan ércek és talán némi só (mellékutakon Aknaszlatina térségéből) érkezhetett. A Maros menti út Erdély szívébe vezet, melynek a só, valamint az arany és talán a réz voltak a fó cikkei. Konkrét régészeti bizonyítékaink vannak, hogy mindkét út fontos szerepet töltött be a vizsgált periódusban.

\section{Környezet-átalakítás}

A táj természetes növényzetének és az emberi hatásoknak a rekonstrukciójára a Maty-ér medrében mélyített pollenfúrás eredményeit használtam fel. Itt Sümegi Pál öt pollenzónát különített el, melyek közül az utolsó kettőben érhető tetten emberi hatás. Ezek közül is az utolsóban több al-periódust figyeltem meg a fás szárú, a taposást elviselő gyomnövényzet és a gabona mennyisége alapján. Az ülepedési sebességet a cal BC dátumok alapján számoltam, és ennek mértékét azonosnak véve (értéke 0,017-0,025 cm/év, azaz $1 \mathrm{~cm}$ üledék 40-60 évente rakódik le) finom kronológiai tagolással azonosítottam a középső bronzkor, a Halomsíros kultúra, a pre-Gáva időszak és a korai vaskor rétegeit.

$\mathrm{Az}$ ember a késő rézkortól kezdve válik a táj legfontosabb alakítójává. A késő rézkorban a Quercus (tölgy), Salix (füz), Ulmus (szil), Tilia (hárs) állományában bekövetkező ciklikus ingadozások alapján intenzívebb erdőirtási periódusok követték egymást, melyeket regenerációs időszakok választanak el. A gabonapollenek megjelennek a területen, azaz ez a lakosság nem teljesen állattenyésztő, hanem inkább komplex életmódot folytatott. Az erdőirtási és regenerációs ciklusok úgy képzelhetőek el, hogy a meder környezetében egy erdőirtást legeltetés és gabonatermesztés követett, majd a területet kimerülése után felhagyták, és csak jóval később, kb. 150 év múlva tértek oda vissza, mialatt a fás vegetáció jobbára regenerálódott.

$70 \mathrm{~cm}$ körül a fás pollenek aránya drasztikusan (egyes fajok esetében felére, harmadára) csökken, azonban megjelenik a bükk. Drasztikusan emelkedik a heliofil lágyszárúak (Centaurea, Plantago, Artemisia) mennyisége. Ennek a korszaknak a kezdete a késő rézkorra (klasszikus badeni kultúra, kostolaci kultúra) tehető, és magában foglalja a teljes korai bronzkort is.

Az erdőirtások nyomán legeltetett, taposott területek, a nyílt vegetáció alakult ki. A gabonapollen ugyanakkor nagyon alacsony, vagyis elsősorban legelőket, utakat és településeket alakítottak ki, nem szántóföldeket. A megtelepedés környezetében kismértékü gabonatermesztést is folytathattak a pollenanyag összetétele alapján. A taposást is elviselő gyomok alapján a meder közvetlen környezetében lakóházak és utak húzódhattak a rézkor 
végén és a bronzkor első felében. Mindez a kostolaci periódustól kezdődő és egészen a kora bronzkor végéig tartó régészeti periódussal jól párhuzamba állítható, hiszen a korszak élete, életmódja rendkívül mobilissá vált az állattenyésztés, valamint a réz nyersanyaghoz való hozzájutást biztosító kereskedelem, cserekapcsolatok megélénkülése miatt.

A pollenszekvencia ötödik, utolsó pollenzónája 32-2 cm között fejlődött ki, és 1800500 cal BC közé helyezhető. A középső bronzkortól a középső vaskor elejéig tart ez a zóna, a magasabban lévő rétegek megsemmisültek.

A középső bronzkor utolsó szakaszában, a koszideri periódusban egy rövidebb (100150 éves) erős gabonapollen-csúcs fejlődött ki, melyet a Vatya-kultúrához köthetünk. Ugyanakkor a fúrás közvetlen környezetében nem ismerünk Vatya lelőhelyeket, a legközelebbiek északi, északnyugati irányban kb. $30 \mathrm{~km}$-re találhatóak. A vizsgált terület ebben a korszakban szinte üres volt, terepbejárásokon sem találtak értékelhető leletanyagot ebből a korszakból. Így a magas pollenszám szélfúvás eredménye, miközben a régió a nagyobb Vatya telepek hinterlandjaként funkcionálhatott, ahol legelők és kisebb szántók lehettek, néhány tanyával és szállással. Ilyen tanyákra régészeti bizonyíték még nincs.

A koszideri periódus végén már megjelennek a Halomsíros közösségek is, egyik településüket Domaszék-Börcsök tanyán hozzák létre. Itt korábban a Nagyrév-kultúra kis szállástelepülése volt (Kr. e. III. évezred második felében, pontosabban nem datálható).

Ez, a 23-18 cm kifejlődött, kb. 5 cm-es zóna (interpolációval kb. 200 év) a Halomsíroskultúra, valamint a pre-Gáva (V. Szabó, 2004a) időszak hagyatéka. A Halomsíros-kultúra datálása, valamint a település keltezése szintén egy Kr. e. 1500/1400-1300/1250 között virágzó, kb. 200 éves régészeti kultúrára, archeosztratigráfiai egységre enged következtetni (lásd a régészeti fejezetben). Ebben a zónában a legmagasabb az útifú (Plantago) aránya az egész szelvényben. A későbronzkori lakosság másik, időben a domaszékit követő települését néhány kilométerrel északabbra, szintén az M5 autópálya nyomvonalán, Szeged-KiskundorozsmaSubasa lelőhelyen találták meg (Róka, 2010). A két település között a régészeti leletek alapján nincs közvetlen kapcsolat, a domaszéki telep felhagyása után néhány generációval később alapitották a kiskundorozsmai telepet. A Maty-ér délebbi régióját ez a pre-Gáva lakosság legelöként hasznosította, de a település néhány km-es közelsége miatt gabonapollenek is megjelennek. A késő bronzkor későbbi időszakában (Kr. e. 1100-tól) és a kora vaskorban a gabonapollen szinte nullára csökken, de a heliofil gyomok aránya magas marad, ami a térség legeltető állattartásra való használatát, illetve kifejlett úthálózatot mutat, a közelben szántóföld nem volt. Az Urnamezős periódus települései a Dorozsma-Majsai Homokhátságon ritkásan fordulnak elő, de nem ürül ki teljesen a terület.

A fák pollenje összességében nagyon erősen lecsökken, a késő rézkortól kezdődően erdőirtás mutatható ki. Igen érdekes, hogy a bükk és a gyertyán (Fagus és Carpinus) csak a kora bronzkorban jelenik meg. Ennek okát nem tudjuk.

Az éger (enyves éger, Alnus glutinosa) ártéri állománya a késő rézkorig állandó, enyhén változó. A késő rézkorban több irtási ciklus figyelhető meg, az egyik az állomány felét elpusztítja (80-82 cm körül). Ezután az éger állománya regenerálódik, és mennyisége holocén (őskori) maximumot ér el a kora bronzkorban, $48 \mathrm{~cm}$ körül. Mindez arra utal, hogy ebben az 
időszakban a lakosság az árterületet nem, vagy alig hasznosította, legalábbis fakitermelést a környéken nem végzett az ártérben.

Az éger állománya a középsö bronzkor közepén kezd el számottevően csökkenni, és egy igen jelentös minimumot ér el 22 cm-nél, a vizsgált Halomsiros település időszakában. Az éger kiirtásának fö oka mindenképp a legelők, esetleg alacsony térszíneken fekvő szántók létrehozása volt. $15 \mathrm{~cm}$ táján, a késő bronzkorban (Kr. e. 1000 körül) az égen populációja gyakorlatilag ismét regenerálódik. Ez a változás jól szinkronizálható a Halstatt A1 periódus végével és a Gáva-, Kyjatice-kultúra kialakulásával és az Urnamezős-kultúra késői szakaszának kezdetével. Igen valószínűnek tartjuk, hogy e nagy kultúrák kialakulása és/vagy átrendeződése áll a terület elnéptelenedésének, a településszerkezet változásának hátterében.

\section{A település helye a térség bronzkorában. Időrend és történeti folyamatok}

A település kétség nélkül a Halomsíros-kultúrkör része. Ugyanakkor a településen élt lakosság anyagi kultúrája számos vonásában eltér a klasszikus, közép-európai Halomsíros kultúrától (Willvonseder, 1937, Torbrügge, 1959, stb.), azokban a helyi középső bronzkori, különösen a Vatya fazekasság tradíciói is megjelennek, a Vatya-Alpár csoport folytatásának tekinthető a leletanyag. Ezt a Halomsíros csoportot Kőszegi Frigyes Kiskőrös-Pusztaszer csoport néven különítette el és a klasszikus, késő Halomsíros időszakra keltezte (Kőszegi, 1964). A már akkor ismert Szeged-bogárzói leletek és az általa közölt szórványok között azonban akkor - a kevés számú lelet miatt - még nem lehetett biztos időrendi kapcsolatot kimutatni. A Halomsíros kultúra hullámszerü bevándorlásáról beszéltek a későbbi kutatók is, akik véleményüket a nagy sírszámú temetők előkerülése után alakították ki, s egy nagy létszámú második Halomsíros bevándorlást feltételeztek (Bóna, 1992, Trogmayer, 1975, stb.). A hullámszerü, nagy létszámú Halomsíros betelepülés elképzelését ma nagyjából teljes egészében el kell vetni.

A Dorozsma-Majsai Homokhátság Halomsíros kultúrája nem kizárólag a késő Halomsíros periódusban létezik, hanem a bilisicsi, bogárzói, kiskundorozsmai (Kiskundorozsma-E és Öreghegy) leletek alapján a koszideri időszak második felében, végén telepedtek meg első közösségeik, a Vatya és a Perjámos kultúrák közötti, lakatlan területen, a Tisza-Maros szöggel átellenben (V. Szabó, 1999). A nagy temetők alapján felállított elméletek feltétlenül tükrözik a kutatás esetlegességét, hiszen mind a bogárzói, mind a tápéi temetők véletlenül kerültek elő, és a tápéi temető sírjainak kétharmada - az ásató véleménye szerint - a korábbi agyagbányászat során megsemmisült. Feltételezhető, hogy ebben a temetőben is lehetett korai temetkezési periódus, de az esetleg elpusztult. Söt, a megmaradt kb. 650 sír között is található több, a (fém)mellékletei alapján korainak tünő temetkezés (452. sír, tüskés-körbordás tutulus, Trogmayer, 1975, Taf. 37. 452., 534. sír, 4 nittszeges trapéz markolatú tőr, Taf. 49. 534/2., 301-302. sír, korai tálforma, egyedüliként a temetőben, Taf. 27. 301-302/8.). A temető zöme azonban nem tartalmaz Reincke BB2-nél korábbi leleteket. A fentiek alapján a tápéi temető valószínüleg tartalmazhatott korai sírokat, de azok eleve kis számban lehettek jelen, és zömük elpusztulhatott. A bogárzói típusú temetőkben eleve nagyon kevés sírt tártak fel. 
Az ezekhez a temetőkhöz tartozó településeket nem ismerték, az első - bizonytalanul kezelt, olykor rosszul azonosított - telepnyomok az 1970-es években meginduló régészeti topográfiai munkák során kerültek elő. A munkák a Maros völgyében és Hódmezővásárhely határában kezdődtek, a Dorozsma-Majsai Homokhát bejárására az 1990-es, 2000-es években került sor. Ekkor már sokkal biztosabban azonosították és keltezték a telepnyomokat az elökerült kerámia (csücskös és megvastagított tálperemek, bögretípusok és jellegzetes díszítések) alapján. A régészeti feltárások azonban jórészt elmaradtak, az első komolyabb, és nagy felületủ Halomsíros telepfeltárás a régióban épp Domaszék-Börcsök tanyán zajlott.

A szegedi városi múzeum megalapítása (1885) előtt, és azután számos szórványlelet vált ismertté, majd megkezdődtek a rendszeres ásatások. Zömmel temetők egy-egy sírjának leletei, melyek kisebb-nagyobb földmunkák során láttak napvilágot. Ezeket a leleteket az eltelt idő alatt senki nem értékelte, csak néhányukat tette közzé Reizner János és Tömörkény István az Archaeologiai Értesítőben (Reizner, 1892, Tömörkény, 1902, 1903). Igen izgalmas őskori leleteket találtak 1880-ban az egykori Sövényházán (ma Dóc határában), árvízmentesítési munkák (gátépítéshez kapcsolódó földkitermelés) közben, melyek gr. Tisza Lajos birtokába, majd 1885-ben a frissen megalakult szeged-városi múzeumba kerültek (említi Reizner, 1890, Reizner, 1891, 355.). Az érdekes lelet jelentős része közöletlen maradt, így a bronzkori leletek is. Ezúttal a középső bronzkori Füzesabony-kultúra jellegzetes korsóit emeltem ki, illetve néhány késő bronzkori edényt, melyek az 98. ábrán láthatóak.

A 98. ábra 1-2. edénye a Füzesabony-kultúra jellegzetes típusa, melyeket pontosabban datálni nem lehetséges. P. Fischl Klára a Szelevény-menyasszonyparti leletek elemzésekor arra a következtetésre jutott, hogy az ott megjelenő Füzesabonyi stílusú leletek csak kulturális hatásokat, és nem etnikai jelenlétet igazolnak (P. Fischl 1997, 21). Sövényházán később a Halomsíros-kultúra is megtelepült (98. ábra 3-5.). A 98. ábra 6. edény a Felsőszőcs-kultúra (Kalicz, 1960, Bader, 1979) formajegyeit hordozza, és annak bizonyítéka, hogy a késő bronzkor első évszázadaiban, tehát a domaszéki település fennállása idején, volt némi kapcsolat a Felső-Tiszavidék és a Tisza- Maros-szög között. A Felsőszőcs-kultúrát a Reinecke BB1/2-től a Reinecke BD-ig datálják (Bader 1979, Kalicz 1960, Bóna, 1993).

Magyartés határában szintén gátépítési munkák során kerültek napvilágra az előzőekhez hasonló leletek (99. ábra), ezek szintén közöletlenek. A jellegzetes középső bronzkori leletanyagban a Füzesabony- (99. ábra 1-3.) és a Hatvan-kultúra (99. ábra 4-6.) edényformái és díszítései ismerhetőek fel. Mind a sövényházai, mind a magyartési leletek sírokból származhatnak, hiszen az edények épek.

A jelzett leletek formái és díszítései a szelevényi leletek között tűnnek fel, így bizonyítható a velük való egykorúságuk. Turbántekercses korsók (P. Fischl, 1997, 1. kép 49.), bordázott hasú bögrék (P. Fischl, 1997, 3. kép, 3-4, 6. kép 7.), bütyökkel és karcolt dísszel ellátott hasú bögrék (P. Fischl 1997, 3. kép 1) egyaránt vannak közöttük, így rokonságuk nem vitatható. A szelevényi leletek alapján ezt a két lelőhelyet a koszideri korszakba sorolom, a késő Hatvan-kultúrához kötöm, mely a Tisza mentén dél felé, jelentős mértékben elmozdult, és telepeket alapított. Ebben nem vettek részt nagy létszámú közösségek, hanem kisebb csoportokról, talán kereskedőkröl lehet szó. Mindez a tiszai útvonal koszideri periódusban való fontosságát igazolja. Ez az észak-déli irányú 
hatásmechanizmus szorosan illeszkedik a koszideri periódusról kialakított régészeti képbe, mely szerint az egyes kultúrák közötti határvonalak elmosódtak, egyes stílusjegyek kultúra felettivé váltak. Így nem kell szükségszerüen a Füzesabony-kultúra etnikai jelenlétét feltételezni Magyartés és Sövényháza határában, de a Füzesabony-stílusú edények megjelenése egy messze észak felé mutató, kereskedelmi rendszer felélénkülését mutatja. A koszideri időszak stíluskeveredése mögött a kereskedelmi kapcsolatok intenzívebbé válását gyanítják, melyben a fő csereáru a bronz és ötvözőfémei lehettek (P. Fischl, 1999, V. Szabó, 1999).

A térség egyik meghatározó régészeti egysége a Perjámos-kultúra, melynek településterülete a Tisza bal partján és a Maros mentén volt (épp emiatt Maros-kultúrának is nevezték), a Tiszát nem lépte át. Ugyanakkor nemrégiben terepbejáráson az SZTE régészhallgatói találtak egy Perjámos települést Magyarkanizsa (Kaniža, SR) területén, a Tisza jobb partján. Az általam megszemlélt leletanyagban egy-két korai Perjámos lelet mellett döntően késő Perjámos településleletek voltak (100. ábra), melyekhez hasonlóakat Klárafalva telljéről ismerünk (P. Fischl, 1998). Néhány táltöredéken a Halomsíros-kultúrára jellemzőnek tartott csücsökdíszítés is megfigyelhető. A tálak peremének csücsökdíszítése azonban az összes kárpát-medencei müveltség koszideri korú anyagában jelen van, ezért önmagában kultúrajelzőnek nem tartható. A magyarkanizsai telep a Tisza magaspartjának peremén található, a folyó túlsó partján ugyancsak Perjámos telep van (Törökkanizsa). Ez a két telep valószínűleg egy igen fontos átkelőhelyet védelmezhetett, s a kultúra többi tell vagy tell jellegű településével kapcsolatban is arra a következtetésre jutottak, hogy szerepük elsősorban a kereskedelmi út ellenőrzése volt (P. Fischl, 2003). A Perjámos-kultúra tell telepei közül csak a klárafalvi és a pécskai éli meg a késői korszakot, ez utóbbit a korai Halomsíros időszakkal is párhuzamosnak tartják (Soroceanu, 1991). A szőregi temetőben is van biztosan BB2-re datálható temetkezés (P. Fischl et al. 1999).

$\mathrm{Az}$ itt leírtak azért fontosak, mert vizsgált településünkön egy késő Perjámos és egy Vattina import töredék is előkerült. Ezek a leletek közvetlenül bizonyítják a domaszéki kora Halomsíros telep és a jelzett középső bronzkori kultúrák utolsó szakaszának részleges egyidejűségét. Ez a déli-délkeleti irányú hatásmechanizmus nem volt egyoldalú, hisz ismerünk Halomsíros leleteket a Vattina- majd Belegis-karakterü Stubarlijából, MošorinFeudvar (Mozsor-Földvár, SR) temetőjéből (Medović, 2007, 17., 42., 47. kép). A Titelilöszplató északi peremén található lelőhely anyagában mészbetétes (Szeremle) és Vatya elemek is előfordulnak (Medović, 2007, 20., 27/1-2., 32. kép, stb.), Litzenkerámia mellett (Medović, 2007, 33/1. kép). A középső és későbronzkori temetőt régészeti megfontolások alapján 1600-1300 BC közé keltezik (Medović, 2007, 84).

A térség másik igen fontos, talán a legfontosabb kultúrája a Vatya. Életének késői szakaszában délkelet felé mozdul el (Kovács, 1984), ekkor jön létre Alpár-Várdomb, Kelebia, Csanytelek települése a Tisza és a Körös-ér mentén. A belső homokterületen BaksHomokbánya (P. Fischl et al. 1999), Felsőpusztaszer (Foltiny 1944-45) és Csengele tanúskodnak Vatya megtelepedésről. A Csengele-(Belső)-Mételyes lelőhelyről előkerült leleteket még nem közölték. Egy szórvány késő Vatya bögre (magyarádi formajegyekkel) Ruzsán látott napvilágot (13. ábra 1.). A sírokból származó tárgyak között egyszerű késő 
Vatya bögréket (101. ábra 3-5., 7.), Füzesabony jellegü bögrét (101. ábra 6.) és egy Lovas típusú korsót (101. ábra 1.) találhatunk, a temető fémanyagát egyetlen tüskés-körbordás tutulus képviseli (101. ábra 2.). A Lovas típusú korsó és a tüskés-körbordás csüngő a temetőt a koszideri időszakra helyezi. A Lovas típus a Vattina-kultúra kerámiatípusa, így megjelenése a terület Bácskával és Bánáttal kialakult kapcsolatát jelzi a koszideri periódusban, csakúgy, mint a domaszéki import Vattina töredék (P. Fischl, 2003, P. Fischl - Kiss, 2002).

A késő Vatya kultúra történetét részben megvilágítja a nemrég közölt DunaújvárosDuna-dűlői temető (a Kosziderpadlás temetője). Itt a Nagyrév időszaktól folyamatosan fejlődő társadalom képe bontakozik ki, melynek záró szakaszában 33 késő bronzkorra keltezhető temetkezés található. A késő Vatya-Rákóczifalva-Halomsíros karakterrel, jellemző edénytípusokkal rendelkező sírok a temető rendjébe illeszkednek, forma- és díszítésviláguk törés nélkül követi a Vatya-Koszider típusokat (Vicze, 2011, 139).

A Domaszék-Börcsök tanyai településrészletet a leletek analógiái, különösen a Szegedbogárzói és a Dunaújváros-Duna-dűlői temetővel való összehasonlítása alapján, a korai, részben klasszikus Halomsíros periódusba, a Reinecke BB1 szakasz végétől a Reinecke BCig keltezem. A telep biztosan nem éri meg a tápéi temető végét, mivel függőlegesen kannelúrázott hasú edények nincsenek az anyagban. Az adatok csak a település feltárt negyedére vonatkoznak, nem tudható, hogy a fel nem tárt területen nincsenek-e korábbi, vagy épp későbbi jelenségek. A korai datálás alapját a már említett import tárgyakon kívül az 1. gödörből előkerült bütyöklábas korsótöredék képezi, mely kizárólag a koszideri időszakra jellemző. Továbbá a 425. gödörből napvilágot látott, beböködött háromszögekkel díszített edénytöredék, amely a késő Magyarád kultúra sajátja. A késői időszakhoz kötöttem a kiöntőcsöves korsót és a 305. objektum fekete, fényezett, félgömbös testü bögréjét.

A 16. táblázatban a település korjelző leleteinek kontextusát (milyen típusú tárgyakkal együtt fordulnak elő), a 17. táblázatban egyes Csongrád megyei késő bronzkori lelőhelyek típus-gyakoriságát hasonlítom össze. Datálásuk a koszideri időszak végétől a Hallstatt A2-ig terjed.

Jól látható, hogy egyes tárgytípusok vagy díszítések csak néhány lelőhelyre jellemzőek, míg számos jellegzetesség az egész korszakon végigvonul. A legfőbb megállapítás ezzel kapcsolatosan az, hogy néhány igen jellegzetes tárgytípuson és formajegyen kívül (mint amilyen a bütyöklábas korsó vagy a külső bordás csücsök) nincs olyan edény vagy díszítés, mely egyértelmüen meghatározna egy rövidebb periódust a Halomsíros kultúrán belül. Másik konklúziónk a lelőhelyeket összehasonlítva az, hogy egyes típusok eltérő gyakorisággal fordulnak elő a különböző korszakok anyagában.

Ilyenek bizonyos táltípusok. A legkorábbiak az egyenes, vagy vízszintesen levágott, vízszintesen vagy 45 fokban kihajló csücskökkel tagolt peremü tálak (tipológiai rendszerünkben a B1b-c-d), valamint a klasszikus T-peremü tálak (B1a). A perem megvastagodó $\mathrm{T}$ alakja a tál belseje felé mindinkább rézsűssé válik (B1h), majd a klasszikus időszakban a leggyakoribbá a belül a tálperemmel párhuzamosan megvastagított tálak válnak (B1g). Ezzel párhuzamosan eltünik a külső bordával ellátott csücsök és a réselés. Az egyes táltípusok nem önmagukban rendelkeznek datáló értékkel, hanem az adott leletegyüttesben való gyakoriságuk a döntő. 
Munkámnak nem volt fó célja a Csongrád megyei Halomsíros leletanyag belső kronológiájának finomítása, de fontosnak érzem, hogy leírjam ezzel kapcsolatos megállapításaimat.

1. A Halomsiros kerámia 3 szakaszra osztható, és ezek: I. Reinecke BB1 második fele (Koszider vége, jellegzetes leletanyag a Dunántúlról, pl. Vicze, 2011, Kiss, 2011, stb.) és BB2 eleje. II. Reinecke BB2 és BC (eleje?). III. BC második fele (?) és BD periódus eleje.

A BD-Ha Al szakaszt (Pre-Gáva) önálló települések képviselik.

2. A koszideri korú Halomsíros kultúra kerámiaanyagának legfontosabb vezértípusa a bütyöklábas korsó, ivelt bordadísz, valamint az egyes peremü, félgömbös tál, vízszintesen vagy 45 fokban kihajló, kívül bordázott csücskökkel, gyakran réseléssel. Feltételezhetö, hogy ezek a jellegzetességek a BB2 szakasz elején még léteztek.

3. A BB2-BC korú leletanyag dél-alföldi típuslelöhelye a tápéi temetö, melyben a kerámia alapján - leszámítva a legkorábbi és a legkésöbbi leleteket - pontosabb kronológiát nem tudunk felállitani. A korszak telepkerámiáját többek közt Zákányszéken találták meg (Sánta 2004).

4. A BC második felétöl kezdödö szakasz leletanyagára az edények hasán megjelenö függőleges kannelúrázás jellemzö, az edényeket sötétebbre égetik, majd a felületet grafitozni is kezdik. Ez a szakasz belenyúlik a BD periódusba, amikor is a temetöket és a telepeket elhagyják, majd újakat létesítenek a pre-Gáva periódusban (V. Szabó, 1996).

A fent jelzett kronológiai szakaszokat, a Halomsíros kultúra tagolását elméleti megfontolások, és a törzsterület kronológiájával való összevetés alapján többen is leírták, a rendszert nem én alkottam meg (Trogmayer, 1975, Kovács, 1975, Kovács, 1995, V. Szabó, 1999). A belső kronológiát eddig a BB1, BB2-C és BD-Ha A1 szakaszokra választották szét, mivel a datálás alapja a fémművesség volt, és csak kisebb részben a kerámia. Megfelelő mennyiségü és minőségü leletanyag hiányában elmaradt a Halomsíros kerámiaművesség periodizációjának alapos körüljárása, a régészeti leletek statisztikai és szeriációs elemzése. Ebben a dolgozatban ennek a munkának az első lépéseit tettem meg nagyobb mennyiségü de még messze nem elégséges - leletanyag bevonásával. A munka további lépcsőfokaként szükséges újabb, a domaszékihez hasonló nagy Halomsíros telepek feltárása és tipokronológiai elemzése. A leletanyag relatív datálását radiokarbon mérési sorozatokkal kell majd hitelesíteni.

A BD és Hallstatt A1 szakaszokat reprezentáló Kiskundorozsma-subasai telep, és a Ruzsa-csorvai temető korai szakasza feketére égetett, fényezett, grafitozott és kannelúrázott kerámiát tartalmaz, perem fölé húzott, gyakran ötszög átmetszetű fülekkel. A peremek síkozása a BD időszak végétől terjed el, lehetőséget adva egy későbbi finomabb régészeti tipokronológiai beosztásnak (V. Szabó, 1996). Ezeket a stílusjegyeket Jiří Ř́hovsky (1963, 1982) a korai Urnamezős kultúra jegyeiként írta le. Az ő kronológiai rendszerében a fentebb emlitett négy szakasz nagyjából megfeleltethetö a Mistelbach-Regelsbrunn, MaisbirbaumZohor, Strechotin-Velké Hosterádky, és Blučina-Kopčany horizontoknak. Tehát a leletanyag szeriációs vizsgálatával igazolható, hogy a Csongrád megyei Halomsíros kultúra hasonló fejlődési állomásokon ment keresztül, mint az alsó-ausztriai, morvaországi területek Halomsíros kultúrája (az egyes periódusok határai nem szükségszerűen esnek egybe). A két 
terület kulturálisan hasonló jellegzetességekkel bírt, melyek nem csak a kialakuláskor voltak erősek. A két régió nem szigetelődött el egymástól, hanem a koszideri periódus végén létrejött szoros, nyugati, északnyugati irányú kapcsolatok megmaradtak. E szálak a kereskedelem révén szövődtek, melynek fő terméke a Közép-Duna-vidéken előforduló ón és a réz volt. Fel kell tennünk a kérdést, hogy nem esetleg az ónhoz való hozzájutás áll-e a koszideri korszaktól megélénkülő kapcsolatrendszer középpontjában, mely végül elvezetett a Közép-Duna-völgyben a sok tekintetben azonos jegyekkel bíró, de eltérő etnikumokat magába foglaló Halomsíros-kultúra létrejöttéhez? Ez a kapcsolatrendszer töretlenül hatott tovább az Urnamezős kultúra időszakában is. Az ónhoz való hozzájutás könnyebbé válására az általunk megelemzett kb. 50 Halomsíros bronztárgy igen magas, 6-10\%-os óntartalma is utal, mely magasabb a középső bronzkori tárgyakban mérhető értékeknél.

A település legalább 15-20 km-es körzetében nem voltak középsö bronzkori települések. A Halomsiros lakosság egy látszólag üres területet vett birtokba, ahol nagyállattartó pásztorkodást és némi földmüvelést folytattak. Ez a lakosság ugyanakkor sok tekintetben a Vatya-kultúra örököse. A telepnek létezik egy olyan kora Halomsíros szakasza, mely egykorú a Vatyával, és a telep ezután folyamatosan, zavartalanul fejlödik, ennek ellenére számos Vatya jelleg ismerhetö fel benne. Fel kell tenni a kérdést: ez a lakosság lehet-e a koszideri korú Vatya (Alpár csoport), egy kultúraváltozás alatt álló, vagy épp kultúrát váltott, elödeitöl (kortársaitól?) eltérö létfenntartást folytató közössége, mely valamilyen - egyelöre ismeretlen - okból Halomsíros jegyeket vett fel? Ha igen, miért és hogyan zajlott a kultúraváltozás?

\section{Kultúraváltozás}

A Halomsíros kultúra megjelenését, térfoglalását a korábbi kutatás egy Közép-Dunavidék felől történő népmozgásnak tulajdonította (Bóna, 1958, 1992, Mozsolics, 1957, Kovács, 1975a, Csányi, 1980, Trogmayer, 1975, stb.). Nagyszámú Halomsíros lakosság több hullámban történő bevándorlását, és a korábbi lakosság eltünését a későbbi régészeti adatok nem támasztották alá, hiszen a leletek között számos jel utal az őslakosság továbbélésére (Kovács, 1965, 1981, Trogmayer, 1975, stb.). Az alpári telep (házi)kerámiája szinte „zavaróan” köszön vissza a Halomsíros temetőkben (Bóna-Nováki, 1982). A Halomsíroskultúra első szakaszának és a középső bronzkor végének egyidejüségét a Szeged-bogárzói temető fémanyagán (Foltiny, 1957), a kevert, Vatya-Perjámos-Halomsíros jellegü felsőpusztaszeri leleten (Foltiny 1944-45) és a Szőreg-Perjámos kultúra néhány adatán (P. Fischl et al. 1999, Soroceanu, 1991) kívül eddig nem sok minden támasztotta alá. A Rákóczifalva csoportot már régen a Vatya és Füzesabony müveltségből vezették le, és a koszideri időszak végére keltezték a kezdetét (Kovács, 1981, Trogmayer, 1985, Kőszegi, 1984), de az igazi bizonyítékot a Dunaújváros-Duna-dűlő temető feldolgozása adta meg. Itt a kora bronzkor végétől folyamatosan fejlődő társadalom képe bontakozik ki előttünk, melynek záró szakaszában 33 késő bronzkorra keltezhető temetkezés található. A késö VatyaRákóczifalva-Halomsíros karakterü edénytípusokkal rendelkezö sírok a temetö rendjébe illeszkednek és forma-valamint díszitésviláguk törés nélkül követik a Vatya-Koszider idöszak tipusait (Vicze, 2011, 46, 139, Pl. 171-229.). 
Ez a megfigyelés mélyen elgondolkodtat arról, hogy pontosan mi is történt a középső bronzkor végén a Kárpát-medencében. Az világos, hogy a nagy létszámú, valamiféle homályos „katonai fölény” (hosszú kardok) birtokában lévő nagyszámú Halomsíros népesség bevándorlásának elmélete nem tartható tovább. Sőt, az is kérdéses, hogy kisebb csoportok beköltöztek-e, hisz az egész Vatya fejlődési tendenciái ebbe az irányba mutatnak, csak néhány díszedény-típus és díszítés jelenik meg a Halomsíros periódussal, melyek egy része ráadásul a szomszédos Magyarád és késő Vêtêřov (Böheimkirchen) kultúrákból is származtatható.

A Halomsíros időszakban a kerámia kivitelének romlása és az általános díszítetlenség véleményem szerint a fazekas-centrumok szétesésével, a társadalom atomizálódásával magyarázható. Láttuk, hogy nem lehet Domaszéken „főállású” fazekasokkal számolni, de hasonló érvrendszerrel, mint amit a kerámia elemzésekor követtünk, belátható, hogy egy nagy Vatya telep már igényelt, és a kerámia mennyisége, jó minősége (Vicze, 2011 táblái) feltételez is fóállású fazekasokat, és ilyen fazekasműhelyt Százhalombattán fel is tártak. A monolitikus, szigorúan kötött rítusú és messzemenően egységes Vatya (I-III) kultúra a VatyaKoszider fázisban csoportokra (Bóna-Nováki, 1982, Schreiber, 1967, P. Fischl, 2000) bomlik, mely jelzi a belső kohézió meggyengülését. A csoportok ugyanis a velük szomszédos kultúra anyagi kultúrájának jegyeit veszik át, jelezve, hogy kapcsolatrendszerük sokkal inkább mutat a korábban egységes kultúrából kifelé, mint a centrum irányába. A korábbi egység, és a később bekövetkező széthullás a Vatya centralizált törzsi struktúrájában bekövetkező kohézió meggyengülését, majd talán eltűnését jelzi. A centralizált főnöki struktúra bizonyítékai:

1. Maga a fémmüvesség, melynek nyersanyag-beszerzése egy feleslegen alapuló kereskedelmi rendszert feltételez (Halstead - O’Shea, 1982, Reményi, 2003).

2. A föld- és kőszerkezetes, több részből álló várak (102. ábra, Nováki, 1952, F. Petres Bándi, 1969, stb.), és a bennük, környékükön elrejtett kincsek (Kovács, 1984). A várak erődítése nem a késő Vatya időszakban, a Halomsíros „invázió” ellen történik, hanem korábban, és a kései időszakban a sáncokra is felhúzódnak a telepek (Bóna - Nováki, 1982, F. Petres - Bándi, 1969, Poroszlai, 1993). A várak a társadalom vezetőrétegének lakhelyei, „politikai”, gazdasági és szakrális centrumok, ahogy azt a legújabb kutatások a Berettyó vidékén is kimutatták (Dani, 2009).

3. A diadémok, az aranyleletek (pl. a dunavecsei arany kartekercs), melyek egy (szakrális?) elit létének, és a luxusjavak felhalmozásának bizonyítékai (Bóna, 1959, Kovács, 1991, Halstead - O’Shea, 1982). Az aranyleletek a várakhoz, a magterülethez köthetőek (103. ábra, Kovács, 1991, Abb. 6. alapján).

Kérdés, hogy van-e a tellek és földvárak rendszerében olyan lelőhely, mely egyértelmúen vezető szerepet játszhatott volna a Vatya kultúrában. Talán ilyen volt Dunaújváros-Kosziderpadlás, ahonnan három kincs került elő, mérete 400x250 m (Vicze, 2011, Fig 1. és Fig 7.), és innen ismert a legnagyobb sírszámú temető is (Vicze, 2011), ugyanakkor a többi Vatya telep temetője is lehet ugyanekkora, hisz teljes feltárás nem történt. A várak szerepével kapcsolatban Thiessen-elemzést végeztem (102. ábra). A Mezöföldön szinte teljesen szabályos hatszöges struktúra alakult ki, mely a javak egyenletes eloszlásából 
adódik. Nincs jele annak, hogy a várrendszer valami védelmi vonalat alkotna, ez a látszat csupán a Duna menti löszpart, mint természetes geomorfológiai határ miatt jön létre. Dunaújváros-Kosziderpadlás tell telep és földvár mérete azonban legalább kétszerese a többi várénak, továbbá két másik telep fekszik a közelében a Duna partján, melyek szokatlanul kis méretűek (Adony, Baracs). A Thiessen-elemzés azt mutatta, hogy a kosziderpadlási tell méretéhez képest aránytalanul kicsi területet birtokol. Ezért elképzelhetö, söt valószinü, hogy az adonyi és baracsi vár a Kosziderpadlás fennhatósága alá tartozott. Északabbra, a Velencei-hegység környékén a várak sürübb hálózata más típusú településszerkezetre utal. A Duna-Tisza közén Solt-Tételhalom (Szentpéteri - Rosta, 2005, Szentpéteri, 2006) 200x100 m-es vára és $\mathrm{kb} .1 \mathrm{~km}$-es külső telepe nagyságrendileg ugyanakkora centrum lehetett, mint Dunaújváros. A két lelöhely környezetében került elö a Vatya kultúra 16 db aranylelete közül hét (4 Dunaújváros, 3 Solt környékén), és Solt mellöl, Dunavecséröl ismert a legnagyobb aranytárgy is (Kovács, 1991). Mindezek felvetik két, talán három hierarchia-szint létét a várak között. A 102. ábra térképe nem ábrázolja az összes várat és nem tünteti fel az összes vár méretét, csak azokat az adatokat, melyekhez jelenleg hozzáfértem, ezért hiányos. A célja csak az volt, hogy kiderüljön: van-e esély rá, hogy egy vagy több vár kiemelkedik a többi közül. A hiányos adatok erre utalnak: Dunaújváros, Solt és Nagykőrös a többinél nagyobb, és talán fontosabb várnak tünik (Nagykőröshöz: Poroszlai, 1992).

A kincsek szerepével kapcsolatban az eddig felmerült magyarázatokon (Bóna, 1958, Kovács, 1994, V. Szabó, 1999), túl megkockáztatható az a felvetés, hogy ezek, a tellekhez és a nagyobb telepekhez köthető ,áldozati” leletek valamiképp összefüggésben lehettek a Vatya „törzs” („törzsszövetség?”) feletti „fơhatalom” gyakorlásával. Talán a nagy centrumok (tellek, földvárak) a hatalmat felváltva gyakorolták, és a hatalom átruházásának jelképei, a ceremómia tárgyiasult bizonyítékai lennének az igen gazdag depók? Természetesen tudom, hogy e modell egyelőre közvetlenül nem bizonyítható, de a jelzett tények megengedik egy ilyen következtetés levonását is. Az adatok jelenleg inkább amellett szólnak, hogy a tellek és oikumenéjük volt a legmagasabb gazdasági szervezeti egység, a centrum fennhatósága néhol (Dunaújváros) egy-két másik várra is kiterjedhetett. Ugyanakkor az anyagi kultúra igen nagyfokú egysége a Vatya területen belül a központok közötti nagyfokú interakciót és erős kohéziót bizonyítja a Vatya I-III időszakban, ami egy, a tellek, várak feletti társadalmigazdasági struktúra létére enged következtetni.

Mi is történhetett tehát? A Vatya-Koszider népesség határozottan szorosabbra füzi kapcsolatrendszerét a szomszédos területekkel és kultúrákkal, köztük a Magyarád és korai Halomsíros népességgel is (V. Szabó, 1999, P. Fischl, 1999, P. Fischl et al. 1999, stb.), ugyanakkor a kulturális határok elmosódnak, temetkezési rítusok keverednek (P. Fischl 1999, Lőrinczy-Trogmayer, 1996, stb.). A kor kutatóinak határozott válasza szerint kapcsolatrendszer megélénkülése a fémkereskedelemhez kötődik (V. Szabó, 1999, további irodalommal). Ez a fém a bronz, melynek két fö összetevője a jelek szerint nem egy területről származik, sőt az ón beszerzése távolsági kereskedelmet igényel. Az ón lelöhelyei a majdani Halomsíros-kultúra centrális területének közelében, Csehországban vannak. A Halomsíros komplexum Kovács Tibor szerint gazdasági-politikai egység (Kovács, 1995), melynek 
kialakulását szerintem az ón megélénkülő kereskedelme segítette, ez a fém félkész termékek, részben magas (20\% körüli) óntartalmú csüngők formájában vándorolt.

Ha azt feltételezzük, hogy a Vatya valamiképpen kultúrát és legfőképp életmódot váltott, akkor meg kell vizsgálni, vannak-e a dunaújvárosi temetőhöz és a domaszéki telephez hasonló bizonyítékok erre a változásra. Ahogy azt már több helyen hangsúlyoztuk, a Vatya életmódja a földmüvelésre épült, és lassú délkeleti elmozdulása (Kovács, 1984) során végig ragaszkodott a löszpartokhoz. Azonban megjelennek a homoktalajokon is Vatya telepek, pl. Bakson, Csengelén és Ruzsán. Kelebia-Vasútföld-dűlőben (22. 1h.) a Vatya-kultúra településén Litzen-díszes urnatöredék került elő Bató Szilvia terepbejárásán (Bató, 2001, 5253, 11. kép 2-3.). A Litzen-díszt a föként a koszideri korszakhoz és a korai Halomsíros kultúrához szokták kötni (Kovács, 1975a, Benkovsky-Pivovarová et al, 1988, Kiss, 2000, további irodalommal). Ez a lelőhely talán az ,átmeneti időszak” leleteit is tartalmazza.

A sor folytatásaként Halomsíros jellegü, de a Vatyához éppúgy ezer szállal kötődő telepet találunk Domaszék-Börcsök tanyán. Úgy vélem, ez a folyamat a Vatya lakosság életmódváltásának bizonyítéka lehet, bár kétségtelen, hogy újabb hiteles feltárásoknak kell történniük a Bakshoz hasonló telepeken. Az életmódváltást az a környezeti-éghajlati átalakulás hajthatta, melynek geológiai-környezettörténeti bizonyítékait Sóskúton tárták fel (Sümegi-Bodor, 2005). A szántóföldek kiterjedtek a kor viszonyai között megmüvelhetö összes földterületre, s ez még akkor is feszültséget generálhatott a feleslegtől, és azon keresztül az import fémtől függő Vatya gazdaságban, ha nem történt azonnal komoly éghajlatváltozás. Elindulhatott a vagyon állatállományba fektetésének folyamata (HalsteadO’Shea, 1982), mely a törzsi kohézió gyengülésekor, az éghajlatváltozás és a Halomsíros magterülettel fennálló kapcsolatok (esetleg kisebb csoportok beköltözése) révén elvezethetett a dél-alföldi Halomsíros csoportok kialakulásához.

A fent vázolt modell számos eleme nehezen bizonyítható, vagy további bizonyítékokat igényel. Ugyanakkor a dolgozat célja volt az újonnan megismert tények segítségével felvázolni egy lehetséges „forgatókönyvet” a középső és késő bronzkor határán lezajlott változásokra. A modellt így olyan hipotézisként kell kelezni, melynek bizonyítása vagy cáfolata is komoly előrelépést jelent majd a korszak megértése felé.

\section{Településszerkezet}

A régészeti feltárás egy nagyobb település részletét érintette, annak kb. negyede-ötöde került feltárásra. Nem tudhatjuk, a fel nem tárt területen milyen sürüségben és mekkora kiterjedésben fordulnak elő Halomsíros telepjelenségek. A feltárt részen öt objektumcsoportot tudtam elkülöníteni, melyek a leletanyag alapján egy időben létezhettek, és a lakosság társadalmi szerkezetével állhattak összefüggésben. A csoportok mindegyikében felszíni, cölöpszerkezetes házak álltak, és gödrök, karámok, ólak is megtalálhatóak voltak. A csoportokat egy háztartási egység lakó- és munkaterének foghatjuk fel. Megfigyeléseim alapján megkíséreltem összefoglaló képet nyújtani a Halomsíros időszak településeiről, különösen a házakról (Sánta, 2011). Azt a megállapítást tettem, hogy a felmenő falú, cölöpszerkezetes házak - melyek a korábbi, és a későbbi szakaszokban is jellemzőek - a Halomsíros településeknek is sajátjai, földbe ásott házakat csak ritkán találni. 


\section{Lakosság, társadalom}

A feltárt és feltáratlan terület arányára vonatkozó nagyságrendi becslést (1:4) és a háztartási egységeket felhasználva megkísérelek becslést adni a település lakosságának létszámára. Ha a teleprészleten 5 csoport volt, akkor a teljes településen kb. 20 csoport létezhetett egyidejüleg. Ha egy csoportban 1-2 házzal számolunk, akkor ez 20-40 épületet jelent. A 8x10 méteres épületek kiscsaládok lakóhelyeiként szolgálhattak, míg maguk az objektumcsoportok egy nagycsalád vagy ágazat életterei voltak. A régészetben a néprajzi kiscsaládoknál megfigyelt, általánosnak tekinthető, házanként 5 fős létszámmal szokás számolni. Így a telep lakossága 100-200 fő lehetett egyszerre. Nincs konkrét bizonyíték a nagycsaládnál nagyobb szerveződés jelenlétére a faluközösségen kívül. Azt azonban meg kell jegyezni, hogy létezik egy olyan edénytípus, melye a sírokba nem kerül be, de a telep gödreiben többször megtalálható (230., 320. gödör). Ezek hatalmas, kb. $50 \mathrm{~cm}$ szájátmérőjü tálak, melyek - rövid számolás után belátható - kb. 30-50 liter ürtartalommal rendelkeztek. Ez az ételmennyiség messze túl van egy kis- vagy nagycsalád igényein. A legtipikusabb eset a 230. gödör, melyben kizárólag egyetlen ilyen tál 1/3 része hevert. A tál többi darabját a szántás és a gépi humuszolás pusztíthatta el. Az, hogy a tálat összetörése után egy, csak a számára ásott gödörben helyezték el, olyan ritka eseményre enged következtetni, melyen nagyszámú: 30 vagy több személy vett részt. Ez a szám túl van a puszta családi kereteken, inkább egy ágazat vagy nemzetség, a család tágabb rokonsága lehet. Az is elképzelhető, hogy ezeken az eseményeken a település egész lakossága, vagy felnőtt lakossága, esetleg felnőtt férfi lakossága részt vett. Óvatosan azt lehet mondani, hogy a tálakat olyan összejöveteleken használták, melyeken a családnál nagyobb társadalmi struktúrák jutottak szerephez. Hasonló összejövetelek emlékei a késő bronzkori edénydepók, melyeket a harcos férfiak gyüléseivel és ünnepeivel kapcsoltak össze (V. Szabó, 2004b). Az értelmezésben ilyen messzire nem merészkedhetek, csak annyi jelenthető ki, hogy néha egyes, a családnál nagyobb csoportok valamilyen társas összejövetelt tartottak, melyeken $50 \mathrm{~cm}$ körüli átméröjü tálakban kb. 30 fő részére ételt szolgáltak fel, és ezek a tálak a társas esemény alatt (?) néha összetörtek.

Még magasabb, fönöki struktúrára nem utalnak jelek a Halomsíros kultúrán belül. Bizonyos, hogy a társadalom vezetö rétege a fegyveres arisztokrácia volt, de ennek a hatalma leginkább nemzetségi, és nem törzsi szinten érvényesült, mivel olyan települési centrumokat, kiemelkedö leleteket, melyek erre engednének következtetni, nem ismerünk. Ez a centralizált szerkezetü, (telleken élö) fegyveres arisztokrácia által vezetett középső bronzkori társadalomtól élesen különbözik. A társadalom alapvető szerveződési szintje a család, a faluközösség és a nemzetség lehetett. A nagy kiterjedésű temetők (Tápé, Tiszafüred, stb.) nemzetségi temetőknek tarthatóak, melyekben a sírcsoportok a telep objektumcsoportjaihoz hasonlóan a családok temetkezőhelyei voltak (Tápé, Trogmayer, 1975, Tiszafüred, Kovács, 1975b).

\section{Létfenntartás}

A település lakossága a leletek alapján elsősorban állattenyésztéssel foglalkozott, főleg szarvasmarhát és juhot tenyésztettek, de szerepet kapott a ló és a kutya is. A pollenfúrás adatai egyértelmüen bizonyitják, hogy a telep élete idején a közelben hatalmas legelöket 
alakitottak ki, és elkezdték az ártéri erdők irtását/szálalását, ártéri legelőket létesítve. Az állatállomány értékesebb a gabonánál vagy más terménynél, mert a felnevelésébe fektetett javak mennyisége magas, ezért az állat csereértéke is jobb. Veszélyhelyzetben könnyen mobilizálható - elhajtható vagy megehetö, bőség idején könnyen cserélhetö - rézre, ónra, bronz félkész termékre, sóra, aranyra (Halstead - O’Shea, 1982). Nem véletlen, hogy a Halomsíros temetőkben számos, bronzmellékletben gazdag sírt találtak.

A homokhátság gyenge talaja kifejezetten kedvezett a legeltetö állattartásnak. A Halomsíros közösségek létfenntartása kifejezetten sikeres volt, mely remekül alkalmazkodott a természeti adottságokhoz.

A középső bronzkori lakosság életmódja a földművelés dominanciáján alapult. Ezért a klasszikus Vatya a homokterületen nem telepedett meg, a Duna-Tisza közén is a löszös talajú helyeket kereste (Kelebia: Körös-ér mente, kb. 30 Vatya telep, egy késő Vatya temető, Csongrád környéke: G. Szénászky, 1977). Csak a késő Vatya kultúra jelenik meg homoktalajon (Baks-Homokbánya, P. Fischl et al, 1999, Csengele-Mételyes, Felsőpusztaszer: Foltiny, 1944-45). A késő bronzkor elején ugyanakkor csapadékosabbá és hüvösebbé vált az éghajlat, ami a növénytermesztésnek nem kedvezett (a szántók felvizesedtek?), az állattenyésztést viszont segítette (Sümegi et al, 2003, Sümegi 2009).

A növénytermesztés, bár jelentősége csökken a középső bronzkorhoz képest, nem tünik el teljesen. Településünkön az árpa-tönke-köles nagyjából 40-40-20\% arányú termelésére épülő mezőgazdaság képe rajzolódik ki, ugyanakkor a fajok száma jelentösen lecsökken a Vatya lelőhelyekhez képest. Az igénytelenebb, rövid tenyészidejű fajok elötérbe kerülése folytatása a Vatya III - Vatya-Koszider periódusban zajló folyamatnak (köles megjelenése), a tönke azonban a teljes Vatya időszakban is a Duna-Tisza köze DK-i részének kedvelt terménye volt. Végső soron a Halomsíros periódus növénytermesztése fajokban szegényes volt, de a három fó faj jól illeszkedik a tágabb térség Koszideri korú termesztési struktúrájához, annak folytatásaként fogható fel. Ezek a tendenciák azonban - a rövid tenyészidejü, igénytelen, szárazságtürő fajok elötérbe kerülése - az állattenyésztés egyre növekvö súlyára is utalnak.

A régészeti keltezés a településünk korai fázisát a legkésőbbi Vatya településekkel részben párhuzamosnak feltételezi. Ehhez képest a különbség nem is olyan nagy: hasonló fajokat termesztenek eltérö talajon, kihagyva az igényesebb gabonafajtákat, hüvelyeseket.

\section{Technológia}

A kultúra technológiai alrendszere mindazokat a cselekvéseket, a hozzájuk kapcsolódó ismeretanyagot tartalmazza, mely a többi alrendszer müködéséhez szükséges tárgyakat előállítja.

A lakosságnak szüksége volt hajlékokra, házakra. A házakat facölöpök, gerendaszerkezet alkotta, melyek közeit sövénnyel befonták és agyaggal betapasztották. Egy épület 6-8x10-12 m alapterületü volt, átlagban tehát 7x11 m. A tartóoszlopok kb. 2-2,5 m-re emelkedtek ki, és legalább 0,5 m mélyre ásták őket, ez összesen 3-4 méter. Rövidebb oldalán 3, hosszanti oldalán 5-6 nagyobb oszloppal számolhatunk (a megmaradt cölöplyukak és más, hasonló korú házak alapján), az osztófalat 2-4 cölöp alkotta. A tetőszerkezethez és a 
koszorúhoz összesen kb. 50 folyóméter fát használtak. Ha a cölöpök hosszát 4 méternek, átmérőjüket $15 \mathrm{~cm}$-nek, a gerendák átmérőjét kb. $15 \mathrm{~cm}$-nek vesszük, akkor egy épület minimális faigénye - csak a fö tartószerkezetet számítva - 2 köbméter vagy 110-120 folyóméter lehetett.

A falhoz szükséges anyag mennyiségét is kiszámolhatjuk. 2,5 m magas, $20 \mathrm{~cm}$ vastag paticsfallal számolva a fal térfogata - elhagyva az osztófalat - 18 köbméternek adódik. A falnak nem teljes térfogata agyag, hiszen ott vannak a cölöpök, valamint a sövényfal is. Ha kb. 10 köbméterrel kalkulálunk, nem tévedünk nagyot. A vályog sürüségét $2 \mathrm{~kg} / \mathrm{dm} 3-n e k$ véve (http://valyog.uw.hu/b2.htm, 2011. október 24.), kb. 20 tonnát kapunk eredményül. Ehhez hozzászámíthatjuk a padló sározását, amelyre konkrét bizonyítékunk nincs. Ha a padlók 10-15 cm vastagon tapasztottak voltak, akkor ez újabb 7-10 m3 agyagot jelent. A telep lakosságának legnagyobb mennyiségben szükséges nyersanyaga az agyag és a fa volt.

A kérdéses korszak egyik épületének rekonstrukcióját Ilon Gábor készítette el. A Németbánya-Felsőerdei-dülőben feltárt épület 8,5x3,5 méteres alaprajzával kisebb, mint a Halomsíros telepen feltárt házak zöme. Az egyhelyiséges, tapasztott padlós épület fő tartóeleme két szelementartó ágasfa, valamint négy sarokoszlop. A rekonstrukció $12-15 \mathrm{~cm}$ vastag paticsfallal számol, míg én a fal vastagságát $20 \mathrm{~cm}$-nek választottam. Ettől eltekintve a domaszéki épületek hasonló szerkezetűek. Az Urnamezős kultúrában, csakúgy, mint a Halomsírosban, kisebb és nagyobb épületek különíthetőek el (Ilon, 2005, Sánta, 2011). Egyes hazai kísérleti régészeti eredmények igazolják a rendkívül nagymérvü agyagfelhasználást (Raczky et al, 2005). ${ }^{2}$

Az agyagot a vizsgálatok szerint kőzetlisztet tartalmazó feltárásból nyerték. Az agyagbánya így a Maty-ér vagy Maty-ágazat közelében, aleuritos-agyagos kőzetanyagú területen volt, ahol a kitermelt nyersanyagot akár ülepítéssel is finomíthatták. Ezt az elgondolást az is alátámasztja, hogy a nagy mennyiségü agyagfelhasználás ellenére sem találunk a településen belül agyagnyerö gödröket - nem is találhatunk, mert a település alapkőzete közép- és finomszemü homok! Így ezt a rendkívüli fontosságú nyersanyagot is a településtől kissé távolabbról, néhány kilométeres távolságból kellett odaszállítani. Erre a rézkorban feltalált kocsit használták, mely az egész bronzkorban igen elterjedt volt, sőt a szakrális szférában is szerepet kapott (kocsimodellek, pl. Pocsaj, Dani, 2009). A kordészerü szekerekre egyszerre 1-2 m3 agyagot tudtak felpakolni, és ez az a mennyiség, mely a korabeli technikai szinten, azaz emberi erővel egyszerre megdolgozható volt. A házépítés 4-8 ember min. 30 napi munkáját igényli Raczky Pál és Anders Alexandra kísérlete szerint, melyben néha modern eszközöket is alkalmaztak. A bronzkorban a bronzfejszék, fürészek (lásd a telepről előkerült példányt), vésők segítségével a neolitikus embereknél jóval hatékonyabban építhették fel a házakat, de így is legalább 1-1,5 hónap időráfordítással számolhatunk a nagycsalád tagjainak részvételével (Raczky et al, 2005). Ezek után biztosak lehetünk benne, hogy a házépítés nem gyakran ismétlődő jelenség volt a telep életében. A régi, elöregedett

\footnotetext{
${ }^{2}$ A neolit házépítés témájának, a házak kísérleti rekonstrukciójának hatalmas irodalma van, melynek áttekintése a dolgozatnak nem feladata, s a téma nem is igényli. A jelzett cikk hivatkozásának alapja az, hogy a bronzkori, különösen Halomsíros házakra vonatkozóan ilyen kísérletre nem került sor, én viszont szerettem volna legalább nagy vonalakban megbecsülni, mennyi volt egy ház nyersanyag- és munkaigénye. Ilon Gábor cikke ezt a kérdést nem érinti, s az általa publikált ház is későbbi a domaszékieknél.
} 
házakat bizonyos időközönként lebontották, vagy ha tüz pusztította el, omladékát eltávolították, gödrökben helyezték el (114. obj.). Új ház építésére a például a fiatal generáció házasságkötésekor kerülhetett sor.

Fa a fütéshez, főzéshez, szerszámnyélhez, bútorokhoz, a halottak hamvasztásához, és még számtalan máshoz (faedények?) szükséges nyersanyag volt. Az így kitermelt fa mennyiségét még megbecsülni sem lehet. Ugyanakkor az erdőirtás legfőbb oka legelők létesítése volt.

A kő, mechanikai tulajdonságaitól függően, számos célra kitünően felhasználható őskori nyersanyag. Az Alföld, különösen a Dél-Alföld kőben különösen szegény vidék legalábbis a szó klasszikus értelmében vett kőzetanyag igen ritka. A semlyékekben képződött ún. réti mészkövet az ember több régészeti korszakban is felhasználta. Egy esetben találtam ezt a nyersanyagot (211. obj.), rendeltetése nem ismert. A löszben sürün előforduló karbonátos konkréciók többször fordultak elő (25., 308. és 427. obj.), az átégett darabok kemence tapasztásában lehettek. A konkréciókat azért hagyhatták benne a löszös-agyagos tapasztóanyagban, hogy a kemencefal hőtartó képességét fokozzák, így tehát ugyanazt a funkciót töltötték be, mint máshol a bányászott terméskövek.

A kemencetapasztásban átégett kőzetdarab és a felszínről előkerült üveges felületű kőzet anyaga andezit és mikrogránit, származási helyük Lippa/Lipova (RO) környéke, mely a lelőhelyhez legközelebbi felszíni kőzetkibúvás, és a Maros menti úton könnyen elérhető.

A településen feltehetőleg nem folyt önálló fémfeldolgozás, vagy a mühely a feltáratlan részen lehet. Valószínübb, hogy a térségben több, esetleg vándor fémmüves szolgálta ki a lakosság igényeit. A réz és ón félkész termékek formájában került a területre, itt csak a tisztítás és ötvözés, a végleges formák elkészítése zajlott. A fémművességet a teleppel kapcsolatban azért vizsgáltunk, hogy a szükebb régió kapcsolatrendszerébe, technológiájába bepillanthassunk.

Ezért a megállapításaink a települést csak annyiban érintik, hogy az egyik, különleges összetételü bronztárgy itt került elő. Az összes többi tárgy a szükebb régió hasonló korú temetőiből származik. A fejtegetések mégsem haszontalanok, hiszen ha a telepen nem folyt fémmüvesség - ami valószínü -, akkor a környék, hasonló korú leletei között kell keresni a választ a fémmüvesség kérdéseire.

A fém nyersanyag alapvetően két területről érkezhetett, a Tisza menti úton észak (a Felvidék) felől, valamint a Maros mentén kelet-délkeletről. A Tisza menti út a koszideri periódusban igen fontossá vált, ahogy az egyre délebbre megjelenő késő Hatvan-Füzesabony jellegzetességek sugallják. Ez a kapcsolat fennmaradhatott, mivel a tápéi temetőben több Rákóczifalva import tárgy található, és Sövényházán egy késő Felsőszőcs edény is előkerült. A Tisza mentén észak felé, egészen a hegyek lábáig a Halomsíros-kultúra különféle lokális színezetű csoportjai éltek. A Maros menti út fontosságára a marosvásárhelyi sírleletek világítanak rá. Fontos bizonyítékot jelent még a Maros mentének folyamatos Halomsíros megszállása, a Szárazér mentén létrejött sürü településhálózat (Sánta 2004a, 2011, Sz. Kállay, 1980), mely kapcsolatrendszert nem a réz, hanem a só és az arany beszerzése mozgatta. 
A fém összetétele AsNi, ,dasni” és ASN (Einheitskupfer/ostalpines Kupfer, Krause, 2003) csoportokba sorolható. Gyakori az arzén-nikkel szennyezőkkel rendelkező, de minimális antimont és ezüstöt tartalmazó réz, melynek használatát David Liversage nagyjából a koszideri időszakunkra keltezi. A Dobsina-i rézlelőhely nagy mennyiségben tartalmaz gersdorffitot, nikkel-arzén szulfidot, mely a kohósításkor ilyen nyomelemösszetételt eredményezhet. Az északi út koszideri időszakban bekövetkező aktivizálódása talán épp a Dobsina környéki rézbányákkal függhet össze.

\section{Szakrális szféra}

A településen több esetben is elökerültek építési áldozatként azonosítható leletegyüttesek (104. ábra). A következők állapítható meg: mindkét esetben egy, azonos típusú korsó volt kisméretű gödörbe állítva vagy annak oldalához támasztva. A korsók épek voltak, a talaj nyomása során törtek össze és a kiemelésük során több apró töredékük elkallódott. Az ásatási leírások, fényképek és rajzok megerősítik, hogy egykor ép állapotban kerültek földbe, méghozzá a hulladék deponálásánál tudatosabb cselekvéssor részeként. Mindkét jelenség házakhoz kapcsolódott, egyikük (202. objektum) valószínűleg az épület belsejében került elhelyezésre. A korsókban folyadék lehetett, mivel a szilárd táplálék tárolására más edénytípusokat használhattak (tálak, tárolóedények). A jelzett gödrök közelében álló épületek és a hozzájuk kapcsolódó gödrök leletanyaga - különösen a 2. objektumcsoportban előkerült gödörcsoporté - egyértelműen a település legkorábbi fázisához köthető. A gödöráldozatokra - a korsóba töltött folyadék gödörbe helyezésére és szertartásos eltemetésére - a ház felépítése előtt kerülhetett sor, az ilyen építési áldozatok szinte minden korszak régészeti leletanyagában, és az etnográfiában is meglehetősen gyakran visszatérő elemek.

Természetesen két adat alapján nem lehet általánosítani, de annyi elmondható, hogy ismert volt egy, a házépítést megelőző szertartás, építési vagy „megszentelő”, a területet „,birtokba vevő” áldozat a Halomsíros lakosság körében. Hasonló áldozati gödröt (hamvak és csontok nélkül, eredetileg jelképes sírnak meghatározva), és benne egy szimbolikus jelekkel gazdagon díszített, kiöntőcsöves korsót Tápé-Széntéglaégetőn tártak fel (Trogmayer, 1975), és lehetséges, hogy az Ásotthalom-Bilisicsről ismert, hasonlóan díszített edény is erre a célra szolgált, amely mellett ugyancsak nem került elő semmilyen emberi csontmaradvány (104. ábra 3., Tömörkény, 1902, 1903). A Halomsíros kultúra hitvilágában a víz szerepét már korábban felismerték a folyókba dobott kardleleteik nyomán (Szathmáry, 2005, további irodalommal). A Halomsíros kultúra hitvilágában jelen voltak a folyadékkal végzett megelőző, megszentelő áldozatok (pl. az átkelés előtt a folyóba vetett kard, Szegednél is), és a házak felépítését, valamint a temetők (esetleg sírcsoportok) kialakítását is megelőzhették ezek a rítusok. 


\section{Köszönetnyilvánítás}

A doktori dolgozat nem jöhetett volna létre Paluch Tibor nélkül, aki az általa feltárt Domaszék-Börcsök tanyai lelőhely feldolgozásának jogát számomra átengedte. Köszönettel tartozom témavezetőmnek, Dr. Sümegi Pálnak folyamatos biztatásáért, rengeteg hasznos tanácsáért és közöletlen adatok közlésre átengedéséért; legföképpen pedig a beszélgetésekért, melyek a korszakról és a témáról alkotott véleményemet formálták. Úgyszintén rendkívül sokat segítettek konzulenseim, Dr. Bánffy Eszter és Dr. P. Fischl Klára. Dr. Kiss Viktóriának az irodalom összegyüjtésében nyújtott segítéségét köszönöm. Továbbá köszönettel tartozok Dr. Bozsó Gábornak és Dr. Geiger Jánosnak, akikkel a fémelemzések egy részét végeztük. Ugyancsak köszönetet mondok Páll Dávid Gergelynek, Veres Zsoltnak, Persaits Gergőnek, Molnár Dávidnak, és az SZTE TTIK Földtani és Öslénytani Tanszék minden doktoranduszának és hallgatójának, akik munkámat bármilyen módon segítették. Köszönet illeti Barkóczi Zoltánnét, aki mindig segítőkész volt adminisztrációs ügyekben. Köszönöm az SZTE BTK Régészeti Tanszék egykori és jelenlegi oktatóinak, először is Dr. Horváth Ferencnek a segítségét, hiszen Ő volt az, aki utamon elindított a bronzkor felé. Köszönettel tartozom Dr. Révész Lászlónak, Dr. B. Tóth Ágnesnek, Dr. Kulcsár Valériának, Dr. Vörös Gabriellának amiért megteremtették a munka elvégzéséhez szükséges munkahelyi és szakmai feltételeket, továbbá hasznos tanácsokkal láttak.

Köszönetet mondok Dr. Gyulai Ferencnek azért, hogy a lelőhely növénytani maradványait az ásatási dokumentációhoz csatolt elsődleges jelentésében feldolgozta, Tóth Anikónak az állatcsontanyag részletes elemzéséért, s hogy a közöletlen, lektorált kéziratot, megjelenése előtt, rendelkezésemre bocsátotta. Rajtuk kívül köszönettel tartozok Dr. Marcsik Antóniának, Tóth Katalin Piroskának, Véninger Péternek és Gucsi Lászlónak hasznos tanácsaikért, a velük folytatott érdekfeszítő beszélgetésekért.

Köszönettel tartozok mindazoknak is, akik talán itt lehettek volna a felsorolásban, de az én véges emlékezetem most felidézni képtelen őket. Azoknak is, akik talán maguk sem tudják, hogy segítettek: hallgatóimnak köszönöm a szakmai beszélgetéseket és vitákat, valamint azokat az előadásokat, melyeken a doktori dolgozat lényeges elemeit kifejtettem, és együtt elemeztük őket.

Végül és legfőképpen köszönettel tartozok családomnak, így édesanyámnak, néhai Sári Editnek, édesapámnak, Sánta Gábor Árpádnak, testvéremnek, Sánta Attilának, valamint nagyszüleimnek a munka szüneteiben nyújtott nyugodt családi otthonért. Köszönöm minden barátomnak, hogy mellettem álltak, és hogy hittek bennem, a munkámban.

Szeged, 2011. október 24. 


\section{Irodalomjegyzék}

AITKEN, M. J. 1974. Physics and Archaeology. Interscience 1961, 2. Auflage Oxford, Clarendon Press 1974. ANDÓ, M. 1983. A megtelepedés természeti feltételei. In: KRISTÓ, GY. (szerk.): Szeged története I. A kezdetektől 1686-ig. Szeged, 1983, pp. 19-42.

BÁCSMEGI, G. - SÜMEGI, P. 2005. Héhalom-Templomdomb bronzkori tell geoarcheológiai vizsgálata. Héhalom-Templomdomb: geoarchaeological Investigations of a Bronze Age Tell. CommArchHung 2005. pp. 167-176.

BADER, T. 1979. Die Suciu de Sus-Kultur in Nordwestrumänien. Praehistorische Zeitschrift 54 (1979), pp. 331.

BÁlinT, A. - PÁRDUCZ, M. 1933-34. Újabb őskori telep Ószentiván határában. - Neuere urzeitliche Siedlung am Rand von Ószentiván. Dolg 9-10 (1933-34) pp. 44-50.

BÁLINT, M. 1997. Ásotthalom régészeti topográfiája és településtörténete. Egyetemi szakdolgozat a JATE BTK Régészeti Tanszékén. Témavezető: Dr. Trogmayer Ottó, Kürti Béla. Szeged, 1997.

BANNER, J. 1956. Die Péceler Kultur. ArchHung 35. Bp., 1956.

BANNER, J. - KUTZIÁN, I. 1960. Angaben zur Kupferzeitlichen Chronologie des Karpatenbeckens. Swiatowit 25 (1960) pp. 341-361.

BANNER, J. - KUTZIÁN, I. 1961. Beiträge zur Chronologie der Kupferzeit des Karpatenbeckens. AAH 13 (1961) pp. 1-32.

BARTOSIEWICZ, L. 2006. Régenvolt háziállatok. Bevezetés a régészeti állattanba. - Domestic Animals in the past. An Introduction to Archaeozoology. Bibliotheca Archaeologica, Bp. 2006.

BATÓ, SZ. 2001. Kelebia régészeti topográfiája. Egyetemi szakdolgozat az SZTE BTK Régészeti Tanszékén. Konzulens: Lörinczy Gábor. Szeged, 2001.

BÁTORA, J.2003. Kupferne Schaftlochäxte in Mittel-, Ost- und Südosteuropa. (Zu Kulturkontakten und Datierung - Äneolithikum/Frühbronzezeit.) SlovArch 51/1. (2003) pp. 1-38.

BENKOVSKY-PIVOVAROVÁ, Z. 1976. Zur Enddatierung der Kulturkreises Mad'arovce-VĕtěrovBöheimkirchen. Germania 54 (1976) pp. 341-359.

BENKOVSKY-PIVOVAROVÁ, Z. - GÖMÖRI, J. - KAUS, K. 1988. Az álzsinegdíszes (Litzen-) kerámia kultúrájához tartozó sírleletek Nyugat-Magyarországon és Kelet-Ausztriában. - Finds from burials belonging to the Litzenkeramik Culture in western Hungary and eastern Austria. Arrabona 24 (1988) pp. 5-19.

K. BERZSÉNYI, B. - GYULAI, F. 1998. The Archaeobotanical Analysis of the Middle Bronze Age Settlement at Bölcske-Vörösgyir. 31st International Symposium of Archaeometry. Budapest, 27 April - 1 May 1998, Lectures, Abstracts, p.25.

BODROGI, T. 1997. Mesterségek, társadalmak születése. Budapest 1997.

BOGNÁR-KUTZIÁN, I. 1973. The relationship between the Bodrogkeresztúr and the Baden Cultures. In: Symposium über die Entstehung und Chronologie der Badener Kultur. (1973) Bratislava, 1973, pp. 31-50.

BÓNA, I. 1958. Chronologie der Hortfunde vom Koszider-Typus. AAH 9 (1958). pp. 211-243.

BÓNA, I. 1959. Bronzkori övkapcsok és diadémák. Adatok a középduna-medencei bronzkori viselethez. — Bronze Age girdle-clasps and diadems. Data to the costumes of the Bronze Age in the Middle Danube Basin. ArchÉrt 86 (1959), pp. 49-59.

BÓNA, I. 1963. The Cemeteries of the Nagyrév Culture. Alba Regia 2-3 (1963) pp. 11-23.

BÓNA, I. 1975. Mittlere Bronzezeit in Ungarn und ihre südöstlichen Beziehungen. Bp. 1975 
BÓNA, I. 1992. Bronzezeitliche Tell-kulturen in Ungarn. In: MEIER-ARENDT, W. (Hrsg): Bronzezeit in Ungarn. Forschungen in Tell-Siedlungen an Donau und Theiss. Frankfurt am Main, 1992. pp. 9-42.

BÓNA, I. 1993. A honfoglalás elötti kultúrák és népek. In: CSERVENYÁK, L. (szerk.): Szabolcs-SzatmárBereg megye monográfiája. I. köt., Nyíregyháza, 1993, pp. 63-137.

BÓNA, I. - NOVÁKI, GY. 1982. Alpár bronzkori és Árpád-kori vára - Alpár, eine bronzezeitliche und mittelalterliche Burg. Cumania 7. (1982) pp. 17-164.

BONDÁR, M. 1984. Neue Funde der Kostolac und Spätbadener Kultur in Ungarn. AAH 36. (1984) pp. 59-84.

BORSY Z. 1973. A magyarországi futóhomok területek lösz, homokos lösz és löszös homok takarója. Földrajzi Közlemények, 21. pp. 181-184.

BORSY, Z. 1978. Evolution of relief forms in Hungarian wind-blown sand areas. Acta Geographica, Geologica et Meteorologica Debrecina, 26. pp. 3-12

BORSY, Z. 1990. Evolution of the Aluvial Fans of the Alföld. pp. 229-246. In: RACHOCKI, A. H. - CHURCH, M. (eds.): Aluvial Fans: Field Approach. Wiley and Sons, New York.

BORSY, Z. 1991. Blown sand territories in Hungary. Zeitschrift für Geomorphologie. N.F. Supp. 1. pp. 1-14.

BOZSÓ, G. - PÁL-MOLNÁR, E. 2011. A szegedi Fehér-tó szikes üledékének környezet-geokémiai tulajdonságai. Geoszférák 2010. (2011) pp. 41-78.

BÖKÖNYI, S. 1974. History of Domestic Mammals in Central and Eastern Europe. Bp. 1974.

CHRISTALLER, W. 1933. Die zentralen Orte in Süddeutschland. Gustav Fischer, Jena, 1933.

CLARKE, D. L. (ed.) 1977. Spatial Archaeology. London, Academic Press, 1977.

CRONYN, J. M 1992. The elements of archeaological conservation. London, 1992.

CSÁNYI, M. 1980. Árokkal körülvett sírok a halomsíros kultúra jánoshidai temetöjében — Graves surrounded by ditches in the Jánoshida cemetery of the tumulus grave culture. ArchÉrt 107. (1980). pp. 153-165.

CSIPPÁN, P. 2010. Az archaeozoológia és a régészet kapcsolata. In: PETÖ, Á. - KREITER, A. (eds): Mikroszkóppal a régészet szolgálatában. A KÖSZ Alkalmazott Természettudományi Laboratóriumában végzett természet- és környezettudományos vizsgálatok bemutatása. KÖSZ, Bp, 2010. p. 30.

CSIPPÁN, P. - KOVÁCS, ZS. - TUGYA, B. 2010. Archaeozoológia. In: PETÖ, Á. - KREITER, A. (eds): Mikroszkóppal a régészet szolgálatában. A KÖSZ Alkalmazott Természettudományi Laboratóriumában végzett természet- és környezettudományos vizsgálatok bemutatása. KÖSZ, Bp, 2010. pp. 35-42.

CZAJLIK, Z. 1996. Ein spätbronzezeitliches Halbfertigprodukt: Der Gusskuchen. Eine Untersuchung anhand von Funden aus Westungarn. ArchA 80 (1996) pp. 165-180.

CZAJLIK, Z. - MOLNÁR, F. - SÓLYMOS, K. G. 1995. Angaben zu den spätbronzezeitlichen Metallrohmaterialversorgung am Velem-St. Veit Berg (Westungarn). Archäologie Österreichs 6 (1995) pp. 3035.

CZAJLIK, Z. - MOLNÁR, F. - SÓLYMOS, K. G. 1999. On the Origin of Late Bronze Age Semi-products Found at Celldömölk-Sághegy According to Electron-microprobe (EPMA) Studies. CommArchHung (1999) pp. $35-46$.

DANI, J. 2009. A Berettyó-völgy középsö bronzkori eröditett tell-településeinek társadalmi vonatkozásai. - The social aspects of the Middle Bronze Age tell-settlements of the Berettyó Valley. A Debreceni Déri Múzeum Évkönyve 2008-2009 (2009) pp. 17-21.

DEAN, W: E. 1974. Determination of the carbonate and organic matter in calcareous sediments and sedimentary rocks by loss on ignitions: comparison with order methods. Journal of Sedimentary Petrology, 44. (1974). pp. 242-248. 
DUŠEK, M. 1969. Bronzezeitliche Gräberfelder in der Südwestslowakei. Bratislava, 1969.

ECSEDY, I. 1978. Die Siedlung der Somogyvár-Vinkovci Kultur bei Szava und einige Fragen der Frühbronzezeit in Südpannonien. JPMÉ XXIII. (1978). pp. 97-136.

ECSEDY, I. 1982.: Ásatások Zók-Várhegyen (1977-82). Elözetes jelentés. JPMÉ 27 (1982) pp. 59-105.

ECSEDY, I. 1984. Öskori leletek Dunaszekcsö-Várhegyről. - Prehistoric finds from Dunaszekcsö-Várhegy. JPMÉ XXIX. (1984) pp. 89-125.

ECSEDY, I. 1995a. A bronzkor kezdete. In: MARÁZ, B. (szerk.): A bronzkor kincsei Magyarországon. Pécs, 1995, pp. 14-18.

ECSEDY, I. 1995b. Rézkori hagyományok és a bronzkori technika kezdetei. In: MARÁZ, B. (szerk.): A bronzkor kincsei Magyarországon. Pécs, 1995, pp. 31-37.

ECSEDY, I. 1999. Zók-Várhegy. Egy szőlőhegy évezredei. - Zók-Várhegy: Millenia ont he Hill of Vineyards. Zók, 1999.

EGRY, I. 1986. Domaszék régészeti topográfiája és településtörténete. Szakdolgozat a JATE BTK Régészeti tanszékén. Kézirat, 1986.

EGRY, I., 2002. Kora halomsíros nép települése Kóny-Barbacsi tóparton. - Die Siedlung eines Volkes mit frühen Hügelgäber-Kultur in Kóny am Ufer des Barbacser Teichs. Arrabona 40. (2002) pp. 9-32.

EIBNER-PERSY, A. - EIBNER, C. 1970. Erste Grossgrabung auf dem bronzezeitlichen Bergbaugelände von Mitterberg. Der Anschnitt 22/5 (1970) pp. 12-19.

ENDRŐDI, A. - GYULAI, F.1999. Soroksár-Várhegy. A Fortified Bronze Age Settlement in the Outskirts of Budapest. Plant Cultivation of Middle Bronze Age Fortified Settlements. CommArchHung 1999. pp. 6-34.

ENDRÖDI, A. - REMÉNYI, L. 2005. Kora bronzkori ház- és településrekonstrukció a Harangedény-Csepelcsoport Budapest (XI. kerület) - Albertfalva lelöhelyén. - Reconstruction of an Early Bronze Age house and a settlement at the Budapest Albertfalva site of the Bell Beaker-Csepel group. Ösrégészeti Levelek 7. (2005) pp. 128-134.

P. FISCHL, K. 1997. Középső bronzkori leletek Szelevényröl. Adatok a Tiszazug középső bronzkorának kronológiai és terminológiai kérdéseihez. - Mittelbronzezeitliche Funde aus Szelevény. Angaben zu den chronologischen und terminologischen Fragen der mittleren Bronzezeit in Tiszazug. MFMÉ-StudArch III. (1997) pp. 7-37.

P. FISCHL, K. 1998. Klárafalva-Hajdova bronzkori telltelepülése II. - Die bronzezeitliche Tell-Siedlung in Klárafalva-Hajdova II. MFMÉ-StudArch IV. (1998) pp. 81-175.

P. FISCHL, K. 1999. Mártély-Szekfü. A Perjámos-kultúra szerepe a Dél-Alföld vegyes rítusú temetőiben Mártély-Szekfü. Die Rolle der Perjámos-Kultur in der Gräberfelder mit gemischtem Ritus an der Süd-Tiefbene. Savaria 24/3 (1998-1999) (1999) pp. 215-237.

P. FISCHL, K. 2000. A Gerjen-csoport kritikai vizsgálata. Die kritische Untersuchung der Gerjen-Gruppe. A Komárom-Esztergom Megyei Múzeumok Közleményei 7. (2000) pp. 135-147.

P. FISCHL, K. 2003. A Perjámos-kultúra települései. - Die Siedlungen der Perjámos-Kultur. MFMÉ-StudArch IX. (2003) pp. 111-120.

P. FISCHL, K. - KISS, V. 2002. A Vattina-kultúra kutatása és északi kapcsolatainak kérdése. - Die Forschung der Vattina-Kultur und die Frage ihrer nrdlichen Verbindungen. MFMÉ-StudArch VIII. (2002) pp. 125-145.

P. FISCHL, K. - KISS, V. - KULCSÁR, G. 1999. Korai és középsö bronzkori település Baks-Homokbánya (Csongrád megye) lelöhelyen. - Früh- und mittelbronzezeitliche Siedlungem an dem Fundort BaksHomokbánya (Komitat Csongrád). MFMÉ-StudArch V. (1999) pp. 77-190. 
P. FISCHL, K. - KISS, V. - KULCSÁR, G. 2001. Beiträge zum Gebrauch der tragbaren Feuerherde (Pyraunoi) im Karpatenbecken II. (Spätbronzezeit-Früheisenzeit). In: KACSÓ, C. (hrsg.): Der nordkarpatische Raum in der Bronzezeit. Symposium Baia Mare, 7-10. Oktober 1998. Muzeul Județean Maramureş Bibliotheca Marmatia I. Baia Mare, 2001. pp. 125-156.

FOLTINY, I. 1944-45. Bronzkori leletek Felsőpusztaszerröl és Csengeléröl. ArchÉrt 71. (1944-45) pp. 43-51.

FOLTINY, I. 1957. A halomsiros és lausitzi kultúrák nyomai Szeged környékén - Spuren der Hügelgräber und der Lausitzer Kultur in der Umgebung von Szeged. RégFüz 4. 1957.

FORBES, R. J. 1964. Studies in Ancient Technology. Vol. IX. Leiden, 1964.

FÜZES, M. 1990. A földmüvelés korai szakaszának (neolitikum és rézkor) növényleletei Magyarországon (Archaeobotanikai vázlat). A Tapolcai Városi Múzeum Közleményei 1 (1990) pp. 139-238.

GAZDAPUSZTAI, GY. 1959. Der Gussformfund von Soltvadkert. AAH IX. (1959) pp. 265-288.

GEIGER, J. 2007. Geomatematika. JATEPress Kiadó, Szeged, 2007.

GIMESI, I. M. 1994. A Kárpát-övezet ásványainak magyar bibliográfiája (1859-1951). Szeged, 1994.

GREENE, K. 1990. Archaeology. An Introduction. The History, Principles and Methods of Modern Archaeology. B. T. Batsford Ltd London, 1990.

GYUCHA, A. 1996. Üllés határának régészeti topográfiája és településtörténete. Egyetemi szakdolgozat a JATE BTK Régészeti Tanszékén. Témavezető: Dr. Trogmayer Ottó. Szeged, 1996.

GYULAI, F. 1991. Klíma, vegetáció, növénytermesztés és táplálkozás hazánk területén a bronzkorban. Agrártörténeti Szemle 33 (1991) pp. 114-152.

GYULAI, F. 1993. Environmental and agriculture in bronze age Hungary. Archaeolingua, Bp, 1993.

GYULAI, F. 1996. Balatonmagyaród-Hídvégpuszta késő bronzkori település növényleletei és élelmiszermaradványai. - Plant findings and food remnants of the Late Bronze Age settlement at Balatonmagyaród-Hídvégpuszta. Zalai Múzeum 6 (1996) pp. 169-195.

GYULAI, F. 1999. The einkorn as living part of an ancient landscape. In: JEREM, E. - POROSZLAI, I. (eds.): Archaeology of Bronze and Iron Age. Proceedings of the International Archaeological Conference, Százhalombatta, 3-7 October, 1996, Archaeolingua, Bp, 488p. pp. 297-302.

GYULAI, F. 2001. Archaeobotanika. A kultúrnövények története a Kárpát-medencében a régészeti-növénytani vizsgálatok alapján. Jószöveg Mühely, Bp., 2001.

GYULAI, F. 2004. in Az árpa, edited by TOMCSÁNYI, A. - TURCSÁNYI, G. Akadémiai kiadó, Bp., 2004, pp. 53-79.

GYULAI, F. - TORMA, I. 1993. Az urnasiros kultúra góri településének növényleletei. Nyugat-Dunántúl bronzkora. Acta Musei Papensis 93/3 (1993) pp. 277-286.

HAJDÚ, ZS. 2001. Régészetünk három arculata. Rövid eszmefuttatás a régészet jelen állapotáról, aminek erösen jövőbeli vonatkozásai vannak. - Three Facets of Archaeology. In: DANI, J. - HAJDÚ, ZS. - NAGY, E.

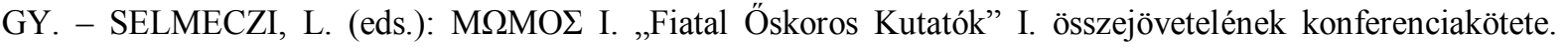
Debrecen, 1997. november 10-13. Debrecen, 2001. pp. 10-16.

HALSTEAD, P. - O'SHEA, J. 1982. A friend in need is a friend indeed: social storage and the origins of social ranking. In. RENFREW, C. - SHENNAN, S. (eds.): Ranking, resource and exchange. Aspects of the archaeology of early european society. Cambridge University Press, Cambridge, 1982. pp. 92-105.

HÄNSEL, B. 1999. Ein älterurnenfelderzeitliches Depot aus Pustacovec, Kot. Čakovec, Kroatien. APA 32 (1999) pp. 76-92.

HARDING, A. F. 2000. European Societies in the Bronze Age. Cambridge University Press, 2000. 
HARRIS, E. 1997: Principles of Archaeological Stratigraphy. Academic Press, 1997.

HORNE, L. 1982. Fuel for the metal worker. The role of charcoal and charcoal production in ancient metallurgy. Expedition 25/1 (1982) pp. 6-13.

HORVÁTH, F. 1981. Ada-type artifacts of the Early Bronze Age in the Southern Alföld. MFMÉ 1980-81/1, pp. 7-30.

HORVÁTH, L. A. 1994. Adatok Délnyugat-Dunántúl késöbronzkorának történetéhez - Angaben zur Geschickte zur Spätbronzezeit in SW-Transdanubien. Zalai Múzeum 5 (1994) pp. 219-235.

HORVÁTH, L. A. - SZILAS, G. - EDRŐDI, A. - HORVÁTH, M. A. 2001. Öskori telepek és sírok feltárása Dunakeszi határában (Dunakeszi-Székes-dülö) - Excavation of prehistoric settlements and graves in Dunakeszi. A BTM Aquincumi Múzeumának ásatásai és leletmentései 2000-ben. (2001) pp. 115-127.

HRABÁK, Z. 2010. Elömunkálatok Horgos régészeti topográfiájához - Bronzkor. Szakdolgozat az SZTE BTK Régészeti Tanszékén. Kézirat. Témavezető: Tóth Katalin, Sánta Gábor, Persaits Gergő. Szeged, 2010.

ILON, G. 1996. A késö halomsiros-kora urnamezös kultúra temetöje és tell-települése Németbánya határában. Acta Musei Papensis 6 (1996) pp. 89-208.

ILON, G. 2005. Houses of the Late Tumulus/Early Urnfield culture. Based on the excavations at Németbánya. A késö halomsiros-korai urnamezös kultúra házai - egy németbányai ház rekonstrukciója. Ösrégészeti Levelek 7. (2005) pp. 135-145.

JACOBSON, G. L. - BRADSHAW, R. H. W. 1981. The selection of sites for paleovegetational studies. Quat. Res. 16:80-96.

JACOMET, S. - KREUZ, A. 1999. Archäobotanik. Aufgaben, Methoden, und Ergebnisse vegetations- und agrargeschichtlicher Forschung. Verlag Eugen Ulmer, Stuttgart, 1999.

JANKOVICH, B. D. 1993. A felszini leletgyüjtés módszerei és szerepe a régészeti kutatásban. Régészeti Továbbképző Füzetek 1. MNM, Bp., 1993.

JUNGHANS, S. - SANGMEISTER, E. - SCHRÖDER, M. 1968. Kupfer und Bronze in der frühen Metallzeit Europas. Die Materialgruppen beim Stand von 12000 Analysen. Studien zu den Anfängen der Metallurgie 2. 13. Berlin, 1968.

KALICZ, N. 1960. A késöbronzkori felsöszöcsi csoport leletei és kronológiai helyzete. - Funde und chronologische Situation der Felsöszöcs-Gruppe der Spätbronzezeit. ArchÉrt 87 (1960). pp. 3-15.

KALICZ, N. - KOÓS, J. 1997. Oszlár-Nyárfaszög. Késö bronzkori telep a Kr.e. XIII. századból. — OszlárNyárfaszög. Late Bronze Age settlement from the $13^{\text {th }}$ century B.C. In: RACZKY, P. - KOVÁCS, T. ANDERS, A. (szerk.): Utak a múltba. Az M3-as autópálya régészeti leletmentései. - Paths into the past. Rescue excavations on the M3 motorway. Bp., 1997. pp. 66-71.

KALICZ-SCHREIBER, R. 1991. A Somogyvár-Vinkovci kultúra dél-északi irányú közvetítö szerepe a korabronzkorban. - Die Vermittungsrolle in Süd-Nord Richtung der Somogyvár-Vinkovci-kultur in der frühen Bronzezeit. BudRég XXVIII.(1991). pp. 9-43.

SZ. KÁLLAY, Á. 1980. A késö bronzkori halomsíros kultúra időszakának leletei Battonya határában - Die Funde der spätbronzezeitlichen Hügelgräberzeit in Battonya. ArchÉrt 110 (1983) pp. 42-60.

KEMENCZEI, T. 1984. Die Spätbronzezeit Nordostungarns. ArchHung 51, Bp, 1984.

KEMENCZEI, T. 1989. Bemerkungen zur Chronologie der Spätbronzezitlichen Grabfunde in Donau-Theiss Zwischengebiet. CommArchHung 1989, pp. 73-93.

KEMENCZEI, T, 1991. A pécskai/Pecica második bronzlelet. - Der zweite Depotfund der Pecica/Pécska. FolArch 42 (1991), pp. 27-48. 
KEVEINÉ BÁRÁNY, I. - GULYÁS, Á. 2001. Zákányszék természeti adottságai. In: Zákányszék földje és népe az ezredfordulón. Zákányszék, 2001. pp. 13-33.

KIENLIN, T. 2010. Traditions and Transformations: Approaches to Eneolithic (Copper Age) and Bronze Age Metalworking and Society in Eastern Central Europe and the Carpathian Basin. BAR International Series 2184 (2010). pp. 1-409.

KISS, V. 1997. A mészbetétes edények népe késöi fázisának sirlelete Veszprémböl - Die Grabfunde aus der spätphase der Kultur der inkrustierten Keramik von Veszprém. CommArchHung 1997, pp. 39-49.

KISS, V. 2000. A mészbetétes kerámia kultúrája kapcsolatai a Kárpát-medence nyugati területeivel és a középeurópai kultúrákkal a középsö bronzkorban. - Die Beziehungen der inkrustierten Keramik in den westlichen Gebieten des Karpatenbeckens und zur mutteleuropäischen Kultur in der mittleren Bronzezeit. A KomáromEsztergom Megyei Múzeumok Közleményei 7. (2000) pp. 15-55.

KISS, V. 2009. A fém nyersanyag-felhasználás kérdései a Dunántúl kora és középső bronzkorában. - Questions of the Use of Metal as Raw Material in the Early and Middle Bronze Age of Transdanubia. In: ILON, G. (szerk.): M $\Omega \mathrm{MO} \Sigma$ VI. Öskoros Kutatók VI. Összejövetelének konferenciakötete. Nyersanyagok és kereskedelem. Köszeg, 2009. március 19-21. Szombathely, 2009, pp. 197-212.

KISSNÉ CSEH, J. 1996. Tatabánya-Bánhida. RFüz Ser. 1. 47. pp. $28-29$.

KOCH, S. 1966. Magyarország ásványai. Bp. 1966.

KOVÁCS, T. 1965. A halomsiros kultúra leletei Bagon - Finds of the Tumulus Culture at Bag. FolArch 17 (1965) pp. 65-86.

KOVÁCS, T. 1966. A halomsíros kultúra leletei az Észak-Alföldön - Die Funde der Hügelgräberkultur. ArchÉrt 93 (1966) pp. 159-202.

KOVÁCS, T. 1975a. Historische und Chronologische Fragen des Überganges von der mittleren- zur spätbronzezeit in Ungarn. AAH 27 (1975). pp. 297-317.

KOVÁCS, T. 1975b. Tumulus culture cemeteries of Tiszafüred. RégFüz. Ser. II. No. 17. Budapest, 1975.

KOVÁCS, T. 1977. A bronzkor Magyarországon. Hereditas sorozat, Corvina, Bp. 1977

KOVÁCS, T. 1981. Zur Problematik der Entstehung der Hügelgräber in Ungarn. SlovArch 29/1 (1981) pp. 8796.

KOVÁCS, T. 1984. Die Vatya-Kultur. In: TASIĆ, N. (hrsg.): Kulturen der Frühbronzezeit des Karpatenbeckens und Nordbalkans. Beograd, 1984. pp. 235-256.

KOVÁCS, T. 1988. Die bronzezeitliche Siedlung von Süttő - Eine kurze Übersicht. SlovArch XXXVI-1.(1988) pp. 119-132.

KOVÁCS, T. 1991. Das bronzezeitliche Goldarmband von Dunavecse. - A dunavecsei arany kartekercs. FolArch XLII. (1991). pp. 7-25.

KOVÁCS, T. 1994. Chronologische Fragen des Überganges von der Mittel- zur Spätbronzezeit in Transdanubien. - A dunántúli középső és késő bronzkor átmeneti idöszakának kronológiai kérdései. Zalai Múzeum 5. (1994) pp. 159-172.

KOVÁCS, T. 1995. A középső bronzkor: a virágkor. In: MARÁZ, B. (szerk.): A bronzkor kincsei Magyarországon. Pécs, 1995, pp. 18-24.

KOVÁCS, T. 1996. The Tumulus Culture in the Middle Danube Region and the Carpathian Basin: Burials of the Warrior Élite. In: BELlARDELI, S. - PERONI, R. (eds.): The bronze age in Europe and in the Mediterranean. The colloquia of the international congress of prehistoric and protohistoric sciences. Forlí, 1996, pp. 113-126. 
KOVÁCS, T. 1997. Das Grab von Ménföcsanak. Internationale Archäologie 1997, pp. 297-301.

KOVÁCS, T. 2000. Neue Angaben und Beobachtungen zur Untersuchung der Gesellschaftsstruktur der Hügelgräberkultur im Karpatenbecken. AAH 51 (1999/2000) pp. 97-109

KÖLTŐ, L. 1996. Néhány nagy antimontartalmú bronzkori bronztárgy röntgenemissziós analizise. Pápai Múzeum Évkönyve 6 (1996) pp. 83-88.

KÖNIG, P. 2004. Spätbronzezeitliche Hortfunde aus Bosnien und der Herzegowina. PBF XX. 11. Stuttgart, 2004.

KÖRÖSI, A. 2005. The animal bones from the early bronze age site at Üllö. In: KÖVÁRI, K. - PATAY, R.: A settlement of the Makó culture at Üllö. New evidence for early bronze age metalworking. CommArchHung 2005. pp. 138-142.

KÖSZEGI, F. 1964. A halomsiros kultúra néhány magyarországi leletéröl. ArchÉrt 91. (1964) pp. 3-15.

KÖSZEGI, F. 1973. Adatok Zugló öskori településtörténetéhez. - Data to the history of prehistoric settlements in Zugló. BudRég 23. (1973) pp. 9-37.

KÖSZEGI, F. 1984. Mittelbronzezeitliche Grabfunde aus Budapest X. Bezirk, Jászberényi Strasse. CommArchHung 1984. pp. 31-40.

KÖSZEGI, F. 1988. A Dunántúl története a késöbronzkorban. - The history of Transdanubia during the Late Bronze Age. BTM Mühely I. Budapest 1988.

KRAUSE, R. 2003. Studien zur kupfer- und frühbronzezeitlichen Metallurgie zwischen Karpatenbecken und Ostsee. Rahden/Westf. 2003.

KREITER, A. 2006. Kerámiatechnológiai vizsgálatok a Halomsíros kultúra Esztergályhorvátialsóbárándpusztai településéröl: hagyomány és identitás. - Technological examination of the Tumulus Culture pottery from Esztergályhorváti-Alsóbárándpuszta: tradition and identity. Zalai Múzeum 15. (2006) pp. 149-170. KREITER, A. 2007. Kerámia technológiai tradíció és az idö koncepciója a bronzkorban. - Ceramic technological tradition and the concept of time in the Bronze Age. Ösrégészeti Levelek 8-9. (2007). pp. 146166.

KREITER, A. 2010. Kerámiavizsgálat. In: PETÖ, Á. - KREITER, A. (szerk.): Mikroszkóppal a régészet szolgálatában. A KÖSZ Alkalmazott Természettudományi Laboratóriumában végzett természet- és környezettudományos vizsgálatok bemutatása. KÖSZ, Bp, 2010. pp. 66-77.

KROLOPP, E. - SÜMEGI, P. - KUTI, L. - HERTELENDI, E. - KORDOS, L. 1995. Szeged-öthalom környéki löszképzödmények keletkezésének paleoökológiai rekonstrukciója. - Paleoecological reconstruction of formation of the Szeged-Öthalom area loess formations. Földtani Közlöny 125/3-4 (1995), pp. 309-361.

KROLOPP, E. - SZÓNOKY, M. 1982. Az Ös-Körös körösladányi rétegsorának paleoökológiai és ősföldrajzi vizsgálata. Alföldi Tanulmányok 6. (1982) pp. 7-23.

KROLOPP, E. - SZÓNOKY, M. 1989. Nagykunsági felszinközeli negyedidöszaki képzödmények üledéktani és paleoökológiai vizsgálata. Alföldi Tanulmányok 13. (1989) pp. 25-46.

KULCSÁR, G. 2000. Kora bronzkori leletek a Tisza jobb partján (Csongrád megye). - Frühbronzezeitliche Funde am rechten Ufer der Theiss (Komitat Csongrád). MFMÉ-StudArch VI. (2000). pp. 47-75.

KULCSÁR, G. 2009. The beginnings of the Bronze Age in the Carpathian Basin. The Makó-Kosihy-Čaka and the Somogyvár-Vinkovci cultures in Hungary. Archaeolingua, Bp. 2009.

KULCSÁR, G. - V. SZABÓ, G. 1997. Kronológia. In: HAVASSY, P. (szerk.): Látták Trója kapuit. Bronzkori leletek a Közép-Tisza vidékéről. Gyulai Katalógusok 3. Gyula, 1997. pp. 154-155. 
KÜRTI, B. 1971. Újabb adatok a Dél-Alföld kora bronzkorához. - Neuere Angaben zur Frühbronzezeit der Süd-Tiefbene. MFMÉ 1971-2. (1971). pp. 29-51.

KUSTÁR, R. - WICKER, E. 2004. Bronzkori halomsiros temetö Csólyospálos-Felsőpáloson. In: SZAKÁLL, A. (ed.): Emlékkönyv a Thorma János Múzeum 130. évfordulójára. [Halasi Múzeum 2.] Kiskunhalas 2004, pp. 63-86.

LIVERSAGE, D. 1994. Interpreting composition patterns in ancient bronze: the Carpathian Basin. Acta Archaeologica 65 (1994), pp. 57-134.

LÖRINCZY, G. - TROGMAYER, O. 1995. Birituális vatyai temetö Csanytelek-Palén - Birituales Gräberfeld der Vatya-Kultur in Csanytelek-Palé. MFMÉ-StudArch I. (1995) pp. 49-90.

LYELL, C. 1833. Principles of Geology. Vols 1-3. John Murray, London, 1830-33.

MARGÓCZI, K. - ARADI, E. 2008. Dorozsma-Majsai-homokhát. In: KIRÁLY, G. - MOLNÁR, ZS. BÖLÖNI, J. - VOJTKÓ, A. (szerk.) (2008): Magyarország földrajzi kistájainak növényzete. MTA Ökológiai és Botanikai Kutatóintézete, Vácrátót.

MAROSI, S. - SOMOGYI, S. 1990. Magyarország kistájainak katasztere. Bp., 1990.

MEDOVIĆ, P. 2007. Stubarlija. Nekropola naselja Feudvar. - Stubarlija. Das Gräberfeld der Siedlung Feudvar bei Mošorin (Bačka). Das Gräberfeld der Mittel- und Spätbronzezeit. Zusammenfassung. Muzej Vojvodine, Novi Sad, 2007.

MIHÁLTZ, I. 1953. Az Észak-Alföld keleti részének földtani térképezése. Földtani Intézet jelentése 1951-ről, pp. 61-68.

MISKE, K. 1908. Die prähistorische Ansiedlung Velem St. Vid. Wien, 1908.

MOLNÁR, B. 1960. Pliocén és pleisztocén lehordási területek az Alföldön. Földtani Közlöny, 89. pp. 403-413.

MOLNÁR, B. 1964. A magyarországi folyók homoküledékeinek nehézásvány-összetétel vizsgálata. Hidrológiai Közlöny, pp. 347-355.

MOLNÁR, B. 1967. A Dél-Alföld feltöltödésének ritmusai és vizföldtani jelentöségük. Hidrológiai Közlöny, pp. 537-552.

MOLNÁR, B. 1973. Az Alföld harmadidöszak-végi és negyedkori feltöltödési ciklusai. Földtani Közlöny, 103. 294-310.

MOLNÁR, B. 1977. A Duna-Tisza köz felsö-pliocén (levantei) és pleisztocén földtani fejlödéstörténete. Földtani Közlöny 107. 1. Budapest, pp. 1-16.

MOLNÁR, B. 1980. Hiperszalin dolomitképzödés a Duna-Tisza közén. Földtani Közlöny 110/1 (1980) pp. 4564.

MOLNÁR, B. 1990. A Nagyalföld DK-i része harmadidöszak végi és negyedidöszaki feltöltödésének modellezése, In: Az arzéntartalom származása és alakulásának kérdései a Békés megyei vízmü kútjaiban. - MTA Szegedi Akadémiai Bizottságának Kiadványai, Szeged, pp. 31-57.

MOLNÁR, B. 1991. Modern Lacustrine Calcite, Dolomite and Magnesite Formation in Hungary. - Publication of the Department of Quaternary Geology University of Turku, 70. Turun Yliopisto, 1991. pp. 1-22.

MOZSOLICS, A. 1957. Archaeologische Beiträge zur Geschichte der grossen Wanderung. AAH 8 (1957) pp. $119-156$.

MOZSOLICS, A. (1967): Bronzefunde des Karpatenbeckens. Depotfundhorizonte von Hajdúsámson und Kosziderpadlás. Budapest, 1967.

MOZSOLICS, A. 1973. Bronze- und Goldfunde des Karpatenbeckens. Depotfundhorizonte von Forró und Ópályi. Budapest 1973. 
MOZSOLICS, A. 1985. Bronzefunde aus Ungarn. Depotfundhorizonte von Aranyos, Kurd und Gyermely. Budapest, 1985.

MOZSOLICS, A. 2000. Bronzefunde aus Ungarn. Depotfundhorizonte Hajdúböszörmény, Románd und Bükkszentlászló. PAS 17. München, 2000.

MUCSI, M. 1963. Finomrétegtani vizsgálatok a kiskunsági édesvizi karbonát-képzödményeken. Földtani Közlöny, 93. pp. 373 - 386.

NESSEL, B. 2009. Funktionelle Aspekte der bronzenen Sägeblätter in der späten Bronze- und Urnenfelderzeit im Karpatenbecken. In: DIETRICH, L. - DIETRICH, O. - HEEB, B. - SZENTMIKLÓSI, A. (hrsg.): Aes Aeterna. Festschrift für Tudor Soroceanu zum 65. Geburstag. Analele Banatului. Serie nouă. Archeologie istorie. XVII. (2009) Timişoara, 2009, pp. 239-259.

NOVÁKI, GY. 1952. Fejér megye öskori földvárai. ArchÉrt 79. (1952). pp. 3-19.

NOVÁKI, GY. 1969. Agrártörténeti adatok az 1966-67. évi magyar régészeti irodalomból. Agrártörténeti Szemle 11 (1969) pp. 219-234.

NYÁRI, D. - KISS, T. 2005. Homokmozgások vizsgálata a Duna-Tisza közén. - Investigations on sand movement in the Danube-Tisza Interfluve. Földrajzi Közlemények CXXIX. (LIV.) kötet, 3-4. szám (2005) pp. $133-147$.

PALUCH, T. 2005. Domaszék-Börcsök tanya. RKM 2005. p. 226.

F. PETRES, É. - BÁNDI, G. 1969. Ásatás Lovasberény-Mihályváron. - Excavations at LovasberényMihályvár. ArchÉrt 96 (1969) pp. 170-177.

PETRESCU-DÎMBOVIȚA, M. 1978. Die Sicheln in Rumänien. PBF XVIII. 1. München, 1978.

PICKIN, J. - TIMBERLAKE, S. 1988. Stone hammers and fire setting: a preliminary experiment at Cwmystwyth mine, Dyfed. Bull. Peak District Mines Historical Soc. 10/3 (1988) pp. 165-167.

PITTIONI, R. 1951. Prehistoric copper-mining in Austria: problems and facts. University of London Institute of Archaeology 7th Annual Report (1951) pp. 16-43.

PITTIONI, R. 1957. Urzeitliche Bergbau auf Kupfererz und Spurenanalyse. ArchA 1 (1957)

PLINIUS, C. S. (2001): Naturalis Historia. - Természetrajz. (XXXII-XXXVII.) Az ásványokról és a müvészetekröl. Enciklopédia Kiadó, Bp., 2001.

POMÁZI, P. 2010. A Fajsz-garadombi (Dél-Magyarország) neolit és bronzkori lelöhely archaeobotanikai vizsgálata. Szakdolgozat az SZTE BTK Régészeti Tanszékén. Témavezetők: Dr. Kulcsár Valéria, Prof. Dr. Angela Kreuz, Dr. Eva Schäfer. Szeged, 2010.

POROSZLAI, I. 1992. Nagykőrös-Földvár. In: RACZKY, P. (szerk.): Dombokká vált évszázadok. Bronzkori tell-kultúrák a Kárpát-medence szívében. Bp. - Szolnok, 1992. p. 59.

POROSZLAI, I. 1993. 4000 év a 100 halom városában: fejezetek Százhalombatta történetéböl. Százhalombatta, 1993.

PRIMAS, M. 2002. Early tin bronze in central and southern Europe. In: BARTELHEIM, M. - PERNICKA, E. - KRAUSE, R. (hrsg.): Die Anfänge der Metallurgie in der alten Welt. - The beginnings of metallurgy int he old world. Rahden/Westf. 2002. pp. 303-314.

RACZKY, P. - ANDERS, A. - SEBÖK, K. 2005. Újkőkori ház kísérleti rekonstrukciója Polgár-Csöszhalom településéröl. - Experimental recostruction of a Neolithic house at the Polgár-Csöszhalom settlement. Ösrégészeti Levelek 7. (2005) pp. 24-49.

REIZNER, J. 1890. A szeged-városi múzeumról. ArchÉrt 1890, pp. 435-439.

REIZNER, J. 1891. A szegedvidéki leletekröl. ArchÉrt 1891, pp. 355-358. 
REMÉNYI, L. 2003. Megjegyzések a Kárpát-medence középső bronzkori „virágkorának” kérdéséhez. Ösrégészeti Levelek 5. (2003) pp. 51-64.

RENFREW, C. 2001. A civilizáció elött. - Before Civilisation. Osiris, Bp. 2001.

RENFREW, C. - PAUL, B. 1999. Régészet. - Elmélet, módszer, gyakorlat. Osiris, 1999.

RICHNOVSKY, A.- PINTÉR, L.: A vízicsigák és kagylók (Mollusca) kishatározója. Vízügyi Hidrobiológia 6. VIZDOK, Bp. 1979, 1-206.).

ŘíHOVSKÝ, J. 1963. K poznání starsi fáze kultúry stredodunajkych popelnichovych poli-velatické kultury. Sborník Ceskoslovenské Spolecnosti Arch., Brno, 1963, pp. 61-115.

̌̌ÍHOVSKÝ, J. 1982. Základy stredodunajkych popelnicovych polí na Morave. Brno 1982.

ROBERTSON, E. C. - SEIBERT, J. D. - FERNANDEZ, D. C. - ZENDER, M. U. (eds.) 2006. Space and Spatial Analysis in Archaeology. University of Calgary Press, 2006.

RÓKA, A. 2010. Késő bronzkori teleprészlet Kiskundorozsma-Subasán. Szakdolgozat az SZTE BTK Régészeti Tanszékén. Témavezető: Dr. Kulcsár Valéria. Konzulens: Sánta Gábor. Szeged, 2010.

RÓNAI A. 1972. Negyedkori üledékképzödés és éghajlattörténet az Alföld medencéjében. MÁFI Évkönyve, 61. Müszaki Könyvkiadó, Budapest.

RÓNAI A. 1977. Negyedidőszaki kéregmozgások a Magyar medencében. Földtani Közlöny, 107. pp. 431-436.

RÓNAI, A. 1981. A földtani ismeretek fejlödése az Alföld medencéjéröl. Alföldi Tanulmányok V. (1981) pp. 735

RÓNAI, A. 1985. Az Alföld földtana. Acta Geologica Hungarica, 21. pp. 1-445.

ROPER, D. C. 1979. The Method and Theory of Site Catchment Analysis: A Review In: Advances in Archaeological Method and Theory Vol. 2, (1979), pp. 119-140.

ROSKA, M. 1942. Erdély régészeti repertóriuma I. Öskor. - Thesaurus Antiquitatum Transsilvanicarum Tom. I. Praehistorica. Kolozsvár, 1942.

SAHLINS, M. D. 1973. Törzsek. - Tribesmen. In: SERVICE, E. R. - SAHLINS, M. D. - WOLF, E. R. 1973: Vadászok, törzsek, parasztok. - The Hunters, Tribesmen, Peasants. Kossuth, Bp., 1973.

SÁNTA, G. 2004a. Sánta G.: A halomsiros kultúra leletei Zákányszék határában. - Die Funde der Hügelgräberkultur in der Gemarkung von Zákányszék. MFMÉ-StudArch X. (2004) pp. 53-80.

SÁNTA, G. 2004b. Bronzkori sír Zákányszék határában - Adatok a halomsíros kultúra fémmüvességéhez. Ösrégészeti Levelek 6. (2004) pp. 40-47.

SÁNTA, G. 2004c. Zákányszék nyugati határának régészeti topográfiája és településtörténete. Öskor és szarmata kor. Egyetemi szakdolgozat az SZTE BTK Régészeti tanszékén. Témavezető: Dr. Horváth Ferenc. Szeged, 2004.

SÁNTA, G. 2009. A halomsiros kultúra Domaszék-Börcsök-tanyai településének legkorábbi szakasza és a telep szerkezete. - Die Früheste Phase und die Struktur der Siedlung der Hügelgräber-Kultur in Domaszék-Börcsök Gehöft. Tisicum XIX. (2009) pp. 255-280.

SÁNTA, G. 2010. Settlements of the Tumulus Culture in Hungary. Antaeus 31-32 (2010) pp. 513-528.

SÁNTA, G. - CSEKÖ, A. - CSÉKI, A. 2004. A halomsíros kultúra leletei Kunfehértón. In: SZAKÁLL, A. (szerk.): Emlékkönyv a Thorma János Múzeum 130. évfordulójára. [Halasi Múzeum 2.] Kiskunhalas 2004, pp. 41-58.

SÁNTA, G. - UZONYI, I. - CSERHÁTI, CS. - DARÓCZI, L. (2007): A halomsiros kultúra néhány dél-alföldi bronztárgyának analitikai vizsgálata. Archeometriai Mủhely 2007/3. pp. 19-31. 
SCHALK, E. 1998. Die Entwicklung der prähistorischen Metallurgie im nördlichen Karpatenbecken. Eine typologische und metallanalytische Untersuchung. Internationale Archäologie - Naturwissenschaft und Technologie Band 1. Rahden/Westf. 1998.

SCHAUER, P., 1996. Hausgrundrisse und Siedelstrukturen der frühen und mittleren Bronzezeit Süddeutschlands. In: CHOCHOROWSKI, J. (hrsg.): Probleme der Bronze- und der frühen Eisenzeit in Mitteleuropa. Kraków. 1996. pp. 451-480.

SCHREIBER, R. 1967. A rákospalotai edénylelet. - The Rákospalota pottery find. ArchÉrt 94. (1967) pp. 4852.

SCHUBERT, F. - SCHUBERT, E. 1967. Spektralanalytische Untersuchungen von Hort- und Einzelfunden der Periode BIII. In: MOZSOLICS, A. (1967): Bronzefunde des Karpatenbeckens. Depotfundhorizonte von Hajdúsámson und Kosziderpadlás. Akadémiai, Bp., 1967.

SÍKHEGYI, F. - GYALOG, L 2005. Magyarország földtani térképei. Szeged. Bp., MÁFI, 2005.

STÖLLNER, T. - CIERNY, J. - EIBNER, J. - BOENKE, N. - HERD, R. - MAASS, A. - RÖTTGER, K. SORMAZ, T. - STEFFENS, G. - THOMAS, P. 2006. Der bronzezeitliche Bergbau in Südrevier des Mittelberggebietes. Bericht zu den Forschungen der Jahre 2002 bis 2006. Achaeologica Austriaca 90 (2006) pp. 87-137.

SÜMEGHY, J. 1944. A Tiszántúl I-II. Bp., 208p+63 t.1944.

SÜMEGI, P. 2001a. A környezetrégészet problémái Magyarországon. - The Problems of Environmental Archaeology in Hungary. In: DANI, J. - HAJDÚ, ZS. - NAGY, E. GY. - SELMECZI, L. (szerk.): M $\Omega$ MO I. „Fiatal Őskoros Kutatók” I. összejövetelének konferenciakötete. Debrecen, 1997. november 10-13. Debrecen, 2001. pp. 17-51.

SÜMEGI, P. 2001b. Negyedidöszak földtana. JATEPress, Szeged, 2001.

SÜMEGI, P. 2001c. A Kiskunság a középkorban - geológus szemmel. In: HORVÁTH, F. (2001) A csengelei kunok ura és népe. Archaeolingua, Bp. 2001.

SÜMEGI, P. 2003. Régészeti geológia és történeti ökológia alapjai. JATEPress, Szeged, 2003.

SÜMEGI, P. 2009. Ember és környezet kapcsolata a középsö bronzkorban: az öskori gazdasági tér fejlödése egy bronzkori tell geoarcheológiai és környezettörténeti feldolgozása nyomán. - Human communities and their environment during middle bronze age: a model of the evolution of the prehistoric economic space based ont he geoarchaeological and environmental historical analyses of a bronze age tell. Tisicum XIX. (2009) pp. 457480.

SÜMEGI, P. - BODOR, E. 2000. Sedimentological, pollen and geoarcheological analysis of core sequence at Tököl. In: POROSZLAI, I. - VICZE, M. (eds.): Százhalombatta Archeological Expedition. Archaeolingua, Bp., 2000. pp. 83-96.

SÜMEGI, P. - BODOR, E. 2005. Geoarcheological and archaeobotanical investigations in the valley of the Benta (Békás) creek. In: POROSZLAI, I. - VICZE, M. (eds.) SAX Reports 2 - Field Season 2000-2003. Matrica Múzeum Kiadványa, Százhalombatta. 2005. pp. 209-236.

SÜMEGI P. - JUHÁSZ I. - HUNYADFALVI Z. - MOLNÁR S. - HERBICH K. 2003. SzegedKiskundorozsma régészeti lelöhelyek geoarcheológiai vizsgálata. In: SZALONTAY, CS. (szerk.): Úton útfélen. A Móra Ferenc Múzeum Kiadványa, Szeged, pp. 169-184.

SÜMEGI, P. - KROLOPP, E. 2002. Quartermalacological analyses for modeling of the Upper Weichselian palaeoenvironmental changes in the Carpathian Basin. Quaternary International 91, pp. 53-63. 
SÜMEGI, P. - LÓKI, J. 1987/1988. A lakiteleki téglagyári feltárás finomrétegtani elemzése. Acta Geographica, Geologica et Meteorologica Debrecina 14-15. pp. 157-167.

SZABÓ, G. 1999. Adatok a velemi késö bronzkori ónbronzok archaeometallurgiai vizsgálataihoz. - Beiträge zu den Archäometallurgischen Untersuchungen der spätbronzezeitlichen Zinnbronzen von Velem. Savaria 24/3 (1998-1999) (1999) pp. 329-357.

SZABÓ, G. 2004. Ásatási megfigyelések és kisérleti régészeti adatok a hamvasztásos temetkezésekhez. Beobachtungen auf Ausgrabungen und experimentalarchäologische Daten zu den Brandbestattungen. In: ILON, G. (szerk.): M $\Omega \mathrm{MO}$ III. Öskoros kutatók III. Összejövetelének konferenciakötete. Halottkultusz és temetkezés. Szombathely-Bozsok, 2002. október 7-9. (2004) pp. 441-458.

V. SZABÓ, G. 1999. A bronzkor Csongrád megyében. In: Csongrádi Múzeumi Füzetek 2. (1999) pp. 51-77.

V. SZABÓ, G. 2004a. Ház, település és településszerkezet a késö bronzkori (BD, HA, HB periódus) Tiszavidéken. - Houses, Settlements and Settlement Structures in the Tisza Region of the Late Bronze Age (Periods $B D, H A, H B$ ). In: NAGY, E. GY. - DANI, J. - HAJDÚ, ZS. (szerk.): M $\Omega \mathrm{MO} \Sigma$ II. Őskoros Kutatók II. Összejövetelének konferenciakötete. Debrecen, 2000. november 6-8. Debrecen, 2004. pp. 137-170.

V. SZABÓ, G. 2004b. A tiszacsegei edénydepó. Újabb adatok a Tisza-vidéki késő bronzkori edénydeponálás szokásához. - Der Gefässdepot von Tiszacsege. Neue Angaben zur Sitte der spätbornzezeitlichen Gefässdeponierung in der Theissgegend. MFMÉ-StudArch X. (2004). pp. 81-113.

V. SZABÓ, G. 2006. Baks, Temetöpart. RKM 2006. p. 152.

V. SZABÓ, G. 2007. Baks, Temetôpart. RKM 2007. pp. 163-164.

V. SZABÓ, G. 2008. Baks, Temetőpart. RKM 2008. p. 143.

SZAKÁLL, S. (ed.) 2002. Minerals of the Carpathians. GRANIT Publ. House. Prague, 2002.

SZAKÁLL, S. - GATTER, I. - SZENDREI, G. 2005. A magyarországi ásványfajok. Kőország, Bp., 2005.

SZATHMÁRY, I. 2005. Folyókból elökerült kardleletek a Magyar Nemzeti Múzeum gyüjteményében. Bronzezeitliche Schwertfunde aus Flüssen in der Sammlung des Ungarisches Nationalmuseums. CommArchHung 2005. pp. 143-166.

SZENTPÉTERI, J. 2006. Solt, Tételhegy. RKM 2006. pp. 275-276.

SZENTPÉTERI, J. - ROSTA, SZ. 2005. Solt, Tételhegy. RKM 2005, pp. 306-308.

G. SZÉNÁSZKY, J. 1977. A vatyai kultúra leletei Csongrád környékén. - Die Funde der Vatya-kultur in der Umgebung von Csongrád. ArchÉrt 104 (1977) pp. 18-46.

TOČÍK, A. 1978. Nitriansky Hrádok-Zámeček - bronzezeitliche befestigte Ansiedlung der Mad'arovce-kultur. Materialia Archaeologica Slovaca. Nitra, 1978

TOČIK, A. - ŽEBRÁK, P. 2003. Ausgrabungen in Špania Dolina-Piesky. Zum Problem des urzeitlichen Kupfererzbergbaus in der Slowakei. In: STÖLLNER, T. - KÖRLIN, G. - STEFFLENS, G. - CIERNY, J. (eds.): Man and Mining - Mensch und Bergbau. Studies in honour of Gerd Weisgerber on occasion of his 65th birthday. Bochum, 2003. pp. 71-78.

TORBRÜGGE, W. 1959. Die Bronzezeit in der Oberpfalz. H. n., 1959.

TÓTH, A. 2011. Bronzkori állatcsontleletek Domaszék-Börcsök tanyán. Lektorált kézirat (lektor: Dr. Vörös István). A szerző engedélyével, 2011.

TÓTH, K. 2003. A kora bronzkor kutatásának helyzete Magyarországon - Die Lage der Frühbronzezeitforschung in Ungarn. NyJAMÉ XLV. pp. 65-111. 
TÓTH, K. 2004. A Makó-Kosihy-Čaka kultúra településeiröl. - On the settlements of the Makó-Kosihy-Čaka Culture. In: NAGY, E. GY. - DANI, J. - HAJDÚ, ZS. (szerk.): M $\Omega M O \Sigma$ II. Öskoros Kutatók II. Összejövetelének konferenciakötete. Debrecen, 2000. november 6-8. Debrecen, 2004. pp. 79-92.

TÖMÖRKÉNY, I. 1902. Leletek a szegedi határban. ArchÉrt ú.f. XXII (1902) pp. 372-376.

TÖMÖRKÉNY, I. 1903. A bilisitsi ásatásokról (Szeged-Alsótanya). ArchÉrt ú.f. XXIII (1903) pp. 50-54.

TRAMPUŽ-OREL, N. - HEATH, D. J. - HUDNIK, V. 1996. Spektrometrične raziskave depojskih najdb pozne bronzaste dobe. - Spektrometric Research of the Late Bronze Age Hoard Finds. In: TERŽAN, B. (ed.): Depojske in posamezne kovinske najdbe bakrene in bronaste doba na Slovenskem. - Hoards and individual metal finds from the Eneolithic and Bronze Ages in Slovenia. Katalogi i monografije 29. Narodni Muzej, Ljubljana, 1996. pp. 165-242.

TROELS-SMITH, J. 1955. Karakterisering af lose jordater. Danmarks geologiske Undersogelse. IV. 3. (10).

TROGMAYER, O. 1963. Beiträge zur Spätbronzezeit des südlichen Teils der ungarischen Tiefebene. AAH XV. (1963) pp. 85-122.

TROGMAYER, O. 1975. Die bronzezeitlichen Gräberfeld bei Tápé. FontesArchHung 1975.

TROGMAYER, O. 1985. A szegedi nagytáj bronz- és koravaskorának néhány kérdéséröl - Über einige Probleme der Bronze- und Früheisenzeit des Szegeder Grossraumes. Acta Ant. Et Arch. Suppl. V. (1985) pp. 316.

VICZE, M. 2011. Bronze Age cemetery at Dunaújváros-Duna-düló. Dissertationes Pannonicae, Ser. IV. Vol. 1. ELTE Institute of Archaeological Sciences, Bp., 2011.

VÖRÖS, G. 1979. Domaszék-Tanya. RégFüz Ser.I. No. 32.

VÖRÖS, I. 1998. Történeti állattani tudnivalók. Panniculus Ser. B. No. 6. (1998) pp. 251-264.

VÖRÖS, I. 1998-1999. Szombathely-Kámon késö bronzkori település állatcsontleletei. - Die Tierknochenfunde der Spätbronzezeitlichen Siedlung Szombathely-Kámon. Savaria 24/3 (1998-1999) (1999) pp. 291-295.

V. VADÁSZ, É. 2001. Az észak-dunántúli mészbetétes kerámia esztergomi alcsoportjának települése Dunaalmás-Foktorokban. - Die Siedlung der Esztergomer Untergruppe der inkrustierten Keramik von Nordtransdanubien in Dunaalmás-Foktorok. Komárom-Esztergom Megyei Önkormányzat Múzeumainak Közleményei 8 (2001) pp. 7-81.

WARREN, P. 1989. Az égei civilizációk. A Múlt születése. Bp., 1989.

VÉNINGER, P. 2011. Különböző soványitó anyagok mennyiségének hatása a kerámiakészitésre. Megjelenés alatt az Archaeometriai Mühely c. elektronikus folyóirat 2011-es legújabb számában. A szerző engedélyével.

WILLIS, K. J. - SÜMEGI, P. - BRAUN, M. - BENNETT, K. D. - TÓTH, A. 1998. Prehistoric land degradation in Hungary: who, how and why? Antiquity 72, pp. 101-113.

WILLVONSEDER, K. 1937. Die mittlere bronzezeit in Österreich. Bücher zur Ur- und Frühgeschichte 3. Wien 1937.

ZALOTAY, E. 1932. Csongrád vármegye öskori települése. Dolgozatok VIII. (1932) pp. 49-102.

ZSCHOCKE, K. - PREUSCHEN, E. 1932. Das Urzeitliche Bergbaugebietvon Mühlbach-Bischhofshofen. Materialen zur Urgeschichte Österreichs 6 (1932) Wienna

ŽEBRÁK, P. 1990. The traces of the primary mining of non-ferrous metals in Slovakia. In: JOVANOVIĆ, B. (ed.): Ancient Mining and Metallurgy in Southeast Europe. Arch. Inst. Beograd Monographs No. 27. Bor, 1990. pp. 13-21. 


\section{Rövidítések jegyzéke}

Acta Ant. Et Arch. = Acta Antiqua Et Archaeologica (Szeged)

$\mathrm{AAH}=$ Acta Archaeologica Hungarica (Budapest)

$\operatorname{Arch} \mathrm{A}=$ Archaeologica Austriaca (Bécs)

ArchÉrt = Archaeologiai Értesítő (Budapest)

ArchHung $=$ Archaeologica Hungarica sorozat (Budapest)

BudRég $=$ Budapest Régiségei (Budapest)

BTM = Budapesti Történeti Múzeum (Budapest)

CommArchHung $=$ Communicationes Archaeologiae Hungariae (Budapest)

Dolg. $=$ Dolgozatok $($ Szeged $)$

ELTE $=$ Eötvös Loránd Tudományegyetem

FolArch = Folia Archaeologica (Budapest)

FontesArchHung $=$ Fontes Archaeologici Hungariae (Budapest)

JATE $=$ József Attila Tudományegyetem

JPMÉ = A Janus Pannonius Múzeum Évkönyve (Pécs)

KÖSZ = Kulturális Örökségvédelmi Szakszolgálat (Magyarország)

MÁFI = Magyar Állami Földtani Intézet

MFMÉ = A Móra Ferenc Múzeum Évkönyve (Szeged)

MFMÉ-StudArch = A Móra Ferenc Múzeum Évkönyve - Studia Archaeologica (Szeged)

MNM = Magyar Nemzeti Múzeum (Budapest)

NyJAMÉ = A Nyíregyházi Józsa András Múzeum Évkönyve (Nyíregyháza)

$\mathrm{PBF}=$ Prähistorische Bronzefunde sorozat (Berlin)

RégFüz $=$ Régészeti Füzetek (Budapest)

RKM = Régészeti Kutatások Magyarországon (Budapest)

SlovArch = Slovenská Archeológia (Nyitra)

SZTE $=$ Szegedi Tudományegyetem

ú. f. = Új folyam (ArchÉrt-nél)

\section{Összefoglalás}

Munkám eredményeképp a dolgozatban egy bronzkori lelöhely teljes körü környezetrégészeti elemzése született meg. A lokálistól a regionális felé haladó vizsgálatsorozatban előbb a lelőhely szükebb térségének régészeti és környezeti adatait vetettem össze, majd időben és térben kibővítettem a vizsgálatot a középső bronzkortól a Hallstatt A-ig, a Dél-Alföldtől Budapest környékéig. A végső összevetésben a Kárpátmedence egészét, sőt a közép-Duna-vidéket érintő következtetéseket is levontam, amikor a fém nyersanyag beszerzési kérdéseit vagy a Halomsíros „,vándorláselméletet” vizsgáltam. Summázva az észrevételeim, a telep inkább sugallja a bronzkor helyi eredetű belső fejlődését, melyet egy közép-Duna-vidéki centrumból kiinduló, az élénk (fém-) kereskedelmi rendszeren - gyakorlatilag egy bronzkori „unión” - keresztül érkező kulturális impulzusok befolyásoltak. A megváltozott éghajlat lehetett a legfontosabb „lökés” a középső és késő 
bronzkor határán lezajlott kultúraváltozásban, de maga a változás a középső bronzkorban kialakult kereskedelmi rendszer hatására és azon belül ment végbe. Ez magyarázhatja a keletKárpát-medence középső bronzkori csoportjainak kultúraváltozást alig mutató, lényegi továbbfejlődését a késő bronzkori létbe. A jelzett kultúrák (Gyulavarsánd, Wietenberg, stb.) nem vagy csak alkalomszerüen voltak részesei ennek a közép-európai „integrációnak”, kapcsolatrendszerük döntően Dél, a mükénéi államok és más mediterrán kultúrák felé irányult.

\section{Summary}

The goal of my work and $\mathrm{PhD}$ Thesis was a complex, archaeological, environmental archaeological, archaeometrical investigation of a selected Bronze Age site (DomaszékBörcsök tanya) connected to the Late Bronze Age Tumulus Culture.

My research was aimed at getting new data to the problem of cultural change that occured in the transition from Middle to Late Bronze Age. Furthermore, if it is possible, reconstruct the causes and the procession of this change, by a complete archaeological, geoarchaeological and archaeometrical analysis of a concrete settlement. My methods included geo-archaeological, archaeological and natural historical ones: organic matter/carbonate content measurement in sediments, wet geochemical analysis, tipology, analogic methods, seriation, local and regional settlement pattern investigation, XRF, PIXE, microPIXE, microscopy (stereobinocular and electronmicroscopy), etc. Anikó Tóth analysed the archaeozoological and Ferenc Gyulai the archaeobotanical material so I used their data in its context with similar finds. To lighten the problem I owerviewed some unpublished Tumulus Culture material of the narrow area, and investigated some questions and problems of the Middle and Late Bronze Age of the wider area (Vatya, Perjámos and Hatvan Cultures).

The site is located in the eastern edge of Dorozsma-Majsai Homokhátság (next to the Tisza Valley). Its soil is sandy and weak. The soil has a bad water-bearing ability, the weather are prone to drought. Breaking up of this soil caused wind-blown sand, and tended to drop erosion the sandhills. There is no evidence of human activity before Middle Copper Age in the pollen sequence of Kiskundorozsma-Putri-rét core drill, so there was no settlements here in the Neolithic and Early Copper Age on the sandhills.

I reconstructed the human environmental conversion from the Neolithic to the early Iron Age in the southeastern region of Dorozsma-Majsai Homokhát. From the late Copper Age human societies became the most important shapers of the landscape. There are evidences of cyclic deforestation and cereal pollen was detected. In the Koszider Phase (the latest period of Middle Bronze Age) a short (100-150 years) but strong cereal pollen maximum built up, which can be connected to the Vatya Culture. However, there aren't any known Vatya settlements in the neighbourhood of the site. The nearest is about $30 \mathrm{~km}$ towards north-northwest.

At the end of the Koszider Period the first Tumulus societies appeared, and settled at Domaszék-Börcsök tanya. This pollen zone has the highest concentration of plantain (Plantago) in the core drill. There is another Late Bronze Age settlement in the area at the 
site Szeged-Kiskundorozsma Subasa (excavated on the rescue excavations of M5 motorway). This settlement is considerably younger (BD-Ha A, Pre-Gáva) than our investigated settlement at Domaszék-Börcsök tanya. Based on the finds, there is no connection (in time or people) between the two settlements. This Pre-Gáva society used the investigated area as pasturelands, but the presence of cereal pollens indicate the closeness of the settlement. During the later phases of the Late Bronze Age (from 1100 BC, Ha B) and in the Early Iron Age, quantity of cereal pollen dropped to zero, while that of heliophil weeds stayed high. This is attributable to the presence of pasturelands, a wide net of roads, but no arables here.

I could estimate the age of the settlement more precisely than the cemeteries. Based on the analogies of the finds, especially from Szeged-Bogárzó and Dunaújváros-Duna-dülö, I could determine the lifetime of the settlement Domaszék-Börcsök tanya from the Reinecke BB1 period (the late Koszider phase), to the Reinecke BC period (maybe its earlier phase). The settlement was not inhabited at the end of the use of the Tápé-Széntéglaégető cemetery.

Dating the earliest phase is based on some imports of Vattina and Perjámos Cultures and some considerably well dated pottery sherds (knot-legged jar and bowl patterned with proded triangles, known types of Koszider period and Magyarád Culture) from features 1. and 425.

I consider the inhabitants of the settlement as the successors of the Vatya Culture. There is an early Tumulus phase of this, which is correlated the Late Vatya, and after it, the settlement developed continuously, but, with a lot of Vatya characteristics. May this society be a community of Vatya-Alpár group in the procession of cultural changing?

I made a model to explain the changes of the transition from the Middle to the Late Bronze Age. First works ascribed the appearance of Tumulus culture in the Hungarian Plain to a wandering from the Middle Danube Region (Bóna, 1958, 1992, Mozsolics, 1957, Kovács, 1975, Csányi, 1980, Trogmayer, 1975, etc.). Nowadays we consider that only small groups may moved here from the Middle Danube Region. In the Vatya cemetery of Dunaújváros-Duna dủlő was discovered a continuously developing society from the Nagyrév to the Tumulus Culture. The 33, Vatya-Rákóczifalva-Tumulus shaped burials fit into the cemetery's order, and, the motifs and shapes of pottery are real successors of the VatyaKoszider pottery (Vicze, 2011, 46, 139, P1. 171-229.).

Late groups of Vatya (Vatya-Koszider) adopted the signs of the neighbouring cultures' material. This process is sign, that these groups' connections was tended more to abroad, as towards the centre of the Vatya. This process is the sign of the weakness or, disappearance of the inner cohesion in the Vatya's centralised tribal society in this period. The level of integration was low, but the level of interaction (e. g. trade of copper) was the same, or increased. I don't explicate here the evidences of centralised tribal structure of Vatya Culture (see Halstead-O’Shea, 1982, Reményi, 2003). Dunaújváros-Kosziderpadlás and SoltTételhalom was more important than other fortified tells based on their dimensions and the quantity (and quality) of the bronze and gold finds that came to light from their neighbourhood. Thiessen Polygon analysis was made to determinate the fortified tells' role (Fig. 102.). In the Mezöföld area there was a typical hexagonal settlement pattern caused by the equable distribution of goods (Christaller, 1933). There is no evidence that the line of tells 
along the Danube's right bank was a defensive line. This pattern was caused only by the geomorphological endowments.

In this time the data suggest that the biggest socio-economical entity of Vatya was the tell (centre) and its oikumene (periphery), sometimes (Dunaújváros) the centre's power was overdosed some next, small fortified tells. However, the plain and very similar material of Vatya suggest strong cohesion and integration during the Vatya I-III period, which may be an evidence for a higher socio-economical structure above the tell settlements.

The assumed changes in culture and lifeways of Vatya was caused by the environmental-climatical changes (climate became cooler and wet) which was suggested by Pál Sümegi and Elvira Bodor based on the analysis of Sóskút mid-Holocene sequence (Sümegi - Bodor, 2005). Plant cultivation was spread onto all lands which was cultivable at that age's cultivation level. If economy is stable only when it is growing, stagnation or recession may generated socio-economical problems in the surplus-depended Vatya. Surplus is needed to trade metal, metal is needed to stabilize the society - wars, or signs of ranking, bronze depots as the signs of the cohesion of society or the ability of the tribal aristocracy to call the gods or good spirits, and keep out the evil ones. They may started to convert plant foods into domesticated animals, and their lifeway from plant cultivation to animal husbandry (Halstead - O'Shea, 1982).

The inhabitants of Domaszék-Börcsök tanya's lifeway in the earliest phase of the Late Bronze Age was pastoralism. They breeded more cow and sheep, and less horse and dog. The pollen data has strong evidence for deforestation and creation of open areas, not only on the banks and sandhills but in the river meadows. Approximately 30-50\% of total forest was logged down.

Domesticated animal stock has higher value than cereals, so the animals' trading value is higher, too. Live stock is easily saved in danger. In the days of surplus, animals were easily traded into metals or any other rare goods - copper, tin, bronze semi-products, gold or salt (Halstead - O'Shea, 1982). This lifeway vas very succesful.

Archaeometallurgy is very important in my work. The measurements of 59 bronze artifacts was complemented in 2009 and, mainly, in 2010 (Ljubljana), and in 2011 (Debrecen). I have cleared the steps of metalwork in the Tumulus Culture and tried to reconstruct the trade roads. Arsenic and nickel as trace elements in the copper are common, accompanied by antimony and silver.

Copper deposit of Dobsina (SK) contains a lot of gersdorffite (AsNiS), releasing As-Ni trace elements after smelting. This evidence suggest that the copper was traded from the former Felvidék (now Slovakia), or eastern Alps (Mitterberg), and maybe from the BorMajdanpek/Vaskö-Dognácska/Rézbánya area. On the Maros, people traded salt and gold. 


\section{Mellékletek}

\section{A dolgozatban bemutatott régészeti leletek leírásai}

1. MFM Ö. 53.4.2. Szürke, benyomásos díszü edény töredéke. (Kostolaci kultúra - Sánta G.) 6. ábra

2. 53.4.7. Köbuzogány fele. 7. ábra

3. 2007.2.1642. Kézzel formált, homokkal és kerámiazúzalékkal soványított, sárgásbarna színü, eredetileg fényesre simított, kopott felületü, gömbös hasú, vállából csonkakúposan összeszükülő nyakú, egyenes peremállású kiegészített edény. (Nagyrév-kultúra) 8. ábra 1 .

4. 2007.2.1643. Kézzel formált, homokkal és kerámiazúzalékkal soványított, külső oldalán sárgásbarna színü, ívelt irányú seprüzéssel durvított felületü, belül barnásszürke színű, kopott felületü, feneke felé erősen összeszükülő testű, profilált aljú edény kiegészített alsó része. (Nagyrév-kultúra) 8. ábra 2.

5. 53.17.1. Szürke, tölcséres szájú kis fülesbögre. A fenék fölött 4 szimmetrikusan elhelyezett bütyök díszíti. (Halomsíros-kultúra) 9. ábra 1.

6. 53.60.1. Félkör átmérőjü bronzhuzalból készült spirál karperec négy fordulattal. (Négymenetes spirális kartekercs, visszapödrött végződéssel, Halomsíros-kultúra - Sánta G.) 9. ábra 3.

7. 53.60.2. Nyitott végü bronz karperec, kétfelé hajló spirálisokkal és bekarcolt díszekkel. (Halomsíros-kultúra) 9. ábra 2.

8. 53.61.1. Lapos gombfejes bronztü. Gomb alatt és derékon vízszintes rovátkolt díszítés. ( $2 \mathrm{db}$, pecsét- vagy szögfejü tü, Halomsíros-kultúra - Sánta G.) 10. ábra 7.

9. 53.61.2. Kerek bronzhuzalból készült, nyitott végü karperec. Elkopott rovátkolt díszek. (Halomsíros-kultúra) 10. ábra 3.

10. 53.61.3. Nyitott végü, kihegyesedő bronz karperec. (Halomsíros-kultúra) 10. ábra 6.

11.53.61.4. Bronz lemezből készült övdarab átlyukasztva. Felületén berovátkolt díszítések. (Girlandmotívumokkal díszített, Halomsíros-kultúra - Sánta G.) 10. ábra 1.

12. 53.61.5. Gömbös, szürke edény füles oldalfala. Fül körül tűzdelt díszek. (Halomsíros kultúra) 10. ábra 5.

13. 53.61.6. Bronzlemezből készült, gömbös végü karperec fele. (Halomsíros-kultúra) 10. ábra 4.

14. 53.61.8. Szürke egyfülü bögre. Tűzdelt díszekkel, 4 bütyökkel. (Halomsíros-kultúra) 10. ábra 2.

15. 53.4.4/1. Pirosasbarna, barázdált bütyökdíszes edénytöredékek. (Többszörösen körülárkolt lelógó bütyök urna hasáról, Halomsíros-kultúra - Sánta G.) 11. ábra 3.

16. 53.4.5. Szürke tálszerü edény peremrésze. Peremet bütyök tagolja. (Csücskös peremü tál töredéke, Halomsíros-kultúra - Sánta G.) 11. ábra 1.

17. 53.4.6. Szürke bordásdíszű edénytöredék füllel. (Halomsíros-kultúra) 11. ábra 2.

18. 53.4.4/2. Pirosasbarna, barázdált bütyökdíszes edénytöredékek. (Spirálisan árkolt bütyökdísz urna vállán, felfelé álló helyzetben, alatta függőleges kannelúrázás, Gáva-kultúra - Sánta G.) 12. ábra 3.

19. 53.61.7. Sárga bronz lándzsa. Széle erősen kitöredezve. Hegye hiányzik, letört, de meg van. (Késő bronzkor Reinecke D- Hallstatt A periódus) 12. ábra 1.

20. 53.88.5. Bronztör nyele. 53.88.4. Bronz tükörfogantyú, vége karikás. (A két darab összeillik. Karikás markolatú bronztőr, késő bronzkor, Reinecke D-Hallstatt A periódus - Sánta G.) 12. ábra 2. 
21. 80.26.1. Szürkésbarna színű, jó égetésű és soványitású, fényezett felületű, kihajló peremű, ívelt nyakú, rendkívül éles vállvonalú, félgömbös aljú bögre. Peremből induló szalagfüle a vállvonalra támaszkodik. (Vatyakultúra) 13. ábra 1.

22. 80.25.1. Szürkésbarna színủ, közepes soványítású, jó égetésủ, fényezett felületü, enyhén kihajló peremü, ívelt nyakú, hangsúlyozott vállvonalú és domború vállú, egyfülü bögre. Peremből induló szalagfüle a vállvonalra támaszkodik. A vállvonal alatt tüzdelt díszítés fut körbe. Az éles hangsúlyozott hasvonalon 4, szimmetrikusan elhelyezkedő hegyes bütyök látható. (Halomsíros-kultúra) 13. ábra 2.

23. 53.129.1. Barnás és feketésbarna edények peremrészei, bütyök-, átfúrt horizontális bütyökfül- és szalagfülekkel. (Halomsíros-kultúra) 13. ábra 4.

24. 53.129.2. Barna színủ edények töredékei, bütyökdíszekkel és szalagfülekkel. (Halomsíros-kultúra) 13. ábra 5-6.

25. 53.129.3. Csónak formájú edénykének a fele, barnáspiros színủ. Egyik hosszoldalon vízszintes bütyök. (Halomsíros-kultúra) 13. ábra 10.

26. 53.129.4. Feketésbarna színủ, csonkakúpos tál töredékei. Peremböl függőleges bütykök emelkednek ki. (Csücskös peremü tál, Halomsíros kultúra - Sánta G.) 13. ábra 3.

27. 2007.2.17. Kerámiazúzalékkal soványított, kézzel formált, simított felületü, közepesen kiégetett, külső oldalán feketésbarna, belső oldalán sötétbarna színủ bütyöklábas korsó ívelt falú oldaltöredéke, alján három darab, kisméretü, lapos bütyöklábbal. 48. ábra 1.

28. 2007.2.732. Kerámiazúzalékkal soványított, kézzel formált, kissé kopott, eredetileg simított felületü, közepesen kiégetett, külső és belső oldalán szürke színủ, ívesen kihajló peremü, hengeres nyakú, kónikus testü, egyenes aljú edény részben összeillesztett töredékei, a vállvonalon kisméretü bütyökdísszel.

48. ábra 2.

29. 2007.2.503/1-2. Kerámiazúzalékkal soványított, kézzel formált, külső és belső oldalán simított felületü, közepesen kiégetett, külső oldalán barna, belső oldalán fekete színü bögre részben összeillesztett perem-, nyak-, és válltöredékei. Pereme enyhén kihajló, nyaka hengeres. Peremből indított, kisívú szalagfüle a vállra támaszkodik. Vállvonalán egy kisméretű, bütyök díszíti. Teste gömbös, vagy félgömbös lehetett. 48. ábra 3.

30. 2007.2.506. Kerámiazúzalékkal soványított, kézzel formált, külső és belső oldalán simított felületű, közepesen kiégetett, külső oldalán világosbarna, belső oldalán sötétbarna és barna színű, enyhén kihajló, lekerekített peremű töredéke. Nyaka hengeres. Pereménél és nyakánál szalagfül indulásának csonkjai láthatók. 48. ábra 4.

31. 2007.2.984. Kerámiazúzalékkal soványított, kézzel formált, simított felületü, közepesen kiégetett, sötétbarna foltos, barna színủ kiöntőcsöves edény kiöntőcsövének töredéke. 48. ábra 5 .

32. 2007.2.1424. Homokkal soványított, kézzel formált, kopott, simított felületủ, jól kiégetett, téglaszínü, az edény falától távolodva fokozatosan elkeskenyedő fül töredéke, a fül közepén futó árkolással.

48. ábra 6.

33. 53.25.6. Szürkésbarna egyfülü bögre. Kihasasodáson 4 szimmetrikusan elhelyezett bütyök. 49. ábra 1 .

34. 53.25.11. Mélyen hasasodó, szürke színü, egyfülủ kis bögre, hasasodáson 4 szimmetrikus bütyök, nyakhajlásban benyomott pontdíszek. 49. ábra 2.

35. 53.25.12. Sárgásbarna egyfülü bögre. 49. ábra 3.

36. 2007.2.2. Kerámiazúzalékkal soványított, kézzel formált, simított felületű, belső oldalán fényezett, közepesen kiégetett, külső és belső oldalán barna színű, ferdén lemetszett szájperemű tál peremtöredéke. 50. ábra 1 . 
37. 2007.2.931-932. Kerámiazúzalékkal soványított, kézzel formált, külső és belső oldalán közepesen elsimított felületü, közepesen kiégetett, külső és belső oldalán sötétbarna színủ, csücskös peremü tál perem- és oldaltöredékei. 50. ábra 2.

38. 2007.2.881. Kerámiazúzalékkal soványított, kézzel formált, külső és belső oldalán simított felületü, közepesen kiégetett, külső és belső oldalán sötétbarna színü, felhúzott csücskös peremű tál peremtöredéke. A csücsök a tál külső oldalán függő̋leges bordában folytatódik. 50. ábra 3.

39. 2007.2.221. Apróra őrölt kerámiazúzalékkal és homokkal soványított, kézzel formált, külső és belső oldalán simított felületü, közepesen kiégetett, külső oldalán barna foltos, fekete, belső oldalán barna színű, lekerekített, egyenes peremű tál töredéke, a tál falának indulásával. 50. ábra 4.

40. 2007.2.62. Homokkal és apróra őrölt kerámiazúzalékkal soványított, kézzel formált, külső és belső oldalán jól elsimított felületủ, közepesen kiégetett, külső oldalán sötétbarna, belső oldalán barna színủ, enyhén behúzott szájperemü tál perem-, váll-, és oldaltöredéke, a vállrészen kisméretü, lapos bütyökkel. A tál fala a perem felé fokozatosan elvékonyodik. 50. ábra 5 .

41. 2007.2.1639. Kerámiazúzalékkal soványított, kézzel formált, külső és belső oldalán kopott, simított felületü, közepesen kiégetett, külső oldalán barna, belső oldalán fekete és barna színű, vastag falú csücskös peremü tál részben összeillesztett perem- és oldaltöredékei. Pereme a tál belső oldala felé ferdén lecsapott. A tál hatalmas méretű, kb. $50 \mathrm{~cm}$ szájátméröjü lehetett. A darab több töredékből ragasztott. 50. ábra 6 .

42. 2007.2.439. Kerámiazúzalékkal soványított, kézzel formált, külső és belső oldalán simított, nyomokban fényezett felületü, közepesen kiégetett, külső és belső oldalán fekete színü, csücskös peremü, a perem felé elvékonyodó falú, egyenes aljú tál, perem-, oldal-, és aljtöredékei. Az aljtöredéken mesterjegy részlete figyelhető meg. 50. ábra 7.

43. 2007.2.1450. Kerámiazúzalékkal soványított, kézzel formált, külső oldalán kopott, simított, belső oldalán jól elsimított, fényezett felületü, közepesen kiégetett, külső oldalán barna, belső oldalán sötétbarna színü, csücskös peremü tál perem- és oldaltöredéke. Szájpereme a tál belső oldala felé ferdén lecsapott, megvastagodó. 50 . ábra 8.

44. 2007.2.1286. Kerámiazúzalékkal soványított, kézzel formált, külső és belső oldalán kopott, simított felületü, közepesen kiégetett, külső oldalán sötét szürkésbarna, belső oldalán fekete színü, közepesen vastag falú tál, belső oldala felé ferdén lecsapott, hullámos peremü töredéke. 50. ábra 9.

45. 2007.2.921. Apróra őrölt kerámiazúzalékkal soványított, kézzel formált, külső és belső oldalán fényesre simított felületü, közepesen kiégetett, külső és belső oldalán fekete színű, felhúzott csücskös peremü tál peremés oldaltöredéke. A tál külső oldalán a csücsök függőleges bordában folytatódik. A csücsök két oldalán réselés nyomai mutatkoznak. 50. ábra 10.

46. 2007.2.1131. Kerámiazúzalékkal soványított, kézzel formált, külső és belső oldalán jól elsimított felületü, közepesen kiégetett, külső oldalán barna és fekete, belső oldalán fekete színű, közepesen vastag falú edény, ívesen kihajló peremü töredéke. Az edény rövid hengeres nyakú, öblös hasú, két, peremből induló és a vállvonalra támaszkodó szalagfüllel ellátott, $40-50 \mathrm{~cm}$ peremátméröjü mély tál. A vállvonal hangsúlyozott és onnan bekarcolt, hegyes, sraffozással kitöltött háromszögek lógnak le. A háromszögek végződése lehet $\mathrm{V}$ alakú vagy egymást keresztező, $X$ alakú, a két végződés feltehetően váltakozott, ahogy az egy olyan töredéken látható, melyen a kétfajta kialakítás egymás mellett maradt meg. Az edény méretei a vállvonal alapján szerkeszthetőek, ezen a szakaszon több töredék $20-25 \mathrm{~cm}$ hosszú darabbá ragasztható össze. 51. ábra 1 .

47. 2007.2.226. Kerámiazúzalékkal soványított, kézzel formált, külső és belső oldalán fényesre simított felületű, közepesen kiégetett, külső és belső oldalán fekete színü, közepesen vastag falú edény perem-, nyak-, és 
válltöredéke. Pereme, lekerekített, ívesen kihajló, nyaka alacsony hengeres, éles töréssel megy át a vállba. 51. ábra 2 .

48. 53.25.17. Piszkosszürke, kissé behajló peremü tál. Ellentett oldalon 1-1 fül. Peremet 4 szimmetrikusan elhelyezett, azonosan kihajló és átlyukasztott bütyök tagolja. Bütykök között, a perem alatt 3-3 lyuk. 52. ábra 12.

49. 53.25.38. Szürke tál töredékei. (Csücskös, réselt peremü tál töredékei - Sánta G.) 52. ábra 3.

50. 53.25.45. Téglapiros, csonkakúpos tál töredékei. (Hullámos, csücskös peremủ tál - Sánta G.) 52. ábra 4.

51. 53.25.7. Sötétszürke tál peremtöredéke. (Belső oldalán megvastagodó - Sánta G.) 52. ábra 5.

52. 53.25.44. Barnás, kissé behajló peremű tál. Perem alatt fül, peremen 4 szimmetrikusan elhelyezett bütyök. (A premeen lévő csücskök alatt kívül rövid, függőleges bordadísz, a 4 bütyök a perem csücskei között félúton van elhelyezve - Sánta G.) 52. ábra 6-7., 9-10.

53. 53.25.52. Barnássárga, tagolt peremü tál töredékei. 52. ábra 8 .

54. 2007.2.1529-1530-1531, 1533. Kerámiazúzalékkal soványított, kézzel formált, külső és belső oldalán kopott, simított felületủ, közepesen kiégetett, külső és belső oldalán barna színủ, közepesen vastag falú, nagyobb méretű edény, részben összeillesztett perem- és oldaltöredékei. Az oldalak alj felé eső töredékeit seprüzés borítja. Az edény egy kihajló peremü, cilindrikus nyakú, hangsúlyozott vállú és tojásdad testű hatalmas amfora lehetett. 54. ábra 1.

55. 2007.2.1266, 1267. Csillámos homokkal és apró kaviccsal soványított, kézzel formált, külső és belső oldalán simított felületü, közepesen kiégetett, külső oldalán barna foltos fekete, belső oldalán fekete színü, egyenes, vízszintesen levágott peremű, csonka kúpos nyakú urna perem- és oldaltöredékei, a vállvonal kis részletével. 54. ábra 2.

56. 2007.2.1598. Kerámiazúzalékkal soványított, kézzel formált, külső és belső oldalán jól elsimított felületü, jól kiégetett, külső és belső oldalán világosbarna színủ, vastag falú edény ívesen kihajló, belső oldalán lépcsősen kannelúrázott peremü töredéke, bevagdalt díszítéssel. (Perjámos-kultúra) 54. ábra 3.

57. 2007.2.969. Apróra örölt kerámiazúzalékkal soványított, kézzel formált, külső és belső oldalán simított felületü, közepesen kiégetett, külső oldalán barna és sötétbarna, belső oldalán barnásfekete színü, gömbös testü edény nyak- és hastöredéke, az edény külső oldalán a nyakból induló és a hasra támaszkodó szalagfüllel és a szalagfül alatt kisméretủ bütyökdísszel. 55. ábra 1 .

58. 2007.2.1253. Kerámiazúzalékkal soványított, kézzel formált, külső oldalán kopott, simított, belső oldalán jól elsimított felületü, közepesen kiégetett, külső és belső oldalán fekete színü, közepesen vastag falú edény oldaltöredéke. Csőtalpas tál csőtalp-töredéke, a palástján kettős, szaggatott vonaldíszekböl kialakított vonalkötegekkel. 55. ábra 2.

59. 2007.2.1192. Kerámiazúzalékkal soványított, kézzel formált, külső és belső oldalán kissé kopott, simított felületü, külső oldalán a peremrésznél fekete foltos szürke, oldalán és alján barna színü, belső oldalán fekete színủ edény perem-, oldal-, és aljtöredékei. Pereme egyenes, enyhén kihajló, alja egyenes. 55. ábra 3.

60. 2007.2.1279, 1283, 1287, 1290, 1302. Kerámiazúzalékkal soványított, kézzel formált, külső és belső oldalán kopott, simított felületű, közepesen kiégetett, külső oldalán barna és fekete, belső oldalán fekete színü, közepesen vastag falú fazék, kihajló peremü töredékei, a fazék vállának részletével. A fazékoldal vékony agyagbevonattal borított, melyet ritkás seprüzés borít. A fazék töredékei több leltári szám alatt lettek nyilvántartásba véve. 56. ábra 1. 
61. 2007.2.849-850. (A két töredék egy edény része.) Kerámiazúzalékkal soványított, kézzel formált, kissé kopott, eredetileg simított felületủ, közepesen kiégetett, külső és belső oldalán sötétbarna színü bütykös peremü fazék töredéke. 56. ábra 2.

62. 2007.2.1449. Kerámiazúzalékkal soványított, kézzel formált, külső és belső oldalán simított felületü, közepesen kiégetett, külső oldalán szürkésbarna és sárgásbarna, belső oldalán világosbarna színü, közepesen vastag falú fazék, bütykös peremü töredéke, külső oldalán kisívű szalagfüllel. 56. ábra 3.

63. 2007.2.4. Kerámiazúzalékkal soványított, kézzel formált, külső oldalán gyengén elsimított, belső oldalán fényezett felületü, közepesen kiégetett, külső oldalán fekete, belső oldalán sötétbarna színü, lekerekített, egyenes peremü, alacsony nyakú, közepesen vastag falú edény perem- és nyaktöredéke. 56. ábra 4.

64. 2007.2.225. Kerámiazúzalékkal soványított, kézzel formált, külső és belső oldalán közepesen elsimított, közepesen kiégetett, külső oldalán barna foltos, sárgásbarna, belső oldalán fekete színü, vastag falú, egyenes peremü, hengeres nyakú edény perem- és oldaltöredéke, a perem alatt kisívü, téglalap átmetszetủ szalagfüllel. 56. ábra 5 .

65. 2007.2.1645. Kézzel formált, kerámiazúzalékkal soványított, kívül sárgásbarna, alsó harmadában narancsbarna színű, belül szürkésbarna színü, törésfelületén fekete színű, gyenge közepesen átégett falú, nagyméretü, 75 db-ból összeragasztott pithosz (és néhány különálló apró töredék). Peremrésze hiányzik. Az edény teste hengeres alakúra formált, alsó harmadában feneke felé fokozatosan összeszükül. Alja enyhén profilált, feneke egyenes. Külső oldalán a felszínére felvitt agyagpépbe függőleges irányú egyenes és kissé ívelt, szabálytalanul behúzott ujjnyomok (schlickwurf) borítják az edény testének felső kétharmadát. Belső oldalán az agyagot vízszintes irányban dolgozták el. 57. ábra

66. 2007.2.74, 2007.2.120, 2007.2.129 (egy edény részei). 2007.2.74. Kerámiazúzalékkal soványított, kézzel formált, közepesen elsimított felületủ, közepesen kiégetett, külső oldalán világos sárgásbarna, a peremnél fekete, belső oldalán fekete foltos barnásszürke színủ, vastag falú, ívesen kihajló peremü, alacsony nyakú hombár perem-, nyak-, és válltöredéke. Külső oldalán, a nyaki részen ujjbenyomásos bordadísz fut körbe.

2007.2.120. Kerámiazúzalékkal soványított, kézzel formált, kopott felületű, eredetileg simított, közepesen kiégetett, külső oldalán világosbarna foltos, barna színü, belső oldalán fekete színü, vastag falú hombár oldaltöredéke.

2007.2.129. Kerámiazúzalékkal soványított, kézzel formált, kopott felületü, közepesen kiégetett, külső oldalán világosbarna, belső oldalán barnásszürke színű edény aljtöredéke, az edényoldal indulásával.

A jelzett edényhez még számos egyszerü oldaltöredék tartozik, ezeket azonban sem összeállítani nem sikerült, sem a rajzon elhelyezni nem tudtam öket. 58. ábra

67. 2007.2.1095. Kerámiazúzalékkal soványított, kézzel formált, külső oldalán durván elsimított, belső oldalán simított felületü, közepesen kiégetett, külső és belső oldalán sötétbarna és világosbarna színű, nagyobb méretü edény egyenes szájperemű töredéke. Az edény külső oldalán vízszintesen ujjbenyomásos bordadísz fut körbe. 59. ábra 1.

68. 2007.2.72, 2007.2.75, 2007.2.81 (egy edény részei). 2007.2.72. Kerámiazúzalékkal soványított, kézzel formált, közepesen elsimított felületü, közepesen kiégetett, külső oldalukon barna, belső oldalukon feketésbarna színủ edények, egyenes peremü töredékei, az edény nyakának indulásával.

2007.2.75. Kerámiazúzalékkal soványított, kézzel formált, közepesen elsimított felületü, közepesen kiégetett, külső oldalán barna, belső oldalán szürke színű, vastag falú, ívesen kihajló peremű, alacsony nyakú hombár perem-, nyak-, és válltöredéke. A nyak alatt, a vállrész indulásánál, vízszintes irányban, ujjbenyomásos bordadísz fut körbe. 
2007.2.81. Kerámiazúzalékkal soványított, kézzel formált, külső oldalán a kerámiazúzalékok miatt érdes, belső oldalán simított felületü, közepesen kiégetett, külső oldalán barna, belső oldalán fekete színủ, vastag falú edény, ívelt falú oldaltöredéke, külső oldalán a kerámiatöredék szélén, bordadísz részletével. 59. ábra 2.

69. 2007.2.1. Kerámiazúzalékkal soványított, kézzel formált, simított felületü, közepesen kiégetett, külső és belső oldalán barna színű, alacsony nyakú edény (parázsborító) peremtöredéke, a peremből vízszintesen kihúzott csücsökkel, a nyakrészen kisméretü kerek átfúrásokkal. 60. ábra 1.

70. 2007.2.1246. Kerámiazúzalékkal soványított, kézzel formált, külső és belső oldalán kopott, simított felületü, közepesen kiégetett, külső oldalán fekete foltos, szürke, belső oldalán sötétszürke színű, vastag falú edény töredéke, alján 1,5 cm átmérőjủ lyukkal. A tárgy ez alatt is folytatódik. Értelmezése: egy hordozható tűzhely peremtöredéke, a palást és a rostély találkozási felületével, ahol a tárgy illesztve volt, és eltört. Külsején vízszintes, hármas vonalköteg van bekarcolva. 60. ábra 2 .

71. 2007.2.1664/11. Kézzel formált, kerámiazúzalékkal és homokkal soványított edények peremtöredéke. Pyraunos töredéke $2 \mathrm{~cm}$ átmérőjü lyukkal. 60. ábra 3.

72. 2007.2.63. Homokkal és apróra örölt kerámiazúzalékkal soványított, kézzel formált, külső és belső oldalán jól elsimított felületü, közepesen kiégetett, külső és belső oldalán világos szürkésbarna színű, lekerekített, behúzott peremü szürőtál perem- és oldaltöredéke, a táloldalon három, kerek kisméretű átfúrással, és a törésfelületnél több hasonló átfúrás nyomával. 60. ábra 4.

73. 2007.2.1644. Kézzel formált, homokkal soványított, szennyezett anyagú, sárgásbarna színén koromfoltos, eredetileg simított, mára lekopott felületű csónak alakú edény orr-rész felöli töredéke. Orra kiöntőnyílás-szerüen kialakított. Halsütő tál lehetett. 60. ábra 5.

74. 2007.2.1664/3. Kézzel formált, kerámiazúzalékkal és homokkal soványított edények peremtöredéke. Fedő töredéke. 60. ábra 6 .

75. 2007.2.1640. Korrodálódott állapotú, lapos átmetszetü, hosszúkás bronz fürészpenge két hosszanti oldalán konkáv kopásnyomokkal és néhol kivehető fürészfogakkal. Az egyik oldalán látható a felerősítésre szolgáló lyuk részlete. 88-89. ábra

76. 1/1904. Tüskés-korongos végü díszítetlen bronzcsákány. 92. ábra 1.

77. 1/1905b. Sarlós tủ korongos fejjel. A fej külön készült, azután szerelték össze a tủ testével. A fej díszítetlen. A szár a hajlított szakaszon csavart. 92. ábra 2.

78. 128/1885/18/3 Ötbordás lemezkarperec töredéke. 92. ábra 4.

79. 53.25.19. Trébelt díszü, korong alakú díszek bronzból. Közepükön tüskével 4, többé-kevésbbé 14 töredék. (Tüskés-körbordás tutulus - Sánta G.) 92. ábra 5.

80. 80.35.2. Körbordás, tüskés tutulus, a felfüggesztésre szolgáló, alápödrött lemezzel. A lemez széle és a tüske hegye letörött. Az alápödrött lemez belső részén kopásnyomok. 92. ábra 6 .

81. 46/1884. Hengeres nyakú, kihajló peremủ korsó, a peremből induló, magasra húzott, a nyak alsó részére támaszkodó szalagfüllel. A has nyomott gömbös, vízszintes, bevagdalt bordadísszel tagolt. Füzesabony-kultúra. 98. ábra 1.

82. 51/1884. Rövid hengeres nyakú, enyhén kihajló peremű bögre, peremből induló és a has felső részén támaszkodó perem fölé húzott szalagfüllel. A nyomott gömbös has turbántekercses kialakítású. Füzesabonykultúra. 98. ábra 2.

83. 48/1884. Rövid tölcséres nyakú, kihajló peremü, kettős kúpos testü bögre peremböl induló és a has felső részén támaszkodó szalagfüllel. A vállvonal hangsúlyozott. Halomsíros-kultúra. 98. ábra 3. 
84. 49/1884. Rövid tölcséres nyakú, kihajló peremű, kettős kúpos testủ bögre peremböl induló és a has felső részén támaszkodó szalagfüllel. A váll vonala jelezve van. A hasvonalon szimmetrikusan 4 bütyök van elhelyezve. Halomsíros-kultúra. 98. ábra 4.

85. 50/1884. Rövid, ívelt nyakú, kihajló peremü, kettőskúpos testü bögre, a vállvonal nincs jelezve. Szalagfüle a peremből indul és a vállrészre támaszkodik. Halomsíros-kultúra 98. ábra 5.

86. 52/1884. Igen rövid nyakú, kihajló peremü, széles, kettőskúpos testü bögre, az éles hasvonalon bevagdosás díszíti, peremből induló, perem fölé magasra húzott szalagfüle a hasvonal felett a has felső részén támaszkodik. Felsőszőcs-kultúra. 98. ábra 6.

87. 153/1885. Hengeres nyakú, alig kihajló peremű korsó, a peremből induló, felhúzott szalagfüllel, mely a has és a váll találkozási pontján támaszkodik. A has nyomott gömbös alakú, turbántekercses kialakítású. Füzesabony-kultúra. 99. ábra 1.

88. 189/1885. Rövid hengeres nyakú, kihajló peremü bögre a peremböl induló, felhúzott, a has felső részén támaszkodó füllel. A has nyomott gömbös, turbántekercses kialakítású. Füzesabony-kultúra. 99. ábra 2.

89. 166/1885. Rövid hengeres nyakú, kihajló peremü bögre, a perem fölé húzott és a has felső részén támaszkodó szalagfüllel. A has nyomott gömbös, felső részén két, vízszintesen körbefutó kannelúra található, melyeknek pereme bevagdosással díszített. Késő Hatvan-kultúra. 99. ábra 3.

90. 165/1885. Rövid, enyhén szélesedö (kissé tölcséres) nyakú, egyenes peremü, nyomott gömbös testü bögre, a perem alól induló és a has felső részén támaszkodó szalagfüllel. Késő Hatvan-kultúra. 99. ábra 4.

91. 180/1885. Tölcséres nyakú, egyenes peremű, nyomott gömbös, kettőskúpos testủ bögre a has felső részén kialakított függőleges irányú bordadíszekkel. Füle a has felső részére támaszkodik. 99. ábra 5.

92. 184/1885. Csonkakúpos nyakú, kihajló peremű, nyomott gömbös testű bögre, a peremből induló és a has felső részén támaszkodó széles, vaskos szalagfüllel. A hason középen 3, körülárkolt bütyök található, a füllel szimmetrikusan 4 részre osztják a has vonalát. A bütykök között függőlegesen bekarcolt hármas vonalkötegek láthatóak. Késő Hatvan-kultúra. 99. ábra 6.

93. Leltározatlan. Ún. svédsisak alakú tál töredéke. Füle a peremböl indul, felül kiszélesedik, két kannelúra díszíti. A fül legfelső részén egy ujjbenyomásos, kétszer körülárkolt lapos bütyök található. A tál nyakának alsó részén kettős vonalkötegből kialakított bekarcolt zeg-zug minta. Alatta párhuzamosan futó hármas vonalköteg. A has vonalán bevagdalt bordadísz, melyet alul és felül vízszintes kannelúra kísér. A tárgy magasan fényezett. Perjámos-kultúra. 100. ábra

94. 80.35.1. Ún. Lovas típusú korsó. Sötétszürke színü, közepesen soványított, jól égett, fényezett felületü, kétoldalt kicsúcsosodó, kihajló peremü, kúpos nyakú, domború vállú, kúpos testủ, kétfülü edény. Peremből induló két szalagfüle a besimítással hangsúlyozott vállra támaszkodik. Kiindulásánál a peremen 2 bütyök látható. Legnagyobb kiöblösödésénél eredetileg 4 lecsüngő bütyök volt. Alja profilált. Vatya-kultúra (Vattinakultúra hatására.) 101. ábra 1.

95. 53.48.1. Hengeres, vágott fenekű, egyfülü bögre. Füle letörve. Vatya-kultúra. 101. ábra 3.

96. 53.48.2. Szürke, gömbös testü, hengeres nyakú, egyfülü szürke bögre. Nyaka kitörve. Vatya-kultúra. 101. ábra 4.

97. 53.48.3. Szürke, gömbös fenekü, kihajló peremü, egyfülü bögre. Nyaka csorba. Vatya-kultúra. 101. ábra 5.

98. 53.48.4. Gömbölyü fenekü, egyfülü szürke bögre. Fül a perem fölé emelkedik. Kívül 3 helyen vonal bekaracolás. Késő Füzesabony-kultúra (?). 101. ábra 6.

99. 53.48.5. Egyfülü, feketésszürke, durva kivitelü, hengeres bögre. Vatya-kultúra. 101. ábra 7. 
100. 2007.2.700. Kerámiazúzalékkal soványított, kézzel formált, külső és belső oldalán kissé kopott, eredetileg simított felületü, közepesen kiégetett, külső és belső oldalán fekete színủ, nyomott gömbös vagy bikónikus testü korsó oldaltöredéke és gyürütalpas aljtöredéke. Oldalán vízszintesen lapított bütyök díszíti, két töredéken fülindulás csonkja látható. Számos töredék van, melyet nem sikerült a rajba belekomponálni. (Az edény felső részét valószínüleg a gép elvitte.) Halomsíros-kultúra. 104. ábra 1.

\section{A dolgozatban szereplő, kerámiavizsgálatnak alávetett darabok leírásai}

1/1. Sötét szürke, finomszemcsés mátrixban sok csillám, szögletes kerámiatöredékek $(0,5-0,1 \mathrm{~mm})$, porózus szerkezet. Eredet: folyómenti agyagos feltárás (75. ábra 1).

1/2. Az előzővel tökéletesen egyező csillámos nyersanyagban 3-0,5 mm-es zúzott kerámia, néhány (1-2) lekerekített, eolikus apróhomok szem $(0,3 \mathrm{~mm})$, a törésfelületen illesztés nyoma. Eredet: folyómenti agyagos feltárás (75. ábra 2).

17/1. Finomszemcsés, csillámos alapanyag, 2-0,3 mm-es kerámiatöredékekkel, porózus szerkezetü, illesztési nyom (szalag) figyelhető meg. Eredet: folyómenti agyagos feltárás (76. ábra).

44/1. Külsőre az eddigiekhez teljesen hasonló, sötét színủ, redukciós égetésủ finomkerámia (tál?) töredék. A mikroszkópban azonban teljesen más: a finom szemcsés alapba durvakőzetliszt frakció keveredik igen nagy mennyiségben, melyben 1-0,1 mm-es kerámiatöredékek és kőzetdarabok, nagyon sok csillám (muszkovit) található. Színe erősen sötét, redukált. Eredete: infúziós löszös vagy áthalmozott löszös-agyagos, folyómenti feltárás (77. ábra).

246/1. Finom kerámia, mely a 44-es gödörböl vizsgálthoz nagyon hasonlít. Erösen soványított, igen porózus, a soványító anyag növényi maradvány, finom homok és durva kőzetliszt (78. ábra).

Vasborsó kihullott helye (vasas bevonattal) ismerhető fel. A finomhomok eolikus, 0,2 $\mathrm{mm}$ körüli szemcsemérettel, ezen kívül nagy mennyiségủ $0,05 \mathrm{~mm}$ alatti durva kőzetliszt látható. Néhány szögletes, folyóvízi homokszemcse is látható. A darabra jellemzőek a mátrixban nagy számban előforduló, nagyjából irányított, $0,1 \mathrm{~mm}$ nagyságrendủ oszlopos amfibol vagy piroxén kristályok, melyek saját alakúak, koptatottság nem látszik rajtuk.

Ez a nyersanyag folyóvízi eredetủ: nehézásványos finomhomokkal, durvakőzetliszttel szennyezett folyami agyag, melybe soványító anyagként eolikus finomhomokot és növényi szárrészeket kevertek. A kőzet minden bizonnyal a Tisza üledékrendszeréből származik.

272/1. „Házi” vagy „durva” kerámia peremtöredéke. A csillámos mátrixban a soványító anyag 5-1 mm-es zúzott kerámia. A mátrix tartalmaz még durvakőzetlisztet és apróhomokot, de nem tartalmaz amfibolt/piroxént. Eredet: kőzetlisztes feltárásból (iszapolva ?).

309/1. Egy korsó vagy bögre peremtöredéke. Benne vasborsó, 0,5-0,2 mm-es igen jól osztályozott (szitált?) kerámiazúzalék, és nagy mennyiségủ durva kőzetliszt. Eredet: infúziós löszös/aleuritos feltárásból (iszapolva?).

309/2. Finomszemcsés mátrixban 3-0,1 mm-es kerámiadarabok, sok csillám - föleg muszkovit, kevesebb biotit, esetleg amfibol/piroxén. Porózus szerkezetủ, a pórusokban karbonátos kitöltés. Eredete: folyóvízi agyagos feltárás, Tisza üledékes rendszere.

309/3. Finomszemcsés alapanyag. Finom homokkal, durva kőzetliszttel soványítva. A finomhomok egy része eolikus. Főleg durva kőzettörmelék jellemzi, melyek szögletes alakúak. Vasas kiválások. 0,2 mm alatti frakció uralja a darabot. Csillámot is tartalmaz. 
Ez a töredék tér el leginkább az összes többi darabtól, ezért felvetődik, hogy import. Ennek ellenére az alapanyag származhat a közeli ártér finomhomokos-durvakőzelisztes-agyagos üledékrendszeréből, melybe kevés eolikus homok keveredett, vagy soványító anyagként belekeverték.

309/4-8. 5 darab, teljesen azonos megjelenésủ és anyagú töredék, egy edény, egy nagy fazék részei. Durva kőzetliszttel soványított mátrix, rajta kívülről vasoxidos, vasborsós, narancsos színü, erősen sovány, repedezett bevonat (79. ábra). A bevonat $1,5 \mathrm{~mm}$ vastag. Ennek külső, változó vastagságú, de $\mathrm{kb} .1 \mathrm{~mm}$ vastag rétege vashidroxidos (limonit), narancsos-barnás színü. A bevonat belső, jellemzően $0,5 \mathrm{~mm}$ vastag rétege vörösesbarna, vasoxidos (hematit). A két szín és a két ásványi színezőanyag átmenete néhol éles, néhol folytonos. A két szín égetéskor kizárja egymást (Véninger Péter keramikus szóbeli közlése). A vashidroxid átalakul vasoxiddá, csak enyhén redukáló atmoszférában nem, a színátmenet így létrejöhet egy oxidatív égetést követő enyhe redukció révén, de ebben az esetben a kerámia mindkét oldalán fel kellene ismernünk ezt a réteget, ahogy az sok esetben látható régészetim kerámiákon (,szendvics” szerkezet). Jobb magyarázatot jelent, ha a bevonat eleve vasas volt, és festékként került fel. Az égetéskor az oxidatív főfázis után kissé lefojtották a kemencét, s így alakult ki a felszíni sárgás bevonat. Az a magyarázat is lehetséges, hogy csak a talajban, utólagos hidratáció révén alakult ki a felületi vashidroxid réteg. Több Halomsíros lelőhelyről (Maroslele, Kunfehértó) ismert festett bevonatú fazék, ezeknél mindig vasoxid a festékanyag (Sánta, 2004a, Sánta et al, 2004).

Eredete: durvakőzetlisztben gazdag agyagos feltárás, vagy azzal soványított agyag.

313/1. Finomszemcsés mátrixban nagy mennyiségű soványító anyag. Jellemző makroalkotók: 1,5-0,5 mm-es zúzott kerámia, 0,5-0,3 mm-es kvarchomok, 0,3-0,05 mm-es csillám. 0,05 mm körüli és az alatti durvakőzetlisztet tartalmaz. 1,5 mm-es vasborsó megfigyelhető. A pórusokban karbonátos kiválások (posztgenetikus). Eredete: infúziós löszös, aleuritos feltárás.

319/1. Finomszemcsés mátrixban finomhomok-durvakőzetliszt frakció és sok csillám, valamint $0,2 \mathrm{~mm}$ hosszú amfibol/piroxén kristályok. Eredete: folyóvízi üledékes, agyagos-aleuritos rendszer.

319/2. Finomszemcsés mátrixban 1,5-0,3 mm-es kerámia, csillám, nagyon sok finomhomok és durvakőzetliszt. Eredete: finomhomokos-aleuritos-agyagos feltárás, valószínüleg típusos vagy infúziós löszből iszapolva.

319/3. Finomszemü alapban sok durva, 5-0,5 mm-es kerámiatöredék, $0,3 \mathrm{~mm}$ alatti finom homok (eolikus), nagyon sok durva, szögletes kőzetliszt, vasborsó. Eredete: homokbefúvásos, infúziós löszös feltárásból iszapolva (80. ábra).

320/1-2. Finomszemcsés alapanyagban sok apróhomok, durvakőzetliszt. A homok lekerekített, de kissé szögletes szemek is vannak. A kerámiazúzalék 3-0,5 mm nagyságrendü. Vasborsók láthatóak. Eredete: infúziós löszös feltárásból iszapolva. Eolikus (?) apróhomokkal és kerámiával soványítva (81. ábra).

320/3. Azonos az előzővel, de kevesebb benne a homok. Eredet: löszböl iszapolva.

320/4. Nagyon hasonló az előzőekhez, de a homok itt egyértelmüen szögletes, tehát folyóvízi eredetű. Eredet: folyóvízi üledékes, agyagos-aleuritos rendszer.

402/1. Finomhomok, durvakőzetliszt a mátrixban. Eredet: löszből iszapolt.

402/2. Eolikus finomhomok, durva kőzetliszt, hasonló a 320/4-hez. Kerámiazúzalék: 5-0,5 mm. Eredet: típusos löszböl, löszös homokból iszapolt.

402/3. Tálperem, korai típusú csücskös peremű tál része. Finomszemcsés mátrix, igen kevés eolikus finomhomok (szennyezés), sok durva kőzetliszt. Infúziós vagy típusos löszös feltárás. 
402/4. Finomszemcsés mátrix. Erősen csillámos $(0,5 \mathrm{~mm}$-es csillámlemez is), csak durva kőzetliszt, nincs homok, oszlopos amfiol/piroxénkristályok szétszórva a mátrixban, egyetlen 0,3 mm-es fekete, kagylós törésü szemcse (obszidián?). Eredete: folyóvízi üledékes rendszer, agyagos-aleuritos üledék.

402/5. Finomszemcsés mátrix. 3-0,3 mm-es kerámiazúzalék, finomhomok 1-2 nagyobb, 0,5 mm-es kvarcszemcsével, sok durva kőzetliszt, rendkívül sovány anyag. Eredete: löszböl, aleuritból iszapolva.

402/6. Finomszemcsés mátrix. Sok kerámiazúzalék, nincs benne homok, durva kőzetliszt és néha, 1-2 amfibol/piroxénkristály. Eredete: folyóvízi üledék.

402/7-8. Finomszemcsés. 3-0,3 mm-es kerámiazúzalék, kevés finomhomok, kőzetliszt. Eredete: löszböl, aleuritból iszapolva.

402/9. Finomszemcsés mátrix. Kevés a homok, föleg $0,05 \mathrm{~mm}$ és az alatti durva kőzetliszt uralja, nagyon erösen soványított. Sok csillám. 1-0,3 mm-es jobban osztályozott kerámiazúzalék. Eredete: agyagos-aleuritos feltárás.

425/1. Finomszemcsés mátrix. Finom homok alsó frakciója $0,1 \mathrm{~mm}$, durva kőzetliszt, $1 \mathrm{~mm}$ körüli kerámia. Erősen soványított, porózus. Szögletes folyóvízi homokszemek. Eredet: folyóvízi üledékes rendszer agyagosaleuritos-finomhomokos feltárása.

425/2. Finomszemcsés mátrix. Makroalkotók: csillám, finom homok, nagy amfibol fenokristály: $0,3 \times 0,05 \mathrm{~mm}-$ es oszlop, durva kőzetliszt. Eredete: folyóvízi üledékes rendszer agyagos-aleuritos-finomhomokos feltárása.

425/3. Finomszemcsés mátrix. 0,15-0,05 mm-es nagyon finom homok, $0,5 \mathrm{~mm}$ körüli kerámia, durva kőzetliszt, sok csillám. Eredete: bizonytalan.

428/1. Finomszemcsés mátrix. Durva szemcsék, szögletes homokszemek, amfibol vagy augit 1-0,5 mm-es fenokristályok, $1 \mathrm{~mm}$-es biotitlemez (idiomorf hatszöges), finom homok frakció, vasborsók helyei, $1 \mathrm{~mm}$ és alatti kerámiazúzalék. Jelentősen különbözik a többi nyersanyagtól a fenokristályok méretében, de összetételében nem. Eredet: folyóvízi üledék, agyagos-aleuritos-homokos feltárás feltárás.

441/1. Finomszemcsés mátrix. Miniatür edény pereme. Anyaga a 425/3-ra hasonlít, apró vasborsók jellemzőek. Eredete: talán vízhatású agyagos-aleuritos feltárás.

479/1. Finomszemcsés mátrix. Sok apró, 0,2x0,05 mm-es amfibol/piroxén oszlop, finomhomok, durvakőzetliszt, az edénytöredék alsó oldalára homok cementálódott karbonát kötőanyaggal posztgenetikusan. Eredete: folyóvízi üledékes rendszer.

479/2. Finomszemcsés mátrix. Az előzővel megegyező anyag, 1 mm-es és akörüli kerámia, vasborsók, felületén repedezett, igen vastag bevonat, mely nagyon erősen sovány. Eredete: folyóvízi üledékes rendszer.

483/1. Finomszemcsés mátrix. Apróhomok, durvakőzetliszt, zúzott kerámia, a kerámia kihullott belőle. Eredete bizonytalan.

\section{A dolgozatban szereplő kőtárgyak leírásai}

1-2. 25. objektum. 2007.2.1646. Két darab kőzet. Az egyik barnás szürke, erősen bontott andezit-dácit, $3 \times 2 \times 1$ cm-es töredéke, 1-4 mm-es táblás földpát fenokristályokkal, felületén erősen mállott. Felhasználása: kemencékben a hőtartás elősegítésére. Származási helye Lippa/Lipova (Ro), szállítási útvonal: vízi út, Maros. A másik szürke színü, középszemcsés, jól osztályozott homokkö, kalcitos cementálóanyaggal, eredete helyi (homokban keletkezett karbonátos konkréció töredéke). Utólag két darabra tört. A gödör datálása: Halomsíroskultúra. 
3. 156. objektum. 2007.2.1647. Világosbarna, néhol kissé vöröses-lilás, folyásos szövetü, repedezett (dehidratált) mátrixban sürủn elhelyezkedő fehér színủ foltok. A kőzet tömött, kriptokristályos vagy amorf szerkezetü, kagylós törésű, törésfelületén kissé fényes felszínű anyag. Több helyütt a példány eredeti, mállott felszíne is megmaradt, régészeti értelemben ez tehát egy magkö-preparációs szilánk. Meghatározása hidrokvarcit-jáspis, esetleg jáspopál. Származási helyeként két lehetséges pont jöhet számításba: VerespatakBrád környéke vagy Tokaji-hegység. A két terület a Maros, illetve a Tisza vízi útján keresztül megközelíthető, távolságuk kb. 100-150, illetve $300 \mathrm{~km}$. Valószínűbb, hogy az Erdélyi-Érchegység a származási területe. A gödör datálása: Nagyrév-kultúra (?).

4. 211. objektum. 2007.2.1648 (83-85. ábra). Világosszürke, fehéres, erősen likacsos szerkezetủ, fosszília-dús tavi mészkő, jelentős homoktartalommal. A homokszemcsék jól osztályozottak, 0,05-0,3 mm átmérőjủek (finom homok frakció), a karbonátos kötőanyagba ágyazva találhatóak. A mátrixban Mollusca héjak és héjtöredékek, valamint fosszilis növényi maradványok ismerhetőek fel. A likacsok tavi növényzetre utalnak (nád, gyökerek). A gyökerek helyén tömör karbonát vagy üreg húzódik, ezt vékonyan vas-hidroxidban (goethit) dús gyürủ övezi, majd a karbonátos kőzet következik. A kőzet származási helye a közelben lévő valamelyik tó (semlyék) üledékes rendszere lehetett, a követ bányászták.

5. 308. objektum. 2007.2.1649. Téglavörösre átégett, szabdalt, barázdált és likacsos, helyenként olvadt/üvegesedett felületü, kőzetszerủ tárgy. A kiindulási kőzet finom szemcsés, osztályozott eolikus üledék (lösz), melyet karbonát cementált, a felületén lévő barázdák talán növényi gyökérzettől származnak. Ez tehát „löszbaba”, mely magas hőhatásnak volt kitéve (olvasztó- ?) kemencében. Színét a vas-hidroxid (limonit) égetés során vas-oxiddá (hematit) való átalakulása okozza. A kőben szegény Alföldön a felhasználás célja a kemencében a hőtartás elősegítése volt, ezért építhették be a kemence aljába vagy oldalába. Tehát nem véletlenszerüen, hanem nagyon is tudatosan használták fel, kő hiányában, a löszbabákat. Ennek hőtartó képessége elmarad a jobb minőségü vulkáni kőzetekétől. Érdekes, hogy annak ellenére is alkalmazták, hogy nagy mennyiségben állt rendelkezésre kerámiatöredék. (Az egyetlen ép sütőkemence (172. objektum) platnijának alapozását kerámiatöredékekkel rakták ki.) A löszbaba származási helye a környék löszös feltárásainak egyike.

6. 308. objektum. 2007.2.1650 (86. ábra). Szürke színủ, porózus, likacsos szerkezetű meszes homokkő, 0,05-0,3 mm-es, osztályozott, lekerekített szemcsékkel. Eolikus finomhomok karbonátos cementációjával alakult ki. Benne növényi maradványok, faszén ismerhető fel, melyek jelentős része gabonamag, pelyva, kalászorsó lenyomat. Növényi szár, gyökér lenyomat is felismerhető. A minta keletkezése: a talajvízből a bronzkorban alakult ki, a magas karbonáttartalom kicsapódásával (beszáradás).

7. 427. objektum. 2007.2.1651. 3 db. Téglavörös színű, kissé szürkés (másodlagos) karbonátos kéreggel borított tapasztás-darabok, melyek kemence platnijából származnak. A platni sima, igen erősen átégett, vékony rétegben összesült, üvegesedett (,metakvarcit”) felülete is jól felismerhetö. A tapasztás anyaga finom homokkal, durva kőzetliszttel erősen soványított agyag, speciálisan erre a célra keverve (a magas kvarctartalom a hőállóságot volt hivatott elősegíteni). A tapasztás réteg kerámiából álló alapra került, a kerámia lenyomatai néhol megőrződtek a minta alján.

8. 427. objektum. 2007.2.1652. Vöröses, helyenként szürkés, gyengén átégett, lekerekített, sima felületü kőzetszerű darab. Apró szemű, igen jól osztályozott kőzetlisztet karbonát cementál, ez tehát egy karbonátos konkréció, feltehetően infúziós löszből. Benne limonitos gömbök találhatóak, felszínét mangándendritek szövik át. Gyengén átégett, ami azt bizonyítja, hogy a darab egy tűzhely vagy kemence aljába, oldalába volt tapasztva. 
Kis mérete miatt valószínüleg nem tudatosan alkalmazták, az agyagos (?) löszben volt, melyből a tüzhely, kemence épült. Származási helye: lokális infúziós löszös feltárás, Maty-ér völgye.

9. Terepbejárás során a felszínröl (87. ábra). Kor: bronzkor. Kb. 6x8 cm-es szögletes elválású kőzetdarab, színe világos vörösesbarna, szemcsemérete középszemü, még viszonylag jól felismerhető ásványszemekkel. Két oldalán erősen átégett, olvadt, üveges, forrásra utaló gázbuborékok nyomaival, rajta ráolvadt kéreggel (salak?). A minta teljes felületét utólagos karbonátos kiválás borítja vékonyan. Anyag: mikrogránit. Származás: Marosvölgy. 


\section{Ábrák}

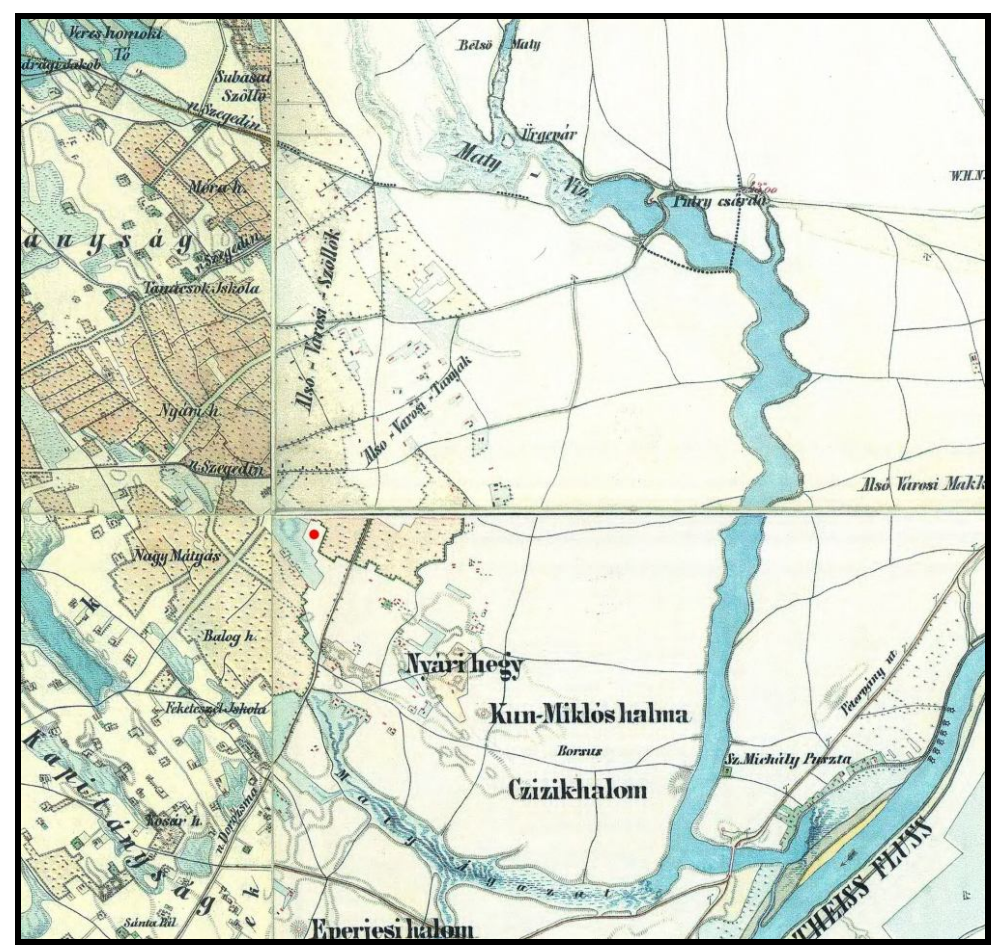

\section{1. ábra}

A lelőhely (pirossal) a II. katonai felmérésen. Jól látható a Maty-ér és a Maty Ágazat, valamint a semlyékek

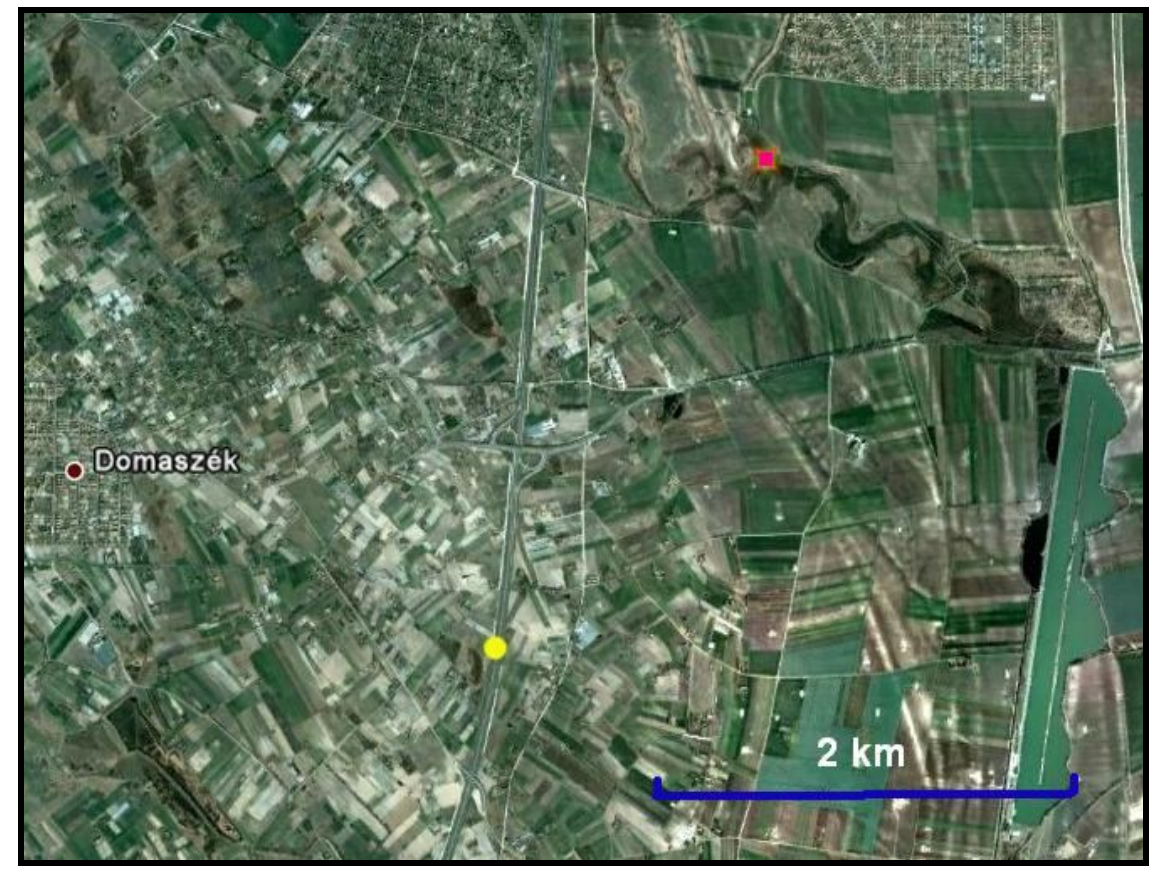

2. ábra A lelőhely (sárga) és a pollenfúrás (Putri-rét, pirossal) elhelyezkedése a müholdfelvételen (Google Earth) 


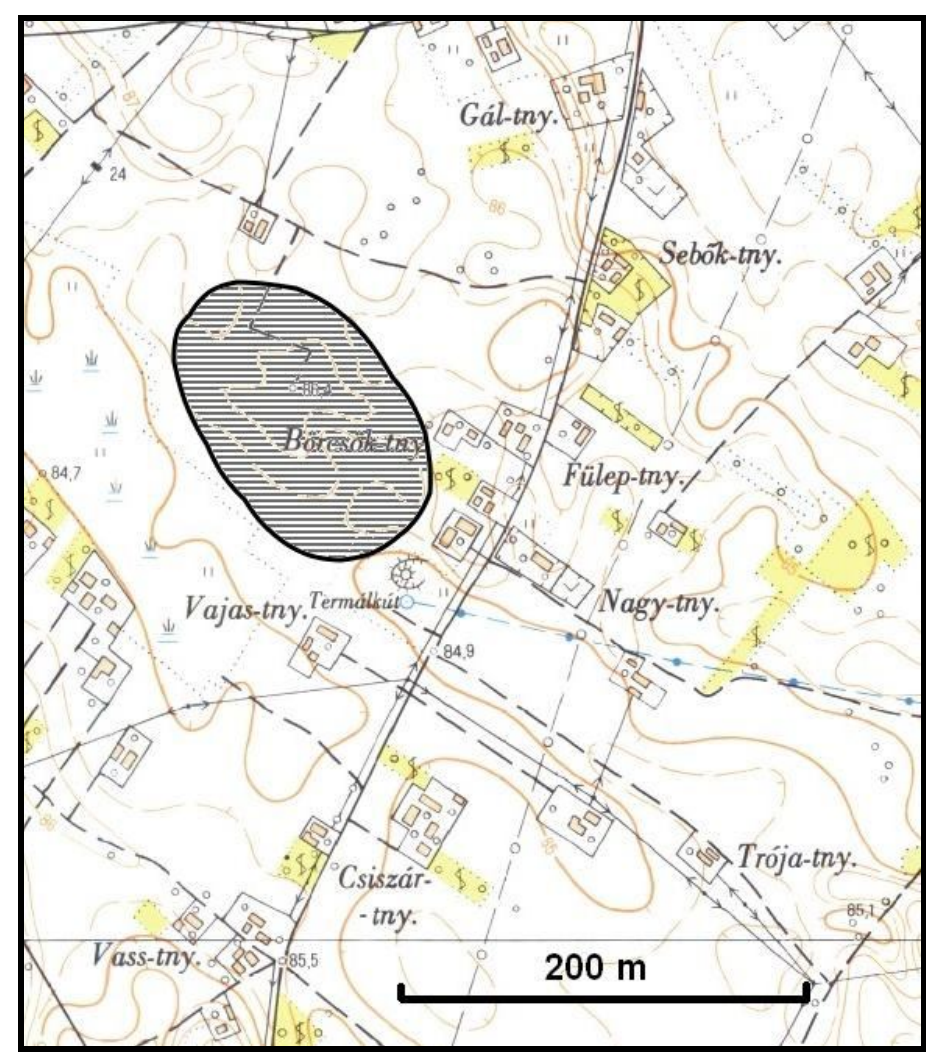

3. ábra A lelőhely (M5/81. 1h.) az 1:10000 méretarányú topográfiai térképen (EOV)

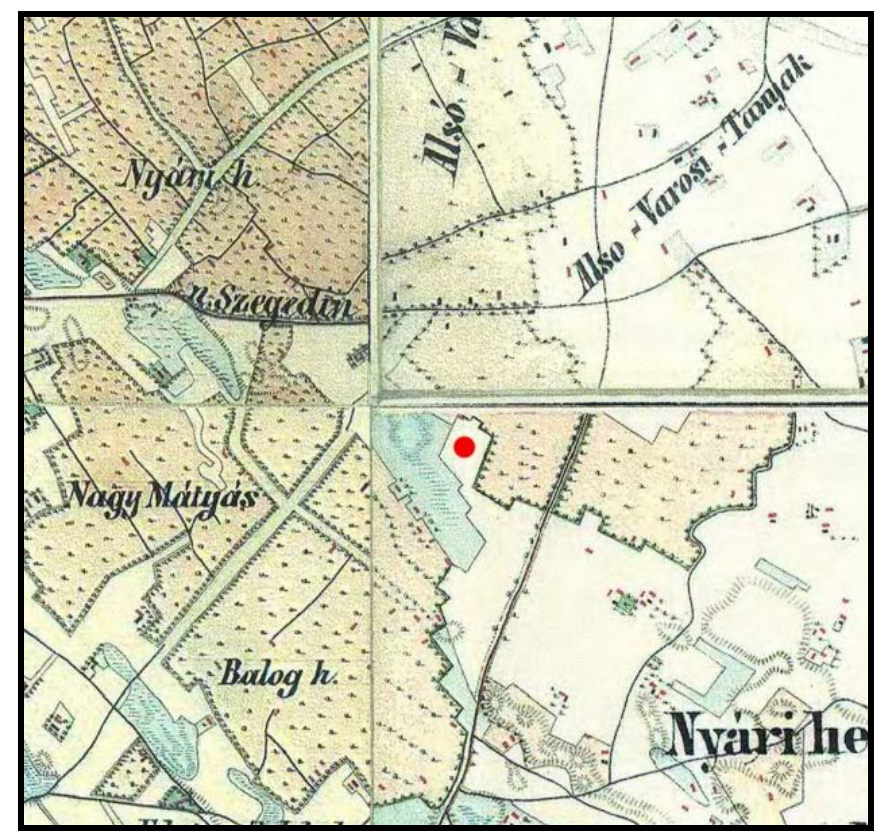

4. ábra A lelőhely környéke a II: katonai felmérésen. Tájhasznosítás a 19. század elején. 


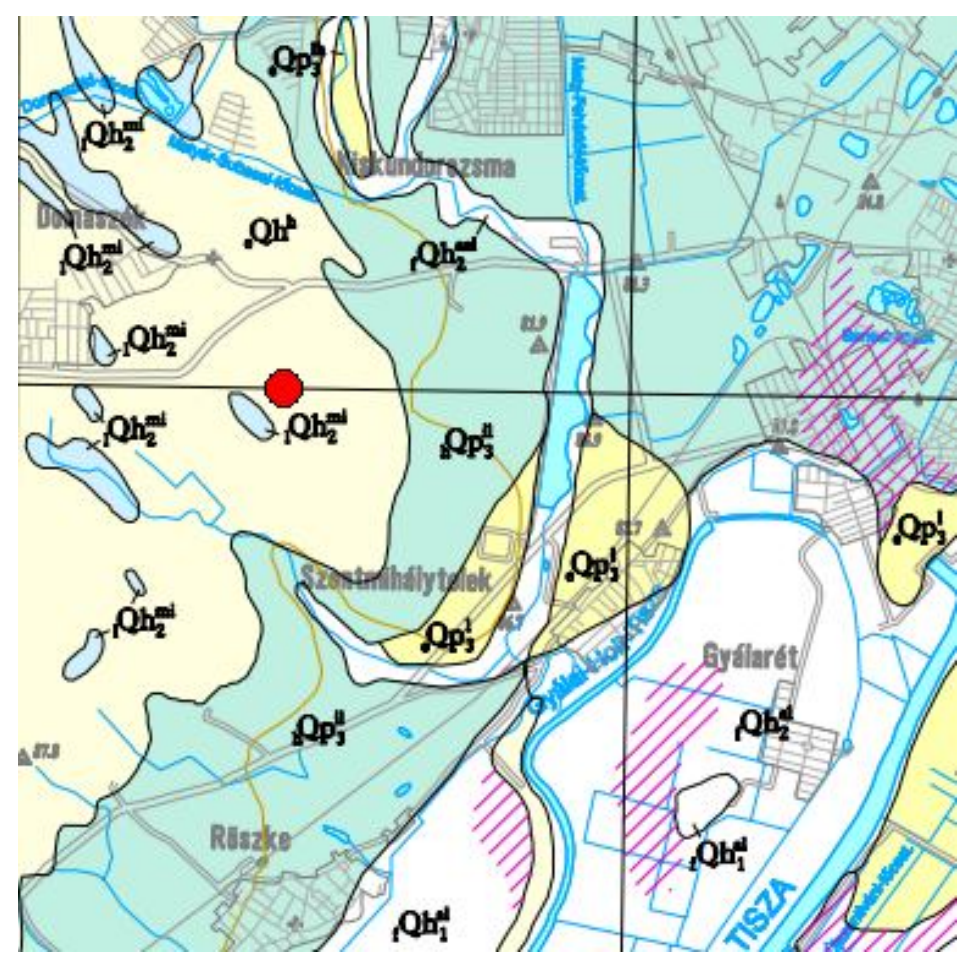

JELMAGYARÁZAT

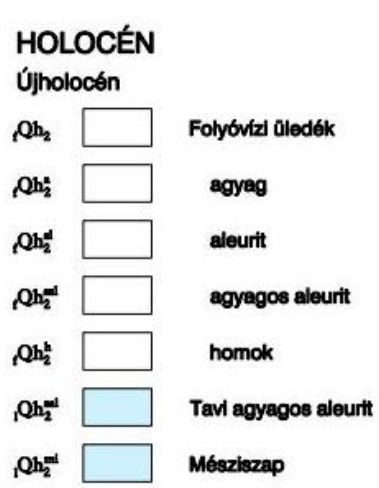

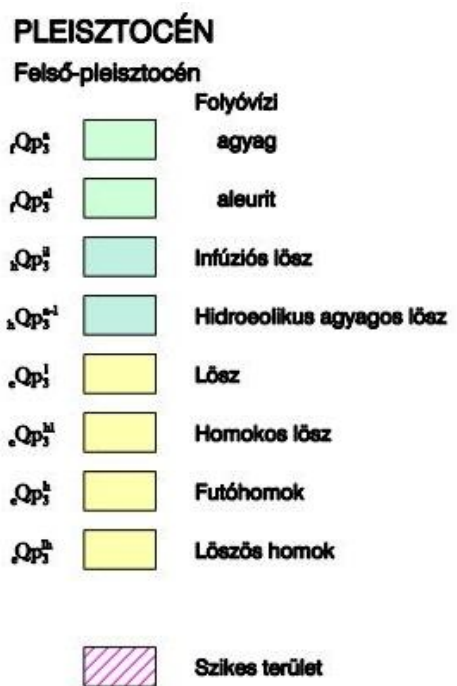

Óholocén

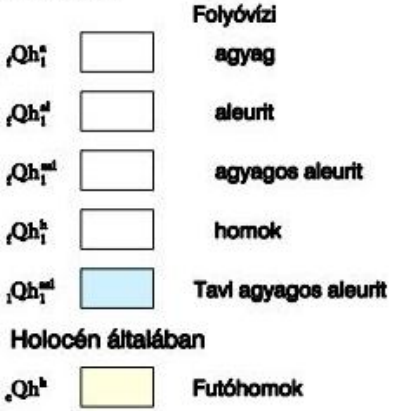

5. ábra A Maty-ér környezetének felszíni földtani térképe (MÁFI) 


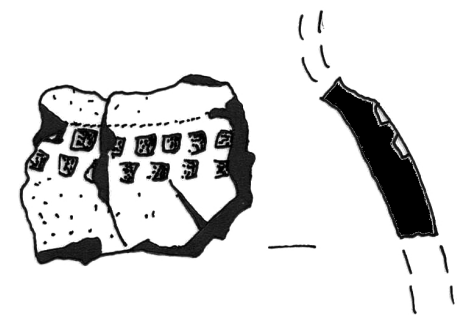

6. ábra Késő rézkori (kostolaci kultúra) edénytöredék Domaszék határából. Szórvány, közöletlen. MFM Ö 53.4.2, M=1:2
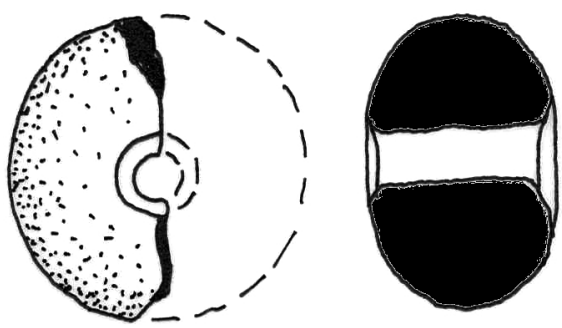

7. ábra Ismeretlen korú (neolit, rézkori vagy bronzkori) kőbuzogány mészkőből csiszolt feje. Domaszék. MFM Ö 53.4.7. $\mathrm{M}=1: 2$

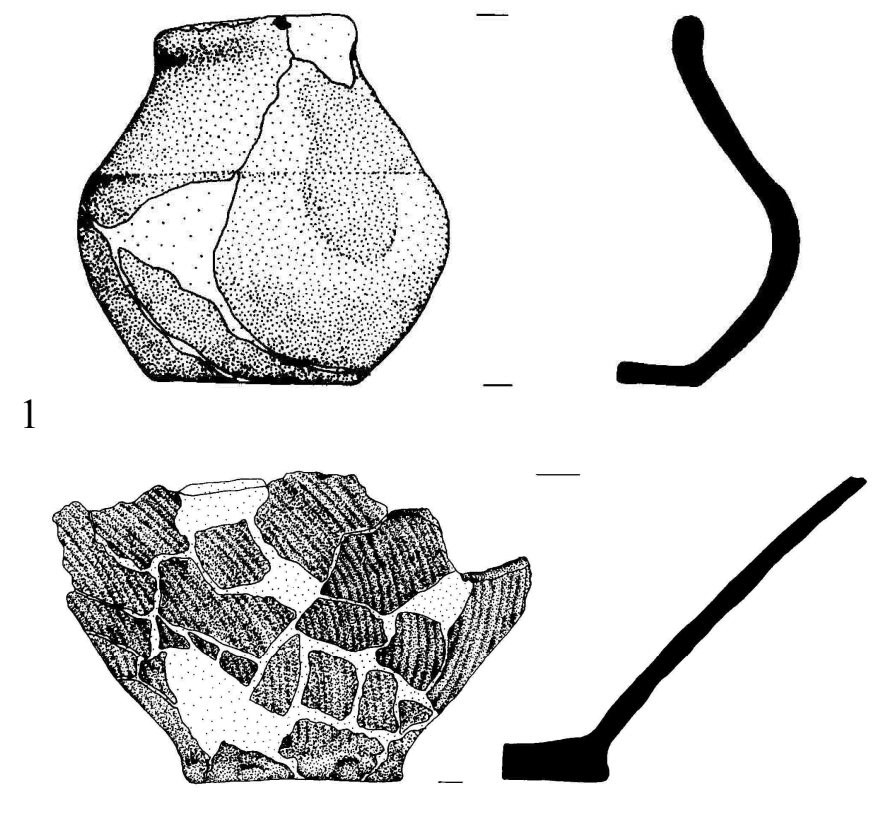

2

8. ábra 1. Nagyrév-kultúra bögréje.

Domaszék-Börcsök tanya, 170. objektum, MFM Ö 2007.2.1642. M=1:2, 2. Nagyrév-kultúra hombárjának aljtöredéke seprüzéssel. Uo., MFM Ö 2007.2.1643. 309. objektum, M=1:4 

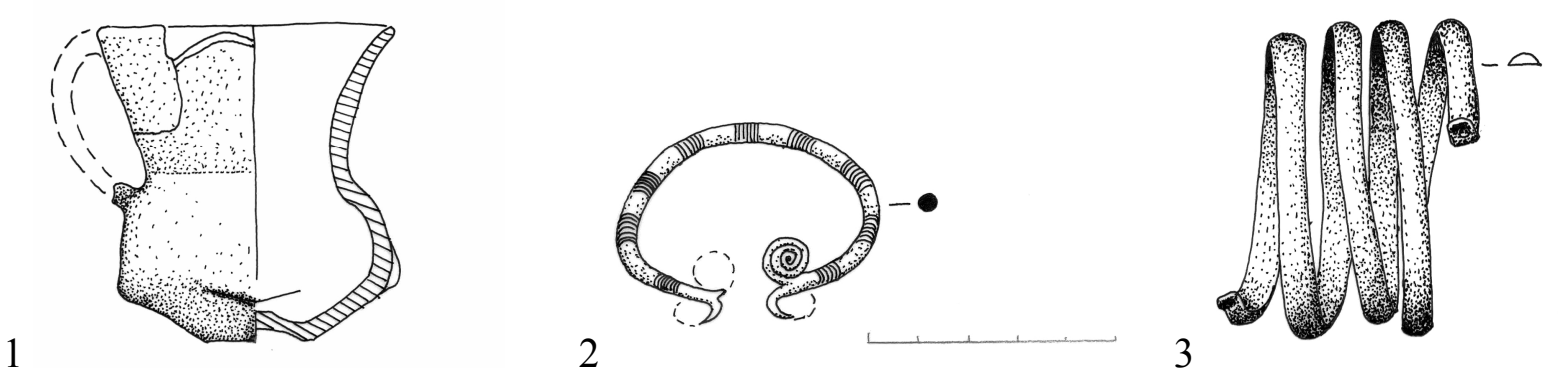

9. ábra Korai halomsíros sír leletanyaga Nagyszéksós-Oltványi tanyáról (Mórahalom). MFM Ö 53.17.1, 53.60.1-2. M=1:2 1. Bögre, 2. Spirálokban végződő karperec, 3. Pödrött végü kartekercs.
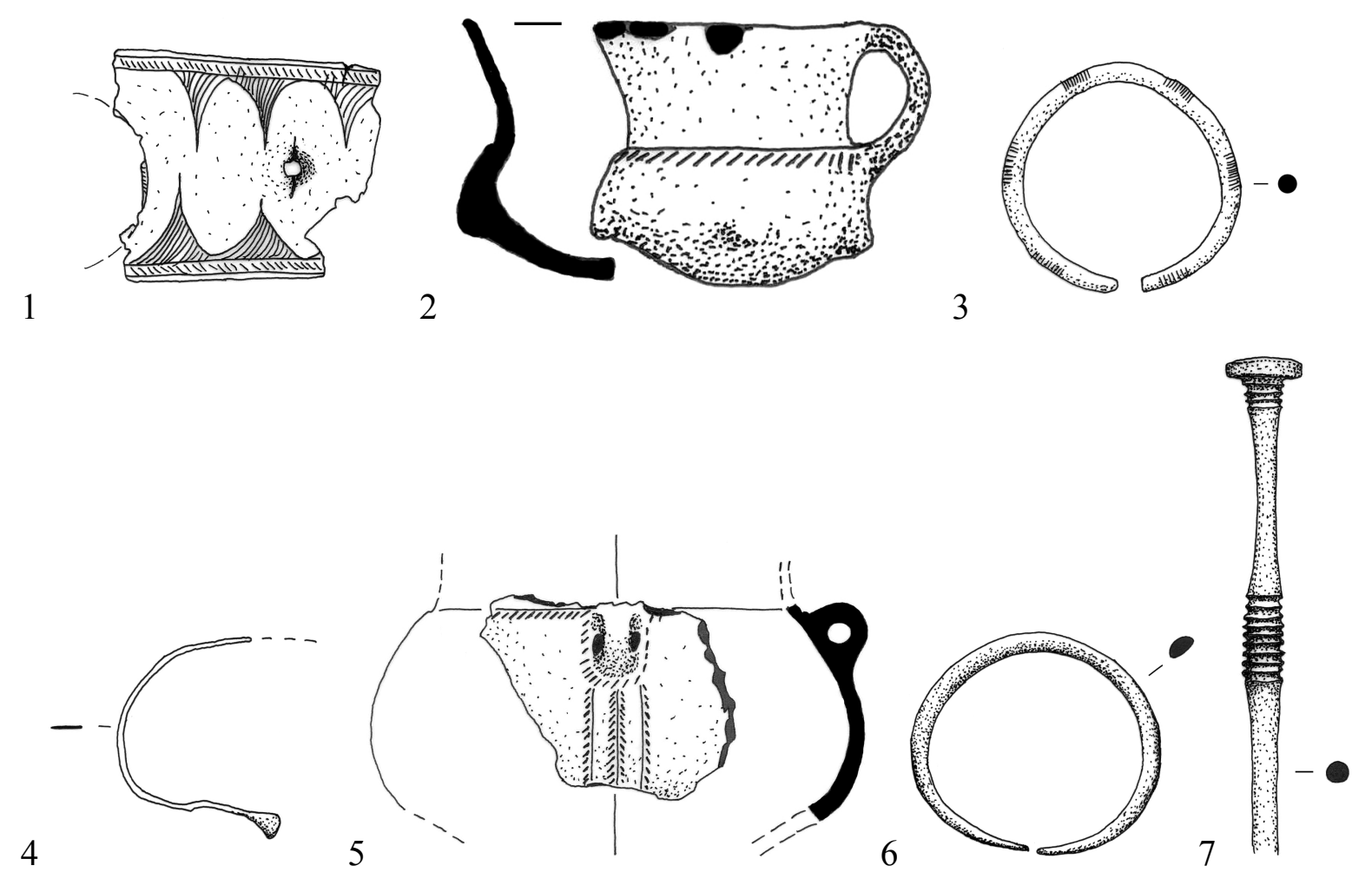

10. ábra Halomsíros síregyüttes Szeged-Kiskundorozsma-Átokháza dűlő lelőhelyről. Szórvány, közöletlen. MFM Ö 53.61.1-6, 8. M=1:2, kivéve az 5., ott M=1:4.

1. Lemezöv töredék, 2. Bögre, 3. Karperec, 4. Karperec töredék, 5. Urna töredék, 6. Karperec pár (2db, egyik rajzolva, a kettő azonos öntőformából), 7. Tủ pár (azonosak, csak az egyik rajzolva). 
1.

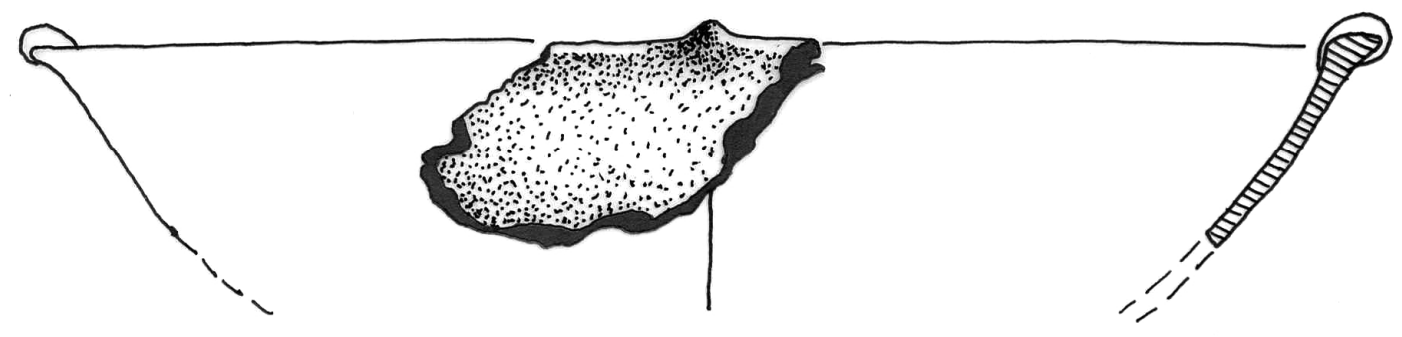

2.

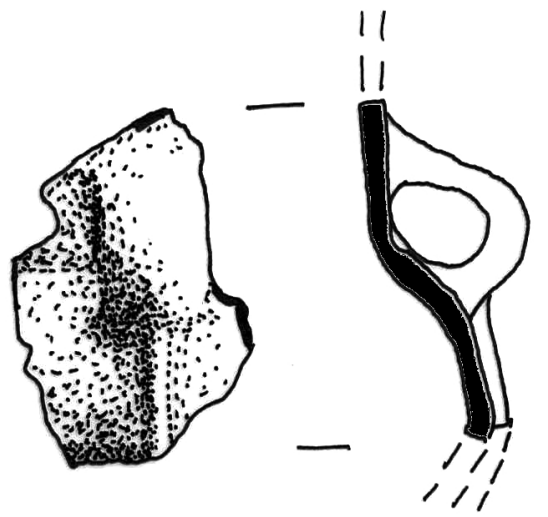

3.

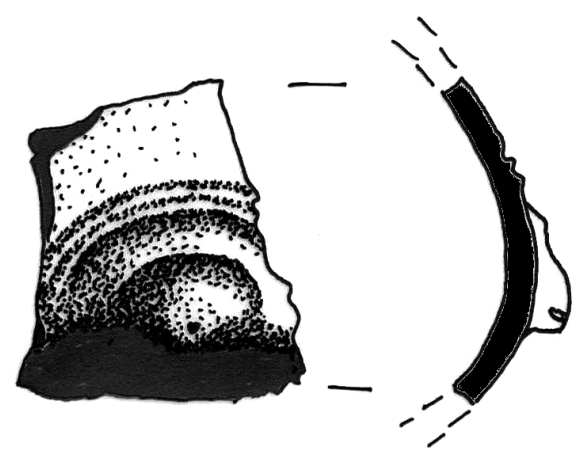

11. ábra 1. Halomsíros tál töredéke. Domaszék, közöletlen szórvány. MFM Ö 53.4.5. M=1:2,

2. Domaszék, közöletlen szórvány. Halomsíros kultúra. MFM Ö 53.4.6. M=1:2, 3. Körülárkolt bütyökkel díszített edénytöredék Domaszék határából. Halomsíros (?) kultúra. MFM Ö 53.4.4/1. M=1:2.
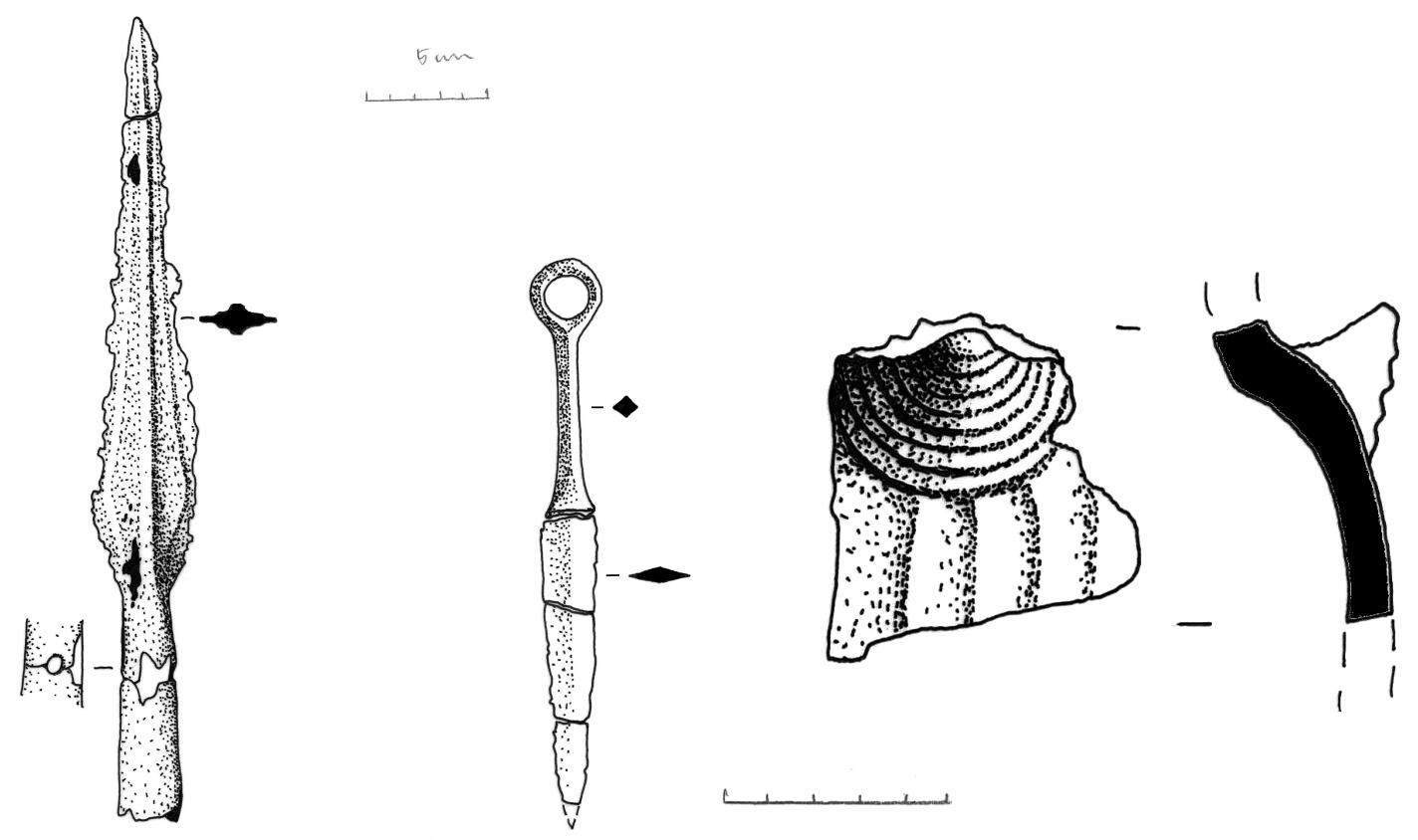

12. ábra 1. Késő bronzkori (Ha A1-2) lándzsahegy 2. Karikás markolatú tőr KiskundorozsmaBábadűlő lelőhelyről. Szórvány, közöletlen. MFM Ö 53.61.7., 53.88.5. M=1:4, M=1:2

3. A Gáva-kultúra edénytöredéke Domaszék határából. Szórvány, közöletlen. MFM Ö 


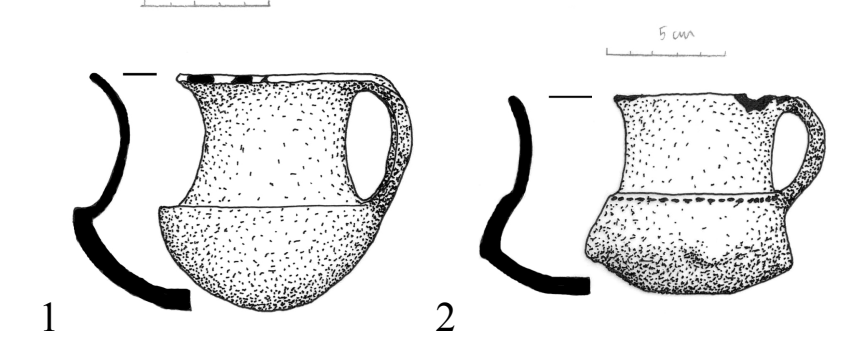

3
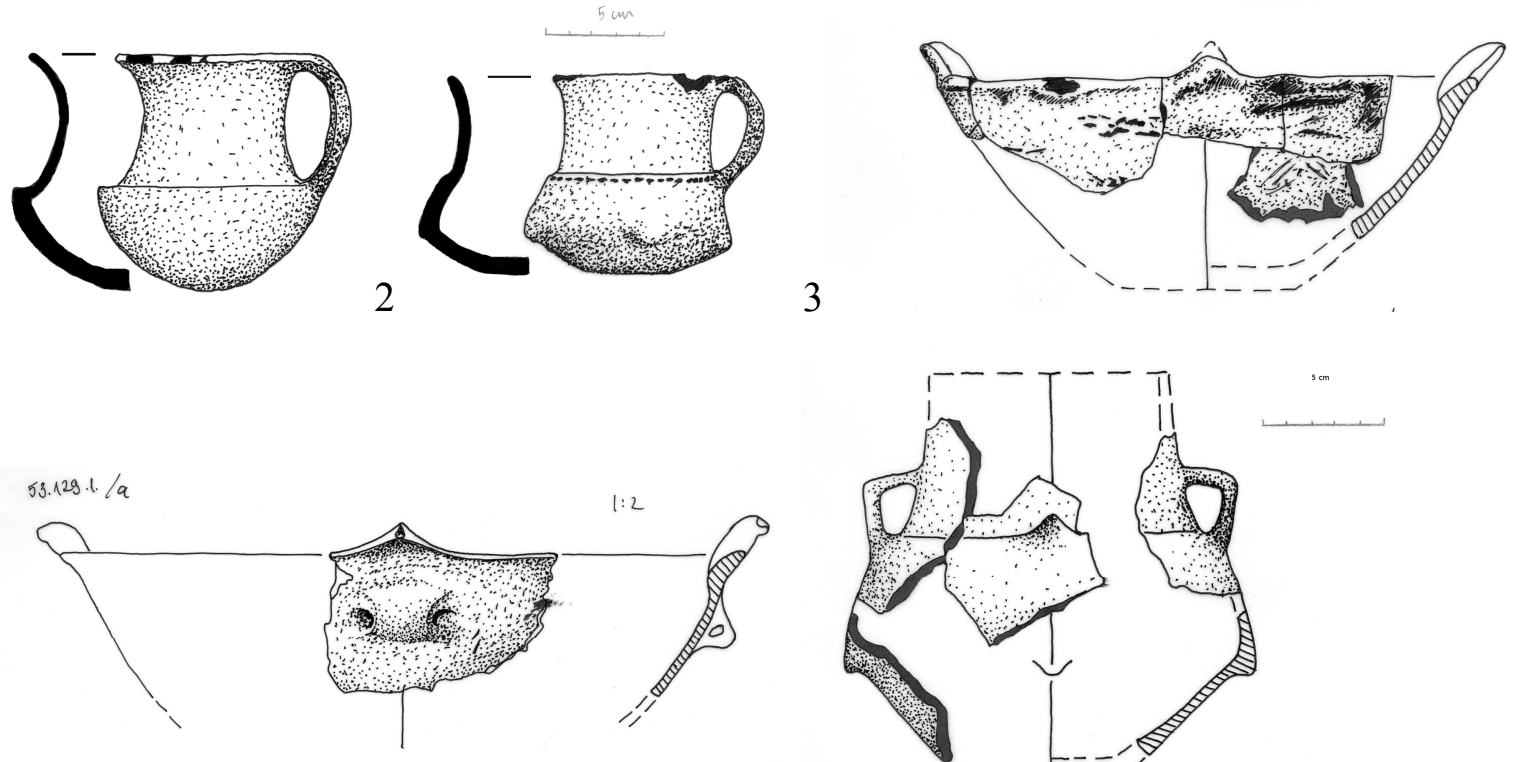

4

5
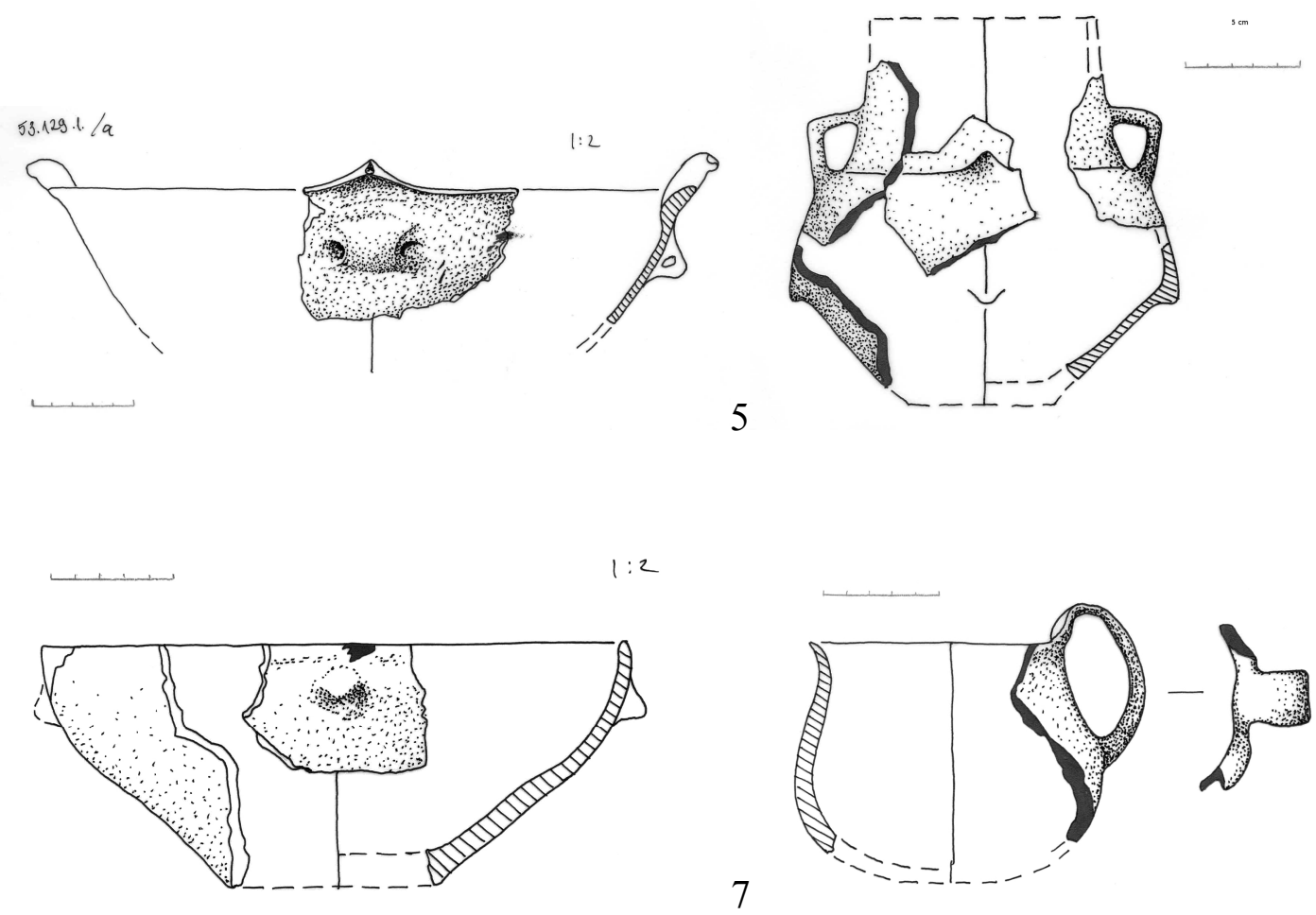

6

7
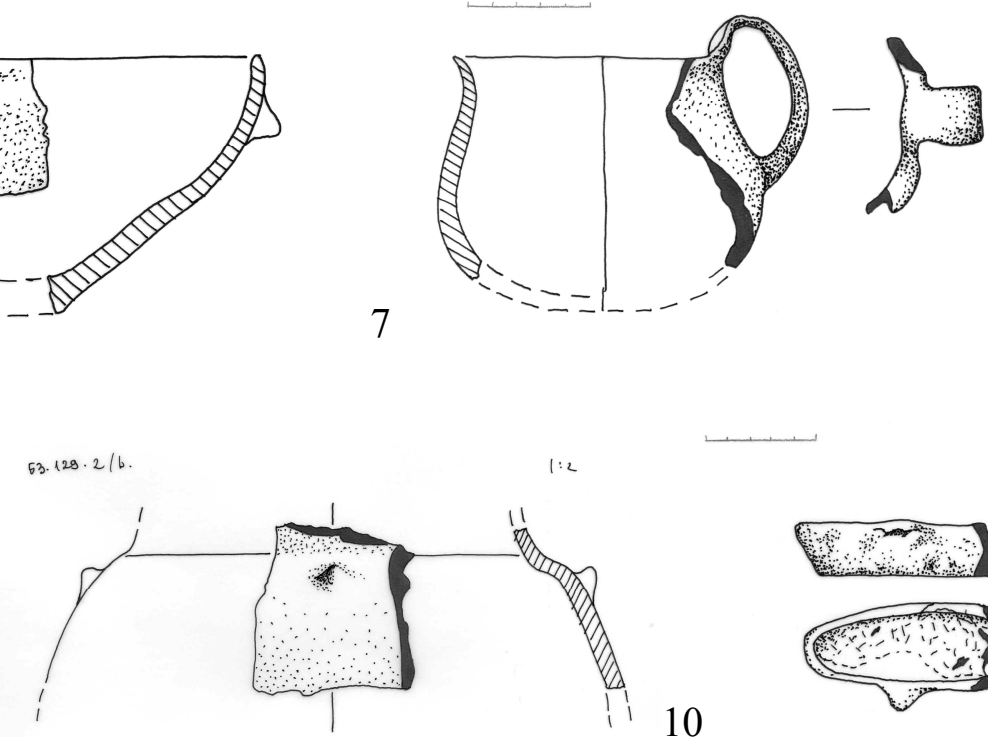

10

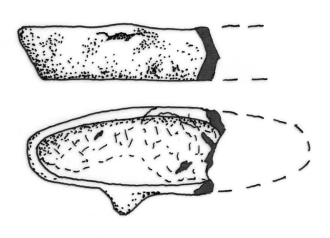

13. ábra 1. Ruzsa, Lapos iskola, szórvány, közöletlen. Késő (?) Vatya kultúra. MFM Ö. 80.26.1. M=1:4. 2. Ruzsa, Honvéd iskola. Szórvány, közöletlen. Korai (?) halomsíros kultúra. MFM Ö. 80.25.1. M=1:4. 3-10. Szeged-Alsóközpont (Ásotthalom) - Dobó (tanya). Szórvány, közöletlen sír- vagy temetőanyag. MFM Ö. 53.129.1-4. M=1:4. 


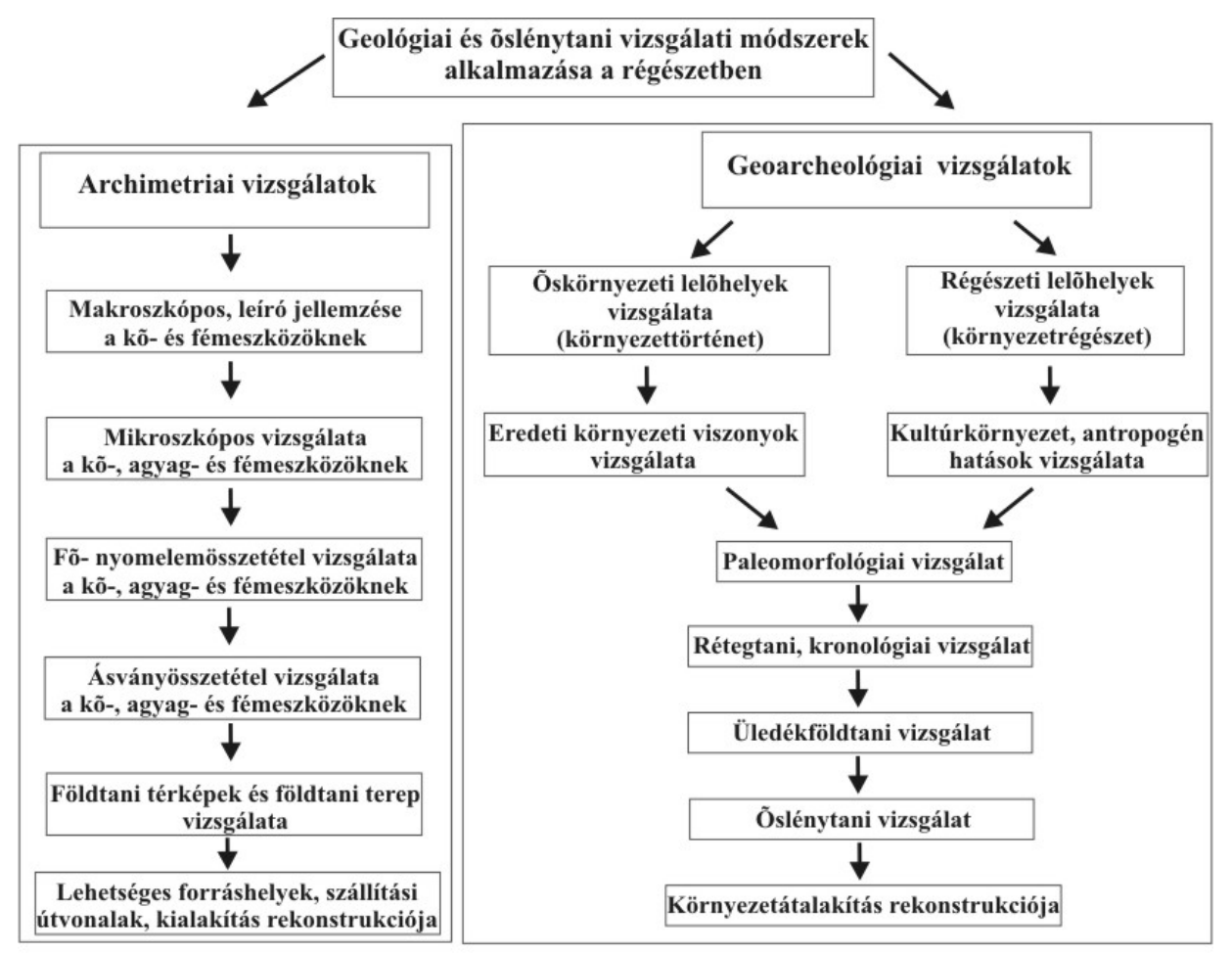

1.ábra A régészeti geológia, történeti ökológia, környezetrégészet, archimetria tudományterületi összefüggései

14. ábra A régészetben alkalmazott geológiai és őslénytani vizsgálati módszerek összefüggései és kutatási logikája (Sümegi, 2003 nyomán)

${ }_{7}^{14} \mathrm{~N}+{ }_{0}^{1} \mathrm{n} \rightarrow{ }_{6}^{14} \mathrm{C}^{*}+{ }_{1}^{1} \mathrm{p}$

15. ábra A radiokarbon keletkezése

${ }_{6}^{14} \mathrm{C}^{*} \rightarrow{ }_{7}^{14} \mathrm{~N}^{*}+{ }_{-1}^{0} \mathrm{e}^{-}+\bar{\nu}$

16. ábra A radiokarbon bomlási folyamata

bp vagy uncal. bp - before present: kalibrálatlan dátum 1950-hez viszonyítva

bc vagy uncal. bc - before christ: kalibrálatlan dátum 0-hoz viszonyítva

BP vagy cal BP - Before Present: kalibrált dátum 1950-hez viszonyítva

BC vagy cal BC - Before Christ: kalibrált dátum 0-hoz viszonyítva.

1. táblázat. A radiokarbon datálás nevezéktana a kalibráció függvényében 

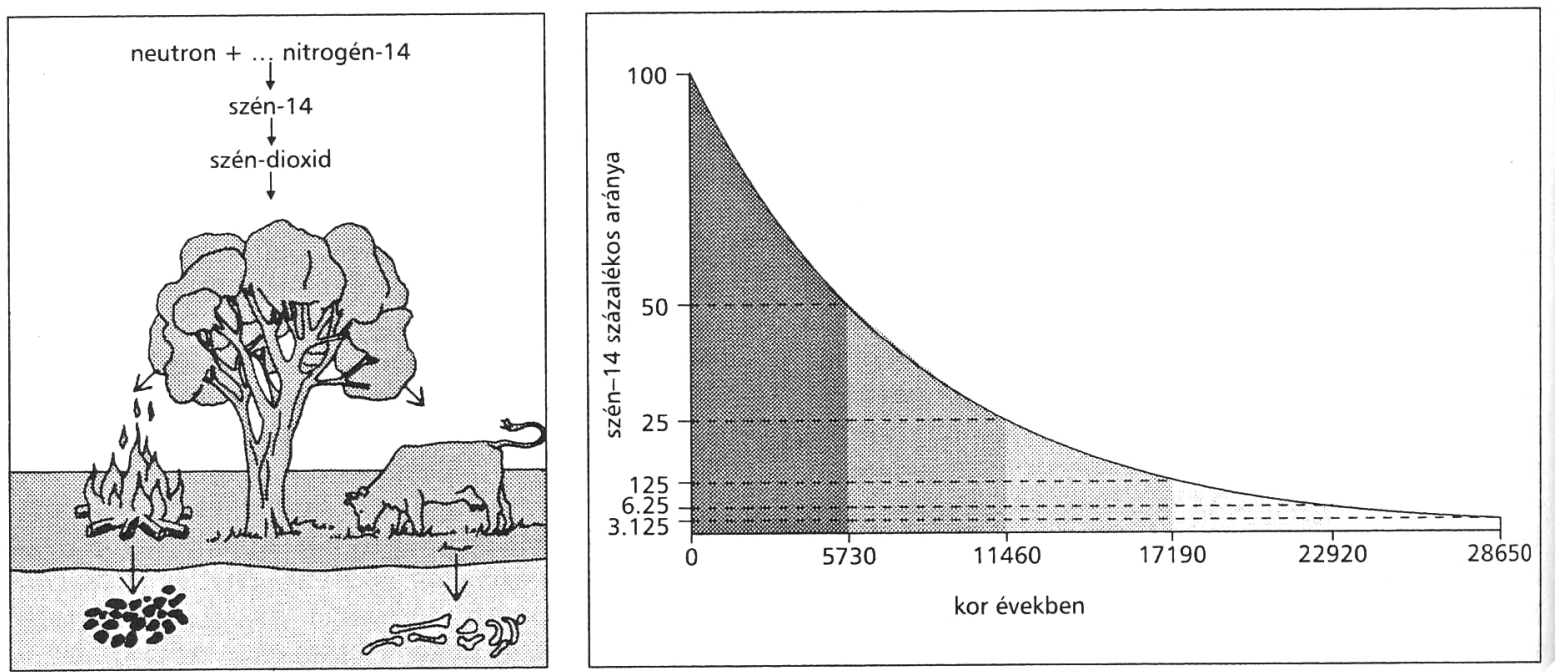

17. ábra A radiokarbon körforgása a természetben (balra), valamint a C14 bomlási görbéje (jobbra) (Renfrew-Bahn, 1999, 132. oldal ábrája nyomán)

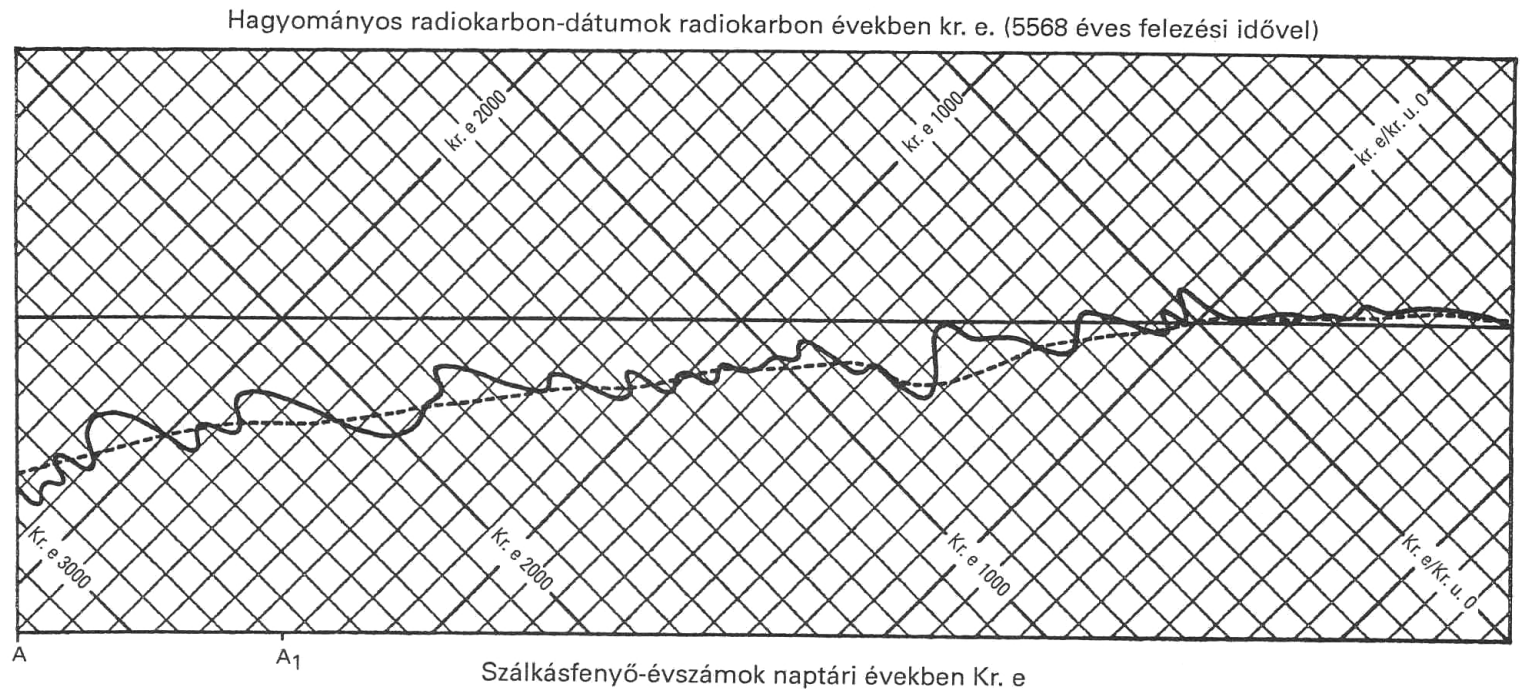

18. ábra A faévgyürüs kalibrációs görbe bronzkori és vaskori szakasza. A minket érdeklő, 1500 cal BC körüli időszakban a görbe kilengése közepes, az (uncal.) bc adatok szórása 200 év, a cal. értékeké csak 50 év (Renfrew 2001, 58. ábra, 285. o. után) 

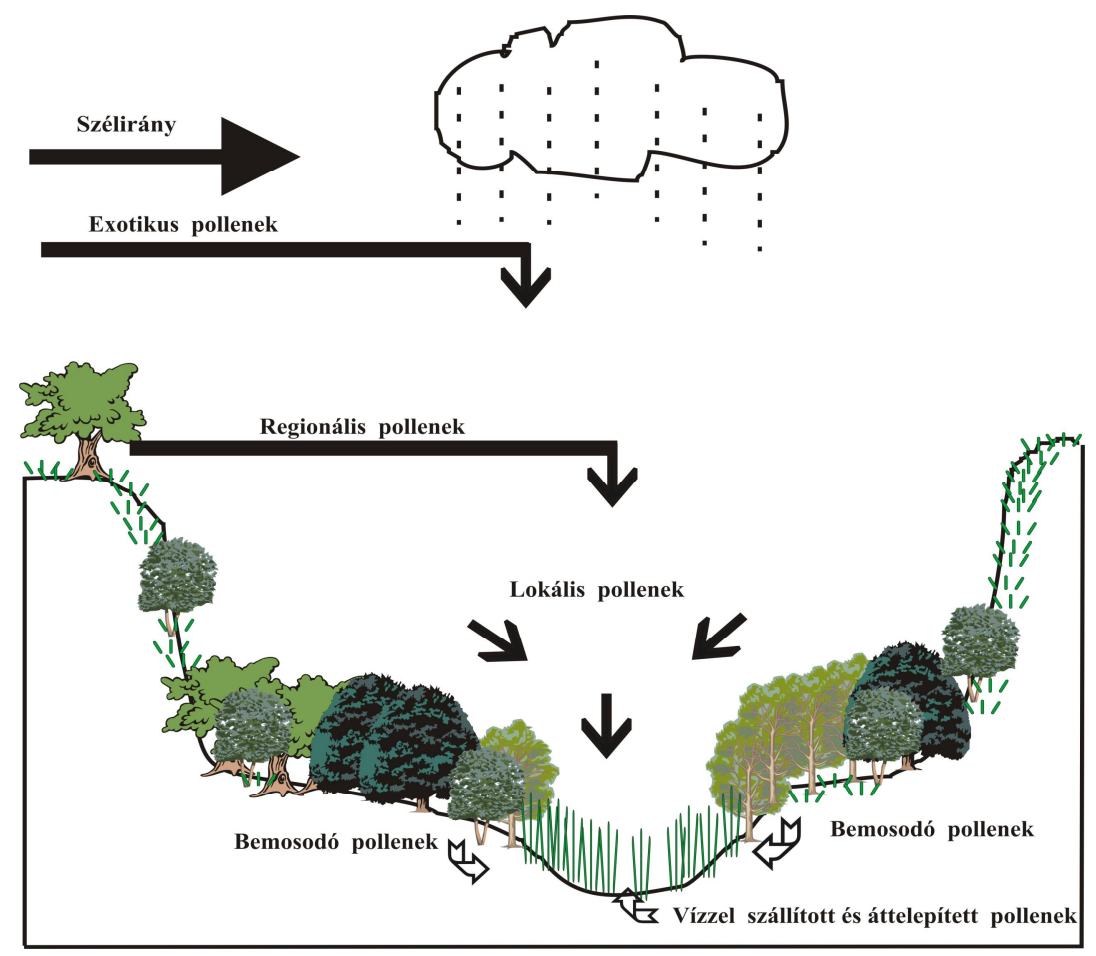

19. ábra A patak- és folyóvölgyben felhalmozódott pollenek eredete. Sümegi 2003 nyomán

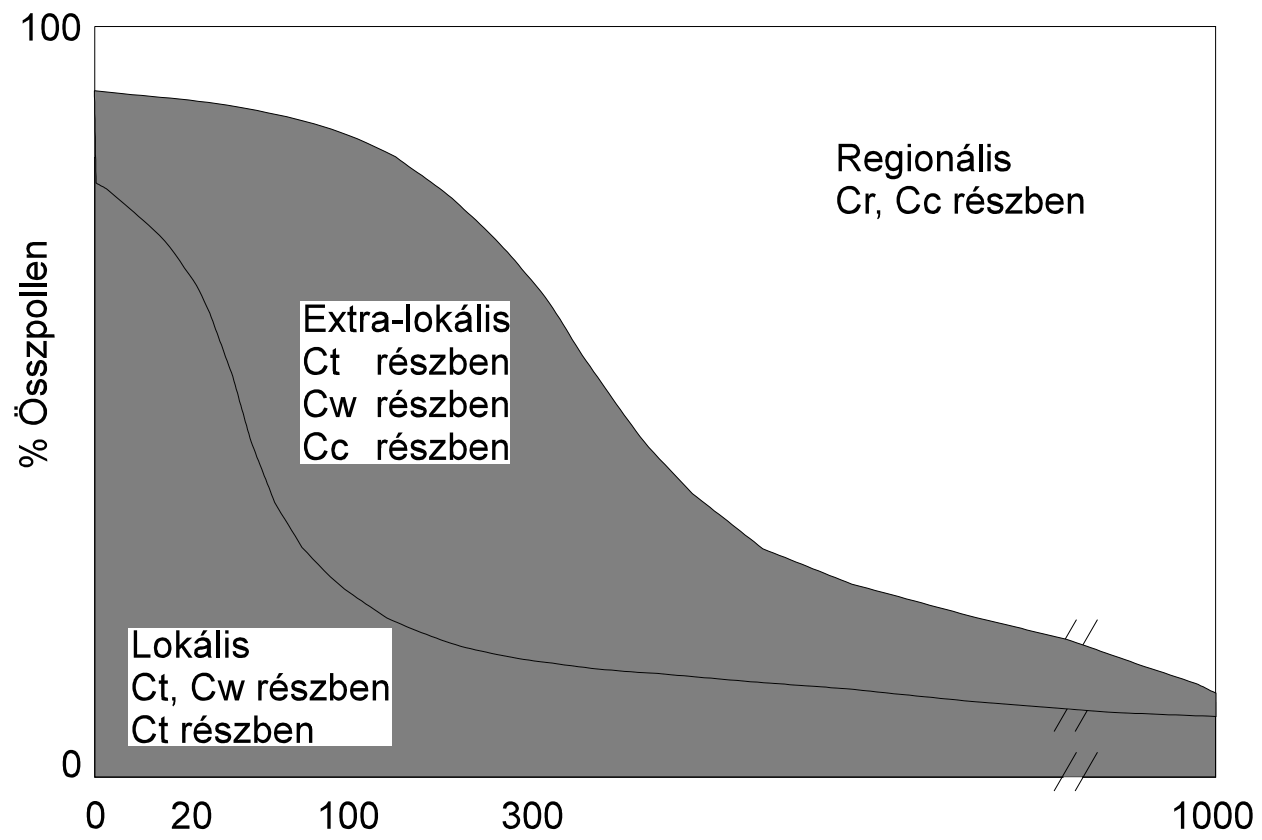

20. ábra A pollengyüjtő medence mérete és a virágporszemek származási területe közötti összefüggés (Jacobson - Bradshaw, 1981 nyomán) 


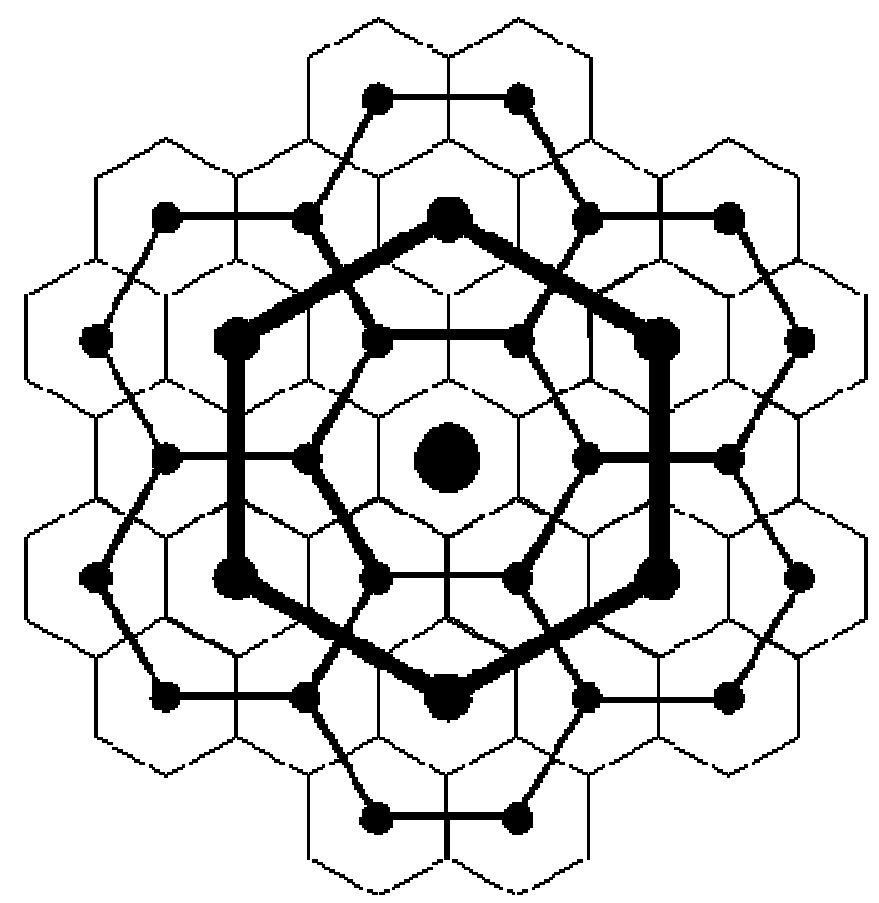

21. ábra Központi hely elmélet, Christaller modell vázlata három településhierachiai szinttel (http://webhost.bridgew.edu/jhayesboh/dissert/chapter02/CHAPTERII.HTML nyomán 2011. január 9. 14:53)

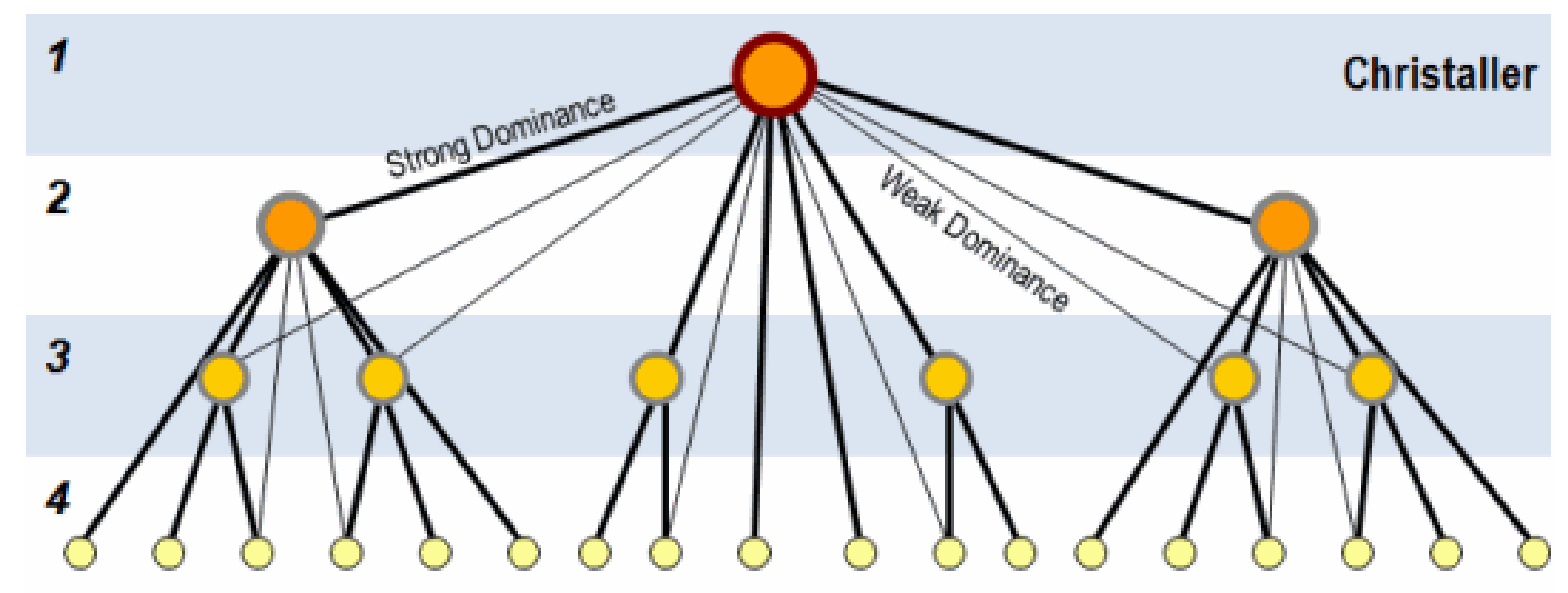

22. ábra Településhierarchia modellje (Christaller-féle modell hierarchia-fája)

(http://people.hofstra.edu/geotrans/eng/ch2en/conc2en/urbanhierarchy.html nyomán 2011. január 9. 14:59) 


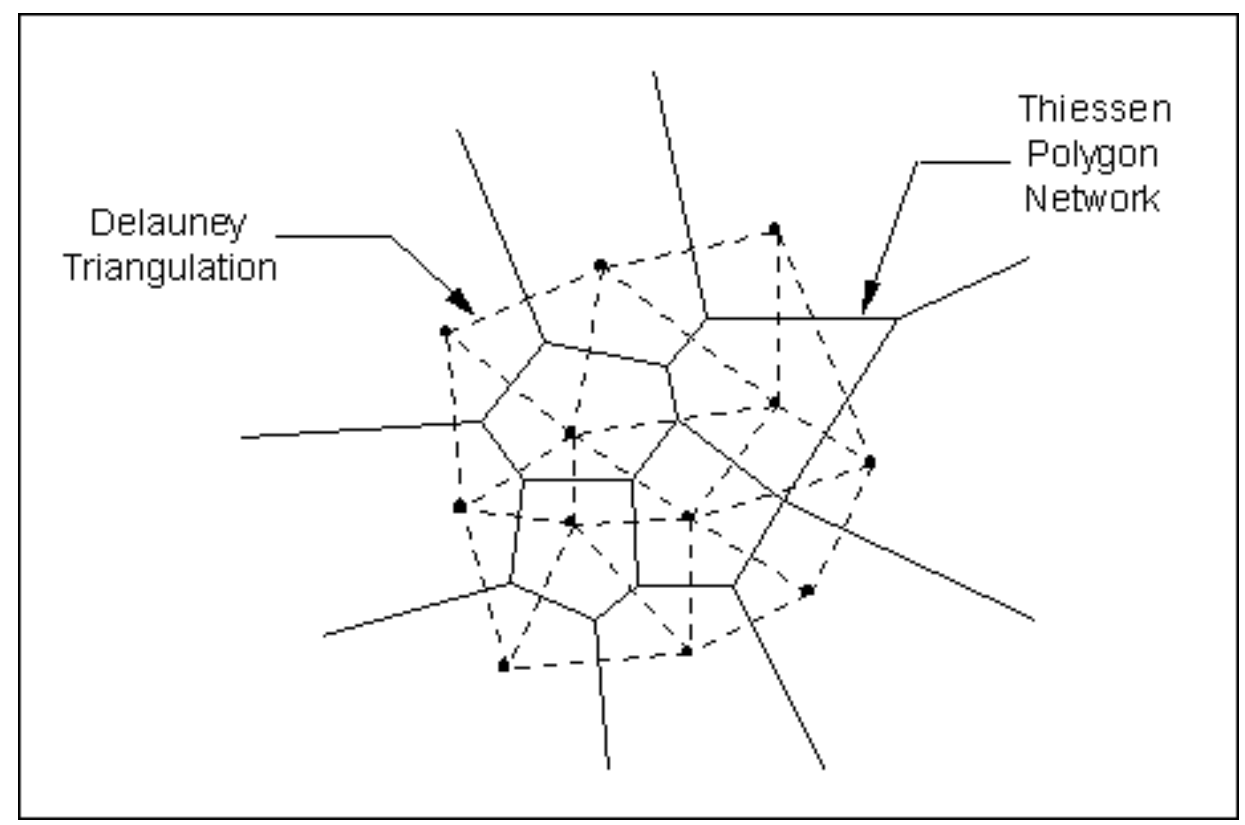

23. ábra Thiessen-poligonok (http://www.ems-

i.com/smshelp/Data_Module/Interpolation/Natural_Neighbor.htm nyomán, 2011. január 9., $14: 42)$

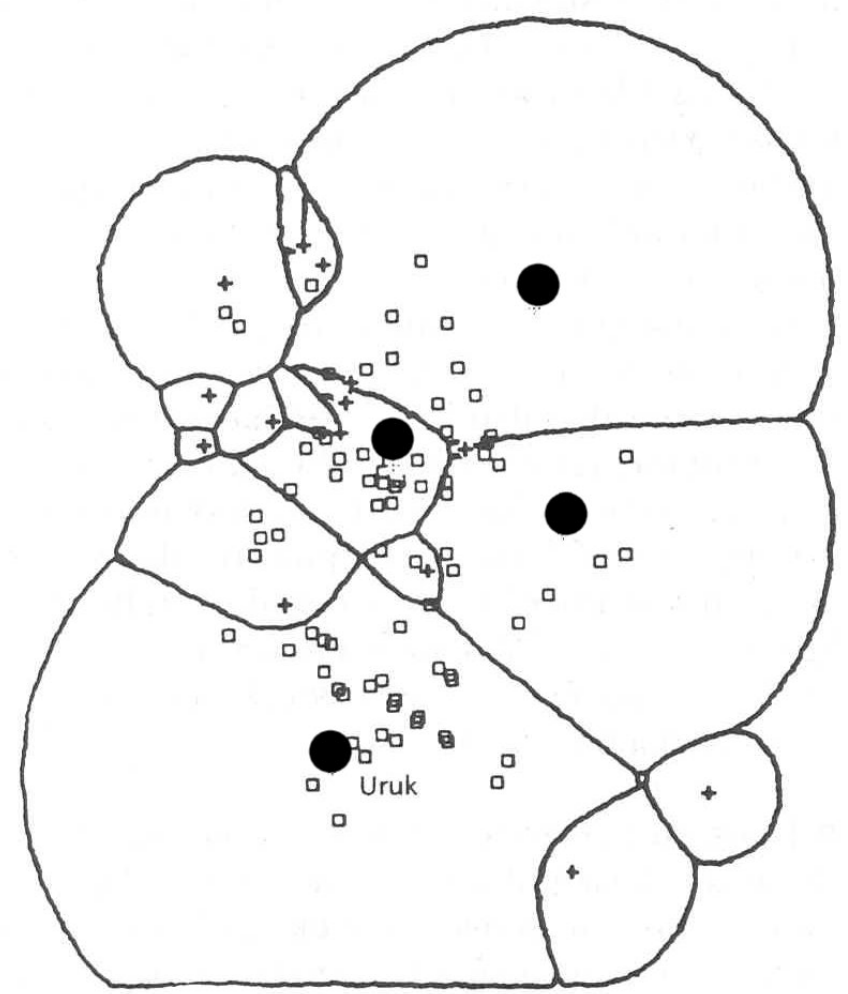

24. ábra XTENT településhierarchia-modell (mezopotámiai példán, az elsődleges centrumokat fekete körök jelölik, Renfrew-Bahn, 1999, 172 nyomán) 


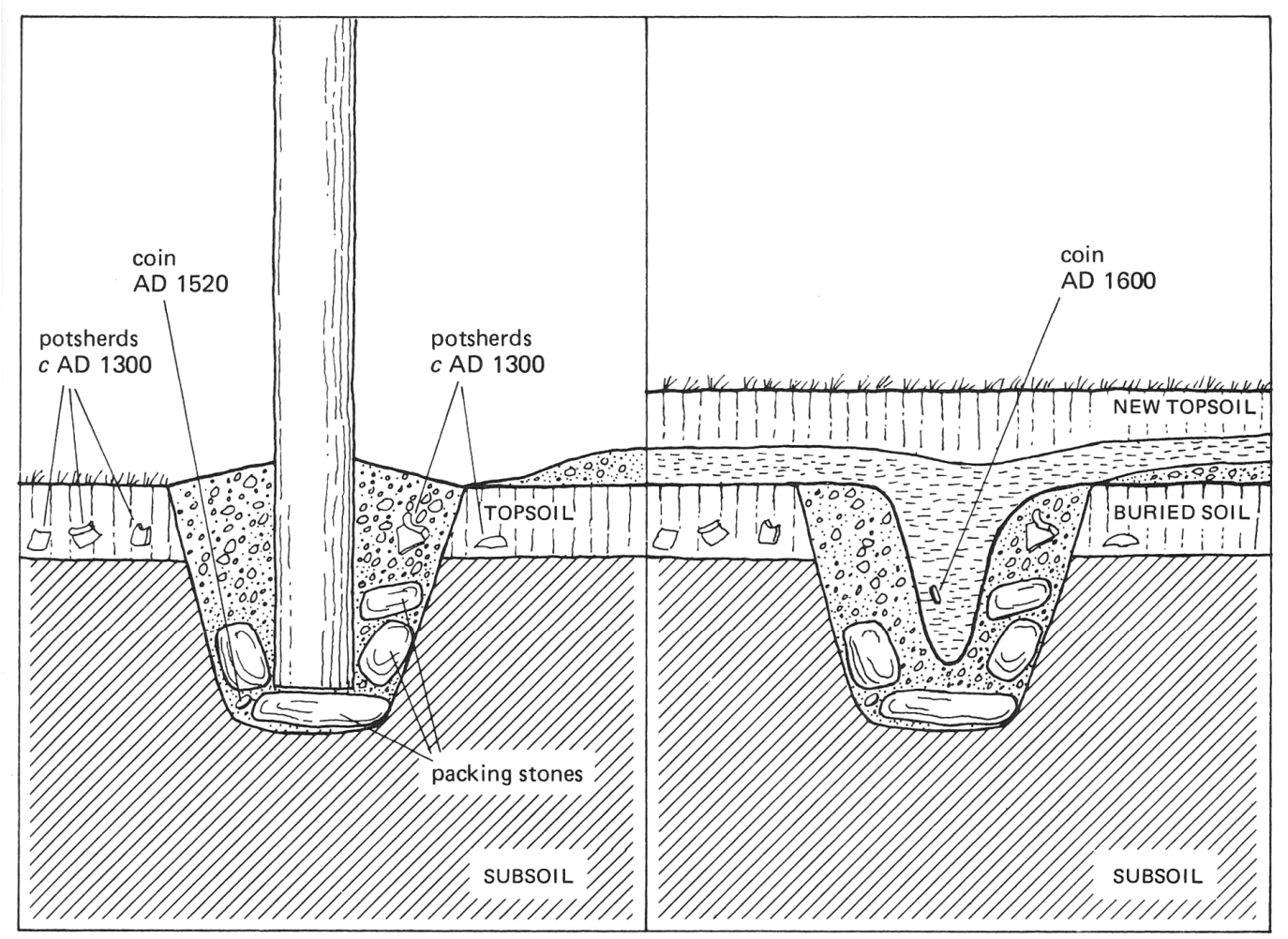

25. ábra Régészeti objektum használata és betemetődése, rétegtani viszonyai, datálása ideális esetben (késő középkori példa) (Greene 1990, 63. old. 33. kép nyomán)

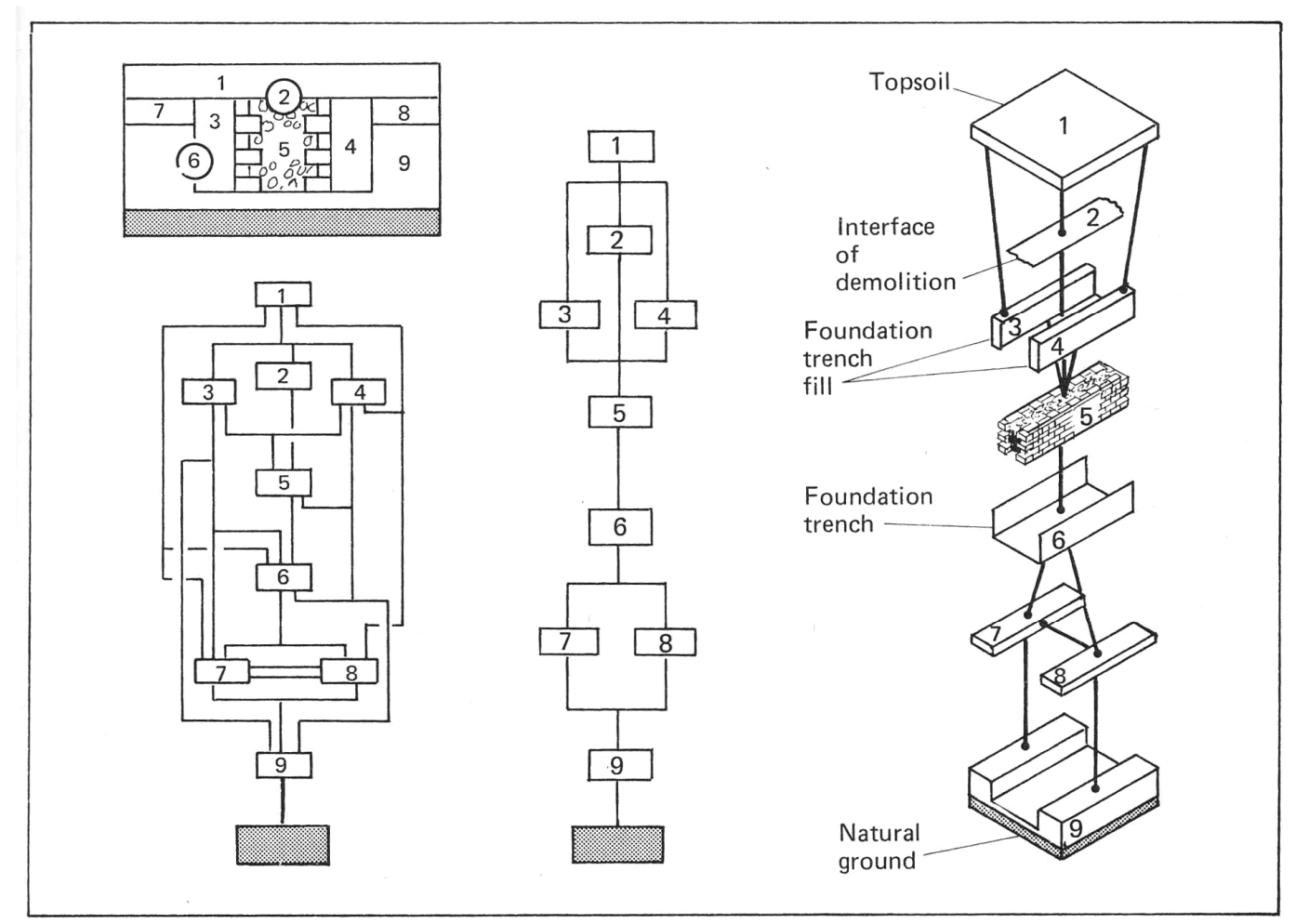

26. ábra A Harris-mátrix, a régészeti rétegtani egységek alapvető logikai ábrázolási eszköze (Greene 1990, 65. o., 35. ábra és Harris 1997, Fig. 12. nyomán) 

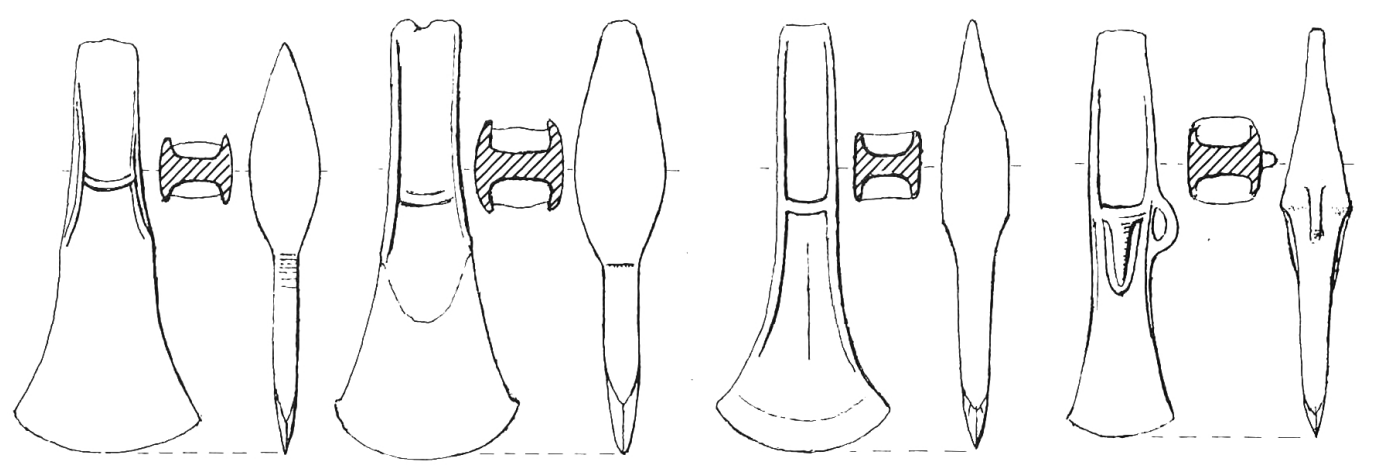

Growth of the stop-ridge
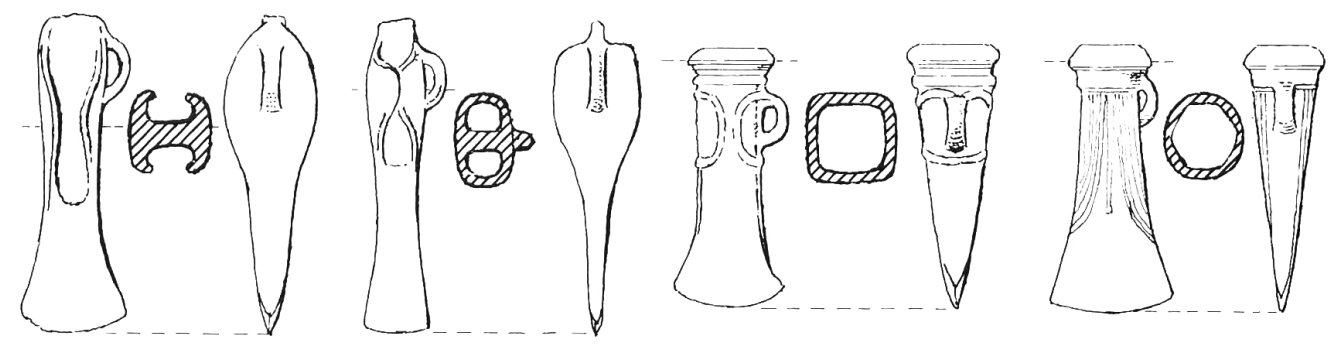

Growth of the wings

27. ábra Tipológiai sorozat az angliai középső és késő bronzkori baltákra (Greene 1990, 100. old., 55. ábra nyomán) 
28. ábra

A Domaszék-Börcsök tanyán (M5/81. lelőhelyen) végzett ásatás felszínrajza. M=1:600 (a nyomtatott változat az eredetinek 3-szoros kicsinyítése).

29. ábra

A Domaszék-Börcsök tanyán feltárt településrészlet Halomsíros objektumai és az azonosított vagy feltételezett épület-alaprajzok.

$\mathrm{M}=1: 600$ (a nyomtatott változat az eredetinek 3-szoros kicsinyítése).

Jelmagyarázat:

Halomsíros objektumok

Feltételezhető Halomsíros objektumok

Halomsíros és Nagyrév leletanyagot

keverten tartalmazó objektumok

Épületek alaprajzát vagy

alaprajz-részletét jelölö körvonalak

Az üresen hagyott objektumok vagy Nagyrévi leletanyagot tartalmaztak, vagy a belőlük előkerült régészeti anyag jellegtelensége miatt nem volt kultúrába sorolható. Az is előfordult, hogy az objektum csak állatcsontot tartalmazott, sőt némely esetben semmiféle régészeti tárgy nem került elő belőle. 


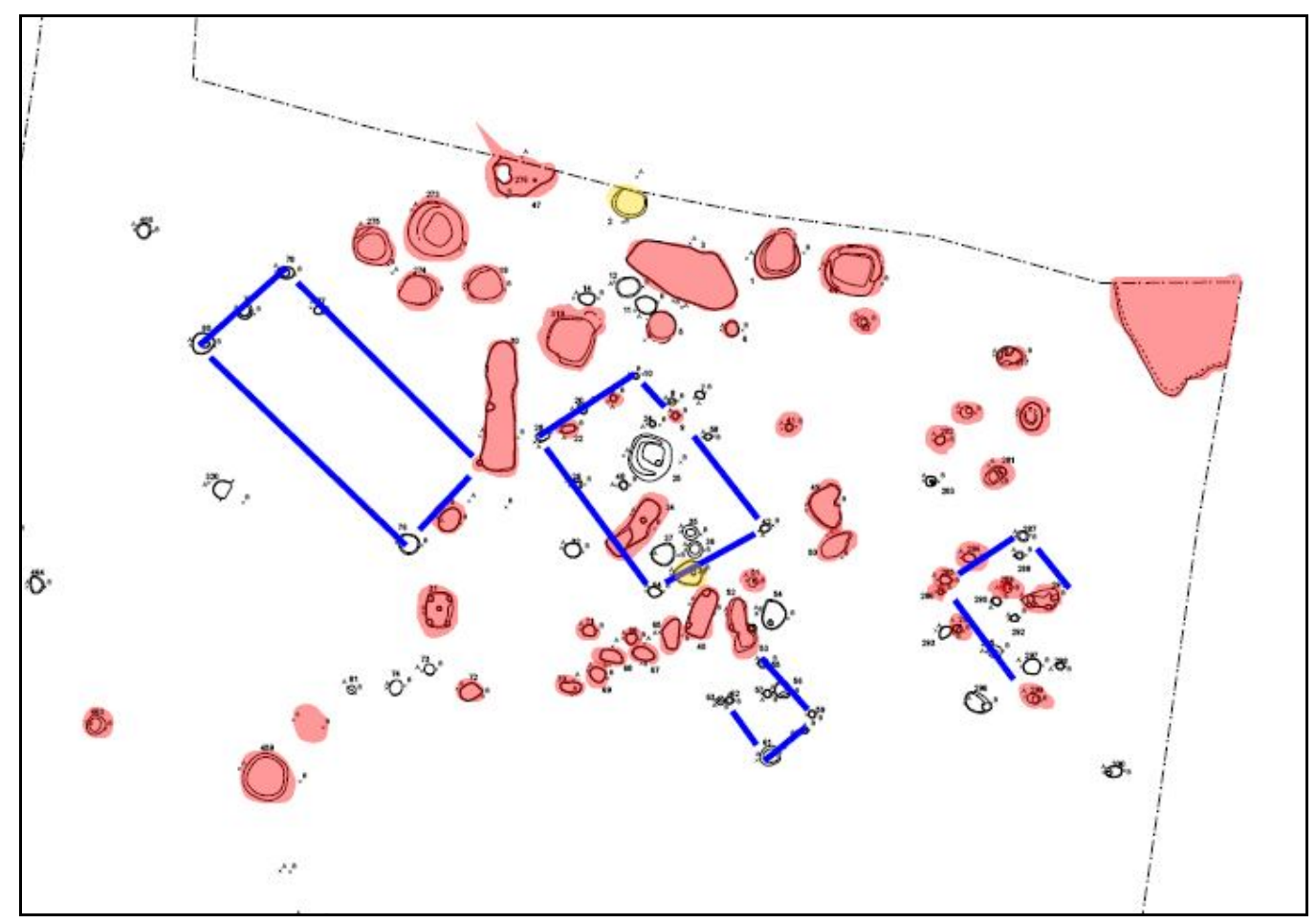

30. ábra Az 1. objektumcsoport, $M=1: 400$ A színek magyarázatát lásd a 29. ábránál

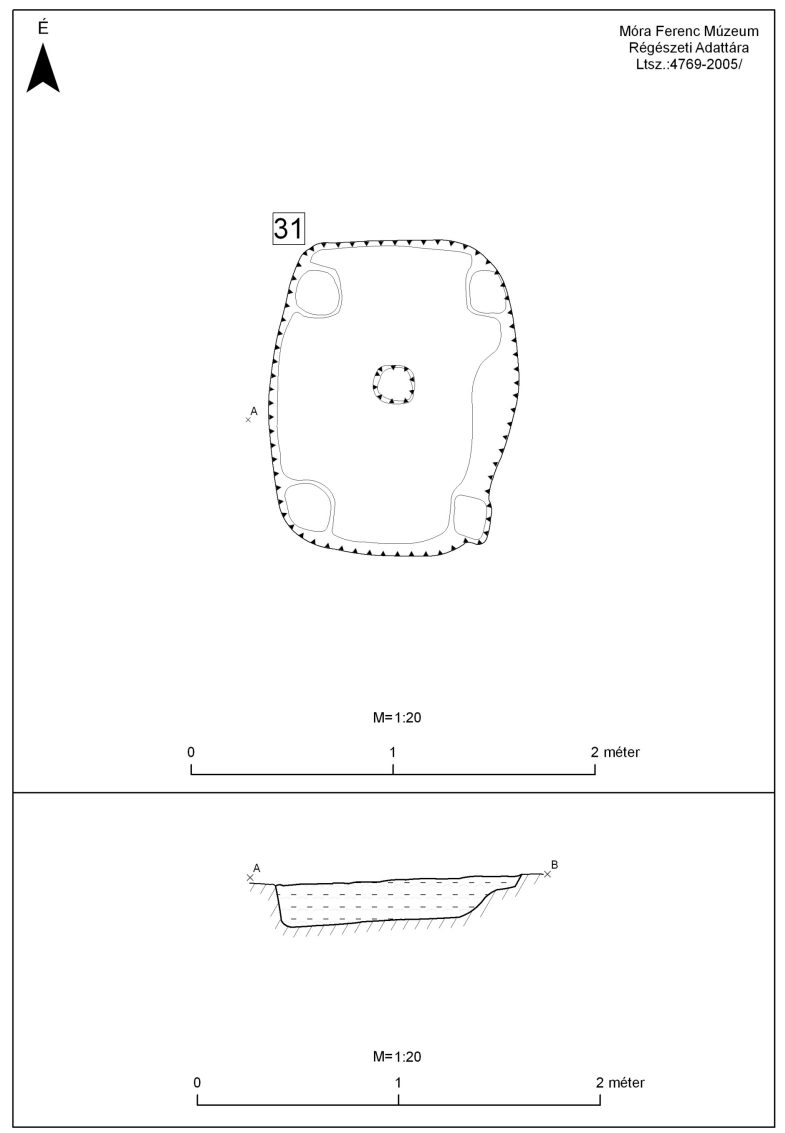

31. ábra A 31. számú objektum (ól, terménytároló vagy más melléképület) $M=1: 40$ (eredeti felére kicsinyítve) 


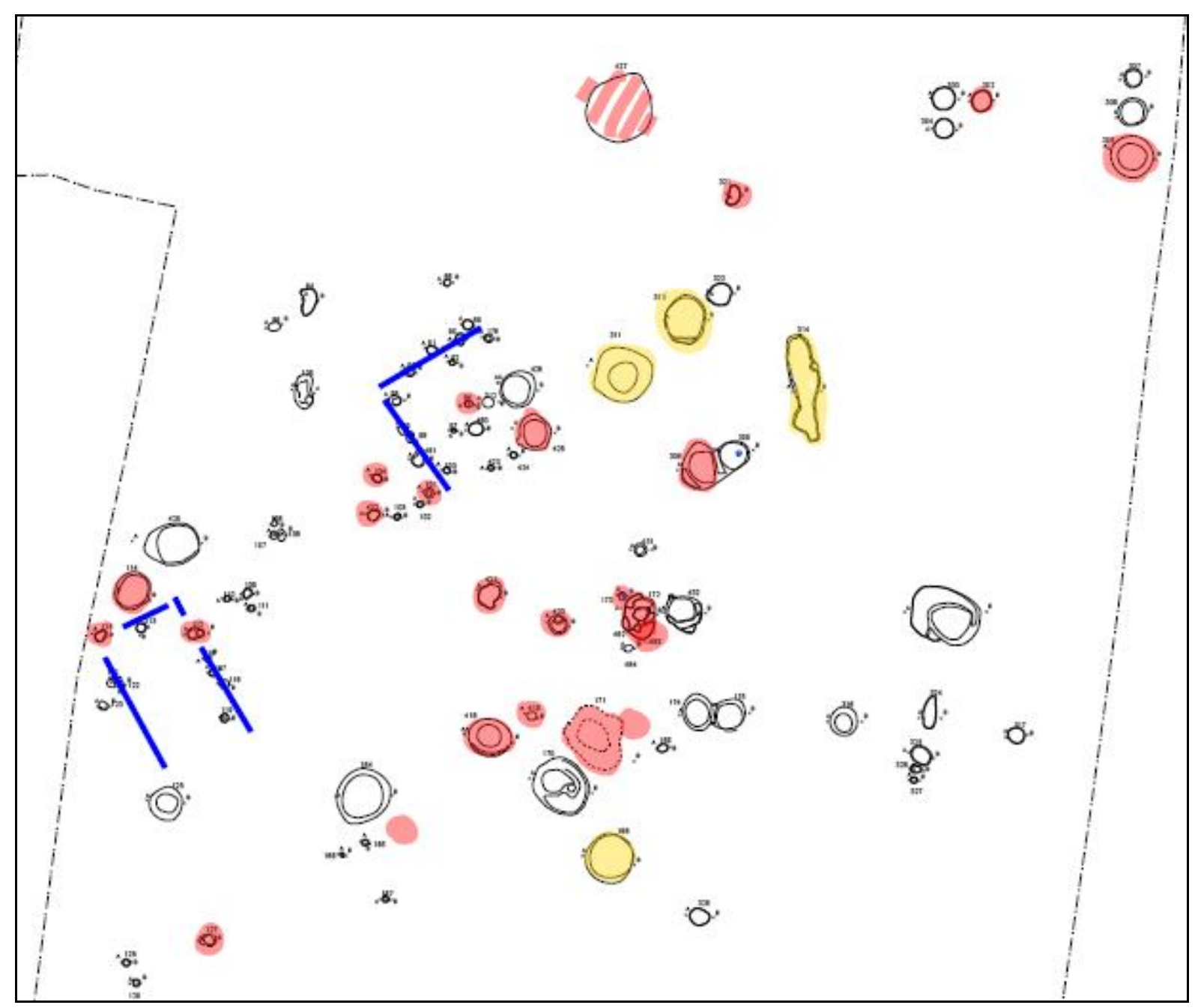

32. ábra A 2. objektumcsoport, $M=1: 400$ A színek magyarázatát lásd a 29. ábránál 


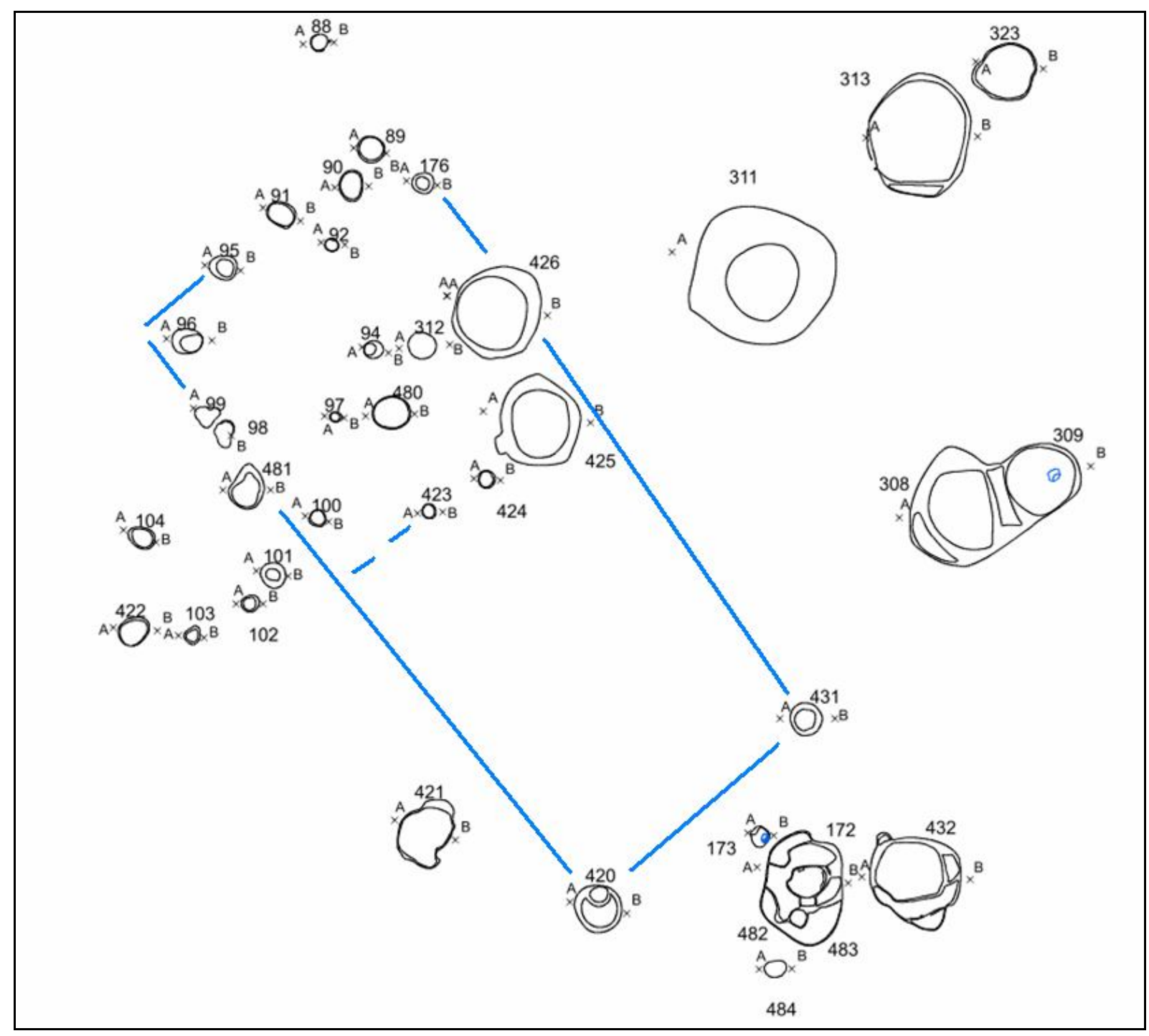

33. ábra A 425. gödör környéke a lehetséges házzal (89-92., 94-104., 481., 420., 431.

objektum) és a kemencével (172. objektum). $M=1: 140$ 

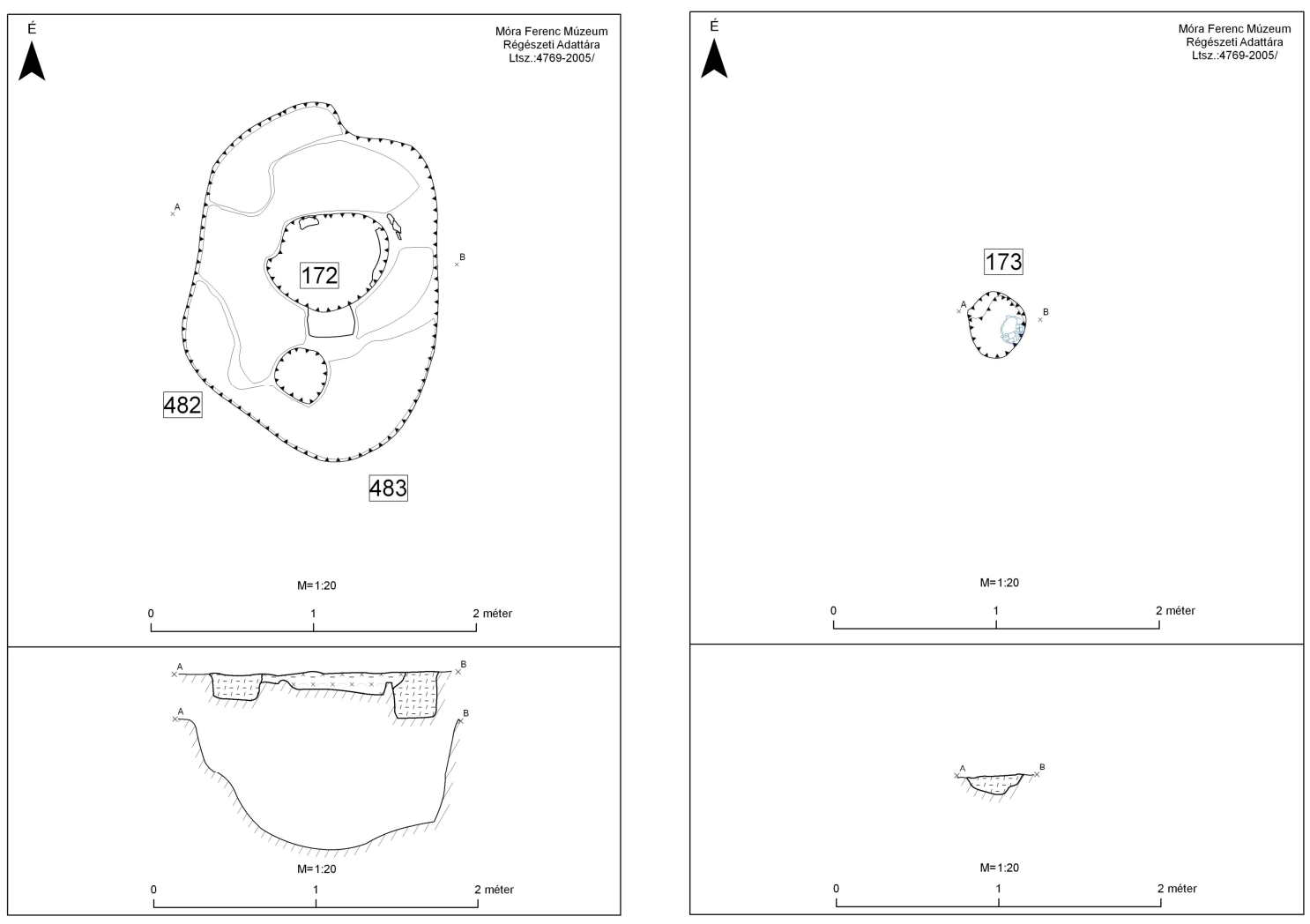

34. ábra A 172., 173., 482. és 483. objektum

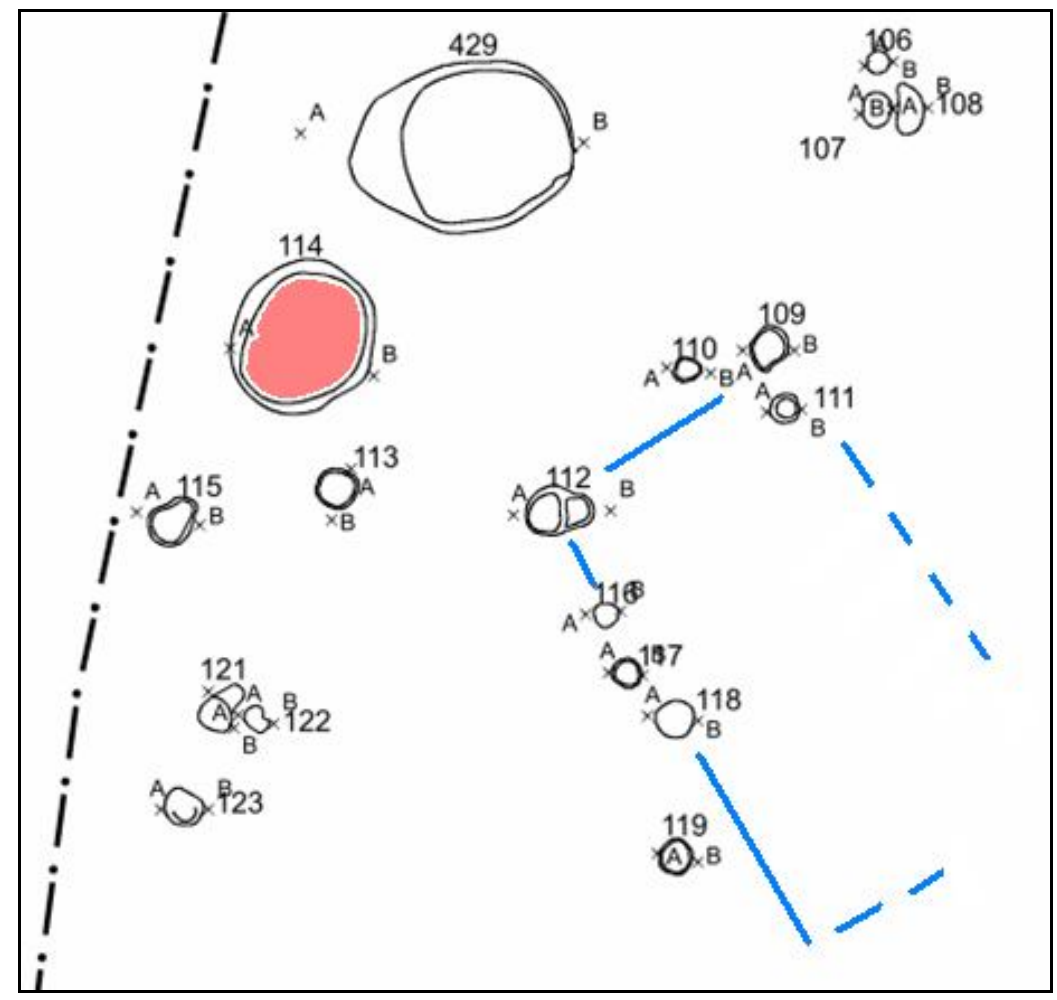

35. ábra A 2. objektumcsoport nyugati szélén lévő ház feltételezett alaprajza a paticstörmeléket tartalmazó gödörrel (piros) $\mathrm{M}=1: 200$ 


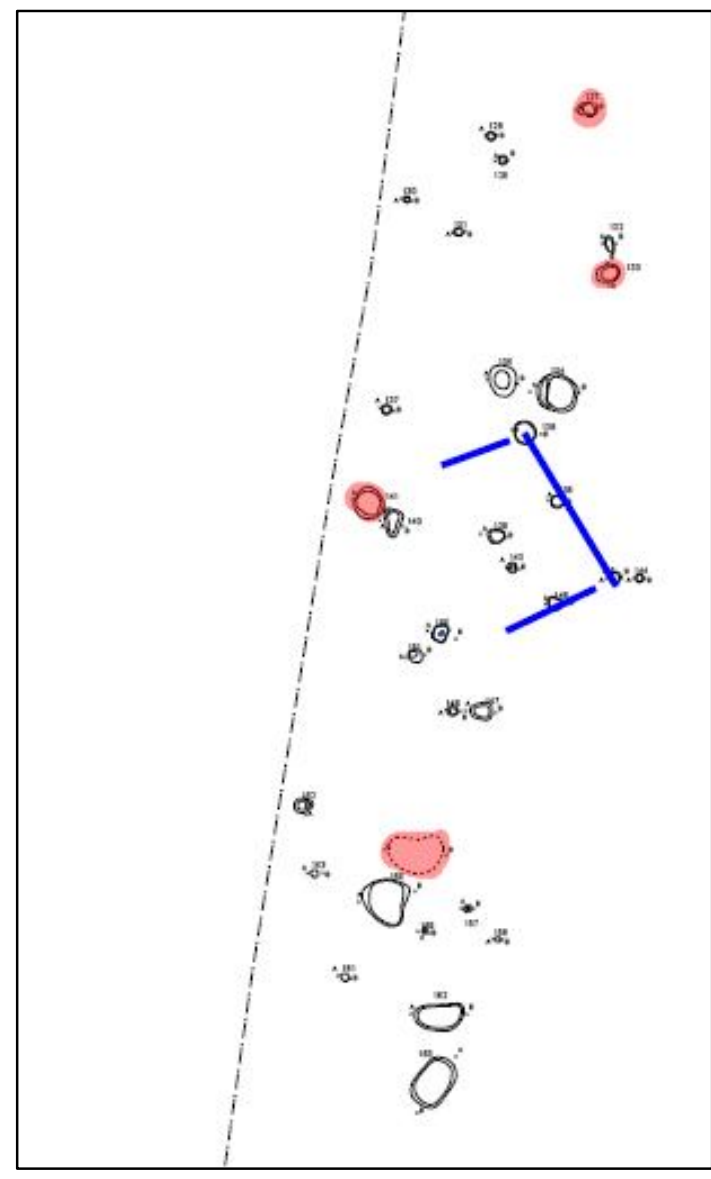

36. ábra A 3. objektumcsoport $\mathrm{M}=1: 400$ A színek magyarázatát lásd a 29. ábránál

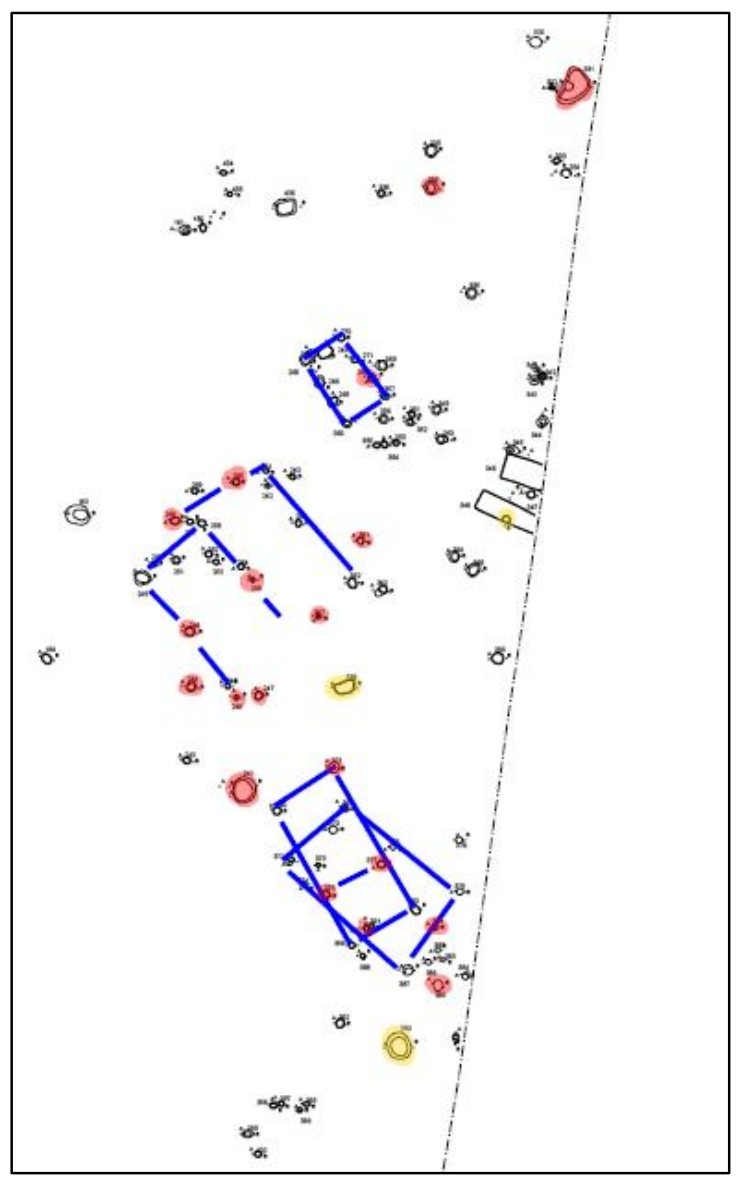

37. ábra A 4. objektumcsoport $M=1: 600$ A színek magyarázatát lásd a 29. ábránál

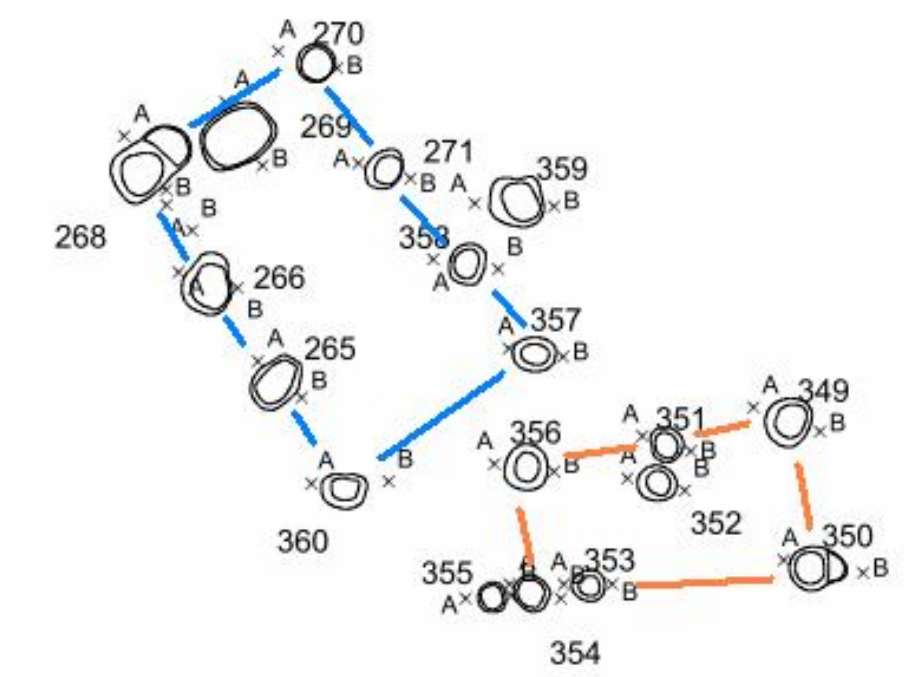

38. ábra A 4. objektumcsoportban feltárt 1. sz. ház (kék) és a mellette lévő, eltérő korú vagy funkciójú épület (narancssárga) $M=1: 200$ 


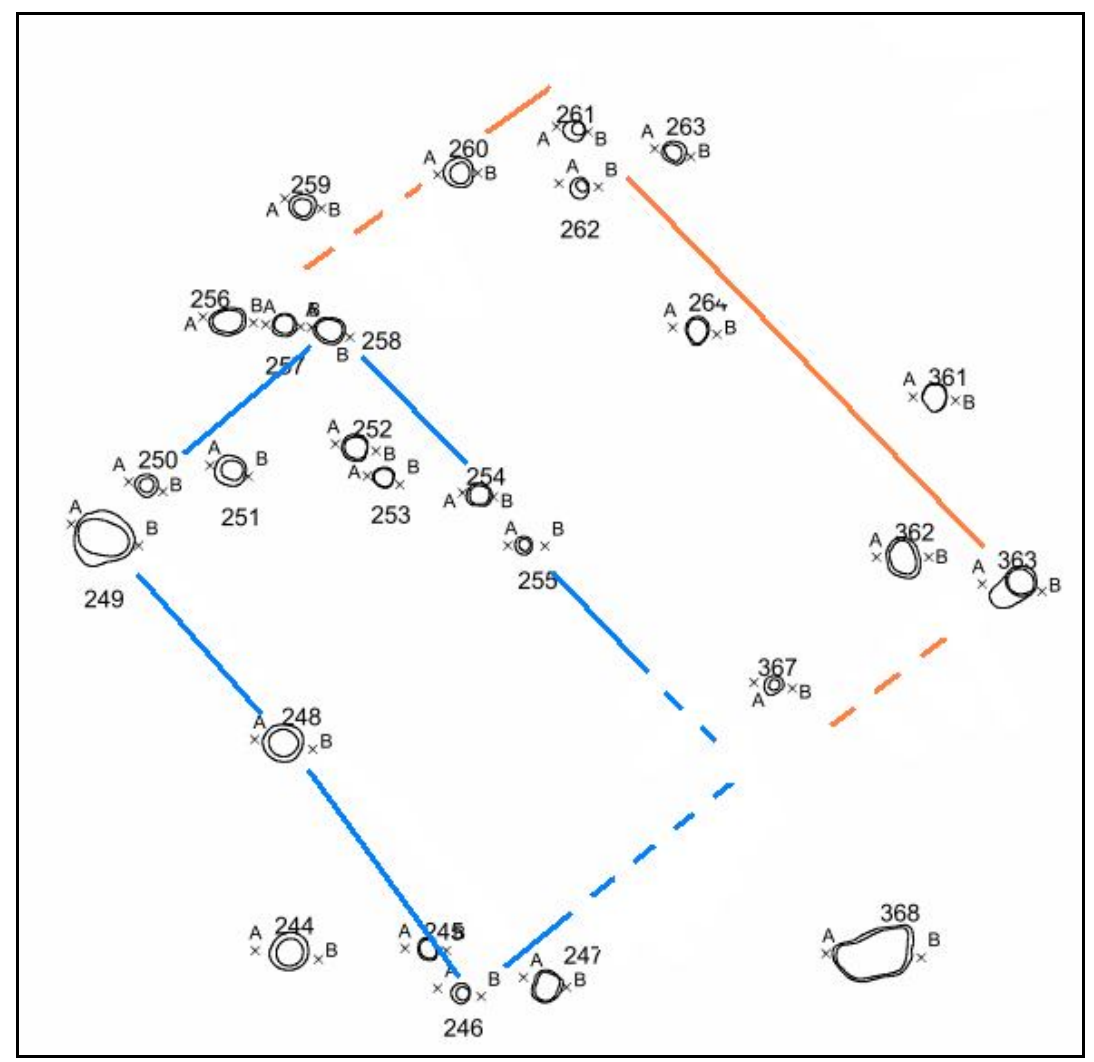

39. ábra A 4. objektumcsoport két eltérő korú, de egymáshoz igazodó épülete. $M=1: 300$

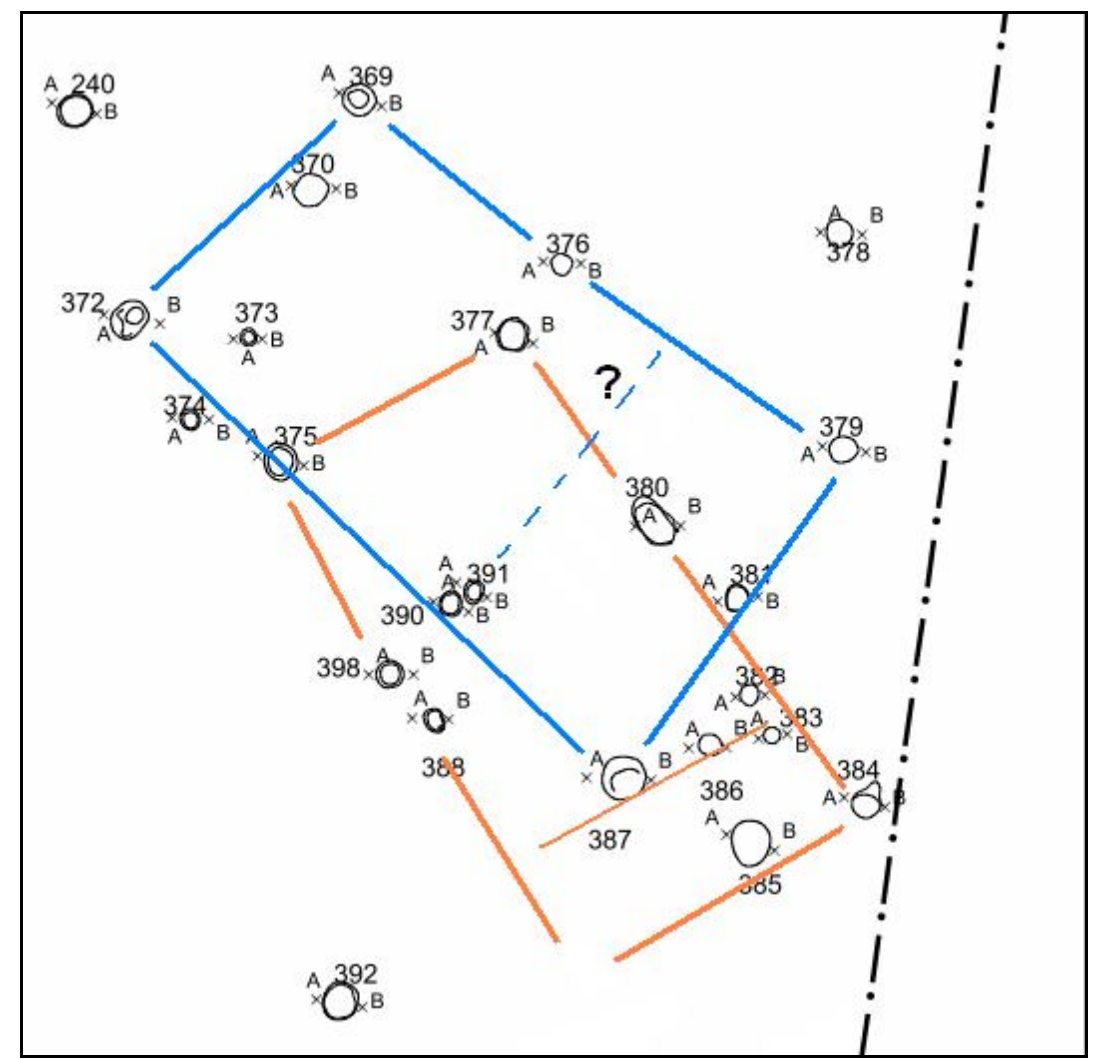

40. ábra A 4. objektumcsoport déli részének két, eltérő korú, egymást fedő épülete. $M=1: 300$ 


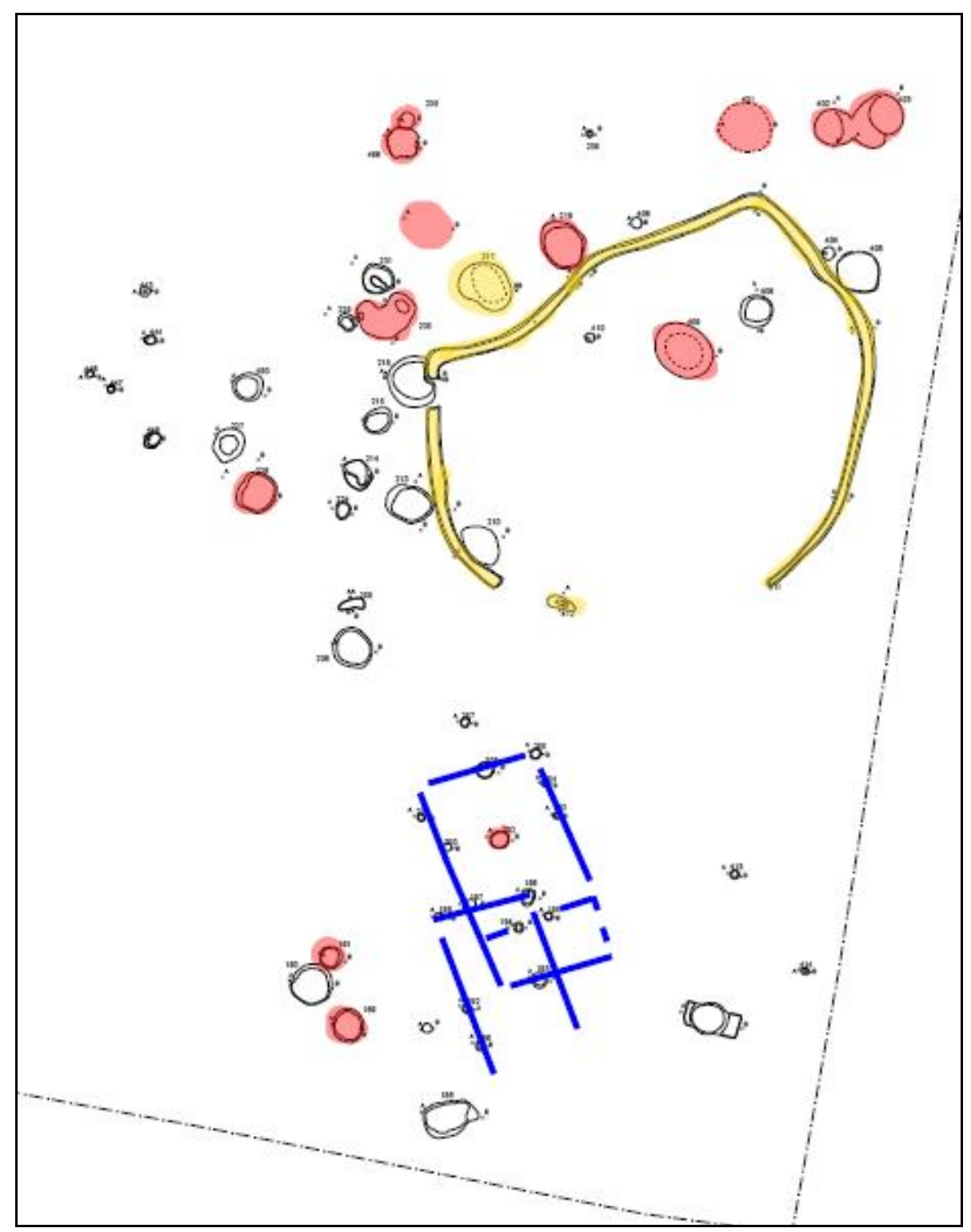

41. ábra $A z$ 5. objektumcsoport $M=1: 400$. A színek magyarázatát lásd a 29. ábránál 


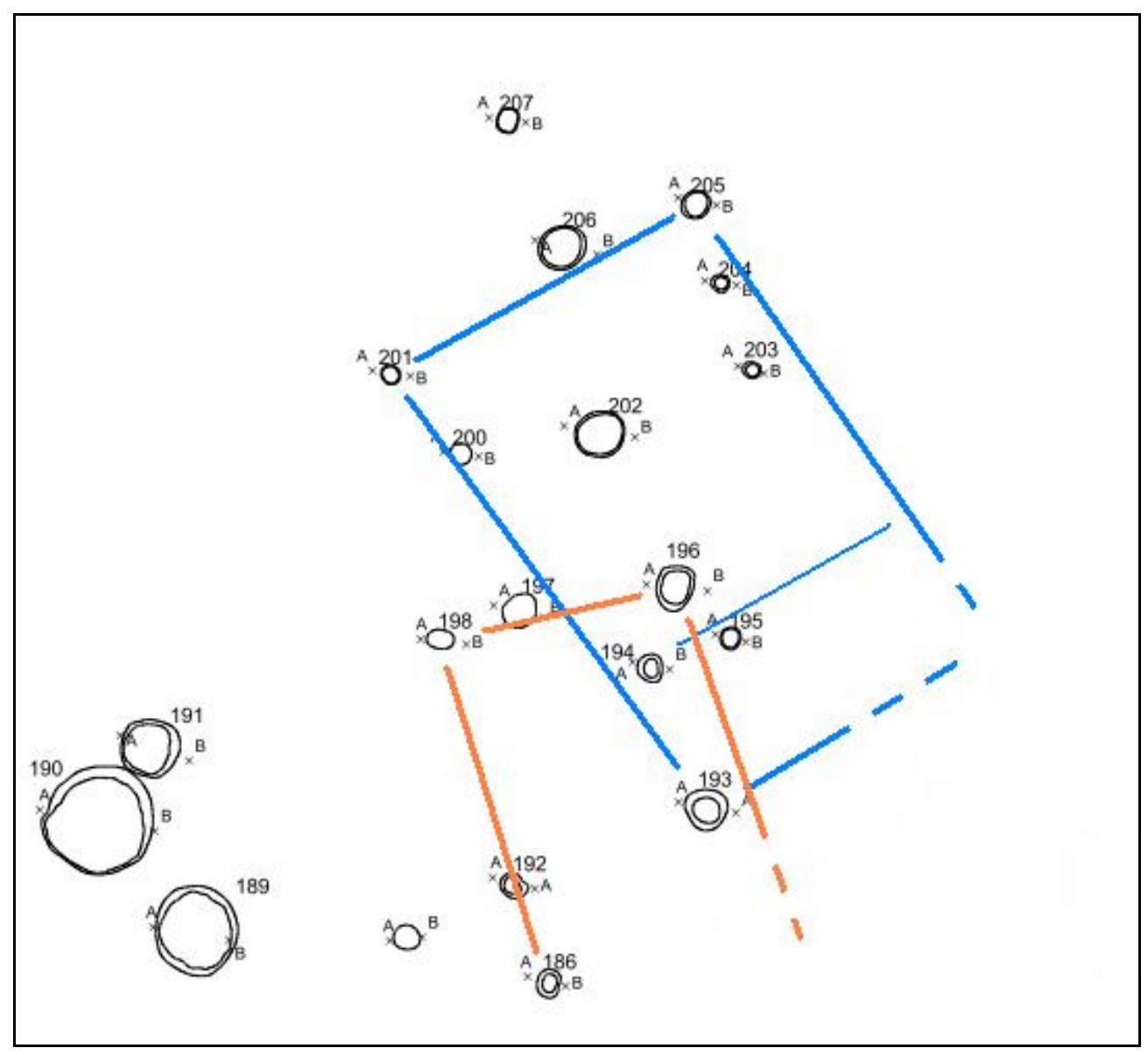

42. ábra $\mathrm{Az}$ 5. objektumcsoport déli részének két háza. $M=1: 300$.

43. ábra A településrészlet tálak töredékeit tartalmazó Halomsíros objektumai (kék színnel). $\mathrm{M}=1: 600$

44. ábra A településrészlet kizárólag vagy legnagyobbrészt durva kerámiát tartalmazó Halomsíros objektumai (világos barna színnel). $M=1: 600$

45. ábra A településrészlet állatcsontot tartalmazó Halomsíros objektumai (zöld színnel) $\mathrm{M}=1: 600$ 


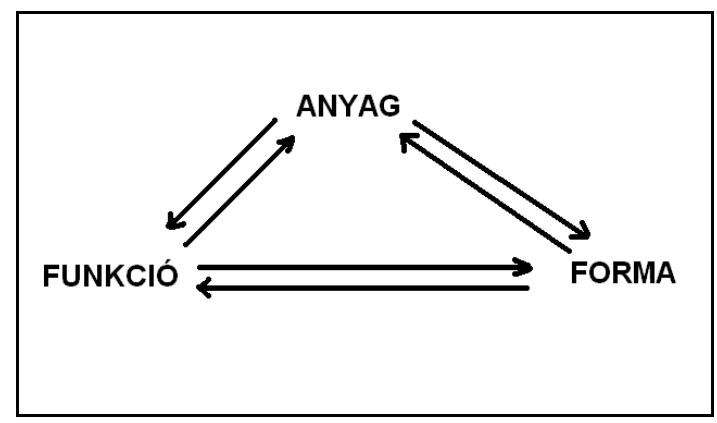

46. ábra Összefüggések anyag, forma és funkció között (Sümegi, 2001 nyomán)

47. ábra A leggazdagabb leletanyagot tartalmazó objektumok (piros) elhelyezkedése az ásatási felszínen. M=1:600 (következő lapon)
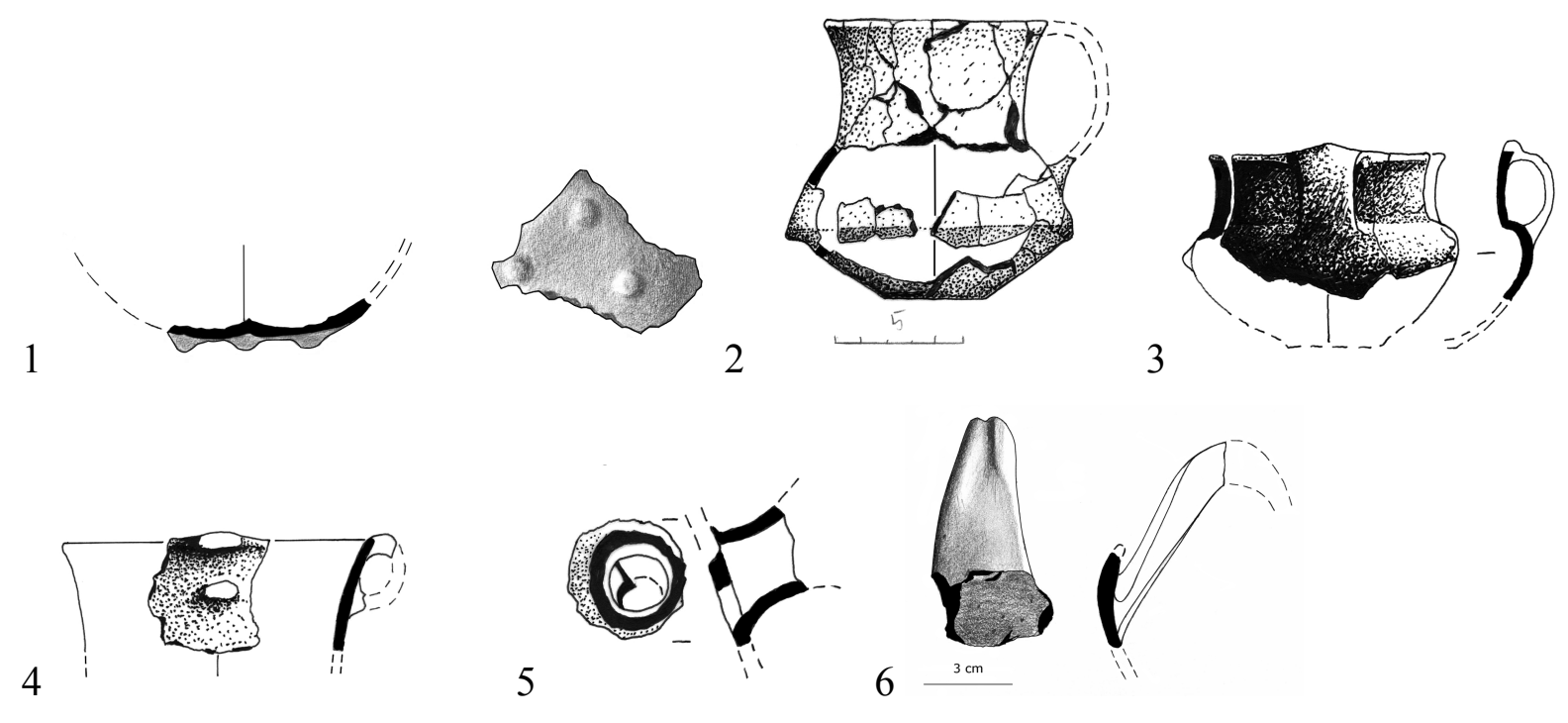

48. ábra Korai és klasszikus típusú bögrék és korsók, import tárgyak. ( $M=1: 4,1$ 1. obj., 2. 202. obj., 3-4. 164. obj. 5. 305. obj., 6. 425. obj.)
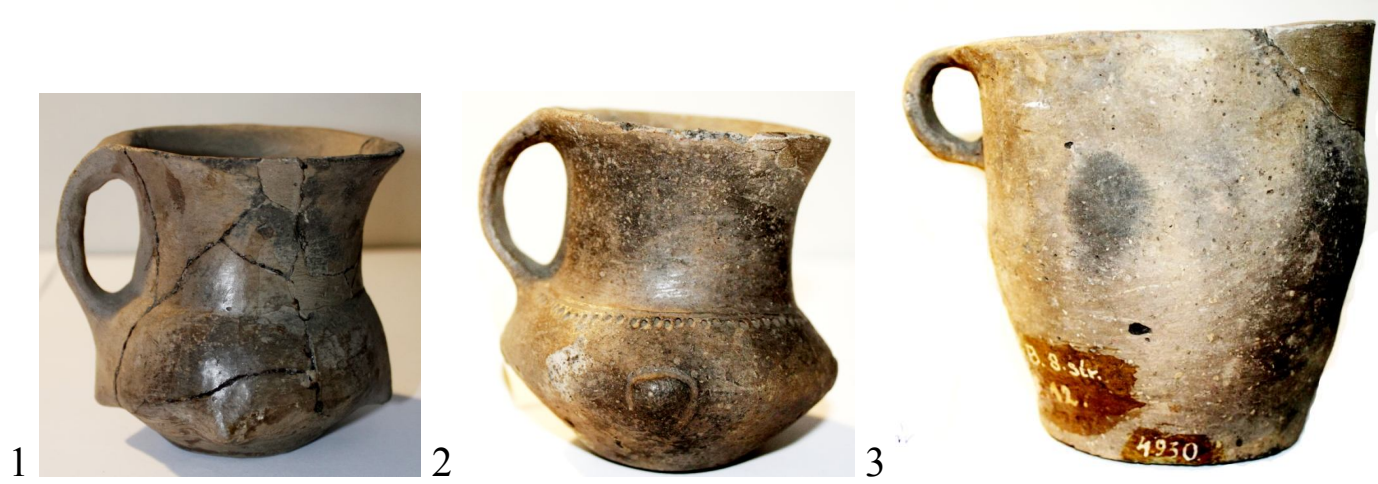

49. ábra Szeged-Bogárzó, bögrék és korsók. M=1:2 1. 1. sír, 53.25.6, vö. 47. ábra 2, 2-3. 8. sír, 53.25.11-12, vö. 47. ábra 4. 

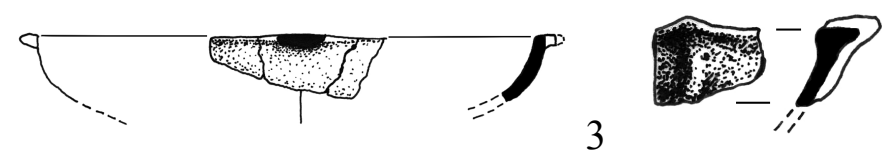

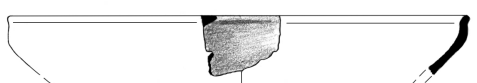

4

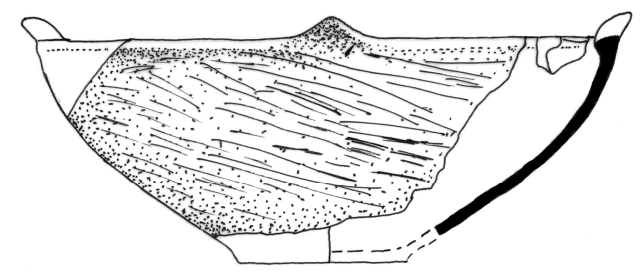

6

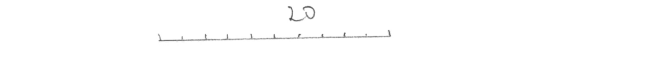

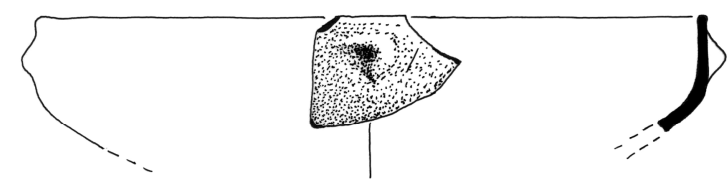

5

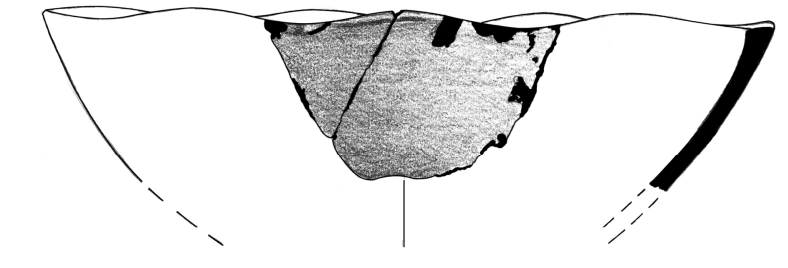

9 $6 \mathrm{~cm}$
10
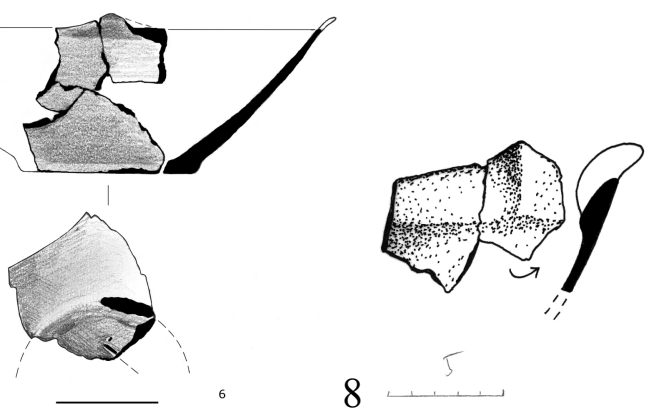

8

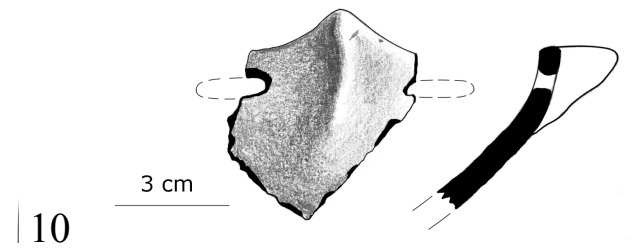

50. ábra Csonka kúpos táltípusok. Ahol nem jelezzük, ott M=1:4.1. 1. obj., 2. 279. obj., 3. 248. obj., 4. 44. obj., 5. 17. obj., 6. 230. obj., $M=1: 8$, 7. 141. obj., 8. 427. obj. 9. 402. obj. 10. 278. obj.
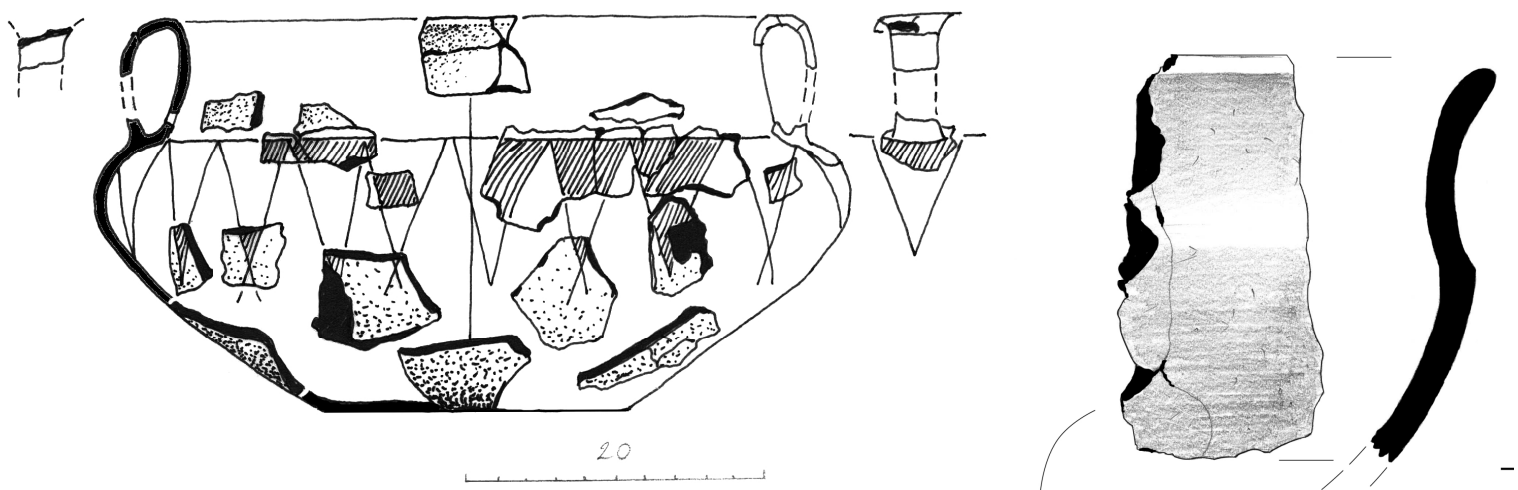

51. ábra 1. Mély tál, 320. obj., $M=$ kb. 1:6, 2. Svédsisak alakú tál töredéke, 44. obj. $M=1: 2$ 

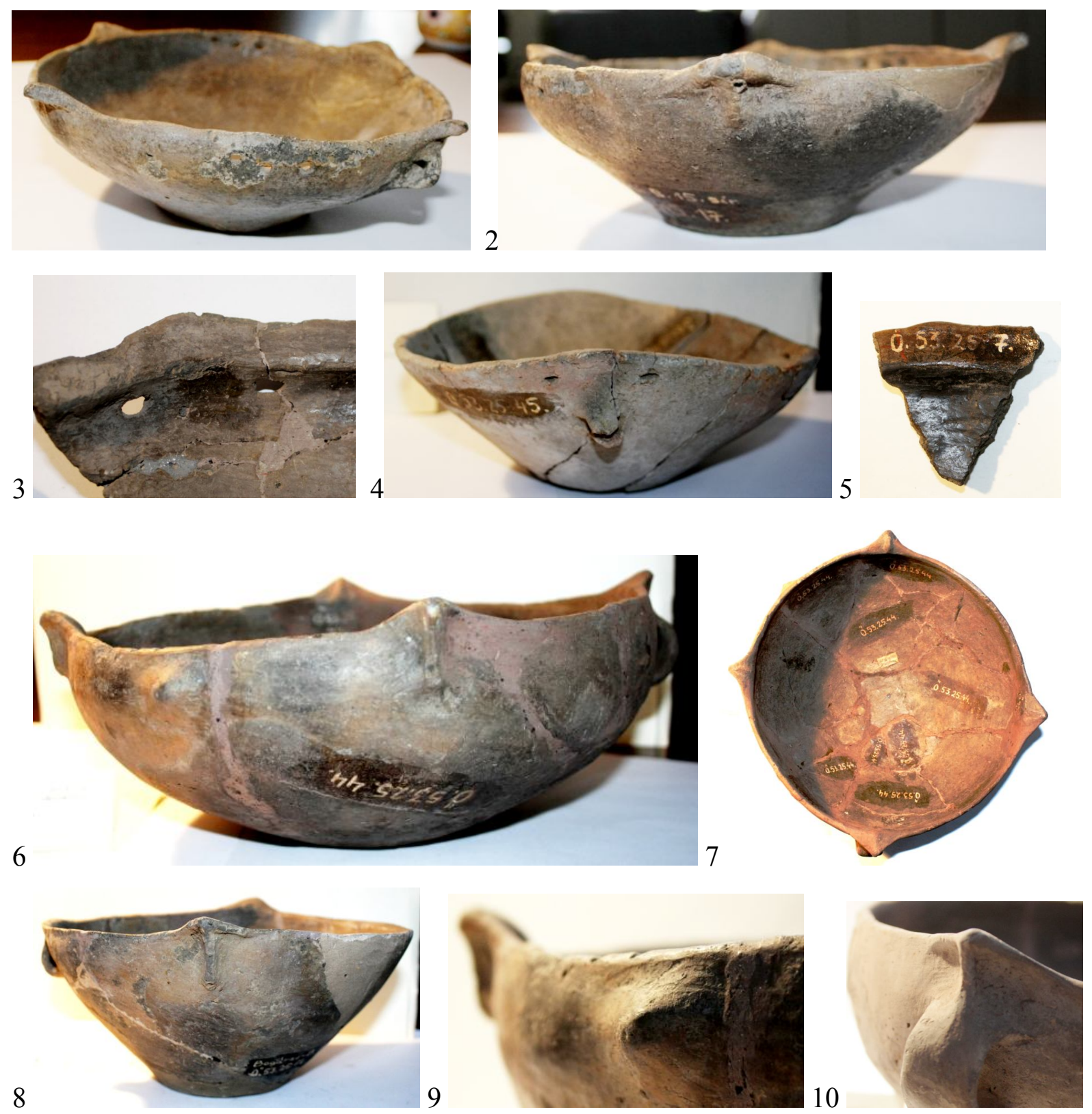

52. ábra Korai típusú tálak Szeged-Bogárzóról. Ahol külön nem jelezzük, ott M=1:4. 1-2. 15. sír, 53.25.17, vö. 50. ábra 2-5, 3. Szórvány, 53.25.38, vö. 50. ábra 10, 4. Hullámos peremü tál, szórvány, 53.25.45. vö. 50. ábra 9, 5. 1. sír, 53.25.7, M=1:3, 6-7. Szórvány, 53.25.44, vö. 50. ábra 5-6, M=1:4 és 1:8, 8. Szórvány, 53.25.52, vö. 50. ábra 7, 9-10. Részletek az 53.25.44 darabról: perem alatti kerek bütyök és a kihúzott csücsök külső bordadísze a fülnél $(\mathrm{M}=1: 2)$ 
53. ábra A csonka kúpos táltípusok elterjedése a lelöhelyen. $M=1: 600$ (lásd a következő lapon)

Jelmagyarázat:

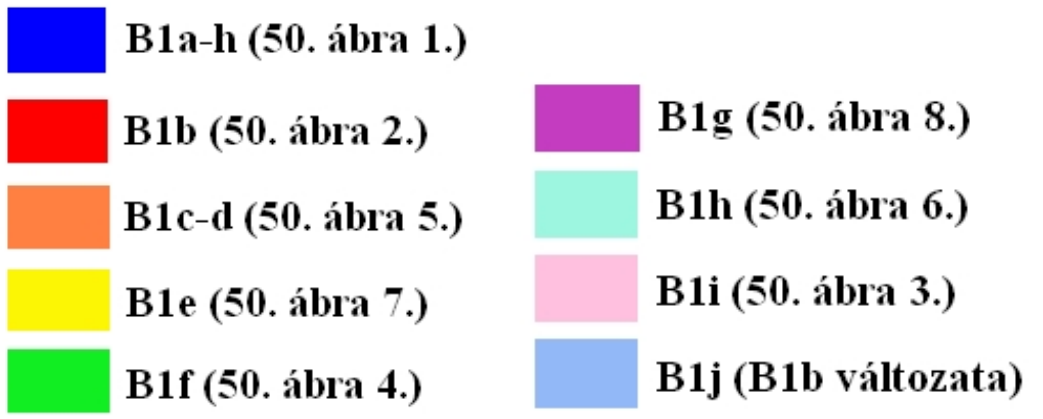

1

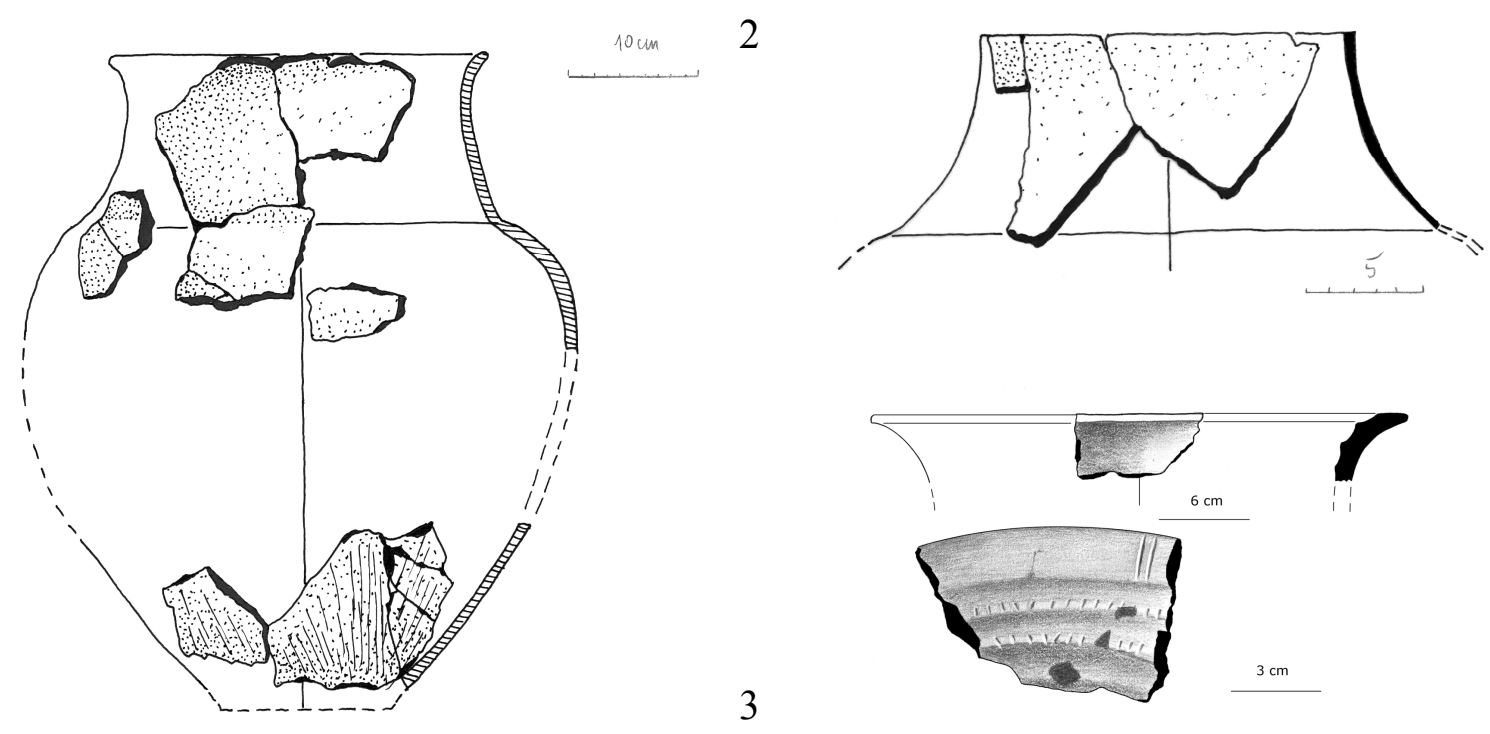

54. ábra Amforák típusai. 1. 463. obj. $M=1: 8$, 2. 402. obj. $M=1: 4$, 3. Szórvány, import (Szőreg-Perjámos kultúra) M=1:4, 1:2

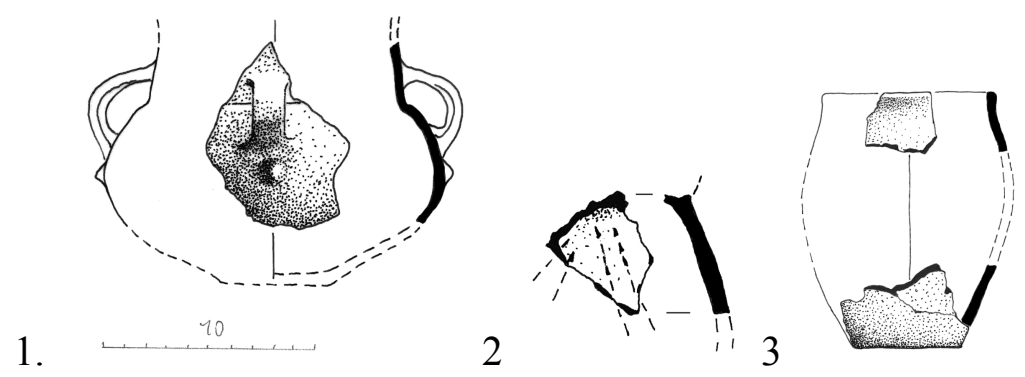

55. ábra Csuprok típusai. $M=1: 4$. 1. 305. obj. 2. 401. obj. 3. 336. obj. 
1

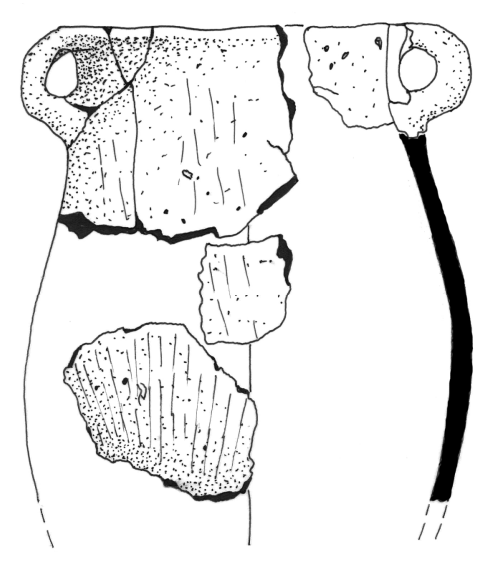

2
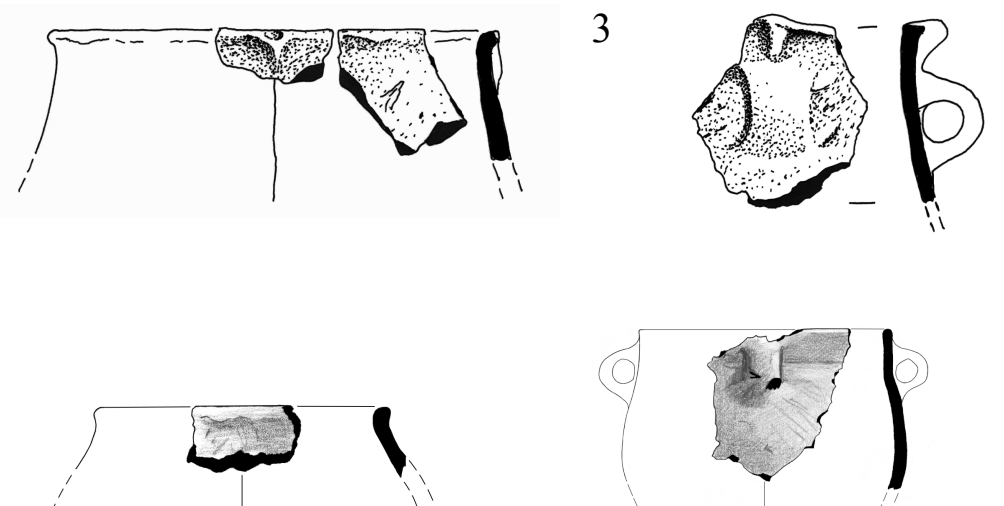

4
3

5

56. ábra Fazéktípusok. M=1:4. 1. Kétfüles, hordó alakú fazék elkent barbotinnal. 402. obj. 2.

Bütykös peremü fazék, 246. obj. 3. Bütykös peremü fazék a tálakra jellemző bütyökkel, 427. obj. 4. Behúzott szájperemü fazék, 1. obj. 5. Rövid nyakú, gömbös testü fazék, 44. obj.

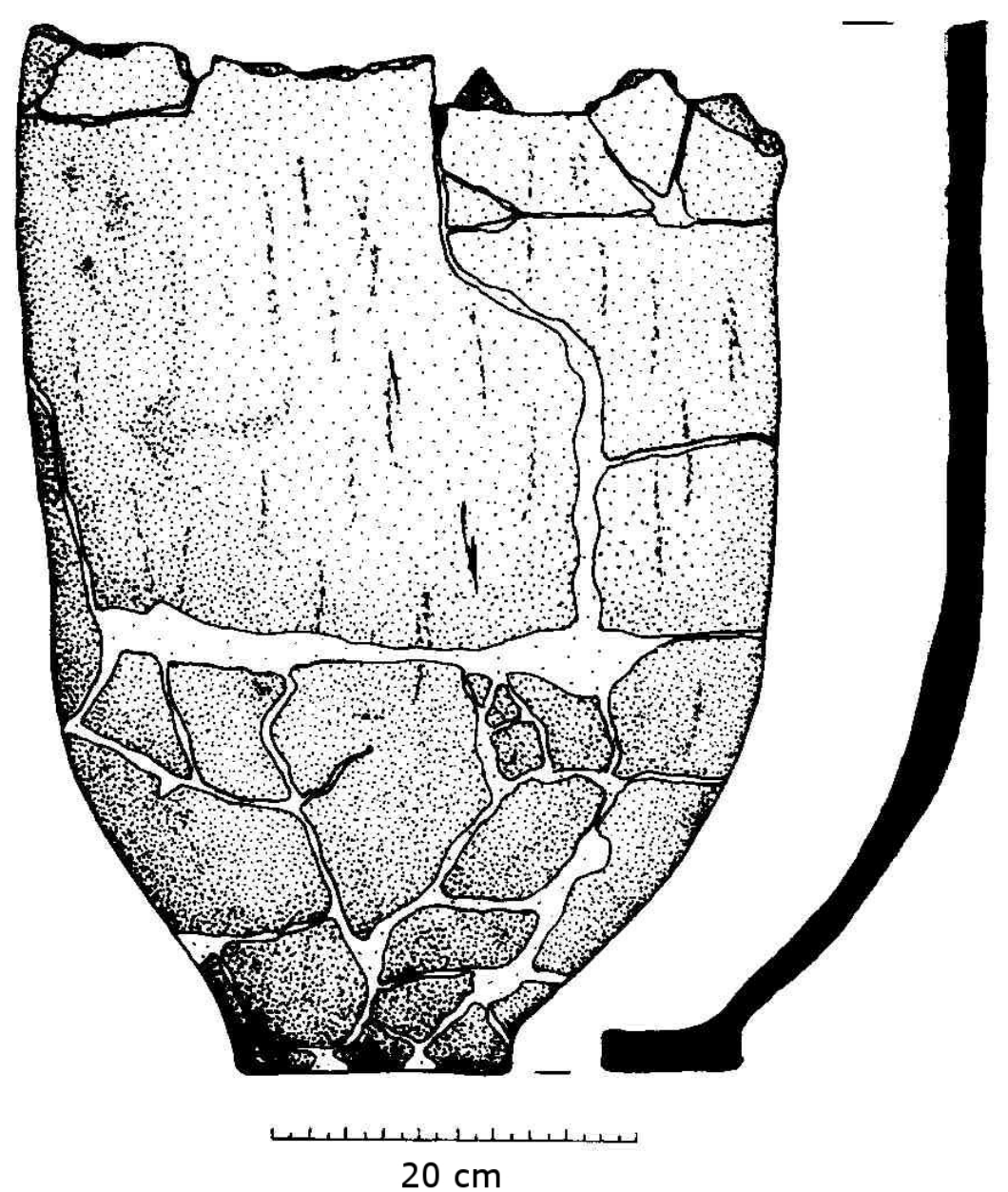

57. ábra Pithosz, mely a 479. gödörben épségben állt. $M=1: 4$. 


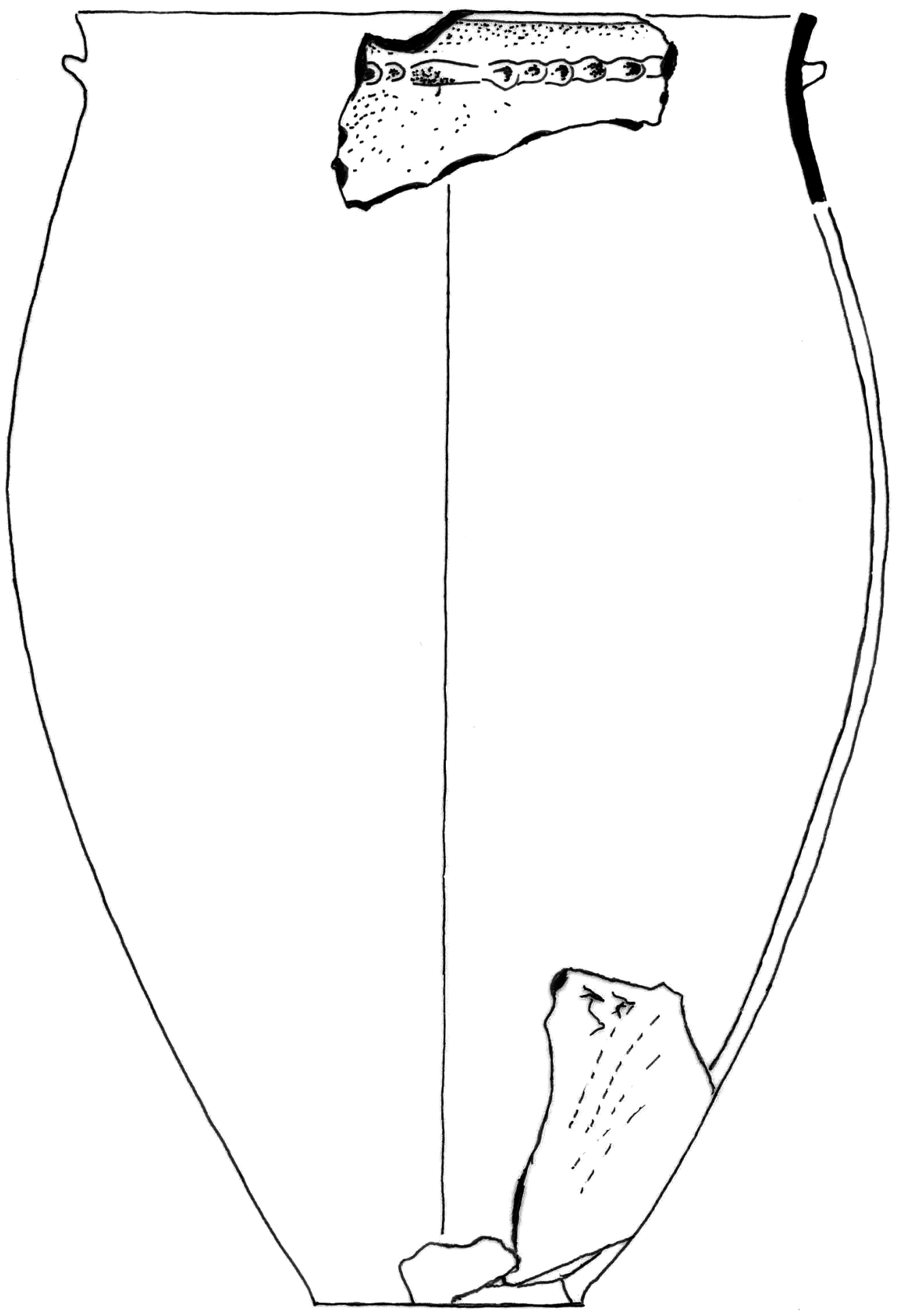

58. ábra Pithosz a 17. objektumból. Rengeteg töredéke közül a legtöbb nem volt összeilleszthető, ezeket nem is jelöltük a rajzon. $M=1: 4$. 


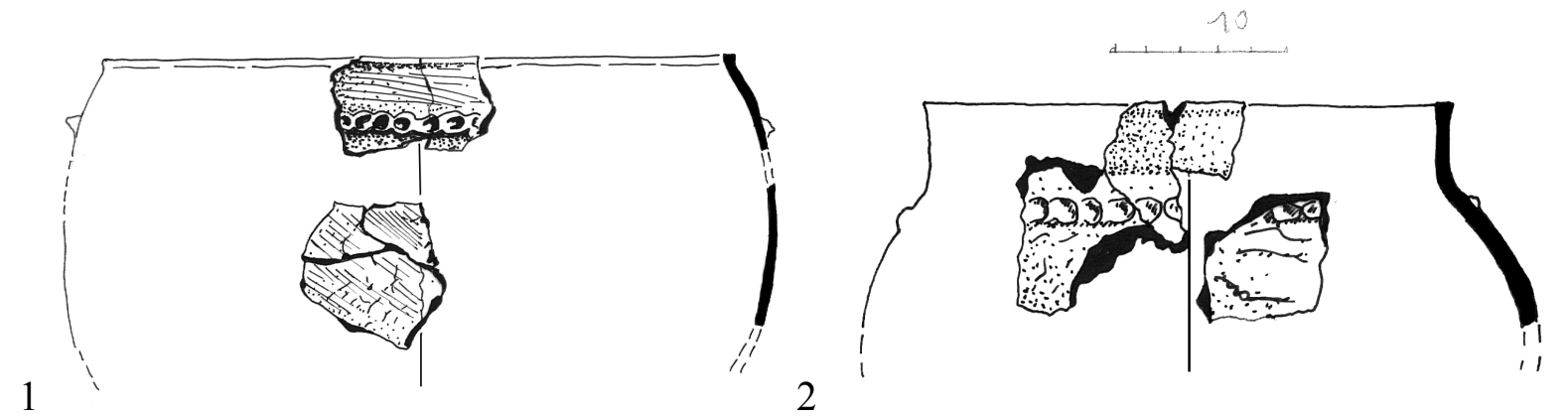

59. ábra További pithosz-típusok. 1. 319. obj. $M=1: 8$. 2. 17. obj. $M=1: 5$

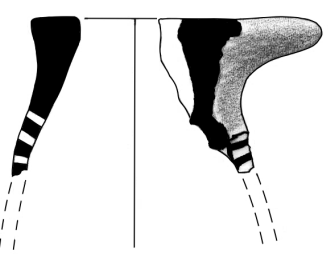

1

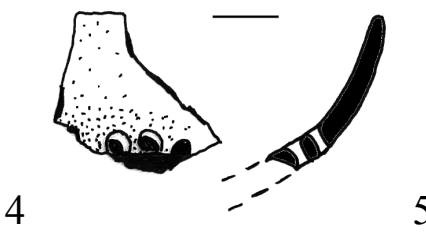

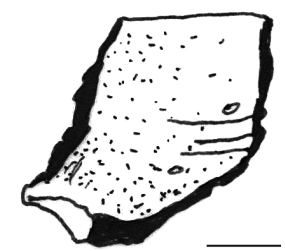

2

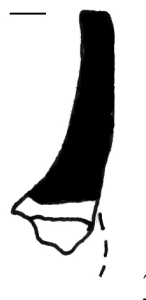

3
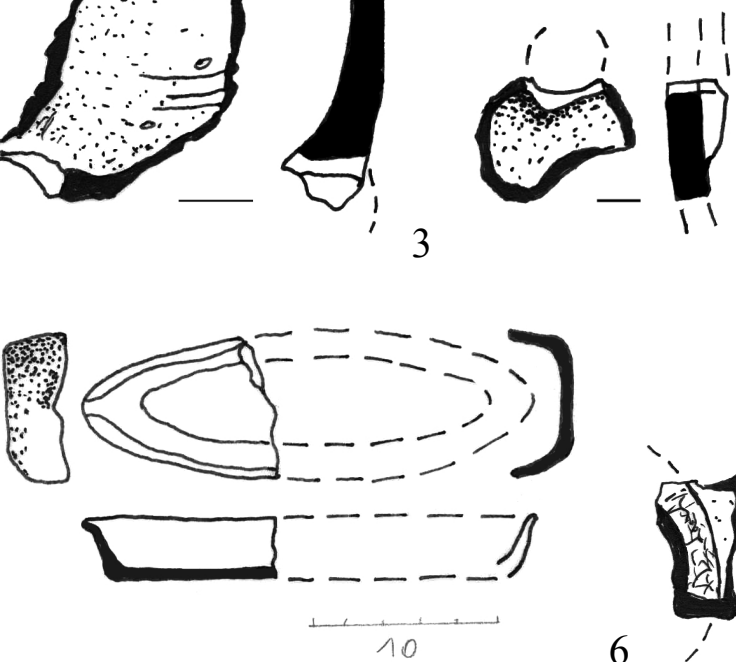

6

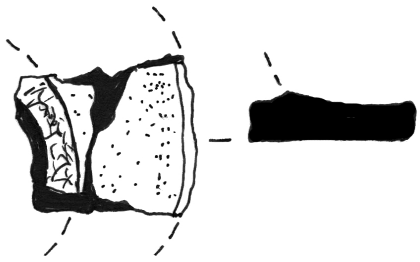

60. ábra Funkcionális kerámia. $M=1: 3$. 1. Parázsborító, 1. obj. 2. Pyraunos (hordozható katlantűzhely) töredékek, 401. obj, 3. Ua. szórvány, 4. Szürőtál töredéke, 17. obj. 5. Halsütő tál töredéke, 483. obj. 6. Fedö töredéke, szórvány.

61. ábra Korai jellegzetességek elterjedése a településen. $M=1: 600$ (lásd a következő lapon) Jelmagyarázat:

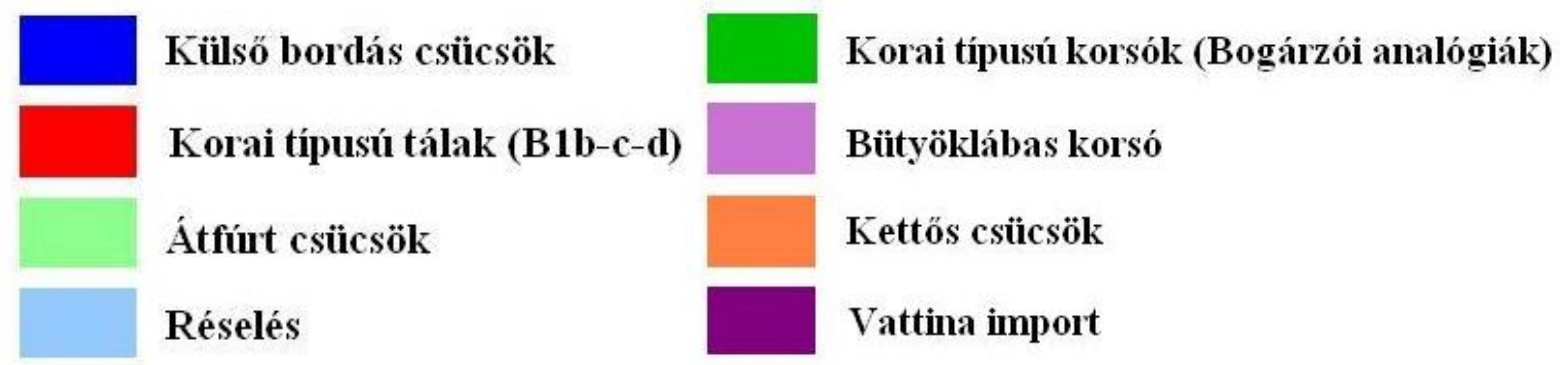




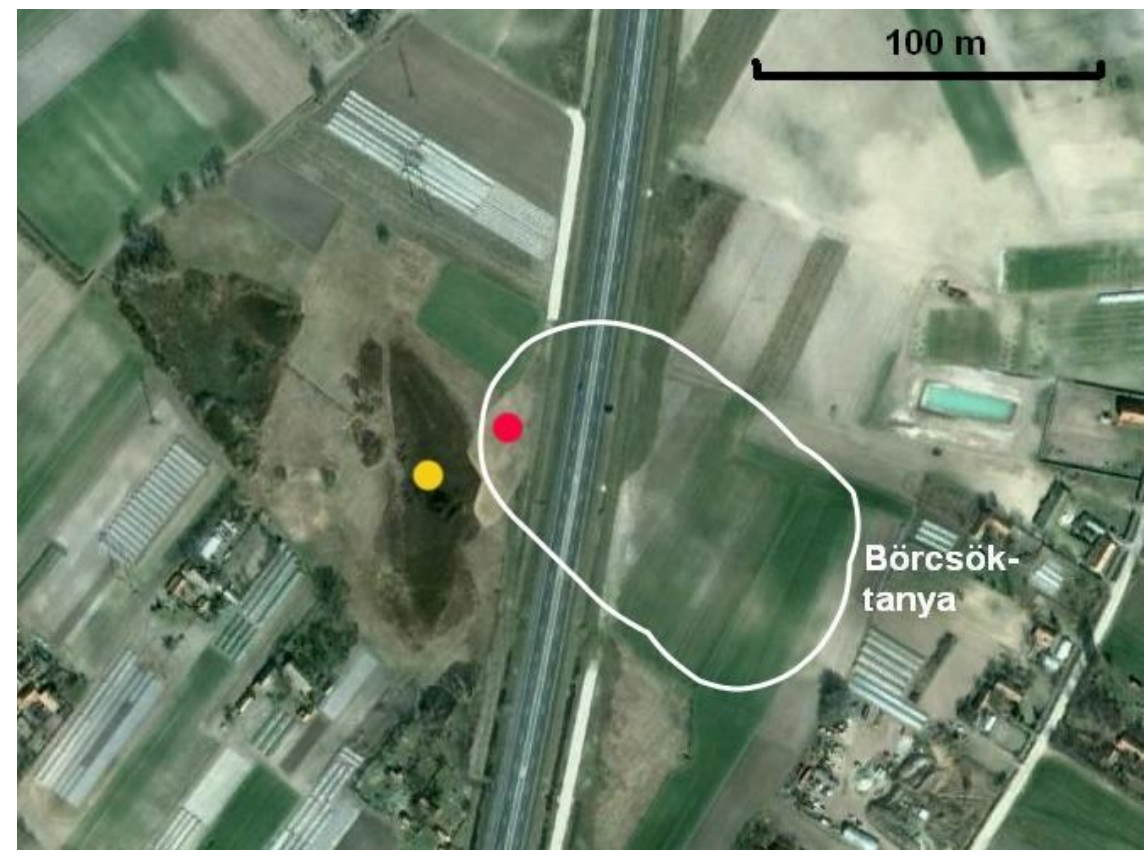

62. ábra A lelőhely nagyfelbontású müholdas felvételen (Google Earth). A régészeti lelőhely körvonalát fehérrel jelöltük. A sárga kör a semlyékben végzett fúrás helyét, a piros kör a településen végzett fúrás és a terepbejárás helyét jelzi

\begin{tabular}{|c|c|c|c|c|c|c|c|c|c|c|c|}
\hline $\begin{array}{l}\text { Tégely } \\
\text { (minta } \\
\text { száma) }\end{array}$ & $\begin{array}{l}\text { Tégely } \\
\text { tömege } \\
\text { (gramm) }\end{array}$ & $\begin{array}{l}105^{\circ} \mathrm{C} \\
(\text { gramm) }\end{array}$ & $\begin{array}{l}550^{\circ} \mathrm{C} \\
(\text { gramm) } \\
(1 .)\end{array}$ & $\begin{array}{l}550{ }^{\circ} \mathrm{C} \\
(\text { gramm) } \\
(2 .)\end{array}$ & $\begin{array}{l}1000{ }^{\circ} \mathrm{C} \\
\text { (gramm) }\end{array}$ & $\begin{array}{l}\text { Légszáraz } \\
\text { tömeg } \\
\text { (gramm) }\end{array}$ & $\begin{array}{l}\text { Szerves } \\
\text { anyag } \\
\text { tart.(gramm) }\end{array}$ & $\begin{array}{l}\text { Szerves } \\
\text { anyag } \\
\text { tart. } \\
(\%)\end{array}$ & $\begin{array}{l}\text { Karbonát } \\
\text { tart. } \\
\text { (gramm) }\end{array}$ & $\begin{array}{l}\text { Karbonát } \\
\text { tart. (\%) }\end{array}$ & $\begin{array}{l}\text { Mélység } \\
\text { (cm) }\end{array}$ \\
\hline 1. & 16.1954 & 20.6736 & 19.7736 & 19.6964 & 19.2200 & 4.4782 & 0.9772 & 21.8213 & 0.4764 & 10.6382 & $0-10$ \\
\hline 2. & 15.6657 & 21.6078 & 20.7897 & 20.6800 & 19.9700 & 5.9421 & 0.9278 & 15.6140 & 0.7100 & 11.9486 & $10--20$ \\
\hline 3. & 16.1028 & 22.7880 & 21.9892 & 21.8716 & 21.1437 & 6.6852 & 0.9164 & 13.7079 & 0.7279 & 10.8882 & $20-30$ \\
\hline 4. & 15.7911 & 21.6805 & 21.1856 & 21.1000 & 20.2002 & 5.8894 & 0.5805 & 9.8567 & 0.8998 & 15.2783 & $30-40$ \\
\hline 5. & 15.6756 & 22.0036 & 21.5896 & 21.5199 & 20.6757 & 6.3280 & 0.4837 & 7.6438 & 0.8442 & 13.3407 & $40-50$ \\
\hline 6. & 15.3325 & 22.4393 & 22.0784 & 22.0045 & 21.2155 & 7.1068 & 0.4348 & 6.1181 & 0.7890 & 11.1020 & $50-60$ \\
\hline 7. & 15.8491 & 24.6220 & 24.1582 & 24.0629 & 22.9437 & 8.7729 & 0.5591 & 6.3730 & 1.1192 & 12.7575 & $60-70$ \\
\hline 8. & 17.1055 & 23.5964 & 23.0756 & 22.9997 & 22.1648 & 6.4909 & 0.5967 & 9.1929 & 0.8349 & 12.8626 & $80-90$ \\
\hline 9. & 17.5935 & 26.1474 & 25.9240 & 25.8885 & 25.5416 & 8.5539 & 0.2589 & 3.0267 & 0.3469 & 4.0555 & $0-5$ \\
\hline 10. & 16.9706 & 27.2292 & 26.9753 & 26.9350 & 26.5718 & 10.2586 & 0.2942 & 2.8678 & 0.3632 & 3.5404 & $5--10$ \\
\hline 11. & 15.0230 & 23.6015 & 23.4023 & 23.3660 & 23.0030 & 8.5785 & 0.2355 & 2.7452 & 0.3657 & 4.2630 & $10--15$ \\
\hline 12. & 16.6906 & 25.2890 & 25.0199 & 24.9846 & 24.5824 & 8.5984 & 0.3044 & 3.5402 & 0.4022 & 4.6776 & $15-20$ \\
\hline 13. & 18.0580 & 26.4055 & 26.2770 & 26.2697 & 26.1968 & 8.3475 & 0.1358 & 1.6268 & 0.0729 & 0.8733 & $20-25$ \\
\hline 14. & 15.3637 & 24.7115 & 24.5840 & 24.5756 & 24.4931 & 9.3478 & 0.1359 & 1.4538 & 0.0825 & 0.8826 & $25-30$ \\
\hline 15. & 16.6589 & 25.7817 & 25.6820 & 25.6743 & 25.5838 & 9.1228 & 0.1074 & 1.1773 & 0.0905 & 0.9920 & $30-35$ \\
\hline 16. & 15.8868 & 25.0492 & 24.9916 & 24.9844 & 24.8052 & 9.1624 & 0.0648 & 0.7072 & 0.1792 & 1.9558 & $35-40$ \\
\hline
\end{tabular}

2. táblázat Domaszék-Börcsök tanya régészeti lelöhely melletti semlyékben (1-8.) és a településen (9-16.) mélyített geoarcheológiai fúrások szervesanyag- és karbonát tartalom elemzési adatai. 


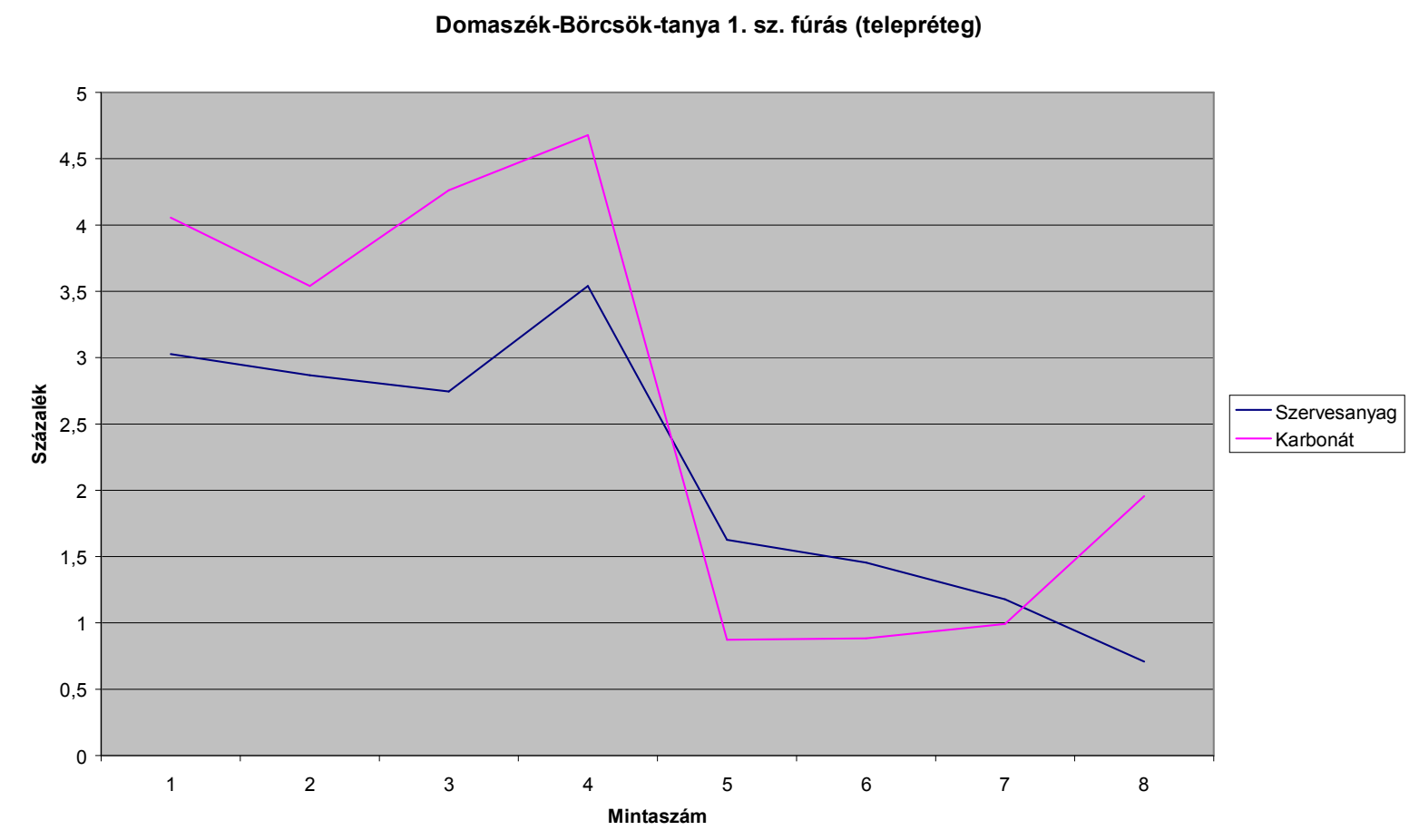

63. ábra A településréteg fúrásának szervesanyag- és karbonáttartalma

\begin{tabular}{|c|c|c|c|c|c|c|c|c|c|}
\hline Mintaszám & $\mathbf{C a}$ & Mg & $\mathrm{Na}$ & $\mathbf{K}$ & $\mathrm{Fe}$ & $\mathbf{C u}$ & Mn & $\mathbf{Z n}$ & $\mathrm{K} / \mathbf{N a}$ \\
\hline 1 & 753 & 1657 & 249 & 281 & 41 & 16 & 5 & 3 & 1,125 \\
\hline 2 & 392 & 1070 & 290 & 239 & 21 & 16 & 5 & 4 & 0,822 \\
\hline 3 & 386 & 1117 & 315 & 224 & 18 & 17 & 2 & 5 & 0,712 \\
\hline 4 & 506 & 913 & 230 & 177 & 25 & 19 & 5 & 6 & 0,770 \\
\hline 5 & 435 & 757 & 238 & 180 & 22 & 20 & 6 & 6 & 0,756 \\
\hline 6 & 479 & 761 & 209 & 162 & 26 & 22 & 8 & 6 & 0,775 \\
\hline 7 & 844 & 1147 & 213 & 161 & 62 & 24 & 11 & 7 & 0,756 \\
\hline 8 & 471 & 763 & 201 & 109 & 21 & 26 & 4 & 7 & 0,541 \\
\hline 9 & 1093 & 541 & 103 & 86 & 52 & 27 & 9 & 8 & 0,828 \\
\hline 10 & 1800 & 1066 & 106 & 132 & 200 & 29 & 19 & 8 & 1,252 \\
\hline 11 & 1101 & 566 & 70 & 60 & 45 & 29 & 17 & 7 & 0,855 \\
\hline 12 & 1312 & 562 & 74 & 63 & 54 & 28 & 21 & 6 & 0,851 \\
\hline 13 & 386 & 101 & 55 & 62 & 44 & 29 & 21 & 5 & 1,136 \\
\hline 14 & 338 & 84 & 66 & 67 & 35 & 31 & 18 & 6 & 1,013 \\
\hline 15 & 471 & 126 & 55 & 78 & 52 & 32 & 20 & 9 & 1,420 \\
\hline 16 & 660 & 152 & 60 & 78 & 66 & 32 & 17 & 8 & 1,294 \\
\hline
\end{tabular}

3. táblázat. A lelőhely melletti semlyékben (1-8.) és a településen végzett fúrások (9-16.) nedves geokémiai elemzésének eredményei. 
Domaszék-Börcsök-tanya 2. sz. fúrás (semlyék)

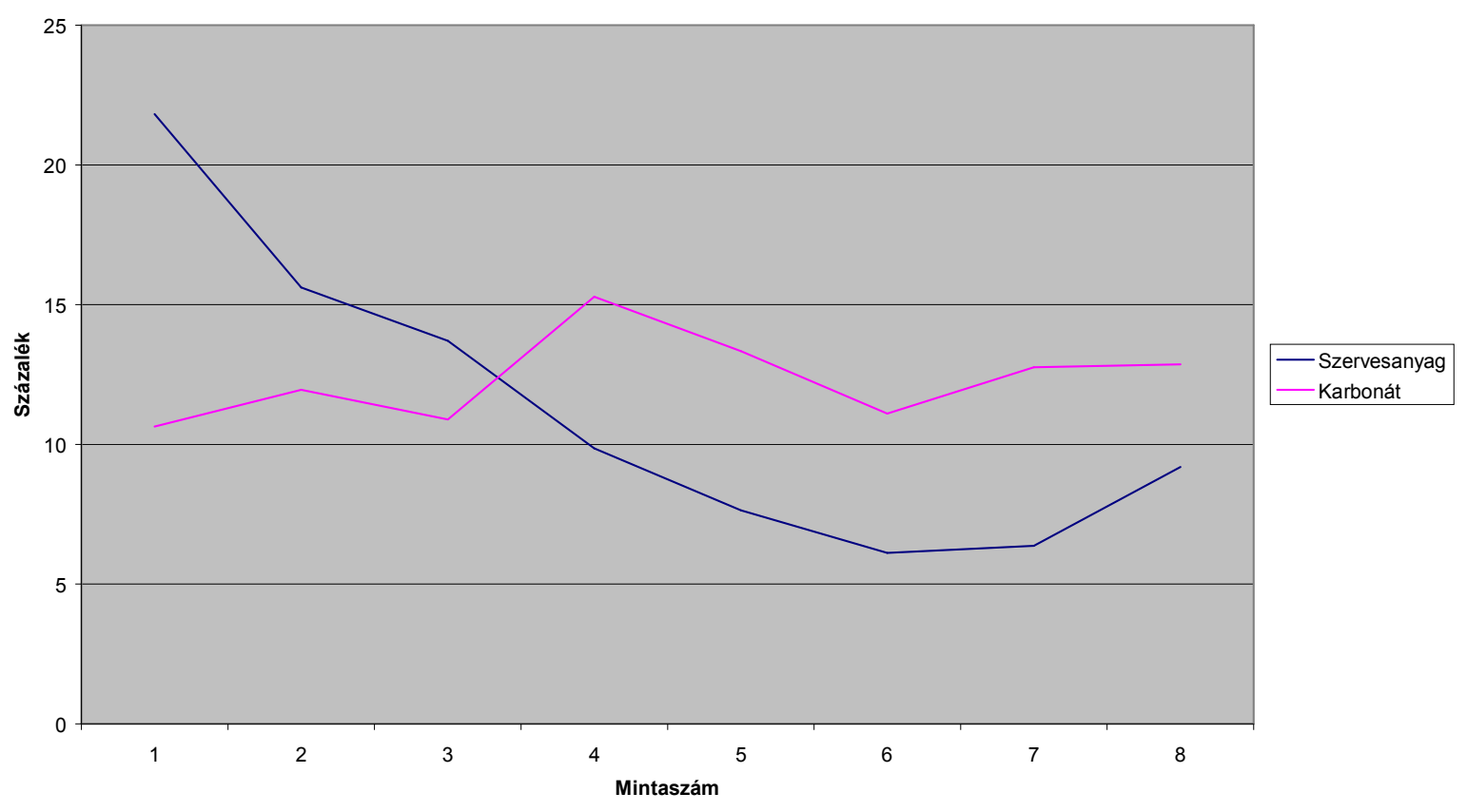

64. ábra A semlyékben mélyített fúrás anyagának szervesanyag- és karbonáttartalma

\begin{tabular}{|c|c|c|c|c|c|c|c|c|c|}
\hline Mintaszám & $\mathbf{C a}$ & Mg & $\mathbf{N a}$ & $\mathbf{K}$ & $\mathrm{Fe}$ & $\mathrm{Cu}$ & Mn & $\mathbf{Z n}$ & $\mathrm{K} / \mathrm{Na}$ \\
\hline 1 & 753 & 1657 & 249 & 281 & 41 & 16 & 5 & 3 & 1,125 \\
\hline 2 & 392 & 1070 & 290 & 239 & 21 & 16 & 5 & 4 & 0,822 \\
\hline 3 & 386 & 1117 & 315 & 224 & 18 & 17 & 2 & 5 & 0,712 \\
\hline 4 & 506 & 913 & 230 & 177 & 25 & 19 & 5 & 6 & 0,770 \\
\hline 5 & 435 & 757 & 238 & 180 & 22 & 20 & 6 & 6 & 0,756 \\
\hline 6 & 479 & 761 & 209 & 162 & 26 & 22 & 8 & 6 & 0,775 \\
\hline 7 & 844 & 1147 & 213 & 161 & 62 & 24 & 11 & 7 & 0,756 \\
\hline 8 & 471 & 763 & 201 & 109 & 21 & 26 & 4 & 7 & 0,541 \\
\hline
\end{tabular}

4. táblázat A semlyékben mélyített fúrás elem-tartalma nedves kémiai feltárás és lángfotometria alapján 


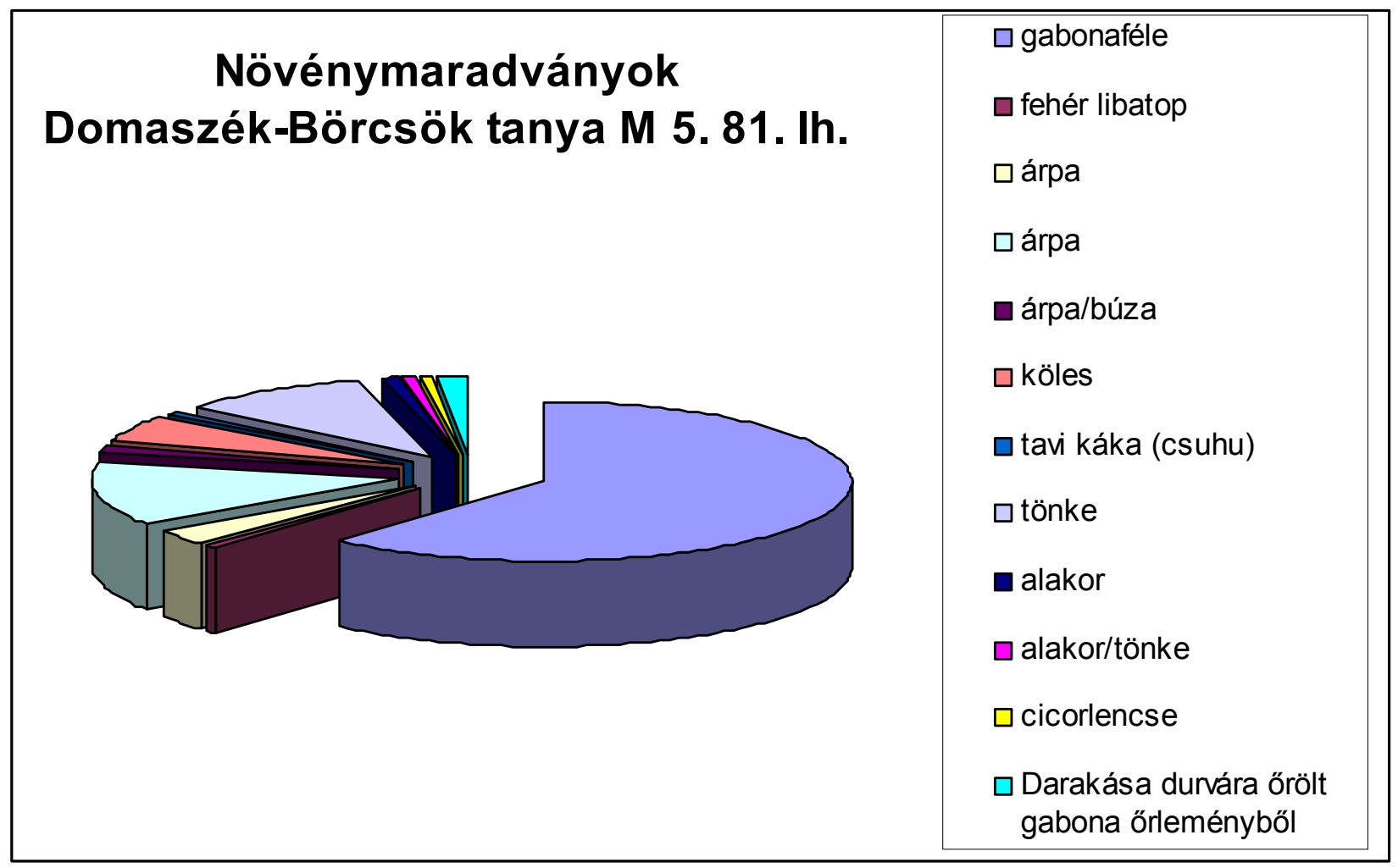

65. ábra A lelőhely biztosan Halomsíros-kultúrához köthető növényi maradványainak megoszlása

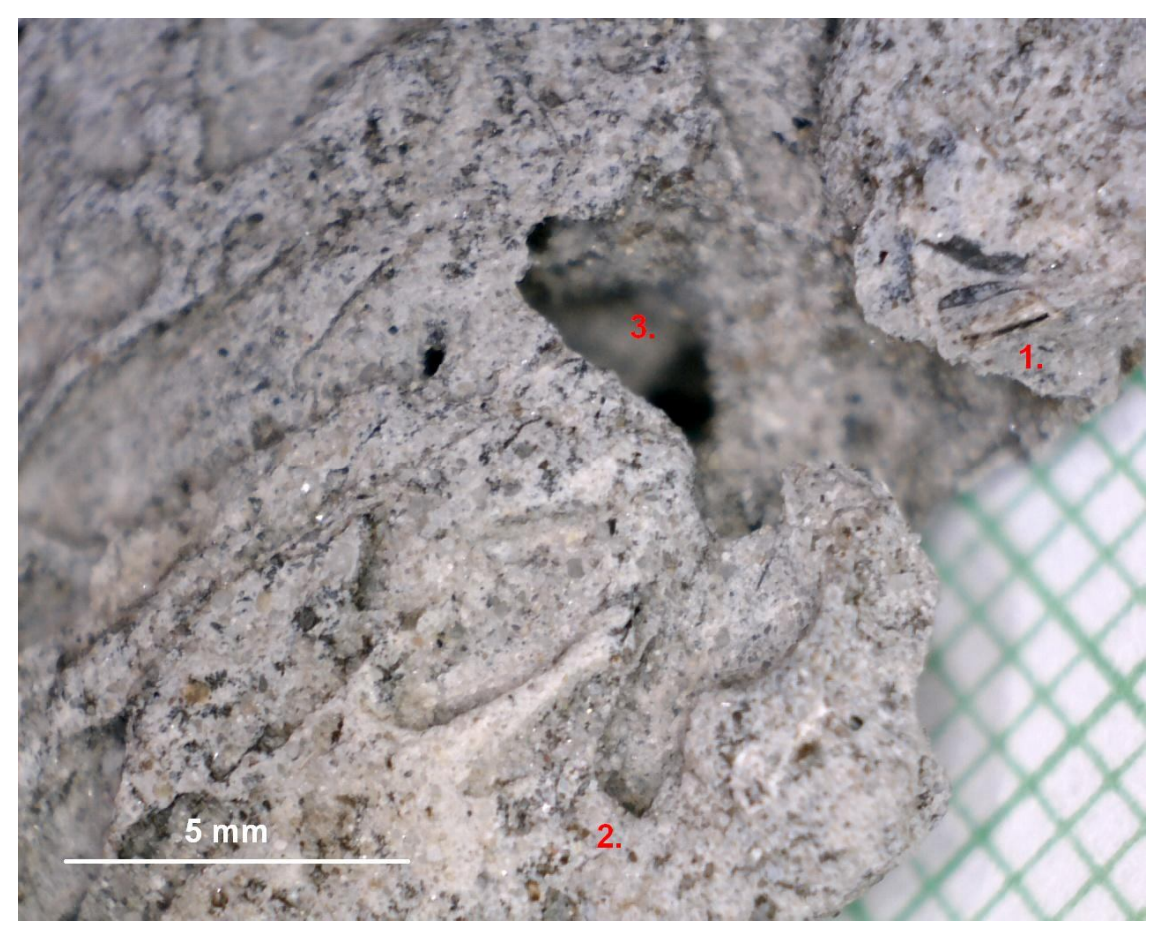

66. ábra A 308. objektumból előkerült karbonátos konkréció növényi lenyomatokkal (digitális sztereomikroszkópos felvétel):

1 - kalászorsó szenült maradványa, 2 - pelyva lenyomatok, 3 - szár nyomán maradt üreg 


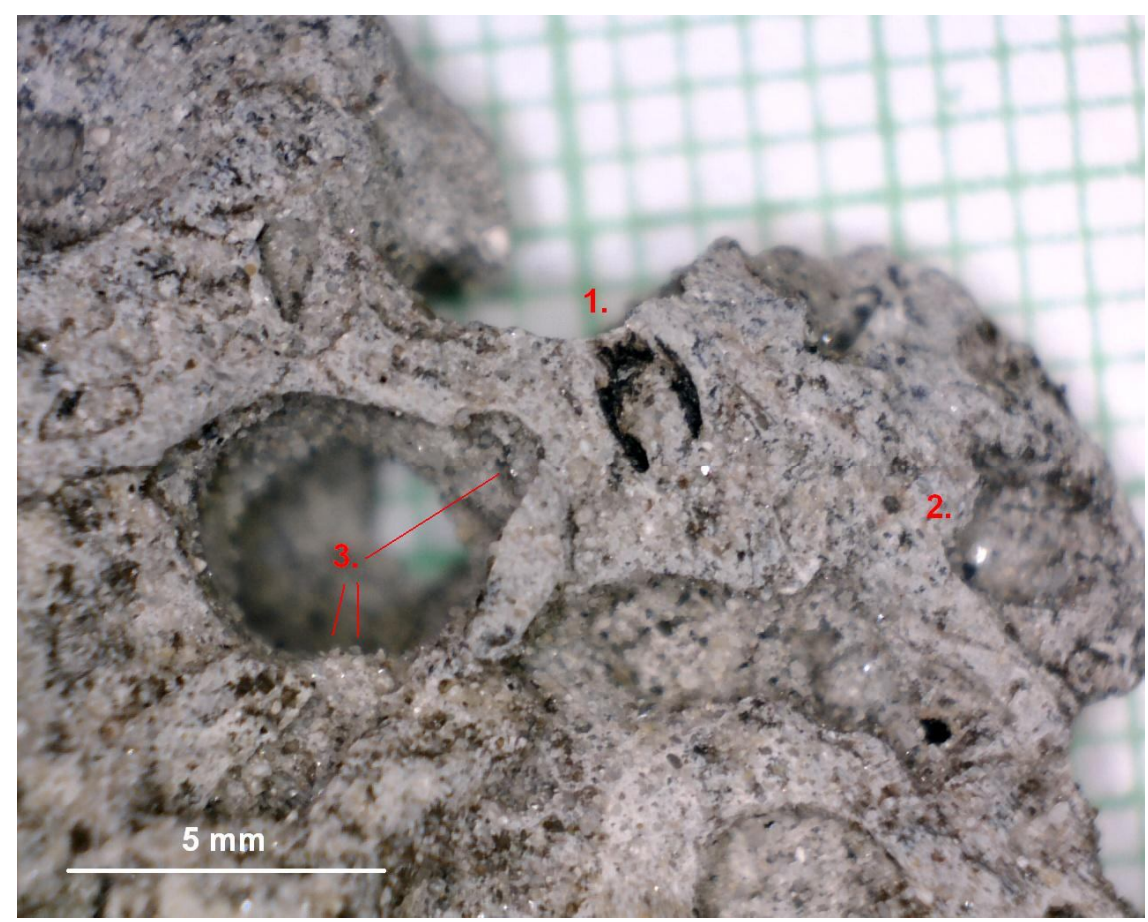

67. ábra A 308. objektumból előkerült lenyomat (digitális sztereomikroszkópos felvétel).

1 - kalászorsó szenült maradványa, 2 - köles lenyomat, 3 - finom, lekerekített kvarchomokszemek

\section{Domaszék-Börcsök tanya Nagyrévi kultúra háziállatcsontleletei (M5 Nr. 81. 17/54)}

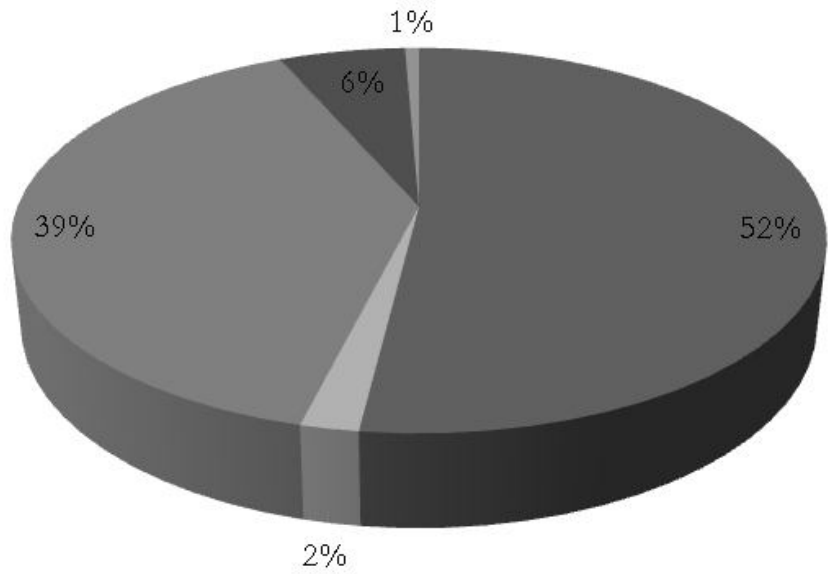

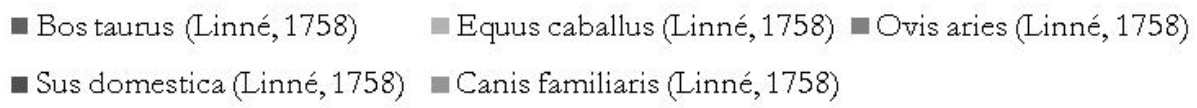

68. ábra A Nagyrév település állatcsontleletei (Tóth 2011, 1. ábra nyomán) 
Domaszék-Börcsök tanya, Halomsíros kultúra, feltehetően Halomsíros kultúra leletei (M5 Nr. 81. 17/54)

Gerinces állatok

Háziállatok

Szarvasmarha

Bos taurus (Linné, 1758)

darabszám

Juh

Sertés

Ovis aries (Linné, 1758)

Sus domestica (Linné, 1758)

Kutya

Canis familiaris (Linné, 1758)

25

Ló

Összesen

Equus caballus (Linné, 1758)

Vadállatok

Gimszarvas

Mezei nyúl

Összesen

Cervus elaphus (Linné, 1758)

Lepus europeus (Linné, 1758)

Rágcsálók

Közönséges ürge

Rágcsáló

Összesen

Madarak

Madár

Halak

$\mathrm{Hal}$

Gerinces állatok összesen

9

Spermophilus citellus (Linné, 1766) 42

Rodentia

Aves sp. Indet $\quad \mathbf{6}$

Pisces sp. Indet 7

Gerinctelen állatok

Csigák/kagylók teknő/héj db

Csiga

Folyami kagyló

Folyami kagyló

Tompa folyami kagyló

Összesen

Meghatározott maradványok száma

Unionidae

Unio tumidus (Linné, 1788)

Unio crassus (Linné, 1788)

5. táblázat. Domaszék-Börcsök tanya, Halomsíros-kultúra állatcsont leletei (db) (Tóth 2011,

4. táblázat nyomán)

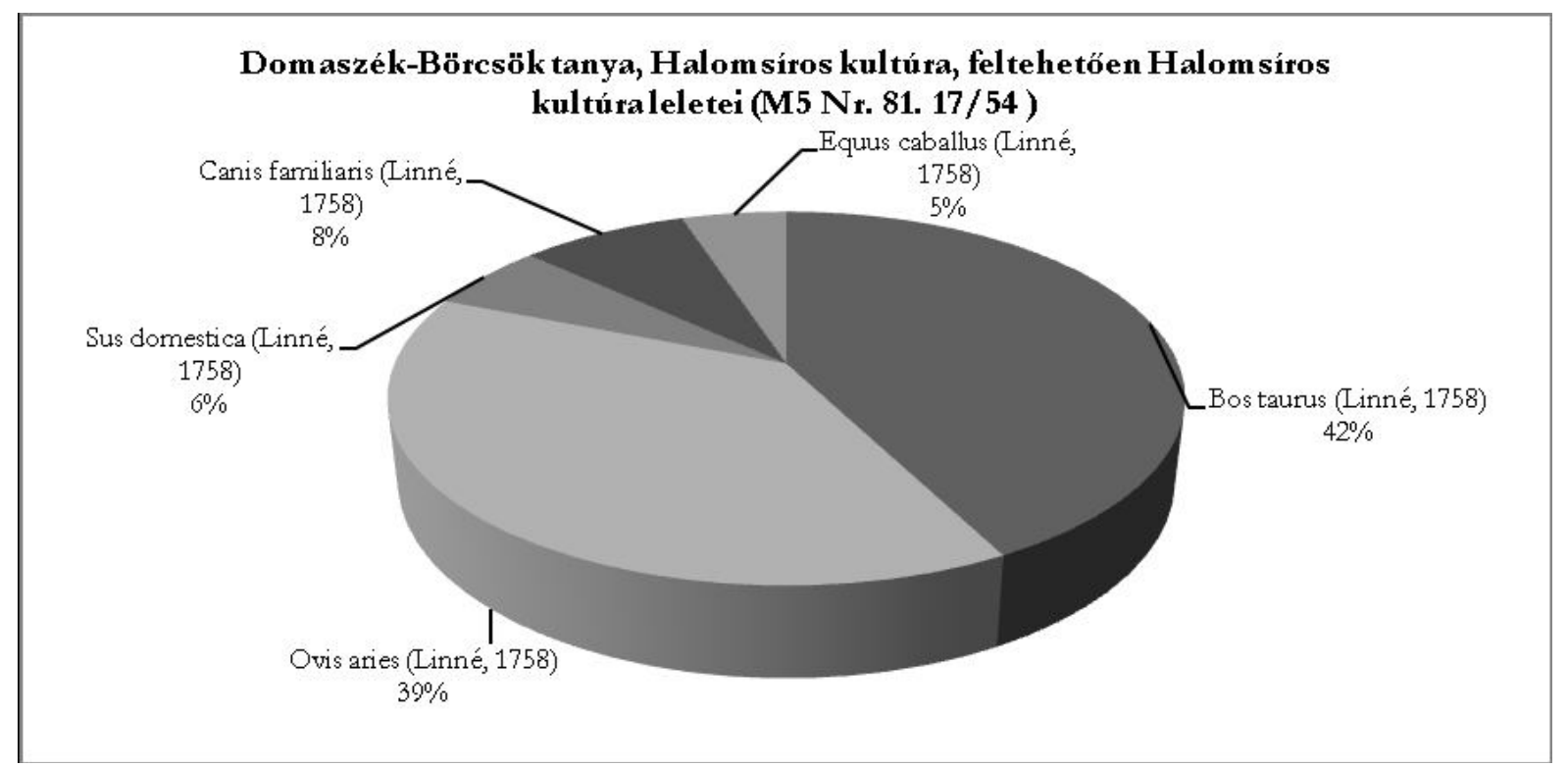

69. ábra A település Halomsíros állatcsont-anyagának megoszlása fajok szerint (db) 


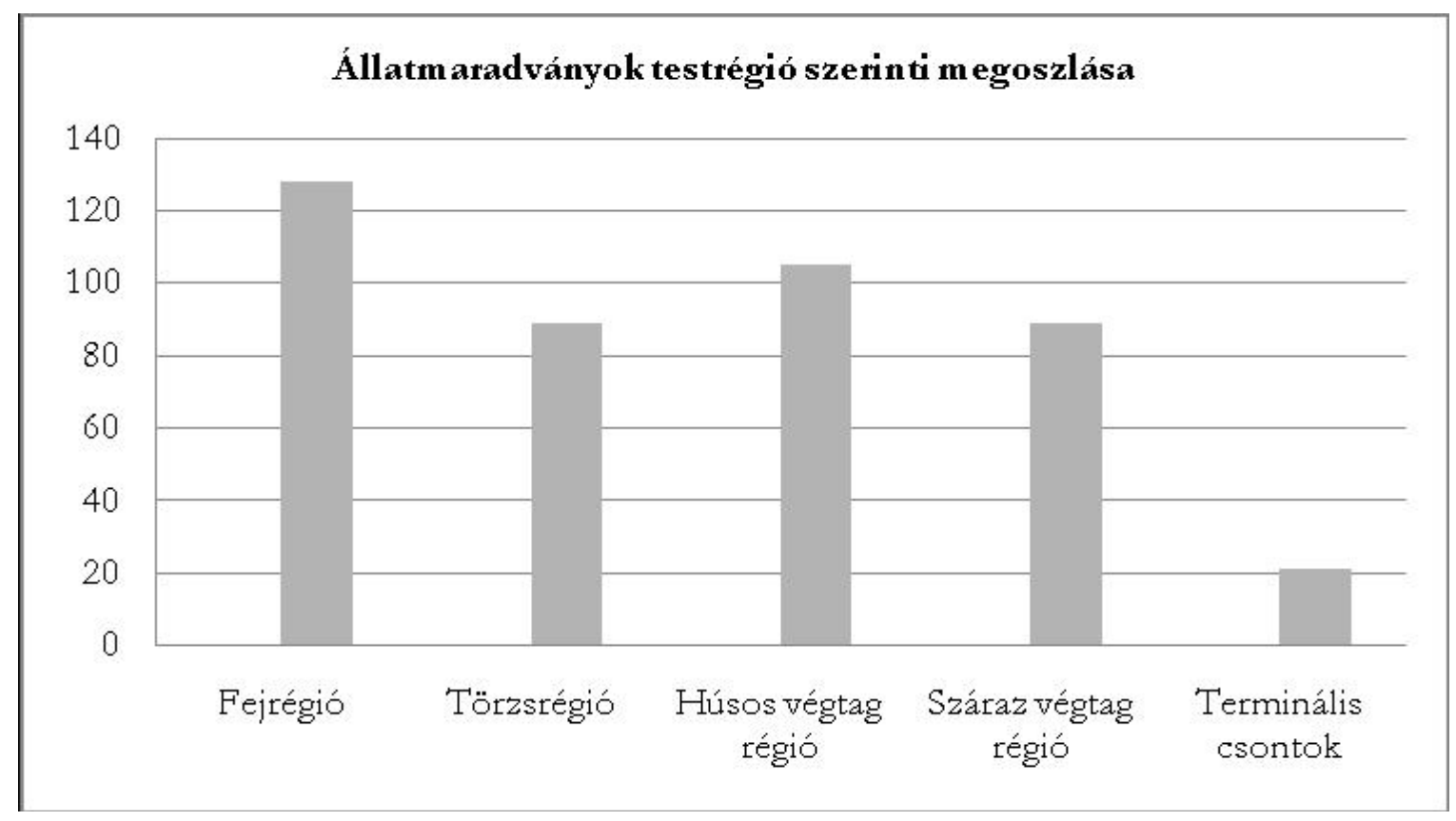

70. ábra A Halomsíros telep állatcsont-leleteinek testtájak szerinti megoszlása (db)

\section{Domaszék-Börcsök tanya (M5 Nr. 81. 17/54) Halom síros kultúra} (Talán Halom síros kultúra), a háziállatok csontleleteinek anatómiai megoszlása (db)
- Fejrégió
" Törzsrégió
n Húsos végtag régió
— Száraz végtag régió "Terminális csontok

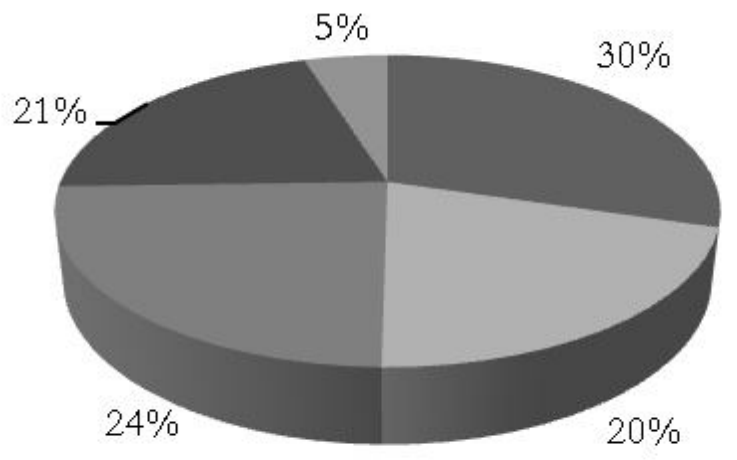

71. ábra Halomsíros állatcsont-leletek testtájak szerinti megoszlása kördiagramon százalékosan 


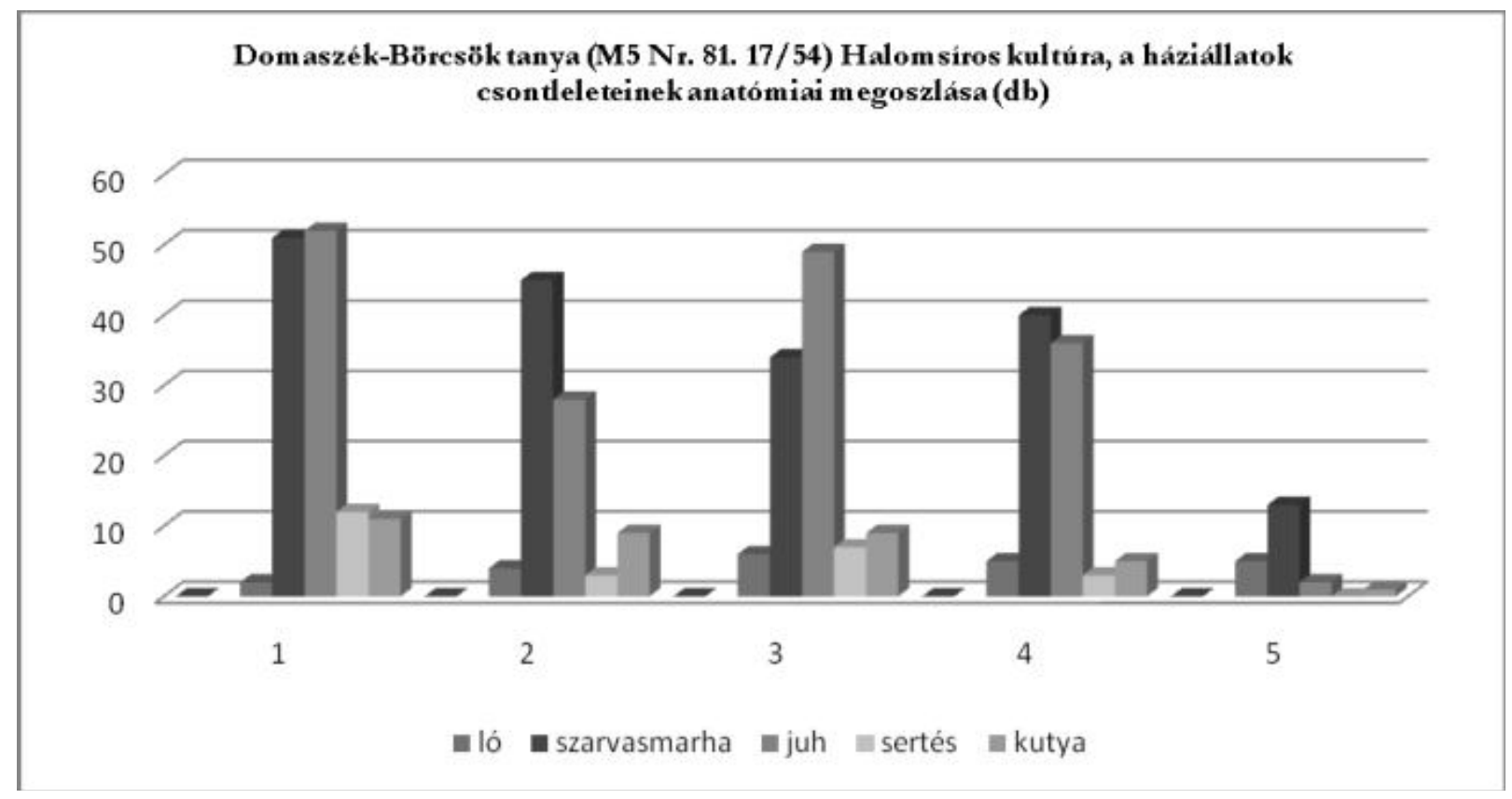

72. ábra. A Halomsíros háziállat csontok fajok és testtájak szerinti megoszlása (Tóth 2011, 68. ábra nyomán)

\begin{tabular}{|c|c|c|c|c|c|c|}
\hline $\begin{array}{l}\text { Testrégió a } \\
\text { feltételezett } \\
\text { Halomsíros } \\
\text { kultúra } \\
\text { objektumain } \\
\text { adataival } \\
\text { Fauna }\end{array}$ & Fejrégió & Törzsrégió & $\begin{array}{l}\text { Húsos végtag } \\
\text { régió }\end{array}$ & $\begin{array}{l}\text { Száraz végtag } \\
\text { régió }\end{array}$ & $\begin{array}{l}\text { Terminális } \\
\text { csontok }\end{array}$ & Összesen \\
\hline \multicolumn{7}{|l|}{ Háziállat } \\
\hline ló & 2 & 4 & 6 & 5 & 5 & 22 \\
\hline szarvasmarha & 51 & 45 & 34 & 40 & 13 & 183 \\
\hline juh & 52 & 28 & 49 & 36 & 2 & 167 \\
\hline házi sertés & 12 & 3 & 7 & 3 & 0 & 25 \\
\hline kutya & 11 & 9 & 9 & 5 & 1 & 35 \\
\hline Összesen & 128 & 89 & 105 & 89 & 21 & 432 \\
\hline
\end{tabular}

6. táblázat: Domaszék-Börcsök tanya (M5 Nr. 81. 17/54 ). Halomsíros kultúra gazdasági haszonállat leleteinek anatómiai megoszlása (db) (Tóth 2011, 5. táblázat nyomán) 


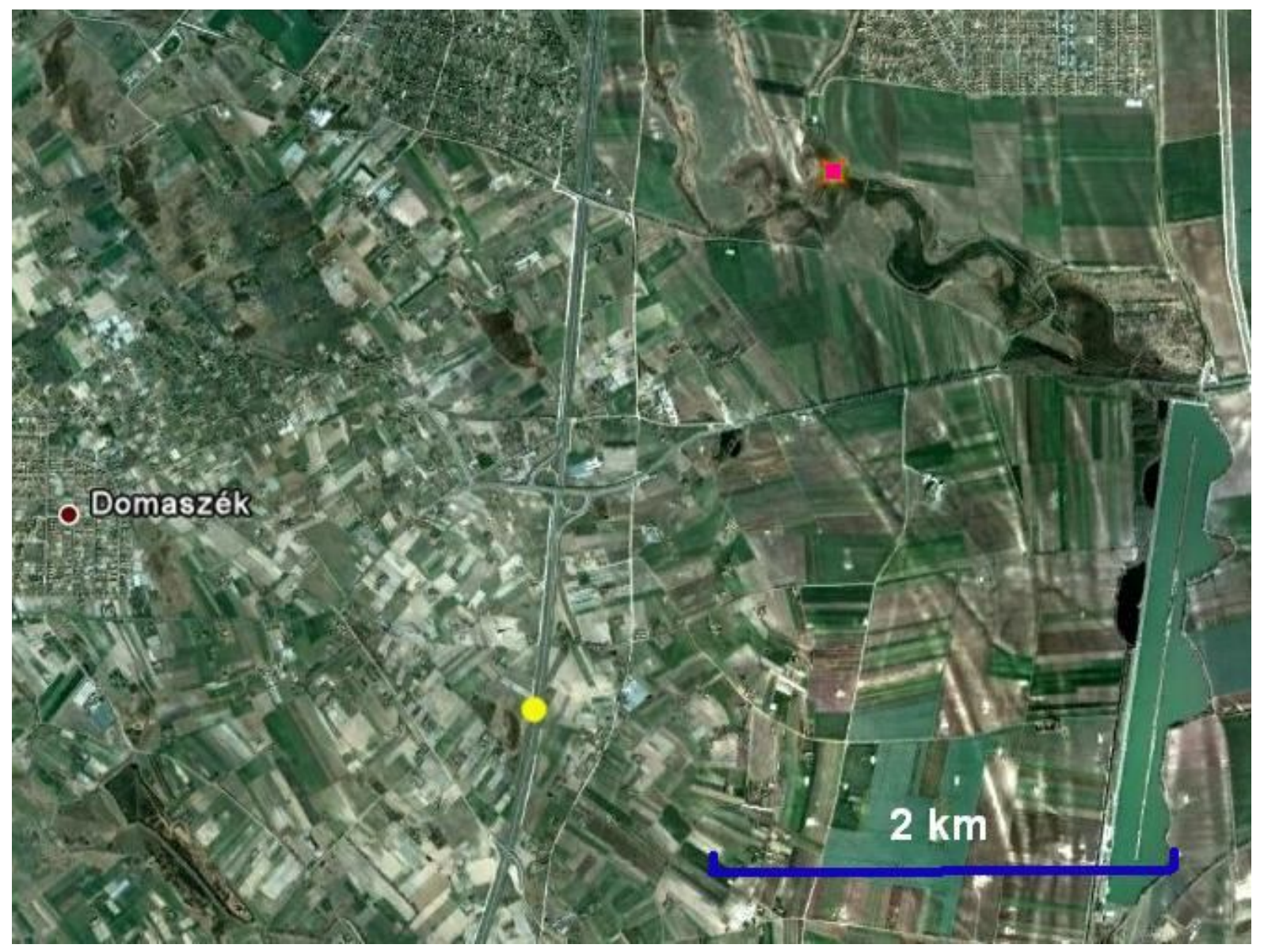

73. ábra: A pollenfúrás és a lelőhely egymáshoz viszonyított elhelyezkedése a müholdas felvételen (Google Earth). A lelőhelyet sárga kör, a pollenfúrást (Putri-rét) piros X jelöli. A lelőhely 3 km-re található a fúrástól 


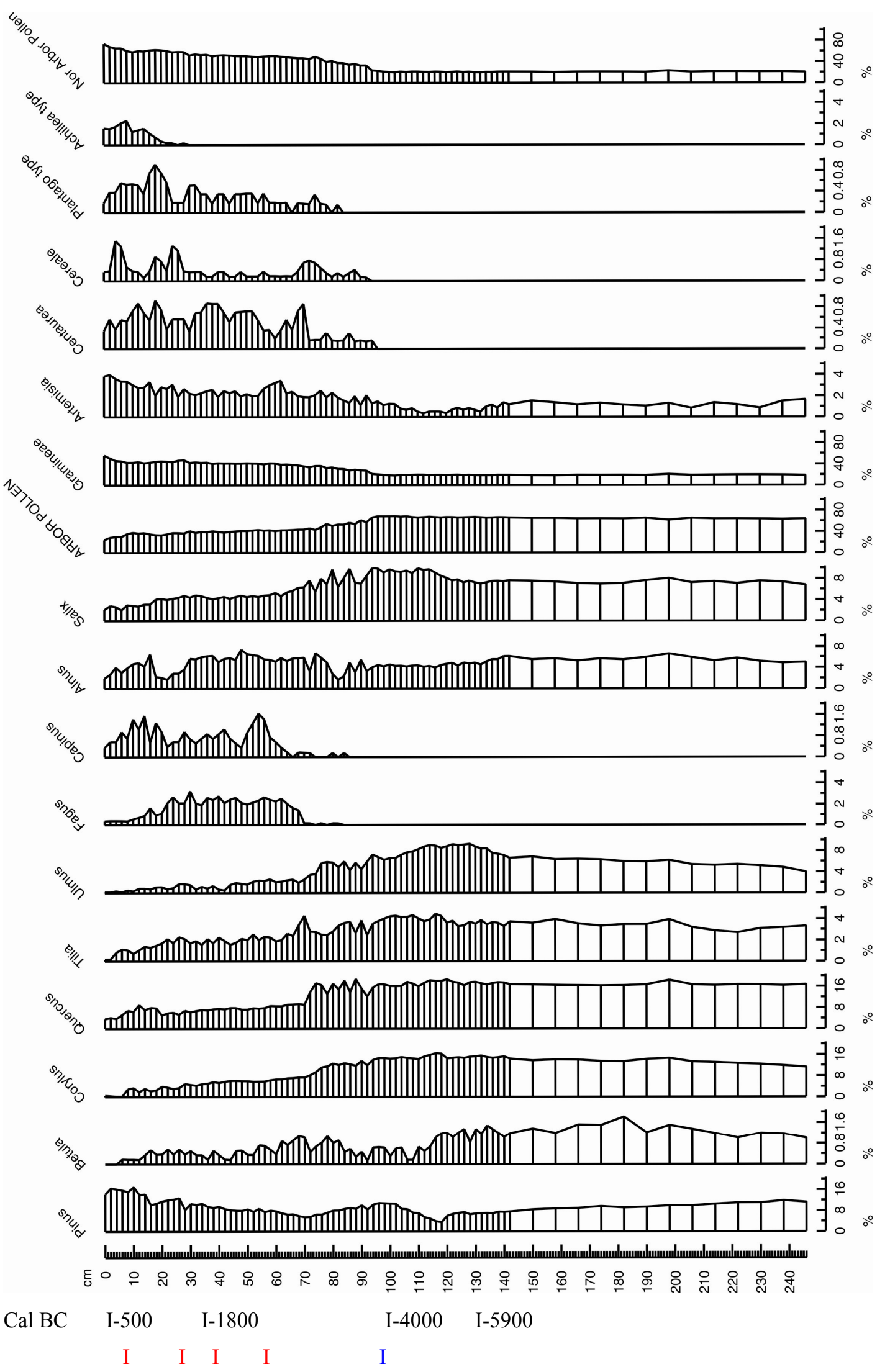

74. ábra A Putri-réti fúrás (Maty-ér) pollendiagramja. Figyeljük meg a gabonapollen, az útifú (Plantago), az imola (Centaurea) és a cickafark (Achillea) egymáshoz viszonyított arányát! (A cal BC adatoknál a vonás azt a szintet jelzi, melyre az adat vonatkozik. A piros vonások a bronzkor 3 szakaszának (korai, középső és késő bronzkor) határait jelzik, a kék az emberi tevékenység kezdetét 

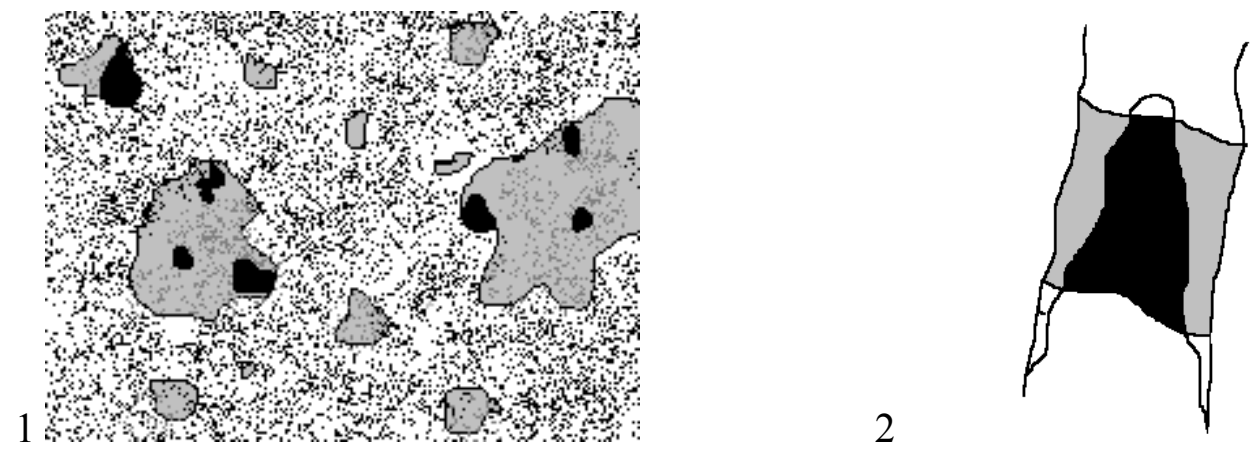

75. ábra 1. 1. gödör 1. tárgy jellegzetes szövete. 2. 1/2. tárgy: Agyaghurka illesztés nyoma Szürke: kerámiatöredékek, fekete: kerámiatöredékek a kerámiatöredékeken belül, pontozott: finomszemcsés, csillámos alapanyag. Sztereobinokuláris mikroszkóp, 40x-es nagyítás

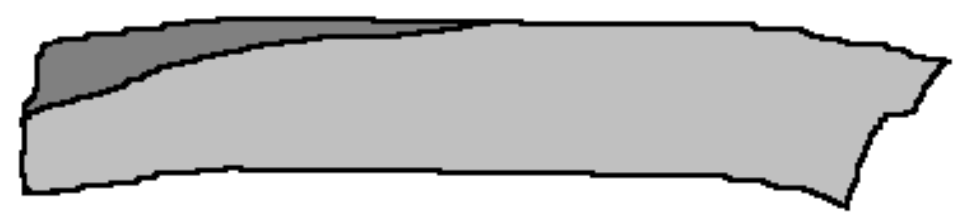

76. ábra A 17/1. tárgy metszete. Agyagszalag illesztésének nyoma

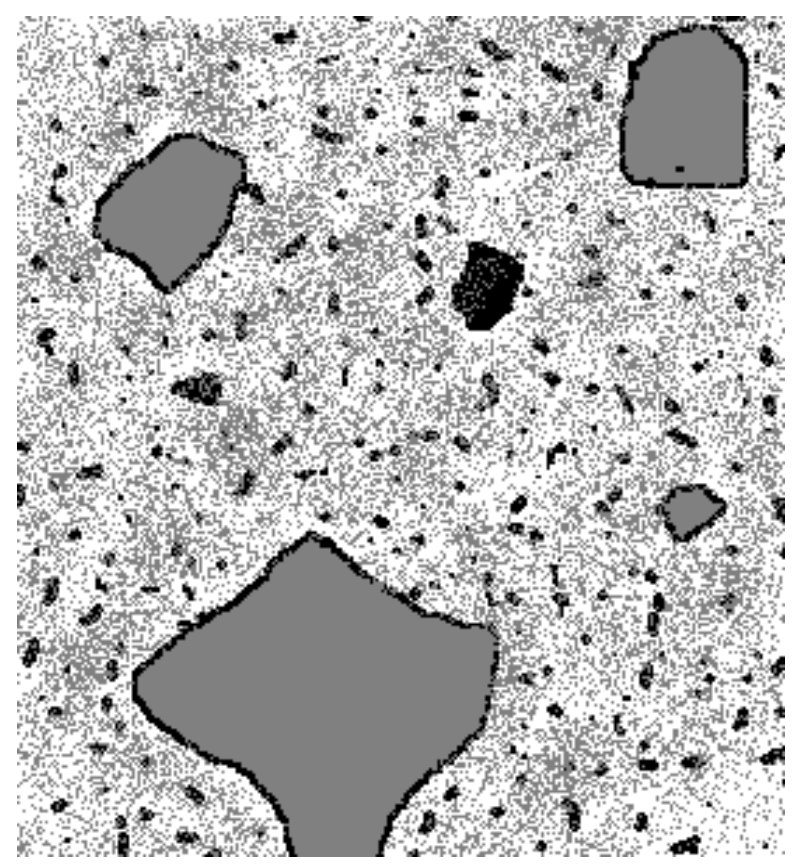

77. ábra A 44/1. lelet rajza. Sztereobinokuláris mikroszkóp, 40x-es nagyítás, felületi mikroszkópia. Szürke: kerámia. Fekete: kőzet, kőzetliszt. 


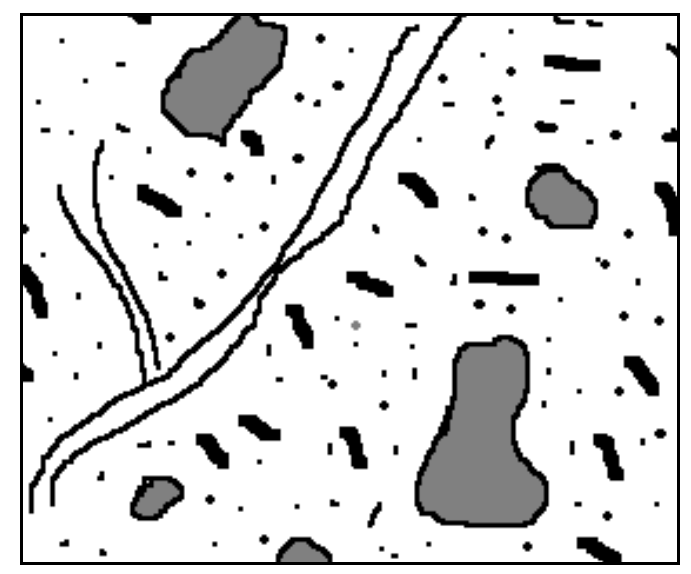

78. ábra A 246/1. tárgy. Sztereobinokuláris mikroszkóp, 40x-es nagyítás, felületi mikroszkópia. Fekete: amfibol vagy piroxén kristályok

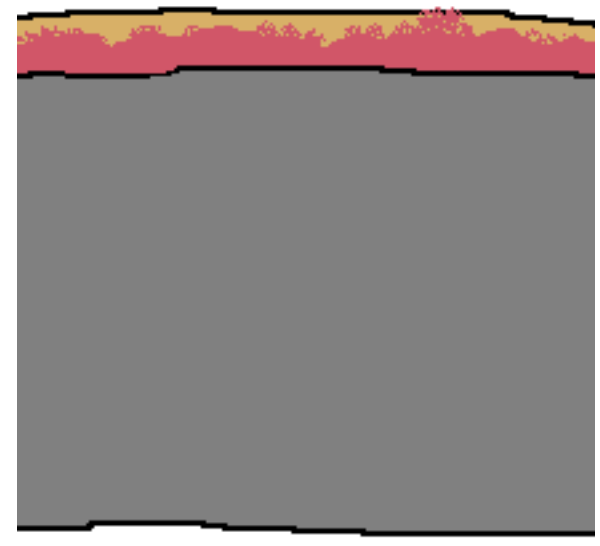

79. ábra A 309/4-8. darabok jellemző metszete. Sztereobinokuláris mikroszkóp, 40x-es nagyítás, törésfelület. Vöröses: vasoxidos bevonat. Sárgás: vashidroxidos bevonat. Szürke: mátrix, ez esetben oxidatív, enyhén reduktív, sárgás-vöröses színü.

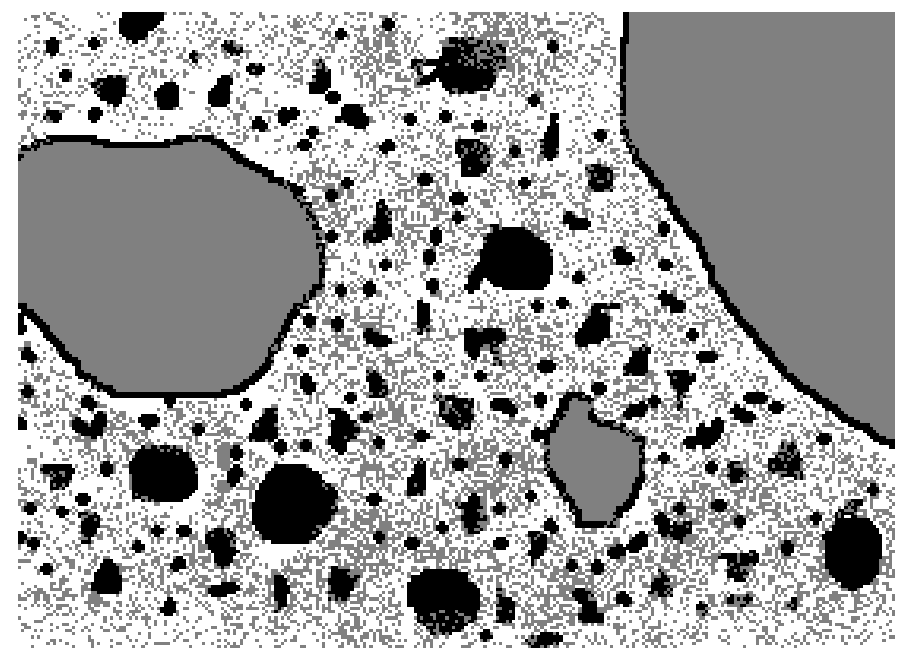

80. ábra A 319/3. minta szövete. Sztereobinokuláris mikroszkóp, 40x-es nagyítás, felületi mikroszkópia. 


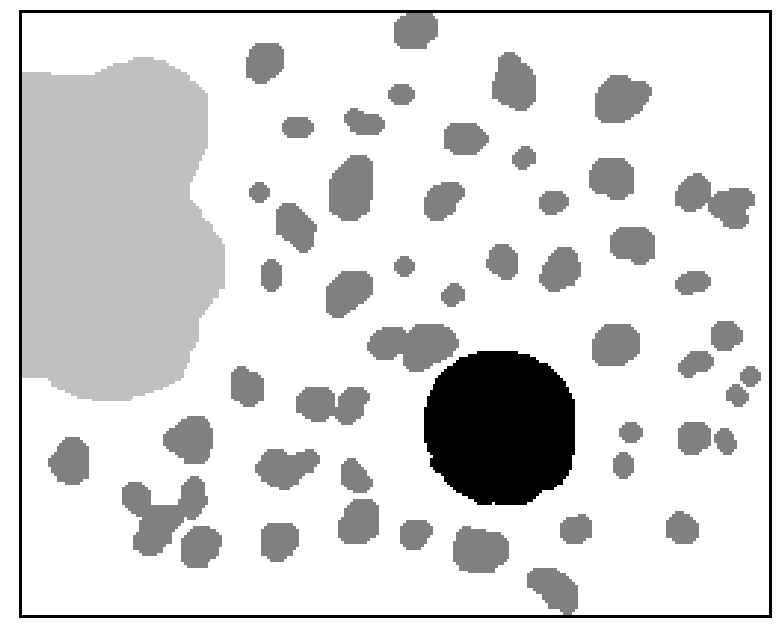

81. ábra A 320/1. minta szövete. Sztereobinokuláris mikroszkóp, 40x-es nagyítás, felületi mikroszkópia. Fekete: vasborsó, sötét szürke: eolikus finomhomok, világos szürke: kerámia.

\begin{tabular}{|c|c|c|c|c|c|c|c|}
\hline Minta & edénytípus & $\begin{array}{l}1 . \\
\text { nyersanyag: } \\
\text { amfibolos }\end{array}$ & $\begin{array}{l}\text { 2. nyersanyag: } \\
\text { szögletes } \\
\text { apróhomok } \\
\text { amfibol nélkül }\end{array}$ & $\begin{array}{l}3 . \\
\text { nyersanyag: } \\
\text { eolikus } \\
\text { apróhomok } \\
\text { szennyezés }\end{array}$ & $\begin{array}{l}4 . \\
\text { nyersanyag: } \\
\text { durvakőzet- } \\
\text { lisztes, } \\
\text { bizonytalan } \\
\text { eredetü } \\
\text { (löszböl } \\
\text { iszapolt?) }\end{array}$ & $\begin{array}{l}5 . \\
\text { nyersanyag: } \\
\text { kőzetliszt- } \\
\text { mentes agyag }\end{array}$ & $\begin{array}{l}\text { 6. nyers- } \\
\text { anyag: } \\
\text { vasborsó, } \\
\text { kőzetliszt }\end{array}$ \\
\hline 1.(1) & finom & & & & & 1 & \\
\hline 1.(2) & finom & & & & & 1 & \\
\hline 17.(1) & finom & & & & & 1 & \\
\hline 44.(1) & finom & & & & 1 & & \\
\hline 246.(1) & finom & 1 & & & & & \\
\hline 272.(1) & durva & & & & 1 & & \\
\hline 309.(1) & finom & & & & & & 1 \\
\hline 309.(2) & - & 1 & & & & & \\
\hline 309.(3) & - & & & & & & 1 \\
\hline 309.(4) & durva & & & & & & 1 \\
\hline 309.(5) & durva & & & & & & 1 \\
\hline 309.(6) & durva & & & & & & 1 \\
\hline 309.(7) & durva & & & & & & 1 \\
\hline $309 .(8)$ & durva & & & & & & 1 \\
\hline 313.(1) & - & & & & & & 1 \\
\hline 319.(1) & - & 1 & & & & & \\
\hline 319.(2) & - & & & & 1 & & \\
\hline 319.(3) & - & & & & & & 1 \\
\hline $320 .(1)$ & - & & & & & & 1 \\
\hline $320 .(2)$ & - & & & & & & 1 \\
\hline $320 .(3)$ & - & & & & & & 1 \\
\hline 320.(4) & - & & 1 & & & & \\
\hline 402.(1) & - & & & & 1 & & \\
\hline 402.(2) & - & & & 1 & & & \\
\hline 402.(3) & finom & & & 1 & & & \\
\hline 402.(4) & - & 1 & & & & & \\
\hline
\end{tabular}




\begin{tabular}{|l|l|l|l|l|l|l|l|}
\hline $402 .(5)$ & - & & & & 1 & & \\
\hline $402 .(6)$ & - & 1 & & & & & \\
\hline $402 .(7)$ & - & & & & 1 & & \\
\hline $402 .(8)$ & - & & & & 1 & & \\
\hline $402 .(9)$ & - & & & & & & \\
\hline $425 .(1)$ & - & & & & & \\
\hline $425 .(2)$ & - & & & & & & \\
\hline $425 .(3)$ & - & 1 & & & & & \\
\hline $428 .(1)$ & - & & & & & & \\
\hline $441 .(1)$ & finom & & & & & & \\
\hline $479 .(1)$ & finom & 1 & & & & & \\
\hline $479 .(2)$ & durva & & & & & & \\
\hline $483 .(1)$ & - & 8 & & & & & \\
\hline Összesen: & & & & & & \\
\hline
\end{tabular}

7. táblázat A kerámiavizsgálatok eredményei: nyersanyag-típusok

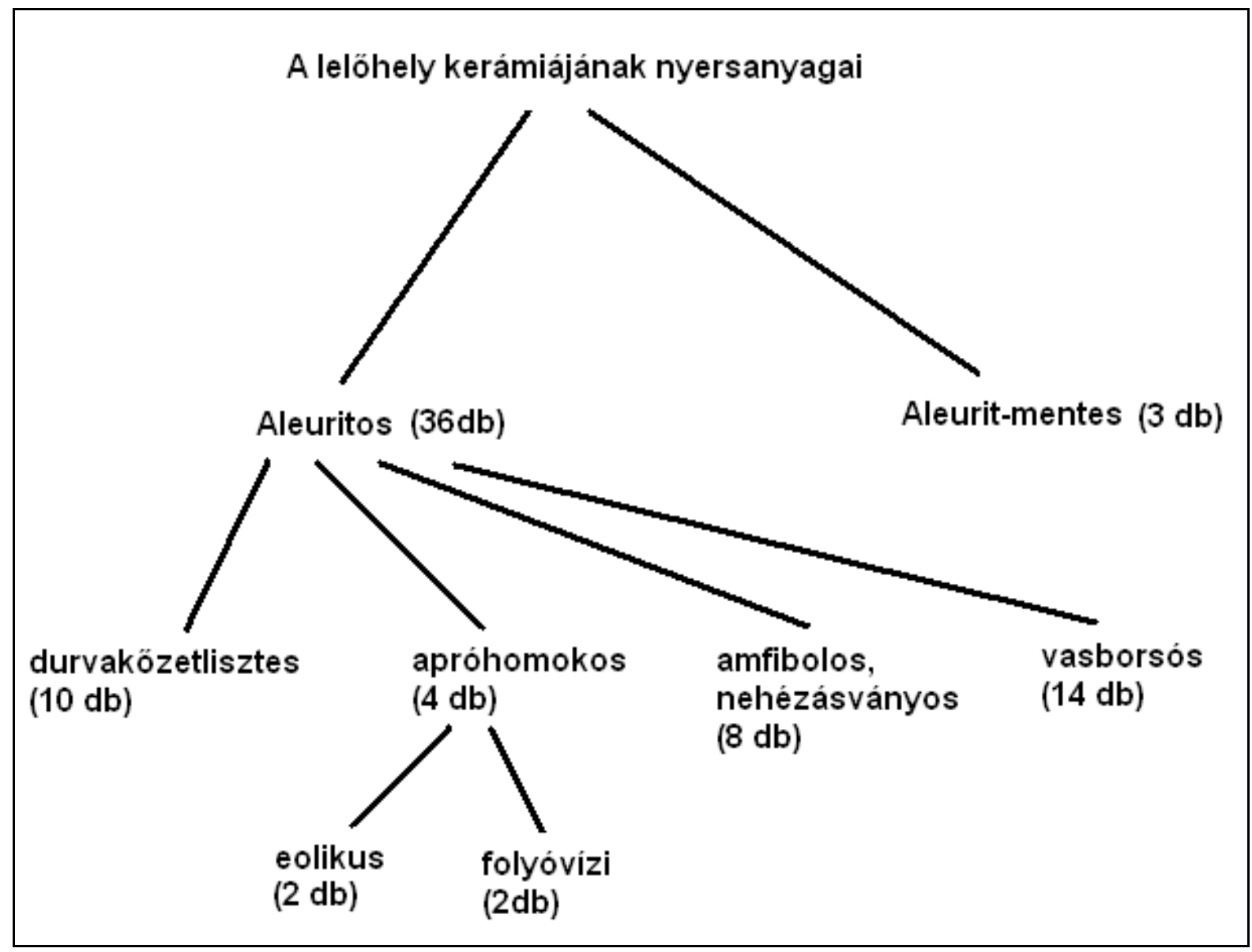

82. ábra A kerámia-nyersanyagok 


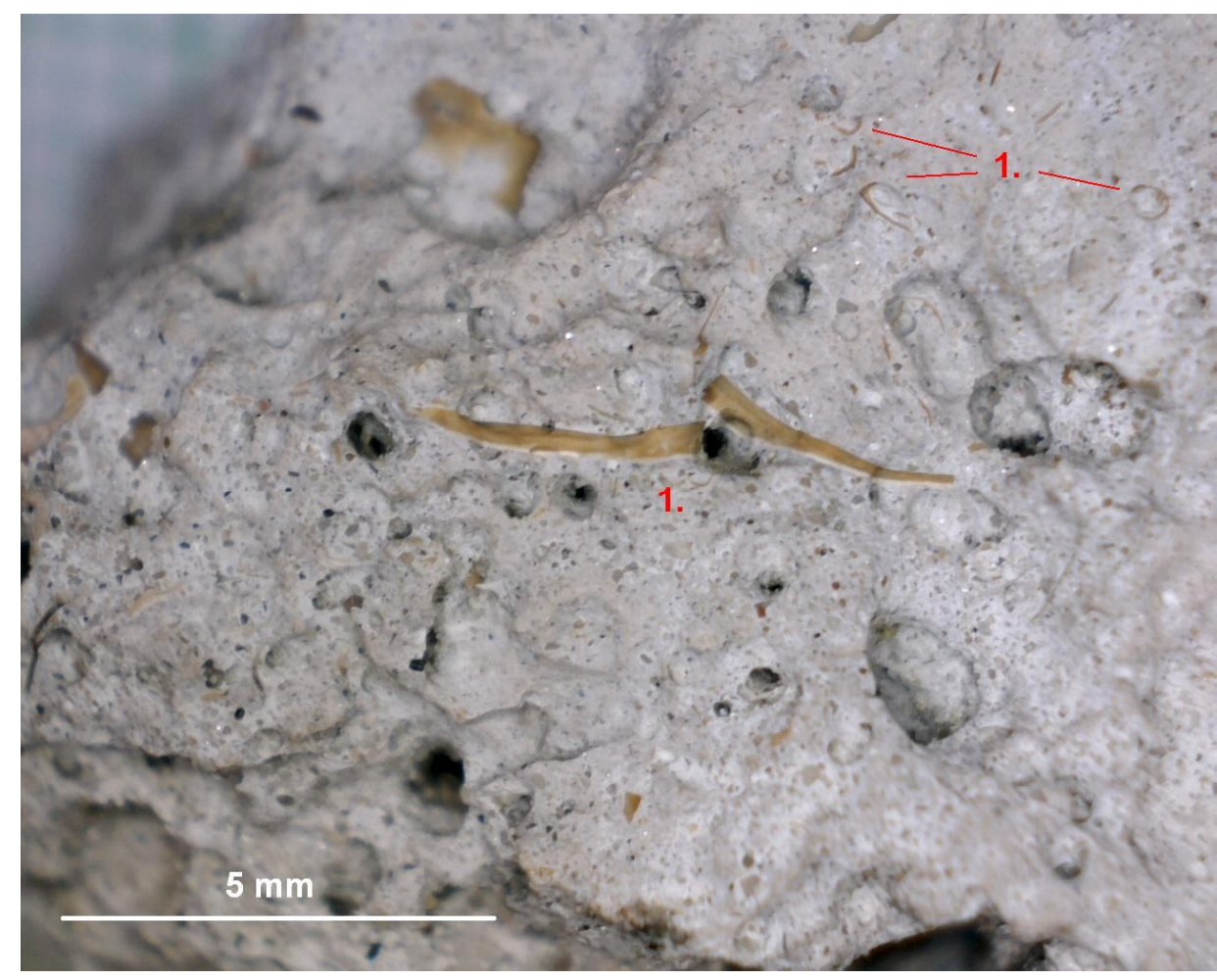

83. ábra 2007.2.1648. Tavi mészkő a 211-es objektumból. 1 - gyökerek mentén kivált vashidroxidos kéreg.

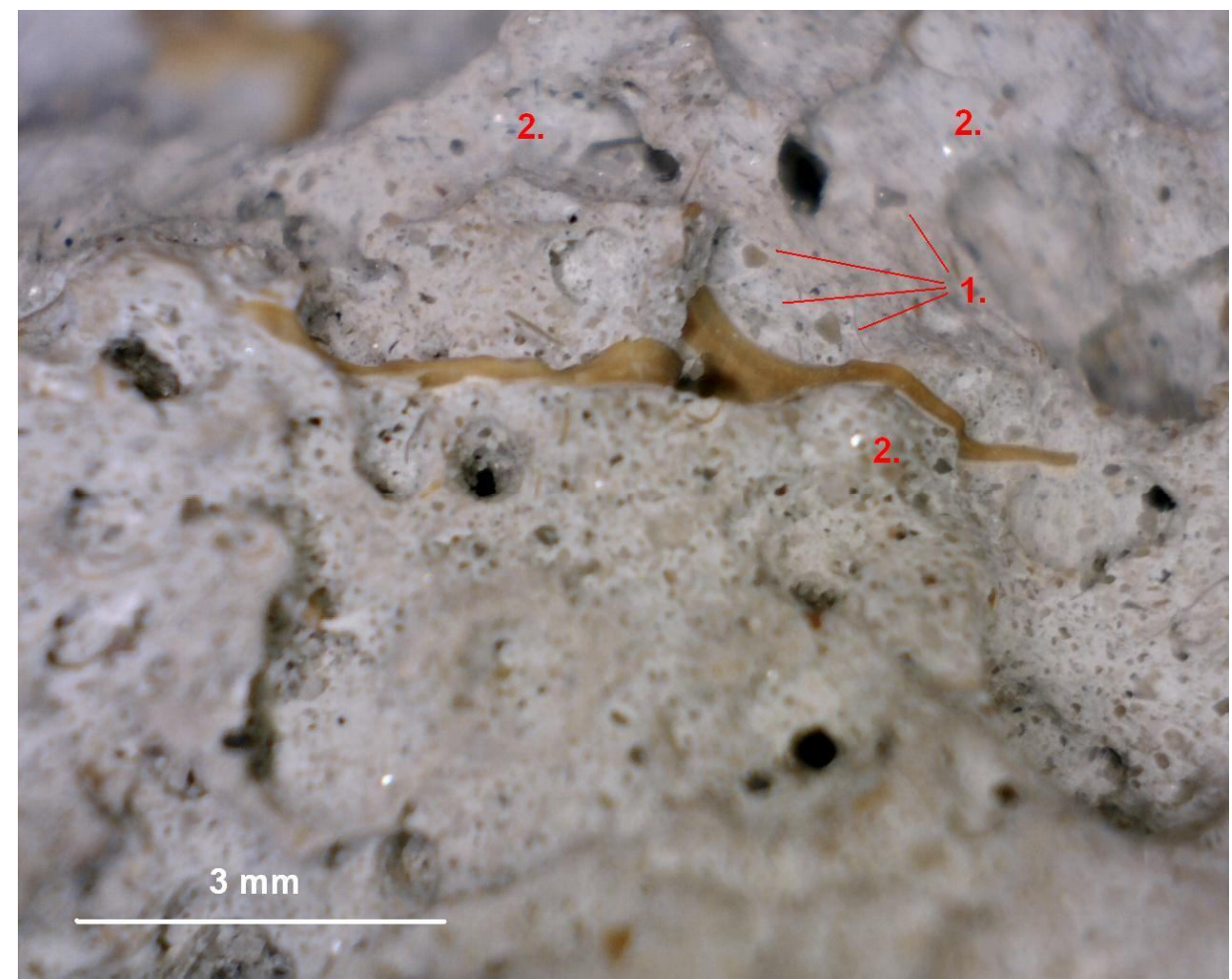

84. ábra 2007.2.1648. Tavi mészkő a 211-es objektumból. 1 - lekerekített kvarchomok szemek, 2 - csillám. 


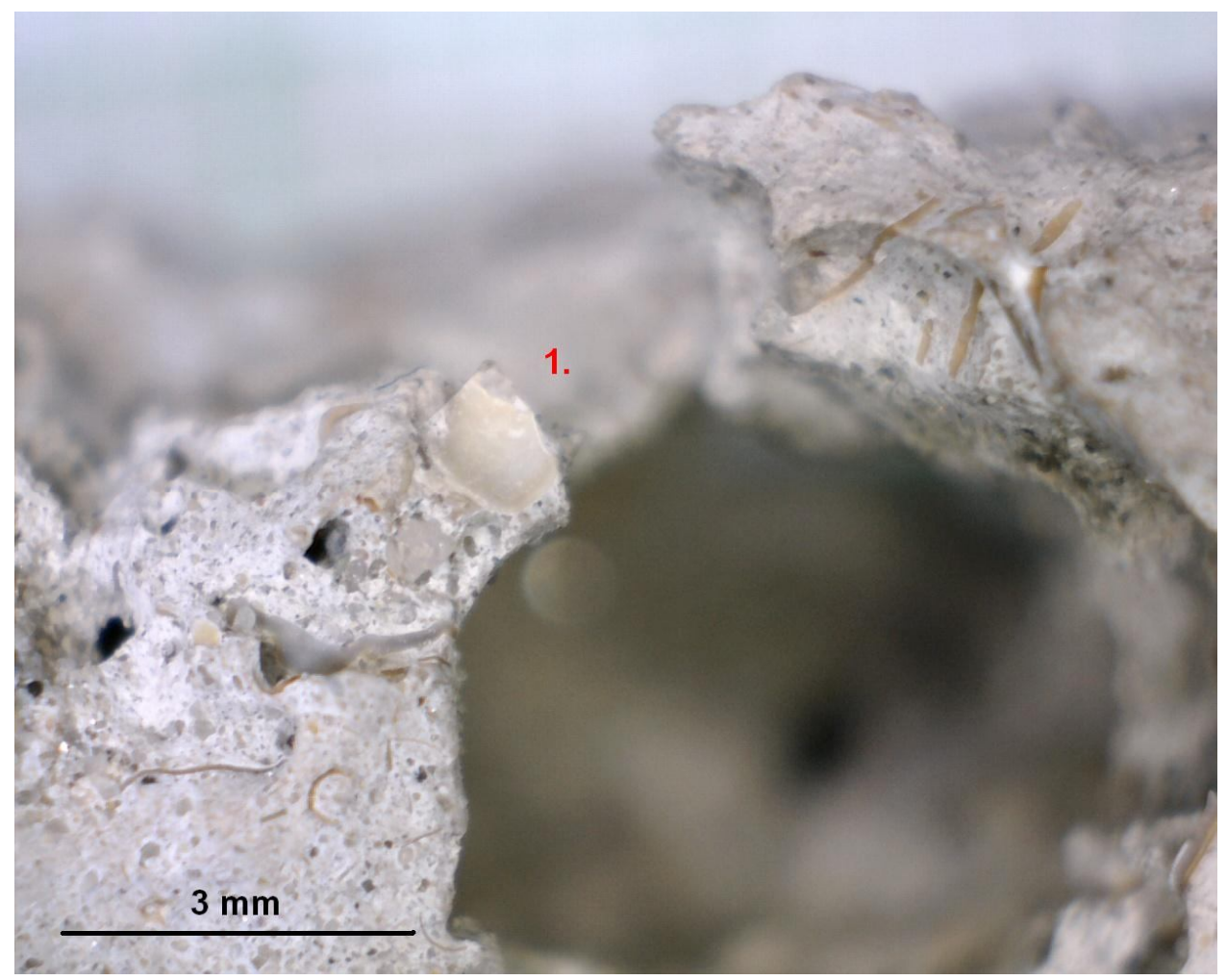

85. ábra 2007.2.1648. Tavi mészkő a 211-es objektumból. 1 - Mollusca héjtöredék.

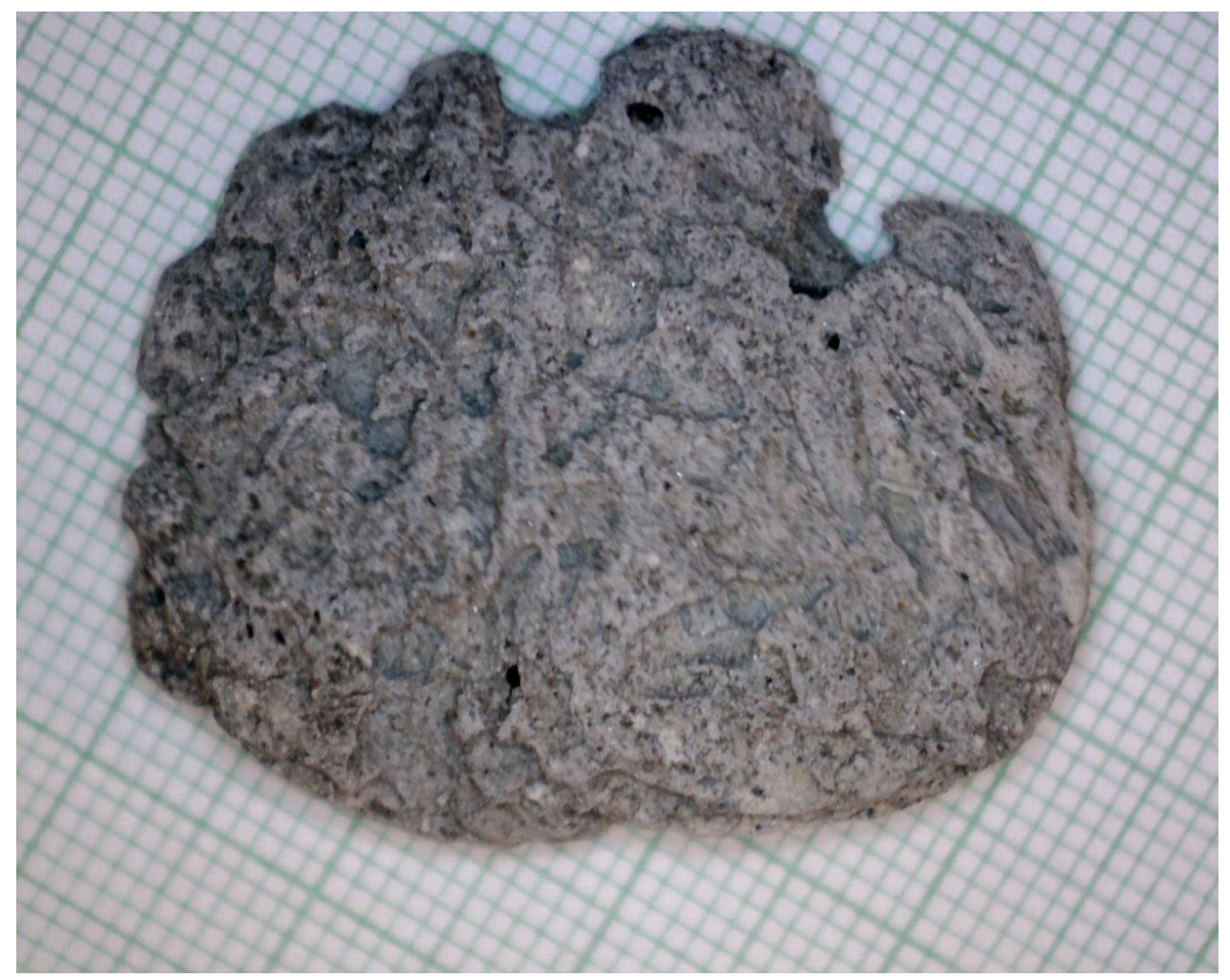

86. ábra 2007.2.1650. Szubrecens karbonátos kiválás gabona lenyomatokkal a 308. objektumból (részletesen lásd a 66-67. ábrán) 


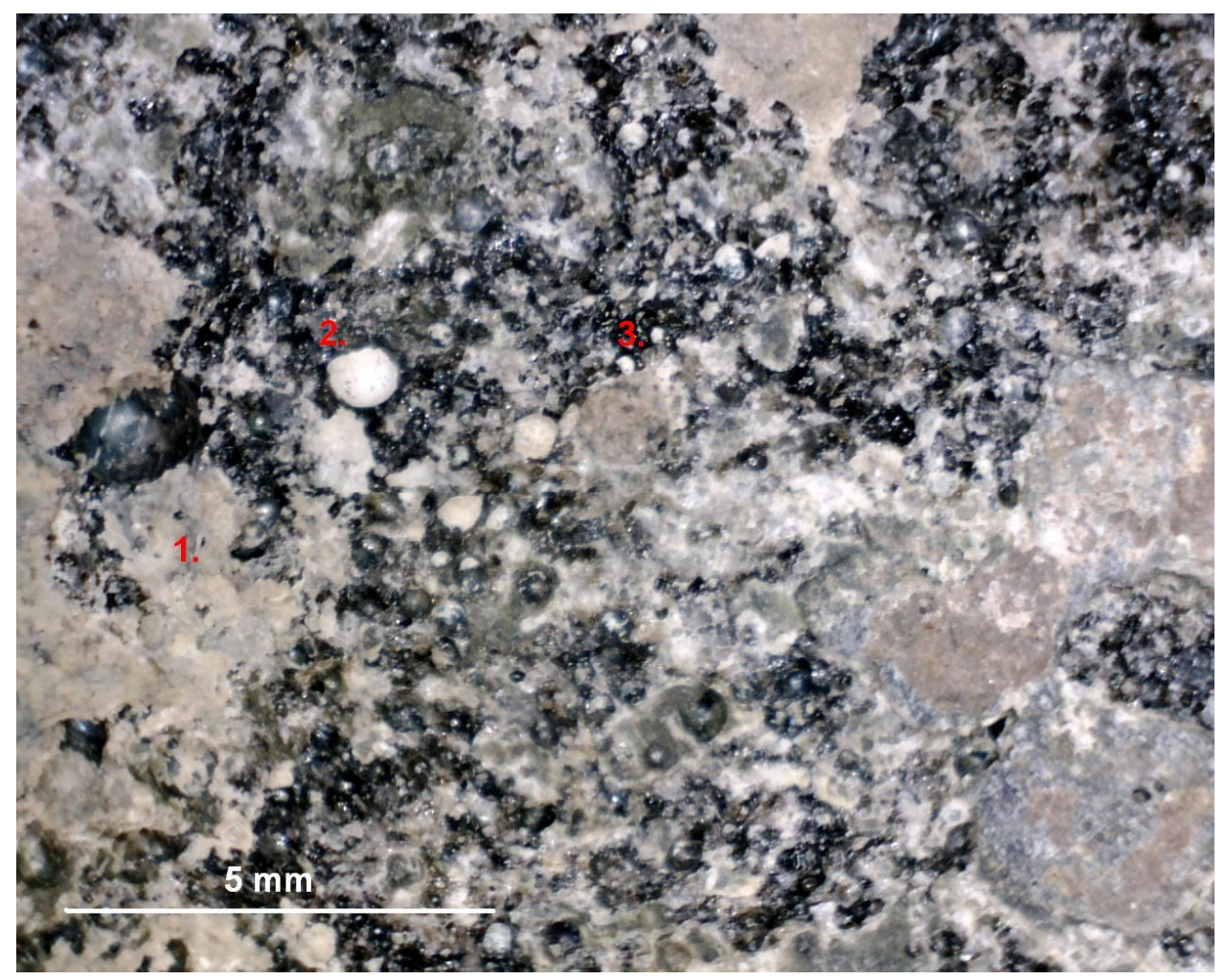

87. ábra Olvadt felület a felszínről származó kőtárgyon. 1 - ráolvadt termék, talán salak, 2 karbonátos kiválás egy felpattant buborékban, 3 - olvadt, üveges felület 


\section{$5 \mathrm{~cm}$}

88. ábra A domaszéki bronzfürész. $M=1: 1$

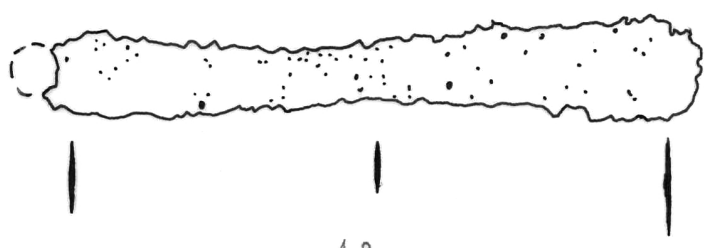

10

89. ábra A domaszéki bronzfürész rajza. $M=1: 2$

\begin{tabular}{|l|l|l|}
\hline Mintaszám & Lelőhely & Datálás, irodalom \\
\hline 1. & $\begin{array}{l}\text { Domaszék-Börcsök tanya, M5 } \\
81 . \text { lh. }\end{array}$ & $\begin{array}{l}\text { Reinecke BB1-BC (Paluch, 2005, Sánta, } \\
2009)\end{array}$ \\
\hline $12-13$. & Ásotthalom-Királyhalom & $\begin{array}{l}\text { Reinecke BB2-BC (Sánta et al, 2007, Sánta, } \\
\text { in print) }\end{array}$ \\
\hline $5-10$. & Szeged-Bogárzó B & Reinecke BB1 (Foltiny, 1957) \\
\hline $14-19$, & Röszke-Sárosvölgy & Reinecke BB1 (Reizner, 1892) \\
\hline $\begin{array}{l}2,2 a, 4,11, \\
20\end{array}$ & Zákányszék-Zákány dülő & $\begin{array}{l}\text { Reinecke BB1-2 (Sánta, 2004, Sánta et al, } \\
\text { 2007) }\end{array}$ \\
\hline
\end{tabular}

8. táblázat Az SZTE-n végzett méréssorozatban elemzett tárgyak lelőhelyei és datálása

\begin{tabular}{|c|c|c|c|c|c|c|c|c|c|c|c|c|}
\hline No. & \multicolumn{4}{|c|}{ 20. (,csüngő”) (\%) } & \multicolumn{4}{|c|}{ 11. („,karperec1”) (\%) } & \multicolumn{4}{|c|}{ 13. („karperec2”) } \\
\hline Element & $\begin{array}{l}2007 \\
\text { result }\end{array}$ & $\begin{array}{l}2007 \\
\text { fault }\end{array}$ & $\begin{array}{l}2009 \\
\text { result }\end{array}$ & $\begin{array}{l}2009 \\
\text { fault }\end{array}$ & $\begin{array}{l}2007 \\
\text { result }\end{array}$ & $\begin{array}{l}2007 \\
\text { fault }\end{array}$ & $\begin{array}{l}2009 \\
\text { result }\end{array}$ & $\begin{array}{l}2009 \\
\text { fault }\end{array}$ & $\begin{array}{l}2007 \\
\text { result }\end{array}$ & $\begin{array}{l}2007 \\
\text { fault }\end{array}$ & $\begin{array}{l}2009 \\
\text { result }\end{array}$ & $\begin{array}{l}2009 \\
\text { fault }\end{array}$ \\
\hline $\mathrm{S}$ & - & - & 0.562 & 0.051 & - & - & - & - & - & - & - & - \\
\hline $\mathrm{Cr}$ & 0.01 & 0 & - & - & 0.01 & 0 & - & - & 0.01 & 0 & - & - \\
\hline $\mathrm{Fe}$ & 0.23 & 0.01 & 0.197 & 0.017 & 0.08 & 0.01 & 0.079 & 0.014 & 0.57 & 0.01 & 0.567 & 0.021 \\
\hline $\mathrm{Ni}$ & 0.32 & 0.01 & 0.421 & 0.021 & 0.29 & 0.01 & 0.343 & 0.019 & 0.33 & 0.01 & 0.382 & 0.022 \\
\hline $\mathrm{Cu}$ & 84.41 & 0.49 & 90.69 & 0.226 & 90.62 & 0.54 & 91.47 & 0.180 & 83.47 & 0.50 & 88.74 & 0.245 \\
\hline As & 0.81 & 0.02 & 0.696 & 0.038 & 0.54 & 0.02 & 0.139 & 0.021 & 0.62 & 0.02 & 0.404 & 0.030 \\
\hline $\mathrm{Sn}$ & 12.17 & 0.06 & 7.433 & 0.222 & 5.84 & 0.05 & 5.124 & 0.128 & 13.40 & 0.07 & 8.784 & 0.022 \\
\hline $\mathrm{Sb}$ & 1.12 & 0.17 & - & - & 1.86 & 0.1 & 1.793 & 0.115 & 0.22 & 0.2 & 0.228 & 0.085 \\
\hline $\mathrm{Pb}$ & 0.21 & 0.07 & - & - & 0.16 & 0.06 & 1.010 & 0.084 & 0.42 & 0.07 & 0.897 & 0.094 \\
\hline
\end{tabular}

9/1. táblázat A 2007 során Debrecenben végzett mérések és a 2009-ben Szegeden mért eredmények összehasonlítása 


\begin{tabular}{|c|c|c|c|c|c|c|c|c|c|c|c|}
\hline \multicolumn{4}{|c|}{ 12. (,karperec3”) (\%) } & \multicolumn{4}{|c|}{ 2. (,kés”) (\%) } & \multicolumn{4}{|c|}{ 4. („tü””) } \\
\hline $\begin{array}{l}2007 \\
\text { result }\end{array}$ & $\begin{array}{l}2007 \\
\text { fault }\end{array}$ & $\begin{array}{l}2009 \\
\text { result }\end{array}$ & $\begin{array}{l}2009 \\
\text { fault }\end{array}$ & $\begin{array}{l}2007 \\
\text { result }\end{array}$ & $\begin{array}{l}2007 \\
\text { fault }\end{array}$ & $\begin{array}{l}2009 \\
\text { result }\end{array}$ & $\begin{array}{l}2009 \\
\text { fault }\end{array}$ & $\begin{array}{l}2007 \\
\text { result }\end{array}$ & $\begin{array}{l}2007 \\
\text { fault }\end{array}$ & $\begin{array}{l}2009 \\
\text { result }\end{array}$ & $\begin{array}{l}2009 \\
\text { fault }\end{array}$ \\
\hline- & - & - & - & - & - & 0.164 & 0,036 & - & - & 0.674 & 0.057 \\
\hline 0.01 & 0 & - & - & 0.01 & 0 & 0.021 & 0.014 & 0.01 & 0 & - & - \\
\hline 0.07 & 0 & 0.062 & $\square .014$ & 0.07 & 0 & 0.066 & 0.014 & 0.18 & 0.01 & 0.233 & 0.016 \\
\hline 0.31 & 0.01 & 0.400 & 0.023 & 0.24 & 0.01 & 0.286 & 0.020 & 0.37 & 0.01 & 0.492 & 0.024 \\
\hline 87.02 & 0.51 & 89.27 & 0.251 & 89.9 & 0.52 & 92.88 & 0.229 & 88.09 & 0.53 & 91.57 & 0.262 \\
\hline 0.56 & 0.02 & 0.239 & 0.028 & 0.4 & 0.02 & 0.143 & 0.024 & 0.75 & 0.02 & 0.738 & 0.038 \\
\hline 10.38 & 0.06 & 8.621 & 0.224 & 7.99 & 0.05 & 5.220 & 0.189 & 9.56 & 0.06 & 6.292 & 0.239 \\
\hline 0.59 & 0.15 & 0.487 & 0.096 & 0.66 & 0.12 & 0.435 & 0.087 & 0.32 & 0.14 & - & - \\
\hline 0.36 & 0.06 & 0.923 & 0.095 & 0.2 & 0.05 & 0.781 & 0.086 & 0.17 & 0.08 & - & - \\
\hline
\end{tabular}

9/2. táblázat A 2007 során Debrecenben végzett mérések és a 2009-ben Szegeden mért eredmények összehasonlítása

\begin{tabular}{|l|l|l|}
\hline Elem & Tömeg\% & Hiba \\
\hline $\mathrm{Cr}$ & 0.035 & 0.017 \\
\hline $\mathrm{Fe}$ & 1.242 & 0.033 \\
\hline $\mathrm{Ni}$ & 0.278 & 0.024 \\
\hline $\mathrm{Cu}$ & 83.72 & 0.310 \\
\hline $\mathrm{Sn}$ & 14.23 & 0.300 \\
\hline $\mathrm{Pb}$ & 0.500 & 0.094 \\
\hline
\end{tabular}

10. táblázat A domaszéki bronzfürész összetétele tömegszázalékban, a hiba megadásával. As-t mértünk benne, de csak 0,001\% koncentrációban, ezért azt elhagytuk

\begin{tabular}{|l|l|l|l|l|l|l|l|l|l|l|}
\hline Nr. & 1. & 2. & 3. & 4. & 5. & 6. & 7. & 8. & 9. & 10. \\
\hline Code & 2007.2 .1640 & Zakany-01 & $*$ & tu & 53.25 .19 & 53.25 .21 & 53.25 .4 & 53.25 .3 & 53.25 .9 & 53.25 .22 \\
\hline
\end{tabular}

* detail measurement of 2

\begin{tabular}{|l|l|l|l|l|l|l|l|l|l|l|}
\hline Nr. & 11. & 12. & 13. & 14. & 15. & 16. & 17. & 18. & 19. & 20. \\
\hline Code & karpe103 & $1 / 1906$ & $2 / 1906$ & $\begin{array}{l}128 / 1885 / \\
14\end{array}$ & $\begin{array}{l}128 / 1885 / \\
14-1\end{array}$ & $\begin{array}{l}128 / 1885 / \\
18-1\end{array}$ & $\begin{array}{l}128 / 1885 / \\
18-2\end{array}$ & $\begin{array}{l}128 / 1885 / \\
18-3\end{array}$ & $\begin{array}{l}128- \\
134 / 1885 / 19\end{array}$ & $\begin{array}{l}\text { Zakany- } \\
02\end{array}$ \\
\hline
\end{tabular}

11. táblázat A tárgyak azonosítói (a sorszám egyezik a 12-13. táblázatban közölt sorszámokkal) 


\begin{tabular}{|l|l|l|l|l|}
\hline Csoport & Minták kódja & Lelőhelyek & Óntartalom & $\begin{array}{c}\text { Fémtípus } \\
\text { (Liversage, 1994) }\end{array}$ \\
\hline A & $1,7,9,15,18$ & $\begin{array}{l}\text { Domaszék-Börcsök tanya, Szeged- } \\
\text { Bogárzó B, Röszke-Sárosvölgy }\end{array}$ & Magas, 10-18 \% & AsNi, ,dasni” \\
\hline B1 & $2,5,6,11,14$ & $\begin{array}{l}\text { Zákányszék-Zákány dülő, Röszke- } \\
\text { Sárosvölgy, Szeged-Bogárzó B }\end{array}$ & Közepes, 5-6 \% & $\begin{array}{l}\text { AsN, AsNi, ,,dasni” } \\
\text { magas óntartalommal }\end{array}$ \\
\hline B2 & $\begin{array}{l}4,8,10,12, \\
13,16,17,19\end{array}$ & $\begin{array}{l}\text { Zákányszék-Zákány dűlö, Szeged- } \\
\text { Bogárzó B, Ásotthalom-Királyhalom, } \\
\text { Röszke-Sárosvölgy }\end{array}$ & Közepes, 7-10 \% & AsNi, ASN \\
\hline Különálló & 20 & Zákányszék-Zákány dülő & Közepes, 10\% & AsNi \\
\hline
\end{tabular}

12. táblázat A leletek fö- és nyomelemei cluster-csoportonként

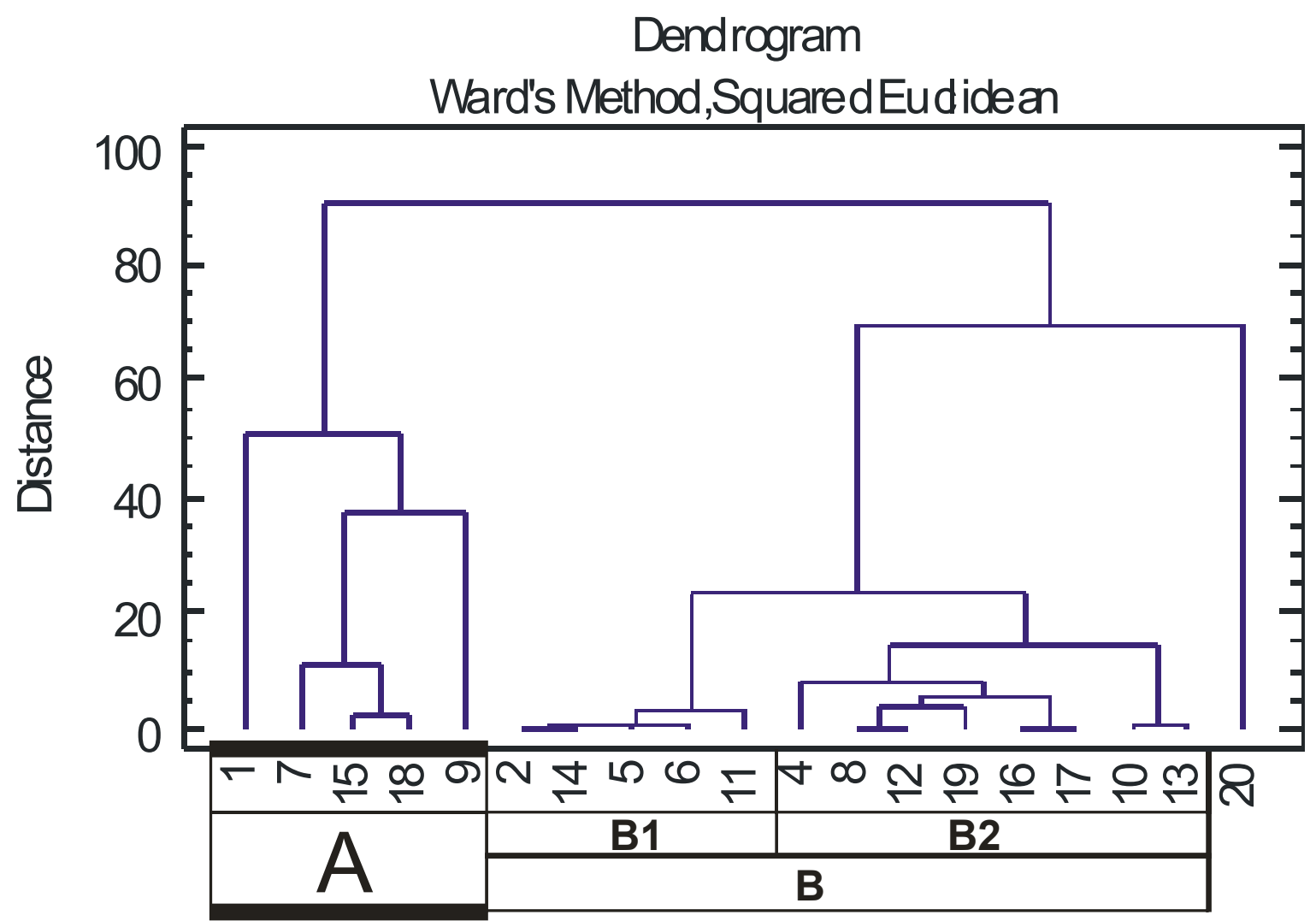

90. ábra Az SZTE-n végzett mérések dendrogramja (Dr. Geiger János munkája) 

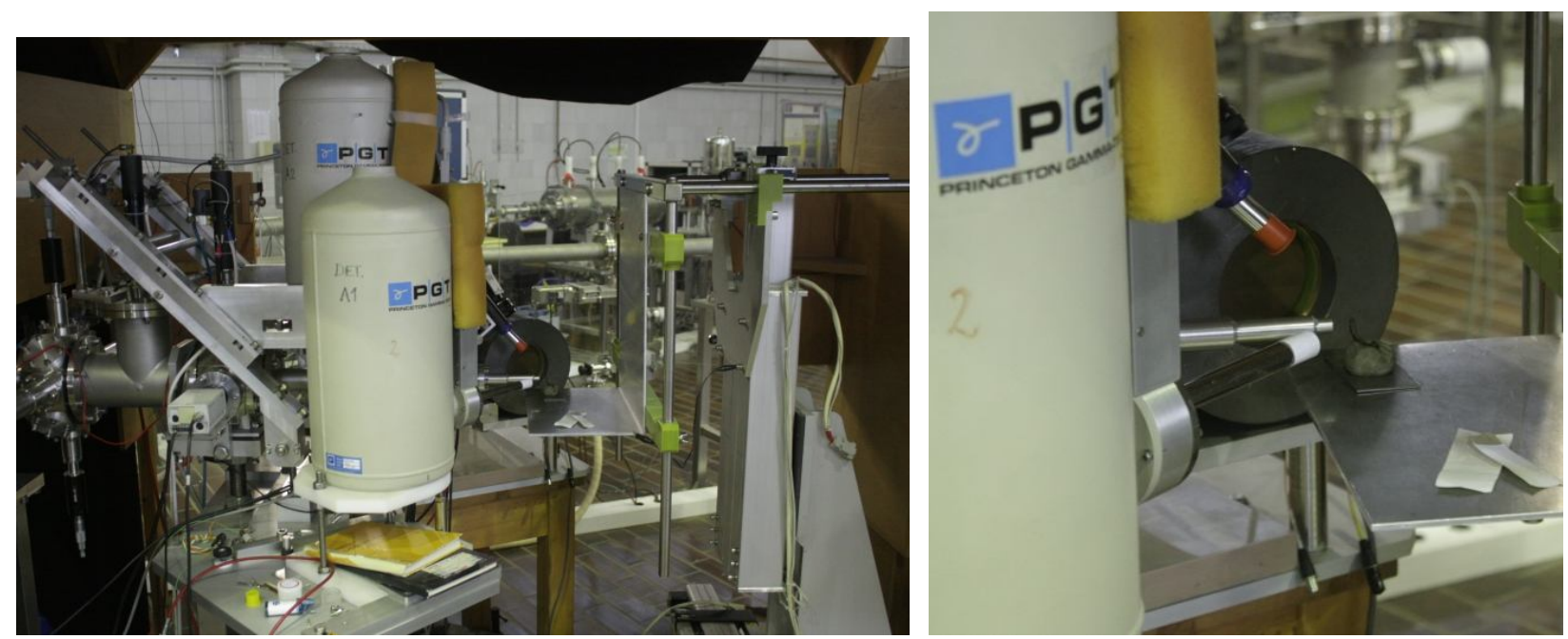

91. ábra A Jožef Štefan Intézet müszere, melyen a méréseket végeztük
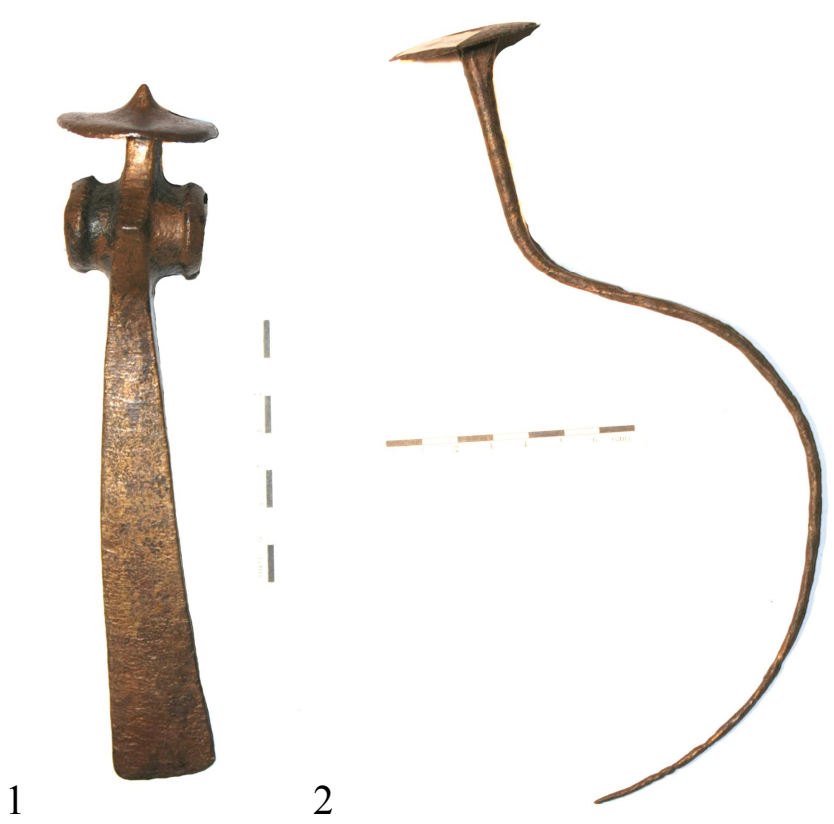

3
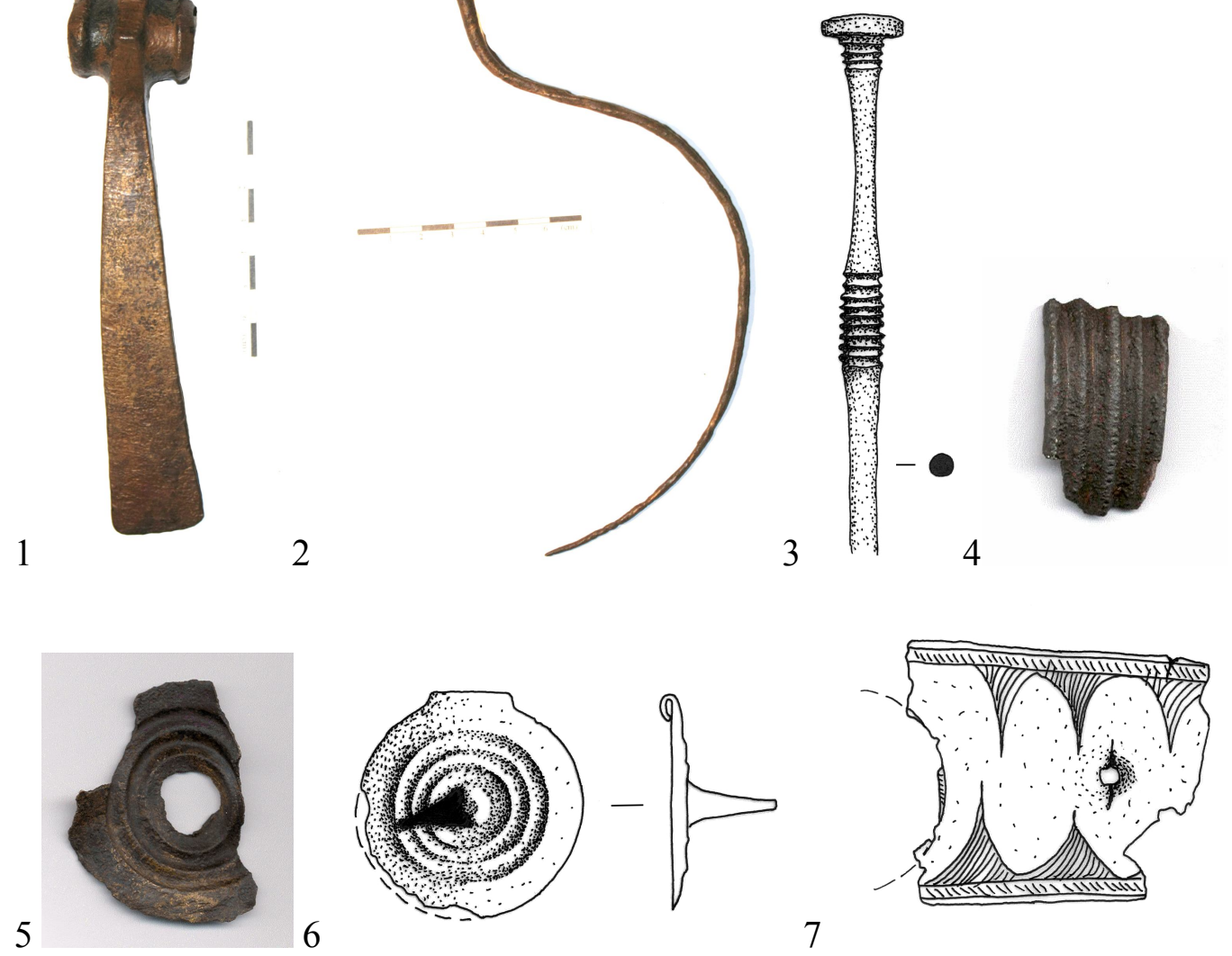

92. ábra Válogatás a 2010-2011-ben vizsgált tárgyak közül. 1. Tüskés-korongos végü csákány, Szeged-Alsótanya-Kancsalszél, 1/1904. 2. Sarlós tü, Ásotthalom-Bilisiscs, 1/1905b. 3. Pecsétfejü tü, Kiskundorozsma-Átokháza, 53.61.1. 4. Ötbordás lemezkarperec töredéke, Röszke-Sárosvölgy, 128/1885/18/3. 5. Tüskés-körbordás tutulus, Szeged-Bogárzó, 15. sír, 53.25.19. 6. Tüskés-körbordás tutulus, Csengele-Mételyes, 80.35.2. 7. Lemezöv töredéke, Kiskundorozsma-Átokháza, 53.61.3. 1-2: $M=1: 3,3$, 5-7: $M=1: 2,4: M=1: 1$. 


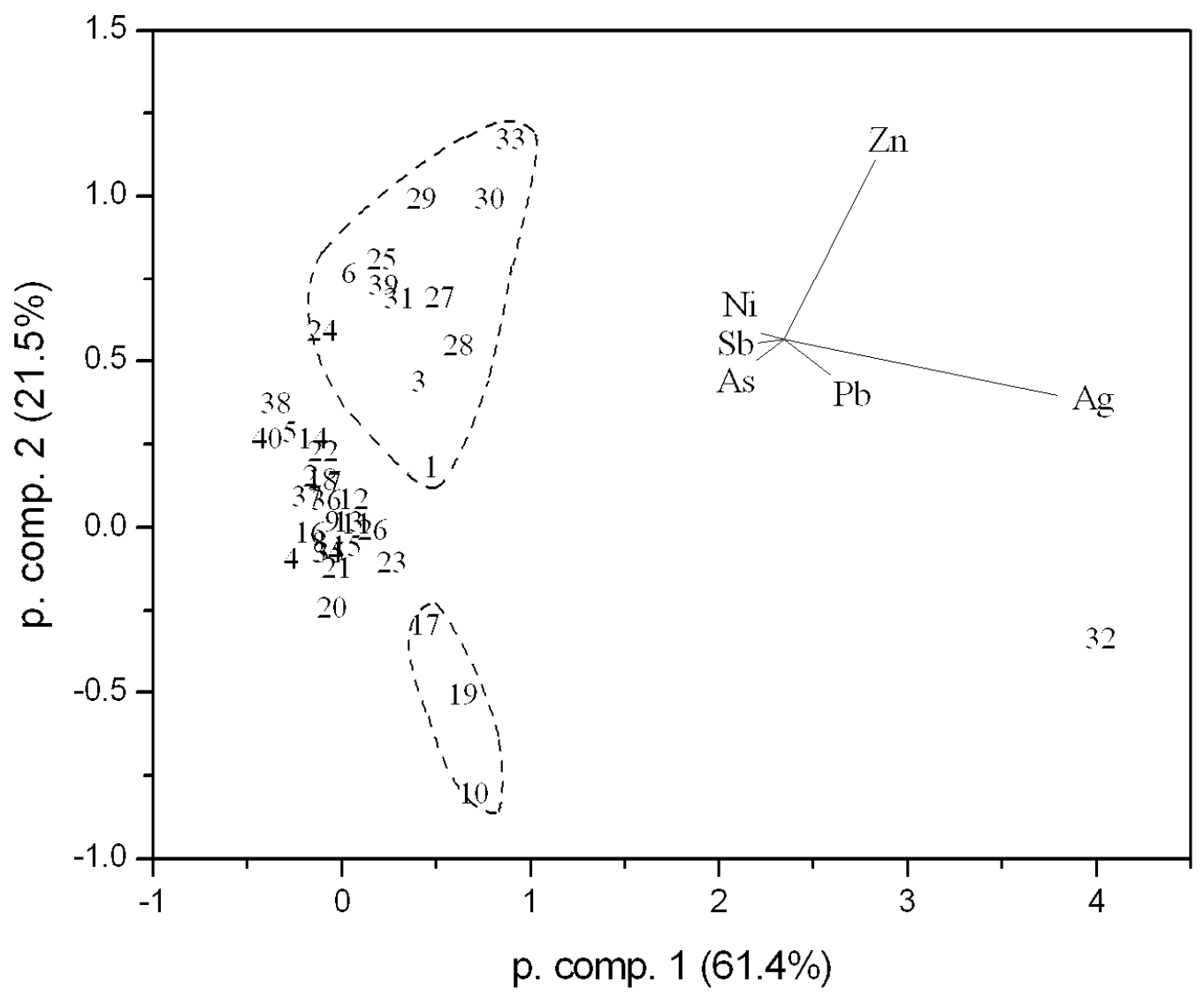

93. ábra Ljubljana-ban vizsgált 40 bronztárgy fókomponens-analízissel létrehozott csoportjai (készítette Dr. Žiga Šmit). A számok megegyeznek az 1-2. táblázat sorszámaival 

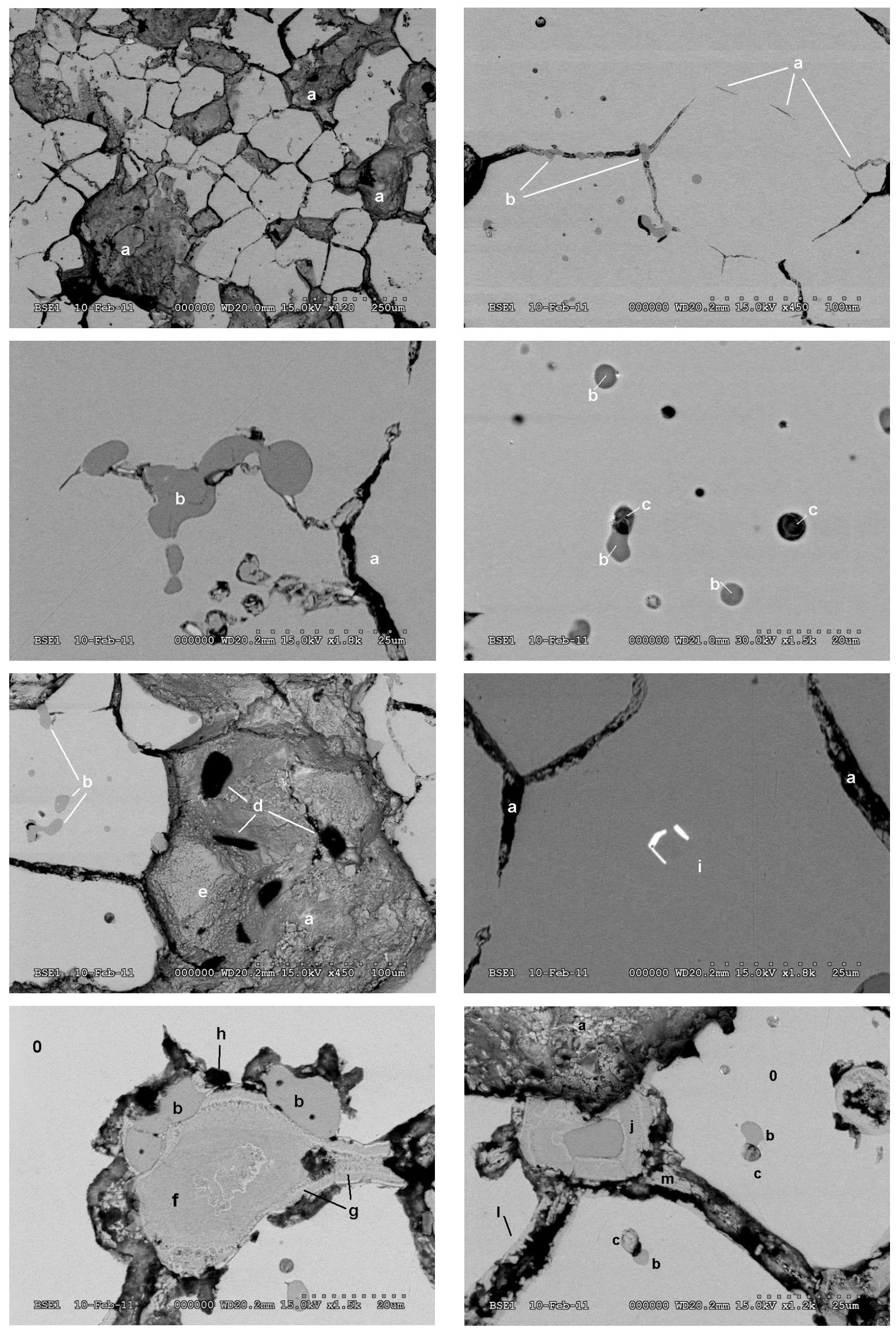

94. ábra A: üreg, b: szulfid (Cu2S), c: salak, d: szénhidrogén (recens), e: karbonát-kéreg, f, j: réz-oxid és réz keveréke, g: réz-oxid kristályok, h: faszén, i: ólom, 0: mátrix, 1: fenn-nőtt (másodlagos) kristályok, m: óndús folt 

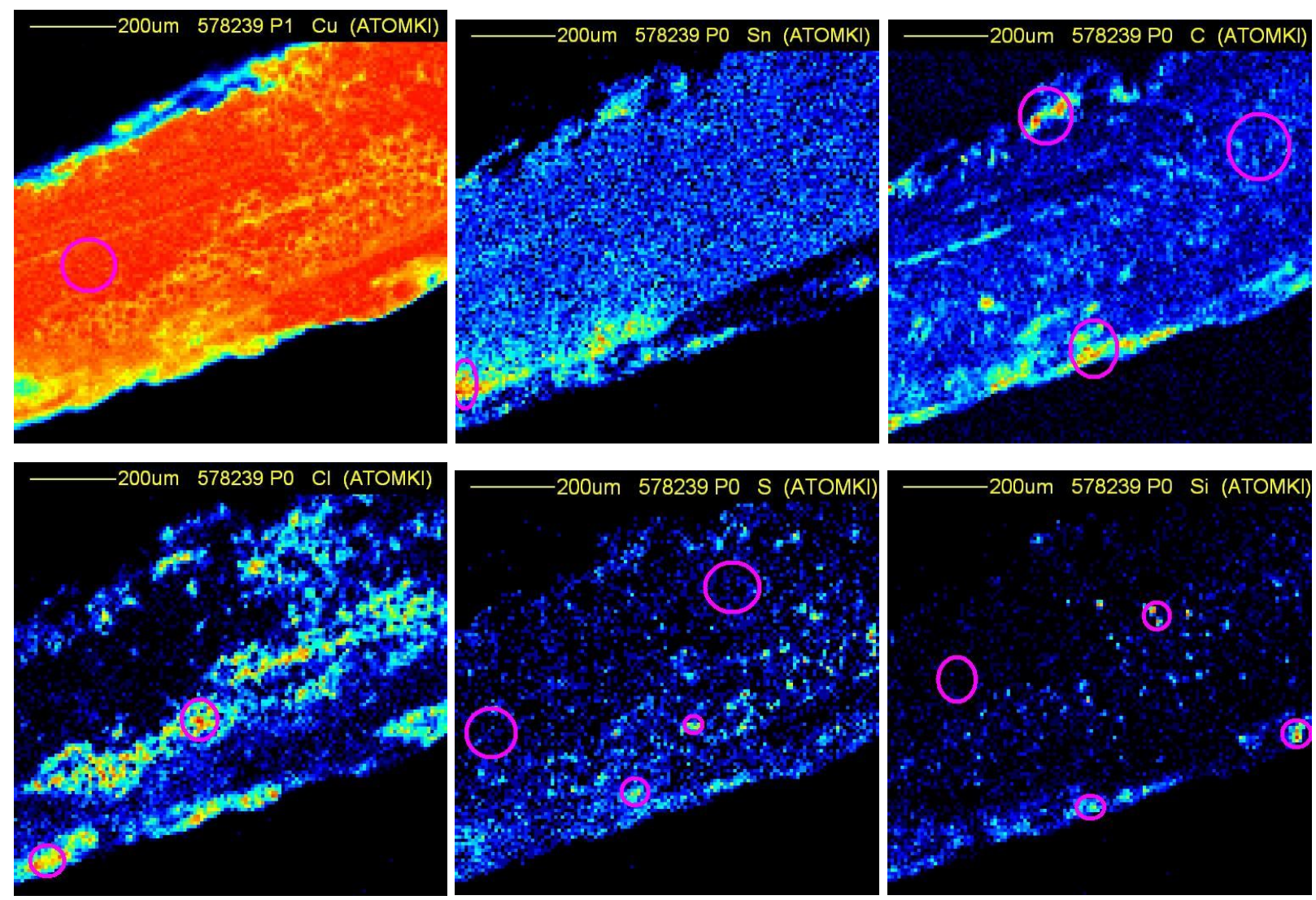

95. ábra A Zákányszék-Zákány dűlő lelőhelyről előkerült ruhadísz metszete. Óndúsulás, szénhidrogén, kloridosodás, szulfidosodás. Az ábrákon a jobb alsó sarokban a minta széle.
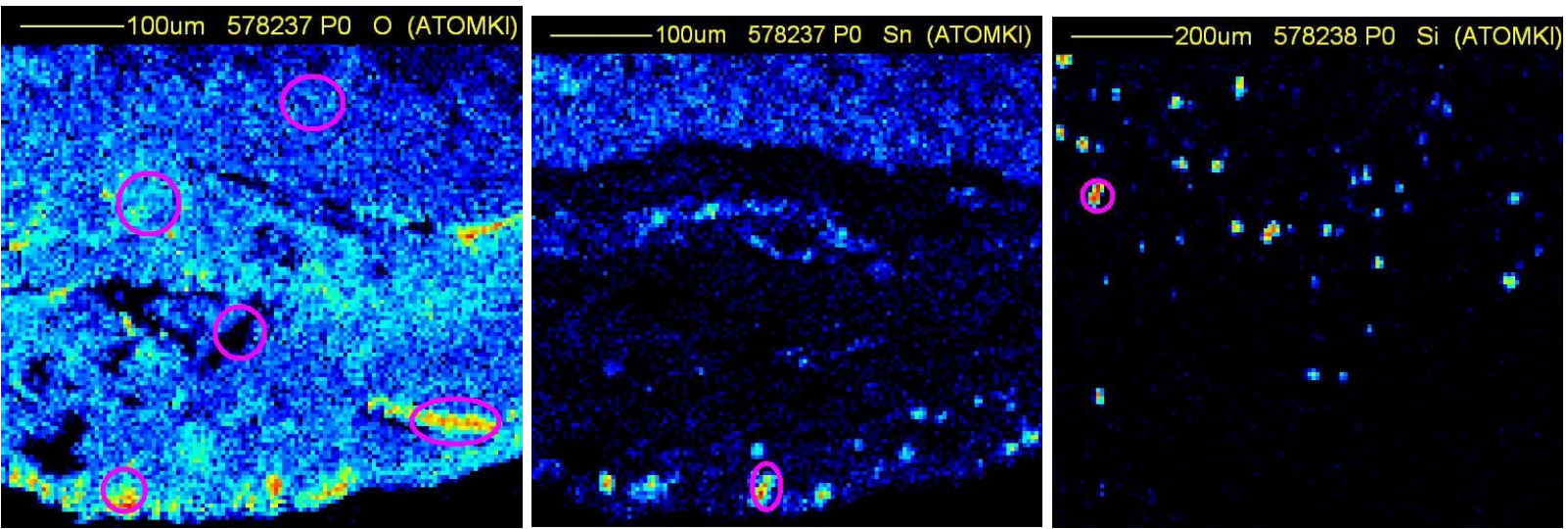

96. ábra Röszke-Sárosvölgy,128/1885/18-2 sz. tárgy metszetének elemtérképei. Oxigén dúsulás (szénhidrogén), üregek, felületi ónhiány/ónszemcsék, Si-gazdag salakzárványok.
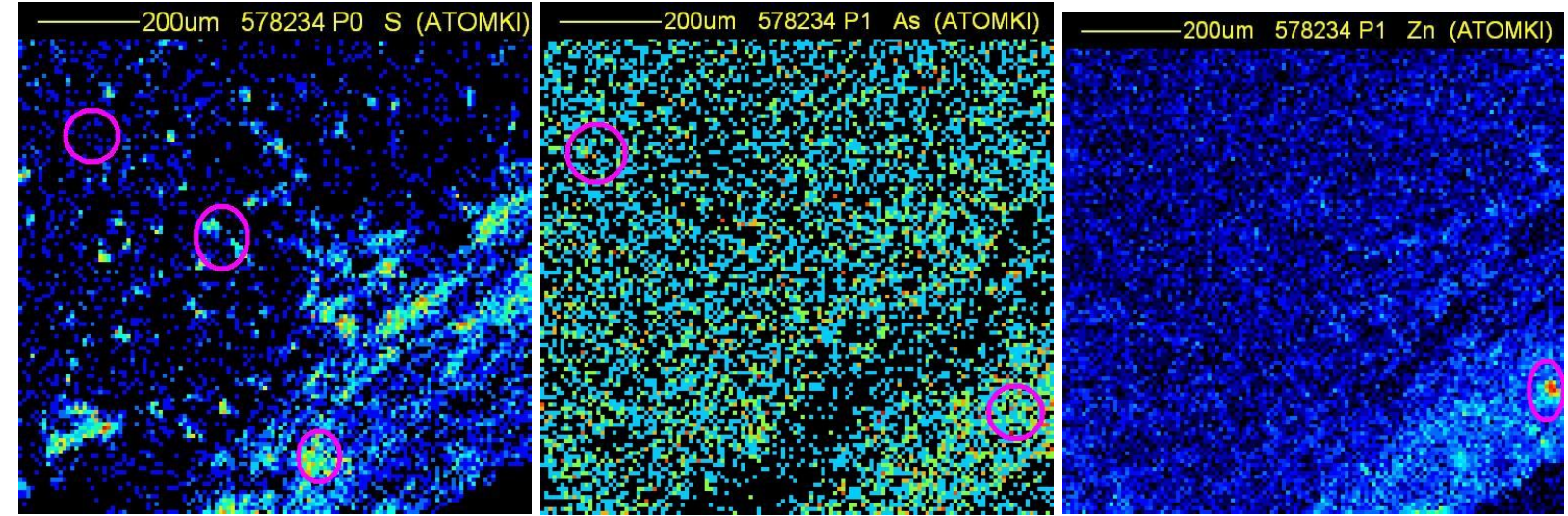

97. ábra Röszke-Sárosvölgy, 128/1885/18-3 tárgy. Kéndúsulás, As- és Zn-dúsulás. 

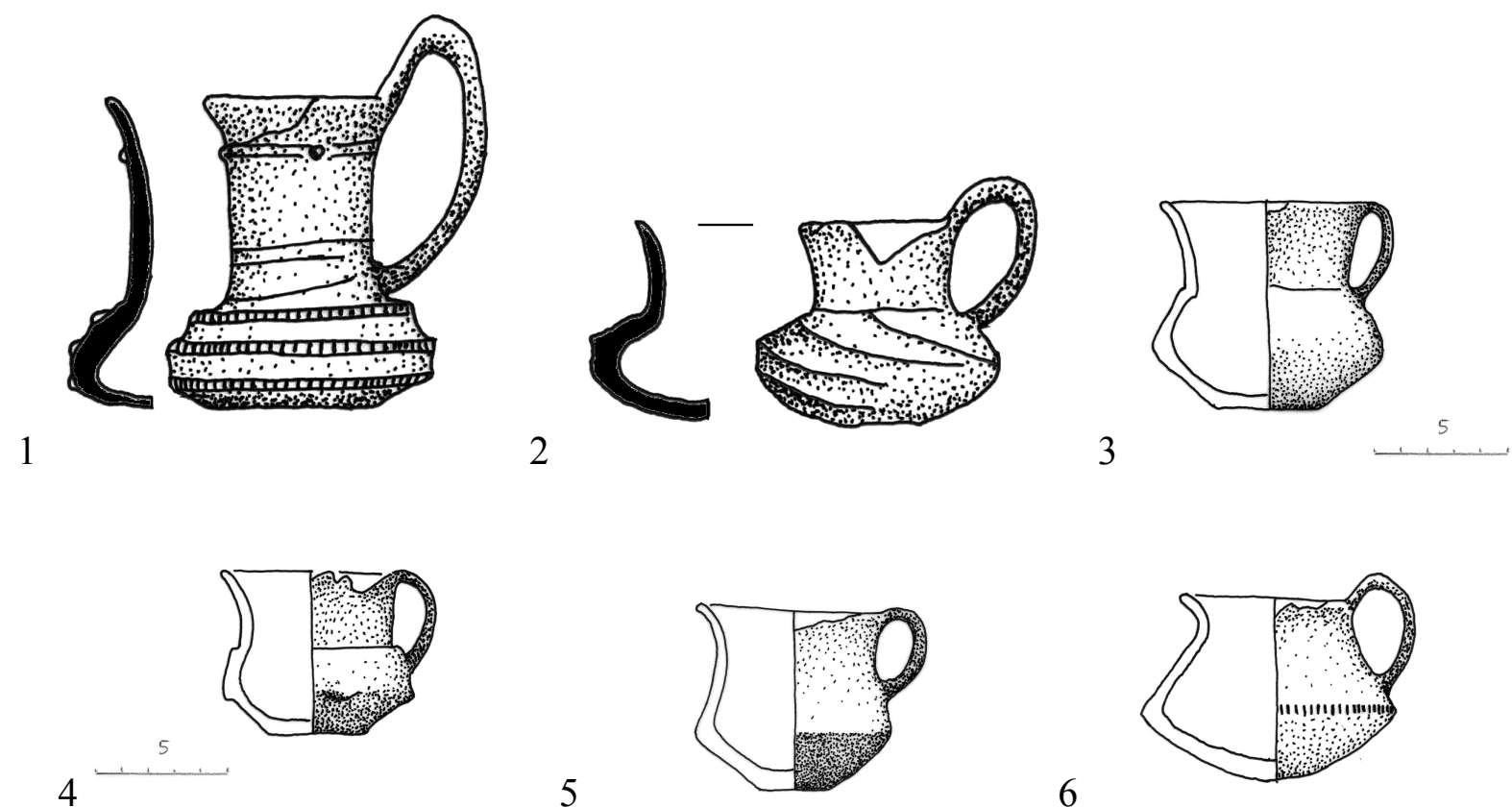

5

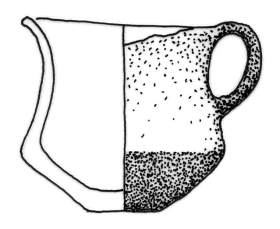

6

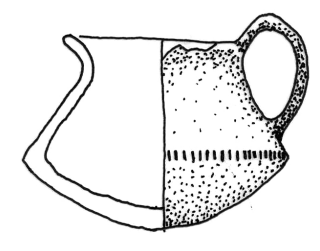

98. ábra Sövényházai középső és késő bronzkori leletek. M=1:4. 1. 46/1884. 2. 51/1884. 3. 48/1884. 4. 49/1884. 5. 50/1884. 6. 52/1884. 

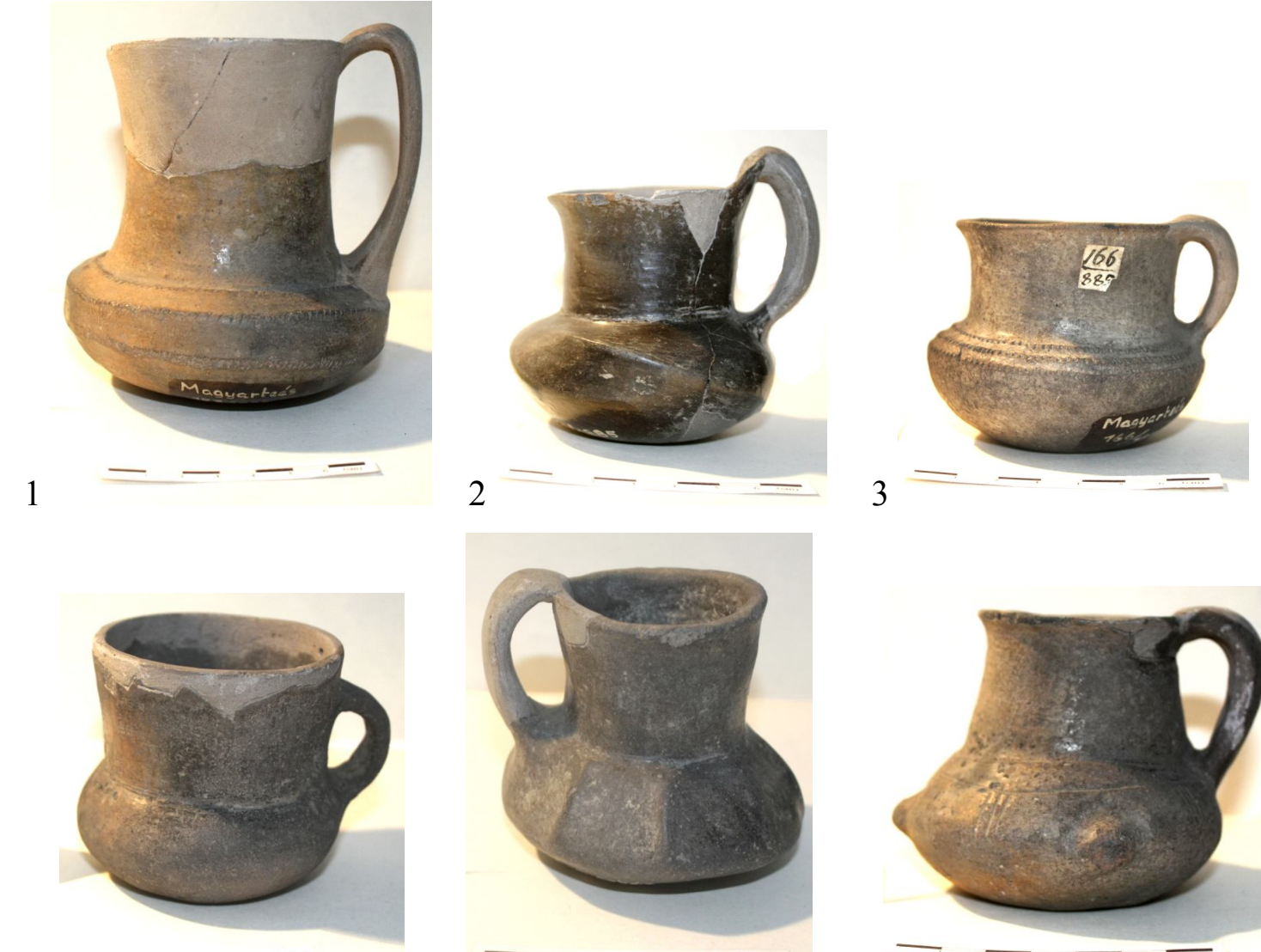

4

\section{5}

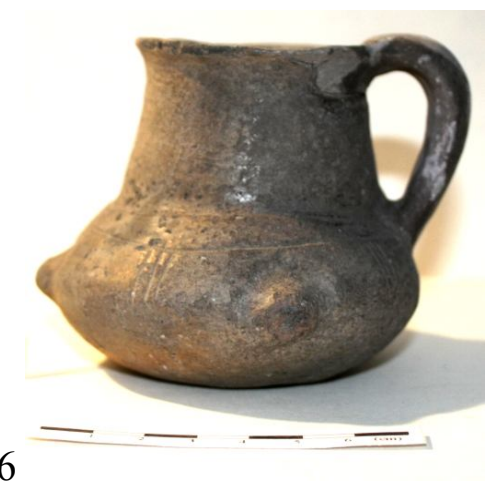

99. ábra Magyartési középső bronzkori leletek. $M=1: 2.1$. 153/1885. 2. 189/1885. 3.

166/1885. 4. 165/1885. 5. 180/1885. 6. 184/1885.

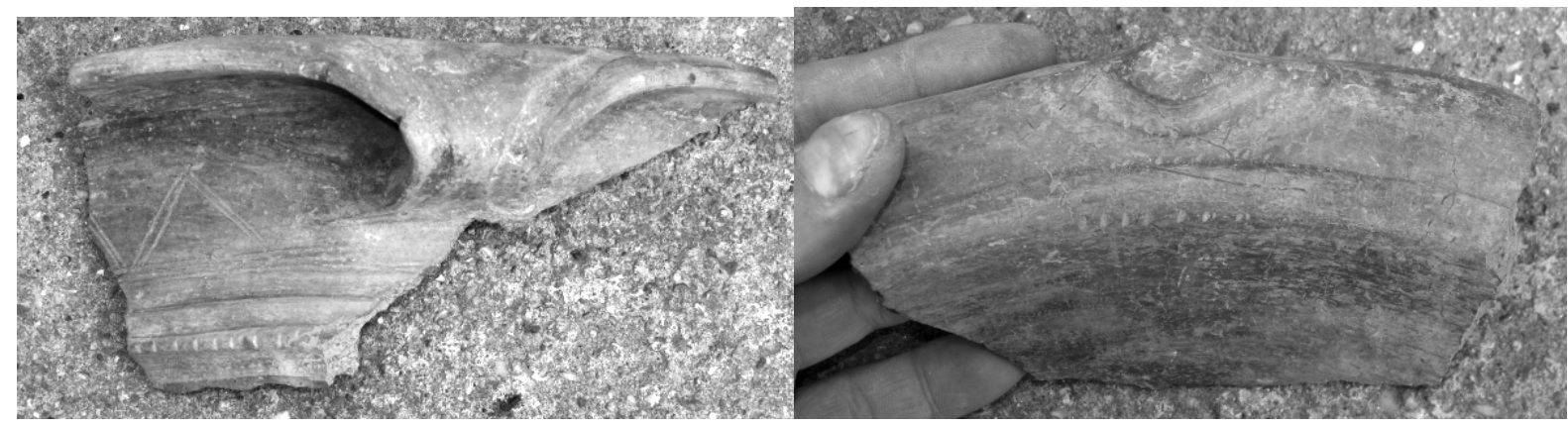

100. ábra Díszes késő Perjámos edénytöredékek Magyarkanizsáról. M=1:2. 1. Táltöredék, 2. Oszlopfüles tál töredéke 

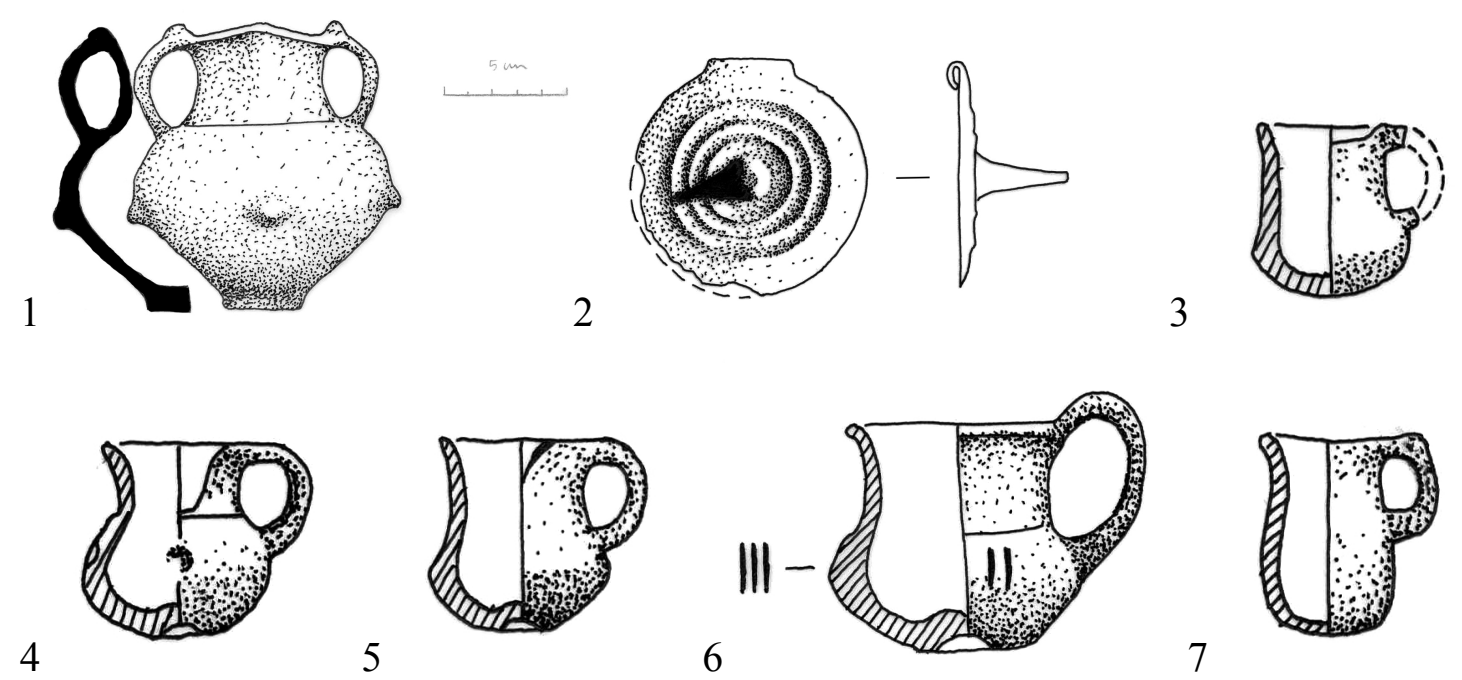

7

101. ábra Késő Vatya leletek Csengele-(Belső)-Mételyes lelőhelyről. 1. 80.35.1, M=1:4, 2. 80.35.2. $\mathrm{M}=1: 2$, 3. 53.48.1, $\mathrm{M}=1: 4$, 4. 53.48.2, $\mathrm{M}=1: 4$, 5. 53.48.3, $\mathrm{M}=1: 4$, 6. 53.48.4, $\mathrm{M}=1: 3$, 7. $53.48 .5, \mathrm{M}=1: 4$.

102. ábra (következő oldalon) A Vatya-kultúra ismert földvárai a fontosabb szakirodalmak alapján (F. Petres - Bándi, 1969, Kovács, 1969 térképe alapján).

Területi felosztás a Thiessen-poligonokkal, és a várak nagyságbeli különbségei. Fekete: a telep kiterjedése pontosan nem állapítható meg a szakirodalomból. Piros ovális: DunaújvárosKosziderpadlás tell telep feltételezett fennhatósági körzete.

1. Százhalombatta-Földvár, 2. Ercsi-Bolondvár, 3. Adony-Bolondvár, 4. DunaújvárosKosziderpadlás, 5. Baracs-Bottyánsánc, 6. Bölcske-Vörösgyir, 7. Dunakömlőd-Bottyánsánc, 8. Alsószentiván-Kazalhegy, 9. Igar-Vámpuszta-Galástya, 10. Sárbogárd-Cifrabolondvár, 11. Aba-Belsőbáránd-Bolondvár, 12. Pákozd-Vár, 13. Fehérvárcsurgó-Várhegy, 14.

Lovasberény-Mihályvár, 15. Lovasberény-Szűzvár, 16. Kajászó-Várdomb, 17. VálPogányvár, 18. Alcsutdoboz-Pogányvár, 19. Sóskút-Kálváriahegy, 20. Mende-Leányvár, 21. Gomba-Várhegy, 22. Káva, 23. Nagykörös-Földvár, 24. Alpár-Várdomb, 25. HajósHildpuszta, 26. Dunapataj-Alsószentkirály-Várhegy, 27. Soroksár-Várhegy, 28. GerjenVárad, 29. Solt-Tételhalom (Irodalom: 1-26: Bándi, 1952, F. Petres - Bándi, 1969, 27 :

Endrődi - Gyulai, 1999, 28: Wosinsky 1891, P. Fischl, 2000, 29: Szentpéteri, 2005, 2006) 


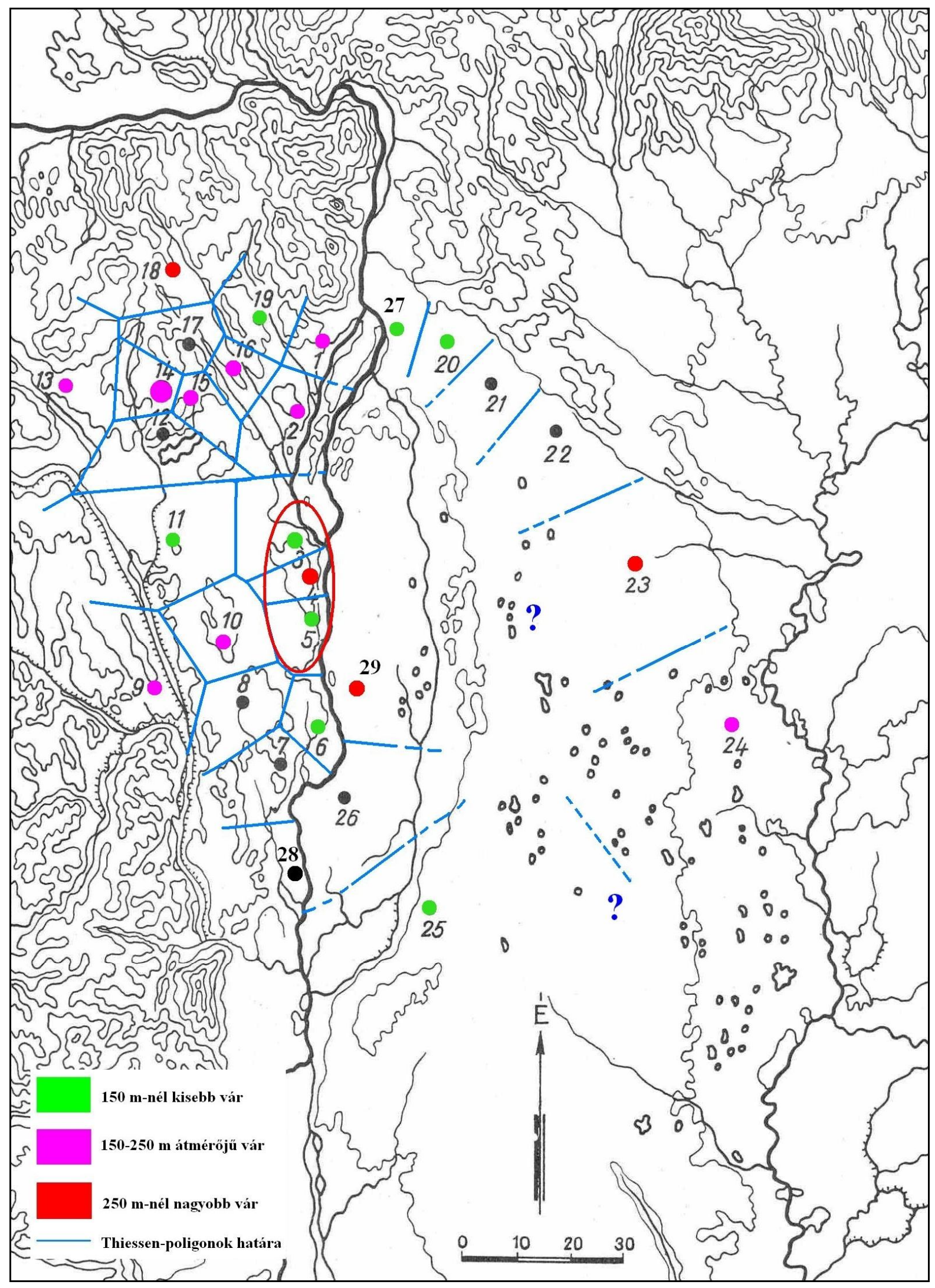

102. ábra (feliratait lásd az előző oldalon) 


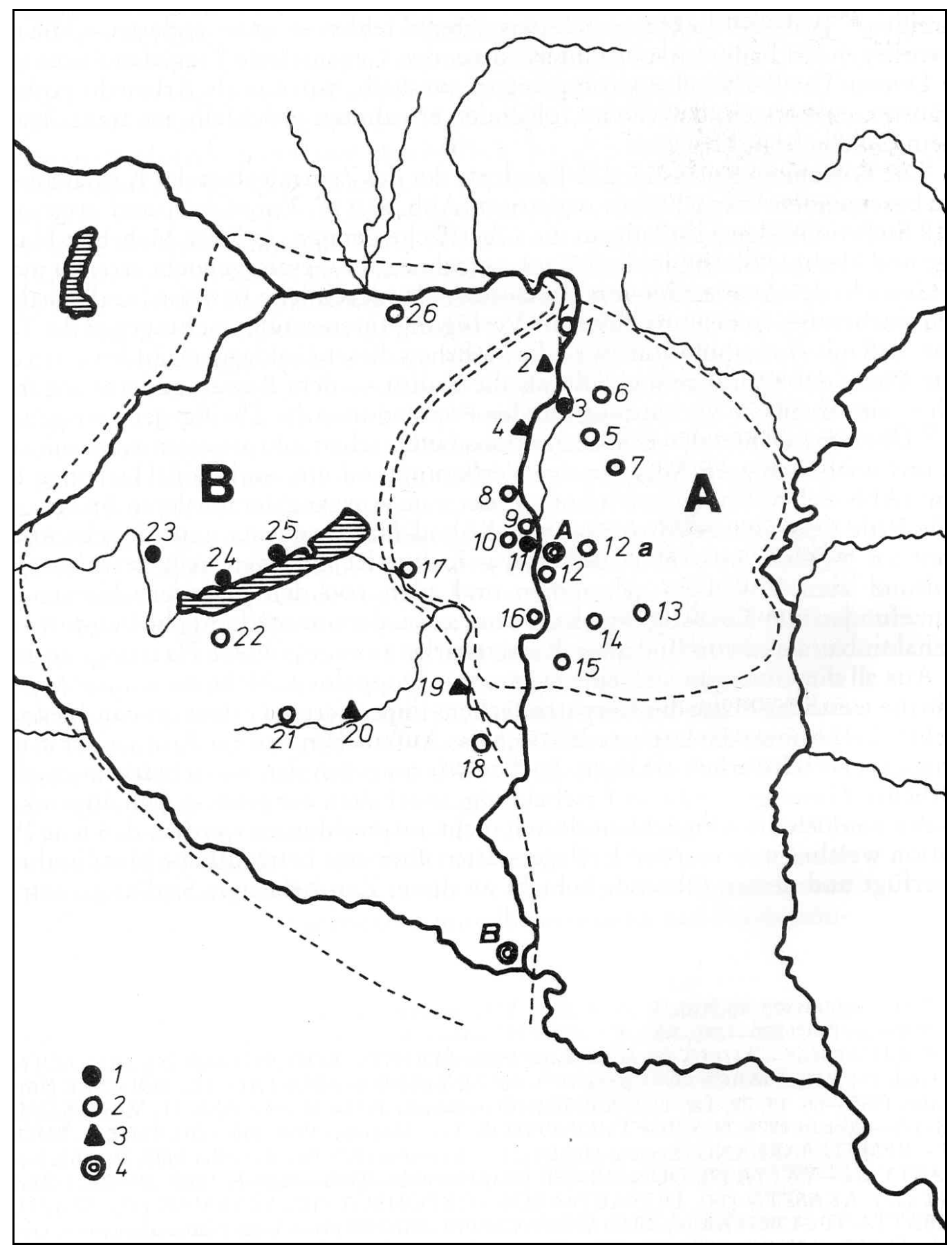

103. ábra A Vatya-kultúra aranyleletei (Kovács, 1991, Abb. 6. nyomán)

A - Vatya-kultúra, B - Mészbetétes edények népe

1 - idősebb, 2 - fiatalabb, 3 - telep, sír- és szórványleletek, kincsleletek, 4 - Félhold

végződésű középső bronzkori arany karékszerek: A - Dunavecsei kartekercs (a Vatya-kultúra legjelentősebb aranylelete), B - A Bellye-i (Bilje) karperec

A lelőhelyszámok feloldása Kovács (1991)-ben sem szerepel

8-11: Dunaújváros-Kosziderpadlás környékén előkerült aranyleletek, A, 12, 12a: Solt-

Tételhalom környékén előkerült aranyleletek 


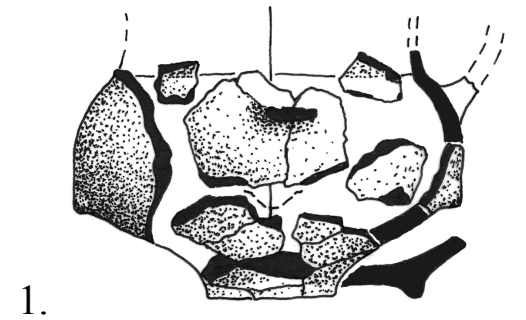

2.

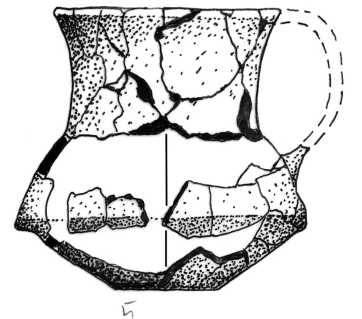

104. ábra Építési áldozathoz (?) köthető edényleletek. 1. 173. objektum, 2007.2.700. $\mathrm{M}=1: 4$, 20/1902i. $M=$ kb. 1:3) 


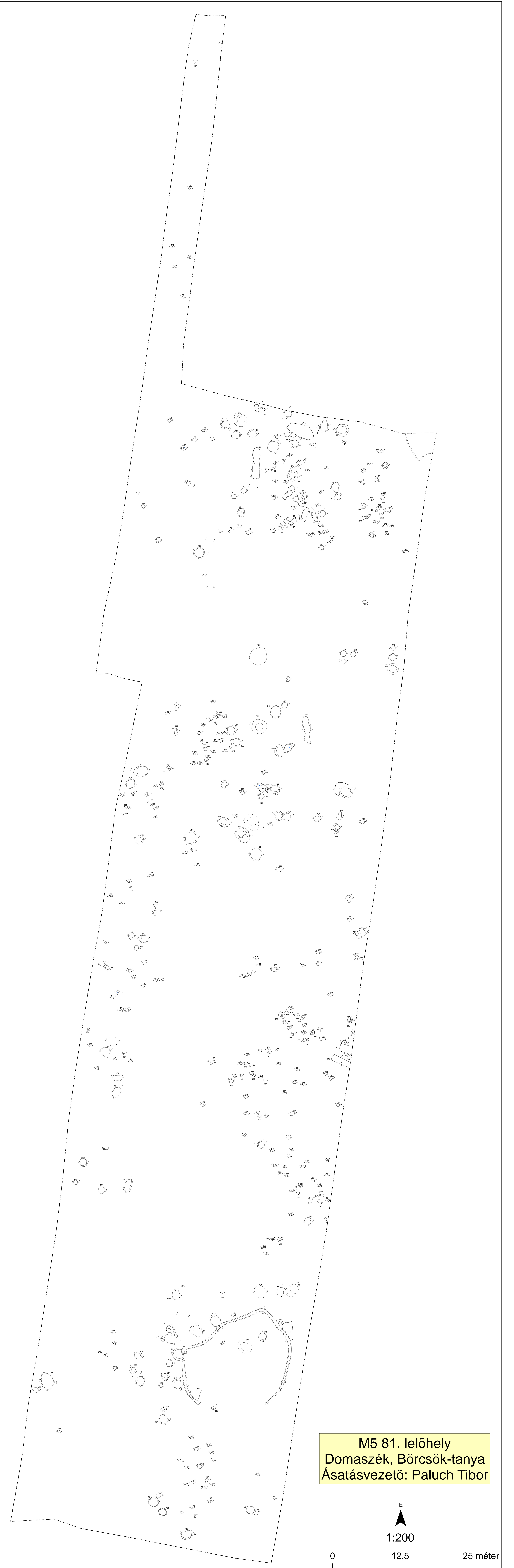




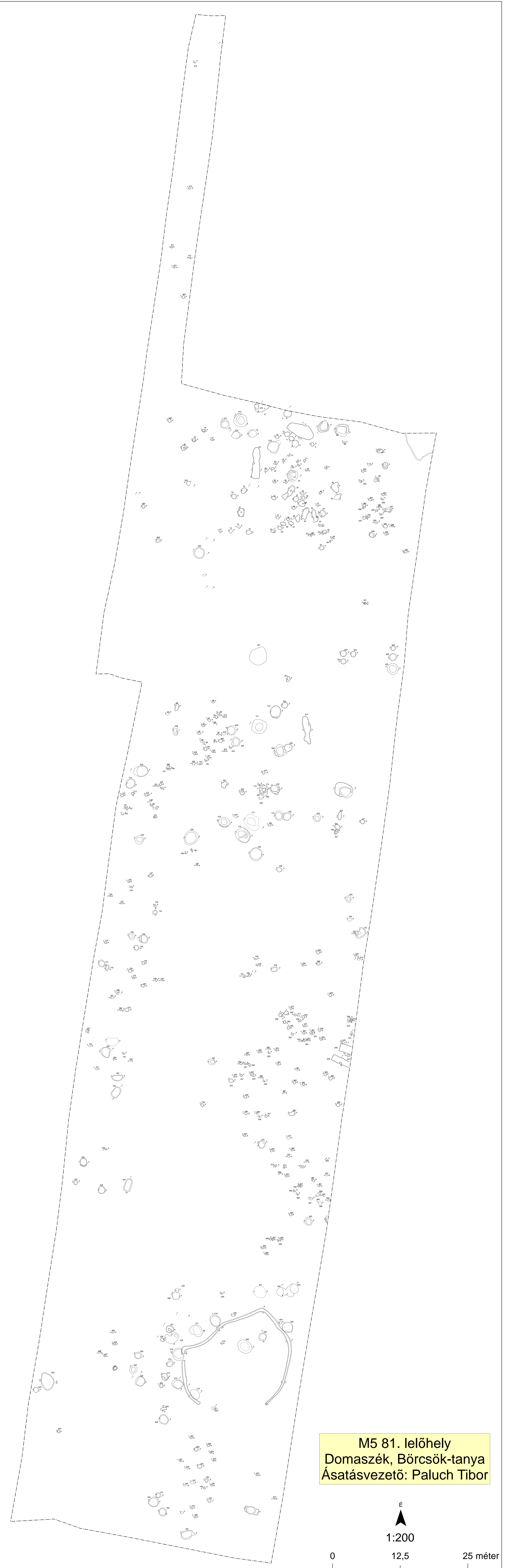




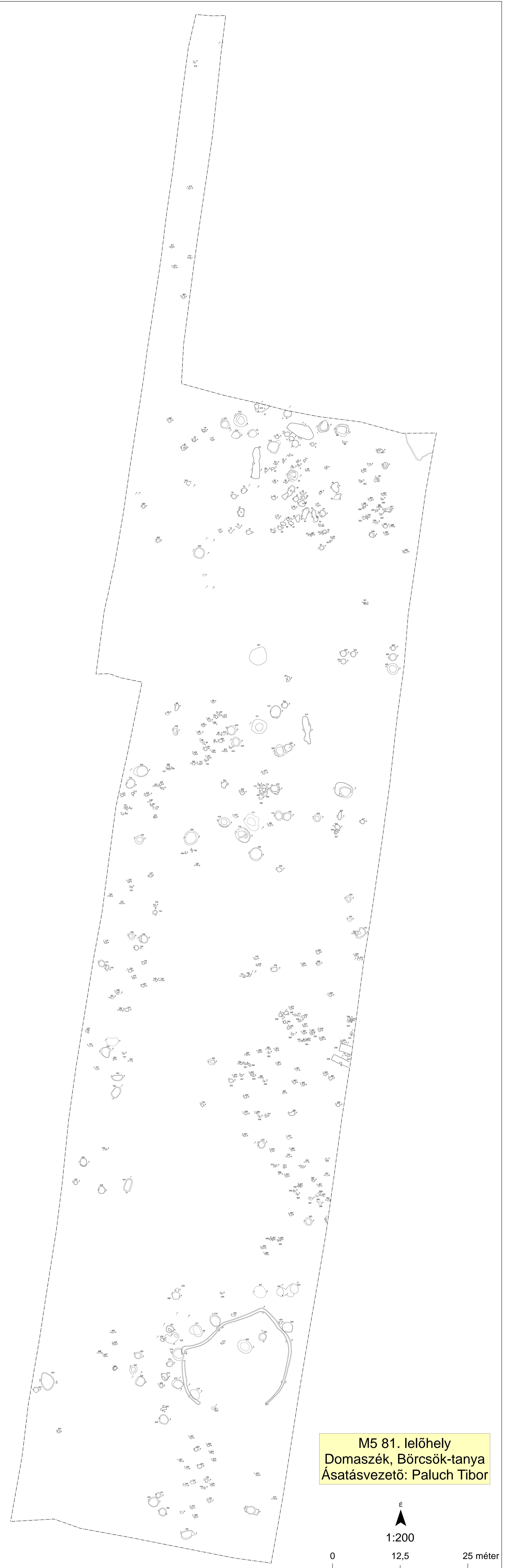




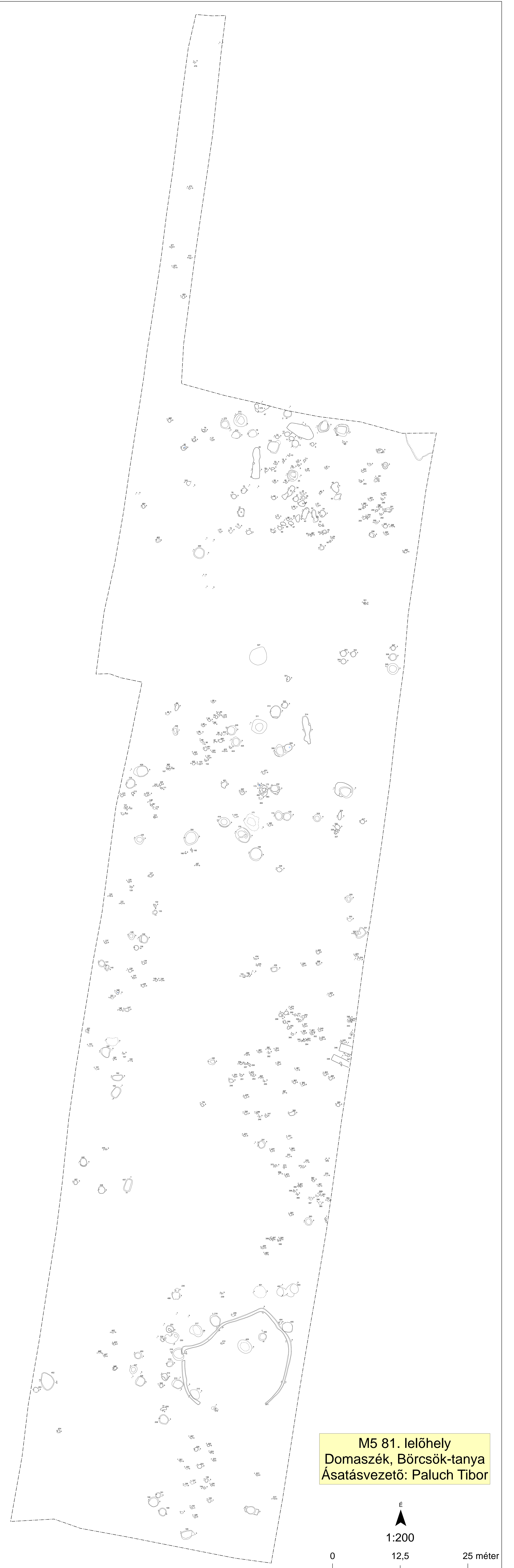




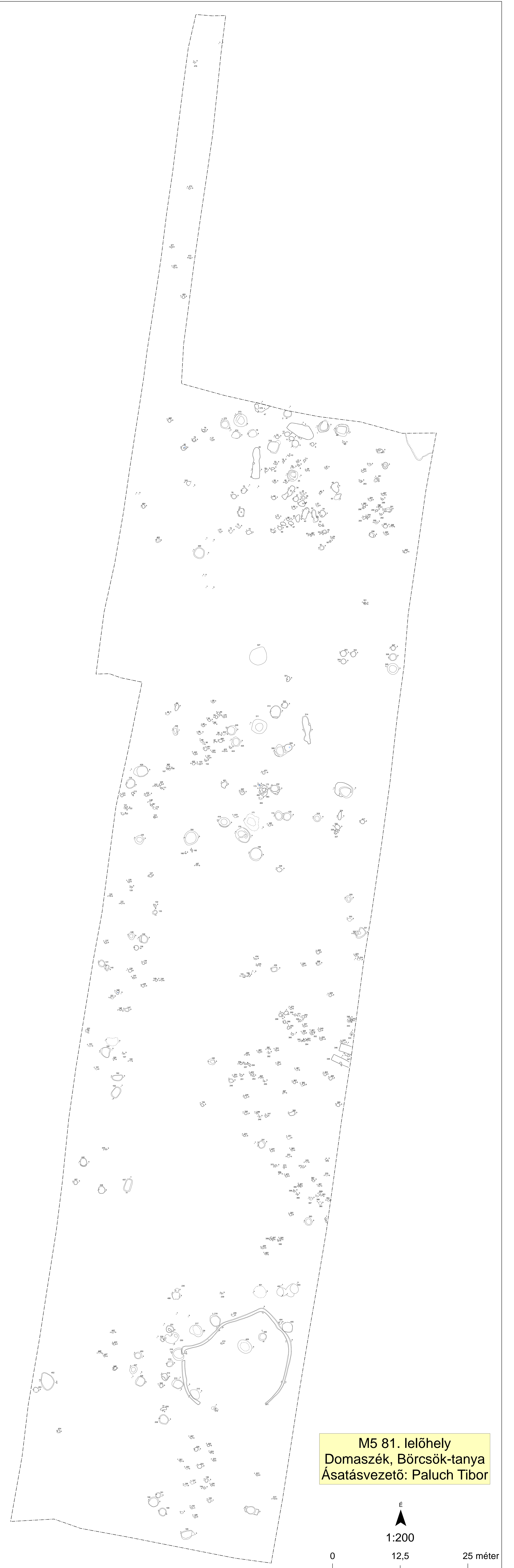




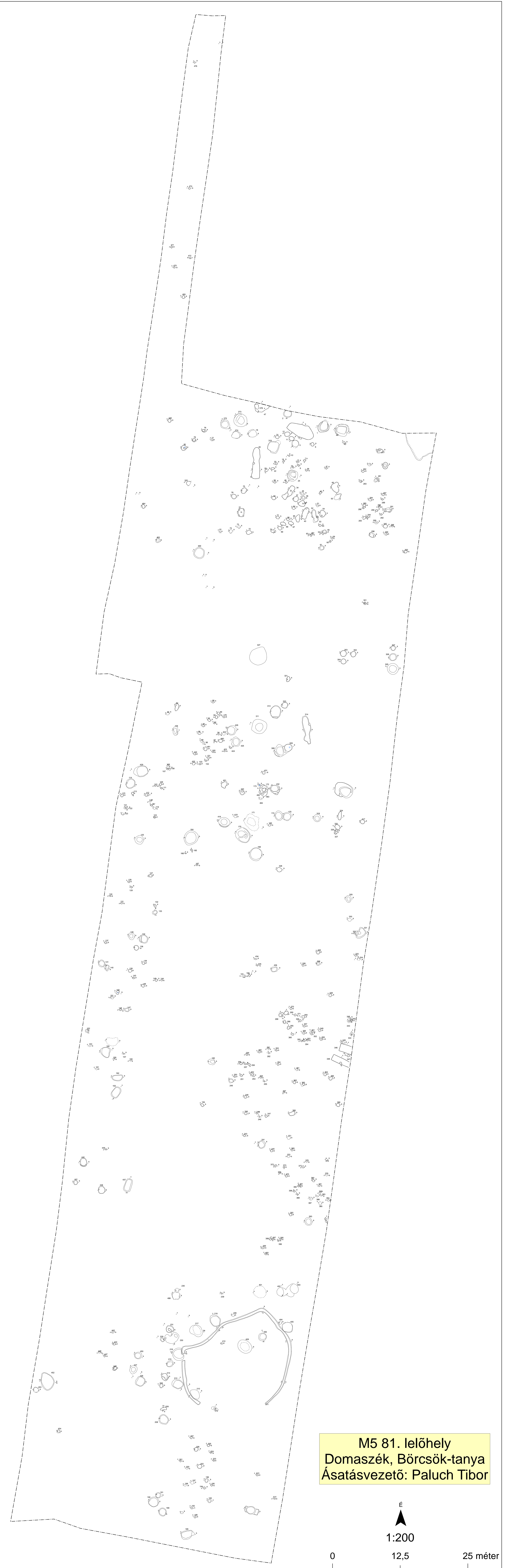




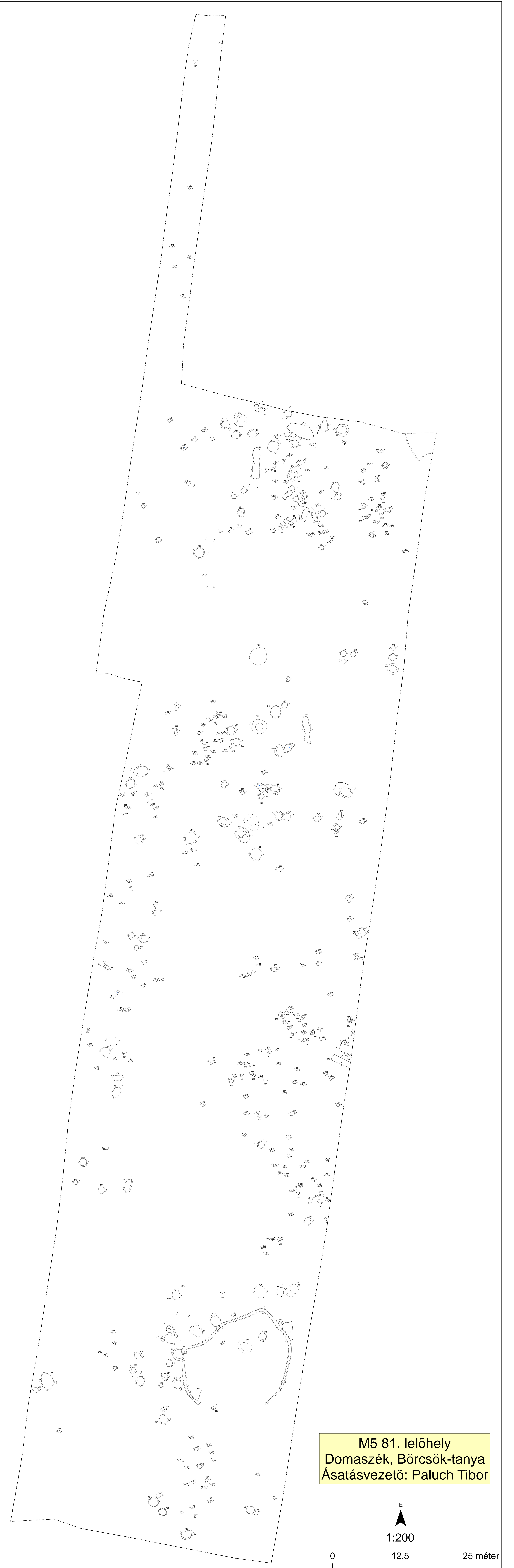




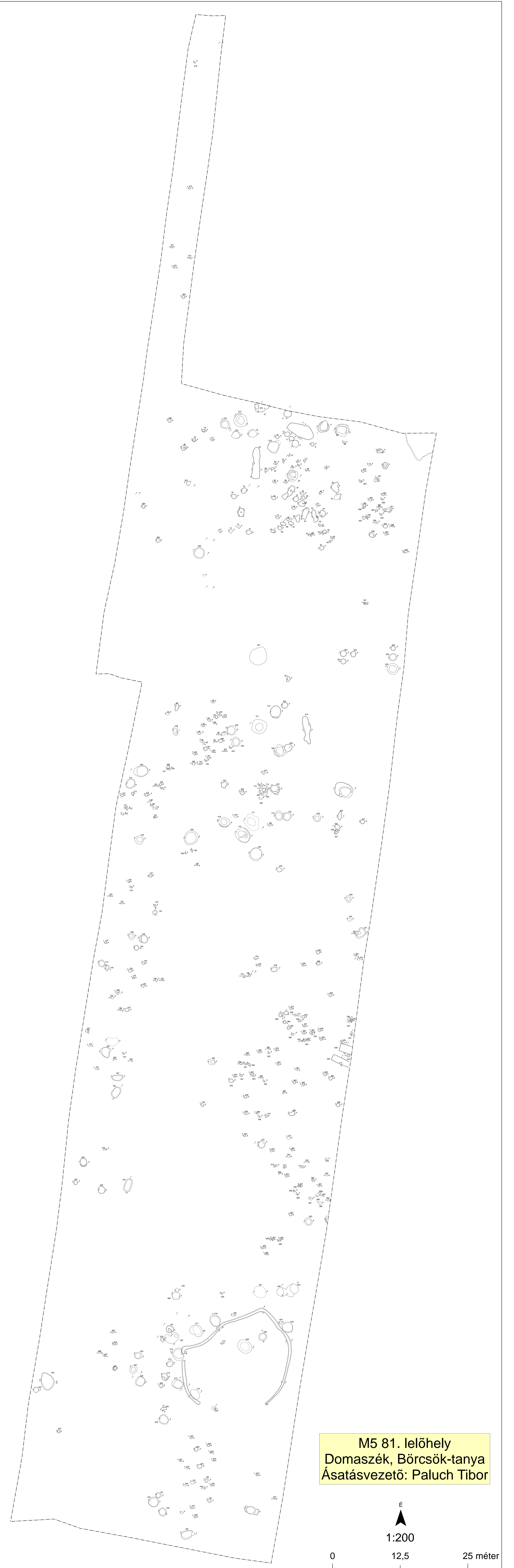




\begin{tabular}{|c|c|c|c|c|c|c|c|c|c|c|c|}
\hline No. & $\mathrm{S}$ & $\mathrm{Cr}$ & $\mathrm{Fe}$ & $\mathrm{Ni}$ & $\mathrm{Cu}$ & $\mathrm{Zn}$ & As & Sn & $\mathrm{Sb}$ & $\mathrm{Pb}$ & típus* \\
\hline 1 & & 0.028 & 0.989 & 0.221 & 66.666 & & 0.001 & 11.330 & & 0.394 & réz** ${ }^{\mathrm{Ni}-}$ \\
\hline 2 & 0.131 & 0.017 & 0.053 & 0.228 & 74.081 & & 0.114 & 4.164 & 0.347 & 0.623 & „dasni” \\
\hline $3 * * *$ & 0.950 & 0.021 & 0.132 & 0.195 & 62.116 & & 0.855 & 12.600 & 0.829 & 1.023 & \\
\hline 4 & 0.533 & & 0.184 & 0.389 & 72.452 & & 0.584 & 4.978 & & & AsNi \\
\hline 5 & & & 0.088 & 0.081 & 74.532 & & 0.121 & 4.951 & & & „dasni” \\
\hline 6 & & & 0.001 & 0.203 & 74.124 & & 0.229 & 5.198 & & & AsNi \\
\hline 7 & 0.136 & & 0.020 & 0.426 & 64.585 & & 0.349 & 13.945 & & & AsNi \\
\hline 8 & 0.322 & & 0.200 & 0.310 & 71.589 & & 0.229 & 6.732 & & & AsNi \\
\hline 9 & 0.255 & & 0.265 & 0.994 & 71.373 & 0.676 & 0.155 & 5.744 & & & „dasni” \\
\hline 10 & 0.040 & & 0.402 & 0.319 & 72.952 & 0.386 & 0.265 & 5.285 & & & AsNi \\
\hline 11 & & & 0.069 & 0.227 & 74.869 & & 0.015 & 2.934 & 1.028 & 0.846 & ASN \\
\hline 12 & & & 0.050 & 0.319 & 71.281 & & 0.191 & 6.884 & 0.389 & 0.737 & ASN \\
\hline 13 & & & 0.452 & 0.305 & 70.770 & & 0.322 & 7.005 & 0.182 & 0.715 & AsNi \\
\hline 14 & & & 0.060 & 0.178 & 73.773 & & 0.133 & 4.459 & 0.538 & 0.770 & $\mathrm{ASN}$ \\
\hline 15 & & & 0.121 & 0.174 & 68.913 & & 0.155 & 8.956 & 0.696 & 0.835 & $\mathrm{ASN}$ \\
\hline 16 & & & 0.093 & 0.211 & 71.027 & & 0.395 & 7.180 & 0.160 & 0.717 & AsNi \\
\hline 17 & & & 0.063 & 0.194 & 72.387 & & 0.390 & 5.824 & 0.182 & 0.777 & AsNi \\
\hline 18 & & & 0.066 & 0.393 & 67.835 & & 0.214 & 10.336 & 0.221 & 0.718 & AsNi \\
\hline 19 & & & 0.046 & 0.460 & 71.732 & & 0.348 & 6.210 & 0.285 & 0.738 & AsNi \\
\hline 20 & 0.562 & & 0.197 & 0.421 & 90.691 & & 0.696 & 7.433 & & & AsNi \\
\hline
\end{tabular}

* Liversage, 1994, **Krause, 2003, Cl.40. 26, 39. *** a 2-es részletmérése, cluster-analízisben nem szerepel

13. táblázat A 2009-es mérések eredményei 


\begin{tabular}{|c|c|c|c|c|c|c|c|c|c|c|c|c|c|c|c|}
\hline Code & Type & Site & $\mathrm{Cr}$ & $\mathrm{Fe}$ & Co & $\mathrm{Ni}$ & $\mathrm{Cu}$ & $\mathrm{Zn}$ & As & $\mathrm{Ag}$ & $\mathrm{Cd}$ & Sn & $\mathrm{Sb}$ & $\mathrm{Pb}$ & $\begin{array}{c}\text { Type [after } \\
\text { Liversage } \\
1994]\end{array}$ \\
\hline $128-134 / 1885 / 19$ & pin fragment & Röszke-Sárosvölgy & 0 & 0,342 & 0 & 0,300 & 84,5 & 0,50 & 0,947 & 0,27 & 0 & 12,4 & 0,36 & 0,41 & AsNi/ASN \\
\hline 53.25 .3 & pendant fragment & Szeged-Bogárzó B, Grave 1 & 0 & 0,067 & 0 & 0,540 & 77,9 & 0 & 0,365 & 0,20 & 0 & 20,5 & 0,38 & 0,05 & AsNi/ASN \\
\hline $128 / 1885 / 18 / 3$ & pendant fragment & Röszke-Sárosvölgy & 0 & 0,117 & 0,068 & 0,717 & 85,9 & 0,78 & 0,693 & 0,12 & 0 & 11,1 & 0,32 & 0,25 & $\mathrm{AsNi}$ \\
\hline $128 / 1885 / 14$ & pendant fragment & Röszke-Sárosvölgy & 0 & 0,099 & 0 & 0,250 & 88,7 & 0 & 0,562 & 0,11 & 0 & 9,3 & 0,93 & 0,03 & ASN \\
\hline 53.25 .19 & pendant fragment & Szeged-Bogárzó B, Grave 15 & 0 & 0,158 & 0 & 0,200 & 91,4 & 0 & 0,162 & 0,09 & 0 & 7,6 & 0,34 & 0,10 & dasni \\
\hline 53.25 .9 & pendant fragment & Szeged-Bogárzó B, Grave 6 & 0 & 0,360 & 0,055 & 0,232 & 91,2 & 0,82 & 0,144 & 0,07 & 0 & 6,9 & 0,19 & 0,01 & dasni \\
\hline Zakany-01 & knife & Zákányszék-Zákány d., Grave 12 & 0 & 0,055 & 0 & 0,365 & 91,9 & 0 & 0,350 & 0,08 & 0 & 6,6 & 0,51 & 0,18 & ASN \\
\hline Zakany-02 & pendant & Zákányszék-Zákány d. NY/69. Ih & 0 & 0,263 & 0 & 0,452 & 89,4 & 0 & 0,654 & 0,12 & 0,044 & 8,2 & 0,71 & 0,09 & ASN \\
\hline Zakany-03 & bracelet & Zákányszék-Zákány d. NY/70. Ih & 0 & 0,132 & 0 & 0,570 & 85,2 & 0 & 0,584 & 0,16 & 0 & 12,7 & 0,51 & 0,11 & ASN \\
\hline Zakany-04 & pendant & Zákányszék-Zákány d. NY/70. Ih & 0 & 0,185 & 0 & 0,421 & 89,7 & 0 & 1,491 & 0,08 & 0 & 5,3 & 0,56 & 2,34 & ASN \\
\hline $1 / 1906$ & bracelet & Ásotthalom-Királyhalom & 0 & 0,050 & 0,063 & 0,445 & 88,2 & 0 & 0,554 & 0,10 & 0 & 9,8 & 0,51 & 0,30 & ASN \\
\hline $2 / 1906$ & bracelet & Ásotthalom-Királyhalom & 0 & 0,610 & 0,131 & 0,444 & 89,0 & 0 & 0,527 & 0,09 & 0 & 8,6 & 0,32 & 0,28 & AsNi/ASN \\
\hline 65.1 .46 & pin fragment & Tápé-Széntéglaégetö, Grave 25 & 0 & 0,579 & 0 & 0,406 & 83,5 & 0 & 0,626 & 0,16 & 0,064 & 14,0 & 0,48 & 0,22 & ASN \\
\hline $65.1 .47 / 1$ & bracelet & Tápé-Széntéglaégetö, Grave 25 & 0 & 0,158 & 0 & 0,361 & 93,0 & 0 & 0,204 & 0,07 & 0 & 5,7 & 0,29 & 0,23 & AsNi/ASN \\
\hline 65.1 .396 & pin fragment & Tápé-Széntéglaégetö, Grave 324 & 0,059 & 0,269 & 0,072 & 0,605 & 80,5 & 0 & 0,631 & 0,17 & 0 & 16,9 & 0,64 & 0,20 & ASN \\
\hline $65.1 .78 / 1$ & pin fragment & Tápé-Széntéglaégetö, Grave 48 & 0 & 0,558 & 0 & 0,416 & 89,5 & 0 & 0,556 & 0,10 & 0 & 8,1 & 0,73 & 0,03 & ASN \\
\hline 65.1 .409 & bracelet & Tápé-Széntéglaégetö, Grave 326 & 0 & 0,268 & 0 & 0,203 & 88,0 & 0 & 0,495 & 0,10 & 0 & 9,1 & 0,84 & 0,97 & ASN \\
\hline 65.1 .575 & pin fragment & Tápé-Széntéglaégetö, Grave 444 & 0 & 0,325 & 0 & 0,456 & 87,4 & 0 & 0,439 & 0,13 & 0 & 10,9 & 0,34 & 0,10 & AsNi/ASN \\
\hline 65.1 .578 & bracelet & Tápé-Széntéglaégetö, Grave 444 & 0 & 0,020 & 0 & 0,387 & 81,8 & 0 & 0,746 & 0,15 & 0 & 14,4 & 0,71 & 1,80 & ASN \\
\hline 65.1 .603 & pin fragment & Tápé-Széntéglaégetö, Grave 463 & 0 & 0,174 & 0 & 0,571 & 83,0 & 0 & 1,120 & 0,17 & 0 & 14,3 & 0,61 & 0,11 & ASN \\
\hline 65.1 .693 & pinzetta & Tápé-Széntéglaégetö, Grave 518 & 0,043 & 0,560 & 0 & 0,718 & 84,4 & 0 & 0,768 & 0,13 & 0 & 12,6 & 0,65 & 0,13 & ASN \\
\hline
\end{tabular}




\begin{tabular}{|c|c|c|c|c|c|c|c|c|c|c|c|c|c|c|c|}
\hline 65.1 .705 & bracelet fragment & Tápé-Széntéglaégetö, Grave 526 & 0 & 0,076 & 0 & 0,185 & 90,3 & 0 & 0,421 & 0,10 & 0 & 8,5 & 0,32 & 0,13 & AsNi/ASN \\
\hline 65.1 .707 & pendant & Tápé-Széntéglaégetö, Grave 526 & 0 & 0,038 & 0 & 0,401 & 88,3 & 0 & 0,424 & 0,13 & 0 & 9,4 & 0,60 & 0,61 & ASN \\
\hline 53.61 .1 & pin & Kiskundorozsma-Átokháza-dülö & 0 & 0,077 & 0 & 0,857 & 89,7 & 0,44 & 0,296 & 0,07 & 0 & 8,4 & 0,12 & 0 & $\mathrm{AsNi}$ \\
\hline 53.61 .2 & bracelet & Kiskundorozsma-Átokháza-dülö & 0 & 0,468 & 0,053 & 0,844 & 83,9 & 1,06 & 0,379 & 0,13 & 0 & 12,9 & 0,30 & 0 & $\mathrm{AsNi}$ \\
\hline 53.61 .3 & bronze belt fragm. & Kiskundorozsma-Átokháza-dülö & 0 & 0,151 & 0 & 0,543 & 86,0 & 0 & 0,421 & 0,11 & 0 & 11,9 & 0,52 & 0,40 & ASN \\
\hline 53.61 .4 & bracelet & Kiskundorozsma-Átokháza-dülö & 0 & 0,435 & 0 & 0,437 & 89,4 & 1,30 & 0,474 & 0,11 & 0 & 7,0 & 0,72 & 0,12 & ASN \\
\hline 53.61 .6 & bracelet fragment & Kiskundorozsma-Átokháza-dülö & 0 & 0,262 & 0,080 & 0,538 & 88,0 & 1,20 & 0,483 & 0,11 & 0 & 8,2 & 0,72 & 0,41 & ASN/AsNi \\
\hline 53.60 .1 & bracelet & Nagyszéksós-Oltványi tanya & 0 & 0,332 & 0,093 & 0,580 & 86,3 & 1,79 & 0,417 & 0,13 & 0 & 10,0 & 0,35 & 0 & AsNi/ASN \\
\hline 53.60 .2 & bracelet & Nagyszéksós-Oltványi tanya & 0 & 0,055 & 0 & 0,378 & 85,1 & 2,45 & 0,352 & 0,14 & 0 & 10,5 & 0,59 & 0,39 & ASN \\
\hline $4 / 1894$ & sickle pin & Tömörkény-Újmajor & 0 & 0,053 & 0 & 0,330 & 88,3 & 0,98 & 0,215 & 0,14 & 0 & 9,5 & 0,44 & 0,07 & $\mathrm{ASN} / \mathrm{AsNi}$ \\
\hline 53.219 .1 & pendant & Кӧтрӧс-Gerzsa & 0 & 0,062 & 0 & 0,047 & 40,2 & 1,88 & 0,030 & 55,3 & 0 & 0,95 & 0 & 1,26 & ----- \\
\hline 53.137 .1 & bronze ornament fr. & Ásotthalom-Királyhalom & 0 & 0,184 & 0 & 0,325 & 86,1 & 3,20 & 0,440 & 0,11 & 0 & 8,6 & 0,53 & 0,48 & ASN \\
\hline 2001.3 .2 & bracelet & Ópusztaszer-Kápolnai erdö & 0 & 0,119 & 0,121 & 0,689 & 86,9 & 0 & 0,759 & 0,13 & 0 & 10,7 & 0,47 & 0,08 & ASN \\
\hline 2001.3 .3 & pin & Ópusztaszer-Kápolnai erdö & 0 & 0,119 & 0,123 & 0,673 & 87,3 & 0 & 0,770 & 0,12 & 0 & 10,4 & 0,48 & 0,10 & ASN \\
\hline 53.135 .1 & pin & Szeged-Rókusi téglagyár & 0 & 0,082 & 0 & 0,574 & 90,5 & 0 & 0,474 & 0,08 & 0 & 7,7 & 0,45 & 0,11 & ASN/AsNi \\
\hline 80.35 .2 & pendant & Csengele-Mételyes & 0 & 0,114 & 0 & 0,436 & 92,0 & 0 & 0,470 & 0,08 & 0 & 6,4 & 0,50 & 0 & ASN \\
\hline $1 / 1904$ & axe & Szeged-Alsótanya & 0 & 0,026 & 0 & 0,369 & 95,1 & 0 & 0,119 & 0,05 & 0 & 4,2 & 0,15 & 0 & $\mathrm{AsNi}$ \\
\hline $10 / 1905 b$ & sickle pin & Ásotthalom-Bilisics & 0 & 0,154 & 0 & 0,306 & 89,7 & 0,98 & 0,404 & 0,09 & 0 & 8,1 & 0,30 & 0 & $\mathrm{AsNi}$ \\
\hline 53.50 .8 & pin & Kiskunmajsa & 0 & 0,099 & 0 & 0,419 & 87,6 & 0 & 0,531 & 0,12 & 0 & 11,2 & 0 & 0 & $\mathrm{AsNi}$ \\
\hline
\end{tabular}

14. táblázat: A tárgyak összetétele tömeg \%-ban és besorolásuk Liversage [1994] rendszere alapján 


\begin{tabular}{|c|c|c|c|c|c|c|c|c|c|c|c|c|c|c|}
\hline Code & Type & Site & $\mathrm{Cr}$ & $\mathrm{Fe}$ & Co & $\mathrm{Ni}$ & $\mathrm{Cu}$ & $\mathrm{Zn}$ & As & $\mathrm{Ag}$ & $\mathrm{Cd}$ & $\mathrm{Sn}$ & $\mathrm{Sb}$ & $\mathrm{Pb}$ \\
\hline $128-134 / 1885 / 19$ & pin fragment & Röszke-Sárosvölgy & 0 & 0,42 & 0 & 0,35 & 90,29 & 0,52 & 0,86 & 0,17 & 0 & 7,06 & 0,20 & 0,14 \\
\hline 53.25 .3 & pendant fragment & Szeged-Bogárzó B, Grave 1 & 0 & 0,08 & 0 & 0,65 & 86,37 & 0 & 0,34 & 0,13 & 0 & 12,19 & 0,22 & 0,02 \\
\hline $128 / 1885 / 18 / 3$ & pendant fragment & Röszke-Sárosvölgy & 0 & 0,14 & 0,08 & 0,82 & 90,93 & 0,80 & 0,62 & 0,07 & 0 & 6,28 & 0,17 & 0,08 \\
\hline $128 / 1885 / 14$ & pendant fragment & Röszke-Sárosvölgy & 0 & 0,12 & 0 & 0,28 & 93,26 & 0 & 0,50 & 0,07 & 0 & 5,25 & 0,51 & 0,01 \\
\hline 53.25 .19 & pendant fragment & Szeged-Bogárzó B, Grave 15 & 0 & 0,19 & 0 & 0,23 & 94,95 & 0 & 0,14 & 0,06 & 0 & 4,23 & 0,19 & 0,03 \\
\hline 53.25 .9 & pendant fragment & Szeged-Bogárzó B, Grave 6 & 0 & 0,42 & 0,06 & 0,26 & 94,32 & 0,83 & 0,13 & 0,04 & 0 & 3,84 & 0,11 & 0 \\
\hline Zakany-01 & knife & Zákányszék-Zákány d., Grave 12 & 0 & 0,07 & 0 & 0,41 & 95,18 & 0 & 0,31 & 0,05 & 0 & 3,66 & 0,27 & 0,06 \\
\hline Zakany-02 & pendant & Zákányszék-Zákány d. NY/69. Ih & 0 & 0,31 & 0 & 0,51 & 93,47 & 0 & 0,58 & 0,07 & 0,03 & 4,61 & 0,39 & 0,03 \\
\hline Zakany-03 & bracelet & Zákányszék-Zákány d. NY/70. Ih & 0 & 0,16 & 0 & 0,66 & 90,95 & 0 & 0,53 & 0,10 & 0 & 7,28 & 0,29 & 0,04 \\
\hline Zakany-04 & pendant & Zákányszék-Zákány d. NY/70. Ih & 0 & 0,22 & 0 & 0,48 & 93,92 & 0 & 1,32 & 0,05 & 0 & 2,95 & 0,30 & 0,75 \\
\hline $1 / 1906$ & bracelet & Ásotthalom-Királyhalom & 0 & 0,06 & 0,07 & 0,51 & 92,89 & 0 & 0,49 & 0,06 & 0 & 5,54 & 0,28 & 0,10 \\
\hline $2 / 1906$ & bracelet & Ásotthalom-Királyhalom & 0 & 0,72 & 0,15 & 0,50 & 93,02 & 0 & 0,47 & 0,06 & 0 & 4,82 & 0,17 & 0,09 \\
\hline 65.1 .46 & pin fragment & Tápé-Széntéglaégetö, Grave 25 & 0 & 0,71 & 0 & 0,47 & 89,70 & 0 & 0,57 & 0,10 & 0,04 & 8,07 & 0,27 & 0,07 \\
\hline $65.1 .47 / 1$ & bracelet & Tápé-Széntéglaégetö, Grave 25 & 0 & 0,19 & 0 & 0,40 & 95,83 & 0 & 0,18 & 0,04 & 0 & 3,13 & 0,16 & 0,07 \\
\hline 65.1 .396 & pin fragment & Tápé-Széntéglaégetö, Grave 324 & 0,08 & 0,33 & 0,08 & 0,71 & 87,81 & 0 & 0,58 & 0,11 & 0 & 9,85 & 0,37 & 0,07 \\
\hline $65.1 .78 / 1$ & pin fragment & Tápé-Széntéglaégetö, Grave 48 & 0 & 0,66 & 0 & 0,47 & 93,40 & 0 & 0,49 & 0,06 & 0 & 4,50 & 0,40 & 0,01 \\
\hline 65.1 .409 & bracelet & Tápé-Széntéglaégetö, Grave 326 & 0 & 0,32 & 0 & 0,23 & 93,00 & 0 & 0,44 & 0,06 & 0 & 5,16 & 0,46 & 0,31 \\
\hline 65.1 .575 & pin fragment & Tápé-Széntéglaégetö, Grave 444 & 0 & 0,39 & 0 & 0,52 & 92,25 & 0 & 0,39 & 0,08 & 0 & 6,14 & 0,19 & 0,03 \\
\hline 65.1 .578 & bracelet & Tápé-Széntéglaégetö, Grave 444 & 0 & 0,03 & 0 & 0,46 & 89,32 & 0 & 0,69 & 0,10 & 0 & 8,41 & 0,40 & 0,60 \\
\hline 65.1 .603 & pin fragment & Tápé-Széntéglaégetö, Grave 463 & 0 & 0,21 & 0 & 0,67 & 89,37 & 0 & 1,02 & 0,11 & 0 & 8,24 & 0,34 & 0,04 \\
\hline 65.1 .693 & pinzetta & Tápé-Széntéglaégetö, Grave 518 & 0,06 & 0,68 & 0 & 0,83 & 90,07 & 0 & 0,69 & 0,08 & 0 & 7,19 & 0,36 & 0,04 \\
\hline 65.1 .705 & bracelet fragment & Tápé-Széntéglaégetö, Grave 526 & 0 & 0,09 & 0 & 0,21 & 94,30 & 0 & 0,37 & 0,06 & 0 & 4,75 & 0,17 & 0,04 \\
\hline
\end{tabular}




\begin{tabular}{|c|c|c|c|c|c|c|c|c|c|c|c|c|c|c|}
\hline 65.1 .707 & pendant & Tápé-Széntéglaégetö, Grave 526 & 0 & 0,05 & 0 & 0,46 & 93,17 & 0 & 0,38 & 0,08 & 0 & 5,34 & 0,33 & 0,20 \\
\hline 53.61 .1 & pin & Kiskundorozsma-Átokháza-dülö & 0 & 0,09 & 0 & 0,97 & 93,45 & 0,44 & 0,26 & 0,04 & 0 & 4,68 & 0,06 & 0 \\
\hline 53.61 .2 & bracelet & Kiskundorozsma-Átokháza-dülö & 0 & 0,57 & 0,06 & 0,97 & 89,36 & 1,09 & 0,34 & 0,08 & 0 & 7,35 & 0,17 & 0 \\
\hline 53.61 .3 & bronze belt fragm. & Kiskundorozsma-Átokháza-dülö & 0 & 0,18 & 0 & 0,63 & 91,57 & 0 & 0,38 & 0,07 & 0 & 6,76 & 0,29 & 0,13 \\
\hline 53.61 .4 & bracelet & Kiskundorozsma-Átokháza-dülö & 0 & 0,51 & 0 & 0,49 & 92,85 & 1,31 & 0,42 & 0,07 & 0 & 3,91 & 0,39 & 0,04 \\
\hline 53.61 .6 & bracelet fragment & Kiskundorozsma-Átokháza-dülö & 0 & 0,31 & 0,09 & 0,61 & 92,17 & 1,23 & 0,43 & 0,07 & 0 & 4,57 & 0,40 & 0,13 \\
\hline 53.60 .1 & bracelet & Nagyszéksós-Oltványi tanya & 0 & 0,40 & 0,11 & 0,66 & 90,74 & 1,82 & 0,37 & 0,08 & 0 & 5,63 & 0,19 & 0 \\
\hline 53.60 .2 & bracelet & Nagyszéksós-Oltványi tanya & 0 & 0,07 & 0 & 0,43 & 90,16 & 2,52 & 0,32 & 0,08 & 0 & 5,96 & 0,33 & 0,13 \\
\hline $4 / 1894$ & sickle pin & Tömörkény-Újmajor & 0 & 0,06 & 0 & 0,37 & 92,70 & 1,00 & 0,19 & 0,09 & 0 & 5,32 & 0,24 & 0,02 \\
\hline 53.219 .1 & pendant & Кӧтрӧс-Gerzsa & 0 & 0,09 & 0 & 0,07 & 53,17 & 2,42 & 0,03 & 43,04 & 0 & 0,67 & 0 & 0,51 \\
\hline 53.137 .1 & bronze ornament fr. & Ásotthalom-Királyhalom & 0 & 0,22 & 0 & 0,37 & 90,40 & 3,27 & 0,39 & 0,07 & 0 & 4,84 & 0,29 & 0,16 \\
\hline 2001.3 .2 & bracelet & Ópusztaszer-Kápolnai erdö & 0 & 0,14 & 0,14 & 0,79 & 91,84 & 0 & 0,68 & 0,08 & 0 & 6,04 & 0,26 & 0,03 \\
\hline 2001.3 .3 & pin & Ópusztaszer-Kápolnai erdö & 0 & 0,14 & 0,14 & 0,77 & 92,04 & 0 & 0,69 & 0,07 & 0 & 5,85 & 0,26 & 0,03 \\
\hline 53.135 .1 & pin & Szeged-Rókusi téglagyár & 0 & 0,10 & 0 & 0,65 & 94,19 & 0 & 0,42 & 0,05 & 0 & 4,31 & 0,25 & 0,03 \\
\hline 80.35 .2 & pendant & Csengele-Mételyes & 0 & 0,13 & 0 & 0,49 & 95,11 & 0 & 0,41 & 0,05 & 0 & 3,54 & 0,27 & 0 \\
\hline $1 / 1904$ & axe & Szeged-Alsótanya & 0 & 0,03 & 0 & 0,41 & 97,05 & 0 & 0,10 & 0,03 & 0 & 2,30 & 0,08 & 0 \\
\hline $10 / 1905 b$ & sickle pin & Ásotthalom-Bilisics & 0 & 0,18 & 0 & 0,35 & 93,39 & 0,99 & 0,36 & 0,06 & 0 & 4,52 & 0,16 & 0 \\
\hline 53.50 .8 & pin & Kiskunmajsa & 0 & 0,12 & 0 & 0,48 & 92,52 & 0 & 0,48 & 0,07 & 0 & 6,34 & 0 & 0 \\
\hline
\end{tabular}

\section{5. táblázat. A mérési eredmények atom \%-ban}




\begin{tabular}{|c|c|c|c|c|c|c|c|c|c|c|c|c|c|c|c|c|c|c|c|}
\hline Korjelzö & réseléssel & bajuszdísz & \begin{tabular}{|l|} 
külsőbordás \\
csücsökkel
\end{tabular} & A8 import & A1a & $\mathrm{A} 1 \mathrm{~b}$ & A1c & A2a & $\mathrm{A} 2 \mathrm{~b}$ & A3 & A4 & A5 & A6 & A7 & A8 & A9a & A9b & A10 & A11 \\
\hline A10, bütyöklábas korsó & & & & & 2 & & & & & & & & & & & & & - & \\
\hline külső bordás csücsök & & & & & 1 & & & & 1 & & & 1 & & & & & & & \\
\hline réselés & 1 & & & & 3 & & & 1 & 1 & & & 1 & & & & & & & \\
\hline bajuszdísz & & & & & 2 & & & & & & & & & & & & & & \\
\hline A8 import & & & & & 1 & & & & & & & & & & & & & & \\
\hline A1a-b-c típusú bögre, korsó & 4 & 1 & 2 & 1 & 1 & & 1 & 1 & 1 & & & & & 1 & & & & 1 & \\
\hline A4 & & & & & & & & & & & - & & & & & & 1 & & \\
\hline \multicolumn{20}{|l|}{ A6 } \\
\hline A9a-b & & & & & & & & & & & 1 & & & & & & 1 & & \\
\hline
\end{tabular}

\begin{tabular}{|c|c|c|c|c|c|c|c|c|c|c|c|c|c|c|c|c|c|c|c|c|c|c|c|c|c|c|c|c|c|}
\hline B1a & B1b & B1c-d & B1e & B1f & B1g & B1h & $\mathrm{B} 1 \mathrm{i}$ & $B 1 j$ & B1k & B2a & B2b & B2C & C1 & $\mathrm{C} 2$ & $\mathrm{C} 3$ & $\mathrm{C} 4 \mathrm{a}$ & C4b & $\mathrm{C} 4 \mathrm{c}$ & $\mathrm{C} 5$ & $\mathrm{C} 6$ & D1a & D1b & D1c & D2 & E1 & E2 & E3a & E3b & E4 \\
\hline \multirow[t]{2}{*}{1} & & & & & & & & & & & & & & & & & & & & & & & & & 1 & & & & \\
\hline & 3 & 1 & & 2 & & & & & & 1 & 1 & & 2 & & 2 & & 1 & & & 1 & & 2 & & & 1 & 2 & & & \\
\hline 1 & 3 & 5 & 1 & 1 & 3 & & 1 & & & & 1 & & 2 & & & & 1 & & 1 & & & & & & 1 & & 2 & 1 & 1 \\
\hline \multirow[t]{2}{*}{1} & & & & & & & 1 & & & & & & & & & & & 1 & & & & & & & 1 & & & 1 & \\
\hline & & & & & & & & & & 1 & & 1 & & & & & & & & & & & & & 1 & & & & \\
\hline \multirow[t]{4}{*}{3} & 6 & 8 & 1 & 1 & 2 & 1 & & & & 1 & 1 & 1 & 4 & 3 & 5 & & 1 & & 1 & 1 & 1 & 2 & 1 & & 3 & & 2 & 2 & 1 \\
\hline & & 1 & & & & & & & & & & & & & & & & & & & & & & & & & & & 1 \\
\hline & & & & & & & & & & & & & & & & & & & & & 1 & & & & & & & & \\
\hline & & 1 & & & & & & & & & & & & & & & & & & & & & & & & & & & 2 \\
\hline
\end{tabular}

\begin{tabular}{|r|r|l|r|r|r|r|l|l|l|}
\hline F1 & F2a & F2b & F3 & F4 & G1 & G2 & G3 & G4 & G5 \\
\hline & & & & & 1 & & & & \\
\hline & & & 1 & 1 & & & & & \\
\hline & 1 & & & & & 1 & & & \\
\hline & & & & & 1 & & & & \\
\hline & & & & & & & & & \\
\hline & 2 & & & 1 & & 2 & & & \\
\hline & & & & & & & & & \\
\hline & & & & & & & & & \\
\hline & & & & & & & & & \\
\hline
\end{tabular}

16. táblázat Típusszeriáció, tipokronológia: az egyes korjelzőnek tartható típusok előfordulási kontextusa - a telep kerámiájának mely más típusaival együtt kerültek elő. A jelzések magyarázatát lásd a Tipológiai táblázatban 


\begin{tabular}{|c|c|c|c|c|c|}
\hline lelőhely & $\begin{array}{l}\text { Domaszék, } \\
\text { Börcsök-tanya }\end{array}$ & $\begin{array}{l}\text { Szeged- } \\
\text { Bogárzó }\end{array}$ & $\begin{array}{l}\text { Kiskundorozsma-E } \\
\text { és Öreghegy }\end{array}$ & $\begin{array}{l}\text { Szentes- } \\
\text { Nagyhegy }\end{array}$ & $\begin{array}{l}\text { Zákányszék- } \\
\text { Homokkultúra }\end{array}$ \\
\hline 1. jelleg & telep & temető & temető & temető & telep \\
\hline 2. kor & $\mathrm{R} B \mathrm{~B} 1-\mathrm{C}$ & $\begin{array}{l}\text { R BB1- } \\
\text { 2(?) }\end{array}$ & R BB1-2-C(?) & R BB1-2(?) & R BB2 \\
\hline 3. ívelt bordadísz & $\mathrm{xx}$ & $\mathrm{xxxx}$ & & & $\mathrm{xx}$ \\
\hline 4. réselés & $\mathrm{xx}$ & $\mathrm{xxxx}$ & & & $\mathrm{xx}$ \\
\hline 5. B1b típusú tál & $\mathrm{xxxx}$ & $\mathrm{xx}$ & & & $\mathrm{x}$ \\
\hline 6. B1c-d típusú tál & $\mathrm{xxxx}$ & $\mathrm{xxx}$ & & & \\
\hline 7. B1h típusú tál & $\mathrm{xx}$ & $\mathrm{x}$ & $\mathrm{xx}$ & $\mathrm{xx}$ & $\mathrm{xxx}$ \\
\hline 8. B1g típusú tál & $\mathrm{x}$ & & & & $\mathrm{xxxx}$ \\
\hline $\begin{array}{l}\text { 9. B1e típusú tál, ill. nem } \\
\text { csücskös peremü tál }\end{array}$ & $\mathrm{xx}$ & $\mathrm{x}$ & $\mathrm{xx}$ & & $\mathrm{xx}$ \\
\hline 10. S-profilú tál (B1f) & $\mathrm{xx}$ & $\mathrm{x}$ & $\mathrm{xx}$ & & $\mathrm{xxx}$ \\
\hline 11. nagy, öblös mély tál & $\mathrm{xx}$ & & & & $\mathrm{xx}$ \\
\hline \multicolumn{6}{|l|}{ 12. behúzott peremú tál } \\
\hline 13. külső bordás csücsök & $\mathrm{xxx}$ & $\mathrm{xxxx}$ & & & $\mathrm{x}$ \\
\hline 14. belső bordás csücsök & $\mathrm{x}$ & $\mathrm{x}$ & $\mathrm{xx}$ & & $\mathrm{xxxx}$ \\
\hline 15. kettős csücsök & $\mathrm{x}$ & & $\mathrm{x}$ & & \\
\hline 16. bütyöklábas korsó & $\mathrm{x}$ & & & & \\
\hline $\begin{array}{l}\text { 17. kettős kónikus, rövid } \\
\text { tölcséres nyakú bögre } \\
\text { (Foltiny, 1957, V. t. 5.) }\end{array}$ & $\mathrm{x}$ & $\mathrm{x}$ & $\mathrm{xx}$ & $\mathrm{xxx}$ & $\mathrm{x}$ \\
\hline $\begin{array}{l}\text { 18. hosszabb, tölcséres } \\
\text { nyakú korsó/bögre }\end{array}$ & $\mathrm{xxx}$ & $\mathrm{xxxx}$ & & & $\mathrm{xx}$ \\
\hline 19. kettős kónikus bögre & & & & $\mathrm{xx}$ & $\mathrm{xx}$ \\
\hline $\begin{array}{l}\text { 20. gömbös testü, rövid } \\
\text { peremü bögre }\end{array}$ & & & & $\mathrm{xx}$ & \\
\hline \multicolumn{6}{|l|}{$\begin{array}{l}\text { 21. kettős kónikus, gyürü- } \\
\text { vagy csőtalpas bögre }\end{array}$} \\
\hline $\begin{array}{l}\text { 22. A4 típusú, félgömbös } \\
\text { testü, rövid nyakú bögre }\end{array}$ & $\mathrm{x}$ & & & & \\
\hline 23. egyfülü, kónikus csésze & $\mathrm{x}$ & $\mathrm{x}$ & & & $\mathrm{x}$ \\
\hline 24. két füles korsó/bögre & & $\mathrm{x}$ & & & \\
\hline 25. kiöntőcsőrös edény & $\mathrm{x}$ & $\mathrm{x}$ & & & \\
\hline $\begin{array}{l}\text { 26. kiöntőcsöves korsó (A6 } \\
\text { típus) }\end{array}$ & $\mathrm{x}$ & & & & \\
\hline $\begin{array}{l}\text { 27. két könyökfüles egyenes } \\
\text { peremú urna vagy csupor }\end{array}$ & $\mathrm{xxx}$ & $\mathrm{xxxx}$ & $\mathrm{xxxx}$ & $\mathrm{xxx}$ & $\mathrm{xxx}$ \\
\hline 28. csőtalpas csupor & $\mathrm{x}$ & $\mathrm{xxx}$ & $\mathrm{xxx}$ & $\mathrm{x}$ & \\
\hline $\begin{array}{l}\text { 29. Rákóczifalva jellegü } \\
\text { edények (korsók, urnák) }\end{array}$ & $\mathrm{x}$ & & & & \\
\hline $\begin{array}{l}\text { 30. gömbös testü, } \\
\text { cilindrikus nyakú, kihajló } \\
\text { peremü urna és csupor (C3 } \\
\text { típus) }\end{array}$ & $\mathrm{xxxx}$ & $\mathrm{xxx}$ & $\mathrm{xx}$ & & $\mathrm{xxx}$ \\
\hline $\begin{array}{l}\text { 31. két füles, hordó alakú } \\
\text { fazék }\end{array}$ & $\mathrm{xxxx}$ & $\mathrm{x}$ & & & $\mathrm{xxxx}$ \\
\hline 32. egyfüles fazék/csupor & & $\mathrm{x}$ & & & \\
\hline 33. halsütő tál & $\mathrm{x}$ & & & & \\
\hline 34. pyraunos & $\mathrm{xx}$ & & & & \\
\hline 35. fedő & $\mathrm{x}$ & & & $\mathrm{xx}$ & \\
\hline \multicolumn{6}{|l|}{ 36. perem fölé húzott fül } \\
\hline 37. fekete fényezés & $\mathrm{x}$ & $\mathrm{x}$ & & & $\mathrm{x}$ \\
\hline \multicolumn{6}{|l|}{ 38. ötszög átmetszetü fül } \\
\hline \multicolumn{6}{|l|}{ 39. síkozás } \\
\hline \multicolumn{6}{|l|}{ 40. kannelúrázás } \\
\hline \multicolumn{6}{|l|}{ 41. ferde kannelúrázás } \\
\hline 42. körülárkolt bütyök & $\mathrm{x}$ & & & & $\mathrm{x}$ \\
\hline 43. girlandmotívum & & $\mathrm{x}$ & & & \\
\hline $\begin{array}{l}\text { 44. sraffozással kitöltött } \\
\text { háromszögmotívum }\end{array}$ & $\mathrm{xx}$ & $\mathrm{xx}$ & & & $\mathrm{xxx}$ \\
\hline
\end{tabular}




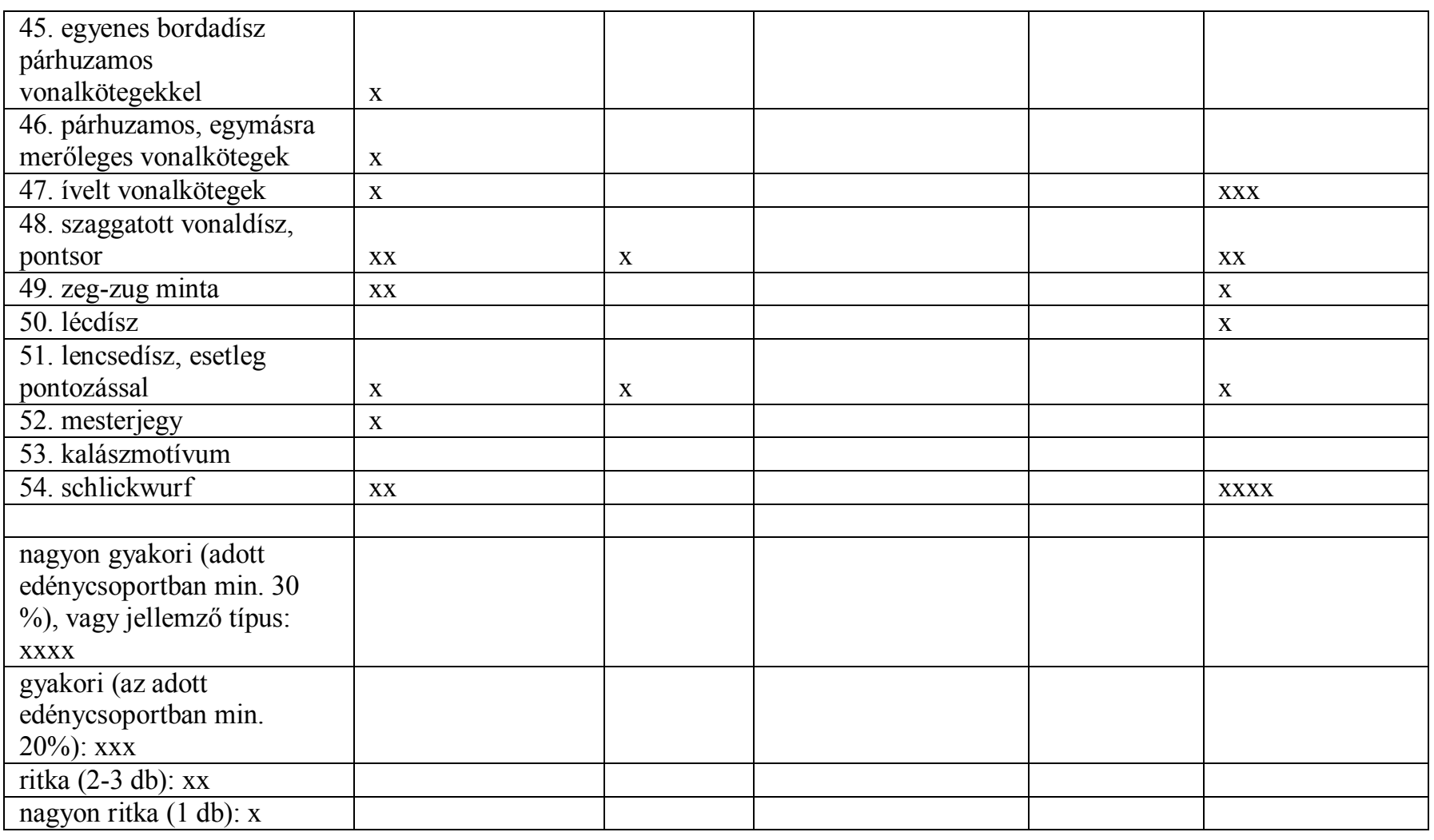

\begin{tabular}{|c|c|c|c|c|c|}
\hline No. & $\begin{array}{l}\text { Tápé- } \\
\text { Széntéglaégető }\end{array}$ & $\begin{array}{l}\text { Szeged- } \\
\text { Alsóközpont-Dobó } \\
\text { (-tanya) }\end{array}$ & $\begin{array}{l}\text { Tápé-Kemeshát és } \\
\text { Szőlőföldek }\end{array}$ & Ruzsa-Csorva & $\begin{array}{l}\text { Kiskundorozsma- } \\
\text { Subasa }\end{array}$ \\
\hline 1. & temető & temető & telep & temető & telep \\
\hline 2. & R BB1(?)-C/D(?) & $\mathrm{R} \mathrm{BC}$ & R BB2-Ha A1 & Ha A1-B1 (?) & R BD-Ha A1 \\
\hline \multicolumn{6}{|l|}{3.} \\
\hline 4. & $\mathrm{x}$ & & & & \\
\hline 5. & $\mathrm{x}$ & & $\mathrm{x}$ & & \\
\hline 6. & & $\mathrm{xx}$ & & & \\
\hline 7. & $\mathrm{xxxx}$ & $\mathrm{xxxx}$ & $\mathrm{xxxx}$ & & \\
\hline 8. & $\mathrm{xxx}$ & $\mathrm{xxxx}$ & $\mathrm{xxxx}$ & & \\
\hline 9. & $\mathrm{x}$ & & & $\mathrm{xxxx}$ & \\
\hline 10. & $\mathrm{x}$ & & $\mathrm{xx}$ & $\mathrm{x}$ & $\mathrm{xx}$ \\
\hline \multicolumn{6}{|l|}{11.} \\
\hline 12. & $\mathrm{x}$ & & $\mathrm{xxx}$ & $\mathrm{xxxx}$ & $\mathrm{xxx}$ \\
\hline \multicolumn{6}{|l|}{13.} \\
\hline 14. & $\mathrm{xxxx}$ & $\mathrm{xxxx}$ & $\mathrm{xxxx}$ & & \\
\hline \multicolumn{6}{|l|}{15.} \\
\hline \multicolumn{6}{|l|}{16.} \\
\hline 17. & $\mathrm{xxx}$ & & & $\mathrm{xx}$ & \\
\hline 18. & $\mathrm{xxx}$ & & $\mathrm{x}$ & & \\
\hline 19. & $\mathrm{xxxx}$ & & $\mathrm{xxxx}$ & $\mathrm{xxx}$ & $\mathrm{xx}$ \\
\hline 20. & $\mathrm{xxxx}$ & $\mathrm{xxxx}$ & $\operatorname{xxxx}$ & $\mathrm{x}$ & $\mathrm{xxxx}$ \\
\hline 21. & $\mathrm{x}$ & & & $\operatorname{xxxx}$ & \\
\hline 22. & $\mathrm{xxx}$ & & $\mathrm{xxx}$ & xxxx & $\mathrm{xxx}$ \\
\hline 23. & $\mathrm{xx}$ & & & $\mathrm{x}$ & \\
\hline 24. & $\mathrm{x}$ & & & & \\
\hline 25. & $\mathrm{x}$ & & & & \\
\hline 26. & $\mathrm{x}$ & & & & \\
\hline 27. & xxxx & $\mathrm{xxxx}$ & $\mathrm{x}$ & $\mathrm{xx}$ & \\
\hline 28. & $\mathrm{xxx}$ & & & & \\
\hline 29. & $\mathrm{xx}$ & & $\mathrm{x}$ & $\mathrm{xxxx}$ & \\
\hline
\end{tabular}




\begin{tabular}{|c|c|c|c|c|c|}
\hline 30. & & & $\mathrm{x}$ & $\mathrm{xx}$ & \\
\hline 31. & $\mathrm{xxx}$ & & & & \\
\hline 32. & $\mathrm{XXXX}$ & & & $\mathrm{XXX}$ & \\
\hline 33. & $\mathrm{x}$ & $\mathrm{xxx}$ & & $\mathrm{x}$ & \\
\hline 34. & & & $\mathrm{xX}$ & & \\
\hline 35. & $x x x$ & & & $\mathrm{xx}$ & \\
\hline 36. & $\mathrm{XXX}$ & $\mathrm{xxx}$ & $\mathrm{x}$ & $\mathrm{xxxx}$ & $\mathrm{xX}$ \\
\hline 37. & $\mathrm{xx}$ & $x x$ & $\mathrm{xxx}$ & $\mathrm{Xxxx}$ & XXXX \\
\hline 38. & & & & $\overline{x x x x}$ & $\mathrm{xxx}$ \\
\hline 39. & $\mathrm{x}$ & & & $\mathrm{xxxx}$ & $\mathrm{XX}$ \\
\hline 40. & $\mathrm{xxxx}$ & & $\mathrm{XXX}$ & $\overline{x x x x}$ & XXxx \\
\hline 41. & & & & $\mathrm{x}$ & Xxxx \\
\hline 42. & $x x$ & & $\mathrm{x}$ & $\mathrm{x}$ & \\
\hline 43. & $x x$ & & $\mathrm{xxx}$ & $\mathrm{xxxx}$ & $\mathrm{XXXX}$ \\
\hline 44. & $\mathrm{xx}$ & & & $x$ & \\
\hline 45. & $\mathrm{xxx}$ & & $\mathrm{x}$ & & \\
\hline 46. & $\mathrm{xxx}$ & & $\mathrm{xx}$ & & \\
\hline 47. & $\mathrm{XXX}$ & & $\mathrm{x}$ & & \\
\hline 48. & $\mathrm{xxx}$ & & $\mathrm{x}$ & & \\
\hline 49. & XXXx & & & $\mathrm{x}$ & $\mathrm{x}$ \\
\hline 50. & $\mathrm{xx}$ & & & & \\
\hline 51. & $x \mathrm{x}$ & & & $\mathrm{x}$ & \\
\hline 52. & $x$ & & $\mathrm{x}$ & & \\
\hline \multicolumn{6}{|l|}{53.} \\
\hline 54. & $\mathrm{x}$ & & $\mathrm{x}$ & & \\
\hline
\end{tabular}

17. táblázat Dél-alföldi későbronzkori lelőhelyek típus-gyakoriság szeriációja 


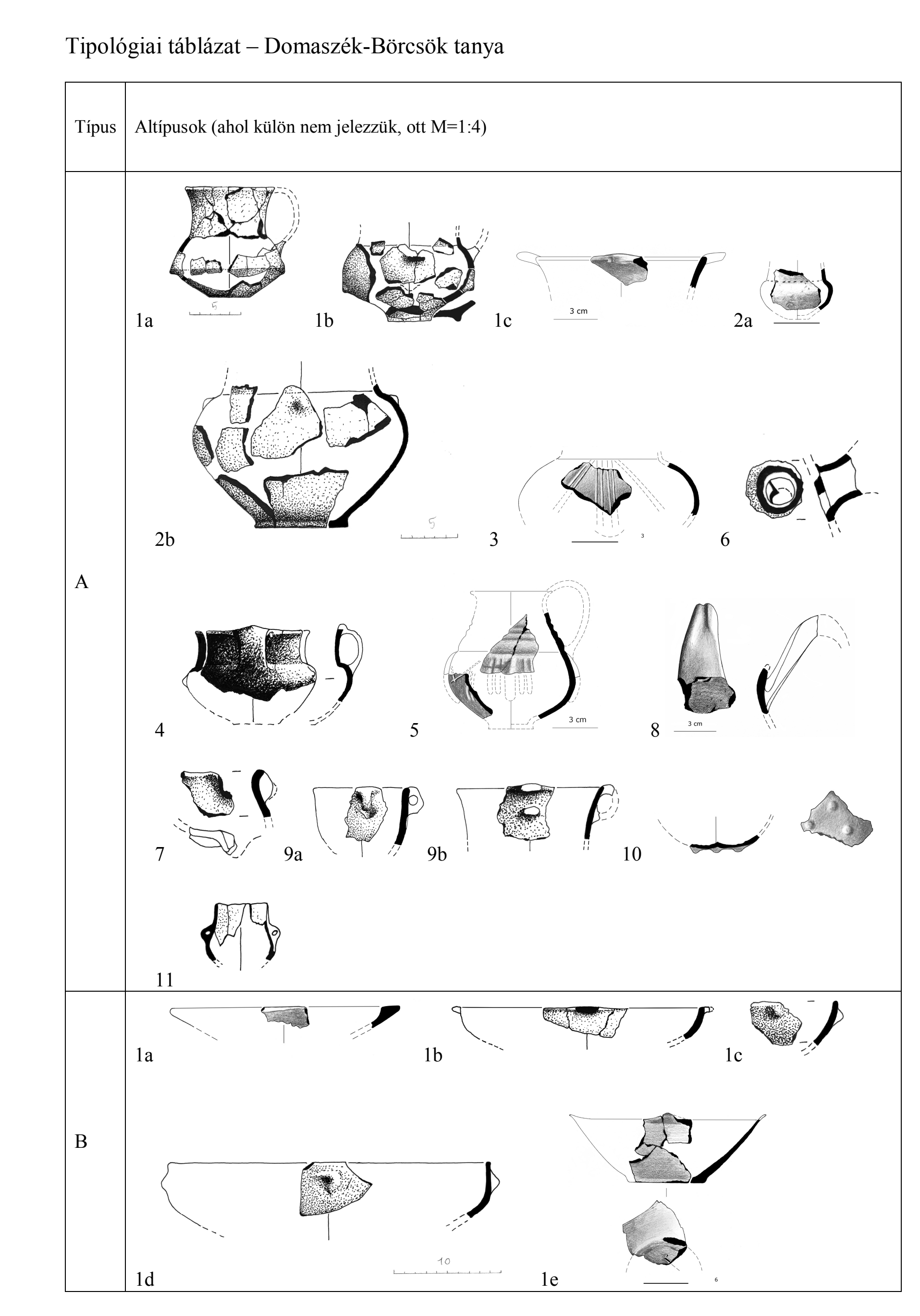





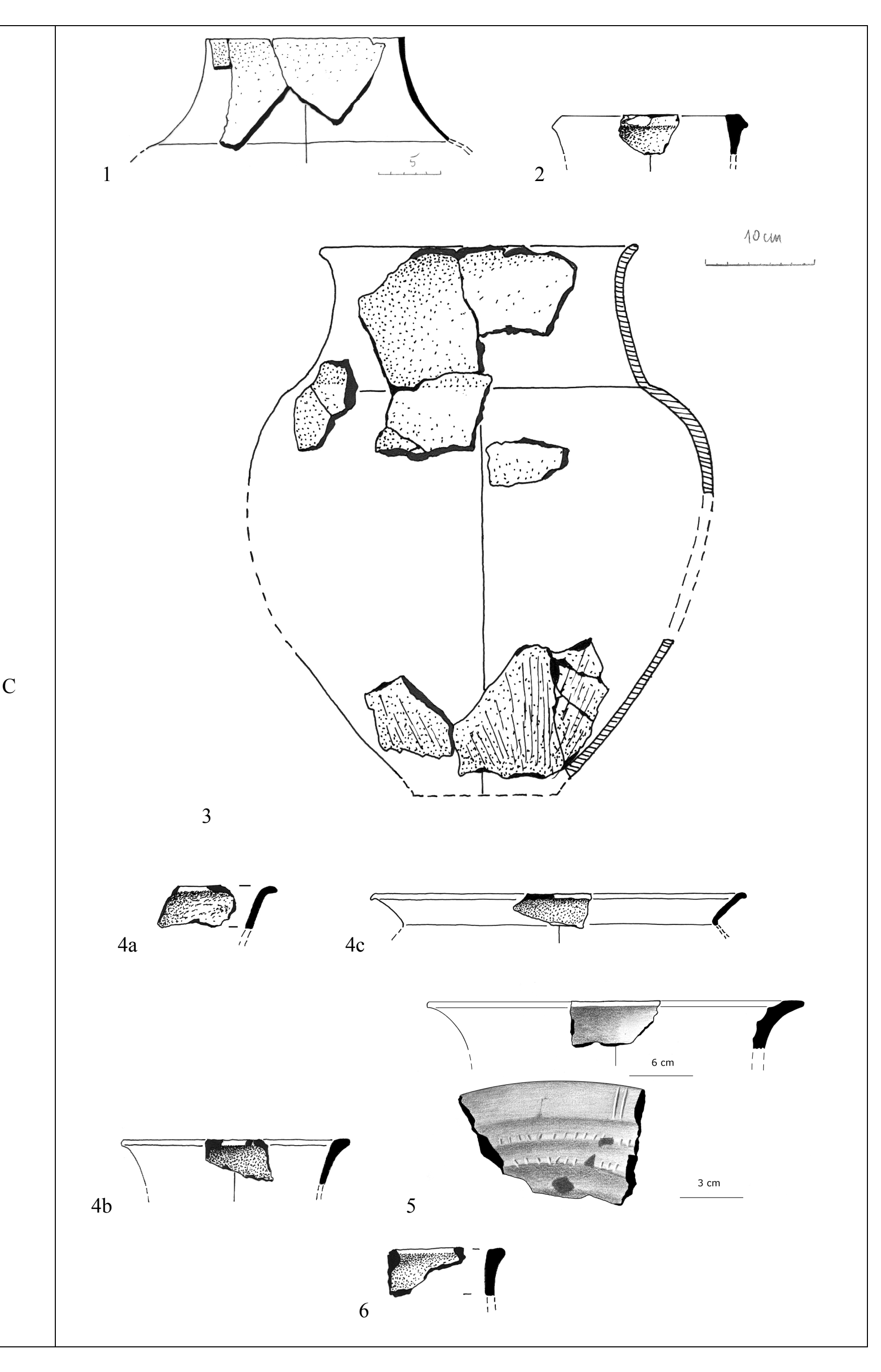




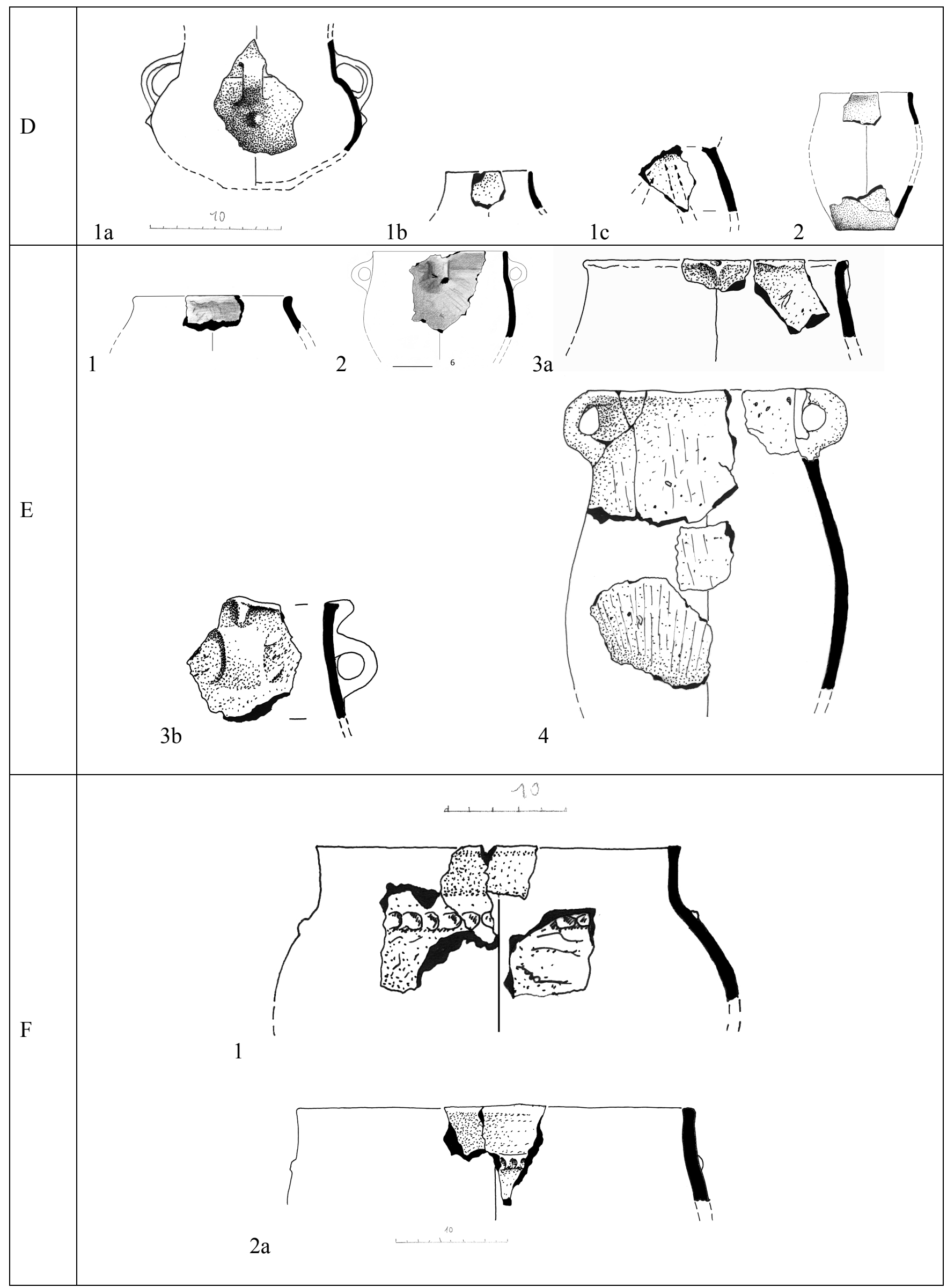




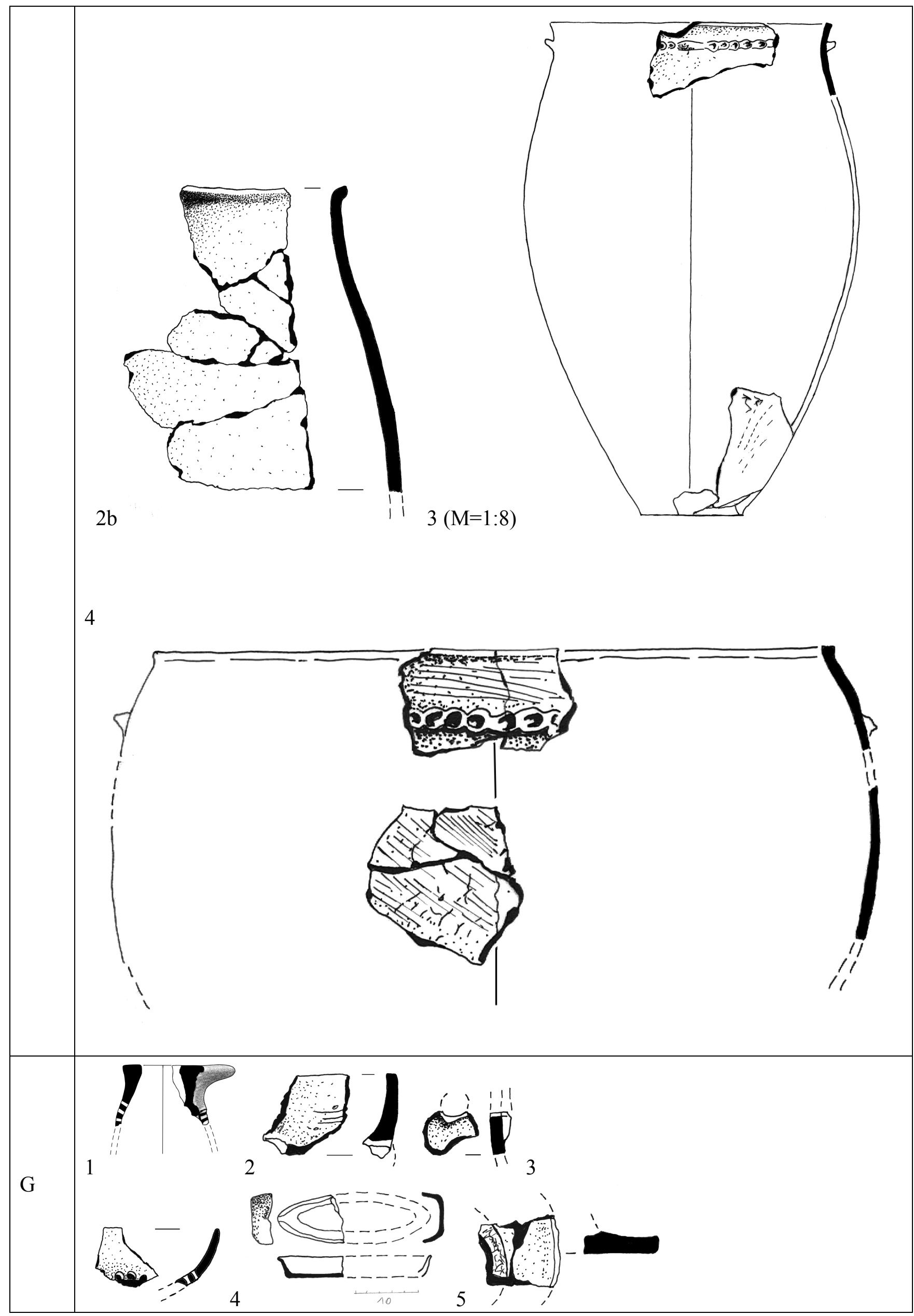




\section{Tisztelt Olvasó!}

A nyomtatott, és bekötött $\mathrm{PhD}$ dolgozattat ellentétben a CD-n és a repozitóriumban szereplő változat ábráinak sorrendje kissé megváltozott. Ennek az az oka, hogy a nagyméretü pdf fájlként mentetett elterjedési térképek és ásatási felszínrajzok csak külön voltak kezelhetők, és nem lehetett öket az egyben elmentett ábra1-7 fájlnevü pdf-ekbe belefüzni. A jelzett táblázatok azért kerültek a dolgozat végére, mert ezeket is külön kellett elkészíteni, mivel nagy méretük és egyedi margóbeállításaik miatt önálló fájlként kellett kezelni őket.

A dolgozat végén, az ábrák után található nagyméretü térképek feliratozására sem volt mód. A mellékelt lista tartalmazza a térképek eredeti fájlnevét abban a sorrendben, amiben mentésre kerültek. Az egyes ábrák aláírásait a sorszámuknak megfelelő helyen olvashatjuk, és a jelmagyarázat is ott található.

Remélem, ez a technikai probléma nem nehezíti jelentősen a dolgozat megértését.

A dolgozat végén szereplő nagyméretü felszínrajzok és elterjedési térképek fájlnevei:

28_abra_osszesitorajz.pdf

29_abra_osszesitorajz_HK_obj_domaszek.pdf

43_abra_talak_szeriacio.pdf

44 abra_durvakeramia.pdf

45_abra_allatcsont.pdf

47_abra_elsorendu_godrok_terkep.pdf

53_ábra_taltipusok_szeriacio.pdf

61_ábra_koraiak.pdf

13 táblázat.pdf

14-15_táblázat.pdf

16_táblázat_Típusszeriáció, tipokronológia.pdf

17_táblázat_Lelöhelyek szeriációja.pdf

tipustabla_mellekletbe1.pdf 